University of Nebraska - Lincoln

DigitalCommons@University of Nebraska - Lincoln

\title{
Progress on Geoenvironmental Models for Selected Mineral Deposit Types
}

Robert R. Seal II

U.S. Geological Survey

Nora K. Foley

U.S. Geological Survey

Follow this and additional works at: https://digitalcommons.unl.edu/usgspubs

Part of the Earth Sciences Commons

Seal, Robert R. II and Foley, Nora K., "Progress on Geoenvironmental Models for Selected Mineral Deposit Types" (2002). Publications of the US Geological Survey. 83.

https://digitalcommons.unl.edu/usgspubs/83

This Article is brought to you for free and open access by the US Geological Survey at DigitalCommons@University of Nebraska - Lincoln. It has been accepted for inclusion in Publications of the US Geological Survey by an authorized administrator of DigitalCommons@University of Nebraska - Lincoln. 


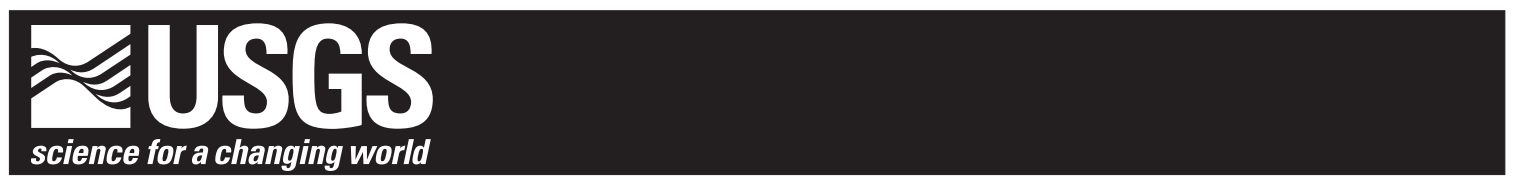

\title{
Progress on Geoenvironmental Models for Selected Mineral Deposit Types
}

\author{
Robert R. Seal II $^{1}$ and Nora K. Foley ${ }^{1}$ \\ Editors
}

U. S. Geological Survey Open-File Report 02-195

This report is preliminary and has not been reviewed for conformity with U. S. Geological Survey editorial standards or with the North American Stratigraphic Code. Any use of trade, product, or firm names is for descriptive purposes only and does not imply endorsement by the U. S. Government.

${ }^{1}$ U. S. Geological Survey, 954 National Center, Reston, VA 20192 


\section{CONTENTS}

\section{CHAPTER}

A. Introduction to Geoenvironmental Models of Mineral Deposits

by Robert R. Seal II, Nora K. Foley, and Richard B. Wanty 1

Introduction

Definition of a Geoenvironmental Model

Anatomy of a Geoenvironmental Model

The State of the Art and Scope

References Cited

B. Geochemical and Mineralogic Characterization of Solids and Their Effects on Waters in Metal-

Mining Environments

by Jane M. Hammarstrom and Kathleen S. Smith

The Role of Mineralogy and Geochemistry of Solids in Geoenvironmental Models

Acid-Base Accounting

Kinetic Testing

Leaching Procedures

Geologic Materials that Contribute to Environmental Signatures

Tools of the Trade

Sampling Media, Methods, and Examples

$\underline{\text { References Cited }}$

C. Toolkit for the Rapid Screening and Characterization of Waste Piles on Abandoned Mine Lands

by Kathleen S. Smith, David L. Campbell, George A. Desborough, Philip L. Hageman,

Reinhard W. Leinz, Mark R. Stanton, Stephen J. Sutley, Gregg A. Swayze, and Douglas

B. Yager .....

Introduction

Sampling and Geochemical Screening Tools

Non-Invasive Screening Tools

Site Characterization Tools

Acknowledgments

$\underline{\text { References Cited }}$

D. Environmental Behavior of Two Molybdenum Porphyry Systems

by Michele L. Tuttle, Richard B. Wanty, and Byron R. Berger

Introduction

Background

Geology

Hydrology and Major-Element Geochemistry

Metal Geochemistry

Conclusions

$\underline{\text { References Cited }}$

E. Environmental geochemistry of platform carbonate-hosted sulfide deposits

by Nora K. Foley

Introduction

Platform Carbonate-Hosted Deposits

Acknowledgments

$\underline{\text { References Cited }}$ 
F. A geoenvironmental lifecycle model: The Austinville platform carbonate deposit, Virginia

by Nora K. Foley

Introduction

Geology of the Deposit

Ore Textures, Mineralogy and Paragenesis

Soil and Sediment Signatures

Drainage Signatures

Climatic Effects

Potential Environmental Concerns

References Cited

G. A Geoenvironmental Mineral Deposit Model for the New World Polymetallic Replacement/Skarn

Deposit

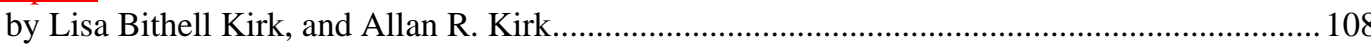

Introduction

Hydrogeochemical Overview of the New World Deposit

Hydrology

Geochemistry

Styles of Mineralization in the New World Deposit

Geoenvironmental Models in Mine Closure

References Cited

H. Environmental Geochemistry of Skarn and Polymetallic Carbonate-Replacement Deposit Models

by Jane M. Hammarstrom

Introduction

$\underline{\text { Skarn and Polymetallic Carbonate-Replacement Deposit Models }}$

Acknowledgments

References Cited

I. A Geoenvironmental Model for Polymetallic Vein Deposits: A Case Study in the Coeur d'Alene Mining District and Comparisons with Drainage from Mineralized Deposits in the Colorado Mineral Belt and Humboldt Basin, Nevada

by Laurie S. Balistrieri, Stephen E. Box, and Arthur A. Bookstrom 143

$\underline{\text { Abstract }}$

Introduction

Study Area

Data Sources

Discussion

Acknowledgments

$\underline{\text { References Cited }}$

J. Mercury Geoenvironmental Models

by James J. Rytuba

Introduction

Global Mercury Cycle and Environmental

Mercury Production

Mercury Deposit Types

Mineralogic Characteristics

Mining and Processing Methods

Environmental Concerns Associates with Mineral Processing

Mercury Mine Drainage Composition

Climate

$\underline{\text { References Cited }}$ 
K. Geoenvironmental Model for Low-Sulfide Gold-Quartz Veins

by Roger P. Ashley

Deposit Geology

Examples

Related Deposit Types

Deposit Size

Host Rocks

Surrounding Geologic Terrane

Wall-Rock Alteration

Nature of Ore

Mining and Ore Processing Methods

Trace Element Geochemistry

Primary Mineralogy and Zonation

Secondary Mineralogy

Pre-Mining Soil and Sediment Signatures

Topography and Physiography

Hydrology

Drainage Signatures

Climatic Effects

Potential Environmental Concerns

References Cited

L. Geoenvironmental Models for Seafloor Massive Sulfide Deposits

by Robert R. Seal, II, Jane M. Hammarstrom, and Nora K. Foley

Introduction

Classification of Massive Sulfide Deposits

Geologic Characteristics

Mining and Ore Processing Methods

Environmental Geochemistry

Potential Environmental Concerns

Conclusions

$\underline{\text { References Cited }}$

APPENDIX: Definitions and References for Aqueous Geochemistry

by Laurie S. Balistrieri. 


\title{
Chapter A
}

\section{INTRODUCTION TO GEOENVIRONMENTAL MODELS OF MINERAL DEPOSITS}

\author{
Robert R. Seal II, Nora K. Foley, and Richard B. Wanty
}

\section{INTRODUCTION}

Since the beginning of economic geology as a subdiscipline of the geological sciences, economic geologists have tended to classify mineral deposits on the basis of geological, mineralogical, and geochemical criteria, in efforts to systematize our understanding of mineral deposits as an aid to exploration. These efforts have lead to classifications based on commodity, geologic setting (Cox and Singer, 1986), inferred temperatures and pressures of ore formation (Lindgren, 1933), and genetic setting (Park and MacDiarmid, 1975; Jensen and Bateman, 1979). None of these classification schemes is mutually exclusive; instead, there is considerable overlap among all of these classifications. A natural outcome of efforts to classify mineral deposits is the development of "mineral deposit models". A mineral deposit model is a systematically arranged body of information that describes some or all of the essential characteristics of a selected group of mineral deposits; it presents a concept within which essential attributes may be distinguished and from which extraneous, coincidental features may be recognized and excluded (Barton, 1993). Barton (1993) noted that the grouping of deposits on the basis of common characteristics forms the basis for a classification, but the specification of the characteristics required for belonging to the group is the basis for a model. Models range from purely descriptive to genetic. A genetic model is superior to a descriptive model because it provides a basis to distinguish essential from extraneous attributes, and it has flexibility to accommodate variability in sources, processes, and local controls. In general, a descriptive model is a necessary prerequisite to a genetic model.

\section{DEFINITION OF A GEOENVIRONMENTAL MODEL}

Geoenvironmental models are natural extensions of mineral deposit models. Plumlee and Nash (1995) defined a geoenvironmental model of a mineral deposit as a compilation of geologic, geochemical, geophysical, hydrologic, and engineering information pertaining to the environmental behavior of geologically similar mineral deposits (1) prior to mining, and (2) resulting from mining, mineral processing, and smelting. Thus, a geoenvironmental model provides information about natural geochemical variations associated with a particular deposit type, and geochemical variations associated with its mining effluents, wastes, and mineral processing facilities, including smelters. Data include information about waters and solids.

From a practical perspective, a geoenvironmental model provides an opportunity to assemble information traditionally within the realm of the economic geologist, and recast it in an "environmentally friendly" format, minimizing the jargon commonly used by economic geologists or mining engineers. Likewise, a model also provides the opportunity to assemble information traditionally outside the realm of the economic geologist, such as water chemistry data, and biologic impact criteria. For both purposes, a major goal is to establish cause-and-effect linkages among the geologic attributes of a deposit, its environmental setting, its mining history (or future), and its environmental behavior. Such information should prove beneficial to (1) environmental scientists interested in mitigating potential environmental problems associated with proposed mines, (2) environmental scientists interested in remediating existing problems at abandoned mine sites, (3) land-use planners that are involved in permitting proposed mines or reclaiming abandoned mine lands, and (4) industry interested in mine planning and mineral exploration.

\section{ANATOMY OF A GEOENVIRONMENTAL MODEL}

Geoenvironmental models provide a variety of information about the geological and geochemical setting of mineral deposits, mining and mineral processing technology as they relate to the generation of mine waste, and the environmental behavior of mineral deposits in the broadest sense. Brief descriptions of key elements of a geoenvironmental model, which have been modified from Plumlee and Nash (1995) and du Bray (1995), are presented below. Plumlee (1999), and Plumlee and others (1999) have discussed many of the salient features of these categories. Each mineral deposit is unique unto itself, and each class of mineral deposit is also unique. Therefore, some degree of flexibility must be maintained in the features considered essential for a given model. Thus, this list is not necessarily considered comprehensive. 


\section{Deposit Type}

The classification of the deposit is the basis for comparisons of the factors that contribute to variations in potential environmental impact. Several levels of classification for a deposit type may be available that shed additional insights into geochemical signatures and environmental behavior. As with any attempt at classification, controversy may exist over which are the defining characteristics. Therefore, specific examples of deposits that belong to a class are essential for clarifying intent in classification. One useful way to look at the classification of mineral deposits is to consider it in terms of a matrix of the major commodity produced (i.e., $\mathrm{Cu}, \mathrm{Zn}, \mathrm{Pb}, \mathrm{Au}$, or $\mathrm{Ag}$ ), and ore and host rocks characteristics (Table 1). The latter has important geotechnical implications for environmental impact in terms of acid-generating potential and acid-neutralizing capacity. This matrix approach highlights the strength of geoenvironmental models, because it provides a framework on which to overlay insights from the genetic attributes of the individual deposit types.

\section{Related Deposit Types}

Mineral deposits are manifestations of parts of larger, complex geochemical systems. Thus, other parts of these complex systems may manifest themselves as different types of mineral deposits, which will probably behave differently in the environment and present different potential environmental problems. For example, there is a common association of seafloor base- and precious-metal massive sulfide deposits with low-sulfide quartz-gold vein ("Mother Lode") deposits. Massive sulfide deposits commonly have associated acid drainage problems due to their abundant pyrite contents, whereas low-sulfide quartz-gold vein deposits do not. However, mercury amalgamation historically was a common technique used to concentrate gold from these ores. In watersheds that contain both types of deposits, constructed wetlands used to remediate acid drainage problems could exacerbate mercury problems by providing a reducing environment to promote mercury methylation. Thus, awareness of potentially associated deposit types and their attributes has important environmental implications.

\section{Deposit Size}

The size of deposits can vary by several orders of magnitude. For seafloor massive sulfide deposits, a single deposit may lie within the watershed of a small perennial stream, whereas for porphyry copper deposits, a single deposit can span several watersheds.

\section{Host Rocks}

The mineralogy and geochemistry of the host rocks are especially important in terms of the acid-generating or acid-neutralizing potential of a mineable rock package. The host rocks of a mineral deposit can also serve to naturally elevate background aqueous contributions of acidity and metals. For example, the unmineralized sulfidic schists of the Anakeesta Formation, which host the Fontana and Hazel Creek massive sulfide deposits in North Carolina, naturally generate acidic waters, which locally exceed water quality guidelines for zinc and other dissolved elements; the water quality of adjacent watersheds underlain by sandstone or carbonates is well within all standards for aquatic health (Seal and others, 1998).

\section{Surrounding Geologic Terrane}

Mineral deposits form in specific geologic settings, which have certain predictable geochemical attributes. Thus, even though the immediate host rocks of a deposit are devoid of carbonate rocks, such as those associated with "Besshi-type" massive sulfide deposits, the larger scale package of rocks can contain significant amounts of limestone and (or) dolomite, which can serve to increase the alkalinity and hardness of watersheds receiving acid drainage from these types of deposits. Also, the structural setting of the deposit can greatly influence the distribution of fractures and associated permeability.

\section{Wall-Rock Alteration}

Wall-rock alteration typically changes the chemistry of the host rock for a significant distance away from the ore zones. Alteration may increase the acid-neutralizing capacity of a rock by introducing carbonate minerals, or it can decreasing the acid-neutralizing capacity of a rock by transforming feldspars into clay minerals.

\section{Nature of Ore}

The nature of the ore affects the potential intensity of adverse environmental effects and the amenability to various mining methods. The potential environmental behavior of a small tonnage, massive sulfide deposit is obviously quite different from a large tonnage porphyry copper deposit, which is characterized by disseminated sulfide minerals that average only a few percent of the rock. For example, the ore from massive sulfide deposits 
typically comprises greater than 50 percent pyrite and (or) pyrrhotite, and a few percent of chalcopyrite, sphalerite, and galena. The chalcopyrite, sphalerite, and galena are recovered for their economic value, but most of the pyrite and pyrrhotite end up in waste piles. At historic mines, the iron-sulfide wastes were discarded with little regard for potential environmental effects. In contrast, typically porphyry ores comprise just a few percent of total sulfide minerals. Also, the mineable tonnage of a typical porphyry deposit is at least an order of magnitude larger than a typical massive sulfide deposit, thus generating more waste material.

Table 1. Selected mineral deposit types arranged by primary commodity and ore/host rock characteristics

\begin{tabular}{|c|c|c|c|c|}
\hline & \multicolumn{4}{|c|}{ Ore/Host Rock Characteristics } \\
\hline & Massive/Silicate & Disseminated/Silicate & Massive/Carbonate & Disseminated/Carbonate \\
\hline $\begin{array}{l}\text { Primary } \\
\text { Commodity }\end{array}$ & & & & \\
\hline Gold & & $\begin{array}{l}\text {-Adularia-sericite } \\
\text { epithermal veins } \\
\text {-Epithermal quartz- } \\
\text { alunite Au } \\
\text {-Carlin-type Au } \\
\text {-Low-sulfide quartz- } \\
\text { gold veins } \\
\text {-Au-Ag telluride veins }\end{array}$ & •Skarn & -Carlin -type Au \\
\hline Silver & $\begin{array}{l}\text {-Sedimentary- } \\
\text { exhalative }\end{array}$ & $\begin{array}{l}\text {-Adularia-sericite } \\
\text { epithermal veins } \\
\text { •Polymetallic veins } \\
\text { Au-Ag telluride veins }\end{array}$ & $\begin{array}{l}\cdot \text {-Skarn } \\
\cdot \text {-Manto-type }\end{array}$ & \\
\hline Copper & $\begin{array}{l}\cdot \text {-Cyprus-type } \\
\text { - Besshi-type } \\
\cdot \text {-Noranda-type } \\
\cdot \text { Magmatic Ni-Cu }\end{array}$ & $\begin{array}{l}\text { •Porphyry } \\
\text { •Sediment-hosted Cu }\end{array}$ & •Skarn & \\
\hline Lead & $\begin{array}{l}\text {-Bathurst-type } \\
\cdot \text {-Kuroko-type } \\
\text {-Sedimentary- } \\
\text { exhalative } \\
\end{array}$ & & $\begin{array}{l}\text { •Mississippi Valley- } \\
\text { type } \\
\text { •Manto/skarn }\end{array}$ & \\
\hline Zinc & $\begin{array}{l}\cdot \text {-Sedimentary- } \\
\text { exhalative } \\
\text { •Kuroko-type } \\
\text { •Bathurst-type } \\
\end{array}$ & & $\begin{array}{l}\text { •Mississippi Valley- } \\
\text { type } \\
\text { •Manto/skarn }\end{array}$ & \\
\hline Mercury & $\begin{array}{l}\text {-Silica-carbonate } \\
\mathrm{Hg}\end{array}$ & $\begin{array}{l}\text {-Almaden Hg } \\
\text {-Silica-carbonate Hg }\end{array}$ & -Silica-carbonate Hg & -Silica-carbonate Hg \\
\hline
\end{tabular}

Deposit types are based on Cox and Singer (1986) and du Bray (1995).

Mining and Ore Processing Methods

Mining and ore-processing methods are influenced by the geology of the deposit. The hydrologic differences between underground and open pit mines are significant. Evaporative concentration is more prominent in open pit settings. With regards to abandoned mines, historic evolution of ore beneficiation techniques can cause different "vintages" of mine wastes to be variably endowed in metals. Flotation circuits and cyanide leach operations add exotic chemicals to mine wastes. Historical use of mercury amalgamation to process gold ores is a major source of mercury contamination at abandoned mine sites.

\section{Deposit Trace Element Geochemistry}

Most deposits are exploited for just a few (or less) primary commodities, yet they can have numerous other potentially toxic elements present in subeconomic quantities. Cadmium is rarely recovered as primary commodity, even though is ubiquitously found substituting for zinc in sphalerite. Similarly, arsenic is common in many deposit types as a solid solution in pyrite or as arsenopyrite. Both pyrite and arsenopyrite are typically discarded in waste. Thus, knowledge of the trace element geochemistry of a deposit is essential for assessing all of the potential environmental impacts. 


\section{Primary Mineralogy and Zonation}

The primary, or original mineralogy of mineral deposits is the ultimate source of metals, acidity, and, in some cases, alkalinity in these systems. In addition, many hydrothermal mineral deposits are zoned. For example, porphyry copper systems can contain significant amounts of lead and zinc. However, the lead- and zinc-rich zones are typically found peripheral to the copper-rich centers of these deposits, and consequently, are rarely mined. Also, the presence of pyrite, as a source of dissolved ferric iron, greatly enhances the acid-generating potential of weathering monosulfide minerals like sphalerite or galena (Plumlee, 1999). The weathering behavior of minerals can vary significantly due to differences in morphological characteristics and trace element compositions. For example, sedimentary environments can contain "framboidal" pyrite, which is much more reactive than cubic crystals of pyrite. Likewise, pyrite that contains significant amounts of arsenic oxidizes more rapidly than arsenicfree pyrite (Plumlee, 1999).

\section{Secondary Mineralogy}

The secondary mineralogy, which forms through the weathering of a deposit or its mine wastes, tends to sequester metals and (or) acidity on either a long-term or short-term basis. Hydrated ferric oxides can sorb metals on a somewhat refractory substrate, whereas efflorescent metal sulfate salts, such as melanterite, serve as a means to store metals and acidity on a temporary basis during dry periods. These salts readily dissolve during rain storms or spring snow melt and deliver their metals and acidity to the surrounding watershed. For many deposit types, premining oxidation of primary ores was a major contributing factor in enriching some deposits to economic grades.

\section{Soil and Sediment Signatures}

Pre-mining soil and stream sediment signatures may be useful for establishing pre-mining backgrounds. Also, soils around abandoned mine and smelter sites represent a significant sink for metals.

\section{Topography and Physiography}

Topography and physiography are important factors controlling the local hydrologic setting, particularly the location of the water table. Also, deposits located in physiographic provinces in the rain shadow of orographic highs, such as the Great Basin of Nevada east of the Sierra Nevada Mountains, will behave quite differently than those located in provinces with high rainfall.

\section{Hydrology}

The hydrologic setting, especially relative to the water table, is a key variable in determining the magnitude of mine drainage problems. The Iron Mountain mine in northern California is dominantly situated above the water table and produces waters with $\mathrm{pH}$ values as low as -3.6 (Nordstrom and others, 2000), whereas much of the Penn mine is below the water table and only produces waters with $\mathrm{pH}$ values as low as 2.8 (Alpers and others, 1999). Similarly, the geologic setting of a deposit can influence the distribution of fracture-controlled permeability, and thus, access to ground water.

\section{Drainage Signatures}

The geology of a deposit exerts a major influence on both pre-mining background water compositions and on mine drainage. Drainage characteristics vary systematically according to deposit type (Fig. 1). Increases in total dissolved base metals generally correlate with increases in associated pyrite content, decreases in acid-neutralizing capacity, and increases in base metal content of deposits (Plumlee, 1999).

\section{Climatic Effects}

Climate plays a key role in the environmental behavior of mineral deposits. Differences in temperature, amount of precipitation, and humidity are probably the most important climatic variables (Plumlee, 1999). Temperature and humidity are the prime variables that control evaporation. Evaporation limits the amount of water in semi-arid to arid climates. Evaporation can concentrate solutes in all climates. Winter freezing conditions can lead to seasonally episodic fluctuations in drainage chemistry. Ecosystems may form a reasonable basis for assessing the role of climatic variability in the environmental behavior of mineral deposits (Bailey, 1996). Nevertheless, more research is needed to better understand the link between climate and the environmental impacts of mineral deposits. 


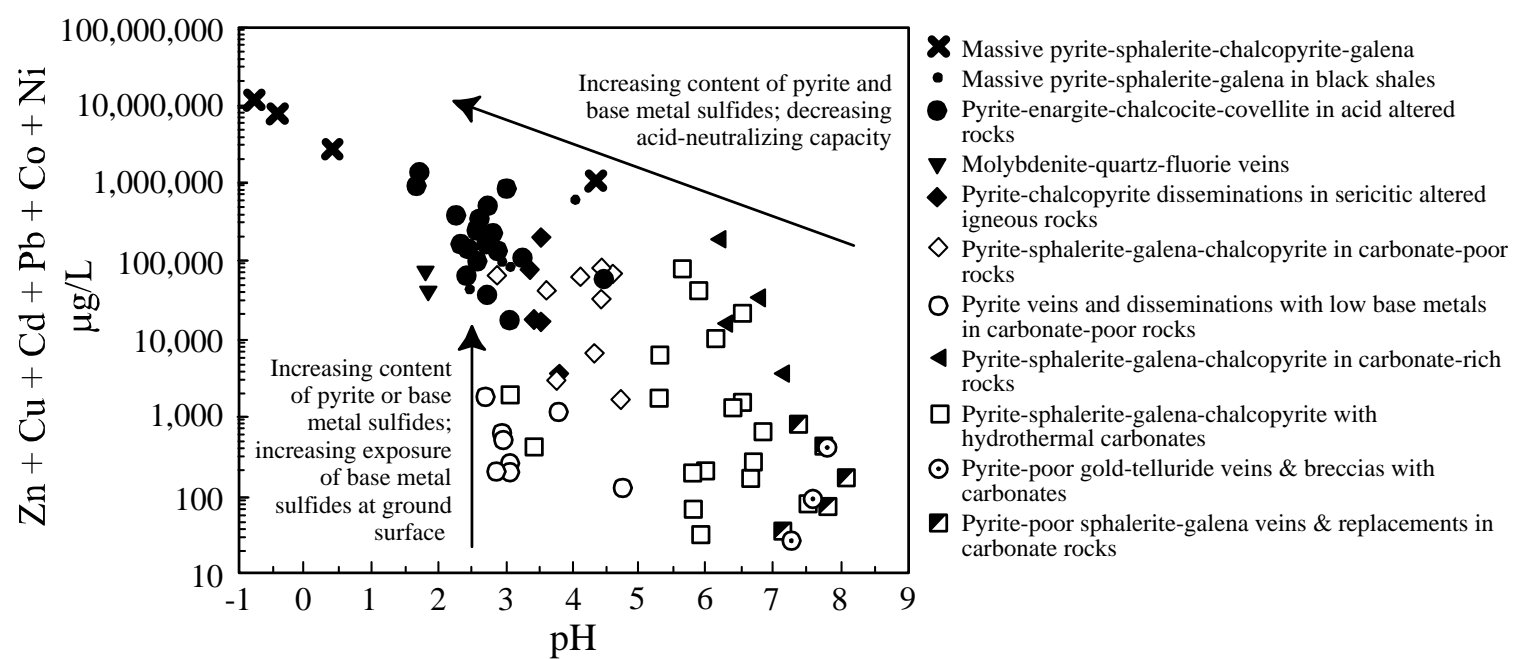

Figure 1. Ficklin plot of the sum of the base metals $\mathrm{Cd}, \mathrm{Co}, \mathrm{Cu}, \mathrm{Ni}, \mathrm{Pb}$, and $\mathrm{Zn}$ versus $\mathrm{pH}$ illustrating the variation of mine drainage chemistry as a function of the geologic characteristics (type) of specific mineral deposits. Modified from Plumlee and Nash (1995), and Plumlee (1999).

\section{Potential Environmental Concerns}

Potential environmental concerns associated with mineral deposits can generally be divided into three broad categories: (1) human health risks; (2) ecosystem risks; and (3) physical hazards. All of these concerns are ultimately rooted in the geologic foundation of the mineral deposit. Human health risks (exclusive of physical hazards) generally focus on metals (lead, arsenic, selenium, and mercury) associated with various mineral deposit types, and elements and compounds used in ore processing, such as mercury or cyanide. Ecosystem risks are associated with acidity and a range of metals. Physical hazards, such as open shafts and open pits, are related to the mining required to exploit specific mineral deposit types.

\section{THE STATE OF THE ART AND SCOPE}

In their present form, geoenvironmental models are largely descriptive in nature. They represent empirical compilations of data that provide a powerful predictive capability of possible ranges of environmental impact. Du Bray (1995) presented preliminary geoenvironmental models for 32 different mineral deposit types.

Geoenvironmental model research at the U.S. Geological Survey since 1995 has tended to concentrate on a more limited number of deposit types. The emphasis has been placed on deposit types that are currently attractive exploration targets and (or) historically environmentally problematic (or both!). Future efforts are expected to develop quantitative genetic geoenvironmental models.

In their present form, geoenvironmental models can serve several purposes including: (1) the establishment of premining baseline conditions for mines, inactive, active, and planned; (2) the improvement of mine planning and development by better anticipating and mitigating potential environmental problems; (3) the improvement of remediation at abandoned mine sites by outlining the spectrum of potential problems that might be encountered at a site; and (4) the assessment of abandoned mine lands issues by providing a tool for identifying, prioritizing, and planning remediation efforts (Plumlee and Nash, 1995). In spite of their power, geoenvironmental models should not be used to predict absolute $\mathrm{pH}$ and metal concentrations that will develop at a particular site, nor should they be used in place of thorough field studies to characterize sites (Plumlee, 1999). Instead, they are best used as guidelines for potential ranges of environmental signatures that may apply to the site.

The material presented in this report has been previously presented as a short course titled "Geoenvironmental Analysis of Ore Deposits" at the $5^{\text {th }}$ International Conference on Acid Rock Drainage (ICARD) held in Denver, Colorado on May 21, 2000. The remainder of this volume is organized first to present brief summaries of basic concepts of the geochemistry of solids (Hammarstrom and Smith, 2002) to ensure that the reader has a minimum background in geochemical concepts that are fundamental to geoenvironmental models. Next, a summary of rapid screening techniques to assess the potential impact of mine wastes is presented (Smith and others, 2002). Finally, individual models will be presented in formats that range from case studies of specific deposits to national and global syntheses. Deposit types include porphyry deposits (Tuttle and others, 2002), polymetallic vein deposits, emphasizing the Couer d'Alene district, Idaho (Balistrieri and others, 2002), carbonate-hosted deposits (Foley, 
2002a,b; Hammarstrom, 2002; Kirk and Kirk, 2002), mercury associated with epithermal deposits (Rytuba, 2002), lode gold deposits (Ashley, 2002), and massive sulfide deposits (Seal and others, 2002).

\section{REFERENCES CITED}

Alpers, C.N., Hamlin, S.N., and Hunerlach, M.P., 1999, Hydrogeology and geochemistry of acid mine drainage in ground water in the vicinity of Penn mine and Camanche reservoir, Calaveras County, California: summary report, 1993-95: U.S. Geological Survey Water-Resources Investigations 96-4287, 59 p.

Ashley, R.P., 2002, Geoenvironmental model for low-sulfide gold-quartz vein deposits, in Seal, R.R., II, and Foley, N.K., eds., Geoenvironmental Models of Mineral Deposits: U.S Geological Survey Open-File Report 02-195, p. 176-195.

Bailey, R.G., 1996, Ecosystem Geography: Springer, New York, 241 p.

Balistrieri, L.S., Box, S.E., and Bookstrom, A.A. 2002, A geoenvironmental model for polymetallic vein deposits: A case study on the Coeur d'Alene mining district and comparisons with drainage from mineralized deposits in the Colorado mineral belt and Humboldt basin, Nevada, in Seal, R.R., II, and Foley, N.K., eds., Geoenvironmental Models of Mineral Deposits: U.S Geological Survey Open-File Report 02-195, p. 143-160.

Barton, P.B., Jr., 1993, Problems and opportunities for mineral deposit models, in Kirkham, R.V., Sinclair, W.D., Thorpe, R.I., and Duke, J.M., eds., Mineral Deposit Modeling: Geological Association of Canada, Special paper 40, p. 7-13.

Cox, D.P., and Singer, D.A., eds., 1986, Mineral deposit models: U.S. Geological Survey Bulletin 1693, 379 p.

du Bray, E.A., ed., 1995, Preliminary compilation of descriptive geoenvironmental mineral deposit models: U.S. Geological Survey Open-File Report 95-831, 272 p.

Foley, N.K., 2002a, Environmental geochemistry of platform carbonate-hosted sulfide deposits, in Seal, R.R., II, and Foley, N.K., eds., Geoenvironmental Models of Mineral Deposits: U.S Geological Survey Open-File Report 02195 , p. 87-100.

Foley, N.K., 2002b, A geoenvironmental lifecycle model: The Austinville platform carbonate deposit, Virginia, in Seal, R.R., II, and Foley, N.K., eds., Geoenvironmental Models of Mineral Deposits: U.S Geological Survey Open-File Report 02-195, p. 101-107.

Hammarstrom, J.M., 2002, Environmental geochemistry of skarn and polymetallic carbonate-replacement deposit models, in Seal, R.R., II, and Foley, N.K., eds., Geoenvironmental Models of Mineral Deposits: U.S Geological Survey Open-File Report 02-195, p. 115-142.

Hammarstrom, J.M., and Smith, K.S., 2002, Geochemical and mineralogic characterization of solids and their effects on waters in metal-mining environments, in Seal, R.R., II, and Foley, N.K., eds., Geoenvironmental Models of Mineral Deposits: U.S Geological Survey Open-File Report 02-195, p. 8-54.

Jensen, M.L., and Bateman, A.M., 1979, Economic Mineral Deposits: $3^{\text {rd }}$ edition, John Wiley and Sons, New York, $593 \mathrm{p}$.

Kirk, L.B., and Kirk, A.R., 2002, A geoenvironmental mineral deposit model for the New World polymetallic replacement/skarn deposit, in Seal, R.R., II, and Foley, N.K., eds., Geoenvironmental Models of Mineral Deposits: U.S Geological Survey Open-File Report 02-195, p. 108-114.

Lindgren, W., 1933, Mineral Deposits: $4^{\text {th }}$ edition, McGraw-Hill Book Company, Inc., New York, 930 p.

Nordstrom, D.K., Alpers, C.N., Ptacek, C.J., and Blowes, D.W., 2000, Negative pH and extremely acidic mine waters from Iron Mountain, California: Environmental Science and Technology, v. 34, p. 254-258.

Park, C.F., Jr., and MacDiarmid, R.A., 1975, Ore Deposits: $3^{\text {rd }}$ edition, W.H. Freeman and Company, San Francisco, $529 \mathrm{p}$.

Plumlee, G.S., 1999, The environmental geology of mineral deposits, in Plumlee, G.S., and Logsdon, M.J., eds., The Environmental Geochemistry of Mineral Deposits, Part A: Processes, Techniques, and Health Issues: Reviews in Economic Geology, v. 6A, p. 71-116.

Plumlee, G.S., Smith, K.S., Montour, M.R., Ficklin, W.H., and Mosier, E.L., 1999, Geologic controls on the composition of natural waters and mine waters draining diverse mineral-deposit types, in Filipek, L.H., and Plumlee, G.S., eds., The Environmental Geochemistry of Mineral Deposits, Part B: Case Studies and Research Topics: Reviews in Economic Geology, v. 6B, p. 373-432.

Plumlee, G.S., and Nash, J.T., 1995, Geoenvironmental models of mineral deposits - fundamentals and applications: U.S. Geological Survey Open-File Report 95-831, p. 1-9.

Rytuba, J.J., 2002, Mercury geoenvironmental models, in Seal, R.R., II, and Foley, N.K., eds., Geoenvironmental Models of Mineral Deposits: U.S Geological Survey Open-File Report 02-195, p. 161-175.

Seal, R.R., II, Hammarstrom, J.M., Southworth, C.S., Meier, A.L., Haffner, D.P., Schultz, A.P., Plumlee, G.S., Flohr, M.J.K., Jackson, J.C., Smith, S.M., and Hageman, P.L., 1998, Preliminary report on water quality 
associated with the abandoned Fontana and Hazel Creek mines, Great Smoky Mountains National Park, North Carolina and Tennessee: U.S. Geological Survey Open-File Report 98-476, 50 p.

Seal, R.R., II, Hammarstrom, J.M., and Foley, N.K, 2002, Seafloor massive sulfide deposits, in Seal, R.R., II, and Foley, N.K., eds., Geoenvironmental Models of Mineral Deposits: U.S Geological Survey Open-File Report 02195, p. 196-212.

Smith,K.S., Campbell, D.L., Desborough, G.A., Hageman, P.L., Leinz, R.W., Stanton, M.R., Sutley, S.J., Swayze, G.A., and Yager, D.B., 2002, Toolkit for the rapid screening and characterization of waste piles on abandoned mine lands, , in Seal, R.R., II, and Foley, N.K., eds., Geoenvironmental Models of Mineral Deposits: U.S Geological Survey Open-File Report 02-195, p. 55-64.

Tuttle, M., Wanty, R.B., and Berger, B.R., 2002, Environmental behavior of two molybdenum porphyry systems, in Seal, R.R., II, and Foley, N.K., eds., Geoenvironmental Models of Mineral Deposits: U.S Geological Survey Open-File Report 02-195, p. 65-86. 


\title{
Chapter B
}

\section{GEOCHEMICAL AND MINERALOGIC CHARACTERIZATION OF SOLIDS AND THEIR EFFECTS ON WATERS IN METAL-MINING ENVIRONMENTS}

\author{
Jane M. Hammarstrom and Kathleen S. Smith
}

THE ROLE OF MINERALOGY AND GEOCHEMISTRY OF SOLIDS IN GEOENVIRONMENTAL MODELS

The geologic characteristics (ore mineralogy, geochemistry, host rock lithology, etc.) that economic geologists use to classify mineral deposits are key to understanding their environmental signatures. Mineralogic characterization and chemical analysis are among the many scientific tools that can be applied to miningenvironmental prediction, mitigation, and remediation (Plumlee and Logsdon, 1999a).

Mineralogy is important because (1) the primary ore and non-ore (gangue) minerals are sources of metals and other elements released into solution upon weathering, (2) these weathering reactions can produce or consume acidity $\left(\mathrm{H}^{+}\right)$, and (3) many secondary minerals that form during the weathering process can permanently or temporarily sequester metals, recycling them and generating or consuming acidity in reactions triggered by changes in moisture, temperature, or $\mathrm{pH}$ in the local environment. The $\mathrm{pH}$ of mine drainage varies depending on the balance between acid-producing and acid-consuming reactions that occur during weathering, the relative rates of these reactions, and the accessibility of minerals that contribute to these reactions (Smith and others, 1994). Thus, the chemical signature of waters and solids associated with a mineral deposit are intimately linked. Most mines are situated along streams and in many cases mine waste is deposited in or adjacent to streams (fig. 1), so surface runoff from and infiltration into mine waste is an important control of drainage water chemistry.

Static tests (acid-base accounting) used to predict acid-rock drainage (ARD) and develop remediation options such as lime requirements are based on assumptions about mineralogy that may or may not be appropriate. These tests are at best a screening tool and provide no information about reaction rates. However, these tests are relatively rapid and inexpensive compared to long-term kinetic tests and are a reality of modern mining and environmental regulation. Knowledge of the mineralogy of the mine waste provides a guide to choosing the most appropriate methods for acid-base accounting because results for different methods vary depending on the minerals that represent the sources of acid and the minerals that provide sources of neutralization. Mineralogic characterization provides information on (1) sources and identity of potential metals and acidity, (2) sources of neutralization, (3) presence of minerals that may contribute to laboratory-based neutralization potential calculations, but behave differently under field conditions, (4) soluble and insoluble constituents of earth materials, and (5) textures and grain sizes that can affect reactivity of different minerals (Price and others, 1997; Jambor and Blowes, 1998). Many active mine operations are starting to incorporate detailed mineralogic characterization in mitigation plans. Modified static tests have been developed to address some of the problems associated with static tests. For abandoned mines, knowledge of mineralogy gleaned from geoenvironmental models can assist with prioritization and choices of appropriate tests and remediation options for different types of mineral deposits, many of which can occur within a single watershed.

Typically, mineralogic characterization of solids includes microscopic examination, x-ray diffraction (XRD), scanning electron microscopy (SEM), and in some cases, electron probe microanalysis (EPMA). A variety of other techniques are available to mineralogists for characterization of individual mineral grains by x-ray diffraction methods and for chemical analysis of minerals (Jambor and Blowes, 1998). Chemical analysis is important because potentially toxic metals, such as cadmium and selenium, are typically sequestered as minor constituents in ore minerals such as sphalerite or galena and their presence may not be apparent from casual examination of ore mineral assemblages. Many secondary minerals (1) occur as very fine-grained or poorly crystalline materials that can sorb and desorb metals, depending on local conditions, (2) form complex solid solutions that incorporate metals, and (3) are transient because they can precipitate and dissolve in a matter of hours depending on changes in the local environment. Geochemical models use complete water chemistry analysis to compute saturation indices, predict what minerals should be stable under equilibrium conditions, and provide insights about the processes that control the release, transport, and fate of contaminants (Alpers and Nordstrom, 1999). However, most models are limited to equilibrium conditions and contain limited data for secondary minerals encountered in weathered mining systems. Mineralogic data can be used to constrain models, and model results provide clues to the presence of secondary minerals involved in precipitation and dissolution reactions. No single technique suffices to identify all the minerals that may be encountered and some combination or iterative use of different methods may be necessary to characterize the mineralogy of a site. 


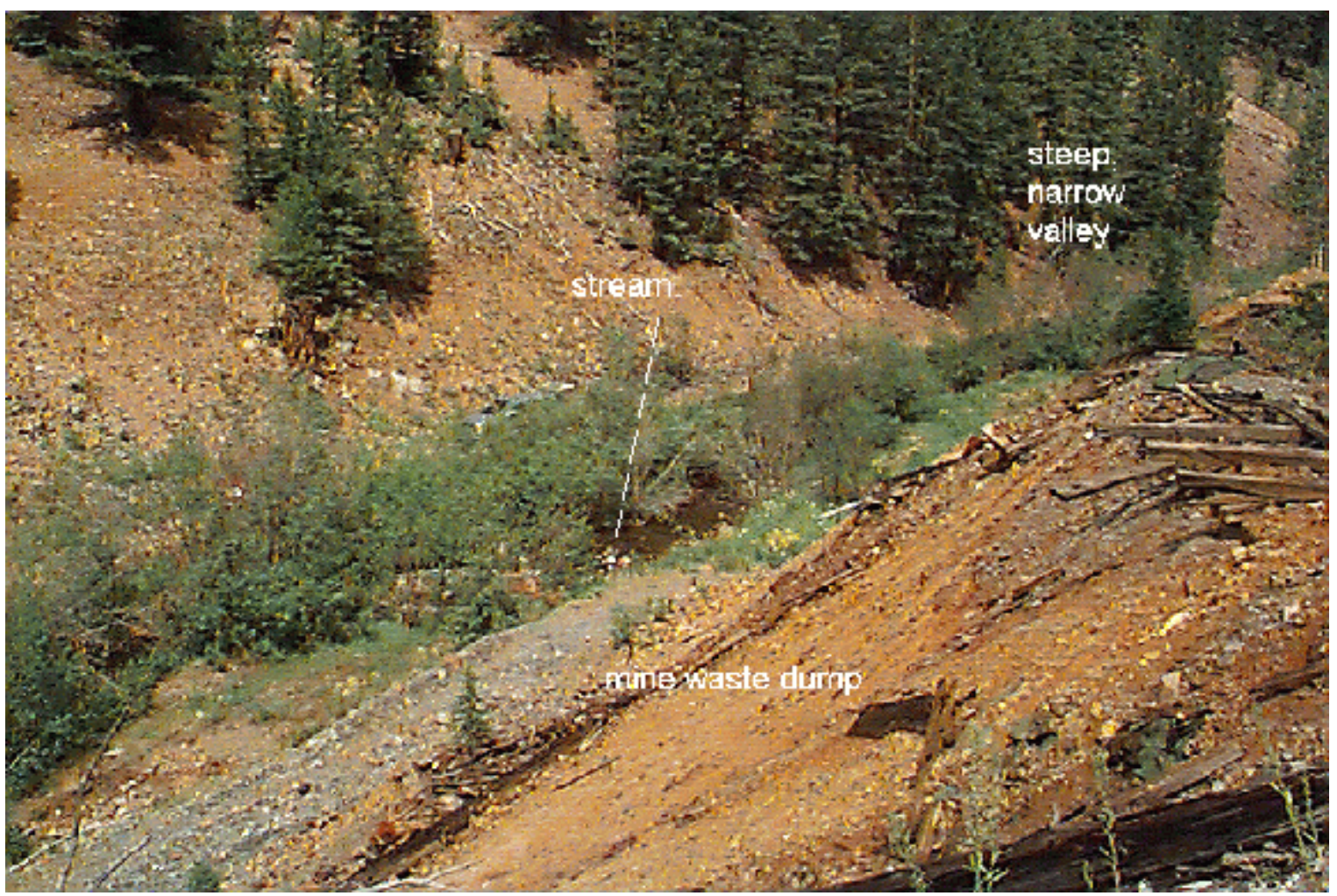

Figure 1. Typical abandoned mine waste dump in the Rocky Mountains of the western U.S. Oxidized ore and soil developed from mine waste material form a steep slope in a narrow valley drained by a perennial stream. Surface runoff from solids on the dump and infiltration through the dump contributes sediments and dissolved metals to the stream. The underground mine here exploited a tungsten skarn deposit that was last worked in 1955. Photo taken August 1999.

Chemical analysis of solid geologic materials (rocks, soils, sediments) provides information on sources and sinks for potentially toxic elements. Chemical data can be used to establish pre- mining backgrounds and baselines and evaluate post-mining or post-reclamation geochemical signatures. Recognition of natural high or low backgrounds or baselines in an area may be a factor in the economic viability of developing a mineral deposit and in setting realistic site remediation goals (Wanty and others, 1999; Wanty and others, in press). Coupled with leaching and sequential extractions, the chemistry of the solids becomes a powerful tool for documenting transport and fate of different elements in the environment and for predicting potential surface runoff problems. Although acid-base accounting techniques are based on assumptions about mineralogy, the values reported rely on chemical analyses of bulk samples for sulfur and carbon species. Multi-element chemical analysis can also provide information on the presence of unsuspected elements. For example, metals that could be detrimental to the environment may be detected that were not assayed for during the mine life or by older analytical techniques. In particular, mercury was used for gold amalgamation at many historic gold mines, especially at placer operations and may contribute to the geochemical signature at a site. Zinc tended to be under-reported in historic production data because of smelter penalties. Geochemical analysis can indicate elevated concentrations of metals that could be recovered by remining, establish the geochemical signature of different parts of a study site (hotspots or neutral zones), and provide a rapid and economical screening tool for ranking large numbers of sites and identifying areas for follow-up studies.

In this chapter, we (1) provide an overview of acid-base accounting, (2) outline tools available for characterizing solids, and (3) discuss different types of solid materials that can be sampled and the information they provide. Chapter $\mathrm{C}$ outlines a toolkit of methods, strategies, and approaches for rapid site characterization of metalmining waste piles. We include examples from USGS efforts to develop uniform approaches to data collection to enhance the preliminary geoenvironmental models in du Bray (1995). These preliminary models were structured to add an environmental component to mineral deposit models used for mineral deposit classification for resource assessment (Cox and Singer, 1986). By developing a consistent data set for a variety of different deposit types in different ecoregions, the effects of climate, latitude, and altitude on the environmental signatures of deposits can be incorporated into models to enhance their predictive value. A number of recent publications discuss processes and 
techniques relevant to solids chemistry and characterization as well as overviews of the behavior of metals in acid drainage environments, case studies, and useful reference tables (mineral resistance to weathering, possible reactions involving ore and gangue minerals, element distributions in different sample media, etc.). See for example, Plumlee and Logsdon, 1999b; Filipek and Plumlee, 1999; Cabri and Vaughn, 1998; Jambor and Blowes, 1994; Kwong, 1993; MEND, 2000, 1994,1989). In addition, the InfoMine website (Robertson Info-Data, Inc.) subscription service provides access to EnviroMine, a reference library, resource, and forum for exchange of current information on mining-related environmental technology.

\section{ACID-BASE ACCOUNTING}

Static acid-base accounting (ABA) is a screening procedure to predict if a waste material will produce acid-rock drainage (ARD). It compares the acid production potential (AP, APP, or AGP) with the acid neutralization potential (NP or ANP) for a given waste material. $\mathrm{ABA}$ results are usually reported in tons $\mathrm{CaCO}_{3}$ per 1,000 tons (ppt) of waste material. The net neutralization potential (NNP) is the difference between NP and AP.

$$
\mathrm{NNP}=\mathrm{NP}-\mathrm{AP}
$$

The neutralization potential ratio (NPR) is the ratio of NP to AP.

$$
\mathrm{NPR}=\mathrm{NP} / \mathrm{AP}
$$

The NNP and NPR are used to categorize the tested material into acid-producing or non-acid-producing material. An excellent discussion of ARD prediction, ABA test procedures, and an ABA overview can be found on the EnviroMine web site at:

http://www.infomine.com/technology/enviromine/ard/welcome.htm.

There is a great deal of controversy about how to interpret NNP and NPR calculations. NNP values in the range of -20 to $20 \mathrm{~g} \mathrm{CaCO}_{3} / \mathrm{kg}$ are generally considered to be uncertain (e.g., Brady and Cravotta, 1992; Lapakko, 1992). NNP values less than -20 are typically taken to indicate acid producing potential while NNP values greater than 20 are usually interpreted to identify materials with little potential to produce net acidity. For NPR, when the ratio is less than one, the material is predicted to generate acidic drainage. However, diPretorio and Rauch (1988) found that materials with ratios less than about 2.4 often produce acidic drainage. Smith $(1997$, p. 291) states that "...a proponent should consider using a conservative 3:1 ANP/AGP ratio for determining, without further testing, that a waste rock will not be acid generating in the long term. Samples which have lower ANP/AGP ratios may not be acid generating; they merely require kinetic tests to establish their long-term behavior." Price $(\underline{1997, p .89})$ states that a NPR of 4 is "a conservative screening criteria selected to ensure the detection of all sites where there is an unfavorable balance between acid generation and neutralization reactions..." Table 1 provides an example of NPR screening criteria for the potential of a mine-waste material to produce ARD. The relative usefulness of NPP versus NPR is affected by the absolute amounts of sulfide sulfur and neutralization potential in the material in question. Very small values might be better evaluated by the ratio (NPR) than the difference (NNP) because of the potential impact of analytical uncertainty.

Many problems associated with NNP and NPR interpretations are directly attributable to the methods used to determine AP and NP. AP and NP determinations involve static procedures, which do not directly take into account rates of reactions. These procedures originally were developed for coal overburden and wastes. Several AP and NP procedures exist, and these procedures often yield different results. The Sobek method (Sobek and others, 1978), and modifications thereof (Coastech, 1989; Lawrence, 1990), is the most commonly used approach for determining ABA. Some guidelines have been developed by permitting and regulatory agencies (e.g., Price and Errington, $\underline{1998}$ ), but there is no standard procedure for conducting ABA. Furthermore, even methods that have been codified as ASTM or EPA methods with specific, detailed procedures are routinely modified by commercial analytical laboratories but not marketed as a "modified" method. Such methods may or may not be inferior to the standard method, but such variability makes comparisons among data sets unreliable. Price (1997) recommends the following analyses be performed for ABA determination:

1. Total sulfur, acid leachable sulfate sulfur, acid insoluble sulfate sulfur, sulfide sulfur, and organic sulfur

2. Bulk neutralization potential

3. Carbonate carbon

4. $\mathrm{pH}$ 
Table 1. Neutralization potential ratio (NPR) screening criteria (from Price, 1997).

$[A R D=$ acid-rock drainage; Note that these are screening criteria and that most sites require further characterization beyond the screening stage.]

\begin{tabular}{lcl} 
ARD Potential & NPR & \multicolumn{1}{c}{ Comments } \\
\hline Likely & $<1$ & Likely ARD generating unless sulfide minerals are non-reactive \\
Possibly & $1-2$ & $\begin{array}{l}\text { Possibly ARD generating if NP is insufficiently reactive or is depleted at a } \\
\text { faster rate than sulfides } \\
\text { Low }\end{array}$ \\
None & $2-4$ & $\begin{array}{l}\text { Not potentially ARD generating unless significant preferential exposure of } \\
\text { sulfides along fracture planes, or extremely reactive sulfides in combination } \\
\text { with insufficiently reactive NP } \\
\text { No further ARD testing required unless materials are to be used as a source of } \\
\text { alkalinity }\end{array}$ \\
\hline
\end{tabular}

Coastech (1989), Smith and others (1992), Kania (1998), White and others (1998, 1999), and the EnviroMine web site provide an overview of procedures to determine AP and NP. Generally, AP is determined by a sulfur assay (either total sulfur or sulfide sulfur). The form of sulfur used in AP determinations is an area of dispute. It is worth remembering that "sulfur forms" are analytically defined (e.g., "sulfide sulfur" is defined as nitric-acid-soluble sulfur even though not all sulfide minerals are soluble in nitric acid). Use of total sulfur in the AP calculation can overestimate AP, but use of other forms of sulfur can underestimate AP, especially if sulfides have been oxidized to sulfates prior to testing. Total sulfur is the most reproducible and verifiable approach to determine the maximum potential acidity (Brady and Smith, 1990). American Society for Testing and Materials (ASTM) methods for total sulfur include D4239-97e1 (Standard Test Methods for Sulfur in the Analysis Sample of Coal and Coke Using High Temperature Tube Furnace Combustion Methods) and D3177-89 (1997, Standard Test Methods for Total Sulfur in the Analysis Sample of Coal and Coke, Method A---Eschka, Method B---Bomb Washing Method). A standard C $\mathrm{S}$ method is currently being developed under ASTM (Draft Test Method for the Analysis of Metal Bearing Ores and Related Materials by Combustion Infrared Absorption Spectrometry, updates are available through

$<$ http://shell.rmi.net/ chb/chemist.html $>$ ). Procedures for determining forms of sulfur are given in Sobek and others (1978), Coastech (1989), and Lawrence (1990).

There is a factor of 31.25 that is typically used to convert weight percent sulfur to standard units of AP (kg $\mathrm{CaCO}_{3} / \mathrm{T}$ rock). It is based on the assumption that all sulfide sulfur is present as pyrite and that all pyrite oxidizes according to a stoichiometry that results in two protons per mole of pyrite. Different sulfide minerals or different reaction paths necessarily mean that the 31.25 factor is incorrect.

Generally, NP is determined by acid digestion followed by titration with a base. The NP procedure usually begins with a fizz test. The fizz test is done by adding one-to-two drops of $25 \%$ hydrochloric acid to the sample (Sobek and others, 1978). The observer rates the extent of reaction and adjusts the amount and strength of acid used for sample digestion accordingly. Data reported by Evans and Skousen (1995) and Skousen and others (1997) indicate that there are problems with this subjective fizz test, and that the amount and strength of acid used to digest a given sample can affect the NP results. It should be noted that not all laboratories perform the fizz test and defer to only one concentration and volume of acid. Also, the presence of siderite in a sample can lead to erroneous NP results. Skousen and others (1997) suggest using a peroxide step in the procedure to address this problem. It is important to be aware of these types of issues when evaluating NP data.

Measurement of NP is often problematic because many common rock-forming minerals are able to neutralize acid but vary greatly in their neutralization capacity and reaction rates. Mineralogic composition controls the ability of a given material to produce or neutralize acid (see previous discussions in this chapter). Morin and Hutt (1994, 1997) make the distinction between effective NP and potential NP sources. Effective NP is the ability of a potential $\mathrm{NP}$ source to neutralize acid and maintain $\mathrm{pH}$-neutral conditions, which is highly dependent on the rate of acid production and the rate of neutralization. Generally, carbonates dissolve relatively quickly whereas sulfides tend to oxidize more slowly. Hence, a mine-waste material may initially generate non-acidic drainage, but eventually may generate acidic drainage as the carbonates become depleted or armored with weathering products of pyrite oxidation (e.g., iron oxides). Conversely, aluminosilicate minerals tend to dissolve relatively slowly and can only effectively 
neutralize acid if the acid production rate is also fairly slow. Hence, if non-carbonate minerals are a significant source of acid neutralization in laboratory tests, then kinetic testing is needed to predict the effective field NP (Price, 1997).

A phased approach to ARD prediction (e.g., simple static tests followed by kinetic testing when necessary) has been suggested by several sources. For example, the B.C. Research Confirmation Test is designed to follow the B.C. Research Initial Test when a test sample is found to be potentially acid producing (Bruynesteyn and Hackl, 1984). However, as noted above, there are no required standard procedures or approaches, and different approaches and different laboratories can generate disparate results.

A subset of ABA tests that are more easily performed in the field include the Net Acid Production (NAP, Coastech, 1989), Net Acid Generation (NAG, Miller and others, 1990), Acid Concentration Present (ACP, C. Bucknam, written communication; <http://shell.rmi.net/ chb/chemist.html $>$ ), and paste $\mathrm{pH}$ (see previous discussions in this chapter) tests. The NAP and NAG are based on addition of hydrogen peroxide to accelerate the oxidation of sulfide minerals. The resulting acid attacks potentially neutralizing minerals. The ACP test determines the presence of acidic material on mine-waste samples.

\section{KINETIC TESTING}

Kinetic tests have been developed to simulate or examine weathering of mine-waste material. These types of tests target the relative rates of reactions of acid producing and acid neutralizing constituents, and generally are used when static ABA tests determine that a test material is in the "gray area" for ARD production. Kinetic tests also can be used to examine the leachability of chemical constituents in the waste material as a function of time. Kinetic tests tend to be expensive and time consuming (varying from several weeks to over a year in duration). Common types of kinetic tests include humidity cells, lysimeters, Soxhlet extractions, column tests, shake-flask tests, biological tests, field-test pads, mine-wall washing, and examination of site drainage. This wide variety of tests measures different parameters, and the tests are not interchangeable (see table 2). Current common practice for obtaining laboratory kinetic data (e.g., humidity cell tests) generally does not allow for scaling up and extrapolating to field weathering rates. Also, common laboratory practice does not routinely quantify important experimental variables, such as temperature, relative humidity, and effects of freezing and thawing, grain size, surface area, and airflow. As a consequence, results may be difficult to compare. The interpretation of kinetic test results can be very complicated, depending upon the mineralogy of the samples tested, their origin, and their history. Valid interpretation depends upon solid knowledge of sample petrology and mineralogy, size distribution, and liberation characteristics (Price, 1997). Overviews of kinetic testing can be found in Coastech (1989), Perkins and others (1995), Hornberger and Brady (1998), and on the EnviroMine web site.

Humidity cell tests are the most commonly used laboratory kinetic tests. An American Society for Testing and Materials (ASTM) method has been adopted for humidity cell tests. The scope of this method (number D5744-96), titled Standard Test Method for Accelerated Weathering of Solid Materials Using a Modified Humidity Cell, states that "this test method covers a procedure that accelerates the natural weathering rate of a solid material sample so that diagnostic weathering products can be produced, collected, and quantified. Soluble weathering products are mobilized by a fixed-volume aqueous leach that is performed, collected, and analyzed weekly. When conducted in accordance with the following protocol, this laboratory test method has accelerated metal-mine waste-rock weathering rates by at least an order of magnitude greater than observed field rates."

A field procedure, termed Minewall, has been developed through the Canadian MEND Program and the British Columbia ARD Task Force (MEND, 1995). This procedure requires the cyclic irrigation of a small (1 $\mathrm{m} \mathrm{by} 1 \mathrm{~m})$, physically isolated, area of exposed pit wall or underground rock exposure, and the collection of leachate. This procedure is in its infancy but appears to provide an order of magnitude calculation of contributions from possible contaminant sources (Price, 1997).

\section{LEACHING PROCEDURES}

Although acid generation has received the most attention, leachable metals are a primary potential source of toxicity (Price and Errington, 1998). For many mine sites, metals are only mobile at fairly low $\mathrm{pH}(\mathrm{pH}<$ about 5). However, some metals, such as zinc and manganese, can be mobile at circumneutral $\mathrm{pH}$, and some metals are more mobile at higher $\mathrm{pH}$ (Smith and Huyck, 1999).

The U.S. Environmental Protection Agency (1994), state agencies, and industry often use the Toxicity Characteristic Leaching Procedure (TCLP, Method 1311) or the Synthetic Precipitation Leaching Procedure (SPLP, Method 1312). These tests were not designed for mining wastes; rather, the TCLP was designed to simulate leaching in a sanitary landfill. The TCLP involves leaching the test material with acetic acid, which preferentially binds lead due to a strong complex between lead and acetate. It is required under the Resource Conservation and 
Recovery Act (RCRA) to define a hazardous waste. The SPLP comes closest to simulating conditions in a wasterock dump (Smith, 1997). There is now a fairly sizable database of information about a variety of mine sites using these leaching methods. The SPLP has been designated an American Society for Testing and Materials (ASTM) method (D6234-98 Standard Test Method for Shake Extraction of Mining Waste by the Synthetic Precipitation Leaching Procedure).

Table 2. Test conditions for various kinetic tests (from Price, 1997). [Primary? $=$ whether the measurement objective is primary mineral weathering or secondary mineral solubility]

\begin{tabular}{lclll}
\multicolumn{1}{c}{ Test Procedure } & Field or Lab & \multicolumn{1}{c}{ Scale } & Primary? & \multicolumn{1}{c}{ Drainage Chemistry? } \\
\hline Humidity cell & Lab & Bench, $<6 \mathrm{~mm}$ particles & Yes & $\begin{array}{l}\text { With numerical geochemical } \\
\text { models or site drainage }\end{array}$ \\
Column & Lab & Bench to pilot & No & Yes \\
Soxhlet extraction & Lab & Bench & Yes & No \\
Field test pads & Field & Pilot & No & Yes \\
Wall washing stations & Field & $1 \mathrm{~m}^{2}$ & Yes & $\begin{array}{l}\text { With numerical geochemical } \\
\text { models or site drainage }\end{array}$ \\
Site drainage & Field & Real & No & Yes \\
\hline
\end{tabular}

Another commonly used test is the Nevada Meteoric Water Mobility Procedure (MWMP). Originally, the procedure was similar to the SPLP but recently has been substantially modified. The current procedure involves a much larger volume of rock with larger particle sizes and is conducted in six-inch-diameter columns. This procedure is currently being reviewed for ASTM codification.

A significant issue related to leaching tests is the interpretation. To what standards should the results be compared? The standards set by EPA for the TCLP results are apparently based on the assumption that a leachate would be diluted by clean water by 100 -fold prior to being used as a drinking water source. It seems clear that the evaluation of leachability results requires an examination of the applicability of the test conditions to the site in question, an assessment of the dilution factors that might occur at the site upstream of a potential receptor, and the water-quality guidelines that should be applied (e.g., aquatic, agricultural, etc.).

\section{GEOLOGIC MATERIALS THAT CONTRIBUTE TO ENVIRONMENTAL SIGNATURES}

A variety of different types of geologic materials can be present on a site depending on the site history. At many historical mines, open-air roasting of sulfide minerals, on-site milling, smelting, and mineral processing occurred at different times and in different parts of the mine area. Older mine waste piles are more likely to contain elevated metal concentrations because of improvements in ore recovery over time. More modern tailings may be highly reactive because of their very fine grain size. On-site smelting may be represented by slag piles and may have contributed elevated metals concentrations to soils over a large area surrounding the smelter sites, depending on the prevailing winds. High-grade ore may remain on-site in stockpiles that were never processed. The following discussion gives an overview of terms encountered in studying solid materials.

Terms related to metals in the environment

Geoavailability: That portion of the total content of a chemical element or compound in an earth material that can be liberated to the surficial or near-surface environment through mechanical, chemical, or biological processes (Smith and Huyck, 1999). Characterization of the mineralogy and chemistry of solid earth materials provides information about geoavailability because geoavailability is a function of total metal content as well as access and susceptibility to weathering.

Bioavailability: The degree to which a contaminant in a potential source is free for uptake (movement into or onto an organism) (Newman and Jagoe, 1994). Bioavailability is a function of geoavailability as well as other factors such as mobility and biologic specificity (Smith and Huyck, 1999). Sequential extractions and leach studies on solid materials can contribute information about the potential bioavailabilty of elements. 
Toxicity: The capacity of an element or a chemical compound to adversely affect any biological function (Smith and Huyck, 1999). In order for an element to be toxic to an organism, it must first be bioavailable. Characterization of solids can provide information about source and transport of potentially toxic materials and identify target areas or materials for follow-up toxicity studies, but does not in and of itself provide any information about toxicity.

Geologic materials related to mine sites

Tailings: Residue of raw material or waste separated out during the processing of crops or mineral ores (USEPA, 1997a). AGI (1997) includes the following definitions: (1) the gangue and other refuse material resulting from washing, concentration, or treatment of ground ore. (2) Those portions of washed ore or coal that are regarded as too poor to be treated further, as distinguished from the concentrates, or material of value. (3) The reject from froth flotation cells. Mill tailings are the waste remaining after physical or chemical extraction of the mineral of interest. Tailings are discharged into impoundments as a very fine-grained wet slurry. At many historical mines, tailings were discharged directly into streams or rivers. Tailings are finer-grained and mineralogically different from other mine waste materials; chemical reagents and solids formed in the flotation process become part of the tailings sediment along with primary minerals. A number of recent case studies of tailings at active and inactive mines document the mineralogy, chemistry, techniques for study, and processes that operate within tailings from different types of mineral deposits (e.g., Al and others, 1994; Dold, 1999; Blowes and Ptacek, 1994; Blowes and others, 1994).

Mine waste: Residue resulting from the extraction of raw materials from the earth. (USEPA, 1997a). Most of the dumps encountered at historic abandoned mines are designated as mine waste, which may include some comminuted material. Materials that are discarded as mine waste can vary over the life of a mine. Many of the massive sulfide mines in the eastern U.S. for example were worked at shallow levels to mine gossan for iron production or to mine pyrite for sulfuric acid production and then later worked by underground methods for base metals. Thus, the pyrite that comprised ore in the early days of mining became a waste product later on. Areas around ore bins and loading chutes may represent "hot spots" of metal concentrations due to weathering of exposed ores. We include hand-sorted ore piles that remain at many abandoned mines as mine waste. Most mine waste piles in the Rocky Mountain region, and many waste piles in other areas, resulted from exploration rather than from actual production.

Spoil: Dirt or rock removed from its original location - destroying the composition of the soil in the process - as in strip mining, dredging, or construction. (USEPA, 1997a). This term is commonly used in coal mining, but occasionally creeps into use for "mine waste" or "tailings" related to metal mining, especially in the eastern U.S.

Slag: The top layer of the multilayer melt formed during some smelting and refining operations. In smelting, slag contains the gangue minerals and the flux. (AGI, 1997; other definitions also). Slag is an impure residue, consisting largely of calcium, iron, aluminum, and magnesium silicate, derived during the process of pig iron and steel production and during the smelting of metals, such as copper, lead, and nickel. Slag from modern iron and steel production is environmentally benign and is used for aggregate, railroad ballast, soil conditioning, and a variety of other applications. Slag from historical metal mining however, can be a source of contamination in dust, soil, ground or surface water. For example, the Palmerton zinc pile site in Pennsylvania became a Superfund site due to lead, zinc, and cadmium contamination associated with 33 million tons of slag from a zinc smelting operation.

Stream sediments: Stream sediment sampling is a well-established tool in mineral exploration that also provides important information about the geoenvironmental signature of a mineral deposit. For regional-scale screening, national databases such as the National Uranium Resource Evaluation (NURE) and databases from past mineral exploration can highlight areas that may be anomalous in certain metals (Smith, 1997; Grossman, 1998). For online access to NURE data, see:

\section{http://pubs.usgs.gov/of/1997/ofr-97-0492/index.html}

Geochemical maps showing the distribution of copper, lead, and zinc in stream sediments in the upper Arkansas River basin in Colorado (Smith, 1994) allowed Church and others (1994) to identify ten metal sources in the basin that had anomalous lead in additional to the known source in the Leadville mining district. In another study, Church and others (1997) coupled bed sediment studies with water, and suspended colloid studies to identify large metal loads and to examine movement and partitioning of metals in the Animas River watershed in Colorado. The Animas 
River drains three significant mineral districts (epithermal deposits, placer gold, unexposed porphyry molybdenum deposits). The synoptic study identified the particular drainage basin in the watershed that was the source area for metals in the river, and showed that metal partitioning among different phases depended on metal source, stream $\mathrm{pH}$, and flow rate. Colloids ( 0.001 to 0.45 microns) carried most of the metal load in bed sediments in some parts of the watershed, where they formed aggregates and settled until flushed by high flow during snowmelt runoff.

\section{Other sample media}

Other solid materials that may be sampled for mineralogy and chemistry to understand the concentrations of major and trace elements include soils and slag. Smith and Huyck (1999) discuss geoavailability and element concentration ranges in soils and vegetation. Analysis of plants and organisms, such as tissue sampling, provides information on bioavailability and metal distributions up the food chain. Such analyses are beyond the scope of this discussion; see Crock and others (1999) and references therein for additional information.

\section{Environmental mineralogy}

Primary minerals: For tailings, Jambor (1994) defined primary minerals as the ore and gangue minerals that were processed and deposited in an impoundment without any changes other than reduction in grain size by comminution. Primary ore and gangue mineral assemblages vary by deposit type. Thus, different types of copper deposits for example, can have very different mineral assemblages and consequently, very different environmental signatures. Recognition of different carbonate minerals is important because some carbonate minerals are effective at neutralizing acid (calcite, dolomite, ankerite) whereas iron- and manganese- carbonate minerals such as siderite and rhodochrosite are neutral or can actually produce acid. The "siderite" problem has been the focus of a number of modifications to acid-base accounting protocols to account for overestimates of neutralization potential obtained by assuming that all the carbonate in a sample is due to calcite (Skousen and others, 1997; Dold, 1999; White and others, 1999). Similarly, some silicate gangue minerals such as calcic feldspars, biotite, chlorite, amphibole, and pyroxene can contribute to acid-neutralization, albeit at much slower rates than calcite, and provide a source of aluminum, magnesium, and other elements that form secondary minerals.

Mineral assemblages for selected deposit types are listed in table 3, along with mineral formulas. Table 3 represents a generalized guide to minerals associated with different deposit types. Arsenopyrite, for example, would be expected in the ore mineral assemblages of most skarn or epithermal vein deposits but not in porphyry copper ores. Arsenic may be associated with other deposit types, but may be present as a trace element in pyrite rather than as a discrete, arsenic-rich mineral. Considerable mineralogic variations can exist within subtypes of these groups, as demonstrated by variations in pyrite: pyrrhotite among different classes of massive sulfide deposits.

The relative resistance of different sulfide ore minerals to weathering is variable, and depends on such factors as grain size, crystallinity, trace element content, and mineral assemblage (Kwong, 2000, 1993). The oxidation products formed depend on the type and composition of the mineral undergoing oxidation. Monosulfide minerals such as sphalerite and galena undergoing oxidation by oxygen do not release acidity $\left(\mathrm{H}^{+}\right)$whereas disulfide minerals such as pyrite can release many moles of acid per mole of pyrite oxidized, depending on the oxidant (oxygen or ferric iron) and the reaction path (see for example, Plumlee, 1999, Table 3.2). Although a variety of different metal sulfide minerals contribute metals and sulfur to the environment upon weathering, it is the weathering of the iron sulfide minerals, especially pyrite, that leads to acid mine drainage. Fine-grained $\mathrm{FeS}_{2}$ (pyrite or marcasite, especially the framboidal varieties commonly associated with coal or black shale) or finely-milled pyrite in tailings is especially reactive when subjected to wet-dry cycles and microbial oxidation; it is the mixture of air and water that leads to acid production. Pyrite (or marcasite) reacts with oxygen and water through a complex series of reactions (Nordstrom and Southam, 1997), which can be simplified in terms of overall reactants and products as:

$$
\mathrm{FeS}_{2}+15 / 4 \mathrm{O}_{2}+7 / 2 \mathrm{H}_{2} \mathrm{O}=\mathrm{Fe}(\mathrm{OH})_{3}+2 \mathrm{H}_{2} \mathrm{SO}_{4}
$$

The actual oxidation paths are complex, and can involve oxidation by dissolved oxygen only, by ferric iron at low $\mathrm{pH}$, and microbial catalysis of the aqueous oxidation of ferrous iron (Nordstrom and Southam, 1997; Nordstrom and Alpers, 1999). The ferric hydroxide oxidation product shown in equation (1) can include a variety of secondary oxyhydroxide or hydroxysulfate minerals such as goethite, ferrihydrite, schwertmannite, and jarosite that form oxidized zones on weathered tailings or mine waste dumps and precipitate along streams.

Trace elements in pyrite, which reduce its resistance to weathering and oxidation, typically include cobalt, nickel, selenium, or arsenic. As much as 6.5 weight percent As is present in arsenic-rich overgrowths on pyrite framboids in a sandstone aquifer in southeastern Michigan (Kolker and others, 1999a) and up to 4.5 weight percent 
arsenic is reported in pyrite in coals in the Black Warrior Basin, Alabama (Kolker and others, 1999b).

Pyrrhotite oxidizes much more rapidly than pyrite (Robertson, 1994; Nicholson and Scharer, 1994). The amount of acid produced or consumed by pyrrhotite weathering depends on the particular oxidation path followed and the pyrrhotite composition. The general chemical formula for pyrrhotite is $\mathrm{Fe}_{1-\mathrm{x}} \mathrm{S}$, where $\mathrm{x}$ can vary from 0.125 to 0 . Reactions that have been proposed to describe pyrrhotite oxidation are as follows (from Jambor and Blowes, 1994):

Complete reaction (amount of acid produced depends on pyrrhotite stoichiometry):

$$
\mathrm{Fe}_{1-\mathrm{x}} \mathrm{S}+(2+\mathrm{x} / 2) \mathrm{O}_{2}+\mathrm{xH}_{2} \mathrm{O}=(1-\mathrm{x}) \mathrm{Fe}^{2+}+\mathrm{SO}_{4}{ }^{2-}+2 \mathrm{xH}^{+}
$$

Partial reaction to produce native $\mathrm{S}$ :

$$
\mathrm{Fe}_{1-\mathrm{x}} \mathrm{S}+(2-2 \mathrm{x}) \mathrm{Fe}^{3+}=(3-3 \mathrm{x}) \mathrm{Fe}^{2+}+\mathrm{S}^{\mathrm{o}}
$$

Rapid oxidation to pyrite/marcasite $\left(\mathrm{FeS}_{2}\right)$ consumes acid:

$$
2 \mathrm{Fe}_{1-\mathrm{x}} \mathrm{S}+(1 / 2-\mathrm{x}) \mathrm{O}_{2}+(2-4 \mathrm{x}) \mathrm{H}^{+}=\mathrm{FeS}_{2}+(1-2 \mathrm{x}) \mathrm{Fe}^{2+}+(1-2 \mathrm{x}) \mathrm{H}_{2} \mathrm{O}
$$

Secondary minerals: Processes that can lead to precipitation include evaporation, oxidation, reduction, dilution, mixing, and neutralization (Alpers and others, 1994). Secondary minerals include efflorescent sulfate salts as well metal oxide, hydroxide, hydroxysulfate, and sulfide minerals. Dissolution and precipitation of secondary minerals is an important mechanism for recycling metals and acidity $\left(\mathrm{H}^{+}\right)$in surficial environments. Based on studies of active mines and recent tailings impoundments, Jambor (1994) further distinguished tailings minerals as tertiary (crystallized from pore waters during drying) and quaternary (oxidation products that form during laboratory storage of dried samples). In some modern flotation plants, secondary materials formed by human activities may be precipitated as part of ore processing and end up as waste in tailings impoundments. For example, the zinc refining circuit at the Kidd Creek massive sulfide deposit operating in the 1980s produced natrojarosite, which formed $2.5 \%$ of the tailings solids (Al and others, 1994). Strictly speaking, "minerals" are naturally occurring or formed accidentally rather than through human intervention [see Jambor and Blowes (1998) for a detailed discussion]. For the purposes of this chapter, we use the term "secondary" to refer to all of the minerals that are not primary because the history and details of human intervention in many abandoned mines may be difficult to ascertain.

Secondary minerals found within a given deposit type can vary dramatically with climate. Many of the hydrated efflorescent salts, for example, are stable within only relatively narrow ranges of temperature and relative humidity. A study of porphyry copper mine tailings in different climate zones in Chile (Dold, 1999) showed that although the primary sulfide mineral assemblage of three different deposits was similar (pyrite, chalcopyrite, bornite, molybdenite, with minor magnetite and hematite), the secondary mineral assemblages that developed on the tailings surfaces differed markedly. In a hyper-arid climate with high rates of evaporation throughout the year (precipitation about $20 \mathrm{~mm} / \mathrm{year}$ ), an evaporite zone formed at the top of the tailings pile containing the secondary mineral assemblage: jarosite, vermiculite, schwertmannite, gypsum, chalcanthite, halotrichite, hexahydrite, bonattite, pickeringite, and magnesioauberite. In more humid climates (precipitation $>540 \mathrm{~mm} / \mathrm{year}$ ), no evaporite zone was noted. In the more humid settings, oxidized tailings contained jarosite, vermiculite, schwertmannite, and gypsum and where evaporation is important during part of the year, the highly soluble mineral chalcanthite was reported in the oxidized zone.

Some of the commonly encountered secondary minerals are listed in table 4, grouped by mineral type. This is not an exhaustive list. Different secondary minerals may appear at different times at the same deposit and in different parts of a site. Melanterite is one of the most commonly reported efflorescent salts from a variety of different deposit types. Gypsum, which does not contribute acidity, is ubiquitous if calcium and sulfate are available. Many of the sulfate minerals are highly soluble, and readily dissolve during rainstorms. Pure melanterite, for example, has a solubility of $15.65 \mathrm{grams} / \mathrm{cc}$ in cold water, whereas gypsum has a solubility of $0.241 \mathrm{grams} / \mathrm{cc}$, and the ferric iron sulfate mineral coquimbite is extremely soluble, at 440 grams/cc cold water (Weast, 1986). Many of the minerals in table 4 are solid solutions. Element substitutions, as well as acid strength of solvents, can decrease solubility. See Jambor and others (2000) for a detailed discussion of solid solution ranges and stabilities of metal-sulfate salts formed from sulfide mineral oxidation.

Some of the minerals included as ore minerals (Table 3A) such as covellite and chalcocite are actually secondary minerals formed by supergene alteration (near-surface alteration by meteoric waters) of primary minerals. 
Climate and topography affect the extent of weathering products that develop in mineral deposits. In deeply weathered deposits, any primary sulfide minerals that were once exposed at the surface are oxidized and decomposed and what remains is a surface cap of reddish-brown, iron-oxide-rich gossan. Gossan typically has an earthy or cellular texture and many ore deposits have been discovered by exploration for gossans. The unweathered primary sulfide minerals lie below the gossan, and as the primary sulfide minerals interact with groundwater, an intermediate zone of supergene enrichment can develop as the sulfide minerals at the surface dissolve and leach elements (such as copper) downward. Supergene zones can be tens of feet thick depending on water table fluctuations and weathering history of a deposit, and can constitute very high-grade ores. Secondary carbonate, sulfate, and silicate minerals may occur with secondary sulfides in supergene zones. Processes of alteration that form gossans are similar to processes that operate on mine dumps and tailings. Studies of the chemical, mineralogic, and textural changes in gossan provide clues to transport and fate of metals during weathering (Boyle, 1994). Some analogies can be drawn between gossan formation and the zones that develop in weathered tailings to the extent that both develop leached, sulfide-depleted caps enriched in iron oxides and hydroxides that overlie zones of precipitation of secondary minerals. However, tailings have much of the primary ore removed and are finely comminuted materials with lots of surface area available for oxidation reactions (Jambor, 1994). In addition, tailings may be very heterogeneous in mineralogy and texture both laterally and vertically, depending on how the tailings pile was constructed, and they may contain reaction products from addition of reagents, such as lime, during mineral processing.

\section{Efflorescent salts}

Efflorescent salts are secondary metal-sulfate minerals that form from the weathering of sulfide minerals. Many salts are highly soluble, hydrated solid solution minerals that react in changing weather conditions; salts exert an important control on metal mobility from mine wastes. Salts can form in open spaces in arid climates or during dry periods in normally humid climates, or can form under protected overhangs. During rainstorms or snow melt, the soluble salts dissolve and contribute metals and acidity to surface runoff. Capillary action draws waters to tailings, soil, rock, or wood surfaces where it evaporates to form salt crusts. Observations of storm runoff at the Sulfur massive sulfide mine in central Virginia (Dagenhart, 1980) demonstrated that dissolution of efflorescent salts from mine tailings can elevate the peak metal load in a nearby creek to as much as fifty times base-flow metal loads. Because salts can store acidity that can be released on dissolution, minor amounts of salts within tailings and mine dump soils contribute to low paste $\mathrm{pH}$ values. Many of the soluble efflorescent salt minerals are white or yellowish. Brightly colored salts (green, blue, purple) usually indicate a transition metal, such as iron or copper, and therefore provide a clue that metals are being sequestered. Salts can be tested in the field for dissolution and acidity generated with a little water and a $\mathrm{pH}$ indicator. Yellow efflorescent salts like copiapite are sometimes misidentified as elemental sulfur in the field. Although these minerals are characteristic of mine waste environments, they can occur on natural outcrops of sulfide-bearing rock away from mineralized areas and can contribute to acidity and metals. Fresh exposures of sulfide-bearing bedrock produced by road cuts, or landslides are especially prone to weathering that produces acid rock drainage. Acid rock drainage can form naturally or can be induced by human activity and can mimic acid mine drainage.

The presence of sulfate minerals is important to recognize because some sulfate minerals, such as barite, are relatively insoluble and therefore sequester barium from dissolution in surface waters whereas highly soluble minerals, such as melanterite or rozenite, are ready sources of iron. Furthermore, the acid-generating potential of a mine waste can be overestimated if one assumes that total sulfur equals sulfide sulfur when in fact much of the sulfur is present as sulfate in barite or gypsum (White and others, 1999). Nordstrom and Alpers (1999) identified ten different soluble iron sulfate salts in addition to gypsum and chalcanthite at the Richmond mine (Iron Mountain, CA massive sulfide deposit). They noted stalactites and stalagmites of rhomboclase in underground workings and other salts coating adit walls and ceilings. They used the chemical information provided by identification of the salts to estimate the mine pool composition that would develop if the mine was plugged and the large quantity of salts dissolved. Secondary ferric iron sulfate minerals, such as copiapite, romerite, and coquimbite (table 4), are commonly reported forming on coal mine wastes. Dissolution of these salts releases $\mathrm{Fe}^{3+}$, which can promote acid generation by pyrite oxidation or hydrolysis (Cravotta, 1994). 
Table 3. Mineralogy of selected deposit types. [Mineral formulas after Mandarino, 1999; X, major; $\mathrm{x}$, minor; S, supergene]

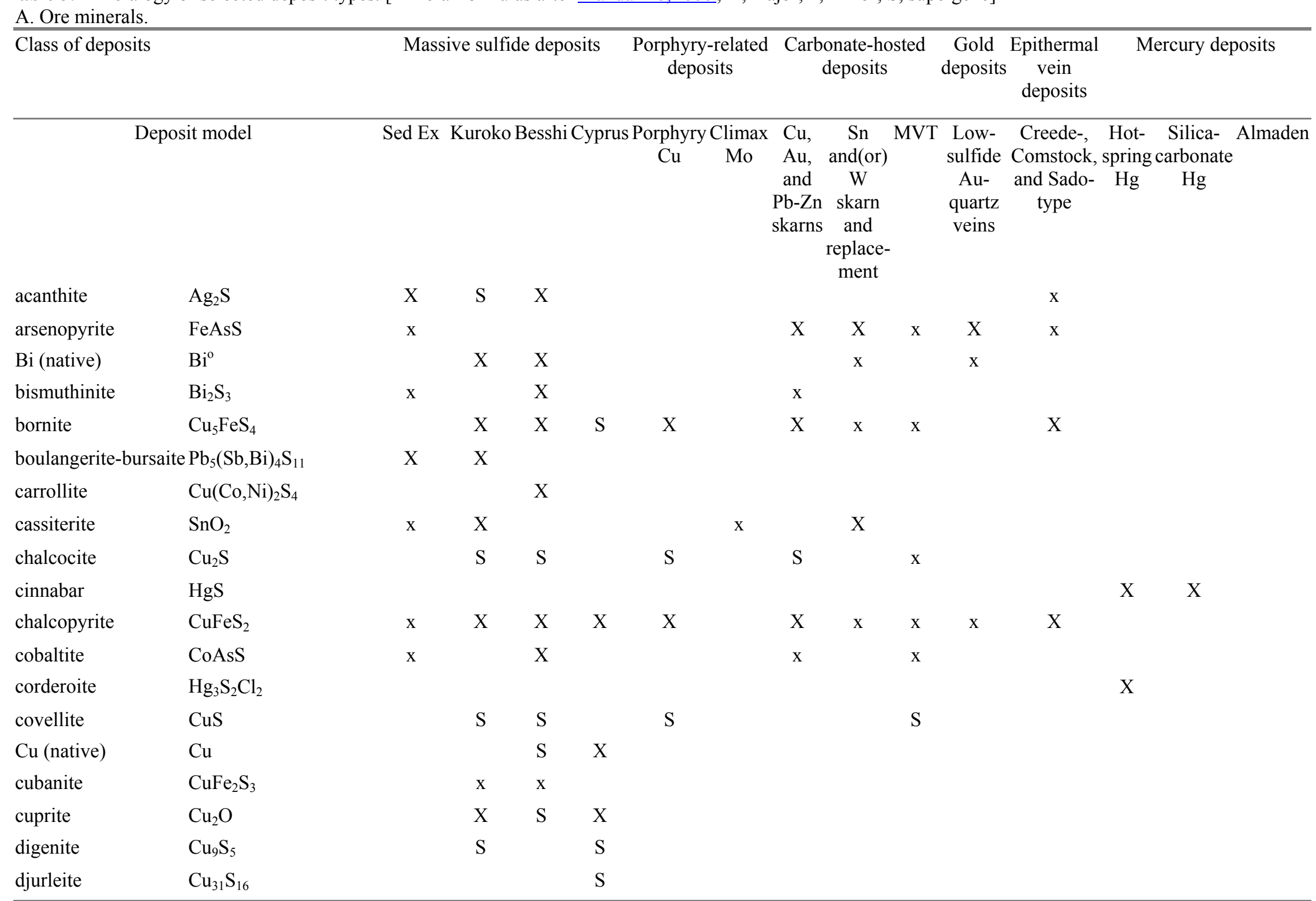




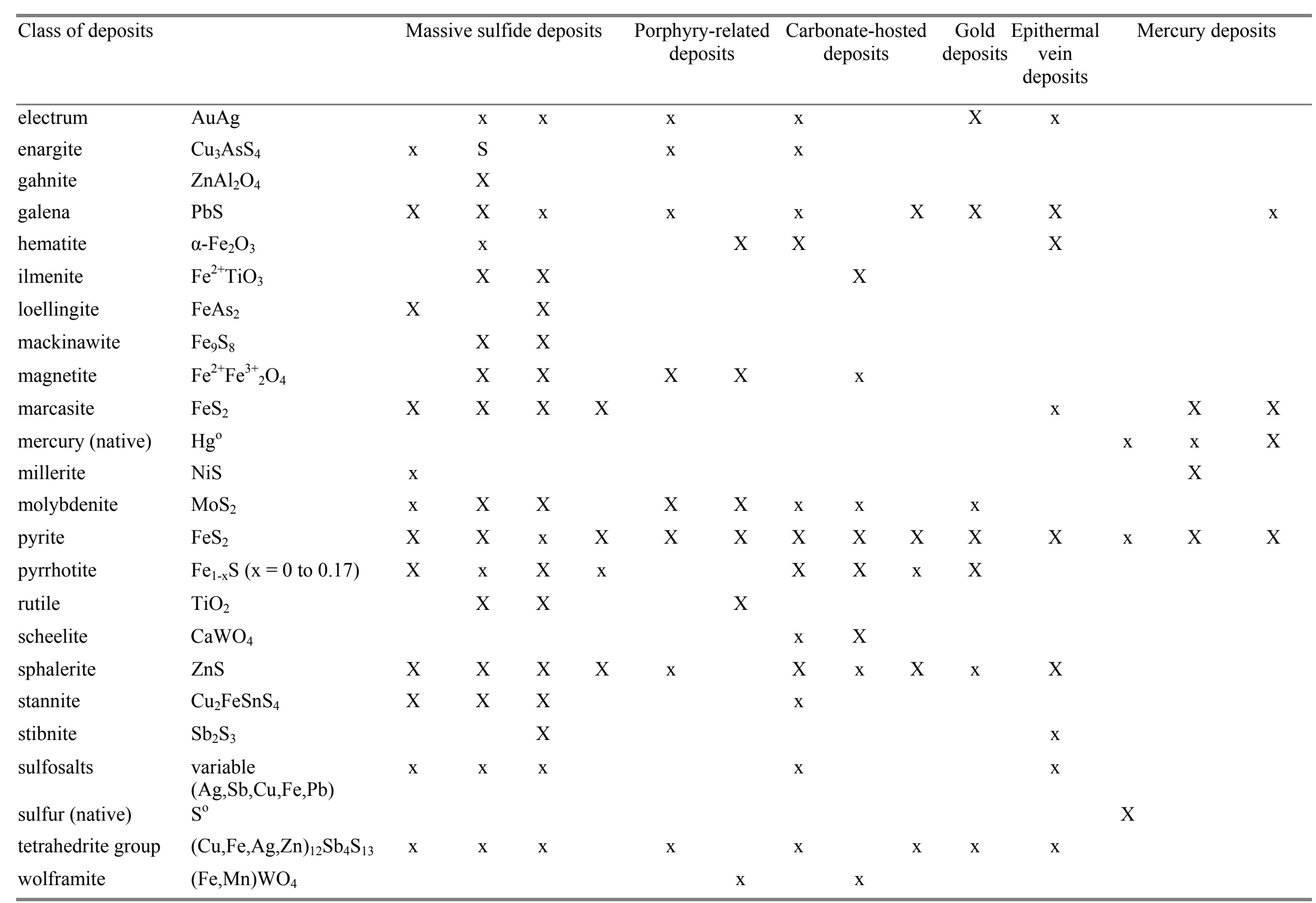


B. Gangue, alteration, and associated primary minerals.

$[*$, generalized formula for mineral group $]$

\begin{tabular}{|c|c|c|c|c|c|c|c|c|c|c|c|c|c|c|c|}
\hline \multicolumn{2}{|c|}{ Class of deposits } & \multicolumn{4}{|c|}{ Massive sulfide deposits } & \multicolumn{4}{|c|}{$\begin{array}{l}\text { Porphyry-related Carbonate-hosted } \\
\text { deposits }\end{array}$} & \multirow{3}{*}{$\begin{array}{c}\text { deposits } \\
\text { MVT } \\
\end{array}$} & \multirow{3}{*}{$\begin{array}{c}\begin{array}{c}\text { Gold } \\
\text { deposits }\end{array} \\
\begin{array}{c}\text { Low- } \\
\text { sulfide } \\
\text { Au- } \\
\text { quartz } \\
\text { veins }\end{array}\end{array}$} & \multirow{3}{*}{$\begin{array}{c}\text { Epithermal } \\
\text { vein } \\
\text { deposits }\end{array}$} & \multicolumn{3}{|c|}{ Mercury deposits } \\
\hline & Deposit model & Sed & curok & Besshi & yprus & Porphy & Climax & $\mathrm{Cu}, \mathrm{Au}$, & & & & & Hot- & Silica- & Almaden \\
\hline & & Ex & & & & $\mathrm{Cu}$ & Mo & $\begin{array}{c}\text { and Pb- } \\
\text { Zn } \\
\text { skarns }\end{array}$ & $\begin{array}{l}\text { and(or) } \\
\text { W } \\
\text { skarn } \\
\text { and } \\
\text { replace- } \\
\text { ment }\end{array}$ & & & & $\begin{array}{c}\text { spring } \\
\mathrm{Hg}\end{array}$ & $\begin{array}{l}\text { carbonate } \\
\mathrm{Hg}\end{array}$ & \\
\hline adularia & $\mathrm{KAlSi}_{3} \mathrm{O}_{8}$ & & & & & & & & & $\mathrm{x}$ & & $\mathrm{X}$ & $\mathrm{X}$ & & \\
\hline albite & $\mathrm{NaAlSi}_{3} \mathrm{O}_{8}$ & $X$ & $\mathrm{X}$ & $X$ & & $\mathrm{X}$ & & & & & $\mathrm{X}$ & & & & \\
\hline alunite & $\mathrm{K}_{2} \mathrm{Al}_{6}\left(\mathrm{SO}_{4}\right)_{4}(\mathrm{OH})_{12}$ & & & & & $\mathrm{X}$ & & & & & & $\mathrm{X}$ & & & \\
\hline amphibole* & $\mathrm{Ca}_{2}(\mathrm{Mg}, \mathrm{Fe})_{5} \mathrm{Si}_{8} \mathrm{O}_{22}(\mathrm{OH})_{2}$ & & $\mathrm{X}$ & $\mathrm{X}$ & & $\mathrm{X}$ & & $\mathrm{X}$ & $X$ & & & & & & \\
\hline andalusite & $\mathrm{Al}_{2} \mathrm{SiO}_{5}$ & & & & & $\mathrm{x}$ & & & & & & & & & \\
\hline anhydrite & $\mathrm{CaSO}_{4}$ & & $\mathrm{x}$ & & $\mathrm{x}$ & $\mathrm{X}$ & & & & $\mathrm{x}$ & & & & & \\
\hline ankerite & $\mathrm{Ca}(\mathrm{Fe}, \mathrm{Mg}, \mathrm{Mn})\left(\mathrm{CO}_{3}\right)_{2}$ & & & & & & & & & & $\mathrm{X}$ & & & & \\
\hline barite & $\mathrm{BaSO}_{4}$ & $\mathrm{X}$ & $\mathrm{X}$ & & & & & & & $\mathrm{X}$ & & $\mathrm{X}$ & & & \\
\hline biotite & $\mathrm{K}(\mathrm{Fe}, \mathrm{Mg})_{2} \mathrm{Al}_{3} \mathrm{Si}_{2} \mathrm{O}_{10}(\mathrm{OH})_{2}$ & & & & & $\mathrm{X}$ & & & & & & & & & \\
\hline calcite & $\mathrm{CaCO}_{3}$ & & & & $\mathrm{x}$ & $\mathrm{x}$ & & & & & & $X$ & & & $X$ \\
\hline chalcedony & $\mathrm{SiO}_{2}$ & & & & $X$ & & & & & & & $\mathrm{X}$ & & $\mathrm{X}$ & \\
\hline chlorite* & $(\mathrm{Mg}, \mathrm{Fe})_{5} \mathrm{Al}\left(\mathrm{Si}_{3} \mathrm{Al}\right) \mathrm{O}_{10}(\mathrm{OH})_{8}$ & $\mathrm{X}$ & $\mathrm{X}$ & $\mathrm{X}$ & $\mathrm{X}$ & $\mathrm{X}$ & & $\mathrm{X}$ & & & $X$ & $\mathrm{X}$ & & & \\
\hline clays* & variable & $\mathrm{X}$ & $\mathrm{x}$ & & $X$ & $\mathrm{X}$ & & $\mathrm{X}$ & & $\mathrm{x}$ & & $\mathrm{X}$ & $\mathrm{X}$ & & \\
\hline dolomite & $\mathrm{CaMg}\left(\mathrm{CO}_{3}\right)_{2}$ & $\mathrm{X}$ & & & & & & & & $\mathrm{X}$ & & & & $\mathrm{X}$ & \\
\hline epidote & $\mathrm{Ca}_{2}\left(\mathrm{Fe}^{3+}, \mathrm{Al}\right)_{3}\left(\mathrm{SiO}_{4}\right)_{3}(\mathrm{OH})$ & & & & & $\mathrm{X}$ & & $\mathrm{X}$ & $\mathrm{X}$ & & & & & & \\
\hline fluorite & $\mathrm{CaF}_{2}$ & & & & & & $\mathrm{X}$ & $\mathrm{x}$ & $\mathrm{x}$ & $\mathrm{x}$ & $\mathrm{x}$ & $\mathrm{X}$ & & & \\
\hline
\end{tabular}




\begin{tabular}{|c|c|c|c|c|c|c|c|c|c|c|c|c|c|c|c|}
\hline \multicolumn{2}{|c|}{ Class of deposits } & \multicolumn{4}{|c|}{ Massive sulfide deposits } & \multicolumn{2}{|c|}{$\begin{array}{c}\text { Porphyry-related } \\
\text { deposits }\end{array}$} & \multicolumn{3}{|c|}{ Carbonate-hosted deposits } & \multirow{2}{*}{$\begin{array}{l}\text { Gold } \\
\text { deposits }\end{array}$} & \multicolumn{2}{|l|}{$\begin{array}{l}\text { Epithermal } \\
\text { vein } \\
\text { deposits }\end{array}$} & \multicolumn{2}{|c|}{ Mercury deposits } \\
\hline garnet* & $\mathrm{Ca}_{3} \mathrm{Al}_{2}\left(\mathrm{SiO}_{4}\right)_{3}$ & & & & & & $\mathrm{X}$ & $\mathrm{X}$ & $\mathrm{X}$ & & & & & & \\
\hline graphite & $\mathrm{C}$ & & $\mathrm{X}$ & & & & & & & & & & & & \\
\hline gypsum & $\mathrm{CaSO}_{4} \cdot 2 \mathrm{H}_{2} \mathrm{O}$ & & $\mathrm{X}$ & & & & & & & $\mathrm{x}$ & & & & & \\
\hline kaolinite & $\mathrm{Al}_{2} \mathrm{Si}_{2} \mathrm{O}_{5}(\mathrm{OH})_{4}$ & & & & & & & & & & & $\mathrm{X}$ & & & \\
\hline muscovite & $\mathrm{KAl}_{3} \mathrm{Si}_{3} \mathrm{O}_{10}(\mathrm{OH})_{2}$ & & $\mathrm{X}$ & $\mathrm{X}$ & & & & & & & & $\mathrm{X}$ & & & \\
\hline pyrophyllite & $\mathrm{Al}_{2} \mathrm{Si}_{4} \mathrm{O}_{10}(\mathrm{OH})_{2}$ & & & & & & & & & & & $\mathrm{X}$ & & & \\
\hline pyroxene* & $\mathrm{CaMgSi}_{2} \mathrm{O}_{6}$ & & & & & & & & & & & & & & \\
\hline quartz & $\mathrm{SiO}_{2}$ & $\mathrm{X}$ & $\mathrm{X}$ & $\mathrm{X}$ & $\mathrm{X}$ & $\mathrm{X}$ & $\mathrm{X}$ & $\mathrm{X}$ & $\mathrm{X}$ & $\mathrm{X}$ & $\mathrm{X}$ & $\mathrm{X}$ & $\mathrm{X}$ & $\mathrm{X}$ & $\mathrm{X}$ \\
\hline rhodochrosite & $\mathrm{MnCO}_{3}$ & & & & & & $\mathrm{X}$ & $\mathrm{X}(\mathrm{Pb}-\mathrm{Zn})$ & & & & $\mathrm{X}$ & & & \\
\hline rhodonite & $(\mathrm{Mn}, \mathrm{Fe}, \mathrm{Mg}, \mathrm{Ca}) \mathrm{SiO}_{3}$ & & & & & & $\mathrm{X}$ & $\mathrm{X}(\mathrm{Pb}-\mathrm{Zn})$ & & & & & & & \\
\hline siderite & $\mathrm{FeCO}_{3}$ & & & & & & & & & & $\mathrm{X}$ & $\mathrm{X}$ & & & \\
\hline topaz & $\mathrm{Al}_{2} \mathrm{SiO}_{4}(\mathrm{~F}, \mathrm{OH})_{2}$ & & & & & & $\mathrm{X}$ & & & & & & & & \\
\hline tourmaline & $\mathrm{NaFe}_{3} \mathrm{Al}_{6}\left(\mathrm{BO}_{3}\right)_{3} \mathrm{Si}_{6} \mathrm{O}_{18}(\mathrm{OH})_{4}$ & $\mathrm{X}$ & $\mathrm{X}$ & $\mathrm{X}$ & & $\mathrm{X}$ & & & $\mathrm{X}$ & & & & & & \\
\hline vesuvianite & $\mathrm{Ca}_{10} \mathrm{Mg}_{2} \mathrm{Al}_{4}\left(\mathrm{SiO}_{4}\right)_{5}\left(\mathrm{Si}_{2} \mathrm{O}_{7}\right)_{2}(\mathrm{OH})_{2}$ & & & & & & & $X$ & $\mathrm{X}$ & & & & & & \\
\hline wollastonite & $\mathrm{CaSiO}_{3}$ & & & & & & & $\mathrm{X}$ & $X$ & & & & & & \\
\hline
\end{tabular}


Table 4. Secondary minerals.

[*, highly soluble; !, relatively insoluble (mineral solubility depends on particle size and degree of crystallinity; mineral formulas from Mandarino, 1999]

\begin{tabular}{|c|c|c|c|}
\hline \multicolumn{2}{|r|}{ Sulfate minerals } & \multicolumn{2}{|c|}{ Carbonate minerals } \\
\hline alunogen* & $\mathrm{Al}_{2}\left(\mathrm{SO}_{4}\right)_{3} \cdot 17 \mathrm{H}_{2} \mathrm{O}$ & aurichalcite & $(\mathrm{Zn}, \mathrm{Cu})_{5}\left(\mathrm{CO}_{3}\right)_{2}(\mathrm{OH})_{6}$ \\
\hline alunite & $\mathrm{K}_{2} \mathrm{Al}_{6}\left(\mathrm{SO}_{4}\right)_{4}(\mathrm{OH})_{12}$ & azurite & $\mathrm{Cu}_{3}\left(\mathrm{CO}_{3}\right)_{2}(\mathrm{OH})_{2}$ \\
\hline anglesite! & $\mathrm{PbSO}_{4}$ & cerussite & $\mathrm{PbCO}_{3}$ \\
\hline antlerite! & $\mathrm{Cu}_{3} \mathrm{SO}_{4}(\mathrm{OH})_{4}$ & hydrozincite & $\mathrm{Zn}_{5}\left(\mathrm{CO}_{3}\right)_{2}(\mathrm{OH})_{6}$ \\
\hline argenojarosite! & $\mathrm{Ag}_{2} \mathrm{Fe}^{3+}{ }_{6}\left(\mathrm{SO}_{4}\right)_{4}(\mathrm{OH})_{12}$ & malachite! & $\mathrm{Cu}_{2} \mathrm{CO}_{3}(\mathrm{OH})_{2}$ \\
\hline barite! & $\mathrm{BaSO}_{4}$ & smithsonite & $\mathrm{ZnCO}_{3}$ \\
\hline basaluminite & $\mathrm{Al}_{4}\left(\mathrm{SO}_{4}\right)(\mathrm{OH})_{10} .5 \mathrm{H}_{2} \mathrm{O}$ & \multicolumn{2}{|c|}{ Iron oxyhydroxide (ochre) minerals } \\
\hline bassanite* & $2 \mathrm{CaSO}_{4} \cdot \mathrm{H}_{2} \mathrm{O}$ & akageneite & $\beta-\mathrm{Fe}^{3+}(\mathrm{O}, \mathrm{OH}, \mathrm{Cl})$ \\
\hline beaverite! & $\mathrm{Pb}\left(\mathrm{Cu}^{2+}, \mathrm{Fe}^{3+}, \mathrm{Al}\right)_{6}\left(\mathrm{SO}_{4}\right)_{4}(\mathrm{OH})_{12}$ & bernalite & $\mathrm{Fe}^{3+}(\mathrm{OH})_{3} \cdot \mathrm{nH} 2 \mathrm{O}(\mathrm{n}=0$ to 0.25$)$ \\
\hline beudantite & $\mathrm{PbFe}_{3}^{3+}\left(\mathrm{AsO}_{4}\right)\left(\mathrm{SO}_{4}\right)(\mathrm{OH})_{6}$ & ferrihydrite & $5 \mathrm{Fe}^{3+}{ }_{2} \mathrm{O}_{3} \cdot 9 \mathrm{H}_{2} \mathrm{O}$ \\
\hline bianchite* & $\left(\mathrm{Zn}, \mathrm{Fe}^{2+}\right) \mathrm{SO}_{4} \cdot 6 \mathrm{H}_{2} \mathrm{O}$ & goethite & $\mathrm{Fe}^{3+} \mathrm{O}(\mathrm{OH})$ \\
\hline bilinite & $\mathrm{Fe}^{2+} \mathrm{Fe}^{3+}{ }_{2}\left(\mathrm{SO}_{4}\right)_{4} \cdot 22 \mathrm{H}_{2} \mathrm{O}$ & hematite & $\mathrm{Fe}^{3+}{ }_{2} \mathrm{O}_{3}$ \\
\hline brochantite! & $\mathrm{Cu}_{4}\left(\mathrm{SO}_{4}\right)(\mathrm{OH})_{6}$ & lepidocrocite & $\mathrm{Fe}^{3+} \mathrm{O}(\mathrm{OH})$ \\
\hline chalcanthite* & $\mathrm{CuSO}_{4} \cdot 5 \mathrm{H}_{2} \mathrm{O}$ & maghemite & $\mathrm{Fe}_{2} \mathrm{O}_{3}$ \\
\hline copiapite* & $\mathrm{Fe}^{2+} \mathrm{Fe}^{3+}{ }_{4}\left(\mathrm{SO}_{4}\right)_{6}(\mathrm{OH})_{2} \cdot 20 \mathrm{H}_{2} \mathrm{O}$ & & Other minerals \\
\hline coquimbite* & $\mathrm{Fe}^{3+}{ }_{2}\left(\mathrm{SO}_{4}\right)_{3} \cdot 9 \mathrm{H}_{2} \mathrm{O}$ & bindheimite & $\overline{\mathrm{Pb}_{2} \mathrm{Sb}_{2} \mathrm{O}_{6}(\mathrm{O}, \mathrm{OH})}$ \\
\hline dietrichite* & $\left(\mathrm{Zn}, \mathrm{Fe}^{2+}, \mathrm{Mn}\right) \mathrm{Al}_{2}\left(\mathrm{SO}_{4}\right)_{4} \cdot 22 \mathrm{H}_{2} \mathrm{O}$ & chalcophanite & $\left(\mathrm{Zn}, \mathrm{Fe}^{2+}, \mathrm{Mn}^{2+}\right) \mathrm{Mn}_{3}^{4+}{ }_{3} \mathrm{O}_{7} .3 \mathrm{H}_{2} \mathrm{O}$ \\
\hline epsomite* & $\mathrm{MgSO}_{4} \cdot 7 \mathrm{H}_{2} \mathrm{O}$ & chlorargyrite grou & $\mathrm{Ag}(\mathrm{Cl}, \mathrm{Br})$ \\
\hline ferricopiapite* & $\mathrm{Fe}^{3+}{ }_{2 / 3} \mathrm{Fe}^{3+}{ }_{4}\left(\mathrm{SO}_{4}\right)_{6}(\mathrm{OH})_{2} \cdot 2 \mathrm{H}_{2} \mathrm{O}$ & chrysocolla & $\left(\mathrm{Cu}^{2+}, \mathrm{Al}\right)_{2} \mathrm{H}_{2} \mathrm{Si}_{2} \mathrm{O}_{5}(\mathrm{OH})_{4} \cdot \mathrm{nH}_{2} \mathrm{O}$ \\
\hline ferrohexahydrite: & $* \mathrm{FeSO}_{4} \cdot 6 \mathrm{H}_{2} \mathrm{O}$ & cinnabar & $\mathrm{HgS}$ \\
\hline fibroferrite! & $\mathrm{Fe}^{3+}\left(\mathrm{SO}_{4}\right)(\mathrm{OH}) .5 \mathrm{H}_{2} \mathrm{O}$ & coronadite & $\mathrm{Pb}\left(\mathrm{Mn}^{4+}, \mathrm{Mn}^{2+}\right)_{8} \mathrm{O}_{16}$ \\
\hline goslarite* & $\mathrm{ZnSO}_{4} \cdot 7 \mathrm{H}_{2} \mathrm{O}$ & ferrimolybdite & $\mathrm{Fe}^{3+}{ }_{2}\left(\mathrm{Mo}^{6+} \mathrm{O}_{4}\right)_{3} \cdot 8 \mathrm{H}_{2} \mathrm{O}(?)$ \\
\hline gunningite* & $\mathrm{ZnSO}_{4} \cdot \mathrm{H}_{2} \mathrm{O}$ & ilsemannite & $\mathrm{Mo}_{3} \mathrm{O}_{8} \cdot \mathrm{nH}_{2} \mathrm{O}(?)$ \\
\hline gypsum & $\mathrm{CaSO}_{4} \cdot 2 \mathrm{H}_{2} \mathrm{O}$ & litharge & $\mathrm{PbO}$ \\
\hline hexahydrite* & $\mathrm{MgSO}_{4} \cdot 6 \mathrm{H}_{2} \mathrm{O}$ & luzonite & $\mathrm{Cu}_{3} \mathrm{AsS}_{4}$ \\
\hline halothrichite* & $\mathrm{FeAl}_{2}\left(\mathrm{SO}_{4}\right)_{4} \cdot 22 \mathrm{H}_{2} \mathrm{O}$ & olivenite & $\mathrm{Cu}_{2}\left(\mathrm{AsO}_{4}\right)(\mathrm{OH})$ \\
\hline hinsdalite & $(\mathrm{Pb}, \mathrm{Sr}) \mathrm{Al}_{3}\left(\mathrm{PO}_{4}\right)\left(\mathrm{SO}_{4}\right)(\mathrm{OH})_{6}$ & psilomelane group & $\left(\mathrm{Ba}, \mathrm{H}_{2} \mathrm{O}\right)_{2}\left(\mathrm{Mn}^{4+}, \mathrm{Mn}^{3+}\right) \mathrm{O}_{10}$ \\
\hline jarosite! & $\mathrm{KFe}^{3+}{ }_{3}\left(\mathrm{SO}_{4}\right)_{2}(\mathrm{OH})_{6}$ & scorodite & $\mathrm{Fe}^{3+} \mathrm{AsO}_{4} \cdot 2 \mathrm{H}_{2} \mathrm{O}$ \\
\hline jurbanite & $\mathrm{Al}\left(\mathrm{SO}_{4}\right)(\mathrm{OH}) .5 \mathrm{H}_{2} \mathrm{O}$ & & \\
\hline kornelite & $\mathrm{Fe}^{3+}{ }_{2}\left(\mathrm{SO}_{4}\right)_{3} \cdot 7 \mathrm{H}_{2} \mathrm{O}$ & & \\
\hline leadhillite! & $\mathrm{Pb}_{4} \mathrm{SO}_{4}\left(\mathrm{CO}_{3}\right)_{2}(\mathrm{OH})_{2}$ & & \\
\hline linarite! & $\mathrm{PbCu}\left(\mathrm{SO}_{4}\right)(\mathrm{OH})_{2}$ & & \\
\hline melanterite* & $\mathrm{FeSO}_{4} \cdot 7 \mathrm{H}_{2} \mathrm{O}$ & & \\
\hline meta-aluminite & $\mathrm{Al}_{2}\left(\mathrm{SO}_{4}\right)(\mathrm{OH})_{4} .5 \mathrm{H}_{2} \mathrm{O}$ & & \\
\hline paracoquimbite* & $=\mathrm{Fe}^{3+}{ }_{2}\left(\mathrm{SO}_{4}\right)_{3} \cdot 9 \mathrm{H}_{2} \mathrm{O}$ & & \\
\hline pentahydrite & $\mathrm{MgSO}_{4} .5 \mathrm{H}_{2} \mathrm{O}$ & & \\
\hline pickeringite* & $\mathrm{MgAl}_{2}\left(\mathrm{SO}_{4}\right)_{4} \cdot 22 \mathrm{H}_{2} \mathrm{O}$ & & \\
\hline plumbojarosite! & $\mathrm{PbFe}^{3+}{ }_{6}\left(\mathrm{SO}_{4}\right)_{4}(\mathrm{OH})_{12}$ & & \\
\hline rhomboclase* & $\left(\mathrm{H}_{3} \mathrm{O}\right) \mathrm{Fe}^{3+}\left(\mathrm{SO}_{4}\right)_{2} \cdot 3 \mathrm{H}_{2} \mathrm{O}$ & & \\
\hline romerite* & $\mathrm{Fe}^{2+} \mathrm{Fe}^{3+}{ }_{2}\left(\mathrm{SO}_{4}\right)_{4} \cdot 14 \mathrm{H}_{2} \mathrm{O}$ & & \\
\hline rozenite* & $\mathrm{FeSO}_{4} \cdot 4 \mathrm{H}_{2} \mathrm{O}$ & & \\
\hline schwertmannite & $\mathrm{Fe}^{3+}{ }_{8} \mathrm{O}_{8}(\mathrm{OH})_{6}\left(\mathrm{SO}_{4}\right) \cdot \mathrm{nH}_{2} \mathrm{O}$ & & \\
\hline serpierite! & $\mathrm{Ca}(\mathrm{Cu}, \mathrm{Zn})_{4}\left(\mathrm{SO}_{4}\right)_{2}(\mathrm{OH})_{6} \cdot 3 \mathrm{H}_{2} \mathrm{O}$ & & \\
\hline siderotil* & $\mathrm{Fe}^{2+} \mathrm{SO}_{4} .5 \mathrm{H}_{2} \mathrm{O}$ & & \\
\hline szomolnokite* & $\mathrm{Fe}^{2+} \mathrm{SO}_{4} \cdot \mathrm{H}_{2} \mathrm{O}$ & & \\
\hline voltaite & $\mathrm{K}_{2} \mathrm{Fe}^{2+}{ }_{5} \mathrm{Fe}^{3+}{ }_{4}\left(\mathrm{SO}_{4}\right)_{12} \cdot 18 \mathrm{H}_{2} \mathrm{O}$ & & \\
\hline woodhouseite & $\mathrm{CaAl}_{3}\left(\mathrm{PO}_{4}\right)\left(\mathrm{SO}_{4}\right)(\mathrm{OH})_{6}$ & & \\
\hline
\end{tabular}




\section{Ochre deposits}

Ochre deposits are concentrations of secondary iron minerals that form from the weathering and oxidation of iron sulfide minerals (Bigham, 1994). Ochres can include hardpan layers in and along streams, layers in tailings piles, soft crusts, and wet (typically slimy) precipitates and flocs that range from amorphous ferric hydroxide to well-crystallized minerals such as goethite and jarosite. "Yellowboy" in and along streams is a hallmark of acid mine drainage. Yellowboy is the informal name for the hydroxysulfate mineral schwertmannite (Bigham and others, 1994; Schwertmann and others, 1995), a poorly crystalline mineral that has only recently been characterized. Both schwertmannite and ferrihydrite (Chukrov and others, 1973), a very poorly crystalline oxyhydroxide mineral, are commonly referred to simply as "mine drainage minerals" (Bigham, 1994), especially in older literature. The exact formulas, solubilities, and the very existence of these minerals have been the subject of considerable debate ( $\mathrm{Yu}$ and others, 1999).

Ochre minerals form by hydrolysis and precipitation of the iron available from sulfide oxidation reactions. Hydrous-oxide minerals form initially as polymers (nanometer size particles) that behave as amorphous solid phases (too poorly crystalline to produce an XRD pattern). These minerals can play a critical role in trace metal transport because they (1) produce acid on formation and (2) can adsorb metals at the solid-water interface, effectively removing them from contaminated waters. Furthermore, the hydrous-oxide minerals consume acid when they precipitate and release any adsorbed metals when they dissolve. All of these reactions are $\mathrm{pH}$ dependent. For example, iron and aluminum hydrous oxides adsorb $\mathrm{Cu}, \mathrm{Pb}$, and $\mathrm{Hg}$ in the $\mathrm{pH}$ range 3 to 5 , and adsorb $\mathrm{Zn}, \mathrm{Co}, \mathrm{Ni}$, and $\mathrm{Cd}$ at higher $\mathrm{pH}$ values (5 to 6.5). Desborough and others (2000) demonstrated that schwertmannite-rich ochre deposits dissolved and generated acid during passive serial leaching tests using deioinzed water. Within 24 hours, pH dropped from 5 to 3.5 in their 200:1 solute: solid ratio leaching experiment.

Ochres are typically iron-rich (up to $50 \mathrm{wt}$. $\% \mathrm{Fe}$ ) but highly variable in composition because they can incorporate other minerals (Winland and others, 1991). Because the iron-rich precipitates cement entrained debris, ochre hardpans (ferricrete) can contain significant $\mathrm{Si}, \mathrm{Al}$, and organic $\mathrm{C}$ as well as grains of ore minerals.

The self-mitigating capacity of mine waters (i.e., the ability of the water to clean itself up by removing dissolved metals from solution by metal sorption on freshly precipitated hydrous ferric oxides) is a function of the amount of dissolved iron and metals, the nature of the metals, and the ratio of available sites for binding to dissolved metals at a particular pH (Smith, 1999). Hammarstrom and others (1999a) found that $\mathrm{Cu} / \mathrm{Zn}$ ratios in ochres precipitating from acidic waters were consistently lower than $\mathrm{Cu} / \mathrm{Zn}$ ratios associated with near-neutral, reduced seeps at the same site. These data indicated that zinc, a metal that is generally difficult to remove in AMD settings, was locally sequestered in ochre deposits. The permanence of the ochres as sinks for various metals depends on the $\mathrm{pH}$ of the environment over time.

The particular ochre minerals that form vary as a function of $\mathrm{pH}$, dissolved sulfate content, and availability of elements such as $\mathrm{K}, \mathrm{Na}$, or $\mathrm{Si}$. Goethite is the most widespread mineral associated with acid drainage. Other ochre minerals are all transient relative to goethite as a stable end-product, following dissolution and reprecipitation of other minerals as conditions vary (Bigham, 1994). Low pH (3 to 4) and moderately high concentrations of dissolved sulfate $(1,000$ to $3,000 \mu \mathrm{g} / \mathrm{L})$ favor schwertmannite formation. Schwertmannite and ferrihydrite, which are stable at higher $\mathrm{pH}$ and lower dissolved sulfate concentrations, are the two most common ochre precipitates associated with acid mine drainage ( $\mathrm{Yu}$ and others, 1999). Ferrihydrite is commonly reported from coalmine drainage. Jarosite tends to form at lower $\mathrm{pH}(<3.0)$ and higher concentrations of dissolved sulfate. The jarosite crystal structure can incorporate $\mathrm{K}, \mathrm{Na}, \mathrm{Pb}$, or $\mathrm{H}_{3} \mathrm{O}^{+}$resulting in the end-member minerals jarosite, natrojarosite, plumbojarosite, and hydronium jarosite, respectively. The spatial distribution of ochre minerals can be mapped using remote sensing tools such as imaging spectroscopy (Swayze and others, 2000) and spectral reflectance (Anderson and Robbins, 1998). Spectral techniques can be more effective than XRD for detecting small amounts of iron ochre minerals (Swayze and others, 2000) in surface materials.

\section{TOOLS OF THE TRADE}

Field observations and measurements

A number of different observations and measurements can be made in the field to assess the potential for acid mine drainage to develop and to evaluate abandoned mine sites. Kwong (1993) proposed a practical checklist for field measurements during the mineral exploration stage and emphasized the role that geologists can play in the prediction and prevention of acid rock drainage before mining commences. He noted, for example, that observations made on rock materials allow estimates of potential maximum acidity, neutralization capacity, and proportion of sulfide minerals susceptible to weathering. Such an approach allows industry to factor in mitigation up-front. Land managers faced with modern mineral development have the benefit of legally mandated environmental impact studies on which to base development decisions. However, when faced with thousands of 
abandoned mines which were developed before modern state and federal regulations were enacted, land managers need quick and cost-effective tools for evaluation and prioritization of sites and allocation of money for clean-up. Given a watershed or national forest full of abandoned mine sites, where single sites may cover tens of acres, the task of characterizing and sampling solid materials is daunting. In table 5, we expand on Kwong's checklist for premining field observations to include mine waste and tailings and additional site considerations. Maps, photos, and historical reports can be compiled beforehand to facilitate site visits - it can take a lot of time to find overgrown mine shafts and pits and identify the various parts of abandoned mine sites. GIS tools including mineral locality databases, smelter sites, etc., can be used to construct maps showing the location and nature of all known mining activities in an area to identify suitable areas for background or baseline sampling and to identify other sites that may have influenced the site of interest. Sometimes, older (15' or smaller scale) topographic maps are useful in historical mining districts because more mine-related features are shown than on newer maps. Short-term and seasonal weather variations that affect stream flow can also affect the distribution of solids materials. Efflorescent salts many be ubiquitous on a hot dry day and disappear following a rainstorm, so weather conditions before and during site visits should be noted. Highly soluble salts may be present even in very humid climates if there is a relatively protected place for them to form.

Field paste $\mathrm{pH}$ measurements provide a quick indication of readily available acidity or alkalinity in fine-grained mine waste materials. Like acid-base accounting, paste $\mathrm{pH}$ is a static procedure that provides no information about reaction rates. Paste $\mathrm{pH}$ procedures vary in amount of sample and standing time before measurement, but most methods use a 1:1 by weight solid: solution ratio on air dried material, distilled or deionized water, and a pH meter calibrated with $\mathrm{pH} 4.00$ and $\mathrm{pH} 7.00$ buffer solutions. The MEND (1990) method for metal mine paste $\mathrm{pH}$ determination is to mix $5 \mathrm{~mL}$ of deionized or distilled water with 10 grams of sieved ( $<60$ mesh) sample and allow it to wet by capillary action without stirring. More water or sample is added as necessary to saturate the sample and a spatula is used to stir the sample to form a thin paste that just slides off the spatula. In the field, we modify this procedure by using the $<2 \mathrm{~mm}$ fraction, weighing out 10 grams of sample in a disposable plastic beaker, adding 10 $\mathrm{mL}$ of water and stirring the paste gently with a disposable wooden coffee stirrer, and measuring the $\mathrm{pH}$ within 5 minutes with a calibrated $\mathrm{pH}$ meter equipped with an appropriate electrode for immersion in soil pastes. Our method is similar to ASTM method D4972-89, a laboratory method that calls for measurement on the $<2 \mathrm{~mm}$ fraction in a 1:1 solid: solution ratio after the sample has been standing at room temperature for an hour. The recommended paste $\mathrm{pH}$ procedure used in British Columbia (Price, 1997) is a method described by Sobek and others (1978) and modified by Page and others (1982) that calls for 20 grams of solid and $20 \mathrm{~mL}$ of distilled water mixed for 5 seconds and allowed to stand for 10 minutes before measurement. Paste $\mathrm{pH}$ values $<5$ suggest that the material contains acidity from prior acid generation whereas paste $\mathrm{pH}$ values $>7$ suggest the presence of reactive carbonate (Price, 1997). This test provides no mineralogic information, but can be a useful screening tool for identifying areas for further sampling. Paste $\mathrm{pH}$ measurements for a variety of mine waste materials from different types of mineral deposits are listed in table 4, along with total sulfur and total carbon determined on the same material. Paste $\mathrm{pH}$ measurements can vary by 2 or more $\mathrm{pH}$ units over a given mine site. The actual $\mathrm{pH}$ reading in the field is not especially significant - the important point is whether the $\mathrm{pH}$ goes acidic or neutral when the sample is wetted. As long as the field procedure is kept consistent, the results can be helpful in characterizing the distribution of readily available acidity on the site.

\section{Useful field equipment}

Pocket-type combination thermometer- hygrometers are handy for recording temperature and relative humidity in the field. Observations of water flow along outcrop fractures, ferricrete deposits, and seeps provide clues to the site hydrology. Color can provide clues about secondary minerals and $\mathrm{pH}$. Munsell field soil color charts are useful for quantifying color variations and communicating color differences in a more or less objective manner. Dilute hydrochloric acid carried in a plastic dropper bottle is useful for identifying calcite (readily effervesces in cold $\mathrm{HCl}$ ) and limestone in the field. Alizarin-red S is also useful because it stains calcite very bright red within 30 seconds of application (Desborough, written communication, 2000). Plastic gold pans are useful for panning heavy minerals to concentrate ore minerals. Pen-type magnets pick up magnetite and the magnetic form of pyrrhotite. Small shovels and augers can be used to determine the thickness of oxidized zones and expose profiles through tailings and mine waste dumps. Large syringes or turkey basters are practical for sampling wet precipitates and flocs in streams and seeps. Solder-free (lead-free) sieve screens are useful for field-sieving soil-size $(<2 \mathrm{~mm})$ fractions of mine waste and tailings and for sampling stream sediments. Note that the sieve opening is $2.00 \mathrm{~mm}$ for 10 mesh (USA ASTM standard), 9 mesh (Tyler mesh number), or 8 mesh (British standard). Portable battery-operated balances facilitate in-field paste $\mathrm{pH}$ measurements. Refillable epoxy $\mathrm{pH}$ electrodes are best suited to sludge and paste-type samples 
and field use. Conductivity equipment can be used to identify inflows of mining effluent to streams. Alkalinity kits can be used to identify waters receiving acidic inflows or waters susceptible to acidic inflows.

Table 5. Field checklist for site assessment (modified from Kwong, 1993).

\begin{tabular}{|c|c|}
\hline Type of material & Measurements and observations \\
\hline Rocks (ore, host rock, altered rock) & $\begin{array}{l}\text { Lithology } \\
\text { Mineralogy and texture } \\
\quad \text { Fizz test for carbonate } \\
\quad \text { Hand magnet (magnetite, some pyrrhotite) } \\
\text { Ore minerals } \\
\text { Nature and extent of weathering } \\
\text { Fractures, joint density } \\
\text { Water flow along fractures? } \\
\text { Efflorescent salts (protected overhangs)? }\end{array}$ \\
\hline $\begin{array}{l}\text { Natural weathering products } \\
\text { (gossan, soil, sediments) } \\
\text { Mine waste } \\
\text { Tailings }\end{array}$ & $\begin{array}{l}\text { Mineralogy and texture } \\
\quad \text { Fizz test for carbonate } \\
\quad \text { Hand magnet (magnetite, some pyrrhotite) } \\
\text { Ore and gangue minerals } \\
\quad \text { Panning and sieving } \\
\text { Color (Munsell color charts) } \\
\text { Moisture content } \\
\text { Profile development (shovels, augers) } \\
\text { Paste pH } \\
\text { Presence and condition of vegetation } \\
\text { Erosion } \\
\text { Efflorescent salts } \\
\text { Presence and distribution of hardpans } \\
\text { Presence and distribution of seeps }\end{array}$ \\
\hline Water bodies & $\begin{array}{l}\mathrm{pH} \text {, conductivity, alkalinity, dissolved oxygen } \\
\text { Presence of secondary minerals } \\
\text { Evidence of microbial activity (biofilms) }\end{array}$ \\
\hline Other considerations & $\begin{array}{l}\text { Weather (temperature, relative humidity, recent } \\
\text { precipitation) } \\
\text { Climate zone (weathering rate, metal transport) } \\
\text { Ecozone } \\
\text { Proximity of waste to an area of risk (stream, wetland) } \\
\text { Site accessibility } \\
\text { Topography } \\
\text { Vegetation (natural wetlands, barren areas) }\end{array}$ \\
\hline
\end{tabular}

\section{Mineralogy}

Instrumental techniques available for determinative mineralogy range from routine optical and scanning electron microscopy and $\mathrm{x}$-ray diffraction to relatively recent microanalysis techniques that are largely used in mineralogic research (proton and ion microprobes, secondary ion mass spectrometry, etc.). Jambor and Blowes (1998) discuss theories and applications of mineralogy in environmental studies of sulfide-bearing mine-waste. Jambor (1994) describes sampling and methods for studying tailings and Bigham (1994) addresses methodologies applicable to ochre deposits. More sophisticated techniques are especially useful for determining trace element distributions and for studying mineral surfaces, but are beyond the scope of routine characterization of the solid phases. Therefore, we limit our discussion to the routine methods that we have applied to solids characterization in our development of geoenvironmental models. Interested readers are referred to Cabri and Vaughns' (1998) overview of modern approaches to ore and environmental mineralogy for an introduction to other techniques. 
No one technique suffices to identify minerals. The very small grain size and complex intergrowths of secondary mineral assemblages can be extremely complicated to unravel. What appears to be a single phase under the optical microscope, such as a white efflorescent crust, may turn out to be a mixture of several phases with different compositions when examined by SEM. Qualitative x-ray energy dispersive spectra acquired by SEM and quantitative wavelength dispersive analysis by electron microprobe can identify most elements in a sample, but cannot distinguish ferrous from ferric iron, sulfide from sulfate sulfur, or provide quantitative data on water present.

Table 6. Paste $\mathrm{pH}$ values for mine waste $(<2 \mathrm{~mm}$ surface material) for different types of mineral deposits.

\begin{tabular}{lccc} 
Deposit type & Paste $\mathrm{pH}$ & Total sulfur (wt.\%) & Total carbon (wt. \%) \\
\hline Tungsten skarn & 2.6 & $7.7 \%$ & $0.23 \%$ \\
Polymetallic replacement & & & \\
(Carbonate-hosted) & & & \\
Dump & 7.5 & $0.79 \%$ & $8.18 \%$ \\
Mill tailings & 7.7 & $1.09 \%$ & $8.33 \%$ \\
& & & \\
Massive sulfide & & $3.77 \%$ & $0.1 \%$ \\
(Besshi-type) & 2.1 & $1.04 \%$ & $0.2 \%$ \\
Dump & 3.0 & & \\
Flotation tailings & & & \\
\hline
\end{tabular}

$X$-ray diffraction $(X R D)$

$X$-ray diffraction has become an invaluable tool for characterizing solids because it provides a quick method for identifying minerals. Diffractograms represent a "fingerprint" of the minerals present in a sample that can be interpreted by comparison with standard reference patterns. Many automated search-match routines are available to access the JCPDS database of standard X-ray powder diffraction patterns (International Centre for Diffraction Data, 1997). Results of these programs must be interpreted with care and with some forehand knowledge of what minerals are likely (or unlikely) to be present. The number of different minerals present in mine waste and tailings can complicate interpretation of patterns. Furthermore, the presence of many of the secondary minerals (soluble, metastable, very poorly crystalline) typical of mine waste environments can pose problems in sample preparation and analysis. In addition to mineral identification, XRD can provide information about the relative abundance of a mineral in a mixture and the degree of crystallinity but not about composition. Amorphous can be a significant component of mine waste (see Chapter C). Materials that are not detected by XRD because they are amorphous or because they are present in concentrations too low to detect may still have a significant impact on surface runoff and infiltration waters. Therefore, chemical analysis and leach studies (Chapter $\mathrm{C}$ ) as well as mineralogic studies are recommended for complete characterization of element mobility from mine wastes.

We routinely run splits of pulverized powders of mine waste chemistry samples as dry-mounted pressed powders in aluminum holders. Quartz is ubiquitous in many samples and serves as an internal standard; quartz or corundum or fluorite can be added to samples if necessary. Sample preparation is a critical step in X-ray powder diffraction because variables such as grinding, sample area, thickness, and packing can produce errors that complicate pattern interpretation (Bish and Reynolds, 1989). Pressed powder mounts have the advantage of providing an "infinite" sample thickness, but they require a fair amount (typically a gram or so) of sample. Small samples and minerals (hand picked under a binocular microscope or concentrated with heavy liquids) can be ground and mounted on glass or preferably zero-background quartz slides using toluene as a binder. Acetone and isopropyl alcohol are used as binders, but can affect metastable minerals. Metastable samples can be placed in capped plastic vials in the field (they make their own atmosphere) or in mineral oil to retard changes in hydration state during transport back to the lab. The mineral oil must be washed out, and grinding can dehydrate some hydrous minerals. In some cases, we have resorted to smearing the mush (a less than ideal sample surface) onto a quartz plate with a spatula to make a mount and running the pattern at a fast scan rate before it dehydrates. Environmental sample chambers are available for diffractometers that allow the sample to reside in a controlled atmosphere during the run; $\mathrm{x}$-rays access the sample through a beryllium window in the sealed chamber. For very small samples, $\mathrm{x}$-ray film techniques that use Debye-Scherrer or Guinier or Gandolfi cameras may be necessary for identification. Bish and Post (1989) provide a good reference for modern x-ray diffraction techniques. 


\section{Scanning electron microscopy}

Scanning electron microscopy (SEM) can be used to determine crystal shape, size, and texture, obtain qualitative or semi-quantitative compositional information, and help identify minerals that are too small to be identified by other means. Scanning electron microscopes have been generally used as cameras for photographing specimens beyond the capabilities of ordinary optical microscopes. While the images obtained look like ordinary photographs, the apparent illumination is a function of emission of secondary electron (SE) particles detected with a SE detector and displayed on a scanning TV display. A bright image will be the result of high secondary electron emission, while the primary influence on high emission is the surface structure of the specimen. The end result therefore, is brightness associated with surface characteristics and an image, which looks very much like a normally illuminated subject. When the SEM is operated in backscattered mode, one can see differences in the images that reflect differences in composition. Backscattered electrons (BSE) are high energy electrons emitted from the specimen as a result of the high-energy electron beam's interaction within the specimen. BSE emission is the result of elastic events between primary electrons and other electrons within the specimen that are relatively tightly bound. BSE emission intensity is very much a function of the specimen's atomic number; i.e., the higher the atomic number (e.g., $\mathrm{Fe}(26)$ vs. $\mathrm{Mg}(12)$ ), the brighter the image. Most SEMs are equipped with an energy-dispersive spectrometer (EDX) that provides a qualitative measure of the elements present in the sample in the form of a spectrum. Energy dispersive detectors (EDX) are quick and easy to use. Turn on the electron beam and the detector, and a display appears of all elements present. The disadvantages are relatively poor spectral resolution and low signal-to-noise, which results in many spectral interferences and poor sensitivity (relative to wavelength dispersive detectors used in electron microprobe analysis). Low-voltage and low-vacuum SEMs are available (generally referred to as "environmental" instruments) which accomodate samples with little or no sample prep such as hydrated or uncoated samples and biological materials.

\section{Electron probe microanalysis (EPMA)}

Electron probe microanalyzers (EPMA) are designed to analyze x-rays generated from the specimen when probed with an electron beam. The design considerations primarily accommodate three to six wave dispersive $\mathrm{x}$-ray spectrometers, which are inherently large. Specimens prepared for x-ray microanalysis are generally flat and polished, and the microprobe analyzer is designed to allow only a considerable amount of $\mathrm{x}$ and $\mathrm{y}$ translation rather than the specimen manipulation which is typical of the SEM. In EPMA, wave dispersive technology is used to detect and count $\mathrm{x}$-rays. These spectrometers are much more sensitive to low elemental concentrations than the energy dispersive detectors used in most SEM applications, and concentrations in the range of $100 \mathrm{ppm}$ can generally be measured. EPMA is useful for obtaining quantitative chemical analyses of the major and minor elements in a mineral. Trace elements can be measured (Robinson and others, 1998), but a variety of other analysis methods such as ion probes, proton probes, or laser-ablation mass spectrometry are starting to be used in research studies of trace element distributions in earth materials. Limitations to EPMA are that not all specimens can be exposed to the high vacuum within the specimen chamber, elements lighter than atomic number 8 (oxygen) cannot be measured without reservations, and EPMA is not sensitive to many elements at concentrations below 100ppm. Analysis of hydrous minerals such as clays, iron oxyhydroxides, and efflorescent salts is possible but generally timeconsuming because of the difficulty of obtaining good flat polished surfaces, suitable standards, and instability in both the vacuum and under the electron beam. Areas of samples can be mapped to show the distribution of various elements. X-ray element maps are powerful tools for monitoring chemical changes that accompany alteration and for identifying mineral grains or zones that contain elements of interest.

\section{Geochemical analysis}

A variety of different analytical techniques are available for geochemical analysis. The choice of method depends on the elements and detection limits sought, the amount and nature of the samples, and cost. Crock and others (1999) reviewed sample preparation and laboratory methods for total and partial analysis of major- minorand trace elements in rock samples, soils, sediments, vegetation, and waters. Geologic materials can pose special problems for analysis because of matrix effects, extreme concentrations of a particular element such as iron, presence of refractory minerals, which are not readily dissolved in sample digestion, and elements that occur in different oxidation states. Methods developed within and (or) adopted by the USGS for analysis of geologic materials are described in detail in Arbogast $(1990,1996)$ and Baedecker $(1987)$.

EPA test methods for evaluating solid waste are documented in SW-846, which includes information on quality control, choosing the correct procedure, and sampling considerations as well as protocols for physical and chemical analysis of inorganic and organic analytes. The EPA documents can be accessed on-line at: 


\section{http://www.epa.gov/epaoswer/hazwaste/test/main.htm}

The most commonly used multi-element methods are inductively coupled plasma-atomic emission spectroscopy (ICP-AES) and inductively coupled plasma-mass spectrometry (ICP-MS). Detection limits by ICP-MS are orders of magnitude lower than detection limits for other methods, so very low concentrations of elements can be measured by this method and it is increasingly becoming the method of choice for trace element analysis of environmental samples. Crock and others (1999) evaluated relative advantages and disadvantages of different spectroscopic methods of analysis for environmental samples and discussed special methods of analysis for elements such as mercury, arsenic, selenium, and antimony. Total carbon and sulfur are typically analyzed by combustion- infrared spectrophotometers (LECO furnaces) using automated carbon and sulfur analyzers. For sulfur species (acid-soluble $\mathrm{S}$, sulfide $\mathrm{S}$, organic $\mathrm{S}$ ), acid leaches and sequential extractions are conducted to obtain residues that are subtracted from total sulfur to obtain the different sulfur species by difference (Arbogast, 1996). Sobek and others (1978) describe a wet-chemical leach procedure for determining sulfur species. Similarly, carbonate carbon is determined by coulometric titration and subtracted from total carbon to get a value for total organic carbon by difference. Some acid-base accounting methods use total sulfur and assume that total sulfur equals sulfide sulfur. Many modifications to acid-base accounting have been developed (see above) to account for mineralogic variation in mine waste that can include insoluble (barite) and soluble sulfate minerals as well as sulfides.

Wavelength dispersive X-ray fluorescence spectroscopy (WD-XRF) is used for determination of major elements (reported as oxides) in geologic materials. XRF is commonly used to determine major element oxides (including silica) in rocks (Taggart and others, 1987) along with loss on ignition (LOI), which includes water and other volatile species released on sample ignition (Mee and others, 1996).

Thermal analysis techniques such as thermogravimetric analysis can be coupled with quadrupole mass spectrometry (QMS) or Fourier-transform infrared detectors (FTIR) to detect water, sulfur, carbon dioxide, and other volatile species released from samples undergoing controlled heating (Morgan and others, 1988). Hammack (1994) described an evolved-gas analysis for determining pyrite, marcasite, and alkaline-earth carbonates in coal overburden and for estimating oxidation rates for coal pyrite to improve the predictive capability of acid-base accounting.

Other techniques that may be needed in certain situations include ion selective electrodes for chlorine or fluorine, determination of redox-sensitive species (iron, arsenic), and instrumental neutron activation analysis (multi-element, rare-earth elements).

\section{SAMPLING MEDIA, METHODS, AND EXAMPLES}

\section{Ore and gangue}

The ore and associated gangue assemblages contain the primary minerals that represent the source of acidgenerating and metal-bearing materials, and in some cases, a source of acid-neutralizing materials in a mineral deposit. The ore and gangue mineral assemblages are typically characteristic of a mineral deposit type. For most deposits that have been explored or developed, some information is available on the nature of the ore and gangue minerals. Worldwide databases such as the USGS Mineral Resources Data System (McFaul and others, 2000) and compilations of mines and prospects maintained by state and provincial geological surveys, contain mineralogic information and references to more detailed data that may be available for a given site. Weathered ore on mine dumps or gossan outcrops provides clues to the behavior particular metals on the site.

The composition and degree of alteration of sulfide minerals in weathered ore provide clues to element mobility. Some ore minerals tend to have ideal stoichiometry, such as chalcopyrite, whereas others, including pyrite and pyrrhotite incorporate trace amounts of other elements. Pyrrhotite generally weathers faster than pyrite, but produces less acid (see equations above). Typically, however, pyrrhotite alters to highly reactive marcasite/pyrite(Jambor, 1994), so the net effect on acid mine drainage can be comparable. Polished thin section study of oxidized ore and gossan can establish the relative degrees of alteration of different minerals and identify carbonate and secondary minerals as well as gangue minerals that may contribute to acid neutralization. Note that routine preparation of sections using water will dissolve any soluble secondary minerals. Alteration halos may extend well beyond "ore", so samples of country rock away from the orebody should be examined to assess the extent of element dispersion and distribution of alteration minerals (such as calcite veining, silica flooding, etc.).

\section{Example}

The Fontana copper mine is a Besshi-type massive sulfide deposit in Great Smoky Mountains National Park that ceased production in 1944. Most of the mine waste was removed from the site at closure and the mine area is heavily overgrown with vegetation that has erased most vestiges of mining. The National Park Service expressed 
concern about drainage from underground workings and impacts on a small stream that drains the mine area and flows into Fontana Lake, a major recreational area. Seal and others (1998) reported on the water quality associated with the mine and showed that although mine waters were characterized by low $\mathrm{pH}$ and elevated metal concentrations, very little effluent is discharged from the underground workings, which are flooded at depth. Secondary copper minerals and drip terraces and stalactites of goethite, schwertmannite, and jarosite are observed along oxidized adit walls (figure 2a). The stream that flows past the mine workings is near neutral $(\mathrm{pH}>6)$ and locally exceeds acute toxicity standards for aquatic life for some elements, such as zinc, but not for others. Water in the lake, which receives the stream flow and sediment load from the mine area, showed no evidence of impact from mine drainage.

We used a number of tools to evaluate metal distributions in the solid materials that could affect water quality at the site. Although no waste piles are observed, some oxidized ore is scattered about the surface at the mine site. Back-scattered electron images (SEM) of an oxidized ore sample (fig. 2b) shows that pyrrhotite, the major sulfide mineral in the deposit, alters to marcasite. Petrography and XRD show that the ores also contain chalcopyrite, sphalerite, galena, cubanite, as primary ore minerals; biotite, chlorite, calcite, magnetite, and quartz as gangue minerals; and a secondary mineral assemblage of acanthite, anglesite, brochantite, chalcocite, covellite, ferrihydrite, goethite, gypsum, hematite, hinsdalite(?), jarosite, and malachite. Quartz is ubiquitous in most mineral deposits. The presence of quartz provides an internal standard for x-ray diffraction patterns, which is especially useful when evaluating XRD patterns for complex mineral mixtures (fig. 2c). Although thin section study revealed the pyrrhotite, it did not show up in the XRD pattern because of the extensive alteration to marcasite(pyrite) and goethite, both of which do appear as prominent mineral phases in the XRD pattern of the crushed rock. This illustrates the need to approach solid samples with a variety of techniques to document the mineralogy of solid materials that can potentially contribute to, or ameliorate, acid mine drainage.

Geochemical analysis of the bulk rock sample (table 7a) shows that ore contains trace amounts of arsenic, cadmium, selenium, and antimony. Note that none of these trace elements are present as major constituents of the ore mineral assemblage (table 3$)$. Electron microprobe analysis of ore minerals (Tble $7 \mathrm{~b}$ ) shows these trace metals are present as minor constituents of the ore minerals. All pyrrhotite in the oxidized ores shows evidence of alteration but most chalcopyrite is intact. Sphalerite is iron-rich and less stable than chalcopyrite. Analysis of the iron oxyhdroxide minerals that form from the excess iron released by alteration of pyrrhotite to marcasite shows that they incorporate minor amounts of copper, zinc, silica, aluminum, or manganese, depending on which particular mineral is being replaced. For example, a goethite vein adjacent to sphalerite (Table $7 \mathrm{~b}$ ) contains elevated zinc (in this case about 4\%). Although secondary copper minerals were observed in some of the oxidized ores, no secondary zinc minerals were noted suggesting that most of the zinc is removed from the system. Cadmium typically substitutes for zinc in sphalerite; in the Fontana mine samples, cadmium was not detected in sphalerite by microprobe.

Geochemically, cadmium and zinc behave similarly, as shown by the smooth decrease in cadmium concentrations with decreasing zinc concentrations in both solids and waters associated with the Fontana mine. Ochres precipitated at groundwater seeps contain significant concentrations of zinc $(1,000 \mathrm{ppm})$ whereas an ochre stalactite formed underground had about $100 \mathrm{ppm}$ zinc. Groundwaters, which interact with oxidizing ore in adit walls, have higher zinc and cadmium concentrations than surface waters. Ochre deposits mark two near-neutral groundwater seeps adjacent to the stream that flows past the mine workings. Dissolved metal concentrations in the water from these seeps have copper/zinc $<1$ whereas the ochres precipitating from these waters have copper/zinc $>>1$ suggesting a natural process is at work to sequester copper, probably via sorption on iron oxyhydroxide minerals. Under the existing $\mathrm{pH}$ conditions at the site, zinc remains in solution and so the processes that are occurring between water and solids at the site explain the reason for the high (in excess of regulatory standards) dissolved zinc concentrations in the mine area. Water samples from the lake and from an adjacent stream unaffected by mining (background samples) contain $<10 \mu \mathrm{g} / \mathrm{L}$ zinc. A number of factors contribute to the lack of acid drainage in the stream that drains the mine site. These include (1) the extremely high rate of precipitation in the Smokies (>800 mm/year) which dilutes any mine discharge and prevents efflorescent salts from forming, (2) the absence of significant amounts of ore and mine waste exposed to weathering at the site, and possibly, (3) the presence of carbonate in the alteration assemblage.

\section{Host rock and alteration}

The practical ability of host rocks to neutralize, or contribute to acid mine drainage is a subject if considerable interest. Alteration associated with hydrothermal alteration typically forms a halo around the actual orebody that may extend for centimeters to kilometers, depending on the deposit type and the local geologic setting. A series of experiments on fresh granitic rocks of the Boulder batholith in Montana showed that those particular granites have significant acid-neutralizing capacity (Desborough and others, 1998a,b). Minor amounts of calcite contribute to 
short-term neutralization potential whereas some of the major rock-forming minerals (biotite, tremolite, and feldpars) contribute to long-term acid neutralization. The minor amount of calcite ( $<5 \mathrm{wt} . \%$ of the rock) was not detected in these rocks by $\mathrm{x}$-ray diffraction; large, sawed rock slabs were stained for calcite with alizarin red-S (Dickson, 1965) and carbonate content was calculated from whole-rock analysis for total carbon (by coulometer) and assuming that all of the carbon was present in calcite. By reacting mine-waste leachate $(\mathrm{pH} 3)$ from mineralized pyrite-rich quartz veins (hosted by the granite) with the pulverized calcite-bearing granite samples, Desborough and others $(1998 \mathrm{~b})$ found that the acid-neutralizing potential of the rocks was higher than expected and higher than could be accounted for by calcite alone. A number of other studies also suggest that when reactive carbonates are absent or depleted, mafic silicates minerals, especially biotite, play a role in long-term acid consumption (Acker and Bricker, 1992; Stromberg and Banwart, 1994; Malmstrom and Banwart, 1997; Dold, 1999) because biotite can alter to vermiculite by rapid removal of potassium and consumption of $\mathrm{H}^{+}$. Vermiculite-type mixed layer minerals have been reported as secondary minerals forming in oxidized zones in sulfide-rich mine tailings associated with deposits that have biotite as a common gangue mineral such as porphyry copper deposits (Dold, 1999). Although a number of gangue minerals in ore or tailings can contribute to long-term acid neutralization (micas, pyroxenes, amphiboles, calcic plagioclase), the phyllosilicate minerals (biotite and chlorite) appear to weather fastest (Nesbitt and Jambor, 1998), probably due to physical properties of the mineral group that promote development of large reactive surface areas relative to other groups of minerals (e.g., layer structure, prefect basal cleavage, low hardness number). Although biotite, phlogopite, and chlorite are fast-weathering minerals, muscovite and illite are very resistant to dissolution.

Alternatively, host rocks may represent sources of natural acid drainage that has nothing to do with mining. Rocks of the regionally extensive Great Smoky Group of the Late Proterozoic Ocoee Supergroup of the southern Appalachians host the massive sulfide deposits at Ducktown and the deposits at the southern end of Great Smoky Mountains National Park, such as the Fontana mine described above (Southworth, 1995; King and others, 1968). Metamorphic pyrite and pyrrhotite occur throughout a number of slate, phyllite, and schist lithologies of the Great Smoky Group. Weathering of exposed outcrops of these rocks, especially where exacerbated by roadcuts or landslides, leads to acid rock rock drainage that can be severe enough to result in fish kills (Bacon and Maas, 1979) due to stream acidification and release of iron, aluminum, and manganese.

In protected areas, weathering of such rocks produces highly soluble efflorescent salt minerals that form via the same processes that result in salt formation on mine waste dumps (Flohr and others, 1995); these salts can contribute pulses of acidity and metals ( $\mathrm{Fe}, \mathrm{Al}, \mathrm{Mg}$ ) to surface runoff. In the parts of the southern Appalachians where such rocks crop out, special efforts are taken in road and powerline construction to mitigate potential acid rock drainage problems (Byerly, 1996; Schaeffer and Clawson, 1996). Seal and others $(1997,1998)$ showed that the $\mathrm{pH}$ of regional streams in the Fontana mine area draining pyritic rocks can be lower than the $\mathrm{pH}$ of stream waters draining the immediate mine area, but total dissolved base metals concentrations are much lower in the regional streams due to differences in geoavailablity of metals in host rock versus ore. Consideration of these types of host rock controls on water quality can be important in setting realistic reclamation goals for treating acid mine drainage.

\section{$\underline{\text { Mine waste and tailings }}$}

Mine waste dumps and tailings piles pose sampling problems because many types and textures of waste may be present at a site. The surface material is the most important contributor to runoff during rainstorm and snow melt. If waste dumps or tailings are to be moved during site remediation, it may be critical to understand the vertical heterogeneity of the piles by sampling at depth using augers or drills. The strategy for sampling such material depends on the information needed. To meet the need for a protocol for cost-effective, rapid screening of large numbers of abandoned mine-waste dumps for prioritization for cleanup, the USGS developed a statistically based sampling strategy (Smith and others, 2000). This protocol provides a representative composite sample for chemical and mineralogic analyses and for leach studies. The sampling protocol is described in Chapter $\mathrm{C}$.

\section{Example}

The Elizabeth mine is an abandoned, Besshi-type massive sulfide deposit in east-central Vermont that was evaluated by EPA in 1999 and listed on EPA's National Priority List (Superfund) in December, 2000 as an ecological threat to the West Branch of the Ompompanoosuc River (Hammarstrom and others, 1999b). The mine was discovered in 1793 and developed for copperas (iron sulfate) production from pyrrhotite in the 1800s. From the 1830s until closure in 1958, the deposit was mined for copper from chalcopyrite. Three large mine-waste piles on the site (fig. 3a) contribute metals and acidity to surface runoff that form the headwaters of Copperas Brook which flows into the West Branch of the Ompompanoosuc River about a kilometer downstream from the mine site. The waste piles have been designated as TP1, TP2, and TP3 (fig. 3a). TP1 is a 30-acre, 30-meter high pile of fine-grained, pyrrhotite-rich 
tailings from a flotation plant that operated on-site until 1958. The flat top surface of the pile is partly vegetated and contains a small pond that receives surface water drainage from the upper piles; water is decanted from the pond to a discharge point at the base of the pile and the decant water coalesces with seeps at the base of the tailings to form Copperas Brook. The north slope of TP1 above the seeps is deeply eroded and barren (fig. 3b). TP2 represents a 5acre tailings pile from an older (early 1900s) phase of mining and is similar in texture and appearance to TP1, but has a thicker $(60 \mathrm{~cm}$ as opposed to $6 \mathrm{~cm})$ orange oxidized zone overlying black, unoxidized tailings. TP3 is a 6-acre area that includes a series of piles of mine waste from the early days of mining and copperas production. We arbitrarily divided TP3 into 6 subareas (A-F) based on differences in surface color and texture (fig. 3c,d). We sampled surface materials from each of the 6 subareas of TP3, as well as from the tops and steep, deeply eroded barren north slopes of TP1 and TP2. Paste $\mathrm{pH}$ of composite samples was measured in the field, and samples were returned to the lab for mineralogy and chemistry. Physical characteristics, paste $\mathrm{pH}$, and dominant minerals determined by XRD are listed in table 8a. Colors were determined on dry materials by comparison with Munsell soil color charts. These data show that the red piles of the old workings (TP3), where open-ore roasting of ore and possibly smelting occurred, are hematite-rich and have slightly higher paste $\mathrm{pH}$ values than the adjacent jarosite-rich piles. Weathered ore and host rock litters the upper parts of TP3 and on dry days, white coatings of efflorescent salts look like snowballs on the dump (fig. 3e). These salts (melanterite, rozenite, a variety of copper-aluminum salts) disappear after a rainstorm. The oxidized surfaces of the more recent flotation tailings (TP2 and TP1) are dominated by jarosite and goethite. The partly vegetated tops of both of these piles are less acidic than the base, eroded slopes. Selected metal concentrations from geochemical analysis of these samples are listed in table 8b, along with reference soil values for normal ranges of metal concentrations in soils and critical values above which plant toxicity is considered to be possible. These data demonstrate a number of points that should be factored into reclamation plans:

(1) Copper and zinc concentrations in all types of mine waste on the site are elevated and locally exceed critical values for acute toxicity for plants; these elevated metal concentration and the acidity of the surface material probably account for the lack of success of revegetation (planted or volunteers) and the stunted appearance of the vegetation that has established itself on parts of the flat tops of the flotation tailings.

(2) Metal concentrations in the older waste piles (smaller volume of waste at the site) are an order of magnitude higher than in the more extensive flotation tailings. For any improvements to stream water quality in Copperas Brook, the continuing cycle of weathering of exposed ore, salt formation, salt dissolution, and release of metals and acidity to the surface materials and to surface runoff from these older dumps has to be broken by moving the problem material, or regrading and capping and diverting surface flow. Casual inspection of the site could lead one to conclude that the large tailings pile (TP1 and TP2) represent the major source of impact to Copperas Brook. Recognition of the presence and role of efflorescent salts at the site, and the elevated metal concentrations documented by this approach to sampling however, indicate that the older mine waste is a significant source of metals and acidity.

(3) A number of potentially toxic metals such as mercury, lead, cadmium, and arsenic are present in low concentrations at this site, reflecting their low abundances in this particular type of mineral deposit.

\section{$\underline{\text { Secondary minerals }}$}

Sampling of secondary minerals can be difficult, but can provide information on temporary metal sequestration and empirical data for comparison with solid phases predicted from saturation index computations based on water chemistry. Efflorescent salts are transient, so they may not be evident when the site is visited. Salts are best observed at times of the year when high evaporation rates prevail at the site, and may be preserved year round in protected areas (under rock overhangs such as shown in fig. 4a, in pipes or other structures on the site). Salts can change during the course of hours depending on the prevailing temperature and relative humidity conditions and can change during transport to the lab, and during grinding to prepare x-ray mounts. Tweezers and wood or plastic spatulas are good for sampling delicate salt encrustations (fig. 4b); storage in tightly capped plastic values allows the salts to control the humidity in the vial. X-ray diffraction is useful for identifying mineral groups, but does not provide chemical information. We have found that an iterative approach using XRD and qualitative SEM analysis on hand-picked concentrates (by color, usually) is most effective for identifying efflorescent salts because these minerals typically form complex solid solutions, tend to be very-fine grained and intimately intergrown. For example, copper can substitute for iron in melanterite rather than form discrete secondary copper minerals. Minerals such as melanterite, a very commonly reported secondary salt, with 7 waters of hydration, can dehydrate to rozenite (4 waters of hydration) as relative humidity falls below about $60 \%$ at $20{ }^{\circ} \mathrm{C}$ (Chou and others, 1999). 
$\underline{\mathrm{A}}$

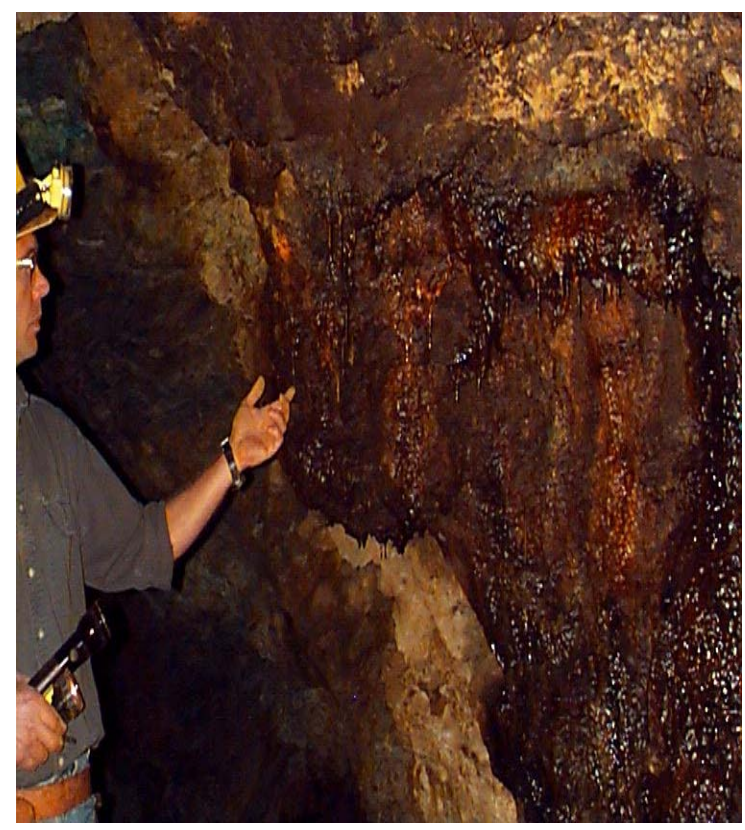

$\underline{B}$

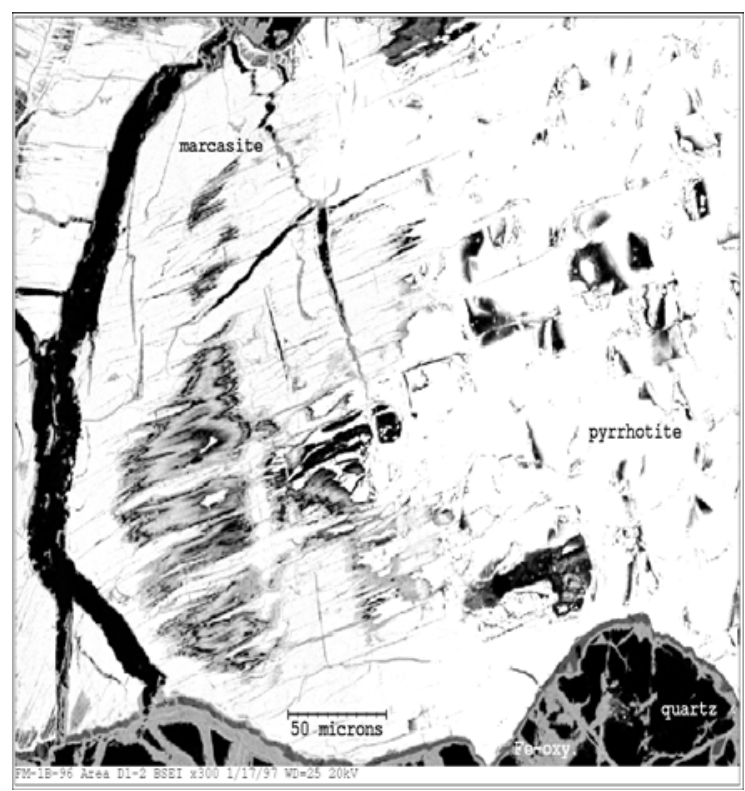

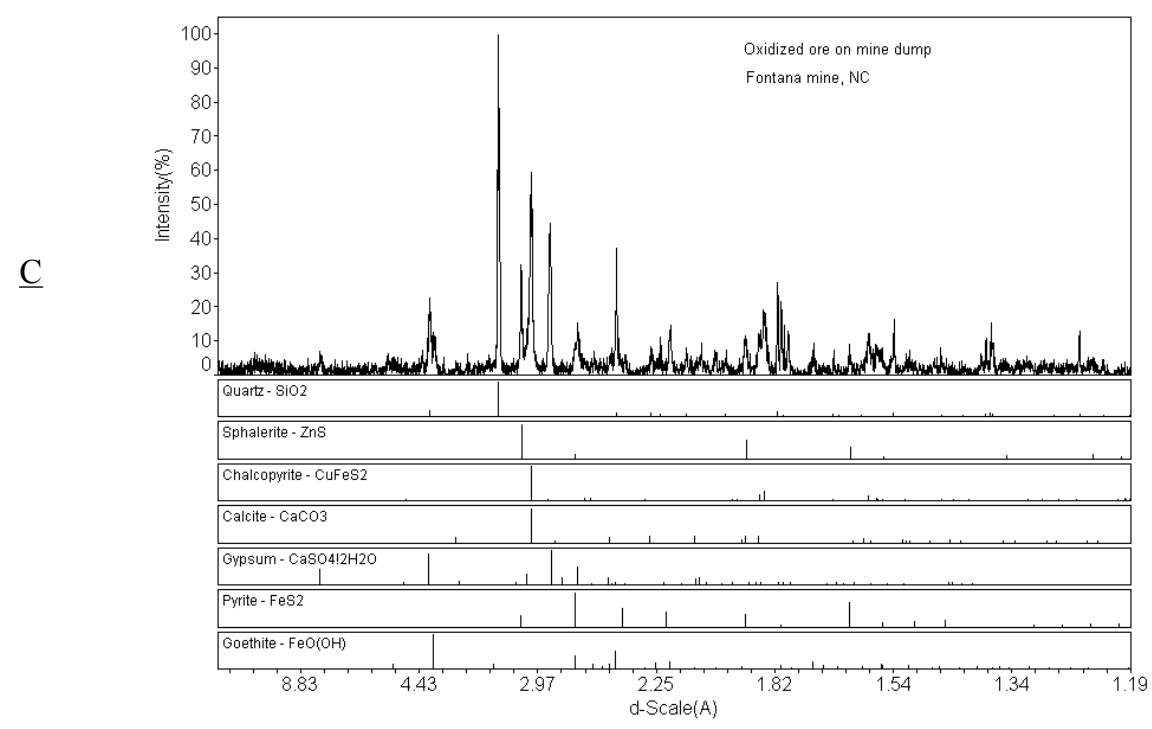

Figure 2. $\underline{\mathrm{A}}$, Secondary ochre minerals forming along adit walls at the Fontana mine, NC. Waters dripping from these stalactites (goethite, schwertmannite, jarosite) have a pH of 3 and over $900 \mathrm{mg} / \mathrm{L}$ dissolved sulfate (Seal and others, 1999). B, Back-scattered electron image of as polished thin section cut through oxidized massive sulfide ore. Marcasite replaces pyrrhotite; excess iron from the alteration forms a network of iron-oxyhydroxide minerals around the sulfides. Field of view about 600 microns. Fontana mine, NC,(sample FM-1B-96).C, X-ray diffractogram of oxidized ore to determine mineralogy (same sample as shown in B). 
Table 7a. Selected geochemical data for oxidized copper ore shown in Figure 2.

\begin{tabular}{|c|c|c|c|}
\hline Element & Concentration & Element & Concentration \\
\hline $\mathrm{Fe}$ & $20 \%$ & $\mathrm{Sb}$ & $2.6 \mathrm{ppm}$ \\
\hline $\mathrm{Al}$ & $0.2 \%$ & As & $0.8 \mathrm{ppm}$ \\
\hline $\mathrm{Cu}$ & $120,000 \mathrm{ppm}$ & $\mathrm{Cd}$ & $44 \mathrm{ppm}$ \\
\hline $\mathrm{Zn}$ & $23,000 \mathrm{ppm}$ & $\mathrm{Se}$ & $61 \mathrm{ppm}$ \\
\hline $\mathrm{Pb}$ & $580 \mathrm{ppm}$ & S (total) & $14.7 \%$ \\
\hline $\mathrm{Mn}$ & $1,900 \mathrm{ppm}$ & $\mathrm{CO}_{2}$ & $9.3 \%$ \\
\hline
\end{tabular}

Table 7b. Mineral chemistry of ore minerals in oxidized copper ore determined by electron microprobe for the sample shown in Figure 2b. [n, number of analyses averaged]

\begin{tabular}{lrrrrr}
\hline $\begin{array}{c}\text { Element } \\
(\mathrm{wt} . \%)\end{array}$ & $\begin{array}{c}\text { Pyrrhotite } \\
(\mathrm{n}=4)\end{array}$ & $\begin{array}{c}\text { Marcasite } \\
(\mathrm{n}=4)\end{array}$ & $\begin{array}{c}\text { Chalcopyrite } \\
(\mathrm{n}=5)\end{array}$ & $\begin{array}{c}\text { Sphalerite } \\
(\mathrm{n}=4)\end{array}$ & Goethite vein \\
\hline $\mathrm{S}$ & 38.1 & 51.6 & 34.3 & 33.2 & 2.23 \\
$\mathrm{Fe}$ & 61.2 & 46.1 & 30.2 & 7.2 & 53.7 \\
$\mathrm{Cu}$ & 0.05 & 0.32 & 34.4 & 0.26 & 0.08 \\
$\mathrm{Zn}$ & 0.02 & 0.02 & 0.05 & 58.6 & 4.17 \\
$\mathrm{Co}$ & 0.09 & 0.07 & 0.04 & 0.01 & 0.05 \\
$\mathrm{Se}$ & 0.02 & 0.02 & 0.01 & 0.02 & 0 \\
$\mathrm{Mn}$ & 0 & 0 & 0 & 0.02 & 0.06 \\
Total & 99.4 & 98.1 & 99.0 & 99.3 & 60.5 \\
\hline
\end{tabular}

\section{Example}

The Mineral Belt of Central Virginia includes over 20 abandoned mines and prospects that worked Kuroko-type massive sulfide deposits. Despite the relatively humid climate of this region where precipitation $(>1,000 \mathrm{~mm} / \mathrm{yr})$ exceeds evaporation, summer droughts occur (Bailey, 1995). During dry periods, efflorescent salts form where capillary action draws metal-rich solutions to the surface. Dagenhart (1980) documented over 20 different secondary sulfate salts associated with massive sulfide mine waste along Contrary Creek in Virginia, and showed that no other metal source could explain the rapid chemical response of the creek to rainfall. Recent (2000) visits to Contrary Creek confirm that salts continue to form in protected areas (fig. 4a) and in dry periods, on tailings surfaces that line the creek (fig. 4b). SEM and XRD show well-developed crystals of copiapite, melanterite, halotrichite (figs. $4 \mathrm{c}$ and d) and other minerals that continue to form and impact the creek some twenty years after unsuccessful and limited attempts at reclamation along the creek.

The Valzinco mine, north of Contrary Creek and in a different watershed, was mined intermittently for lead, zinc, and minor copper from 1914 until the 1940s. Underground workings included five mine levels and more than $5,000 \mathrm{ft}$ of workings (Grosh, 1949). Ore was processed on-site in a flotation plant. Fine-grained tailings from the 1940s mining operations were deposited in and along Knights Branch, a perennial stream (fig. 4e), resulting in an impacted area of about 10 acres. Tailings in and adjacent to Knights Branch and acid seeps from underground workings have impacted the stream. Oxidized tailings surfaces adjacent to the creek are highly acidic (fig. 4e) and Knights Branch is elevated in dissolved iron, lead, manganese, and zinc as it flows through the Valzinco mine site. The state of Virginia is currently implementing a project to restore Knights Branch and reclaim and revegetate more than 10 acres of disturbed lands (MVTechnologies Inc., 1998). Tailings were inspected (by Hammarstrom) during site visits to the Valzinco site in April, July, September, and December of 1999. In July, thick encrustations of 


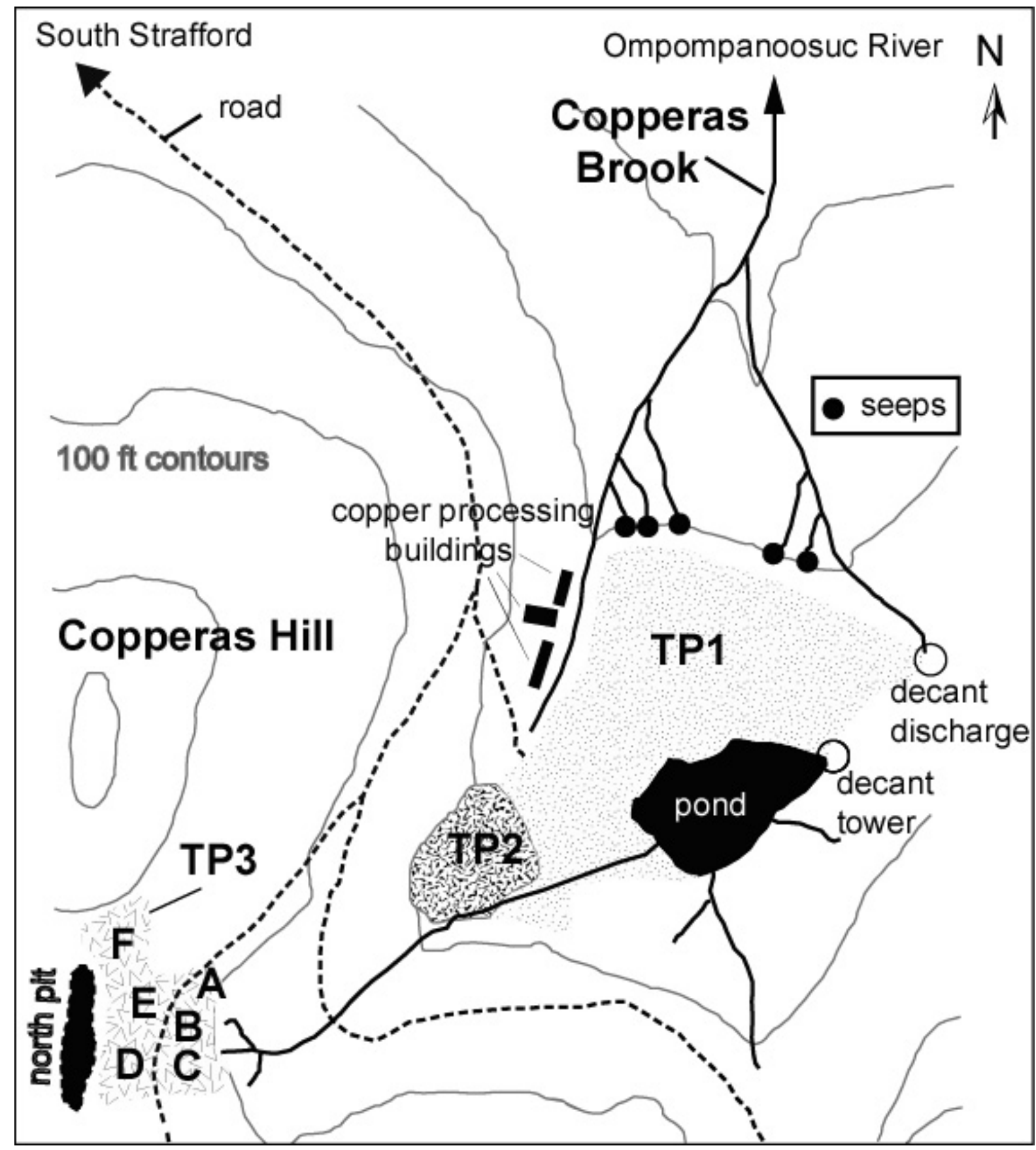

Figure 3. Mine waste and flotation tailings at the abandoned Elizabeth copper mine, VT. $\underline{A}$, Site map showing the relative size and distribution of solid materials that impact Copperas Brook. TP1 and TP2 represent flotation tailings from $20^{\text {th }}$ century mining. TP3 consists of heterogeneous piles of mine waste from $19^{\text {th }}$ century mining and copperas processing. See table 8a for descriptions of individual piles. 
$\underline{\mathrm{B}}$

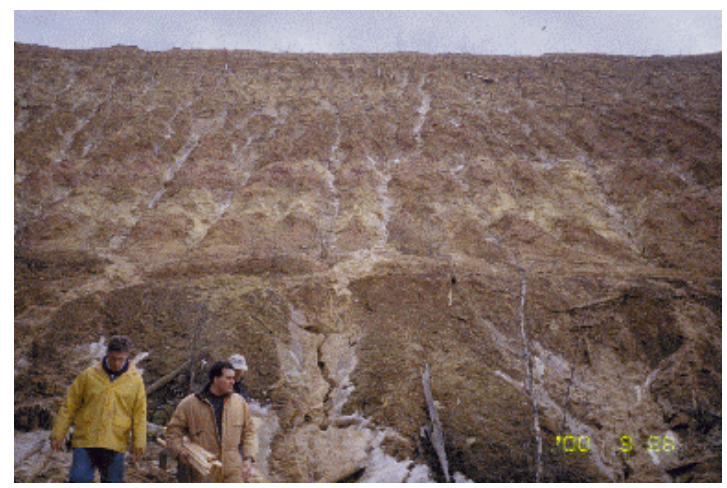

$\underline{\mathrm{D}}$

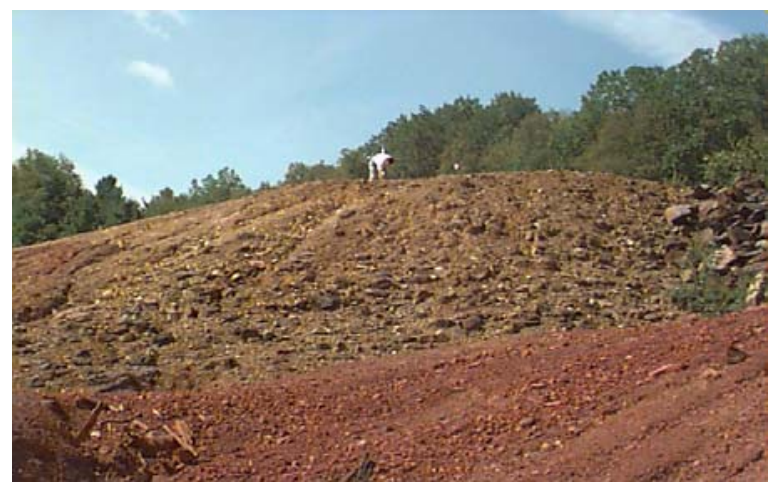

$\underline{\mathrm{C}}$

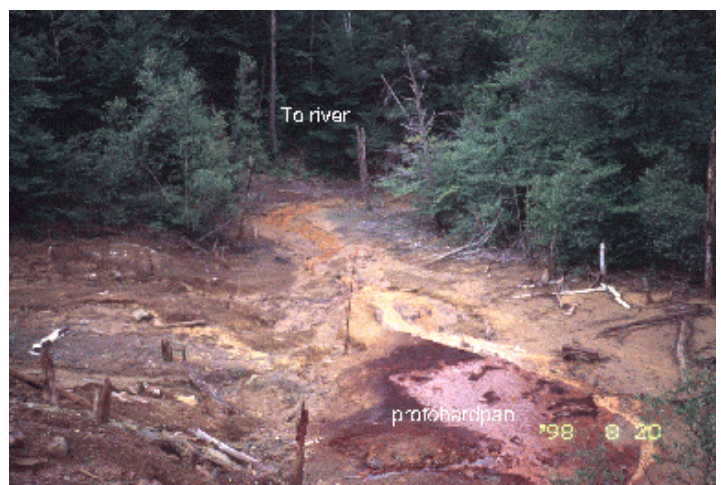

$\underline{E}$

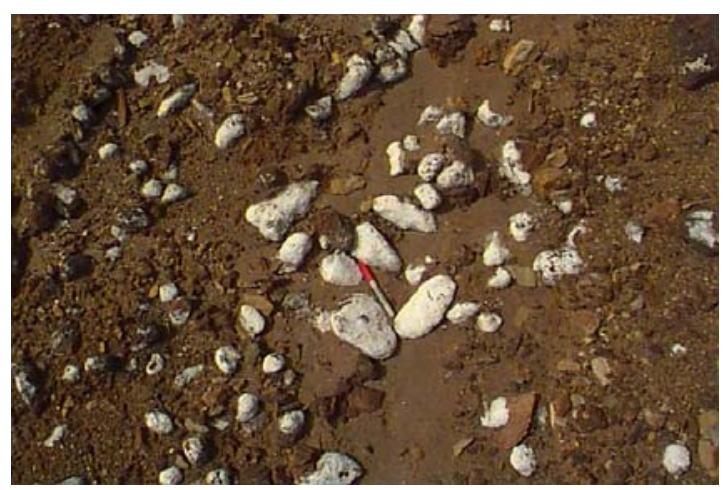

Figure 3. B, Deeply eroded, bare north slope of TP1 above seeps. $\underline{C}$, Ochres precipitating at seeps at base of TP1. D, TP3-D (yellow-brown pile in center of photo) and TP3-E (red pile in foreground). E, Close-up of melanterite-rozenite "snowballs" on weathered ore that litters TP3-F. Salts are observed on hot, dry days; they disappear when it rains.

white, yellow, and locally blue efflorescent salts coated tailings exposed in walls of a former settling pond adjacent to the flotation plant (fig. 4f, g). XRD, SEM, and EMP were used to identify the salts, which include halotrichitepickeringite, goslarite, hexahydrite, and melanterite.

Composite 20-gram salt samples from two sites along Contrary Creek and from Valzinco were dissolved in 400 $\mathrm{mL}$ of deionized water overnight. The solution $\mathrm{pH}$ was measured after 30 minutes, 60 minutes, 12 hours, and 24 hours. The solutions were filtered through 0.45 - micron nitrocellulose filters, and analyzed by inductively coupled plasma-mass spectrometry (ICP-MS) to characterize metal sequestration in readily soluble efflorescent salts. Results are listed in table 9. In all three samples, $\mathrm{pH}$ decreased (from the $\mathrm{pH}$ of 6.8 of the deionized water solvent) and conductivity increased over a 24 -hour period. The most dramatic changes came in the first 30 minutes, attesting to the rapid kinetics of dissolution of these minerals. Significant concentrations of metals known to impact aquatic ecosystems such as iron, aluminum, copper, zinc, and cadmium are sequestered in these salts, as well as sulfate. Cadmium concentrations increase with increasing zinc. Dissolved lead is an order of magnitude lower than other base metals, even at Valzinco which was mined for lead and zinc, reflecting the relatively low mobility of lead and low solubility of secondary lead minerals. These data emphasize the need for turning off sources of metals and acidity by removal and(or) capping of exposed mine waste in addition to diverting or treating mine effluents and surface waters for effective site remediation even in relatively wet climates.

\section{Ochres and other precipitates}

Precipitates of iron, aluminum, or manganese provide clues to water chemistry. These precipitates can sequester metals by cation sorption processes and release sorbed metals as $\mathrm{pH}$ fluctuates. Flocculates and slimes of these 
minerals can form a blanket of poorly crystalline very fine-grained sediment on stream beds and coat rocks and organic matter (twigs, leaves) along streams and seeps. Sampling is best accomplished using some sort of vacuum device or pump, such as a turkey baster or a large syringe because the material tends to float away as soon as it is disturbed. Repeated operations of the sampling device are usually necessary to obtain a large enough sample; sample increments can be placed in a large plastic bottle, allowed to settle, and then excess water can be decanted to concentrate the solid material. Alternatively, rocks coated with the material can be placed in a plastic container with native water, and the precipitates can then be shaken off, decanted, and air-dried. Samples are air dried at room temperature in the lab or freeze dried. In many cases, these materials are amorphous or very poorly crystalline and produce very poor x-ray diffraction patterns (especially ferrihydrite and schwertmannite). SEM is useful for confirming the presence or absence of sulfur and for identifying aluminum in oxyhyroxide and hydroxysulfate minerals.

\section{Example}

A variety of different precipitates are observed at the Elizabeth mine (Hammarstrom and others, 1999). Goethite-rich hardpan layers up to several $\mathrm{cm}$ thick within tailings represent paleosurfaces or in-situ development of cemented layers. Precipitates that range from slimes to protohardpans to hardpans form at seeps at the base of tailings and downstream along the length of Copperas Brook (Fig. 3a). Goethite, schwertmannite, and jarosite occur in these harpdans (Fig. 3c). XRD (fig. 5a) patterns show the diffuse, broad peaks typical of the iron-rich ochre minerals. Although the iron contents of these ochres remains nearly constant downstream from the mine working (about $40 \mathrm{wt} . \% \mathrm{Fe}$ ), base metal concentrations increase(fig. 5a). Jarosite is most prevalent near the seeps (but not necessarily precipitating from the seeps) where it locally forms a nearly pure, yellow muck at the base of the tailings pile. EDX spectra on jarosite analyzed by SEM confirm that the jarosite contains potassium. The seeps discharge near-neutral waters rich in ferrous iron and dissolved sulfate $(>600 \mathrm{mg} / \mathrm{L})$. Jarosite is stable under relatively narrow conditions of low $\mathrm{pH}$ and high dissolved sulfate, and should transform to ferric oxyhydroxide with increasing $\mathrm{pH}$. Ferrous iron oxidizes and hydrolyzes rapidly as the waters emerge from the seeps, precipitating ochre minerals and causing stream $\mathrm{pH}$ to drop to values of about 3 . Lime added to the flotation process and (or) chemical processes operating within the tailings may contribute to the neutral waters at the seeps; white slime precipitates collected on leaf litter in the area of the seeps dried to crystalline gypsum, indicating that calcium is mobile in this environment. Since lime, $\mathrm{Ca}(\mathrm{OH})_{2}$, is highly soluble in water, it has likely washed out of the tailings in the 40 years since the mine closed and lost any neutralization potential. The ochres were sampled in August during low flow and high evaporation. The metal load sequestered in these fine-grained sediments may vary over the course of a year.

Along the Ompompanoosuc River upstream from the confluence of Copperas Brook, a former mine ventilation shaft discharges groundwater ( $\mathrm{pH} \mathrm{5)} \mathrm{from} \mathrm{underground} \mathrm{workings.} \mathrm{The} \mathrm{discharge} \mathrm{pipe} \mathrm{is} \mathrm{grated,} \mathrm{and} \mathrm{the} \mathrm{grate} \mathrm{is}$ encrusted with a thick coating of white and orange precipitate (fig. 5b). The white material is an essentially amorphous aluminum-rich material that is too poorly crystalline to characterize by XRD. EDX spectra document the aluminum-rich nature of the white slime, and show that it also contains minor silicon, iron, and sulfur (fig, 5c). The occurrence of aluminous precipitates at around $\mathrm{pH} 5$ is consistent with other studies that note that aluminum minerals typically precipitate where acidic $(\mathrm{pH}<5)$ and near-neutral waters mix. We have observed such "white slimes" in a number of other locations where acidic tributaries or seeps discharge into near-neutral streams. Such precipitates are also known as "white death" because of their toxicity to fish (Witters and others, 1996). In some cases, we observe "white slimes" at the same location as ocherous precipitates, where they form separate layers but are difficult to sample as discrete phases. These situations probably indicate fluctuations in $\mathrm{pH}$ or other variables at the site over time. Geochemical analysis of a bulk sample of white vent precipitate confirms that it is Al-rich (4.5\% $\mathrm{Al})$, contains moderate Fe (14 wt. \%), significant silicon (28 wt.\%) and manganese (0.5 wt. \%) and greater concentration of base metals $(585 \mathrm{ppm})$ than the iron-rich ochres along Copperas Brook (fig. 5a). Iron-rich precipitates at the air vent are comparable to the stream ochres in iron content (44 wt. \%), but have significantly higher concentrations of base metals $(3,000 \mathrm{ppm})$. These data identify a source of metal-rich fine sediment that enters the river upstream of the confluence of the creek. Dissolution of precipitates will release sorbed metals as dissolved species in the river; dissolution and reprecipitation of these phases effectively recycle dissolved metals and depending on the extent of these processes over the course of a year, may produce pulses in metal loads that would be difficult to characterize unless water quality was monitored on a continuous basis. Although the creek that drains the mine workings is the most visible source of impact on the river, the air vent discharge also affects river water quality. 
Table 8a. Characteristics of Elizabeth mine waste piles.

[Measurements are for 30-increment surface soil samples $(<2 \mathrm{~mm}$ fraction) composited over the pile described; see fig. 3a for locations of piles]

\begin{tabular}{|c|c|c|c|c|}
\hline Sample & Description & Munsell color & Mineralogy & Paste $\mathrm{pH}$ \\
\hline TP3-A & $\begin{array}{l}\text { Northernmost pile east of the road } \\
\text { characterized by a yellow-brown soil } \\
\text { color. }\end{array}$ & $\begin{array}{l}\text { yellow } \\
2.5 \mathrm{Y} 7 / 6\end{array}$ & jarosite + quartz & 2.4 \\
\hline TP3-B & $\begin{array}{l}\text { Central pile east of road; appears to be } \\
\text { site of historic processing. Surface soil } \\
\text { is very heterogeneous, local blue-green } \\
\text { iridescent copper coatings on slag(?). } \\
\text { Red to black soil on pile surface. }\end{array}$ & $\begin{array}{l}\text { dark reddish } \\
\text { brown } \\
5 \text { YR } 3 / 2\end{array}$ & hematite + quartz & 2.6 \\
\hline TP3-C & $\begin{array}{l}\text { Southernmost pile east of the road. } \\
\text { Surface runoff from this pile directly } \\
\text { affects water sample site LIZM13. Red } \\
\text { to orange soil with white salts. }\end{array}$ & $\begin{array}{l}\text { reddish brown } \\
2.5 \mathrm{Y} 4 / 4\end{array}$ & $\begin{array}{l}\text { hematite }+ \text { quartz }+ \\
\text { mica }+ \text { feldspar }\end{array}$ & 2.6 \\
\hline TP3-D & $\begin{array}{l}\text { Southernmost pile west of the road. } \\
\text { Yellow-brown soil similar to TP3-A. }\end{array}$ & $\begin{array}{l}\text { brownish } \\
\text { yellow } \\
\text { 10YR } 6 / 8\end{array}$ & jarosite + quartz & 2.1 \\
\hline TP3-E & $\begin{array}{l}\text { Central pile west of road. Red soil with } \\
\text { some black material, but lacks the } \\
\text { slag(?) noted on TP3-B. }\end{array}$ & $\begin{array}{l}\text { red } \\
2.5 \mathrm{YR} 4 / 6\end{array}$ & $\begin{array}{l}\text { hematite }+ \text { quartz }+ \\
\text { mica }\end{array}$ & 3.2 \\
\hline TP3-F & $\begin{array}{l}\text { Northernmost pile west of the road and } \\
\text { adjacent to the north end of the north } \\
\text { pit. Orange soil littered with salt-coated } \\
\text { ("snowballs") loose pieces of weathered } \\
\text { ore. }\end{array}$ & $\begin{array}{l}\text { yellowish } \\
\text { brown } \\
10 \text { YR } 5 / 6\end{array}$ & $\begin{array}{l}\text { mica }+ \text { quartz }+ \\
\text { jarosite }+ \text { goethite }\end{array}$ & 2.2 \\
\hline TP2-1 & $\begin{array}{l}\text { Partially vegetated, flat top of tailings } \\
\text { pile } 2 .\end{array}$ & $\begin{array}{l}\text { strong brown } \\
7.5 \mathrm{YR} 5 / 8\end{array}$ & $\begin{array}{l}\text { jarosite }+ \text { quartz }+ \\
\text { mica }+ \text { plagioclase } \\
\text { feldspar }\end{array}$ & 5.5 \\
\hline TP2-2 & $\begin{array}{l}\text { Bare, eroded north slope of tailings pile } \\
2 \text {. }\end{array}$ & $\begin{array}{l}\text { strong brown } \\
7.5 \text { YR } 5 / 8\end{array}$ & $\begin{array}{l}\text { jarosite }+ \text { goethite }+ \\
\text { quartz }+ \text { plagioclase } \\
\text { feldspar }+ \text { mica }\end{array}$ & 3.2 \\
\hline TP1-1 & $\begin{array}{l}\text { Bare area of flat top of tailings pile } 1 \\
\text { adjacent to the pond. }\end{array}$ & $\begin{array}{l}\text { strong brown } \\
7.5 \mathrm{YR} 5 / 8\end{array}$ & $\begin{array}{l}\text { quartz }+ \text { mica }+ \\
\text { goethite }+ \text { jarosite }\end{array}$ & 3 \\
\hline TP1-2 & $\begin{array}{l}\text { Vegetated area on flat top of tailings } \\
\text { pile } 1 .\end{array}$ & $\begin{array}{l}\text { strong brown } \\
7.5 \text { YR } 5 / 8\end{array}$ & $\begin{array}{l}\text { quartz }+ \text { mica }+ \\
\text { goethite }+ \text { jarosite }\end{array}$ & 5.9 \\
\hline TP1-3 & $\begin{array}{l}\text { Steep, bare eroded north slope of } \\
\text { tailings pile } 1 \text { with seeps along the base. }\end{array}$ & $\begin{array}{l}\text { strong brown } \\
7.5 \text { YR } 5 / 8\end{array}$ & $\begin{array}{l}\text { quartz }+ \text { mica }+ \\
\text { goethite }+ \text { jarosite }\end{array}$ & 2.8 \\
\hline
\end{tabular}


Table 8b. Heavy metals in Elizabeth mine waste piles $(<2 \mathrm{~mm}$ composite surface materials) in parts per million. [References values from Alloway, 1999. Critical values $=$ total soil concentration ranges above which plant toxicity is considered to be possible. n.d., not determined. Values in excess of upper range values for both normal and critical concentrations are shown in boldface.]

\begin{tabular}{|c|c|c|c|c|c|c|c|}
\hline \multicolumn{3}{|c|}{ Reference soil values (not near orebodies) } & \multicolumn{5}{|c|}{ Elizabeth mine pre-1958 tailings (oxidized surface material) } \\
\hline Element & $\frac{\text { Normal range in }}{\underline{\text { soils }}}$ & $\frac{\text { Critical }}{\text { values }}$ & $\underline{\mathrm{TP} 1-1}$ & TP1-2 & $\underline{\mathrm{TP} 1-3}$ & $\underline{\text { TP2-1 }}$ & $\underline{\mathrm{TP} 2-2}$ \\
\hline $\mathrm{Ag}$ & $\overline{0.01-8}$ & 2 & 1.8 & 0.87 & 1.8 & 0.81 & 0.58 \\
\hline As & $0.1-40$ & $20-50$ & 5.9 & 6.2 & 9.7 & 5.6 & 14 \\
\hline $\mathrm{Au}$ & $0.001-0.02$ & - & n.d. & n.d. & 0.014 & 0.16 & 0.029 \\
\hline $\mathrm{Cd}$ & $0.01-2.0$ & $3-8$ & 0.4 & 0.2 & 0.2 & 0.2 & 0.3 \\
\hline Co & $0.5-65$ & $25-50$ & 26 & 38 & 29 & 48 & 68 \\
\hline $\mathrm{Cr}$ & $5-1,500$ & $75-100$ & 72 & 91 & 57 & 93 & 48 \\
\hline $\mathrm{Cu}$ & $2-250$ & $60-125$ & 680 & 120 & 120 & 230 & 96 \\
\hline $\mathrm{Hg}$ & $0.01-0.5$ & $0.3-5$ & 0.05 & 0.02 & 0.05 & 0.04 & 0.11 \\
\hline $\mathrm{Mn}$ & $20-10,000$ & $1,500-3,000$ & 270 & 600 & 410 & 490 & 650 \\
\hline Mo & $0.1-40$ & 2-10 & 15 & 6.4 & 16 & n.d. & n.d. \\
\hline $\mathrm{Ni}$ & $2-750$ & 100 & 9 & 31 & 12 & 16 & 21 \\
\hline $\mathrm{Pb}$ & $2-300$ & $100-400$ & 49 & 33 & 50 & 42 & 45 \\
\hline $\mathrm{Sb}$ & $0.2-10$ & $5-10$ & $<0.1$ & $<0.1$ & 0.2 & $<0.1$ & 0.1 \\
\hline $\mathrm{Se}$ & $0.1-5$ & $5-10$ & 22 & 11 & 31 & n.d. & n.d \\
\hline $\mathrm{Sn}$ & $1-200$ & 50 & n.d. & n.d. & n.d. & n.d. & n.d. \\
\hline $\mathrm{Tl}$ & $0.1-0.8$ & 1 & $<0.1$ & $<0.1$ & 0.8 & 0.8 & 0.7 \\
\hline $\mathrm{U}$ & $0.7-9$ & - & 0.52 & 1.2 & 0.5 & n.d. & n.d. \\
\hline V & $3-500$ & $50-100$ & 76 & 93 & 83 & 100 & 84 \\
\hline W & $0.5-83$ & - & n.d. & n.d. & n.d. & n.d. & n.d. \\
\hline $\mathrm{Zn}$ & $1-900$ & $70-400$ & 300 & 320 & 380 & 370 & 450 \\
\hline
\end{tabular}


Table 8b. (cont.)

\begin{tabular}{|c|c|c|c|c|c|c|c|c|}
\hline \multicolumn{3}{|c|}{ Reference soil values (not near orebodies) } & \multicolumn{6}{|c|}{ Elizabeth mine older waste dumps (oxidized surface material) } \\
\hline$\underline{\text { Element }}$ & $\frac{\text { Normal range }}{\text { in soils }}$ & $\underline{\text { Critical values }}$ & $\underline{\mathrm{TP} 3-\mathrm{A}}$ & $\underline{\mathrm{TP} 3-\mathrm{B}}$ & $\underline{\mathrm{TP}} 3-\mathrm{C}$ & $\underline{\text { TP3-D }}$ & $\underline{\mathrm{TP} 3-\mathrm{E}}$ & $\underline{\mathrm{TP} 3-\mathrm{F}}$ \\
\hline $\mathrm{Ag}$ & $\frac{\text { in soils }}{0.01-8}$ & 2 & 3.3 & 8.9 & 24.2 & 7 & 11.8 & 10.7 \\
\hline As & $0.1-40$ & $20-50$ & 4 & 10 & 25 & 8 & 20 & 16 \\
\hline $\mathrm{Au}$ & $0.001-0.02$ & - & n.d. & n.d. & n.d. & n.d. & n.d. & n.d \\
\hline $\mathrm{Cd}$ & $0.01-2.0$ & $3-8$ & 0.2 & 2 & 0.8 & 0.3 & 1.1 & 1.3 \\
\hline $\mathrm{Co}$ & $0.5-65$ & $25-50$ & 5 & 100 & 30 & 9.2 & 41 & 22 \\
\hline $\mathrm{Cr}$ & $5-1,500$ & $75-100$ & 100 & 41 & 81 & 65 & 68 & 62 \\
\hline $\mathrm{Cu}$ & $2-250$ & $60-125$ & 1,800 & 2,100 & 1,100 & 3,200 & 850 & 6,600 \\
\hline $\mathrm{Hg}$ & $0.01-0.5$ & $0.3-5$ & 0.23 & 0.08 & 0.51 & 0.17 & 0.35 & 0.24 \\
\hline $\mathrm{Mn}$ & $20-10,000$ & $1,500-3,000$ & 170 & 65 & 220 & 230 & 170 & 83 \\
\hline Mo & $0.1-40$ & $2-10$ & 27 & 34 & 100 & 47 & 67 & 56 \\
\hline $\mathrm{Ni}$ & $2-750$ & 100 & $<2$ & 26 & 8 & $<2$ & 9.2 & 3 \\
\hline $\mathrm{Pb}$ & $2-300$ & $100-400$ & 87 & 51 & 120 & 61 & 84 & 76 \\
\hline $\mathrm{Sb}$ & $0.2-10$ & 5-10 & $<0.1$ & 0.1 & 0.2 & $<0.1$ & .1 & .2 \\
\hline $\mathrm{Se}$ & $0.1-5$ & $5-10$ & 39 & 45 & 170 & 55 & 100 & 75 \\
\hline $\mathrm{Sn}$ & $1-200$ & 50 & n.d. & n.d. & n.d. & n.d. & n.d. & n.d. \\
\hline $\mathrm{Tl}$ & $0.1-0.8$ & 1 & $<0.1$ & $<0.1$ & $<0.1$ & $<0.1$ & $<0.1$ & $<0.1$ \\
\hline $\mathrm{U}$ & $0.7-9$ & - & 0.2 & 0.3 & 0.4 & 0.2 & 0.4 & 0.4 \\
\hline V & $3-500$ & $50-100$ & 90 & 32 & 84 & 78 & 70 & 83 \\
\hline W & $0.5-83$ & - & n.d. & n.d. & n.d. & n.d. & n.d. & n.d. \\
\hline $\mathrm{Zn}$ & $1-900$ & $70-400$ & 170 & 1,200 & 350 & 200 & 400 & 420 \\
\hline
\end{tabular}

$\underline{\text { Stream sediments }}$

Stream sediment samples are, by nature, composite samples. The statistical procedure outlined by Smith and others (2000) for sampling mine waste can also be applied to stream sediments (i.e., a 30-increment sample). In USGS geoenvironmental studies, stream sediments are collected by defining a stretch of the stream as the sampling area (typically 30 meters or less) and sampling the uppermost sediment from the sides and center of streams (where possible). Samples are collected with a plastic or stainless steel scoop, and wet sieved through a solder-free 10 mesh screen $(<2 \mathrm{~mm})$ into a gold pan. Excess water is drained off and the wet sediment is placed in a double thickness of plastic zip-lock bags for transport to the lab. In the lab, the sediment is spread out on a tray (plastic paint pans work well for this) and air-dried - a process that can take more than a week. The bulk sample is weighed, and the $<80$ mesh $(<177 \mu \mathrm{m})$ material is sieved out, weighed, and pulverized for chemical analysis, typically by multi-element ICP-AES and other methods (for gold, mercury, etc.) as warranted by the study. The $<80$ mesh sample fraction is used because this is the sediment fraction most likely to include the fine-grained materials that can sorb metals, interact with benthic organisms, physically affect aquatic ecosystems by increasing turbidity, and be transported farthest downstream from source areas. Stream sediments reflect the geology of the drainage area. Mineral deposits can superimpose a suite of metals on the regional chemical signature. Many types of mineral deposits have distinctive geochemical signatures that can be manifested in associated altered rocks, soils, or stream sediments (Cox and Singer, 1986; du Bray, 1995). Geochemical backgrounds are difficult to establish, especially in areas that have been disturbed by human activities. Geochemical baselines (measured at a point in time) are what can usually be measured. Data from watersheds that drain the same lithology, but are not affected by mining (but may contain unexploited mineral deposits) can be used to approximate background. Acquisition of pre-mining baseline data can provide guidelines for establishing realistic post-mining reclamation goals for both water and sediments. 
$\underline{\mathrm{A}}$

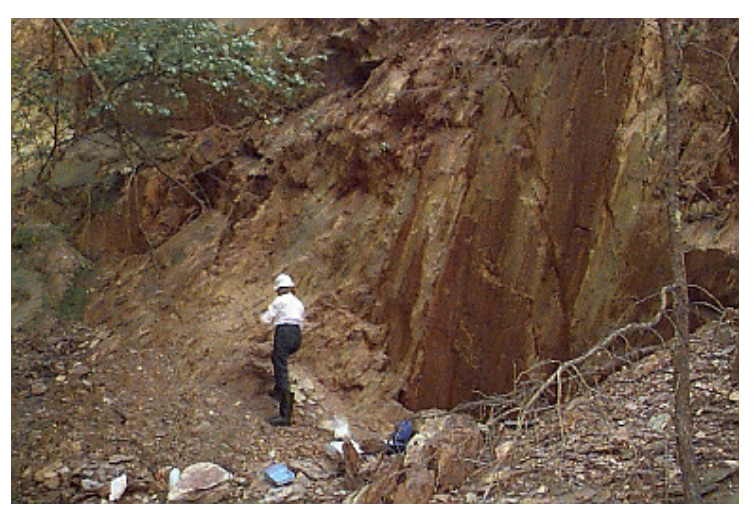

$\underline{\mathrm{C}}$

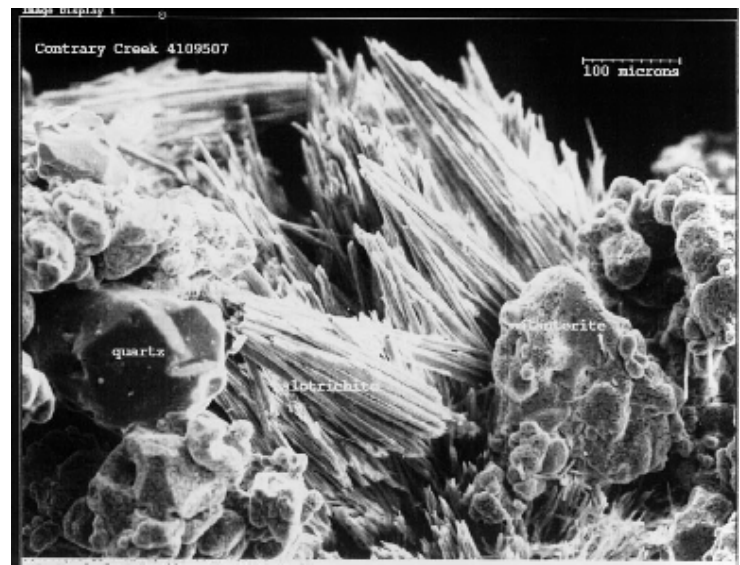

$\underline{\mathrm{B}}$

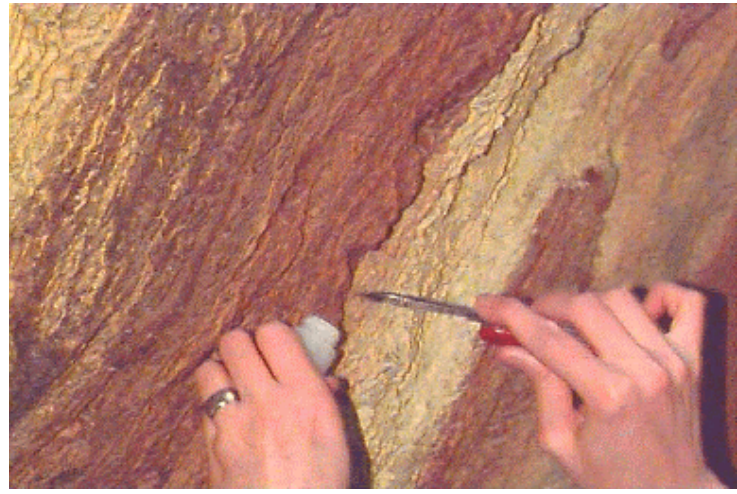

$\underline{\mathrm{D}}$

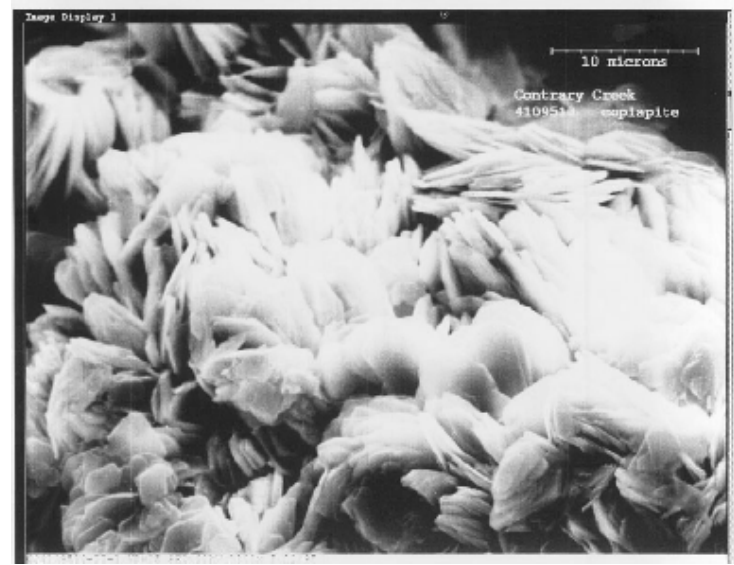

Figure 4. Efflorescent salt minerals along a pit wall. $\underline{\text { A }}$ Salts form colored vertical bands on outcrops under a protected overhang. $\underline{B}$, Sampling techniques. $\underline{\mathrm{C}}$, Secondary-electron SEM image showing needles of halotrichite intergrown with melanterite and quartz. $\underline{\mathrm{D}}$, Secondary-electron SEM image of copiapite crystals (yellow mineral shown in $\underline{B}$ ). 


\section{$\underline{E}$}

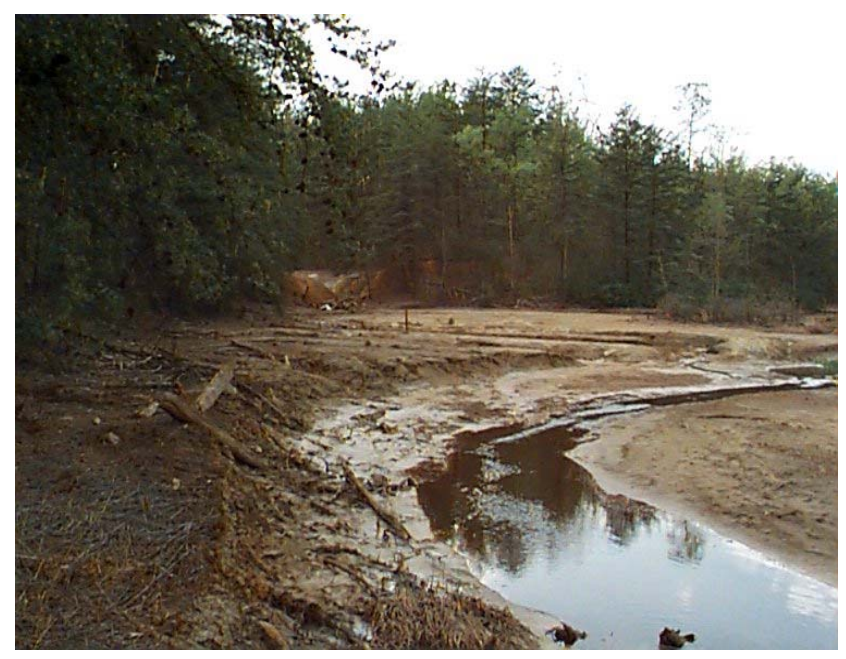

Figure 4. $\underline{\mathrm{E}}$, Knights Branch decreases in $\mathrm{pH}$ from about 6 to 4 as it flows through sulfide-rich (pyrite, sphalerite, galena, chalcopyrite) Valzinco mine tailings. F, Efflorescent salt minerals coating flotation tailings in the process water pit area at Valzinco. These salts were present on a hot, dry day in April, 1999 but were not observed on subsequent visits during more humid periods. $\underline{G}_{\text {. }}$ Close-up of salts on black, unoxidized tailings. Note pen for scale. XRD and SEM show that these salts include a variety of highly soluble hydrated $\mathrm{Al}, \mathrm{Mg}, \mathrm{Fe}$, and $\mathrm{Zn}$-bearing sulfate minerals including pickeringite and goslarite.
$\underline{F}$

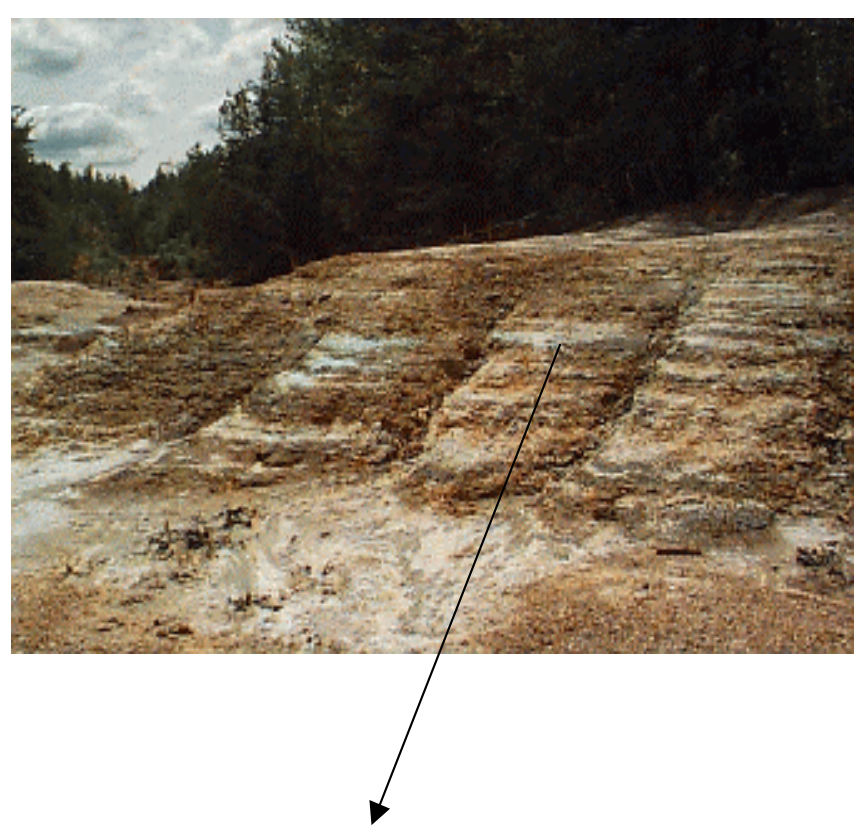

$\underline{\mathrm{G}}$

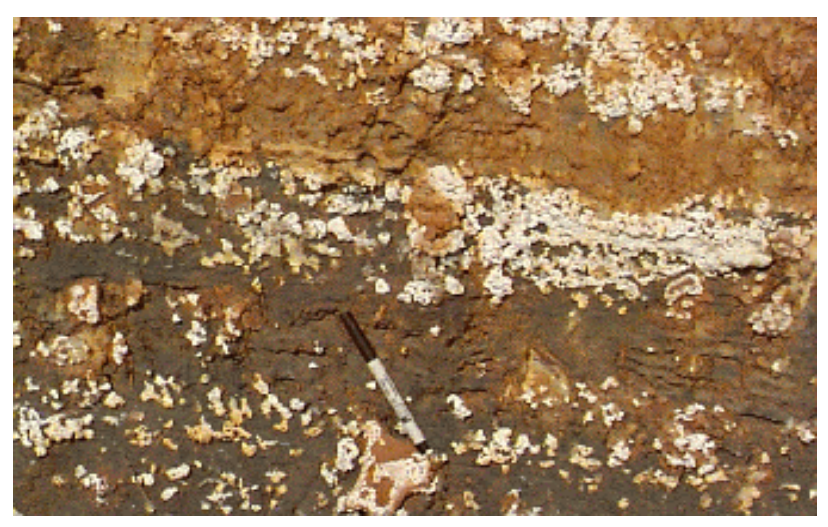


Table 9. Geochemical data for dissolved efflorescent salts collected at Kuroko-type massive sulfide deposits in Virginia.

[Solutions analyzed by ICP-MS; elements of particular environmental concern (Campbell and others, 1985) are highlighted in bold]

\begin{tabular}{|c|c|c|c|c|c|c|c|}
\hline \multirow{2}{*}{\multicolumn{2}{|c|}{$\begin{array}{r}\text { Valzinco } \\
\text { pH measurements }\end{array}$}} & \multirow{2}{*}{\multicolumn{2}{|c|}{$\underline{\text { Arminius }}$}} & \multicolumn{2}{|r|}{$\underline{\text { Valzinco }}$} & lphur & Arminius \\
\hline & & & & \multicolumn{3}{|c|}{ conductivity measurements $(\mathrm{mS} / \mathrm{cm})$} & \\
\hline 0 mins & 3.69 & 2.28 & 3.40 & 0 mins & 9.2 & 1.5 & 3.4 \\
\hline 30 mins & 3.18 & 2.34 & 3.13 & 30 mins & 12 & 7.1 & 7.5 \\
\hline $1 \mathrm{hr}$ & 3.18 & 2.42 & 3.03 & $1 \mathrm{hr}$ & 12 & 7.9 & 7.4 \\
\hline $12 \mathrm{hr}$ & 3.09 & 2.21 & 3.00 & $12 \mathrm{hr}$ & 12 & 8.9 & 7.6 \\
\hline $24 \mathrm{hr}$ & 3.07 & 2.20 & 2.98 & $24 \mathrm{hr}$ & 12 & 9.1 & 7.6 \\
\hline \multicolumn{8}{|c|}{ Dissolved metal concentrations in 24 hour leachates } \\
\hline \multicolumn{4}{|c|}{ Element (units) } & \multicolumn{2}{|c|}{ Element (units) } & & \\
\hline $\operatorname{Ag} \mu \mathrm{g} / \mathrm{L}$ & 0.1 & 0.03 & $<0.01$ & $\mathrm{Na} \mathrm{mg} / \mathrm{L}$ & 0.12 & 0.16 & 0.22 \\
\hline $\mathbf{A l} \mu \mathrm{g} / \mathrm{L}$ & $>30,000$ & $>30,000$ & $>30,000$ & $\mathrm{Nb} \mu \mathrm{g} / \mathrm{L}$ & 0.2 & 0.2 & 0.58 \\
\hline As $\mu \mathrm{g} / \mathrm{L}$ & & 120 & $<0.2$ & $\mathrm{Nd} \mu \mathrm{g} / \mathrm{L}$ & 510 & 1,400 & 500 \\
\hline $\mathrm{Au} \mu \mathrm{g} / \mathrm{L}$ & $<0.01$ & 0.01 & 0.05 & $\mathrm{Ni} \mu \mathrm{g} / \mathrm{L}$ & 970 & 110 & 160 \\
\hline $\mathrm{Ba} \mu \mathrm{g} / \mathrm{L}$ & 9.7 & 22 & 11 & $\mathrm{~Pb} \mu \mathrm{g} / \mathrm{L}$ & 460 & 5.2 & 7.4 \\
\hline $\mathrm{Be} \mu \mathrm{g} / \mathrm{L}$ & 42 & 9.5 & 33 & $\operatorname{Pr} \mu \mathrm{g} / \mathrm{L}$ & 160 & 410 & 120 \\
\hline $\mathrm{Bi} \mu \mathrm{g} / \mathrm{L}$ & 0.06 & 0.53 & $<0.01$ & $\mathrm{Rb} \mu \mathrm{g} / \mathrm{L}$ & 2.7 & 3.7 & 1.8 \\
\hline $\mathrm{Ca} \mathrm{mg/L}$ & 36 & 13 & 120 & $\operatorname{Re} \mu \mathrm{g} / \mathrm{L}$ & 0.1 & 0.06 & 0.04 \\
\hline $\mathbf{C d} \mu \mathrm{g} / \mathrm{L}$ & 6,900 & 13 & 2,600 & $\mathrm{Sb} \mu \mathrm{g} / \mathrm{L}$ & 1.0 & 0.4 & 0.75 \\
\hline $\mathrm{Ce} \mu \mathrm{g} / \mathrm{L}$ & 1,400 & 3,500 & 880 & $\mathrm{Sc} \mu \mathrm{g} / \mathrm{L}$ & 89 & 66 & 240 \\
\hline Co $\mu \mathrm{g} / \mathrm{L}$ & 2,700 & 660 & 250 & $\mathrm{Se} \mu \mathrm{g} / \mathrm{L}$ & 23 & $<0.2$ & $<0.2$ \\
\hline $\mathrm{Cr} \mu \mathrm{g} / \mathrm{L}$ & 260 & 260 & 570 & $\mathrm{SiO}_{2} \mathrm{mg} / \mathrm{L}$ & 2 & $<0.5$ & 2 \\
\hline Cs $\mu \mathrm{g} / \mathrm{L}$ & 0.05 & 0.30 & 0.47 & $\mathrm{Sm} \mu \mathrm{g} / \mathrm{L}$ & 110 & 300 & 150 \\
\hline $\mathbf{C u} \mu \mathrm{g} / \mathrm{L}$ & 59,000 & 4,400 & 88,000 & $\mathrm{Sn} \mu \mathrm{g} / \mathrm{L}$ & $<0.05$ & 1 & 0.1 \\
\hline Dy $\mu \mathrm{g} / \mathrm{L}$ & 43 & 110 & 120 & $\mathrm{SO}_{4} \mathrm{mg} / \mathrm{L}$ & 7,200 & 5,000 & 5,100 \\
\hline $\operatorname{Er} \mu \mathrm{g} / \mathrm{L}$ & 20 & 42 & 58 & $\mathrm{Sr} \mu \mathrm{g} / \mathrm{L}$ & 11 & 8.1 & 82 \\
\hline $\mathrm{Eu} \mu \mathrm{g} / \mathrm{L}$ & 20 & 65 & 79 & $\mathrm{Ta} \mu \mathrm{g} / \mathrm{L}$ & 0.1 & 0.2 & $<0.02$ \\
\hline $\mathbf{F e} \mu \mathrm{g} / \mathrm{L}$ & $>200,000$ & $>200,000$ & 51,000 & $\mathrm{~Tb} \mu \mathrm{g} / \mathrm{L}$ & 9.7 & 24 & 20 \\
\hline $\mathrm{Ga} \mu \mathrm{g} / \mathrm{L}$ & $<0.02$ & 21 & $<0.02$ & $\mathrm{Te} \mu \mathrm{g} / \mathrm{L}$ & $<2$ & $<2$ & $<2$ \\
\hline $\mathrm{Gd} \mu \mathrm{g} / \mathrm{L}$ & 81 & 200 & 130 & $\mathrm{Th} \mu \mathrm{g} / \mathrm{L}$ & 260 & 860 & 160 \\
\hline $\mathrm{Ge} \mu \mathrm{g} / \mathrm{L}$ & $<0.02$ & $<0.02$ & $<0.02$ & $\mathrm{Ti} \mu \mathrm{g} / \mathrm{L}$ & 760 & 290 & 420 \\
\hline $\mathrm{Hf} \mu \mathrm{g} / \mathrm{L}$ & $<0.05$ & 0.76 & $<0.05$ & $\mathrm{Tl} \mu \mathrm{g} / \mathrm{L}$ & $<0.05$ & $<0.05$ & 0.2 \\
\hline Но $\mu \mathrm{g} / \mathrm{L}$ & 6.7 & 17 & 22 & $\mathrm{Tm} \mu \mathrm{g} / \mathrm{L}$ & 2.7 & 5.5 & 8.8 \\
\hline In $\mu \mathrm{g} / \mathrm{L}$ & 15 & 1.3 & 24 & $\mathrm{U} \mu \mathrm{g} / \mathrm{L}$ & 360 & 160 & 450 \\
\hline $\mathrm{K} \mu \mathrm{g} / \mathrm{L}$ & 180 & 340 & 160 & $\mathrm{~V} \mu \mathrm{g} / \mathrm{L}$ & 330 & 22 & 2 \\
\hline $\mathrm{La} \mu \mathrm{g} / \mathrm{L}$ & 520 & 850 & 330 & $\mathrm{~W} \mu \mathrm{g} / \mathrm{L}$ & 1.6 & 0.3 & $<0.02$ \\
\hline $\mathrm{Li} \mu \mathrm{g} / \mathrm{L}$ & 270 & 110 & 250 & $\mathrm{Y} \mu \mathrm{g} / \mathrm{L}$ & 180 & 350 & 490 \\
\hline $\mathrm{Mg} \mathrm{mg/L}$ & 600 & 250 & 460 & $\mathrm{Yb} \mu \mathrm{g} / \mathrm{L}$ & 20 & 37 & 52 \\
\hline $\mathbf{M n} \mu \mathrm{g} / \mathrm{L}$ & 77,000 & 23,000 & 35,000 & $\mathbf{Z n} \mu \mathrm{g} / \mathrm{L}$ & $>1,000,000$ & 1,300 & 610,000 \\
\hline Mo $\mu \mathrm{g} / \mathrm{L}$ & 0.73 & 0.86 & 0.08 & $\mathrm{Zr} \mu \mathrm{g} / \mathrm{L}$ & 3.1 & 92 & 2.6 \\
\hline
\end{tabular}


$\underline{\mathrm{A}}$
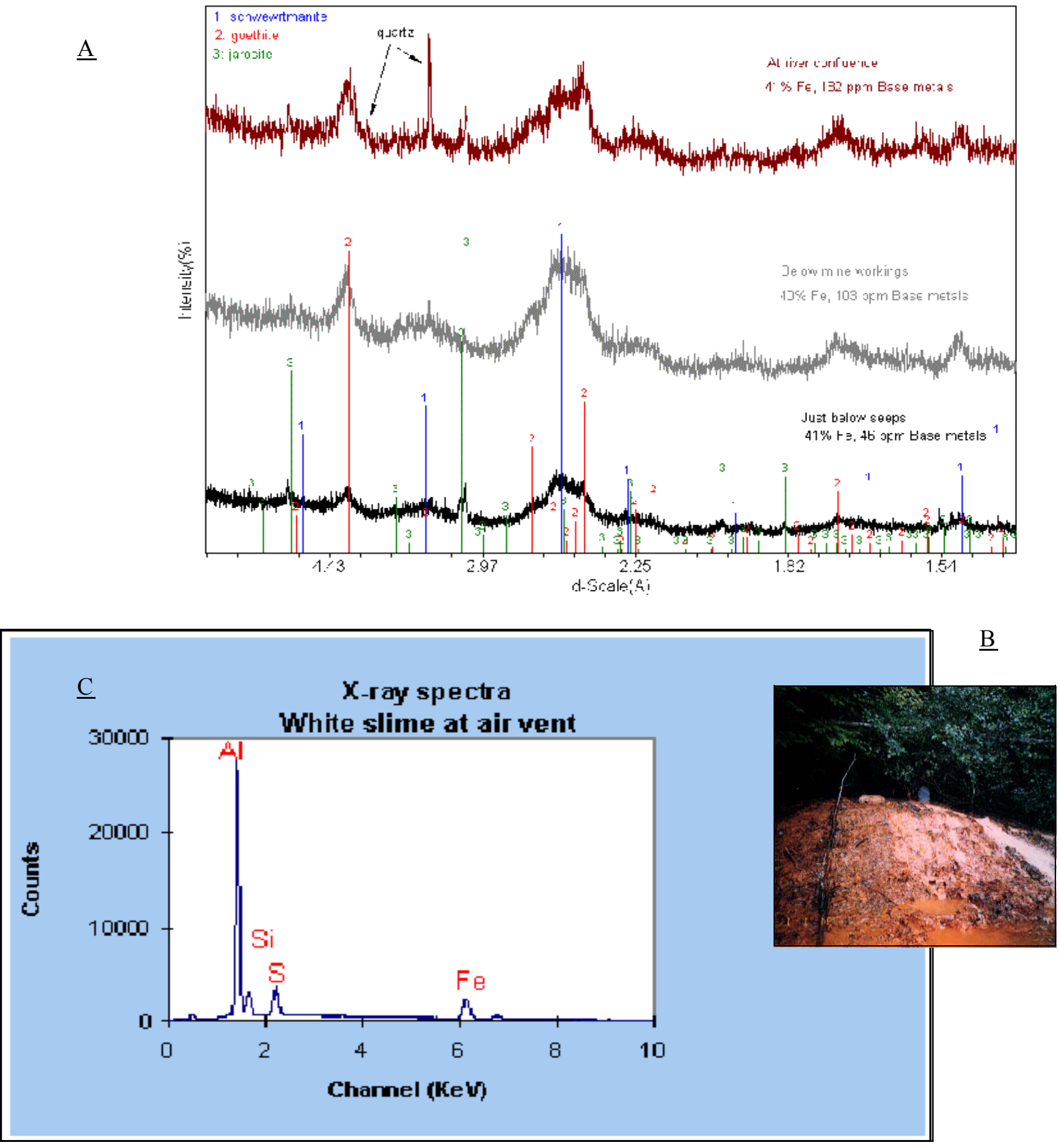

Figure 5. Ochre minerals. $\underline{\text { A }}$ XRD patterns of iron-rich precipitates in Copperas Brook below the Elizabeth mine (fig. 3). Note that base metals incorporated in these ochres increase downstream from the mine workings. $\underline{B}$, White slime at air vent, with a mount of white and red-orange precipitates that engulf leaf litter. $\underline{\mathrm{C}}$, Energy-dispersive spectrum of white slime analyzed by SEM shows that it is aluminum-rich, with minor silicon, iron, and sulfur. 
Stream sediment data can also be compared with crustal abundance values (Fortescue, 1992) or with ranges of element concentrations typical of a particular lithology (Rose and others, 1979). Contaminated stream sediments can affect aquatic ecosystems and human health because of their potential toxicity to benthic organisms and to humans who ingest organisms exposed to contaminated sediments (USEPA, 1997b). Sediments can serve as sources and sinks as well as reservoirs for heavy metals. The use of stream sediment data for aquatic life toxicity assessment is controversial and cannot substitute for bioassay toxicity data; different sediments can represent different degrees of bioavailability for the same total concentration of a trace metal (Di Toro and others, 1990). Nevertheless, stream sediment data provide a useful screening tool to alert investigators to areas that may need further detailed sampling. EPA's National Stream Sediment Survey (USEPA, 1997b, Appendix B) provides a discussion of different stream sediment quality chemical guidelines developed by comparing dry weight sediment metal concentrations with biological effects data, and caveats about the use of chemical data to assess toxicity. More recently, consensus-based stream sediment quality guidelines for freshwater ecosystems have been proposed (MacDonald and others, 2000). Consensus-based guidelines for 28 metals and organic compounds, are based on guidelines previously developed from comparisons of sediment chemistry with toxicity data collected in field studies. Two consensus-based values are reported for each potential contaminant: (1) the threshold effect concentration (TEC) is the concentration below which harmful effects are unlikely to be observed and (2) the probable effects concentration (PEC) is the concentration above which harmful effects are likely to be observed. These values provide a screening tool for more costly and time-consuming field toxicity studies.

\section{Example}

Mining occurred from the early 1800 's to the 1950 's at several sites along an 8-mile stretch of Contrary Creek in central Virginia. The mines along Contrary Creek (fig. 6a) represent stratabound massive sulfide deposits of the regionally extensive Gold-Pyrite Belt of the Virginia Piedmont province. Early mining targeted near-surface gossan iron ore and pyrite, and the most recent mining produced copper, lead, and zinc from underground workings. Gold was mined from surface workings along the northern part of the creek, and the locality continues to be a popular site for recreational placer mining. Tailings and mine waste are present along creek banks and eastern tributaries. Despite reclamation efforts in the 1970's, the water quality has not improved and the area continues to be of concern to state regulators of environmental quality. The creek turns sharply east just north of the Rt. 522 bridge. The Tinder gold placer mine operated along the creek just north of the bridge. A number of small pyrite mines operated in the early 1900's between the Arminius Mine and the headwaters of the creek, but these workings are overgrown and do not appear to have impacted Contrary Creek (Dagenhart, 1980).

Geochemical analysis of the $<80$ mesh fraction of stream sediments collected along Contrary Creek shows that concentrations of copper and lead exceed PEC stream sediment quality guidelines (table 10) at all localities downstream of mine workings and that the streambed sediments at the Arminius mines, where tailings line the stream bank, are a significant source of copper, lead, zinc, and arsenic. Mercury is below PEC guideline concentrations at all localities and exceeds TEC guidelines at only one locality, although it does exceed the headwaters (proxy for background) concentration at all localities downstream. Mercury was probably used in the early placer gold operations (fig. 6a). The stream bank tailings at the Arminius mine develop efflorescent salts during the summer and salts form in protected areas year-round at the Sulfur mine (fig. 4a-d). An acidic (pH 2.9) side drainage from the Boyd Smith mine is a significant source of iron (fig. 6b) in the creek streambed sediments. We also observed a white aluminous precipitate at the point in the stream where the acidic drainage mixed with the main creek flow ( $\mathrm{pH}$ 6.2). Just downstream of this confluence the creek $\mathrm{pH}$ measured 5.6. based probable effects concentration (above which harmful effects are likely to be observed) for metals in stream sediments in freshwater ecosystems (MacDonald and others, 2000).

Dagenhart (1980) identified the primary factors that affect stream water quality along Contrary Creek as (1) production of acid from oxidation of pyrite-rich tailings, (2) mobilization of heavy metals in the tailings, and (3) siltation from erosion of barren mine dumps. He concluded that without further reclamation activity or remining, water quality in Contrary Creek would continue to degrade for at least fifty years. Seal and others (1996) demonstrated that water quality at the Sulfur mine site has not improved in the twenty years since Dagenhart's $(\underline{1980})$ study. Microbiological, remote sensing and mineralogic analysis of Contrary Creek flocculates and precipitates (Robbins and others, 1996; Anderson and Robbins, 1998) document extensive development of poorly 


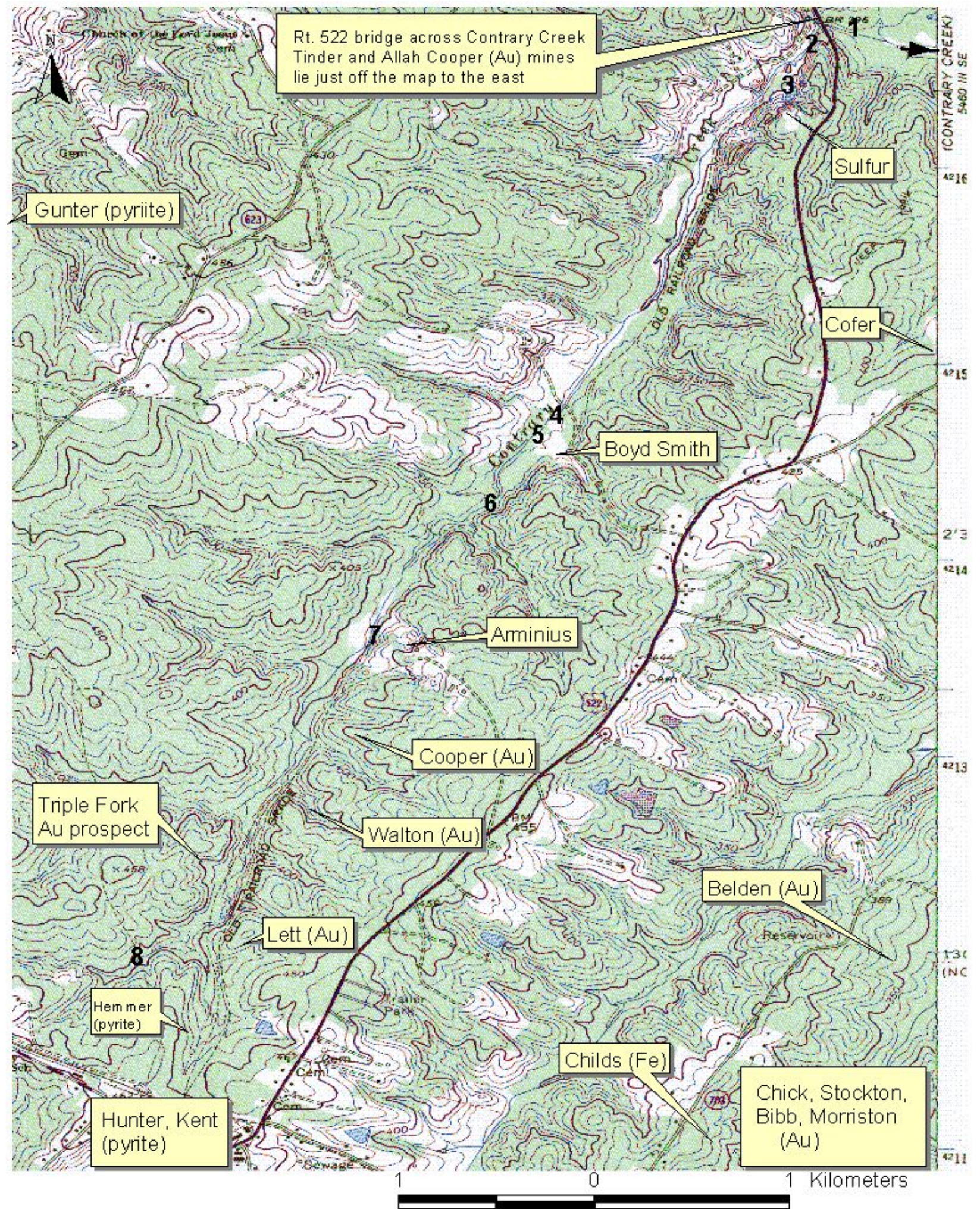

Figure 6a. Mines and prospects near Contrary Creek on the Mineral, VA.7.5' quadrangle. Stream sediments were sampled at localities 1-8 

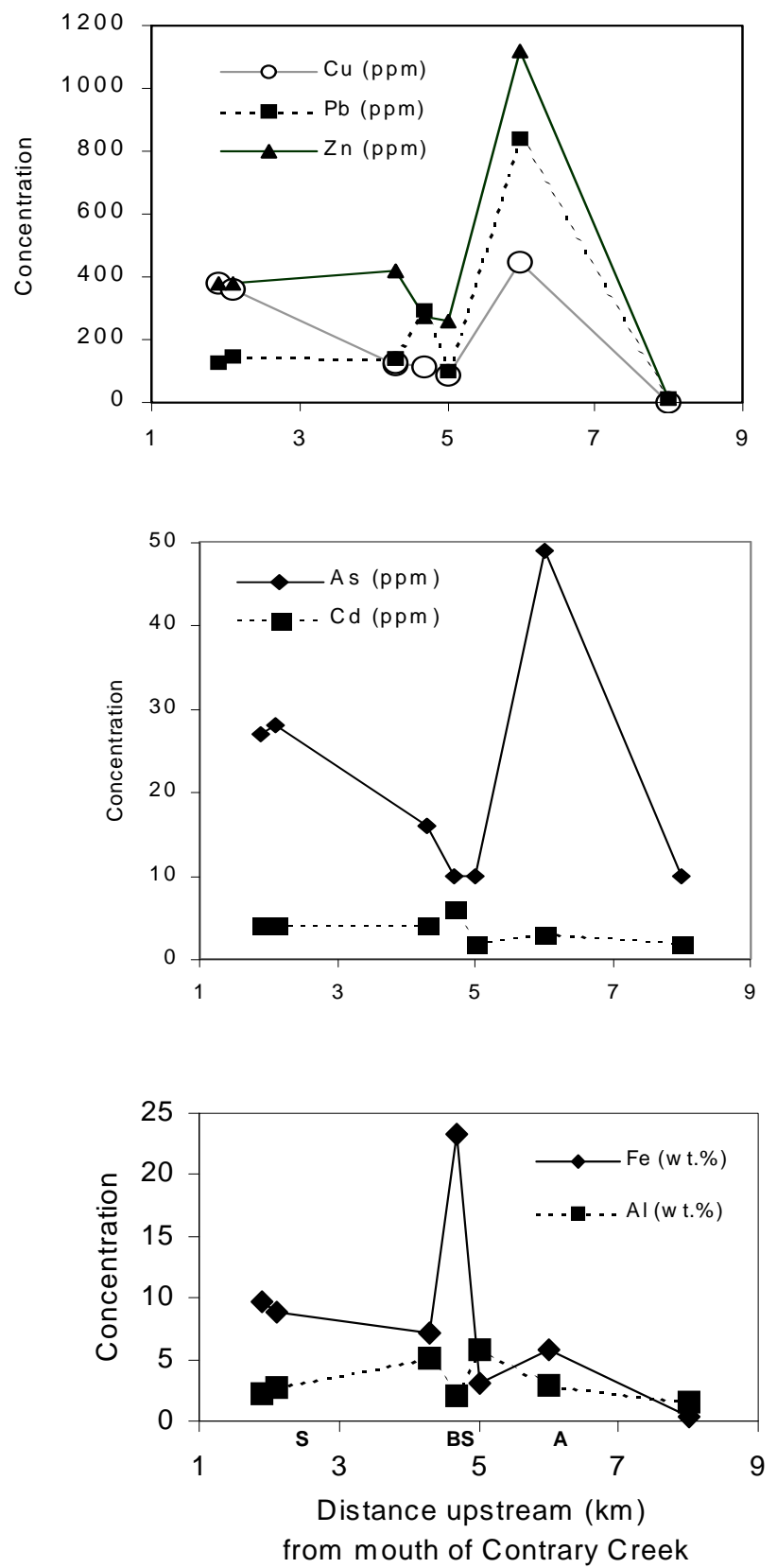

Figure 6. $\underline{B}$, Metal concentrations in $<80$ mesh stream sediments along Contrary Creek as it flow past abandoned mines. See localities 1-8 on fig. 6A for sample locations. S, Sulfur mine; BS, Boyd Smith mine, A, Arminius mine. The Arminius mine near the headwaters of the creek (at $6 \mathrm{~km})$ inputs significant amounts of base metals and arsenic; the Boyd Smith mine area contributes the most iron. Relative to the headwaters area above the mines, all metals increase downstream.

Table 10. Geochemical data for stream sediments ( $<80$ mesh fraction) along Contrary Creek, VA. 


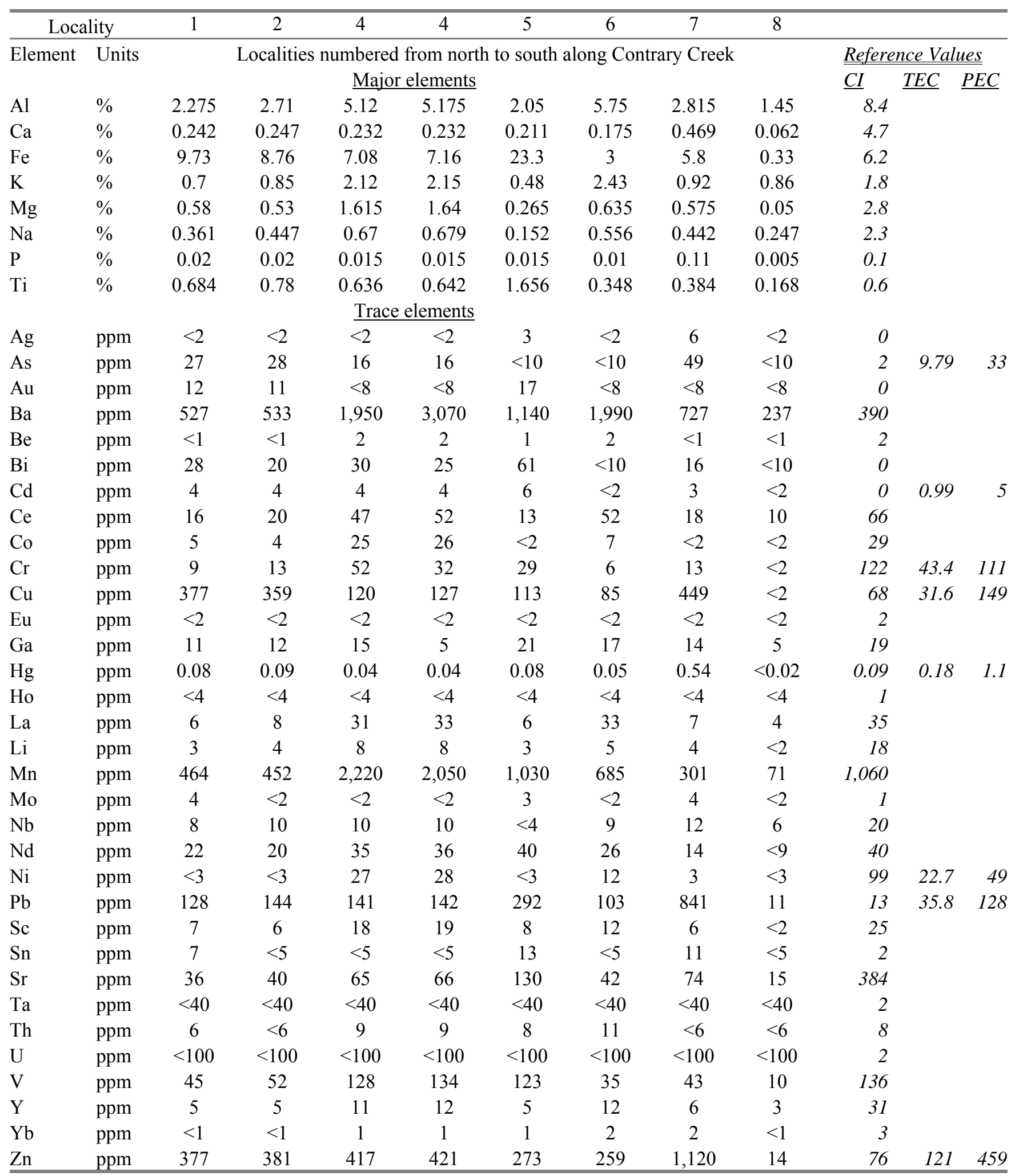

Reference values: CI, Clarke Index value for crustal abundance from Fortescue (1992, table 4). TEC,

Consensus-based threshold effects concentration (below which harmful effects are unlikely to occur)and PEC,

Consensus-

crystalline ferrihydrite in the bed sediment. These studies, along with our new data on stream sediments, indicate

that reclamation of an individual site along Contrary Creek is unlikely to significantly improve water quality and 
that the whole drainage poses a problem some fifty years after mining ceased. The limited reclamation that was done in the 1970s has had no measurable long-term effect.

\section{REFERENCES CITED}

Acker, J.G., and Bricker, O.P., 1992, The influence of $\mathrm{pH}$ on biotite dissolution and alteration kinetics at low temperature: Geochimica et Cosmochimica Acta, v. 56, p. 3073-3092.

AGI (American Geological Institute), Compiler, 1997, Dictionary of mining, mineral, and related terms, $2^{\text {nd }}$ ed.: American Geological Institute in cooperation with the Society for Mining, Metallurgy, and Exploration, Inc., Alexandria, VA, 646 p.

Al, T.A., Blowes, D.W., and Jambor, J.L., 1994, A geochemical study of the main tailings impoundment at the Falconbridge Limited, Kidd Creek Division metallurgical site, Timmins, Ontario, in Jambor, J.L., and Blowes, D.W., eds., 1994, The environmental geochemistry of sulfide mine-wastes: Mineralogical Association of Canada, Short Course Handbook, v. 22, p. 333-364.

Alpers, C.N. and Nordstrom, D.K., 1999, Geochemical modeling of water-rock interactions in mining environments, in Plumlee, G.S., and Logsdon, M.J., eds., The environmental geochemistry of mineral deposits, Part A.: Processes, techniques, and health issues: Society of Economic Geologists, Inc., Reviews in Economic Geology, vol. 6A, p. 289-323.

Alpers, C.N., Blowes, D.W., Nordstrom, D.K., and Jambor, J.L., 1994, Secondary minerals and acid mine-water chemistry, in Jambor, J,L., and Blowes, D.W., eds., 1994, The environmental geochemistry of sulfide minewastes: Mineralogical Association of Canada, Short Course Handbook, v. 22, p. 247-270.

Alloway, B.J., ed., 1995, Heavy metals in soils, $2^{\text {nd }}$ ed., Blackie Academic and Professional, London, 368 p.

Anderson, J.E., and Robbins, E.I., 1998, Spectral reflectance and detection of iron-oxide precipitates associated with acidic mine drainage: Photogrammetric Engineering and Remote Sensing, v. 63, no.12, p. 1201-1208.

Arbogast, B.F. (ed.), 1990, Quality assurance manual for the Branch of Geochemistry, U.S. Geological Survey: U.S. Geological Survey Open- File Report 90-688, 176 p.

Arbogast, B.F. (ed.), 1996, Analytical methods manual for the Mineral Resource Surveys Program, U.S. Geological Survey: U.S. Geological Survey Open- File Report 96-525.

Bacon, J.R., and Maas, R.P., 1979, Contamination of Great Smoky Mountains trout streams by exposed Anakeesta Formations: Journal of Environmental Quality, v.8, no. 4, p. 538-543.

Baedecker, P.A. (ed.), 1987, Methods for geochemical analysis: U.S. Geological Survey Bulletin 1770.

Bailey, R.G., 1995, Descriptions of the ecoregions of the United States, $2^{\text {nd }}$ ed., USDA Forest Service Miscellaneous Publication 1391, 108 p. with a separate map at 1:7,500,000.

Bigham, J.M., 1994, Mineralogy of ochre deposits formed by sulfide oxidation, in Jambor, J.L., and Blowes, D.W., eds., 1994, The environmental geochemistry of sulfide mine-wastes: Mineralogical Association of Canada, Short Course Handbook, v. 22, p. 103-132.

Bigham, J.M., Carlson, L., and Murad, E., 1994, Schwertmannite, a new iron oxyhydroxysulfate from Pyhsalmi, Finland, and other localities: Mineralogical Magazine v. 58, p. 641-648.

Bish, D.L., and Reynolds, R.C., Jr., 1989, Sample preparation for X-ray diffraction, in Bish, D.L., and Post. J.E., eds., 1989, Modern Powder Diffraction: Mineralogical Society of America, Review in Mineralogy, Bookcrafters, Inc., Chelsea, MI, USA, v. 20, p.73-99.

Bish, D.L., and Post. J.E., eds., 1989, Modern Powder Diffraction: Mineralogical Society of America, Review in Mineralogy, Bookcrafters, Inc., Chelsea, MI, USA, v. 20, 369 p.

Blowes, D.W. and Ptacek, C.J., 1994, Acid-neutralization mechanisms in inactive mine tailings, in Jambor, J,L., and Blowes, D.W., eds., 1994, The environmental geochemistry of sulfide mine-wastes: Mineralogical Association of Canada, Short Course Handbook, v. 22, p. 271-291.

Blowes, D.W., Ptacek, C.J., and Jambor, J.L., 1994, Remediation and prevention of low-quality drainage from tailings impoundments, in Jambor, J,L., and Blowes, D.W., eds., 1994, The environmental geochemistry of sulfide mine-wastes: Mineralogical Association of Canada, Short Course Handbook, v. 22, p. 365-379.

Bowell, R.J., and Bruce, I., 1995, Geochemistry of iron ochres and mine waters from Levant Mine, Cornwall: Applied Geochemistry, v.10, no. 2, p. 237-250.

Boyle, D.R., 1994, Oxidation of massive sulfide deposits in the Bathurst mining camp, New Brunswick: Natural analogues for acid drainage in temperate climates, in Alpers, C.N. and Blowes, D.W., Environmental geochemistry of sulfide oxidation, American Chemical Society Symposium Series 550, p. 535-550.

Brady, K.B.C., and Cravotta, C.A., III, 1992, Acid-base accounting - an improved method of interpreting overburden chemistry to predict quality of coal mine drainage, in Proceedings of the $13^{\text {th }}$ Annual Meeting, West Virginia Surface Mine Drainage Task Force, WVU: Morgantown, West Virginia. 
Brady, K.B.C., and Smith, M.W., 1990, Pyritic sulfur analyses for coal overburden: differences between laboratories, in Proceedings of the 1990 National Symposium on Mining, Lexington, Kentucky: University of Kentucky, p. 53-58.

Bruynesteyn, A., and Hackl, R.P., 1984, Evaluation of acid production potential of mining waste materials: Minerals and the Environment, v. 4, p. 5-8.

Byerly, D.W., 1996, Handling acid-producing material during construction: Environmental and Engineering Geoscience, v. II, no. 1, Spring, 1996, p. 49-57.

Cabri, L.J., and Vaughn, D.J., eds., 1998, Modern approaches to ore and environmental mineralogy: Mineralogical Association of Canada, Short Course Series vol. 27, Ottawa, Ontario, 1998, 421 p.

Campbell, P.G.C., Stokes, P.M., and Galloway, J.N., 1985, Acid deposition: effects on geochemical cycling and biological availability of trace elements. Subgroup on metals of the Tri-Academy Committee on acid deposition. National Academy Press, Washington, D.C.

Chou, I.M., Seal, R.R.,II, and Hemingway, B.S., 1999, Determination of melanterite-rozentite and chalcanthitebonatite equilibria at $0.1 \mathrm{MPa}$ by using the humidity buffer technique: Goldschmidt Conference, Boston, Aug. 22-27, 1999.

Church, S.E., Wilson, S.A., Vaughn, R.B., and Fey, D.L., 1994, Geochemical and lead-isotopic studies of river and lake sediments, upper Arkansas River basin, Twin Lakes to Pueblo, Colorado: U.S. Geological Survey OpenFile Report 94-412, 44 p.

Church, S.E., Kimball, B.A., Fey, D.L., Ferderer, D.A., Yager, T.J., and Vaughn, R.B., 1997, Source, transport, and partitioning of metals between water, colloids, and bed sediments of the Animas River, Colorado: $\underline{\text { U.S. }}$ Geological Survey Open-File Report 97-151, 136 p.

Chukrov, F.V., Zvyagin, B.B., Gorshkov, A.I., Ermilova, L.P., and Balashova, V.V., 1973, Ferrihydrite: Izv. Akad. Nauk SSSR, Ser. Geol. V.4, p. 23-33.

Coastech, 1989, Investigation of prediction techniques for acid mine drainage: Coastech Research Inc., MEND Project 1.16.1 a, Mine Environment Neutral Drainage (MEND) Program, Canada Centre for Mineral and Energy Technology, Energy, Mines and Resources Canada, 61 p. plus appendices.

Cox, D.P., and Singer, D.A., eds., 1986, Mineral deposit models: U.S. Geological Survey Bulletin 1693, 379 p.

Cravotta, C.A., III, 1994, Secondary iron-sulfate minerals as sources of sulfate and acidity, in Alpers, C.N. and Blowes, D.W., Environmental geochemistry of sulfide oxidation, American Chemical Society Symposium Series 550, p. 345-364.

Crock, J.G., Lichte, F.E., and Briggs, P.H., 1983, Determination of elements in National Bureau of Standards geological reference materials SRM 278 obsidian and SRM 688 basalt by inductively coupled plasma-atomic emission spectroscopy: Geostandards Newsletter, v. 7, no. 2, p. 335-340.

Crock, J.G., Arbogast, B.F., and Lamothe, P.J., 1999, Laboratory methods for analysis of environmental samples, in Plumlee, G.S., and Logsdon, M.J., eds., The environmental geochemistry of mineral deposits, Part A.:

Processes, techniques, and health issues: Society of Economic Geologists, Inc., Reviews in Economic Geology, vol. 6 A, p. 265-287.

Dagenhart, T.V., Jr., 1980, The acid mine drainage of Contrary Creek, Louisa County, Virginia - Factors causing variations in stream water chemistry: University of Virginia, M.S. Thesis, $215 \mathrm{p}$.

Desborough, G., Leinz, R., Sutley, S., Briggs, P., Swayze, G.A., Smith, K., and Breit, G., 2000, Leaching studies of schwertmannite-rich precipitates from the Animas River headwaters, Colorado and Boulder River headwaters: U.S. Geological Survey Open-File Report 00-004, 16 p.

Desborough, G.A., Briggs, P.H., and Mazza, Nilah, 1998a, Chemical and mineralogical characteristics and acidneutralizing potential of fresh and altered rocks and soils of the Boulder River headwaters in Basin and Cataract Creeks of northern Jefferson County, Montana: U.S. Geological Survey Open-File Report 98-40, 21 p.

Desborough, G.A., Briggs, P.H., Mazza, Nilah, and Driscoll, Rhonda, 1998b, Acid-neutralizing potential of intrusive rocks of the Boulder batholith in northern Jefferson County, Montana: U.S. Geological Survey OpenFile Report 98-364, $21 \mathrm{p}$.

Dickson, J.A.D., 1965, A modified staining technique for carbonates in thin section : Nature, v. 205, p.587.

diPretorio, R.S. and Rauch, H.W., 1988, Use of acid-base accounts in premining prediction of acid drainage potential: a new approach from northern West Virginia: U.S. Bureau of Mines, IC 9183, p. 1-10

Di Toro, D.M., Mahoney, J.D., Hansen, D.J., Scott, K.J., Hicks, M.B., Mays, S.M., and Redmond, M.S., 1990, Toxicity of cadmium in sediments - The role of acid-volatile sulfide: Environmental Toxicology and Chemistry, v. 9 , p. $1487-1502$. 
Dold, Bernhard, 1999, Mineralogical and geochemical changes of copper flotation tailings in relation to their original; composition and climatic setting - Implications for acid mine drainage and element mobility: Terre \& Environment, Section des Sciences de la Terre, Universite de Geneve, vol. 18, 230 p.

du Bray, E.A., ed., 1995, Preliminary compilation of descriptive geoenvironmental models: U.S. Geological Survey Open-File Report 95-831, 272 p. To download in PDF format, see: http://greenwood.cr.usgs.gov/pub/open-file-reports/ofr-95-0831/

Evans, P., and Skousen, J., 1995, Effect of digestion method on neutralization potential of overburden samples containing siderite, in Proceedings of the 1995 National Meeting of the American Society for Surface Mining and Reclamation, Gillette, Wyoming, p. 696-707.

Ferris, F.G., Tazaki, K., and Fyfe, W.S., 1989, Iron oxides in acid mine drainage environments and their association with bacteria: Chemical Geology, v. 74, p. 321-330.

Filipek, L.H. and Plumlee, G.S., 1999, The environmental geochemistry of mineral deposits, Part B: Case studies and research topics: Society of Economic Geologists, Inc., Reviews in Economic Geology, vol. 6B, p. 373-583.

Flohr, M.J.K., Dillenberg, R.G., and Plumlee, G.S., 1995, Characterization of secondary minerals formed as the result of weathering of the Anakeesta Formation, Great Smoky Mountains National Park, Tennessee: U.S. Geological Survey Open-File Report 95-477,18 p.

Flohr, M.J.K., and Hammarstrom, J.M., 1997, Formation of gossan and oxidation of sulfide ores as analogs of oxidation of tailings piles [abs.]: in, Wanty, R.B., Marsh, S.P., and Gough, L.P., eds., 4th International Symposium on Environmental Geochemistry Proceedings: U.S. Geological Survey Open-File Report OF97496, p. 24 .

Fortescue, J.A.C., 1992, Landscape geochemistry: Retrospect and prospect-1990: Applied Geochemistry, v. 7, p. 153.

Grosh, W.A., 1949, Investigations of Valzinco lead-zinc mine, Spotsylvania County, VA: U.S. Bureau of Mines Report of Investigations 4403, $7 \mathrm{p}$.

Grossman, J.N., 1998, National Geochemical Atlas: The geochemical landscape of the conterminous United States derived from stream sediment and other solid sampling media analyzed by the National Uranium Resource Evaluation (NURE) Program: Version 3.01: U.S. Geological Survey Open-File Report 98-622 (CD-ROM).

Hageman, P.L., and Briggs, P.H., 2000, A simple field leach test for rapid screening and qualitative characterization of mine waste dump material on abandoned mine lands: ICARD 2000, Proceedings from the Fifth International Conference on Acid Rock Drainage, v. II, p. 1463-1475.

Hammack, R.W., 1994, Evolved gas analysis - a method for determining pyrite, marcasite, and alkaline-earth carbonates, in Alpers, C.N., and Blowes, D.W., eds, Environmental geochemistry of sulfide oxidation: American Chemical Society, ACS Symposium Series 550, p. 431-444.

Hammarstrom, Jane M., Meier, Allen L. and Seal, Robert R., II, 1999a, Geochemistry and Mineralogy of Ochres Associated with Acid Mine Drainage at Abandoned Massive Sulfide Mines: Geological Society of America, Abstracts with Programs, vol. 31, no. 7, p. A-224.

Hammarstrom, J.M., Meier, A.L., Jackson, J.C., Barden, Ryan, Wormington, P.J., Wormington, J.D., and Seal, R.R., II, 1999b, Characterization of mine waste at the Elizabeth copper mine, Orange County, Vermont: U.S. Geological Survey Open-File Report 99-564, 74 p.

Hornberger, R.J., and Brady, K.B.C., 1998, Kinetic (leaching) tests for the prediction of mine drainage quality, Chapter 7, in Coal mine drainage prediction and pollution prevention in Pennsylvania: Pennsylvania Department of Environmental Protection, 54 p.

International Centre for Diffraction Data, 1997, Powder Diffraction File Sets 1-47.

Jambor, J.L., 1994, Mineralogy of sulfide-rich tailings and their oxidation products, in Jambor, J.L., and Blowes, D.W., eds., 1994, The environmental geochemistry of sulfide mine-wastes: Mineralogical Association of Canada, Short Course Handbook, v. 22, p. 103-132.

Jambor, J.L., and Blowes, D.W., eds., 1994, The environmental geochemistry of sulfide mine-wastes: Mineralogical Association of Canada, Short Course Handbook, v. 22, 438 p.

Jambor, J.L., and Blowes, D.W., 1998, Theory and application of mineralogy in environmental studies of sulfidebearing mine wastes, in Cabri, L.J. and Vaughan, D.L., eds., Modern approaches to ore and environmental mineralogy, Mineralogical Association of Canada Short Course Series, vol. 27, p. 367-401.

Jerz, J.K., and Rimstidt, J.D., 1999, Rate of pyrite oxidation in air (abs.): Geological Society of America, Abstracts with Programs, v. 31, no. 7, p. A-27.

Kania, T., 1998, Laboratory methods for acid-base accounting: an update, Chapter 6, in Coal mine drainage prediction and pollution prevention in Pennsylvania: Pennsylvania Department of Environmental Protection, 9 p. 
King, P.B., Neuman, R.B., and Hadley, J.B., 1968, Geology of the Great Smoky Mountains National Park, Tennessee and North Carolina: U.S. Geological Survey Professional Paper 587, 23 p. and 1:125,000 map.

Kolker, Allan, Cannon, W.F., Woodruff, L.G., Westjohn, D.B., Haack, S.K., and Kim, Myoung-Jin, 1999a, Arsenic in southeastern Michigan ground water: Results of USGS test drilling: American Geophysical Union, Abstracts, 1999 Spring Meeting, published as a supplement to Eos, April 27, 1999, p. S146.

Kolker, Allan, Goldhaber, M.B., Hatch, J.R., Meeker, G.P., and Koeppen, R.P., 1999b, Arsenic-rich pyrite in coals of the Black Warrior Basin, Alabama: Evidence form hydrothermal enrichment of arsenic and other metals: Geological Society of America Abstracts with Programs, v. 31, no. 7, p. A-402.

Kwong, Y.T.J., 2000, Thoughts on ways to improve acid drainage and metal leaching prediction for metal mines: ICARD 2000, Proceedings from the Fifth International Vconference on Acid Rock Drainage, v. I, p. 675-682.

Kwong, Y.T.J., 1993, Prediction and prevention of acid rock drainage from a geological and mineralogical perspective: Canadian National Hydrology Research Centre Contribution CS-92054, 47 p.

Kwong, Y.T.J. and Lawrence, J.R., 1994, Mineralogical controls of sulfide oxidation: Canadian National Hydrology Research Centre Contribution No. 94010, 87 p.

Lapakko, K.A., 1992, Recent literature on static predictive tests, Chapter 16, in S. Chander, ed., Proceedings of the symposium on emerging process technologies for a cleaner environment, Phoenix, Arizona, February 24-27, 1992: Littleton, Colorado, Society for Mining, Metallurgy, and Exploration, Inc., p. 109-119.

Lawrence, R.W., 1990, Prediction of the behaviour of mining and processing wastes in the environment, in F. Doyle, ed., Proceedings of the Western Regional Symposium on Mining and Mineral Processing Wastes: Littleton, Colorado, Society for Mining, Metallurgy, and Exploration, Inc., p. 115-121.

Lichte, F.E., Meier, A.L., and Crock, J.G., 1987, Determination of rare earth elements in geological materials by inductively coupled plasma mass spectrometry: Analytical Chemistry, v. 59, no. 8, p. 1150-1157.

Lin, Z., 1997, Mobilization and retention of heavy metals in mill-tailings from Garpenberg sulfide mines, Sweden: The Science of the Total Environment, v. 198, p. 13-31.

Long, E.R., MacDonald, D.D., Smith, S.L., and Calder, F.D., 1995, Incidence of adverse biological effects within ranges of chemical concentrations in marine and estuarine sediments: Environmental Management, v. 19, no. 1, p. 81-97.

MacDonald, D.D., Ingersoll, C.G., and Berger, T.A., 2000, Development and evaluation of consensus-based sediment quality guidelines for freshwater ecosystems: Archives of Environmental Contamination and Toxicology, v. 39, p. 20-31.

Malmström, M., and Banwart, S., 1997, Biotite dissolution at $25^{\circ} \mathrm{C}$, the $\mathrm{pH}$ dependence of dissolution rate and stoichiometry: Geochimica et Cosmochimica Acta, v. 61, p. 2779-2799.

Mandarino, J.A., 1999, Fleischer's glossary of mineral species 1999: The Mineralogical Record, Inc., Tucson, 225 p.

McFaul, E.J., Mason, G.T., Ferguson, W.B., and Lipin, B.R., 2000, U.S. Geological Survey Mineral Databases MRDS and MAS/MILS: U.S. Geological Survey Digital Data Series DDS-52, 2 discs.

Mee, J.S., Siems, D.F., and Taggart, J.E., Jr., 1996, Major element analysis by wavelength dispersive X-ray fluorescence spectrometry, in Arbogast, B.F., ed., Analytical methods manual for the Mineral Resource Surveys Program, U.S. Geological Survey: U.S. Geological Survey Open- File Report 96-525, p. 237-242.

Meier, A.L., 1980, Flameless atomic absorption determination of gold in geological materials: Journal of Geochemical Exploration, v. 13, p. 75-85.

MEND(Mine Environment Neutral Drainage) technical reports. See http://mend2000.nrcan.gc.ca/report-t.htm

MEND, 1990, Acid rock drainage prediction manual- A manual of chemical evaluation procedures for the prediction of acid generation from mine wastes, MEND Project 1.16.1b: A report prepared for CANMET-MSL Division, Department of Energy, Mines, and Resources, Canada by Coastech Rescearch, Inc., Vancouver, B.C.

MEND, 1994, Review of waste rock sampling techniques. Mine Environement Neutral Drainage (MEND) Program Report 4.5.1. Prepares by SENES Consultants Ltd., Golder Associee Ltee, and Laval University.

MEND, 1995, MINEWALL 2.0, Series of four reports: Literature Review, User's Guide, Application of MINEWALL to Three Minesites and Programmer's Notes and Source Code, plus one diskette, MEND, Ottawa, ON.

Miller, S.D., Jeffery, J.J., and Murray, G.S.C., 1990, Identification and management of acid generating mine wastes-procedures and practices in Southeast Asia and the Pacific Regions, in J.W. Gadsby, J.A. Malick, and S.J. Day, eds., Acid mine drainage designing for closure: Vancouver, BiTech Publishers Ltd., p. 1-11.

Morgan, D.J., Warrington, S.B., and Warne, S. St.J., 1988, Earth science applications of evolved gas analysis- A review: Thermochimica Acta, v. 135., p. 207-212. 
Morin, K.A., and Hutt, N.M, 1994, Observed preferential depletion of neutralization potential over sulphide minerals in kinetic tests: site-specific criteria for safe NP/AP ratios, in Proceedings of the Third International Conference on the Abatement of Acidic Drainage, v. 1, p. 148-156.

Morin, K.A., and Hutt, N.M., 1997, Environmental geochemistry of minesite drainage: practical theory and case studies: Vancouver, MDAG Publishing.

Murad, E., Schwertmann, U., Bigham, J.M., and Carlson, L., 1994, Mineralogical characteristics of poorly crystallized precipitates formed by oxidation of $\mathrm{Fe}^{2+}$ in acid sulfate waters: in Alpers, C.N. and Blowes, D.W., Environmental geochemistry of sulfide oxidation, American Chemical Society Symposium Series 550, p. 190200.

MVTechnologies, Inc., 1998, Reclamation and acid control at Valzinco orphaned land project: MVTI Proposal Number VAMME1-088-898, Unpublished report prepared for the Virginia Department of Mines, Minerals, and Energy.

Nesbitt, H.W., and Jambor, JL., 1998, Role of mafic minerals in neutralizing ARD, demonstrated using a chemical weathering methodology, in Cabri, L.J. and Vaughan, D.L., eds., Modern approaches to ore and environmental mineralogy, Mineralogical Association of Canada Short Course Series, vol. 27, p. 403-421.

Newman, M.C., and Jagoe, C.H., 1994, Inorganic toxicants - ligands and the bioavailability of metals in aquatic environments, in Hamelink, J.L., Landrum, P.F., Bergman, H.L., and Benson, W.H., eds. Bioavailability Physical, chemical, and biological interactions SETAC Special Publication Series: CRC Press, Inc. Boca Raton, FL, p. 39-61.

Nordstrom, D.K., and Alpers, C.N., 1999, Negative pH, efflorescent mineralogy, and consequences for environmental restoration at the Iron Mountain Superfund site, California: Proceedings of the National Academy of Sciences, v. 96, p. 3455-3462.

Nordstrom, D.K., and Southam, Gordon, 1997, Geomicrobiology of sulfide mineral oxidation, in Banfield, J.F., and Nealson, K.H., eds., Geomicrobiology: Interactions between microbes and minerals: Mineralogical Society of America, Reviews in Mineralogy, v. 35, p. 361-390.

Page, A.L., Miller, R.H., and Keeney, D.R., 1982, Methods of soil analysis-Part 2- Chemical and microbiological properties, $2^{\text {nd }}$ ed.: American Society of Agronomy, Inc.; Soil Science Society of America, Inc., p. 199-209.

Perkins, E.H., Nesbitt, H.W., Gunter, W.D., St-Arnaud, L.C., and Mycroft, J.R., 1995, Critical review of geochemical processes and geochemical models adaptable for prediction of acidic drainage from waste rock: MEND Report, No. 1.42.1, MEND, Ottawa, ON, 120 p.

Plumlee, G., 1994, Environmental geology models of mineral deposits: Society of Economic Geologists Newsletter, January 1994, no. 16, p. 5-6.

Plumlee, G.S., 1999, The environmental geology of mineral deposits, in Plumlee, G.S., and Logsdon, M.J., eds., The environmental geochemistry of mineral deposits, Part A, Processes, techniques, and health issues: Society of Economic Geologists, Reviews in Economic Geology, v. 6A, p. 71-116.

Plumlee, G.S., and Logsdon, M.J., 1999a, An earth-system science toolkit for environmentally friendly mineral resource development, in Plumlee, G.S., and Logsdon, M.J., eds., The environmental geochemistry of mineral deposits, Part A.: Processes, techniques, and health issues: Society of Economic Geologists, Inc., Reviews in Economic Geology, vol. 6A, p. 1-27.

Plumlee, G.S., and Logsdon, M.J., eds. 1999b, The environmental geochemistry of mineral deposits, Part A.: Processes, techniques, and health issues: Society of Economic Geologists, Inc., Reviews in Economic Geology, vol. 6A, 371p.

Price, W.A., 1997, DRAFT, Guidelines and recommended methods for the prediction of metal leaching and acid rock drainage at minesites in British Columbia: British Columbia Ministry of Employment and Investment, Energy and Minerals Division, Smithers, BC, 143 p.

Price, W.A., Errington, J., and Koyanagi, V, 1997, Guidelines for the prediction of acid rock drainage and metal leaching for mines in British Columbia: part I. General procedures and information requirements: MEND, Natural Resources Canada, Ottawa, Proceedings of the $4^{\text {th }}$ International Conference on Acid Rock Drainage 1, p. 1-14.

Price, W.A., and Errington, J.C., 1998, Guidelines for metal leaching and acid rock drainage at minesites in British Columbia: British Columbia Ministry of Energy and Mines, 86 p.

Robbins, E.I., Anderson, J.E., Cravotta, C.A., III, Koury, D.J., Podwysocki, M.H., Stanton, M.R., and Growitz, D.J., 1996, Development and preliminary testing of microbial and spectral reflectance techniques to distinguish neutral from acid drainages, in Chiang, S.-H., ed., Proceedings, $13^{\text {th }}$ Annual Pittsburgh Coal Conference on Coal, Energy, and the Environment ( Pittsburgh, PA, p. 768-775.

Robertson Info-Data, Inc., 1999, http://www.infomine.com/technology/enviromine/ 
Robinson, B.W., Ware, N.G., and Smith, D.G.W., 1998, Modern electron-microprobe trace-element analysis in mineralogy, in Cabri, L.J., and Vaughn, D.J., eds., 1998, Modern approaches to ore and environmental mineralogy: Mineralogical Association of Canada, Short Course Series vol. 27, Ottawa, Ontario, 1998, p. 153180.

Rose, A.W., Hawkes, H.E., and Webb, J.S., 1979, Geochemistry in mineral exploration: Acad. Press, London, 657 p.

Schaeffer, M.F., and Clawson, P.A., 1996, Identification and treatment of potential acid-producing rocks and water quality monitoring along a transmission line in the Blue Ridge Province, southwestern North Carolina: Environmental and Engineering Geoscience, v. II, no. 1, Spring, 1996, p. 35-48.

Schwertmann, U., Bigham, J.M., and Murad, E., 1995, The first occurrence of schwertmannite in a natural stream environment: European Journal of Mineralogy, v. 7, p. 547-552.

Seal, R.R., II, Krishnaswamy, R., Flohr, M.J.K., Hammarstrom, J. M., and Robbins, E.I., 1996, Preliminary stable isotope data for acidic drainage from abandoned pyrite mines in the Virginia Piedmont [abs.]: Geological Society of America, Abstracts with Programs, v.28, no. 7, p. 465.

Seal, R.R., II, Hammarstrom, J.M., Southworth, C.S., Schultz, A.P., and Meier, A.L., 1997, Geochemistry of acidic drainage in the Great Smoky Mountains National Park: Implications for the Southern Appalachians [abs]: Proceedings of the Eighth Annual Southern Appalachians Man and The Biosphere Conference, p. 55

Seal, R.R., II, Hammarstrom, J.M., Southworth, C.S., Meier, A.L., Haffner, D.P., Schultz, A.P., Plumlee, G.S., Flohr, M.J.K., Jackson, J.C., Smith, S.M., and Hageman, P.L., 1998, Preliminary report on water quality associated with the abandoned Fontana and Hazel Creek mines, Great Smoky Mountains National Park, North Carolina and Tennessee: U.S. Geological Survey Open-File Report 98-476, 50 p.

Singer, P.C., and Stumm, W., 1970, Acidic mine drainage: The rate determining step: Science, v. 167, p. 1121-1123.

Skousen, J., Renton, J., Brown, H., Evans, P., Leavitt, B., Brady, K., Cohen, L., and Ziemkiewicz, P., 1997, Neutralization potential of overburden samples containing siderite: Journal of Environmental Quality, vol. 6, no. 3, p. 673-681.

Smith, A., 1997, Waste rock characterization, in J.J. Marcus, ed., Mining environmental handbook: London, Imperial College Press, p. 287-293.

Smith, A., Robertson, A., Barton-Bridges, J., and Hutchison, I.P.G., 1992, Prediction of acid generation potential, in I.P.G. Hutchison and R.D. Ellison, eds., Mine waste management: Lewis Publishers, p. 123-199.

Smith, K.S. and Huyck, H.L.O., 1999, An overview of the abundance, relative mobility, bioavailability, and human toxicity of metals; in G.S. Plumlee and M.J. Logsdon, eds., The environmental geochemistry of mineral deposits: Society of Economic Geologists, Inc., Reviews in Economic Geology, v. 6A, p. 29-70.

Smith, K.S., 1999, Metal sorption on mineral surfaces: an overview with examples relating to mineral deposits, in Plumlee, G.S., and Logsdon, M.J., eds., The environmental geochemistry of mineral deposits, Part A.: Processes, techniques, and health issues: Society of Economic Geologists, Inc., Reviews in Economic Geology, vol. 6A, p. 161-182.

Smith, K.S., Ramsey, C.A., and Hageman, P.L., 2000, Sampling strategy for the rapid screening of mine-waste dumps on abandoned mine lands: ICARD 2000, Proceedings from the Fifth International Conference on Acid Rock Drainage, v. II, p. 1453-1461

Smith, K.S., Plumlee, G.S., and Ficklin, W.H., 1994, Predicting water contamination from metal mines and mining wastes: U.S. Geological Survey Open-File Report 94-264, 112 p.

Smith, S.M., 1994, Geochemical maps of copper, lead, and zinc, upper Arkansas River drainage basin, Colorado: U.S. Geological Survey Open-File Report 94-408, 15 p.

Smith, S.M., 1997, National Geochemical Database: U.S. Geological Survey Open-File Report 7-492.

Sobek, A.A., Schuller, W.A., Freeman, J.R., and Smith, R.M., 1978, Field and laboratory methods applicable to overburden and minesoils: EPA 600/2-78-054, 203 p.

Southworth, Scott, 1995, Preliminary geologic map of the Great Smoky Mountains National Park within the Fontana Dam and Tuskeegee Quadrangles, Swain County, North Carolina: U.S. Geological Survey Open-File report 95264, 1:24,000-scale, plate and 33p.

Strömberg, B., and Banwart, S., 1994, Kinetic modelling of geochemical processes at Aitik mining waste rock site in northern Sweden: Applied Geochemistry, v. 9., p. 583-595.

Swayze, G.A., Smith, K.S., Clark, R.N., Sutley, S.J., Pearson, R.M., Rust, G.S., Vance, J.S., Hageman, P.L., Briggs, P.F., Meier, A.L., Singleton, M.J., and Roth, Shelly, 2000, Using imaging spectroscopy to map acidic mine waste: Environmental Science and Technology, v. 34, p. 47-54. 
Taggart, J.E., Jr., Lindsay, J.R., Scott, B.A., Vivit, D.V., Bartel, A.J., and Stewart, K.C., 1987, Analysis of geologic materials by wavelength-dispersive X-ray fluorescence spectrometry, in Baedecker, P.A. (ed.), 1987, Methods for geochemical analysis: U.S. Geological Survey Bulletin 1770, p. E1-E19.

Taylor, C.D., Zierenberg, R.A., Goldfarb, R.J., Kilburn, J.E., Seal, R.R., II, and Kleinkopf, M.D., 1995, Volcanicassociated massive sulfide deposits, in du Bray, E.A., ed., 1995, Preliminary compilation of descriptive geoenvironmental mineral deposit models: U.S. Geological Survey Open-File Report 95-831, p. 137-144.

U.S. Environmental Protection Agency, 1994, Test methods for evaluating solid waste, physical/chemical methods (SW-846), $3^{\text {rd }}$ edition, update 2B: Environmental Protection Agency, National Center for Environmental Publications, Cincinnati, OH 45268, telephone 800-553-6847, order number EPASW-846.3.2B. URL http://www.epa.gov/epaoswer/hazwaste/test/sw846.htm.

U.S. Environmental Protection Agency, 1995, Test methods for evaluating solid waste, physical/chemical methods (SW-846) $3^{\text {rd }}$ edition, update 2B. Environmental Protection Agency, National Center.

U.S. Environmental Protection Agency, 1997a, Terms of Environment: EPA-175B97001. See also: http://www.epa.gov/docs/OCEPAterms/

U. S. Environmental Protection Agency, 1997b, The incidence and severity of sediment contamination in surface waters of the United States. Volume 1: National stream sediment survey: EPA-823-R-97-006.

Wanty, R.B., Berger, B.R., and Plumlee, G.S., 1999, Environmental models of mineral deposits; a state of the art: Geologica Hungarica, Serie Geologica, v. 24, p. 97-106.

Wanty, R.B., Berger, B.R., Plumlee, G.S., and King, T.V.V., in press, Geoenvironmental models, in Fabbri,A., Gaal, G., and McCammon, R., eds., Proceedings, 1998 NATO Advanced Study Institute Workshop, Deposit and Geoenvironmental Models for Resource Exploitation and Environmental Security: Kluwer Academic Publishers, 30 ms. p.

White, W.W., III, Lapakko, K.A., and Cox, R.L., 1998, Effects of protocol variables and sample mineralogy on static-test NP, in Proceedings of the $11^{\text {th }}$ Annual Conference of the Society of Mineral Analysts, Elko, Nevada, April 7-10, 1997, p. 187-233.

White, W.W., III, Lapakko. K.A., and Cox, R.L., 1999, Static-test methods most commonly used to predict acidmine drainage: Practical guidelines for use and interpretation, in Plumlee, G.S., and Logsdon, M.J., eds., The environmental geochemistry of mineral deposits, Part A.: Processes, techniques, and health issues: Society of Economic Geologists, Inc., Reviews in Economic Geology, vol. 6A, p. 325-338.

Winland, R.L., Taina, S.J., Bigham, J.M., 1991, Chemical composition of ochreous precipitates from Ohio Coal Mine Drainage: Journal of Environmental Quality, v. 20, p. 452-460.

Witters, H.E., Van Puymbroeck, S., Stouthart, A.J.H.X., and Bonga, S.E.W., 1996, Physicochemical changes of aluminum in mixing zones: mortality and physiological disturbances in brown trout (Salmo Trutta L.): Environmental Toxicology and Chemistry, v. 15, no. 6, p. 986-996.

Yu, Jae-Young, Heo, B., Choi, I., Cho, J., and Chang, H., 1999, Apparent solubilitites of schwertmannite and ferrihydrite in natural stream waters polluted by mine drainage: Geochimica et Cosmochimica Acta, v. 63, no. 19-20, p. 3407-3416. 


\title{
Chapter C
}

\section{TOOLKIT FOR THE RAPID SCREENING AND CHARACTERIZATION OF WASTE PILES ON ABANDONED MINE LANDS}

\author{
Kathleen S. Smith, David L. Campbell, George A. Desborough, Philip L. Hageman, Reinhard W. Leinz, Mark R. \\ Stanton, Stephen J. Sutley, Gregg A. Swayze, and Douglas B. Yager
}

\section{INTRODUCTION}

There are thousands of historical mine-waste piles present on inactive metal-mining sites, some of which are on Federal lands and have been abandoned. Assessment of metal mobility, acid-drainage production, and toxic effects from the weathering of historical mine-waste piles is an area of growing need as the environmental effects of inactive mine-waste sites across the country are being evaluated and mitigated. The U.S. Geological Survey Mine Waste Characterization Project has taken a multidisciplinary approach to assemble, develop, and refine methods and tools for characterizing and screening weathered solid-mine wastes. Researchers from a variety of disciplines, including geophysics, geochemistry, analytical chemistry, geology, mineralogy, remote sensing, and spatial modeling, have worked together at metal-mining waste sites in Colorado and New Mexico to develop an integrated "toolkit" for the rapid screening and characterization of historical mine-waste piles. Tools developed from this work can be used in ranking and prioritizing historical mine-waste piles. The following is a brief discussion of some of these tools.

\section{SAMPLING AND GEOCHEMICAL SCREENING TOOLS} Sampling Strategy

A statistically based, cost-effective sampling strategy was developed that could provide the foundation for screening and prioritizing mine-waste piles on a regional or watershed basis. Because average properties generally are the emphasis in screening and prioritization, the sampling strategy entails collection of a composite sample from each waste pile. One 30-increment dump-composite sample collected using this sampling strategy contains as much information, relative to the average value, as 30 individual grab samples at $1 / 30$ of the analytical cost. When more detailed site characterization is required, other sampling strategies might be employed, depending on the objectives of the work.

A detailed discussion of the sampling strategy is given in K.S. Smith and others (2000). In order to minimize sampling errors, this strategy requires that a composite sample consist of at least 30 increments (subsamples). Hence, a mine dump is divided into at least 30 cells of roughly equal surface area. Multiple ( $>30)$ surficial samples of roughly equal mass are collected from each cell with a trowel, successively placed in a bucket, and mixed to create a mine-dump composite sample. The sample is air-dried and dry-sieved to $<2 \mathrm{~mm}$. The resulting $<2 \mathrm{~mm}$ mine-dump composite sample should weigh at least one kilogram. For screening and prioritizing historical minewaste piles, use of the $<2 \mathrm{~mm}$ size fraction generally should provide a worst-case scenario for metal leachability and appears to be a good choice to reduce the sampling error and reduce the sample size to one reasonable for reconnaissance field collection.

A main goal of this sampling strategy is to minimize sampling errors. Sampling errors can be categorized into seven major groups: fundamental error, grouping and segregation error, delimitation error, extraction error, preparation error, cycles, and trends. Pitard (1993) provides a detailed discussion of sampling errors and serves as the basis of this sampling strategy. The fundamental error (FE) is often the main source of sampling error and results from the compositional heterogeneity of particles. It cannot be eliminated, but it can be estimated prior to sampling. Based on estimates of FE, steps can be taken to minimize it and thus minimize the overall sampling error. Important factors in the $\mathrm{FE}$ include heterogeneity, particle size, and sample mass. If the population is very heterogeneous or the particle size is large, then more sample mass is required to minimize the FE. If the mass of the population (lot), $M_{L}$, is greater than ten times the mass of the sample, the FE can be estimated by the following equation:

$$
F E^{2}=\frac{c l f g d^{3}}{M_{S}}
$$


where

$F E^{2}$ is a relative variance

$M_{S}$ is the sample mass (g)

$c$ is the mineralogical factor

$l$ is the liberation factor

$f$ is the shape factor

$g$ is the granulometric factor

$d$ is the maximum particle size $(\mathrm{cm})$

The mineralogical factor, $c$, is the maximum heterogeneity generated by the constituent of interest in the target population and can be estimated by dividing the approximate density of the material $\left(\mathrm{g} / \mathrm{cm}^{3}\right)$ by the average concentration of the constituent of interest ( $\mathrm{mg} / \mathrm{kg})$. The liberation factor, $l$, is a correction factor for $c$ that takes into account incomplete liberation of the constituent of interest, and ranges from 0 , when there is no liberation, to 1 , when there is complete liberation. Values for the shape factor, $f$, vary from 0.2 for flakes to 10 for needles, with a value of 0.5 representing a roughly spherical shape. The granulometric factor, $g$, is a correction factor when all the particles are not the same size, with noncalibrated material having a value of 0.25 , and calibrated material having a value of 0.55 .

The other main sampling error of concern is the grouping and segregation error (GSE). To minimize the grouping factor of the GSE, it is necessary to collect as many small increments as practically possible, assuming that sample collection and preparation are properly carried out. (An increment is a group of particles collected from a population with a single operation of the sampling device.) Pitard (1993, p. 187) states that a sample should be made up of at least 30 increments. Minimizing the segregation factor of the GSE is much more difficult because it involves aspects such as differences in particle density, particle size, particle shape, mine-dump construction, etc. The segregation factor should be kept in mind when collecting samples.

Other sources of sampling error generally are less important than the FE or GSE. Delimitation error and extraction error are both related to the choice and use of sampling tools; collectively they are termed the materialization error. Preparation errors take place after sample collection and before analysis. These errors encompass such factors as sample preservation, contamination, loss, sieving, etc. Both cycles and trends relate to changes in the concentration of an analyte of interest with respect to time or space.

Metal Leachability Determination --A Field Method

Leaching tests are one of the main screening procedures used to evaluate and prioritize mine-waste piles. A leaching test has been developed that can be performed easily in the field, can provide on-site $\mathrm{pH}$ and conductivity information (for field prioritization), and can furnish samples for elemental analysis. Hageman and Briggs (2000) describe the Field Leach Test (FLT) in detail. It is based on the premise that the most chemically reactive material in weathered mine waste consists of relatively soluble components in the fine fraction $(<2 \mathrm{~mm})$ of the waste. In general, higher concentrations of chemical constituents are leached from the smaller size fractions in the weathered mine-waste piles studied. The choice of the $<2 \mathrm{~mm}$ size fraction may tend to slightly overestimate the leachability of the mine-waste material as a whole, but this size-fraction cutoff does not appear to "miss" any readily leachable phases (K.S. Smith and others, 2000).

The FLT involves combining 50.0 grams of a $<2 \mathrm{~mm}$ mine-dump composite sample with 1,000 grams of deionized water in a capped one-liter polyethylene bottle. The mixture is vigorously shaken for five minutes, and then allowed to settle for 10 minutes. Specific conductance and $\mathrm{pH}$ can be measured in the field, and subsamples can be filtered and preserved for analysis of chemical constituents. Hageman and Briggs (2000) showed that results from the FLT reveal geochemical trends that correlate favorably with results from the Synthetic Precipitation Leaching Procedure (SPLP, EPA-1312, U.S. Environmental Protection Agency, 1994). Table 1 and figure 1 provide a comparison of leaching results from the FLT and the SPLP.

\section{Net Acid Production Determination}

There are a variety of methods to determine the potential of a mine-waste material to generate acid. For historical metal-mining waste piles that consist of weathered material, it is necessary to adopt a method that incorporates the potential acid production of both primary and secondary minerals, and the potential acid-consuming capacity of host-rock minerals (e.g., carbonates, chlorite, biotite). Primary minerals constitute the original ore and gangue assemblages of the mineral deposit, and secondary minerals are those that form upon oxidation and weathering of the primary minerals. 
Table 1. Comparison of results from the Field Leach Test and the Synthetic Precipitation Leaching Procedure for specific conductance and $\mathrm{pH}$ in leachates of $<2 \mathrm{~mm}$ fraction mine-dump composites from sites in Colorado and New Mexico. Data are from Hageman and Briggs (2000). [SPLP = Synthetic Precipitation Leaching Procedure; FLT $=$ Field Leach Test $]$

\begin{tabular}{lcccc} 
& \multicolumn{2}{c}{$\underline{\mathrm{pH}}$} & \multicolumn{2}{c}{ Specific Conductance $(\mu \mathrm{S} / \mathrm{cm})$} \\
Mine-Dump Site & SPLP & FLT & SPLP & FLT \\
\hline Venir & 2.7 & 2.9 & 1,080 & 760 \\
Sunday \#2 & 2.8 & 3.0 & 810 & 620 \\
Yukon & 3.1 & 3.2 & 660 & 530 \\
Mayday & 3.5 & 3.6 & 200 & 120 \\
Carlisle & 5.4 & 5.1 & 500 & 390 \\
Tucson & 7.0 & 6.7 & 850 & 550 \\
Main Iron Incline & 8.5 & 7.8 & 230 & 160 \\
Petroglyph & 8.8 & 9.5 & 85 & 41 \\
\hline
\end{tabular}

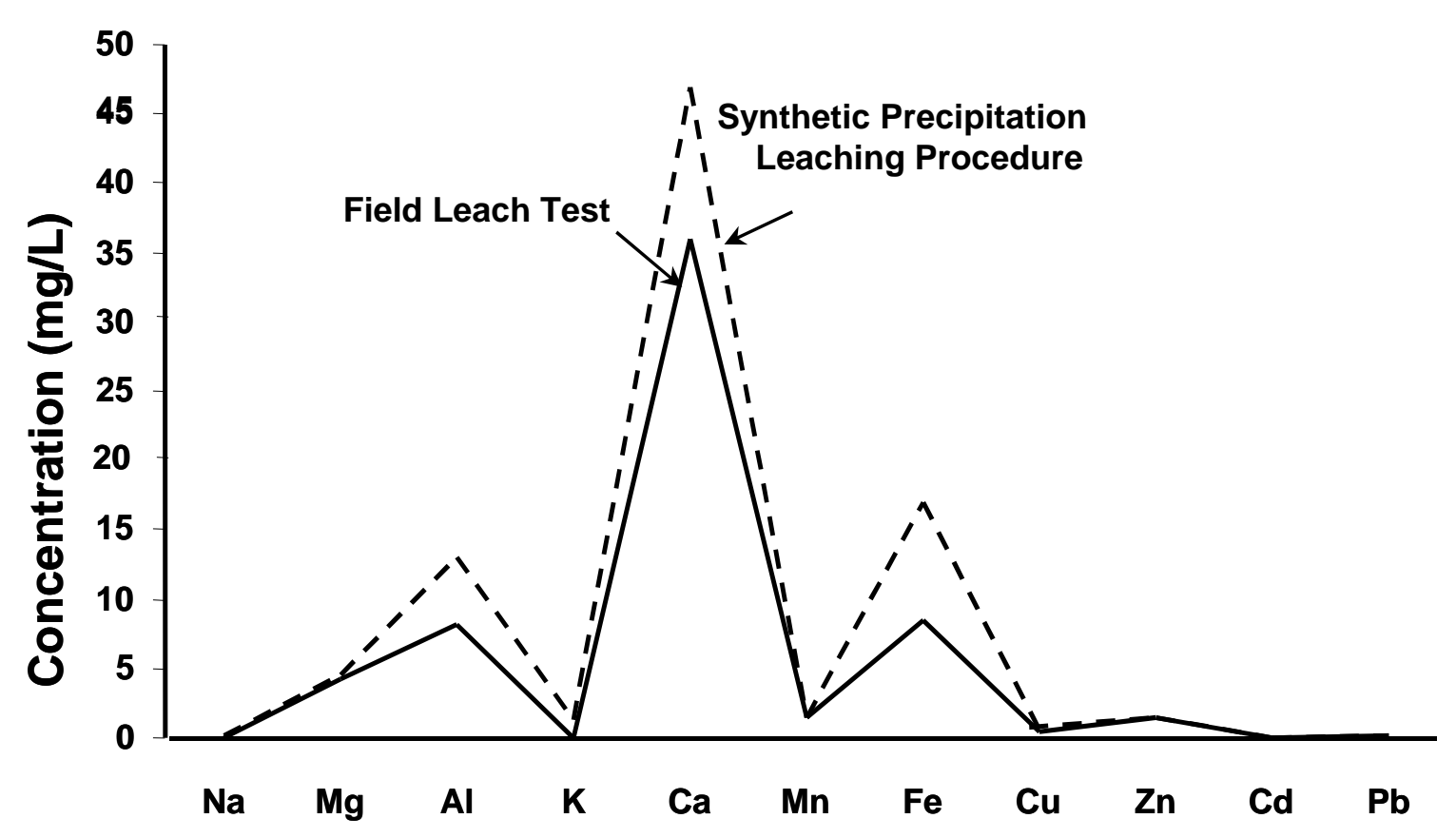

Figure 1. Comparison of leaching results of a $<2 \mathrm{~mm}$ fraction mine-dump composite from the Yukon mine near Silverton, Colorado. The dashed line represents results from the Synthetic Precipitation Leaching Procedure and the solid line represents results from the Field Leach Test. Modified from Hageman and Briggs (2000).

The net acid production (NAP) method of Lapakko and Lawrence (1993) has been slightly modified for use with weathered mine-waste piles. In this method, a 1.0-gram sample of pulverized (minus 200 mesh) waste material is digested with a heated solution of $30 \%$ hydrogen peroxide for one hour, cooled, and filtered. Acidic filtrates are titrated to $\mathrm{pH} 7$ with $\mathrm{NaOH}$, and NAP is calculated in terms of kilograms $\mathrm{CaCO}_{3}$ per metric ton of waste. It is possible to perform this method in the field if necessary. Fey and others (2000) demonstrated that mine-waste piles 
segregate into different groups when NAP is plotted against either the sum of five leachable metals (arsenic, cadmium, copper, lead, and zinc) or against leachable iron from a number of waste piles from polymetallic deposit types. The choice of leachable metals to plot against NAP can be adapted for the mineral deposit type(s) of interest. This approach can be used to rank the potential of mine-waste material to degrade water quality.

\section{NON-INVASIVE SCREENING TOOLS}

\section{Imaging Spectroscopy}

Imaging spectroscopy is a tool that can be used to map specific minerals by detecting distinctive chemical bonds within their structure. For remote sensing purposes, imaging spectroscopy can be used to map minerals contained in exposed surficial materials. One of the imaging spectroscopy sensors is the NASA/JPL AVIRIS system (Airborne Visual and Infra-Red Imaging Spectrometer). AVIRIS is flown on an ER-2 (U2) aircraft at 65,000 feet (19,800 meters) and yields a 17-meter pixel spacing with a 10.5-km swath (improvements in pixel spacing are expected soon). AVIRIS information can be analyzed using the USGS Tetracorder (Clark and others, 1995), which is an expert system that utilizes a database of more than 300 laboratory spectra and picks the best spectral match. Imaging spectroscopy also can be used for hand specimens and for on-site characterization using portable field spectrometers (spatial resolution in the millimeter to several meter range); future uses from satellites are planned. For additional information about imaging spectroscopy, see <http://speclab.cr.usgs.gov>.

Swayze and others (2000a, 2000b) have demonstrated that AVIRIS, combined with Tetracorder, can be used to map spectrally dominant iron-bearing minerals resulting from weathering of acidic mine-waste material. This approach is based on identifying iron-bearing secondary minerals, such as jarosite, goethite, and hematite (figure 2), that form on the surface of mine-waste piles as products of the oxidation of sulfide minerals. The best indicator mineral for acidic conditions appears to be jarosite. This approach can be used to screen large areas for potentially acidic mine-waste material and to identify sites that warrant closer examination. Figures 3 and $\underline{4}$ demonstrate how $\mathrm{pH}$ and specific conductance of leachates correspond to spectral zones along a traverse of a mine-waste dump. Hand-held spectrometers can be used for on-site work. Dalton and others (2000) have used imaging spectroscopy to map the distribution of acid-generating and acid-neutralizing minerals in a mineralized watershed.

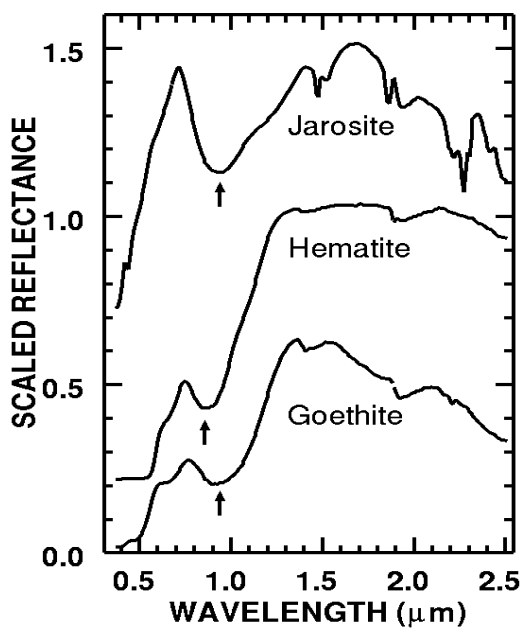

Figure 2. Spectra of some iron-bearing secondary minerals. Note the different shapes of the spectra, which are diagnostic for mineral identification. After Dalton and others (2000). 

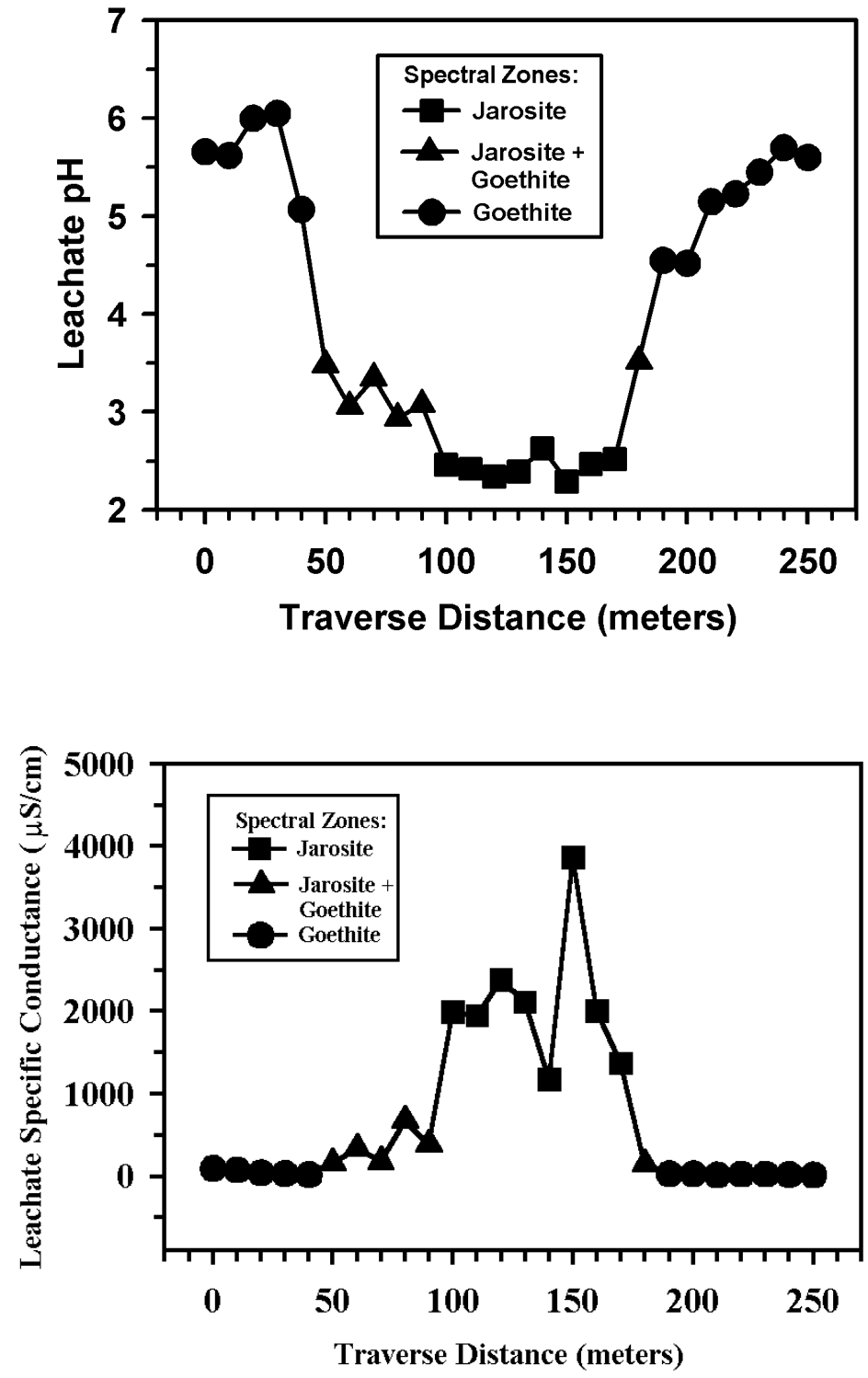

Figure 3. Surficial mine-waste leachate $\mathrm{pH}$ versus distance along a mine-waste pile traverse. Each spectral mineral zone is denoted by a different symbol. Note that the $\mathrm{pH}$ is lowest in the jarosite spectral zone. After Swayze and others (2000b).
Figure 4. Surficial mine-waste leachate specific conductance along a mine-waste pile traverse. Note that jarosite zone leachates have higher specific conductance values than do leachates from the other spectral mineral zones. Specific conductance closely tracks sulfate concentrations in the leachates. After Swayze and others (2000b).

\section{Geophysical Methods}

Combining geological mapping with airborne geophysical surveying facilitates the task of screening large areas to locate historical mine dumps and assigning them initial priorities for further study. Airborne techniques include radiometric, magnetic, and electromagnetic mapping and can be used to map subsurface lithology, structure, and ground-water flow. B.D. Smith and others (2000) illustrated how airborne geophysical techniques can be applied at both a regional scale (e.g., state) and a local scale (e.g., watershed, mining district).

Geoelectrical methods, such as direct current resistivity, electromagnetic, and induced polarization, can be used to study conditions at depth within particular mine-waste piles. These methods can infer information about lithology, mineralogy (especially sulfide minerals), pore-water saturation, or location of pore water or groundwater containing high total-dissolved solids. Hence, these methods can be used to trace plumes of contaminated water and

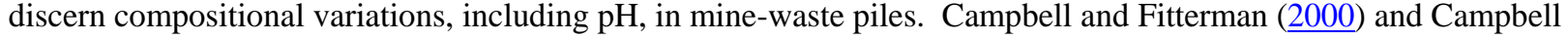
and others (1999) provided an overview of geophysical methods in mine-waste characterization. Table 2 summarizes the potential use of geophysical methods in mine-waste studies. 
Table 2. Potential uses of geophysical methods in mine-waste characterization. Modified from Campbell and Fitterman (2000).

\begin{tabular}{|c|c|c|c|}
\hline Method & Measures & Caused By & Mine-Waste Applications \\
\hline $\begin{array}{l}\text { EM (Frequency- } \\
\text { Domain } \\
\text { Electromagnetics) }\end{array}$ & $\begin{array}{l}\text { Electrical conductivity } \\
(\mathrm{mS} / \mathrm{m})\end{array}$ & $\begin{array}{l}\text { Ground water, } \\
\text { lithology }\end{array}$ & Tracing AMD plumes \\
\hline $\begin{array}{l}\text { DC (Direct-Current } \\
\text { Resistivity) }\end{array}$ & $\begin{array}{l}\text { Electrical resistivity } \\
(\text { Ohm-m) }\end{array}$ & $\begin{array}{l}\text { Ground water, } \\
\text { lithology }\end{array}$ & $\begin{array}{l}\text { Shallow }(<10 \mathrm{~m}) \text { water tables in, } \\
\text { and bottoms of, shallow }(<20 \mathrm{~m}) \\
\text { waste dumps }\end{array}$ \\
\hline $\begin{array}{l}\text { TEM (Time-Domain } \\
\text { Electromagnetics) }\end{array}$ & $\begin{array}{l}\text { Electrical conductivity } \\
(\mathrm{mS} / \mathrm{m})\end{array}$ & $\begin{array}{l}\text { Ground water, } \\
\text { lithology }\end{array}$ & $\begin{array}{l}\text { Deeper }(10-30 \mathrm{~m}) \text { water tables } \\
\text { in waste dumps }\end{array}$ \\
\hline $\begin{array}{l}\text { CSAMT (Controlled- } \\
\text { Source Audio } \\
\text { Magnetotellurics) }\end{array}$ & $\begin{array}{l}\text { Electrical resistivity } \\
\text { (Ohm-m) }\end{array}$ & $\begin{array}{l}\text { Ground water, } \\
\text { lithology }\end{array}$ & $\begin{array}{l}\text { Deeper (10-50 m) bottoms of } \\
\text { waste dumps }\end{array}$ \\
\hline $\begin{array}{l}\text { IP (Induced } \\
\text { Polarization) }\end{array}$ & $\begin{array}{l}\text { Electrical chargeability } \\
\text { (usually mV-sec/V) }\end{array}$ & $\begin{array}{l}\text { Electrochemical } \\
\text { reactions at grain } \\
\text { surfaces }\end{array}$ & $\begin{array}{l}\text { Concentrations of sulfides in } \\
\text { waste dumps }\end{array}$ \\
\hline $\begin{array}{l}\text { SP (Spontaneous } \\
\text { Polarization) }\end{array}$ & Ground voltages $(\mathrm{mV})$ & $\begin{array}{l}\text { Redox and } \\
\text { streaming potentials }\end{array}$ & $\begin{array}{l}\text { Experimental (no proven } \\
\text { successes) }\end{array}$ \\
\hline $\begin{array}{l}\text { GPR (Ground- } \\
\text { Penetrating Radar) }\end{array}$ & $\begin{array}{l}\text { Speed of } \\
\text { electromagnetic } \\
\text { radiation (cm/ns) }\end{array}$ & $\begin{array}{l}\text { Ground textures and } \\
\text { included pore water }\end{array}$ & $\begin{array}{l}\text { Possibly monitoring plume } \\
\text { remediation }\end{array}$ \\
\hline Magnetics & Magnetic field (nT) & Magnetization & $\begin{array}{l}\text { Ferrous junk (e.g., rebar) in } \\
\text { mine dumps (other mine-waste } \\
\text { applications unproven) }\end{array}$ \\
\hline Seismic & $\begin{array}{l}\text { Acoustic wave velocity } \\
(\mathrm{m} / \mathrm{s})\end{array}$ & $\begin{array}{l}\text { Compaction and } \\
\text { ground water } \\
\text { content }\end{array}$ & $\begin{array}{l}\text { Tracing bottoms and edges of } \\
\text { waste dumps, and basement } \\
\text { under plume areas (all mine- } \\
\text { waste applications are still in } \\
\text { experimental stages) }\end{array}$ \\
\hline
\end{tabular}

\section{SITE CHARACTERIZATION TOOLS}

In the study of the potential impact of a mine-waste pile on the environment, it is important to understand the source(s) of possible metal contaminants, the processes controlling their release into the environment, and their transport mechanisms (Plumlee and others, 1999). These processes are related to the susceptibility and availability of the resident mineral phase(s) of the contaminant(s) to alteration, weathering, and dissolution reactions (Smith and Huyck, 1999). Understanding these processes is key to making informed decisions about mitigation, cleanup, disposal, and remediation of mined sites.

\section{Mineralogy Determination by X-Ray Diffraction}

$\mathrm{X}$-ray diffraction (XRD) methods (described in the previous chapter) can be used to identify mineral phases in mine-waste samples. This information can be combined with bulk chemical analysis to try to account for residence phase(s) of chemical constituents. However, weathered mine-waste material commonly contains a significant portion (often as high as $40-50 \%$ ) of non- or poorly crystalline material that is amorphous and undetectable by XRD techniques. This amorphous material likely contributes to the mobility of some constituents. Hence, it is often necessary to supplement XRD methods with other methods, such as sequential chemical extractions (see below) or microanalysis techniques (see previous chapter) that can identify and assess the amorphous phases in the mine-waste material.

The limit of detection for XRD is around 1 to $5 \%$, depending on the mineral phase and sample composition. Many secondary minerals resulting from the weathering of sulfide minerals can comprise less than $1 \%$ of the whole rock, yet can be important in metal transport or acid generation. An example is efflorescent salts (see previous 
chapter), which often are below the XRD limit of detection in whole-rock samples and which commonly have a large influence on drainage-water quality.

Metal Partitioning Determination by Sequential Chemical Extractions

In sequential chemical extractions, constituents are extracted from some or all of operationally defined solid phases through reaction with a sequence of solvents (Chao, 1984). The sequence of extractions exposes the sample to increasingly rigorous chemical treatments. This provides a means for evaluating the availability and potential mobility of metals extracted from the various phases. There are many operationally defined sequential-extraction schemes. Leinz and others $(\underline{1999,2000})$ have adopted the following scheme for weathered mine-waste material: 1. Water-soluble constituents -- A 0.25-g sample, with $0.25 \mathrm{~g}$ silica gel added, is extracted with $25 \mathrm{~mL}$ deionized water in a 50-mL centrifuge tube for two hours in a horizontal reciprocating shaker at ambient temperature.

2. Ion-exchangeable constituents -- The residue from step 1 is extracted with $25 \mathrm{~mL}$ of $1 \mathrm{M}$ sodium acetate for one hour in a horizontal reciprocating shaker at ambient temperature.

3. Constituents associated with carbonates -- The residue from step 2 is extracted with $25 \mathrm{~mL}$ of $1 \mathrm{M}$ sodium acetate buffered to $\mathrm{pH} 5$ (using acetic acid) for two hours in a horizontal reciprocating shaker at ambient temperature. (This extraction mostly pertains to calcite and magnesite. Some carbonates, such as siderite, are minimally extracted.)

4. Constituents associated with manganese oxides and amorphous iron oxides -- The residue from step 3 is extracted with a $25 \mathrm{~mL}$ of $0.25 \mathrm{M}$ solution hydroxylamine hydrochloride in $0.25 \mathrm{M}$ hydrochloric acid for 30 minutes in a $50^{\circ} \mathrm{C}$ water bath.

5. Constituents associated with crystalline iron oxides -- The residue from step 4 is extracted with $25 \mathrm{~mL}$ of $4 \mathrm{M}$ hydrochloric acid for 30 minutes at $94^{\circ} \mathrm{C}$ in a boiling water bath.

6. Constituents occurring as or in sulfide minerals -- The residue from step 5 is extracted with $2 \mathrm{~g}$ of sodium chlorate followed by the careful addition of $10 \mathrm{~mL}$ of concentrated hydrochloric acid. The extraction is allowed to continue for 45 minutes at room temperature. Following separation, the aqueous phase is diluted to $25 \mathrm{~mL}$ with deionized water and the residue is treated with $4 \mathrm{M}$ nitric acid for 40 minutes in a boiling water bath. The two extracts are analyzed separately and the results combined.

7. Constituents occurring as or in silicate minerals -- The residue from step 6 is transferred to a Teflon beaker and digested with $10 \mathrm{~mL}$ each of concentrated nitric acid, perchloric acid, and hydrofluoric acid at $220^{\circ} \mathrm{C}$, to a moist bead. The moist bead is treated with $25 \mathrm{~mL}$ of $4 \mathrm{M}$ hydrochloric acid for 30 minutes at $100^{\circ} \mathrm{C}$. The final volume is adjusted to $25 \mathrm{~mL}$ with deionized water.

Isolation and Enumeration of Iron- and Sulfur-Oxidizing Bacteria

Iron- and sulfur-oxidizing bacteria enhance the degradation of sulfide minerals. A determination of their numbers can provide an estimate of the contribution of biological activity to mine-waste decomposition and aciddrainage generation. Bacteria of the genus Thiobacillus have long been recognized as active agents in the formation of acid-mine drainage. At acidic $\mathrm{pH}$, these bacteria can catalyze iron-oxidation reactions nearly $10^{6}$ times faster than is possible through inorganic mechanisms alone.

Although generally considered ubiquitous in the acid-mine drainage environment, microbiological techniques must be used to confirm the presence of thiobacilli. Newer molecular-based techniques to isolate and identify microbes are rapidly being developed. However, most studies have relied on "classical" microbiological methods to identify the presence of thiobacilli in sediments and waters associated with mine wastes. Such methods employ media specially formulated to meet growth and nutritional needs of the microbes of interest. After the initial isolation of the microbes is complete, additional tests can be run to characterize the biochemistry of the organisms, and laboratory simulation experiments can be run to estimate microbial action upon the mine-waste material.

Thiobacillus ferrooxidans and Thiobacillus thiooxidans were isolated from the Mayday mine dump near Silverton, Colorado, using the MPN (most probable number) culture technique (Stanton, 2000). An initial set of MPN tubes using small volumes of inoculum was used to assess and select core samples for detailed study and enumeration of cell numbers. For Mayday drill core 1, an additional MPN test was run using inocula of 10, 1, and $0.1 \mathrm{~mL}$ into prepared media. Cell numbers of approximately 1000/g were obtained from some samples from the Mayday mine dump (Table 3). 
Table 3. Results from microbiological most probable number tests and selected elemental concentrations for cored samples from the Mayday mine-waste pile near Silverton, Colorado. [NA = not analyzed; depth is the midpoint of the interval]

\begin{tabular}{ccrrrrrrr}
$\begin{array}{c}\text { Sample } \\
\text { Number }\end{array}$ & $\begin{array}{c}\text { Depth } \\
(\mathrm{ft} .)\end{array}$ & $\begin{array}{c}\mathrm{Cu} \\
(\mathrm{ppm})\end{array}$ & $\begin{array}{c}\mathrm{Pb} \\
(\mathrm{ppm})\end{array}$ & $\begin{array}{c}\mathrm{Zn} \\
(\mathrm{ppm})\end{array}$ & $\begin{array}{c}\text { Total C } \\
(\%)\end{array}$ & $\begin{array}{c}\text { Total S } \\
(\%)\end{array}$ & $\begin{array}{c}\text { Th. ferro. } \\
\text { per g }\end{array}$ & $\begin{array}{c}\text { Th. thio. } \\
\text { per g }\end{array}$ \\
\hline H1-C1-T & 0.8 & 100 & 2,200 & 730 & 0.17 & 1.5 & 210 & 2 \\
H1-C1-B & 2.4 & 40 & 400 & 90 & 0.10 & 0.54 & 1,100 & 2 \\
H1-C2-T & 4.3 & 30 & 270 & 230 & 0.73 & 0.36 & 9 & 460 \\
H1-C2-M & 6.0 & 870 & 32,100 & 27,100 & 1.08 & 4.34 & 1,100 & 4 \\
H1-C2-B & 7.64 & 4,600 & 8,600 & 5,900 & 0.14 & 9.14 & 210 & 75 \\
H1-C3-T & 9.75 & 25 & 60 & 160 & 0.02 & 1.91 & 21 & 9 \\
H1-C3-B & 11.12 & 50 & 100 & 150 & 0.05 & 1.09 & 1,100 & 210 \\
H1-C4 & 15.1 & 45 & 130 & 130 & 0.05 & 2.0 & NA & NA \\
H1-C5 & 17.5 & 160 & 1,450 & 880 & 0.15 & 1.02 & NA & NA \\
\hline
\end{tabular}

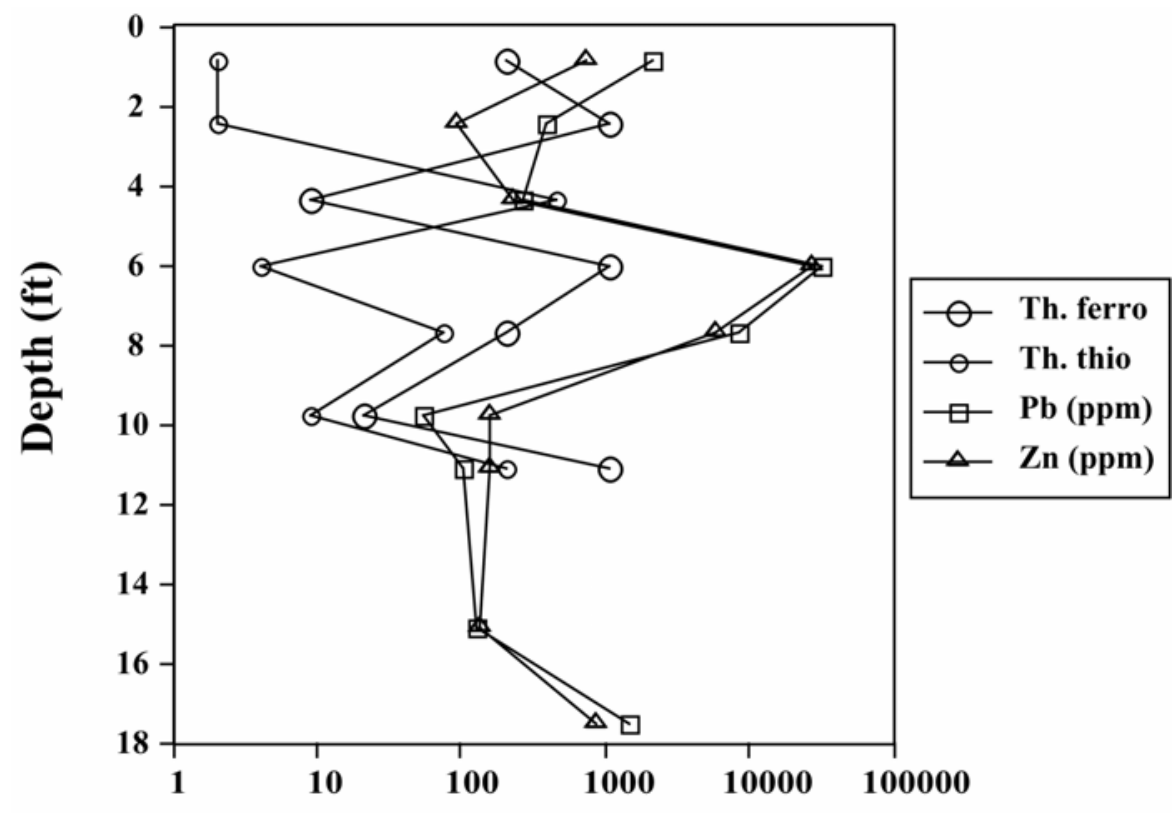

\section{Concentration (ppm or cells per gram)}

Figure 5. Plot of microbiological data (Thiobacillus ferrooxidans and Thiobacillus thiooxidans counts) and lead and zinc concentrations with depth in drill core 1 from the Mayday mine-waste pile near Silverton, Colorado.

Below $6 \mathrm{ft}(2 \mathrm{~m})$, Thiobacillus ferrooxidans shows a strong relation of cell numbers to $\mathrm{Pb}$ and $\mathrm{Zn}$ concentrations whereas Thiobacillus thiooxidans shows lower cell numbers with respect to these elements (figure 5). Additionally, there appears to be an antagonistic effect between the two organisms in the mine dump above $6 \mathrm{ft}$. That is, when Thiobacillus ferrooxidans numbers are high, Thiobacillus thiooxidans numbers are low, and vice versa. 


\section{Use of Multidimensional Spatial Modeling}

Multidimensional spatial modeling techniques can be used to integrate and synthesize disparate information about a mine site. Using these techniques, it is possible to simultaneously view two-dimensional and threedimensional information. This approach can be a visually intuitive tool to examine spatial relationships and to view digital data. Yager and Stanton (2000) provided an example of spatial modeling by combining topographical, geophysical, and geochemical data for a mine-waste pile (Fig. 6).
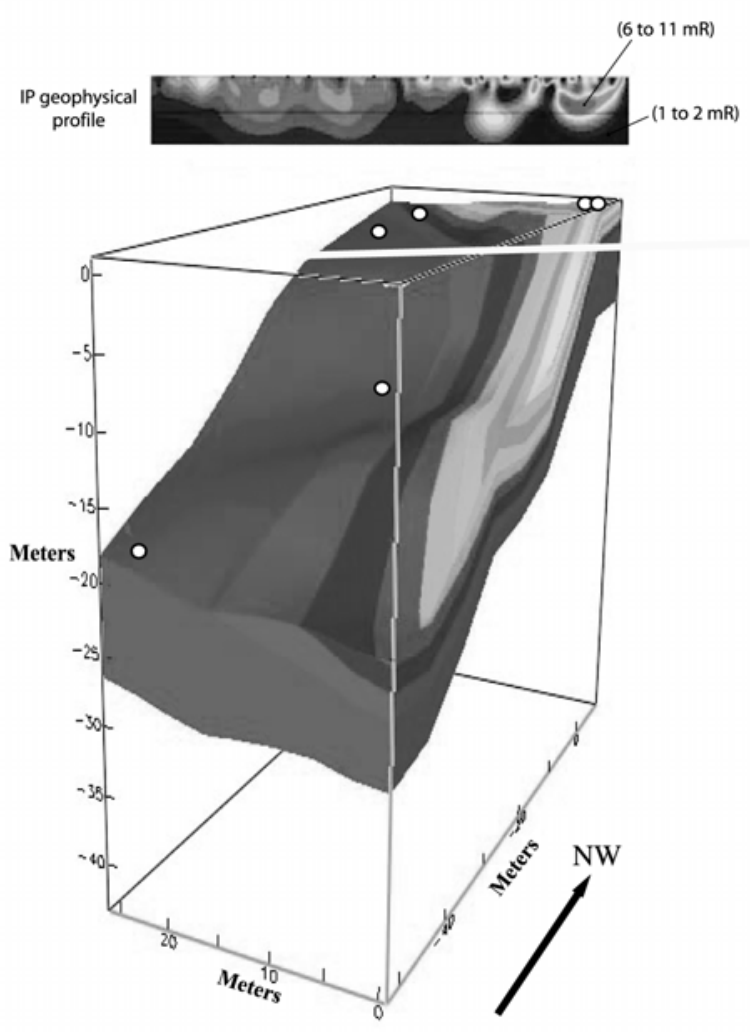

Figure 6. Synthesis of two-dimensional topographic data, three-dimensional geochemical gridded data for Zn (ppm), and geophysical induced polarization (IP) profile for the Mayday mine-waste pile near Silverton, Colorado. The white line across the face of the upper bench indicates the approximate IP profile location. Arrows point to relatively high IP signals (the arrow along the lower right edge of the block diagram indicates orientation of the waste pile). Note that high concentrations of zinc (lighter gray shades) in the upper right (northern) part of the pile coincide with a relatively high IP (6-11 milliradian) signal, although zinc alone is not responsible for the relatively high IP signal in the northern part of the pile. Modified from Yager and Stanton (2000).

\section{ACKNOWLEDGMENTS}

The U.S. Geological Survey Mineral Resources Program funded this work.

\section{REFERENCES CITED}

Campbell, D.L., Horton, R.J., Bisdorf, R.J., Fey, D.L., Powers, M.H., and Fitterman, D.V., 1999, Some geophysical methods for tailings/mine waste work, in Tailings and Mine Waste '99 - Proceedings of the Sixth International Conference on Tailings and Mine Waste, Fort Collins, Colorado, January 24-27, 1999: Rotterdam, A.A. Balkema, p. 35-43.

Campbell, D.L., and Fitterman, D.V., 2000, Geoelectrical methods for investigating mine dumps, in ICARD 2000: Proceedings from the Fifth International Conference on Acid Rock Drainage, Denver, Colorado, May 21-24, 2000: Society for Mining, Metallurgy, and Exploration, Inc., p. 1513-1523.

Chao, T.T., 1984, Use of partial dissolution techniques in geochemical exploration: J. Geochem. Explor., v. 20, p. 101-135.

Clark, R.N., and Swayze, G.A., 1995, Mapping minerals, amorphous materials, environmental materials, vegetation, water, ice and snow, and other materials: the USGS Tricorder algorithm, in R.O. Green, ed., Summaries of the Fifth Annual JPL Airborne Earth Science Workshop, January 23-26, Vol. 1: AVIRIS Workshop: Jet Propulsion Laboratory Publication 95-1, p. 39-40. 
Dalton, J.B., King, T.V.V., Bove, D.J., Kokaly, R.F., Clark, R.N., Vance, J.S., and Swayze, G.A., 2000, Distribution of acid-generating and acid-buffering minerals in the Animas River watershed as determined by AVIRIS spectroscopy, in ICARD 2000: Proceedings from the Fifth International Conference on Acid Rock Drainage, Denver, Colorado, May 21-24, 2000: Society for Mining, Metallurgy, and Exploration, Inc., p. 1541-1550.

Fey, D.L., Desborough, G.A., and Church, S.E., 2000, Comparison of two leach procedures applied to metal-mining related wastes in Colorado and Montana and a relative ranking method for mine wastes, in ICARD 2000: Proceedings from the Fifth International Conference on Acid Rock Drainage, Denver, Colorado, May 21-24, 2000: Society for Mining, Metallurgy, and Exploration, Inc., p. 1477-1487.

Hageman, P.L., and Briggs, P.H., 2000, A simple field leach test for rapid screening and qualitative characterization of mine waste dump material on abandoned lands, in ICARD 2000: Proceedings from the Fifth International Conference on Acid Rock Drainage, Denver, Colorado, May 21-24, 2000: Society for Mining, Metallurgy, and Exploration, Inc., p. 1463-1475.

Lapakko, K.A., and Lawrence, R.W., 1993, Modification of the Net Acid Production (NAP) test, in Proceedings, British Columbia Mine Reclamation Symposium, Port Hardy, B.C., May 4-7, 1993, p. 145-159.

Leinz, R.W., Sutley, S.J., and Briggs, P.H, 1999, The use of sequential extractions for the chemical speciation of mine wastes, in Tailings and Mine Waste '99 - Proceedings of the Sixth International Conference on Tailings and Mine Waste, Fort Collins, Colorado, January 24-27, 1999: Rotterdam, A.A. Balkema, p. 555-561.

Leinz, R.W., Sutley, S.J., Desborough, G.A., and Briggs, P.H., 2000, An investigation of the partitioning of metals in mine wastes using sequential extractions, in ICARD 2000: Proceedings from the Fifth International Conference on Acid Rock Drainage, Denver, Colorado, May 21-24, 2000: Society for Mining, Metallurgy, and Exploration, Inc., p. 1489-1499.

Pitard, F.F., 1993, Pierre Gy's sampling theory and sampling practice-heterogeneity, sampling correctness, and statistical process control, $2^{\text {nd }}$ edition: Boca Raton, Florida, CRC Press.

Plumlee, G.S., Smith, K.S., Montour, M.R., Ficklin, W.H., and Mosier, E.L., 1999, Geologic controls on the composition of natural waters and mine waters draining diverse mineral-deposit types, in L.H. Filipek and G.S. Plumlee, eds., The Environmental Geochemistry of Mineral Deposits, Part B: Society of Economic Geologists, Reviews in Economic Geology, v. 6B. p. 373-432.

Smith, B.D., McCafferty, A.E., and McDougal, R.R., 2000, Utilization of airborne magnetic, electromagnetic, and radiometric data in abandoned mine land investigations, in ICARD 2000: Proceedings from the Fifth International Conference on Acid Rock Drainage, Denver, Colorado, May 21-24, 2000: Society for Mining, Metallurgy, and Exploration, Inc., p. 1525-1530.

Smith, K.S. and Huyck, H.L.O., 1999, An overview of the abundance, relative mobility, bioavailability, and human toxicity of metals, in G.S. Plumlee and M.J. Logsdon, eds., The Environmental Geochemistry of Mineral Deposits, Part A: Society of Economic Geologists, Reviews in Economic Geology, v. 6A., p. 29-70.

Smith, K.S., Ramsey, C.A., and Hageman, P.L., 2000, Sampling strategy for the rapid screening of mine-waste dumps on abandoned mine lands, in ICARD 2000: Proceedings from the Fifth International Conference on Acid Rock Drainage, Denver, Colorado, May 21-24, 2000: Society for Mining, Metallurgy, and Exploration, Inc., p. 1453-1461.

Stanton, M.R., 2000, The role of weathering in trace metal redistributions in the Mayday Mine Dump near Silverton, Colorado, in ICARD 2000: Proceedings from the Fifth International Conference on Acid Rock Drainage, Denver, Colorado, May 21-24, 2000: Society for Mining, Metallurgy, and Exploration, Inc., p. 1501-1509.

Swayze, G.A., Smith, K.S., Clark, R.N., and Sutley, S.J., 2000a, Imaging spectroscopy: a new screening tool for mapping acidic mine waste, in ICARD 2000: Proceedings from the Fifth International Conference on Acid Rock Drainage, Denver, Colorado, May 21-24, 2000: Society for Mining, Metallurgy, and Exploration, Inc., p. 1531-1539.

Swayze, G.A., Smith, K.S., Clark, R.N., Sutley, S.J., Pearson, R.M., Vance, J.S., Hageman, P.L., Briggs, P.H., Meier, A.L., Singleton, M.J., and Roth, S., 2000b, Using imaging spectroscopy to map acidic mine waste. Environmental Science and Technology, v. 34, p. 47-54.

U.S. Environmental Protection Agency, 1994, Test methods for evaluating solid waste, physical/chemical methods (SW-846), $3^{\text {rd }}$ edition, update 2B: Environmental Protection Agency, National Center for Environmental Publications, Cincinnati, OH 45268, telephone 800-553-6847, order number EPASW-846.3.2B. URL $<$ http://www.epa.gov/epaoswer/hazwaste/test/sw846.htm>.

Yager, D.B., and Stanton, M.R., 2000, Multidimensional spatial modeling of the Mayday Mine Waste Pile, Silverton, Colorado, in ICARD 2000: Proceedings from the Fifth International Conference on Acid Rock Drainage, Denver, Colorado, May 21-24, 2000: Society for Mining, Metallurgy, and Exploration, Inc., p. 297301. 


\title{
Chapter D
}

\section{ENVIRONMENTAL BEHAVIOR OF TWO MOLYBDENUM PORPHYRY SYSTEMS}

\author{
Michele L.W. Tuttle, Richard B. Wanty, and Byron R. Berger
}

\section{INTRODUCTION}

This paper compiles geological, hydrological, and geochemical data required to understand the environmental behavior of metals associated with two molybdenum (Mo) porphyry systems. The two systems represent a high fluorine, granite Mo system (Climax-type) and a low fluorine granodiorite system (deposit types described in Cox and Singer, 1985; Soregaroli and Sutherland Brown, 1976). The lowfluorine deposit (Buckingham Stockwork Mo deposit) is located on Battle Mountain in Nevada and the Climax type deposit (Mount Emmons/Redwell deposit) is beneath Red Lady and Redwell Basins, Colorado (fig. 1). The water quality of streams, natural springs, mine discharge, and ground water from drill holes are assessed in the region of these two deposits. In addition, the geology and controls on the hydrology are used to establish a framework for the water quality data.

The goals of this work are:

1. Establish background concentrations of metals in streams flowing through undisturbed mineralized Mo porphyry deposits,

2. Describe geochemical characteristics of waters associated with both high- and low-fluorine Mo porphyry deposits in undisturbed and mined drainages,

3. Recognize the important geochemical processes that control these characteristics (e.g. metal adsorption and precipitation),

4. Determine the appropriate sampling density needed to recognize diagnostic geochemical characteristics to assess water quality near and downstream from the deposits,

5. Understand how climate affects water composition, and

6. Integrate geochemical data with the geology and hydrology within the drainage basins.

\section{BACKGROUND}

Battle Mountain, Nevada

Long Canyon and Licking Creek cross the Buckingham Stockwork Mo deposit (also referred to as the Buckingham porphyry Mo deposit). There are very few mines in the Long Canyon drainage. The lower portion of the canyon represents an undisturbed mineralized area with its upper reaches well outside the mineralized area (fig. 1). Samples from the upper reaches of the stream provide valuable data to assess the water quality attributed to the unmineralized host-rock lithology in the area. A small spring (perhaps an uncompleted drill hole; sample site 1) just outside the Mo deposit produces waters that may be in contact with the Mo mineralized stockworks at depth. We have interpreted this spring water to be a natural "deposit drainage" into Long Canyon.

All samples collected along Licking Creek were within the boundary of the Buckingham Stockwork Mo deposit (fig. 1). As mines and their dumps are common throughout the drainage, we have characterized Licking Creek as a disturbed mineralized area. Buckingham Camp Creek, a tributary to Licking Creek, was a site of the Buckingham Camp where ore was processed. Water from the Buckingham Camp Creek, a small tributary into Licking Creek, represents drainage from the mines and processing dumps. Along the Buckingham fault at the confluence of Buckingham Camp Creek and Licking Creek, a spring discharges high contents of trace metals. We interpret this spring water as "deposit drainage" and, although natural, is geochemically similar to water in Buckingham Camp Creek. 


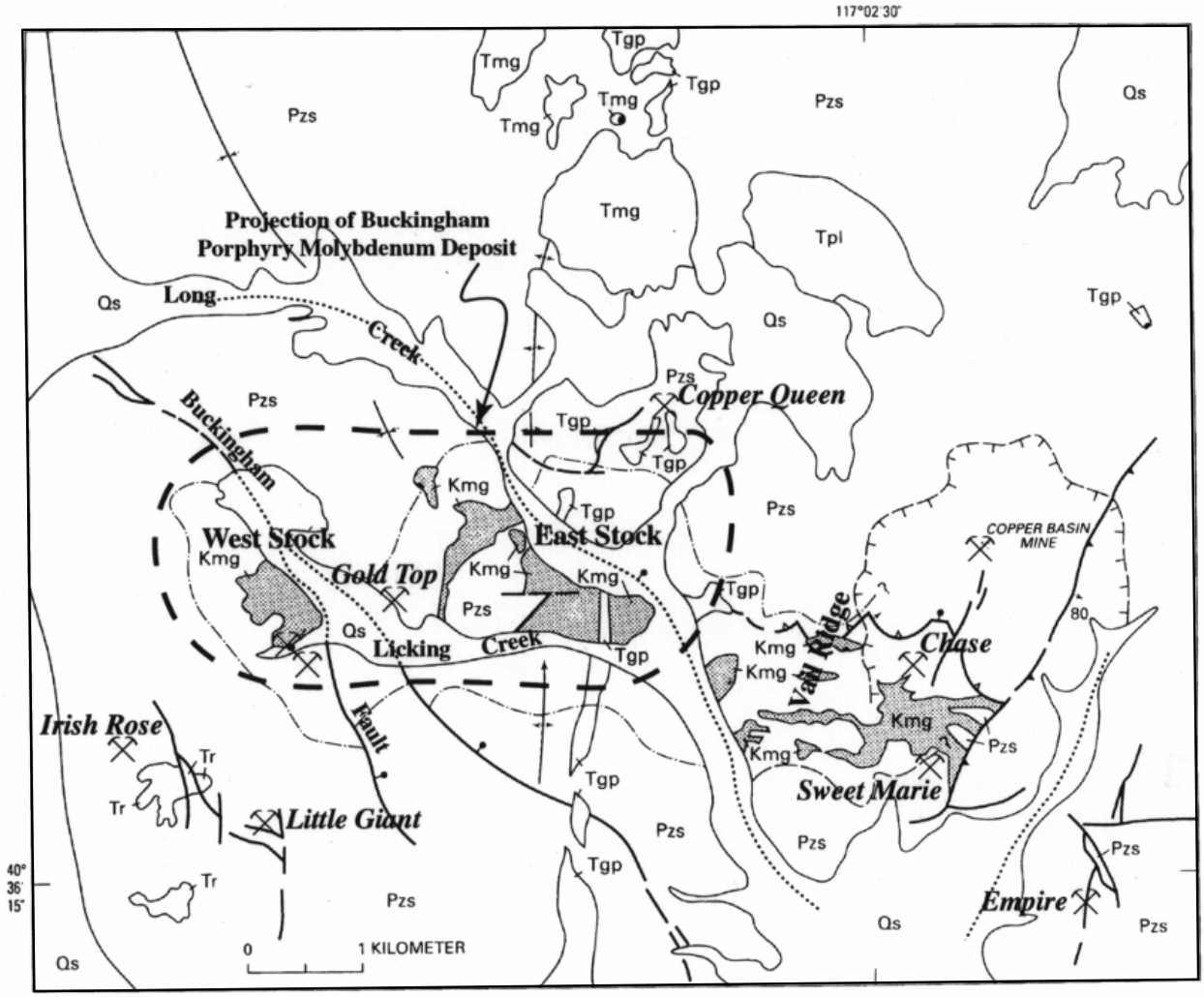

EXPLANATION

Rhyolite (Tertiary) Surficial

Superficial deposits (Quaternary)

Granodiorite porphyry (Tertiary)

Monzogranite (Teriary)

Porphyritic leucogranite (Tertiary)

Monzogranite porphyry (Cretaceous)

Sedimentary rocks (Paleozoic)

Faults-Dashed where approximate; dotted where concealed. Bar and ball on downdropped side. May show dip

1 Normal

Lـ Low-angle gravity glide-Sawteeth on upper plate

Thrust-Sawteeth on upper plate

_. Anticline-May show direction of plunge

- Syncline

oundary of Buckingham quartz stockwork-Queried where location uncertain

$\perp+\perp$ Boundary of Copper Basin open-pit mine

Figure 1. Generalized geologic map of the Late Cretaceous Buckingham porphyry molybdenum deposit, Battle Mountain, Nevada (Theodore and others, 1992). A projection of the outer boundary of the molydenum deposit is indicated by the dashed line. Some of the major Late Cretaceous and Early Tertiary polymetallic vein and skarn deposits are indicated in italics. 
Redwell Basin, Colorado

Redwell Basin was mined for base metals (zinc, lead, and copper) that occur in the breccia pipe above the two Redwell deposits (fig. 2). Ground-water discharges into the Redwell Basin from these old mine workings. Above most of these seeps, an old drill hole produces water that flows into a small tributary of Redwell stream. The ground water flowing from the drill hole likely is from various levels within the porphyry/breccia pipe complex, making it impossible to isolate the geochemical characteristics of the Mo porphyry from that of the accompanying epithermal base-metal mineralization. This complexity affects most drainages associated with Mo porphyry systems due to the proximal position of base metals, or, as is the case at Battle Mountain, later mineralization events that overprint the porphyry system. The ground water being discharged at the drill hole, although derived from a composite of deposit types, provides the best approximation of the geochemistry of water draining from the high fluorine Mo porphyry system in this relatively undisturbed drainage basin.

\section{Climate}

The climate is distinctly different between the Nevada and Colorado study sites, and, because climate is thought to be an important control on the environmental behavior of metals, these differences were

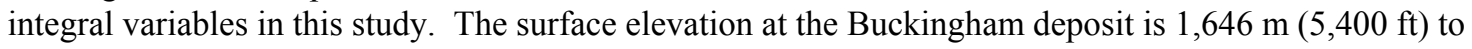
$2,011 \mathrm{~m}(6,600 \mathrm{ft})$. The town of Battle Mountain (elevation 1,383 m) some $10 \mathrm{~km}$ to the north of the deposit receives $19 \mathrm{~cm}$ precipitation per year and has a mean annual temperature of $9.5^{\circ} \mathrm{C}$. Average annual evapotranspiration as calculated by Shevenell (1996) is between 60 and $120 \mathrm{~cm}$ and depends strongly on elevation. The Mount Emmons/Redwell deposit sits beneath high alpine valleys. The Redwell basin is at $2,865 \mathrm{~m}(9,400 \mathrm{ft})$ to $3,658 \mathrm{~m}(12,000 \mathrm{ft})$ elevation. The town of Crested Butte (elevation 2,700 m) receives $60 \mathrm{~cm}$ precipitation per year and has a mean annual temperature of $1.1^{\circ} \mathrm{C}$.

\section{GEOLOGY}

Buckingham Porphyry Molybdenum Deposit, Battle Mountain, Nevada

The study site is the location of an unmined, largely buried porphyry molybdenum deposit and associated veins (fig. 1). The deposit is related to a $\sim 86$ Ma composite, porphyritic intrusive into feldspathic sandstone, quartz arenite, and shale of the Upper Cambrian Harmony Formation (Theodore and others, 1992).

1. Lithology. The Cambrian(?) Harmony Formation in the Battle Mountain range consists of interbedded quartz arenite, subarkose, arkose, pebbly quartz arenite, shale, and minor limestone (Roberts, 1964). In the Buckingham area, the Harmony consists predominantly of graded sandstone including quartz arenite, arkose, subarkose, and litharenite with minor amounts of shale, calcareous shale, and greenstone (Theodore and others, 1992). According to Roberts (1964), the mineralogy of the sandstones is quite variable, but generally consists of quartz (60-80\%), feldspar ( $\geq 20 \%)$, mica (2-5\%), and matrix cement. The feldspars are a mix of orthoclase, microcline, and sodic plagioclase in proportions that regionally average $\approx 65 \%$ potassium feldspar and $\approx 35 \%$ oligoclase to sodic andesine. The matrix cements variably consist of clays, calcite, and quartz. Compaction, diagenetic clay growth, and hydrothermal metasomatism have reduced porosity in the Harmony Formation to $<1 \%$ (Theodore and others, 1992). Ranges of whole-rock chemical analyses of the Harmony Formation from Theodore and others (1994) are given in Table 1.

Intrusive igneous rocks in the Buckingham area range from Late Cretaceous monzogranite to Eocene monzogranite to Early Oligocene(?) rhyolite, porphyritic leucogranite, and granodiorite porphyry (fig. 1). The porphyry molybdenum deposit is genetically related to $\approx 86$ Ma monzogranites that occur in a generally east-west zone that may be divided into three groups- West stock, East stock, and Vail Ridge dikes and plugs (cf. Theodore and others, 1992). There are four main compositional groups of monzogranitic rocks: 1) monzogranite porphyry, 2) megacrystic monzogranite porphyry, 3) aplite, and 4) a late-stage breccia pipe.

The Cretaceous intrusive phases show variable degrees of hydrothermal alteration. In the West stock, there are quartz, less abundant K-feldspar and clay- or white mica-altered plagioclase, and white mica- or chlorite-altered biotite phenocrysts. The groundmass consists predominantly of fine-grained white mica and disseminated pyrite. Locally, the white mica is intergrown with molybdenite. Stockwork quartz or quartz- 
Figure 2. Geologic map of the Redwell Basin study area (from Gaskill and others, 1967).

Stratigraphic units include Km: Mancos Shale, Kmv: Mesa Verde Formation, Toc: Ohio Creek Formation, Tw: Wasatch Formation, gp: granodiorite porphyry, f: Redwell Basin breccia pipe.

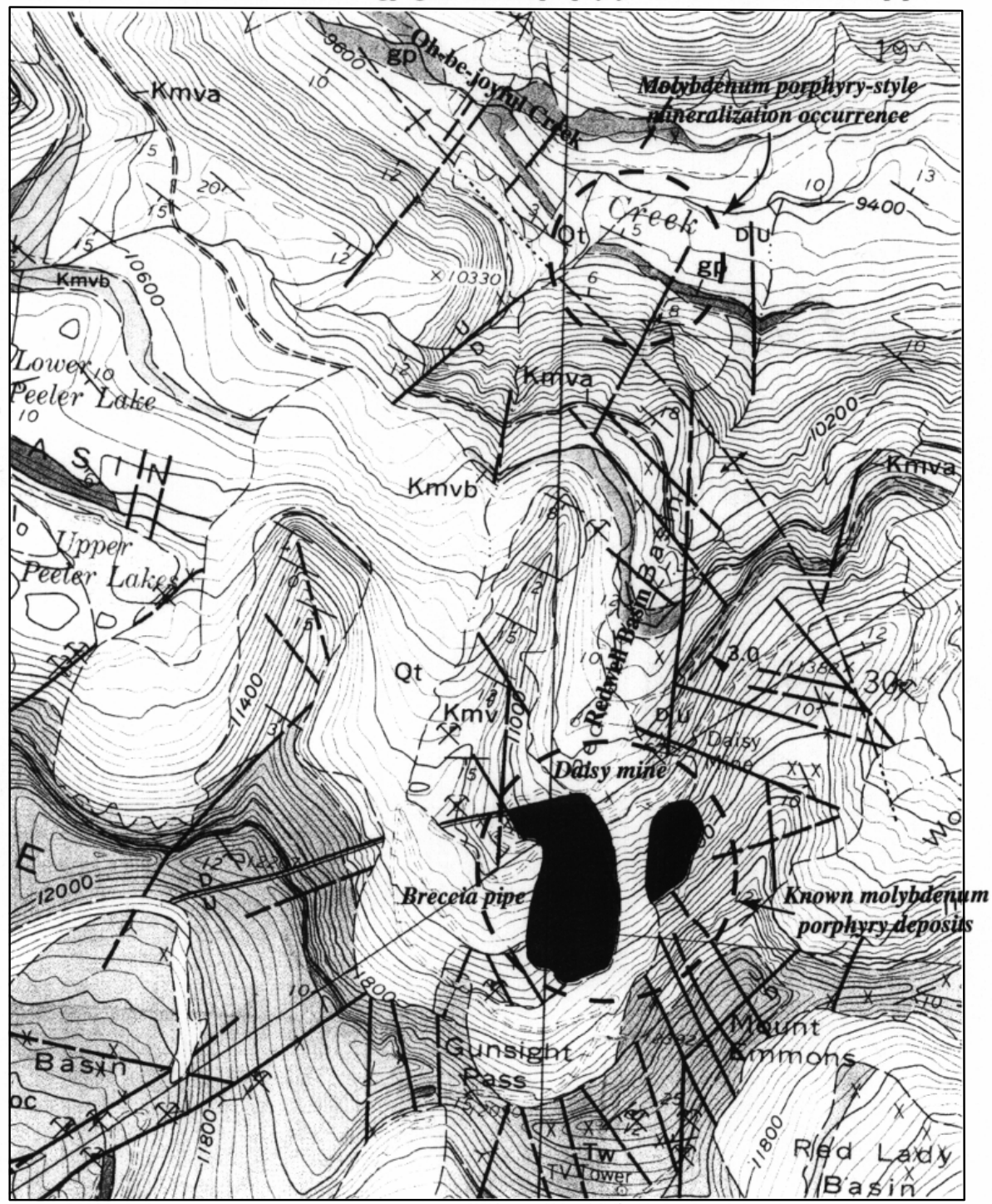


Table 1. Ranges of analytical data in weight-percent on the Upper Cambrian Harmony Formation in the Buckingham Camp region, Nevada (from Theodore and others, 1992).

$\begin{array}{lc}\mathrm{SiO}_{2} & 57.8-88.3 \\ \mathrm{Al}_{2} \mathrm{O}_{3} & 5.48-19.6 \\ \mathrm{Fe}_{2} \mathrm{O}_{3} & 0.76-2.55 \\ \mathrm{FeO} & 0.12-5.5 \\ \mathrm{MgO} & 0.45-3.03 \\ \mathrm{CaO} & 0.16-8.26 \\ \mathrm{Na} 2 \mathrm{O} & 0.53-2.05 \\ \mathrm{~K}_{2} \mathrm{O} & 1.17-5.83 \\ \mathrm{TiO}_{2} & 0.38-1.03 \\ \mathrm{P}_{2} \mathrm{O}_{5} & <0.05-0.11 \\ \mathrm{MnO} & <0.02-0.08 \\ \mathrm{CO}_{2} & 0.01-6.3 \\ \mathrm{~F} & 0.02-0.05\end{array}$

sericite veins characterize the West stock and can be up to 40-50 volume percent of the rocks locally (Theodore and others, 1992). Pyrite occurs in the veins as well as molybdenite. The East stock is similar to the West stock, but there is an early-stage potassic alteration stage and pervasive clay alteration of plagioclase is more common. The Vail Ridge intrusions consist of narrow dikes and small equant masses and are located east of the porphyry molybdenum deposit. Nevertheless, phyllic to argillic hydrothermal alteration is intensive and there is disseminated molybdenite. Megacrystic monzogranite is most abundant in the East stock and it is inferred to intrude the porphyritic monzogranite. Aplite is a minor component of the intrusive system. The breccia pipe is located in the East stock and is interpreted to be part of the latest stage of porphyry molybdenum deposit formation.

Between about 39 and $37 \mathrm{Ma}$, numerous dikes and plutons were emplaced in the Buckingham area (Theodore and others, 1992). The main loci are north of the Buckingham porphyry molybdenum deposit just north of the Copper Queen mine (fig. 1) and south of Buckingham in the vicinity of the Little Giant mine (fig. 1). These rocks include a diverse variety of compositions such as biotite-hornblende monzogranite, porphyritic leucogranite, rhyolite, granodiorite, and minor diorite. Ranges of analytical data for some of these rock types are given in Table 2 .

2. Structural geology. The Battle Mountain range is bounded on the north and south by regional, northwest-southeast striking right-lateral strike-slip faults (T. Hildenbrand, USGS, unpublished data, 2000). The faults within the range form a system of faults linking these two strike-slip fault zones. This duplex of faults provided the permeability and structural control for Cretaceous to Pliocene igneous intrusions and related hydrothermal activity.

Veins within and adjacent to the Buckingham Cretaceous monzogranites parallel the east-west trend of the intrusions, although the most strongly developed vein sets strike from east-west to $\mathrm{N} 60^{\circ} \mathrm{W}$ (Theodore and others, 1992). In the molybdenum orebodies in the East and West stocks, post-mineralization $\mathrm{N} 25^{\circ} \mathrm{W}$ faults cross-cut the orebodies and are interpreted to be normal-oblique faults by T. Loucks and C. Johnson (in Theodore and others, 1992). These faults consist of significant gouge and breccia zones, but the amount of rotation along these faults is unknown. One of them, the Buckingham fault, is estimated by Loucks and Johnson (in Theodore and others, 1992) to be 100-225 m thick and have had $520 \mathrm{~m}$ of dip slip and $175 \mathrm{~m}$ of right-lateral slip.

3. Mineral Deposits. The Late Cretaceous Buckingham porphyry molybdenum deposit is a composite of seven mineralizing events (cf. Loucks and Johnson in Theodore and others, 1992). The molybdenum deposit encompasses five events related to two phases of intrusion in the West stock and three in the East stock. Some events form conical zones of veins localized at the apices of monzogranitic intrusions. The highest grades are developed where the mineralization events overlap. Accompanying stockwork and disseminated pyrite-molybdenite mineralization are chalcopyrite, scheelite and tetrahedrite. Some chalcopyrite occurs in the quartz-pyrite-molybdenite veinlets. However, copper concentrations tend to be highest in the peripheral parts of the molybdenum orebodies, occurring in chalcopyrite and freibergite. 
Low-grade, disseminated chalcopyrite, pyrrhotite, tetrahedrite, and pyrite are found in late-stage dikes that crosscut the molybdenum mineralization (cf. Loucks and Johnson in Theodore and others, 1992).

Table 2. Ranges (in wt \%) of analyses on Late Eocene to Early Oligocene intrusive rocks in the Buckingham Camp region. Column 2 are data from biotite-hornblende monzogranite, column 3 from porphyritic leucogranite, and column 3 from rhyolite (from Theodore and others, 1992).

$\begin{array}{lccc} & \text { Monzogranite } & \frac{\text { Leucogranite }}{\text { Rhyolite }} \\ \mathrm{SiO}_{2} & 66.0-70.25 & 61.52-69.3 & 72.82-76.9 \\ \mathrm{Al}_{2} \mathrm{O}_{3} & 13.46-15.73 & 14.1-16.48 & 12.7-13.27 \\ \mathrm{Fe}_{2} \mathrm{O}_{3} & 0.62-4.29 & 0.05-1.83 & 0.03-1.48 \\ \mathrm{FeO} & 1.8-2.73 & 0.58-3.82 & 0.12-1.11 \\ \mathrm{MgO} & 1.14-2.84 & 1.9-2.8 & <0.01-0.39 \\ \mathrm{CaO} & 2.32-5.38 & 4.41-7.64 & 0.55-1.14 \\ \mathrm{Na} & 2.02-3.75 & 2.55-3.9 & 2.3-3.55 \\ \mathrm{~K}_{2} \mathrm{O} & 2.73-4.88 & 0.47-3.77 & 4.3-5.73 \\ \mathrm{TiO}_{2} & 0.33-0.54 & 0.37-0.73 & 0.08-0.28 \\ \mathrm{P}_{2} \mathrm{O}_{5} & 0.12-0.19 & 0.11-0.25 & 0.02-0.07 \\ \mathrm{MnO} & 0.02-0.08 & <0.02-0.08 & 0.01-0.06 \\ \mathrm{CO}_{2} & 0.03-0.13 & 0.04-0.64 & 0.03-0.08 \\ \mathrm{~F} & 0.09 & 0.02-0.08 & 0.01-0.02 \\ \mathrm{Cl} & -- & -- & 0.0012-.0055\end{array}$

High-grade, Late Eocene to Early Oligocene polymetallic veins crosscut the Buckingham porphyry orebodies and also crosscut Early Tertiary intrusive rocks (Theodore and others, 1992). Examples include the Little Giant and Irish Rose mines (fig. 1). Veins in the Little Giant mine occur along faults that strike $\mathrm{N} 20^{\circ} \mathrm{W}$ to $\mathrm{N} 65^{\circ} \mathrm{W}$ in the Harmony Formation (Roberts and Arnold, 1965). Oxide ores consisted of iron oxides, jarosite, cerussite, anglesite, and pyrargyrite with some remnant argentite and polybasite. The primary ore minerals include pyrite, arsenopyrite, galena, sphalerite, and minor tetrahedrite. The Irish Rose mine ores were mined from veins that strike $\mathrm{N} 20^{\circ} \mathrm{W}$ to $\mathrm{N} 10^{\circ} \mathrm{E}$ in the Harmony Formation. The primary ores consist of arsenopyrite, pyrite, sphalerite, galena, chalcopyrite, and minor stibnite in a gangue of quartz and calcite (Roberts and Arnold, 1965).

Redwell Basin Porphyry Molybdenum Deposit, Redwell Basin, Colorado

The study site is the location of an unmined buried porphyry molybdenum deposit and associated veins (fig. 2). The deposit is related to a 17-16 Ma porphyritic granitic intrusive into the Cretaceous Mancos Shale and Mesa Verde Formations and the Tertiary Ohio Creek and Wasatch Formations (Gaskill and others, 1967).

1. Lithology. In the study area, the Cretaceous Mancos Shale consists of silty marine shale with interbeds of silty sandstone, sandy limestone, and carbonaceous shale. Shale intertongues with and is transitional into the overlying Cretaceous Mesa Verde Formation. The basal unit of the Mesa Verde, exposed in the lower reaches of Redwell Basin, consists of thick bedded and massive fine- to very fine-grained sandstone. A marine shale separates this lower sandstone from an overlying thick-bedded to massive medium-grained sandstone. Most of Redwell Basin drains across interbedded sandstone, shale, coal, and carbonaceous shale. The sedimentary rocks are altered in the vicinity of Miocene intrusions to pyrite-pyrrhotite-bearing hornfels (Thomas and Galey, 1982).

The Early Tertiary Ohio Creek Formation consists of massive feldspathic sandstone with pebbly lenses, interbedded sandstone, siltstone, shale, and carbonaceous shale, and feldspathic conglomeratic sandstone. The overlying Wasatch Formation consists of well-indurated conglomerates, sandstone, siltstone, and conglomeratic feldspathic sandstone (Gaskill and others, 1967). Near intrusive rocks, these formations are metamorphosed to quartzite, argillite, and argillaceous hornfels.

An igneous breccia pipe complex (fig. 2) crops out in the wall and floor of upper Redwell Basin (Gaskill and others, 1967). The pipes are composite, consisting at the surface of rhyolite and rhyolitic 
breccia (Sharp, 1978). The rock is very fine grained and intensely altered. Partial chemical analysis of the altered rocks at the surface are given in Table 3 .

Table 3. Ranges (in wt. \%) of partial chemical analyses of altered Miocene granitic rocks in the Redwell and adjacent Red Lady basins (after Thomas and Galey, 1982).

$\begin{array}{ll}\mathrm{SiO}_{2} & 70.5-78.5 \\ \mathrm{~K}_{2} \mathrm{O} & 3.1-4.6 \\ \mathrm{Na}_{2} \mathrm{O} & 0.04-2.08 \\ \mathrm{CaO} & 0.49-.80 \\ \mathrm{~F} & 0.15-.80\end{array}$

2. Structural Geology. The Redwell Basin molybdenum deposit is localized in a zone of predominantly N50 E-striking faults (fig. 2) referred to as the Elk Basin fault zone by Sharp (1978). The deposit is located where a $\mathrm{N} 30^{\circ} \mathrm{W}$ fault system intersects the northeastern zone. Northerly-striking faults bound the Redwell Basin, one of which (Redwell Basin fault) controls the strike of the lower reaches of the drainage.

3. Mineral Deposits. Two vertically-stacked stockwork molybdenum deposits were discovered during the 1970 s beneath Redwell Basin (Thomas and Galey, 1982). The uppermost deposit is at a depth of $\approx 2400$ feet. This deposit is just beneath the base of the breccia pipes exposed in the upper reaches of Redwell Basin (fig. 2). The breccia pipes show a distinct geochemical zoning from higher concentrations of molybdenum and tungsten at the base of the pipe to higher concentrations of lead and zinc in the upper part of the pipe and copper throughout the pipe (Sharp, 1978). The lead occurs in galena and argentiferous galena, the zinc in iron-rich sphalerite, and the copper in chalcopyrite and minor bornite. There are some vein zones in the breccia pipe where the total sulfide content exceeds $50 \%$. Surrounding the breccia pipe, the sedimentary rocks contain secondary epidote, chlorite, and iron sulfide.

Exploration drilling in an area of hornfels and quartz veining found granitic intrusions and some molybdenite in stockwork veins at depth indicating porphyry-style mineralization at depth beneath an area just west of where the Redwell Basin drains into Oh-be-joyful Creek (Ludington and Ellis, 1983).

\section{HYDROLOGY AND MAJOR-ELEMENT GEOCHEMISTRY}

Battle Mountain, Nevada

Hydrology of the Battle Mountain area is characterized by mostly ephemeral surface runoff, superimposed on a fracture-controlled ground-water system. Streams flow during the spring and early summer months during snowmelt and periods of thunderstorms. Low annual precipitation results in overall sparse vegetation, with lush growth only within a few meters of perennial streams or in seep areas. Our samples were collected in May 1998, following a wetter than average winter and spring, at the locations shown in Figure 3. Estimated stream discharges ranged from $1 \mathrm{~L} / \mathrm{min}$ to approximately $2000 \mathrm{~L} / \mathrm{min}$, based on measurements and visual estimates. Surface-water runoff is confined to deeply incised canyons in this high-relief region. Typical stream gradients are in the range of $6 \%$ to greater than $11 \%$. During peak spring flows, the filled channels are typically less than a few meters wide, and tens of centimeters deep.

No completed wells were available for sampling on Battle Mountain at the time of our sampling trip. However, several "ground-water" samples were collected from mouths of springs distributed around Battle Mountain at a variety of elevations. Sample site 1, a spring near Long Creek (fig. 3), may actually be an uncompleted exploration well drilled into the Buckingham stock. Other springs sampled in the area include seeps such as at sample site 8. Because the aquifers on Battle Mountain are characterized by fracture flow, it is reasonable to assume a geologic-structural control on the location of springs and gaining stream reaches.

Interactions between ground water and surface water are exhibited throughout the Battle Mountain area, as springs, seeps, and gaining and losing stream reaches. As documented by Winter and others (1998), connections between ground and surface water are too numerous to be ignored. In Long and Licking creeks, numerous gaining and losing stream reaches were observed. These hydraulic data are supported by chemical measurements of major and trace elements, providing a consistent evaluation of the local hydrology around fracture systems. For example, sites 3 and 4 combine near the headwaters of Long Creek; site 2 is below the confluence. Based on the major-element chemistry of those samples, the water at 
site 2 must also include at least one other water source. The cation composition of these samples, as shown in a piper diagram (fig. 4) shows sites 3 and 4, with site 2 shifted slightly towards the composition of site 1 . The rare-earth element (REE) compositions (fig. 5) suggest an input of a water like sample 1 to the stream at site 2, consistent with the major cation compositions. Flow at site 2 was greater than the sum of sites 3 and 4 , and a large positive vertical hydraulic gradient was observed at site 1 , supporting the possibility of ground-water discharge in the vicinity of site 2 . Sites 1 and 2 are located along Long Canyon just below the intersection of north to northwest faults with the Long Canyon fault (Theodore and others, 1992). Site 12 is approximately $2 \mathrm{~km}$ downstream from site 2 and its major and REE compositions are close to those for site 2 , suggesting no further ground-water discharge, but not precluding the possibility of ground-water recharge.

In the Licking Creek drainage, the chemistry of the surface-water also implies some areas of groundwater discharge. For example, sites 5, 6, and 10 occur along a continuous reach of stream with no other surface-water tributaries. The major anion and cation compositions for sites 5 and 6 are indistinguishable, but sample 10 has higher concentrations of many major and trace elements, but lower concentrations of others. This observation suggests an additional input of ground-water discharge between sites 6 and 10 (approximately $1 \mathrm{~km}$ stream reach). Similarly, sites 7 (stream) and 8 (spring) are adjacent to each other, and appear similar from the Piper diagram (fig. 6 ). The concentrations of many trace elements and rare earth elements (REE) are significantly higher in sample 8 than in 7, but the concentration ratios of most of those elements for the two samples lie within a very narrow range (2.5 to 3.0, fig. 7$)$. A likely scenario that would explain this narrow range of variation would be discharge of a ground water with a chemical composition similar to that of site 8 into a slightly more dilute, metal-poor stream to produce the observed chemistry of site 7. In support of this hypothesis, site 8 is a typical acidic, metal-rich drainage ( $\mathrm{pH} 4.0$; conductivity $>1,100 \mu \mathrm{S} / \mathrm{cm} ; \mathrm{SO}_{4}>600 \mathrm{ppm}$; and $\mathrm{Al}, \mathrm{Mn}$, and $\mathrm{Zn}$ at ppm levels), whereas the other end member would have major elements similar in concentration to site 7, but with low metals and REE concentrations. A ground-water discharge scenario also makes sense based on the observations that sites 7 and 8 are within a few meters of each other, and the fact that the hydraulic head of ground water is sufficiently high to create the seeps at site 8 .

Farther downstream on Licking Creek there is some evidence for ground-water discharge, but most of the changes are attributable to normal water-rock interactions. The primary change in water chemistry between sites 9 and 11 (approx. $2 \mathrm{~km}$ ) is an increase in $\mathrm{pH}$ from approximately 7 to 8 . This unit increase in $\mathrm{pH}$ appears to drive the adsorption or precipitation of metals such as $\mathrm{Zn}, \mathrm{Cu}, \mathrm{Mn}, \mathrm{Ni}, \mathrm{Co}, \mathrm{Cd}$, and REE's, and the desorption of oxyanion species such as As, Mo, V, and Sb. Aluminum concentrations increased slightly, consistent with a slightly increased solubility of gibbsite from $\mathrm{pH} 7$ to 8 . No appreciable change was observed in the major cation and anion concentrations.

\section{Redwell Basin, Colorado}

Surface water in the Redwell Basin originates from a variety of sources: springs and seeps, gaining stream reaches, mine drainages, and an uncapped drill hole with artesian flow. The average gradient of Redwell Creek is $28 \%$, in a tightly confined drainage that is approximately $1 \mathrm{~km}$ wide and $2.5 \mathrm{~km}$ long. Discharge measurements made during the sampling trip ranged from $20 \mathrm{~L} / \mathrm{min}$ to approximately 2000 $\mathrm{L} / \mathrm{min}$. Our sampling trip in August 1997 occurred during a typical pattern of clear mornings followed by intermittent afternoon thunderstorms. Sample sites are shown on Figure 3.

From the top of Mount Emmons to the bottom of the Redwell Basin, the land surface follows a series of slopes and ledges formed by outcrops of resistant sedimentary layers. These sedimentary boundaries, as well as the numerous steeply dipping fractures that crosscut the sediments and intrusive rocks, may be hydraulic conduits for ground water. The possibility of intergranular flow within these sediments is 

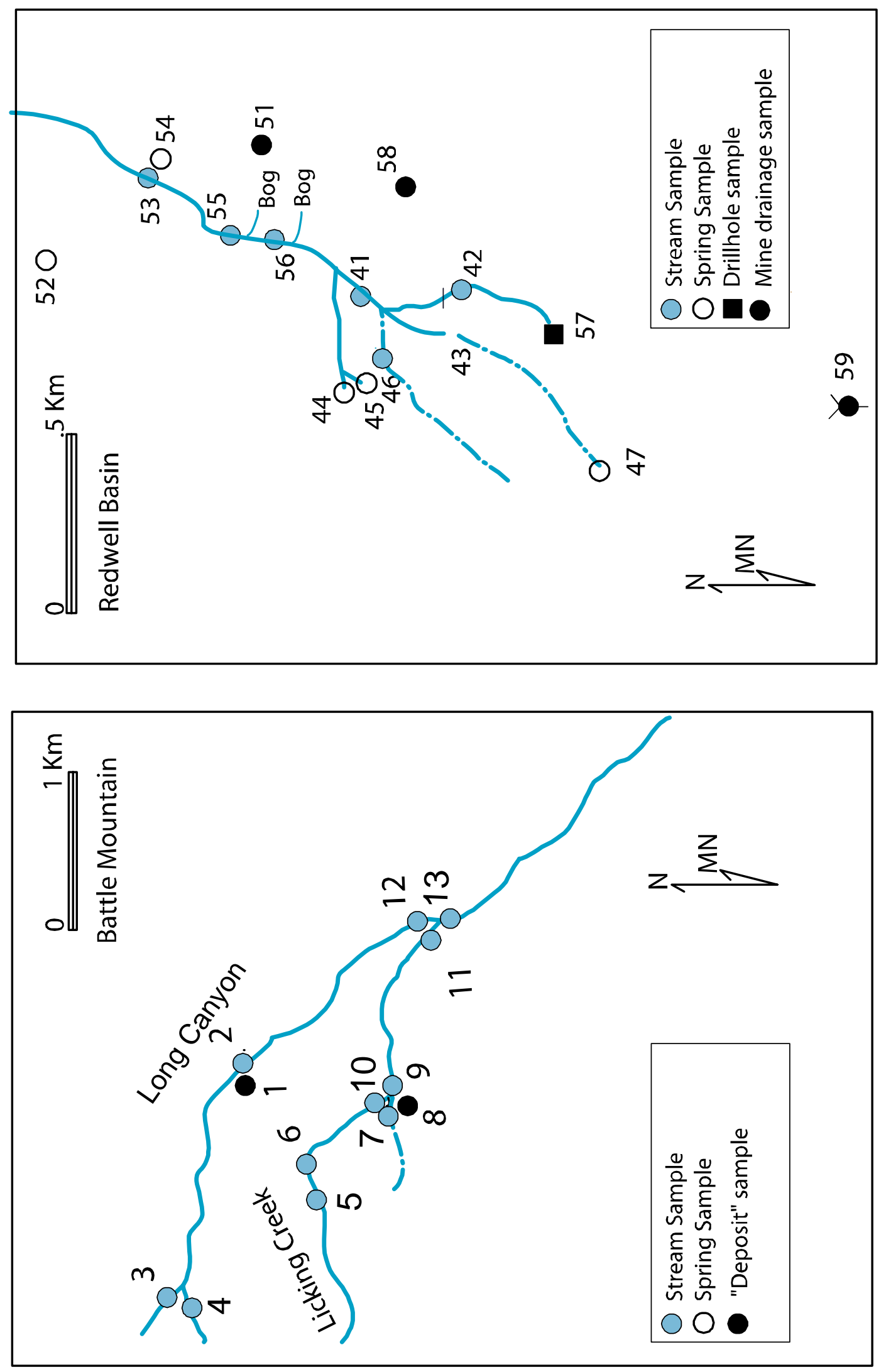

Figure 3. Map showing sample locations. 


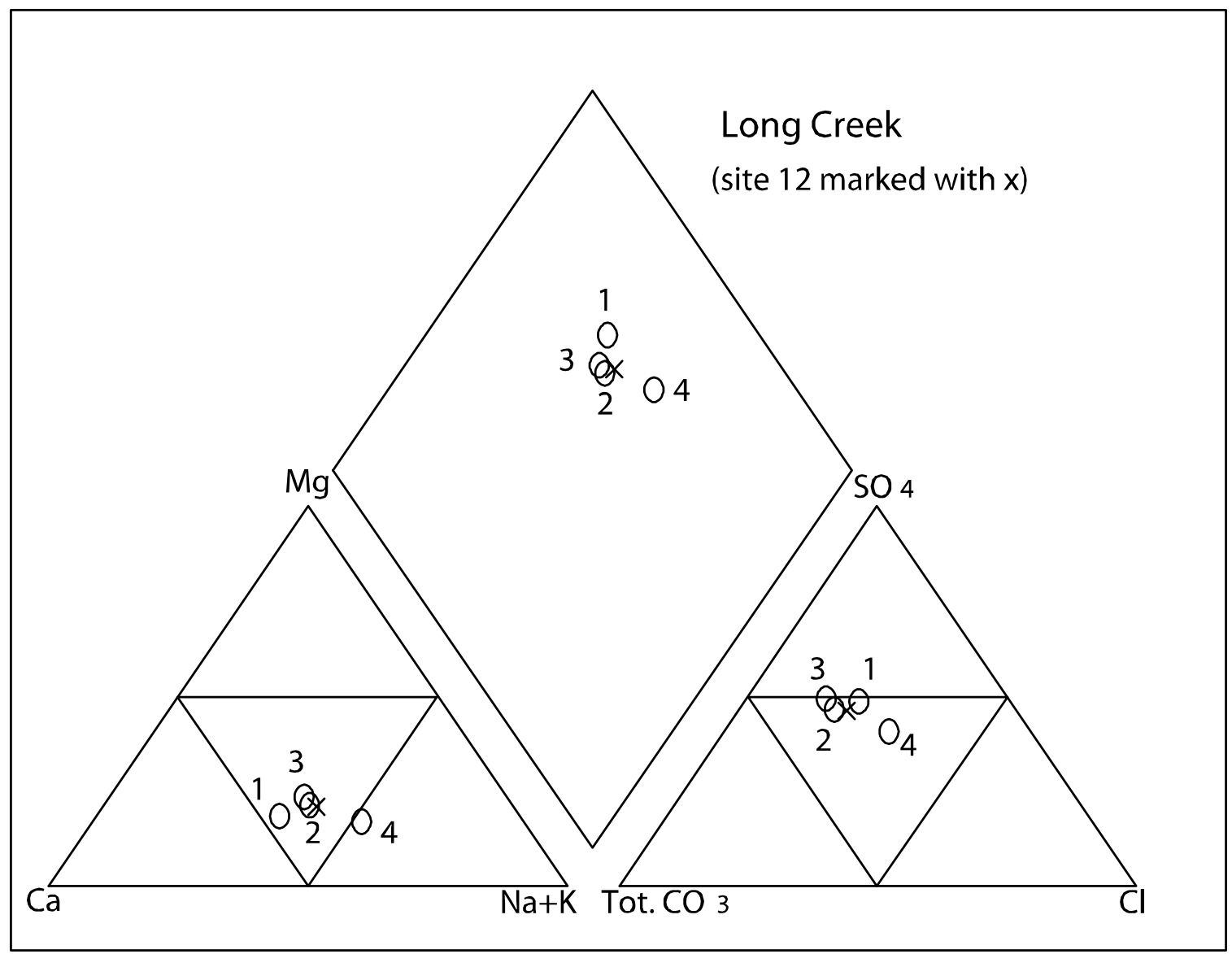

Figure 4. Piper diagram fro samples collected from Long Canyon, Battle Mountain, Nevada.

limited, as most of the rocks appear to be well cemented, especially in the vicinity of the intrusive rock body in the upper part of the basin. Further, distinct differences in water chemistries are observed over very short distances, suggesting a fracture-dominated flow system.

A remarkable feature of the ground-water chemistry in the Redwell Basin is the compartmentalization and isolation of chemically distinct packages of water within short distances. For example, site 44 (the "Red Well," a natural spring) has a pH of 3.6, is actively precipitating ferricrete, and has a conductivity of $200 \mu \mathrm{S} / \mathrm{cm}$, but a few meters away, site 45 has a $\mathrm{pH}$ of 7 and a conductivity of $40 \mu \mathrm{S} / \mathrm{cm}$. Similarly, sites 47 and 59, a few hundred meters apart, have $\mathrm{pH}$ values of 7.2 and 3.9, and conductivities of 40 and 130 $\mu \mathrm{S} / \mathrm{cm}$, respectively (fig. 8). The Piper diagram (fig. 9) also demonstrates compartmentalization in the form of "outlier" groups of points in both the cation and anion triangular fields. Other examples of dramatic chemical differences in close proximity exist in the Redwell Basin, and demonstrate the effective "trapping" of chemically distinct waters in non-connected (or minimally connected) fracture sets. As mapped by Gaskill and others (1967; see fig. 2), the Redwell Basin is extensively fractured, and, as discussed previously, the various fracture networks represent several structural elements.

Interactions between ground water and surface water were observed mostly in the form of discharge areas, including springs, seeps, and artesian wells. Because of the extremely high relief of the Redwell Basin and the highly variable slopes, numerous springs and seeps occur in the basin, which, together with the relatively high rainfall, document the proximity of the water table to the ground surface. 


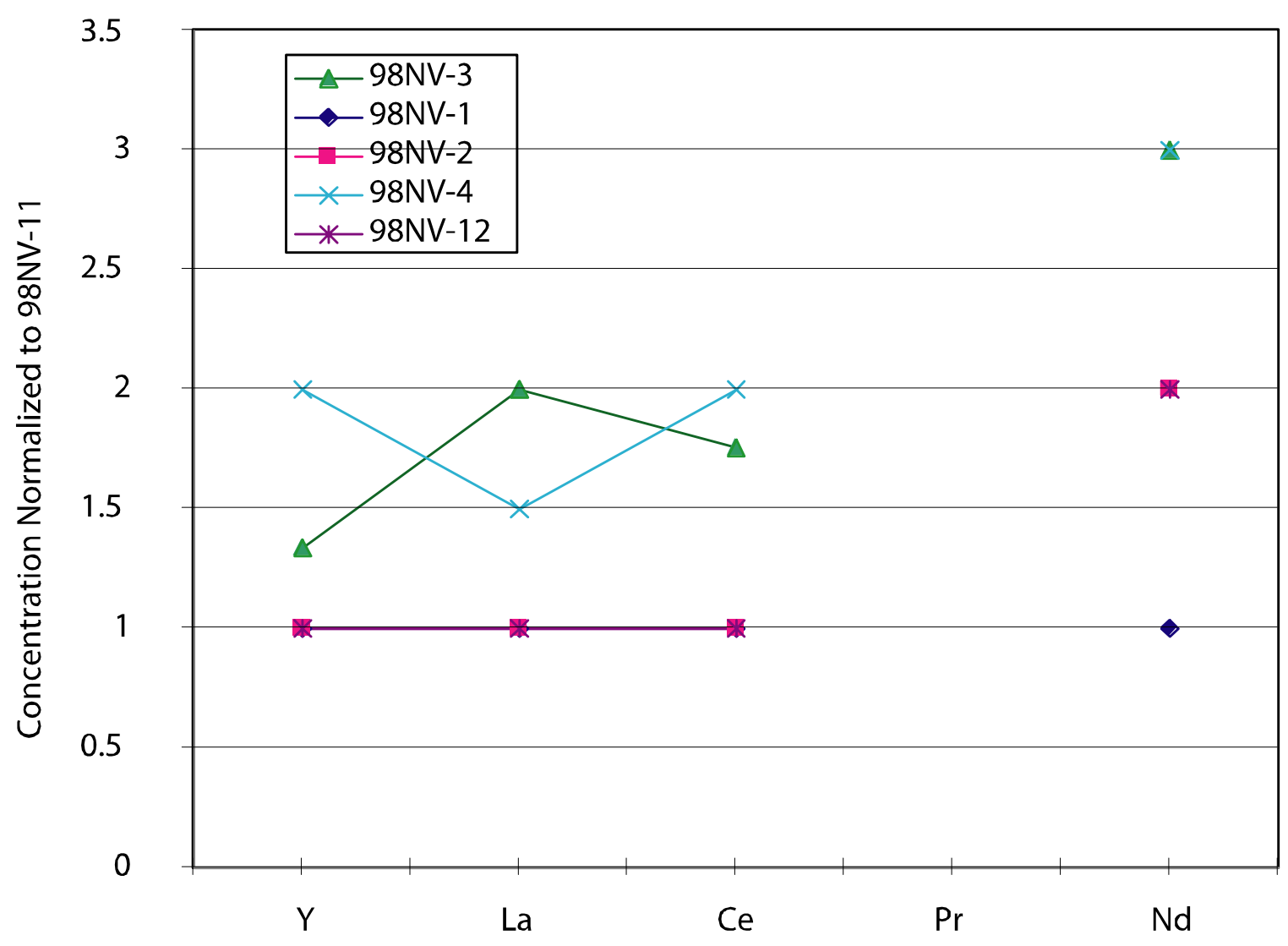

Figure 5. Rare earth element distribution in samples from Long Canyon.

Complexity introduced by epithermal systems overprinting on porphyry systems

Although our interest in the Redwell Basin stems from the occurrence of the porphyry-molybdenum deposits, there also are genetically related epithermal vein systems nearer to the surface. The latter have historically been mined and now contribute acidic, metal-rich drainage to the Redwell Basin. Resolving the discrete contributions of these chemically distinct waters is difficult, but may be possible using some geochemical tools. For example, sulfur isotope compositions will be discussed in a later section. Other parameters, such as certain element ratios or concentrations, might also be useful. For example, the ratios of $\mathrm{F}^{-}$to $\mathrm{Cl}^{-}$concentrations in the waters are distinctly high, owing to the presence of F-bearing minerals (fluorite, topaz, etc.) in the porphyry deposits and associated alteration. As shown in Figure 10, $\mathrm{F}^{-} / \mathrm{Cl}^{-}$ molar ratios generally are greater than 2 and as high as 9.5. Such high $\mathrm{F}^{-} / \mathrm{Cl}^{-}$molar ratios can only be attributed to the leaching of $\mathrm{F}^{-}$from minerals such as those mentioned. The rather large range of $\mathrm{F}^{-} / \mathrm{Cl}^{-}$ molar ratios in the Redwell Basin (0.5 to 9.5) is a further indication of the compartmentalization of flow within the basin. Unfortunately, owing to analytical difficulties, the $\mathrm{F}^{-} / \mathrm{Cl}^{-}$molar ratios for samples 51 and 58 (drainages from epithermal-vein mines) could not be determined. As discussed below, sulfur isotopes suggest that the contribution of the "porphyry water" to site 57 (the artesian drill hole) is approximately $70 \%$. The use of sulfur isotopes for this purpose makes the most sense, because the richest zone of sulfides coincides more closely with the ore zones. Other alteration haloes may extend spatially outward from the mineralized centers, and affect the water chemistry at a broader spatial scale. For instance, the "Red Well" (site 44) has the highest $\mathrm{F}^{-} / \mathrm{Cl}^{-}$molar ratio of all our samples, plus the concentrations of many major and trace cations in the artesian well lie between those of the Red Well and the mine drainages. There are, however, a number of exceptions to this mixing model indicating that the source of constituents in the Red Well remain inconclusive. Even though the spatial density of samples in the Redwell Basin is quite large, the relative contributions of epithermal vs. porphyry drainage chemistries are difficult to resolve. 


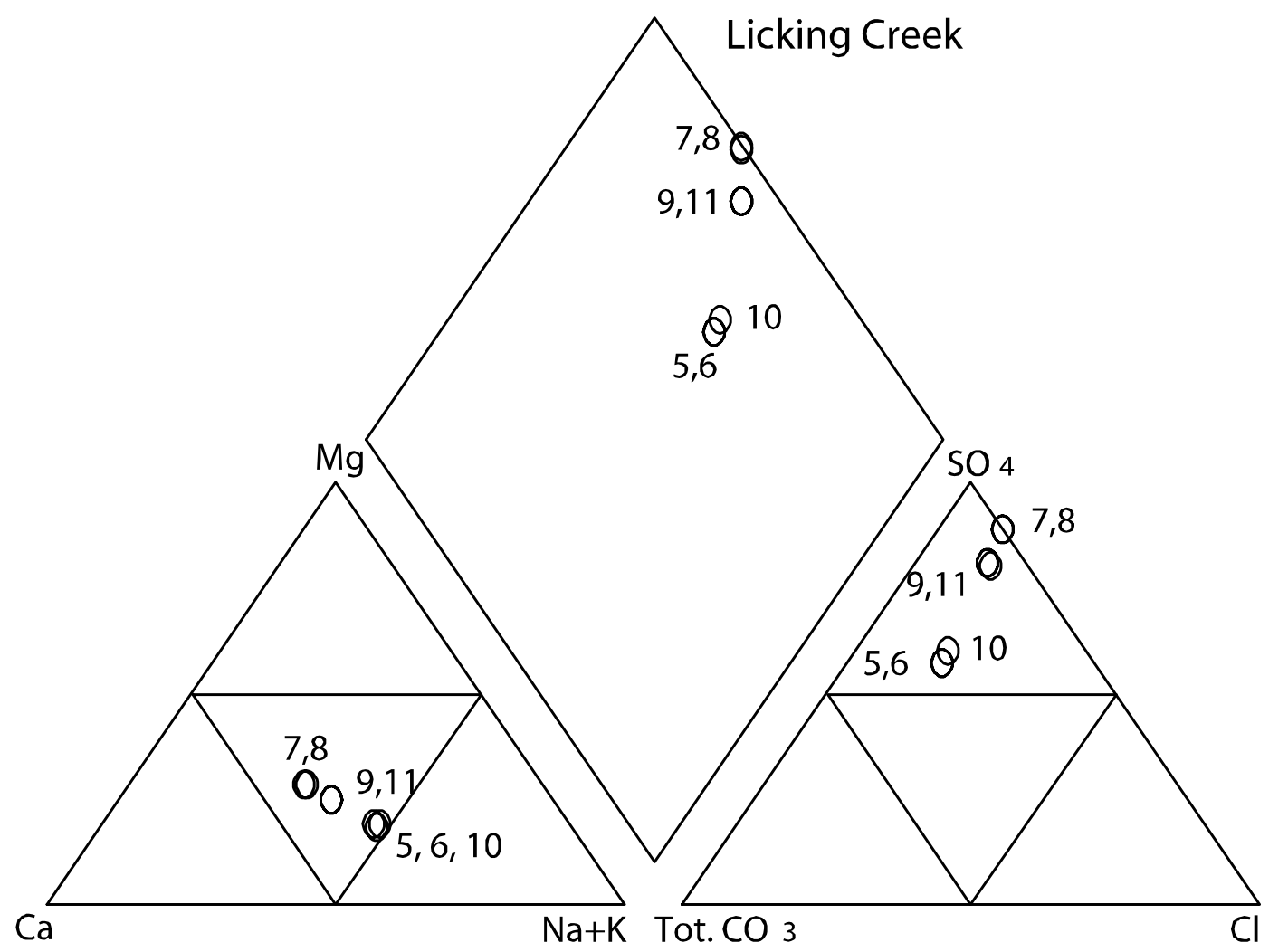

Figure 6. Piper diagram for samples collected from Licking Creek, Battle Mountain, Nevada.

\section{METAL GEOCHEMISTRY}

Chemistry and sulfur isotope geochemistry of deposit drainage

At each of the drainage basins sampled, waters draining the Mo deposits were collected (compositions are in Table 3). As discussed earlier, these waters may also include a component of waters draining the associated base-metal mineralization. At Battle Mountain, two such water samples were collected. The Buckingham "deposit" sample was collected from the seep flowing from the Buckingham Fault zone within the boundary of the Buckingham Stock Mo Deposit (site 8). This water has a pH of 4.0 and contains relatively little iron, although iron oxyhydroxides are found around the seep. Zinc accounts for almost $90 \%$ of the metal load. ${ }^{1}$ The sulfur isotopic composition of the sulfate $\left(\delta^{34} \mathrm{~S}_{\mathrm{SO} 4}\right)$ in the water is $+5.1 \%$; the value of the sulfur in molybdenite $\left(\mathrm{MoS}_{2}\right)$ in the deposit is +4.3 to $+5.2 \%$ (T.G. Theodore as cited in Theodore and others, 1992).

The Long Canyon "deposit" sample was collected from a seep near the deposit boundary on the inferred Long Canyon Fault (site 1 on fig. 3). The water has a $\mathrm{pH}$ of 7.4 and was weakly effervescent, the likely gas is carbon dioxide. The dominant metal in this water is iron, however, nickel accounts for almost $50 \%$ and Mo for almost $30 \%$ of the metal load as defined previously. The sulfur isotopic composition of the sulfate $\left(\delta^{34} \mathrm{~S}_{\mathrm{SO} 4}\right)$ in the water is $+5.2 \%$. Both the Long Canyon and Buckingham waters have very low fluoride to chloride molar ratios ( $\mathrm{F}: \mathrm{Cl}$ ratio, 0.02 and 0.04 respectively), consistent with the Buckingham stock hosting a low-fluorine type Mo deposit.

The Redwell "deposit" sample was collected from the drill hole known to penetrate the Redwell deposit (site 57 on fig. 3). The water has a pH of 2.9, a high iron concentration, and a high $\mathrm{F}: \mathrm{Cl}$ molar ratio of 6.6. Zinc accounts for almost $80 \%$ of the metal load with copper and lead each accounting for

\footnotetext{
${ }^{1}$ Metal load is defined in this paper as the sum of metals excluding iron on a molal basis.
} 
about $10 \%$. The sulfur isotopic composition of the sulfate $\left(\delta^{34} \mathrm{~S}_{\mathrm{SO} 4}\right)$ in the water is $+2.7 \%$; the value of the sulfur in molybdenite $\left(\mathrm{MoS}_{2}\right)$ in the deposit is +3.7 to $+4.6 \%$ (Stein and Hannah, 1985). Sulfate associated with base-metal mine drainage ranges from +1.0 to $-0.5 \%$ (see below). The higher $\delta^{34} \mathrm{~S}_{\mathrm{SO} 4}$ value in the drill hole sample supports the hypothesis that discharging water contacted the Mo porphyry deposits as well as the base metal (mass balance calculations using sulfur isotopes suggests that $70 \%$ of the sulfate sulfur is from the porphyry system and $30 \%$ from the base-metal deposits).

\section{Dissolved concentrations of metal in the stream drainages}

Figures 11 through 13 graphically show how the log of the elemental concentrations in stream water spatially changes relative to concentrations in the "deposit samples." ${ }^{2}$ In Long Canyon (fig. 11), the mineralized, undisturbed site, only $\mathrm{pH}$ and $\mathrm{Mo}$ are consistently higher than in the deposit sample. Stream $\mathrm{pH}$ values are between 7.6 and 8.4; these alkaline values represent weathering of the volcaniclastic country rocks (see composition in Geology section), with possible contributions from removal of $\mathrm{CO}_{2}$ by algal growth. High $\mathrm{pH}$ enhances the mobility of Mo by inhibiting adsorption on to iron oxides. The dissolved iron concentrations remain nearly constant throughout the stream and are very similar to those in the "deposit" sample, suggesting that precipitation of a mineral phase (goethite or amorphous $\mathrm{Fe}(\mathrm{OH})_{3}$ ) controls its concentration. Concentrations of most other metals in stream water are less than $1 \%$ of the concentration in the "deposit" sample and do not significally change concentrations until Licking Creek enters the drainage (fig. 11).

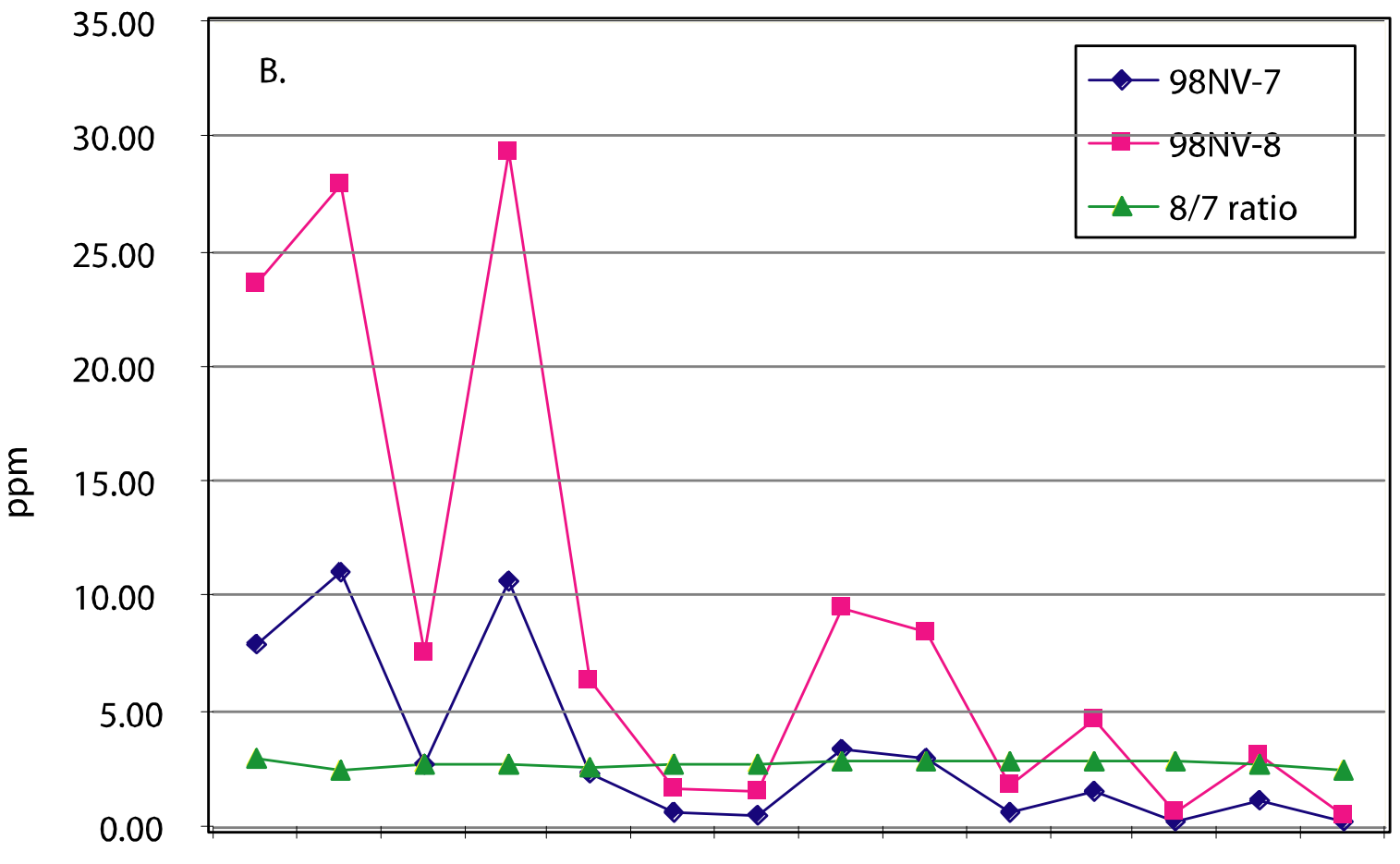

La Ce Pr Nd Sm Eu Tb Gd Dy Ho Er Tm Yb Lu

Figure 7. Rare earth element distribution in selected samples from Licking Creek.

\footnotetext{
${ }^{2} \log$ (variable in stream sample / variable in "deposit" sample). Samples that plot on the zero line have the same value as that of the "deposit" sample in the drainage. Samples with negative values have lower values and those with positive values have higher values than the "deposit" sample.
} 


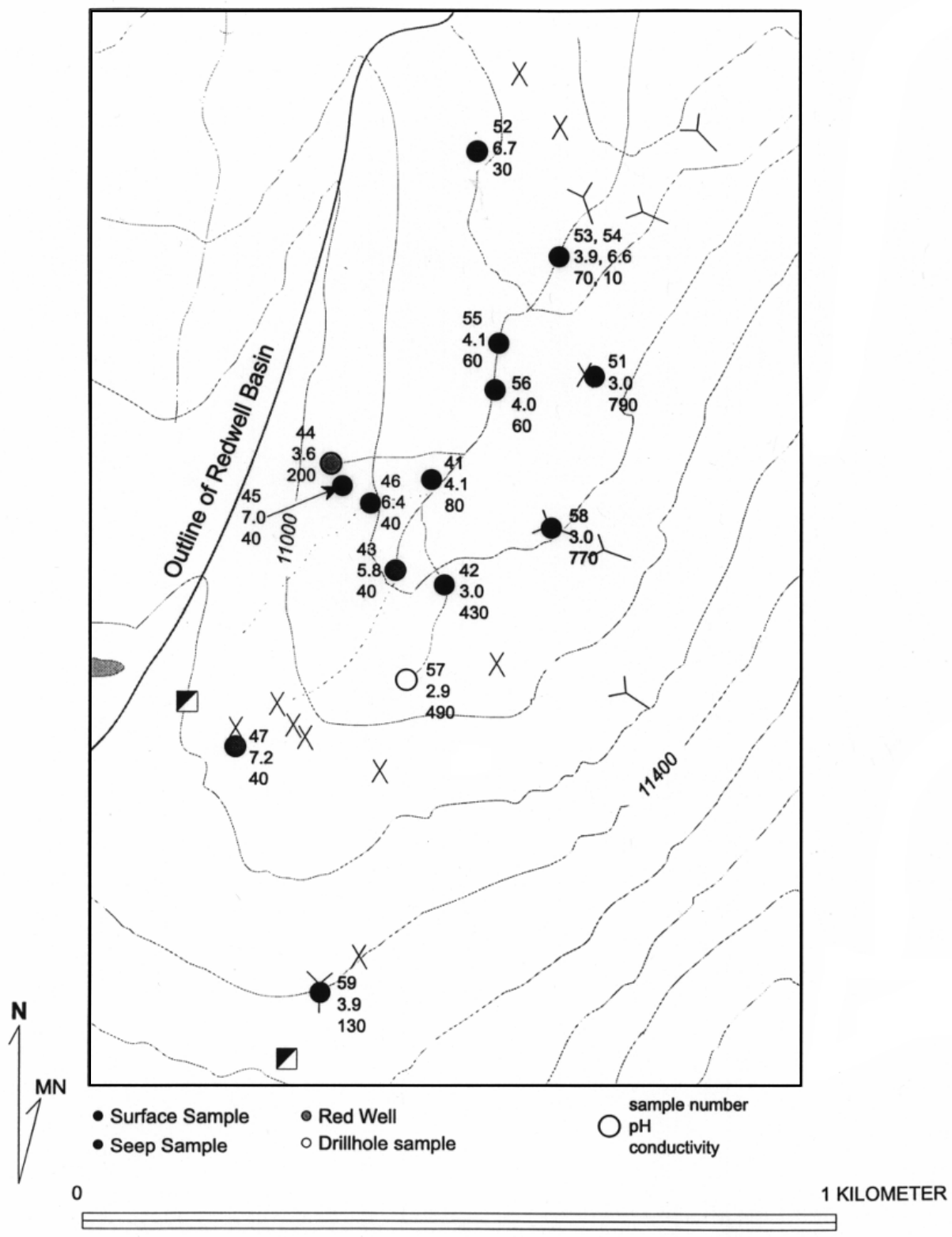

Figure 8. Map showing the distribution of $\mathrm{pH}$ and conductivity of samples from Redwell basin, Colorado. 


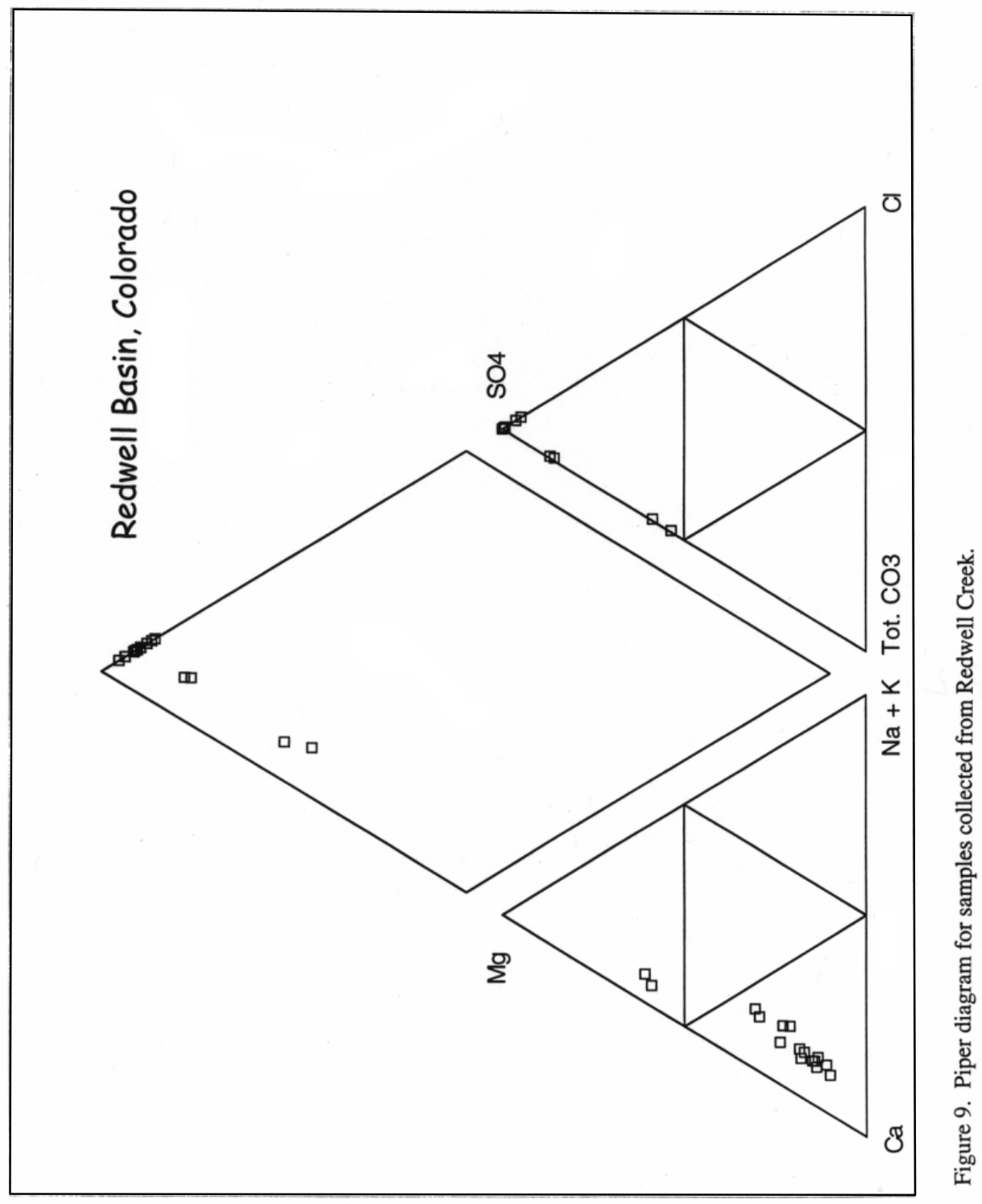




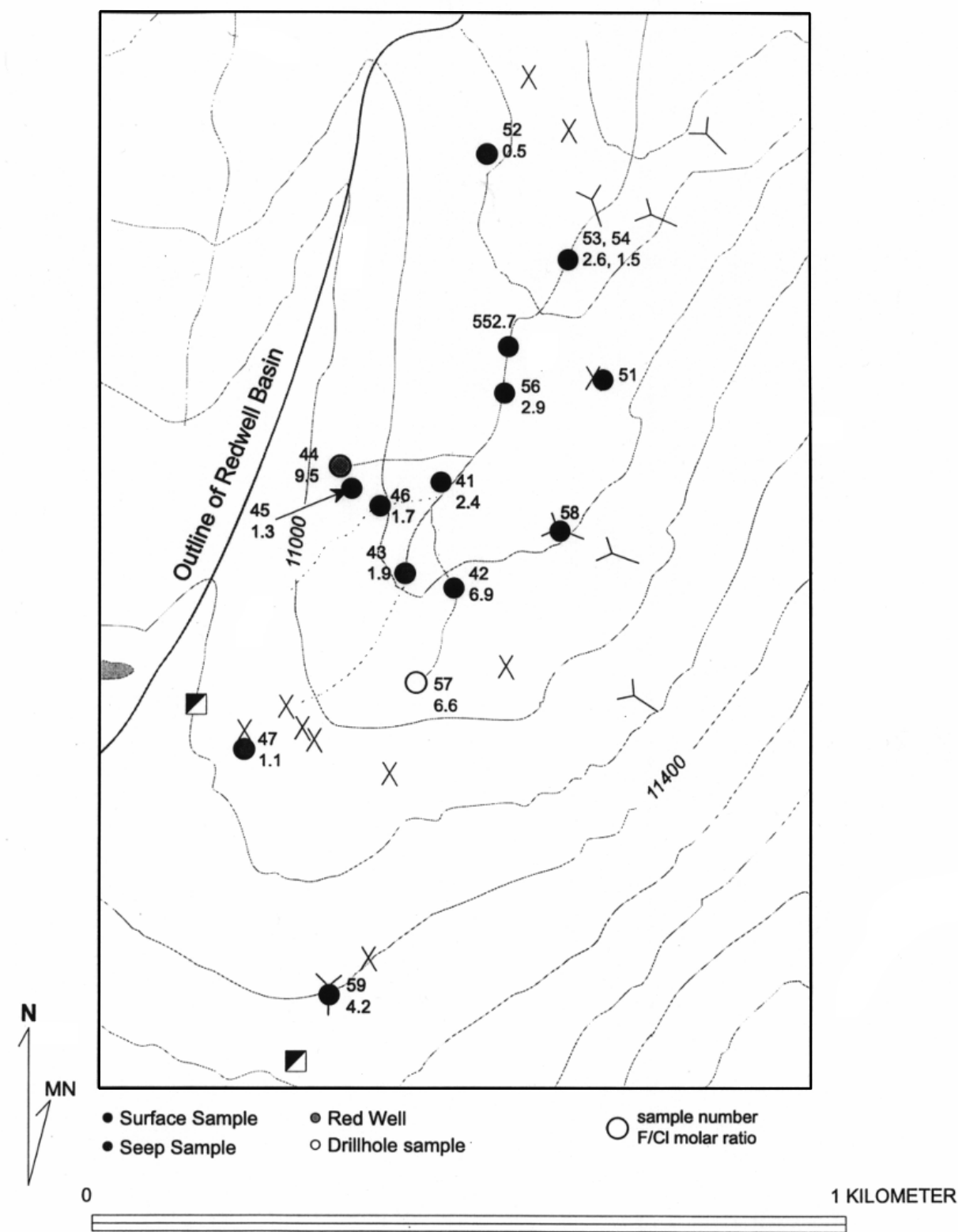

Figure 10. Map showing the distribution of $\mathrm{F} / \mathrm{Cl}$ molar ratios of samples from Redwell basin, Colorado. 
In comparison to Long Canyon, the base-metal load in Licking Creek (mineralized, disturbed site), increases substantially after the "deposit" sample enters the stream (fig. 12). Iron is similar in concentration to that in the deposit sample due precipitation of oxyhydroxides. Molybdenum and arsenic are higher in the stream water than in the deposit sample, consistent with the higher $\mathrm{pH}$ in the stream limiting adsorption onto freshly precipitated iron oxyhydroxides. Most metal concentrations decrease slightly when Licking Creek mixes with the more dilute Long Canyon, however, the relative metal concentrations are consistent with values ascribed to the "deposit" sample.
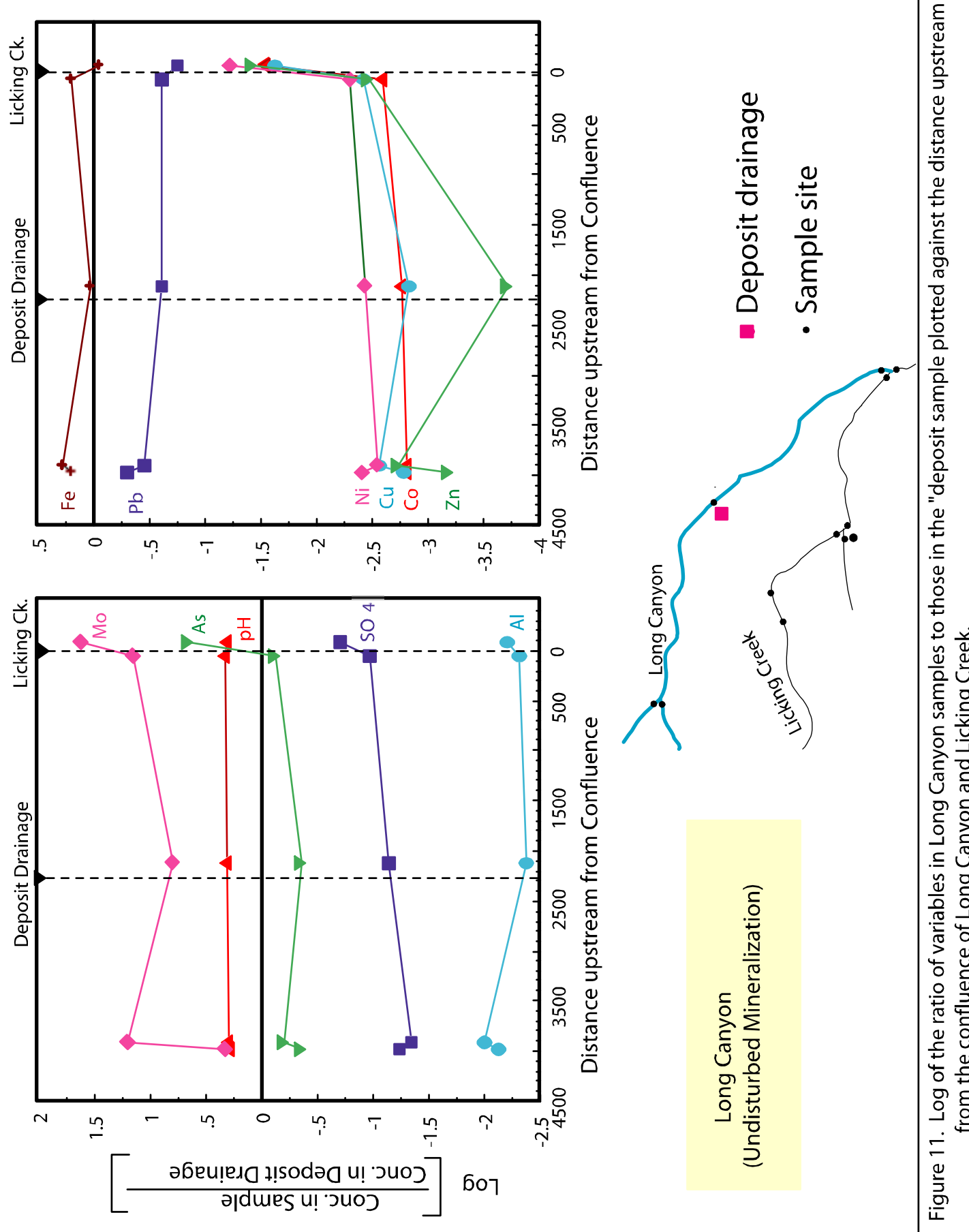


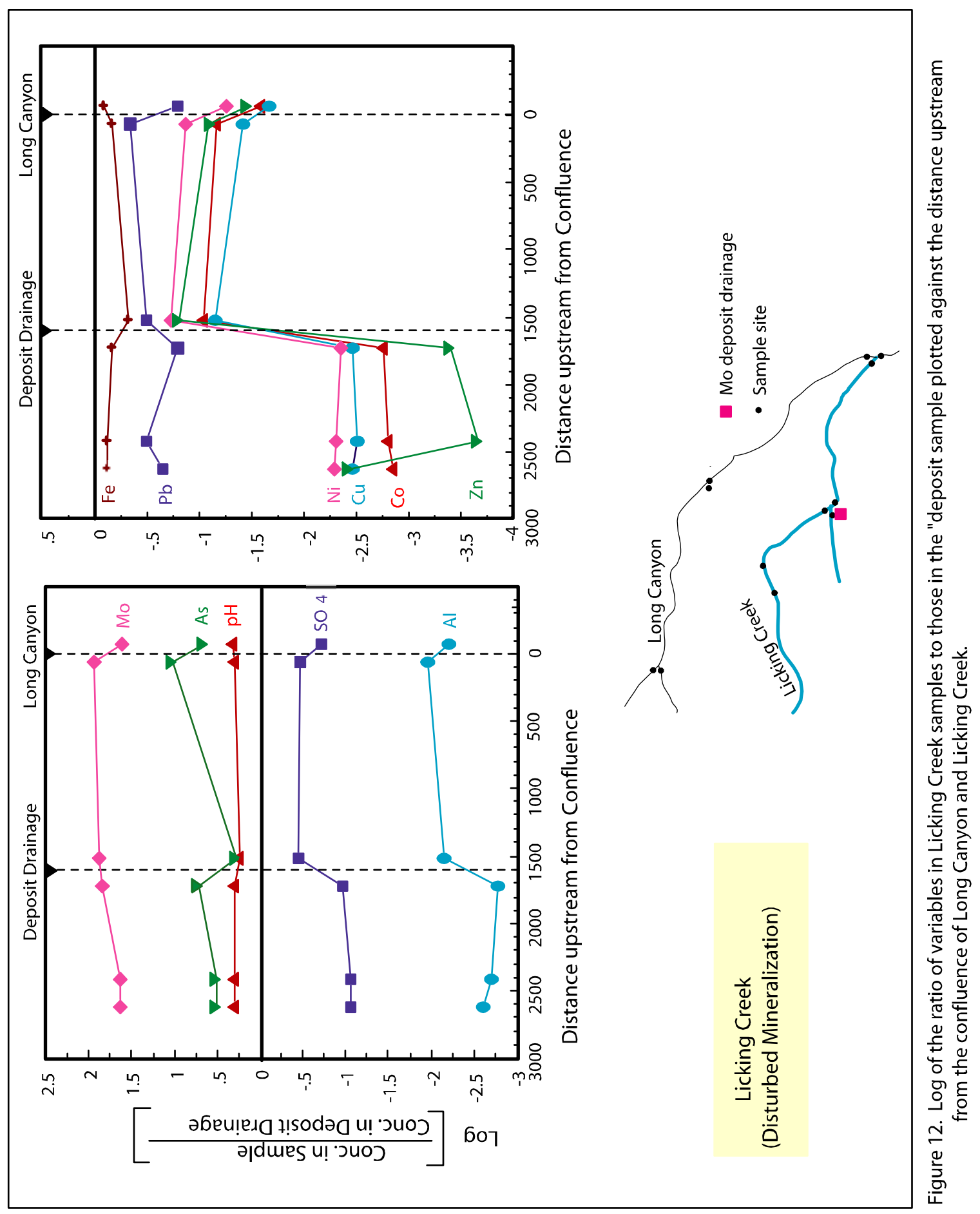



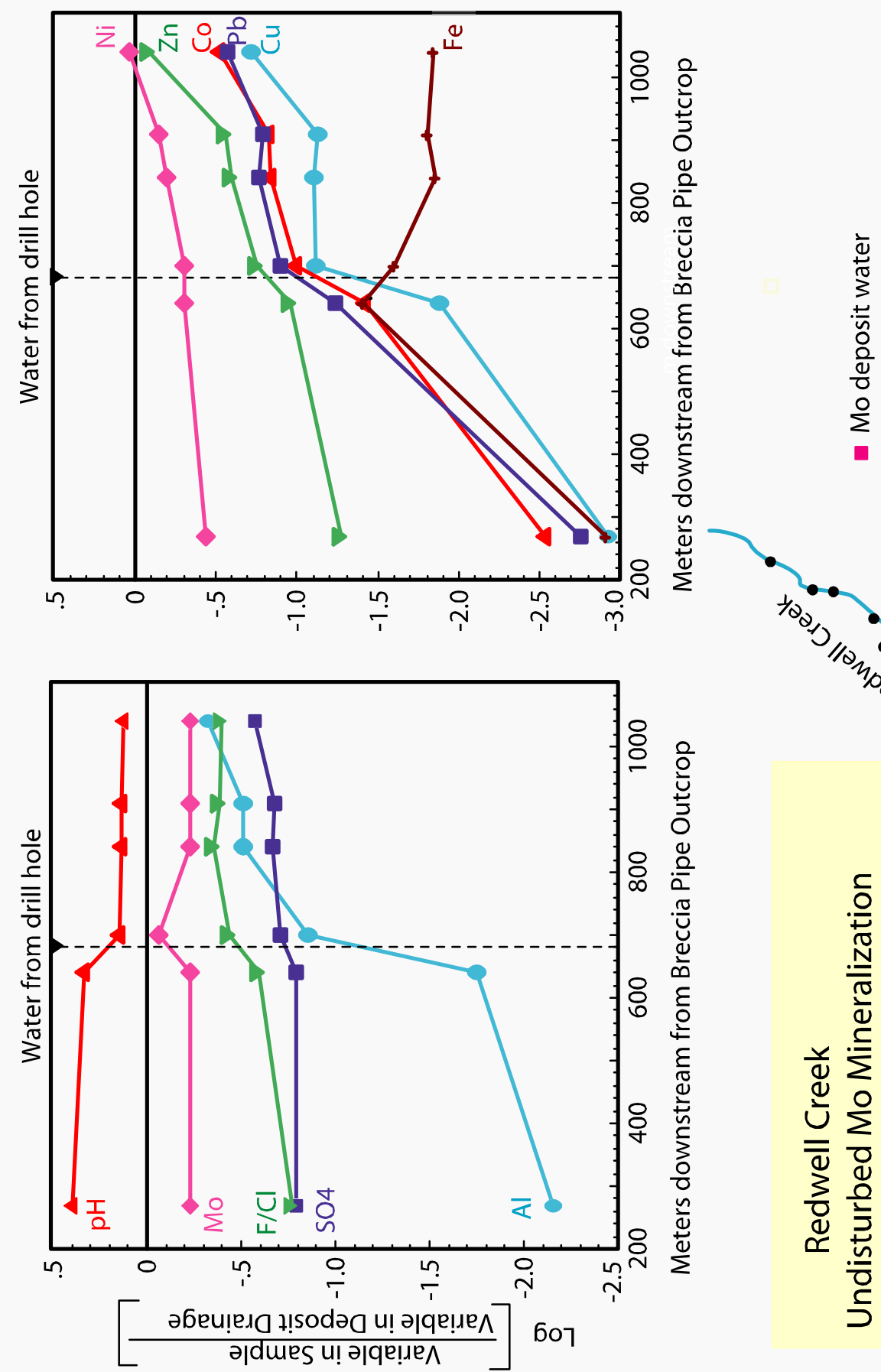

है

Redwell Creek is compositionally distinct from background ground water (most upstream sample). Water in the stream mixes with inflow from the drill hole, and water with a high content of metals downstream of the drill hole (fig. 13). With the exception of Fe, most constituents plotted increase downstream from the drillhole. In contrast to concentrations at Battle Mountain, iron increases upon mixing with deposit drainage and then decreases as iron precipitates to form oxyhydroxides. Metal 
adsorption is not apparent based on water composition. The $\mathrm{pH}$ of Redwell stream decreases upon input of the water from the drill hole and remains acidic downstream (3.9-4.1).

Figures 11, 12, and 13 show that the composition of the "deposit" sample is preserved downstream in the both Licking Creek and Redwell basin. Metal loads in Redwell basin are derived from base-metal mineralization with some contribution from the molybdenum porphyry system. In contrast, the composition of stream water in Long Canyon is not changed by the mineralization that occurs lower in the drainage.

Trends in sulfur isotopic composition of stream sulfate

To better understand the extent that the Mo porphyry and associated base-metal systems affect the water quality in Long Canyon and Redwell Stream, sulfur isotopes were investigated. Figure 14 shows the sulfur isotopic composition $\left(\delta^{34} \mathrm{~S}_{\mathrm{SO} 4}, \%\right.$ ) of sulfate in the stream water, acid mine drainage (base-metal mineralization), and Mo porphyry "deposit" samples for all three streams.

The $\delta^{34} \mathrm{~S}_{\mathrm{SO} 4}$ values in Long Canyon decrease from near $6.8 \%$ outside the mineralized zone to $6.4 \%$ o after mixing with the deposit drainage to $5.7 \%$ just before mixing with Licking Creek. The decrease from 6.4 to $5.7 \%$ suggests that some water associated with the Mo porphyry deposit besides the seep sampled is entering Long Canyon. Values in Licking Creek, although decreasing downstream, are never above 5.4\%o (just above the value for sulfur in the molybdenites). This general decrease is likely reflecting a continuous input of sulfur from mineralization to the stream as it flows across the Mo porphyry system.

In Redwell Basin, the relative input of sulfur associated with base-metal mine drainage and the Mo porphyry can be estimated. Sulfate in base-metal mine drainage is always isotopically depleted in ${ }^{34} \mathrm{~S}$ relative to the sulfate in the drill hole by over $2.5 \%$ - this difference increases downstream. The effect of drill-hole water is apparent in Figure 14. The continual input of ${ }^{34} \mathrm{~S}$-depleted sulfate can be seen in the decrease of $\delta^{34} \mathrm{~S}_{\mathrm{SO} 4}$ values in the stream. Values approach those of sulfate in the water draining base-metal deposits that enter Redwell Creek downstream through ground-water seepage. The decrease in $\delta^{34} \mathrm{~S}_{\mathrm{SO} 4}$ values of base-metal drainage as a function of distance from the breccia pipe is consistent with the incorporation of sedimentary sulfur depleted in ${ }^{34} \mathrm{~S}$ in the more distal base-metal deposits formed during emplacement of the Mo porphyry system (see Stein and Hannah, 1985).

\section{CONCLUSIONS}

The conclusions from our study are:

1. The $\mathrm{F}: \mathrm{Cl}$ molar ratio in stream samples appears to be a reliable variable for distinguishing low- and high-fluorine Mo porphyry systems

2. Because the isotope composition of sulfur in the two Mo deposits is different from associated base metal mineralization, the relative contribution of each deposit type to sulfate in the streams can be estimated.

3. Geochemical processes such as metal adsorption and precipitation occur in all drainages, but in a disturbed area, the processes do not attenuate all the trace metals from deposit weathering.

4. The sulfur isotope data are more sensitive than chemical concentration data for tracking the influence of mineralization on water quality, especially in drainages that have not been disturbed by mining.

5. Fracture flow dominates ground-water flow in both study areas and is controlled by the local hydraulic head and regional stresses.

6. Climate, especially precipitation rates, plays an important role in ground-water discharge to and recharge from the streams.

7. Integration of chemistry, hydrology and regional geology provides a comprehensive understanding of the environmental behavior of both types of Mo porphyry systems. 

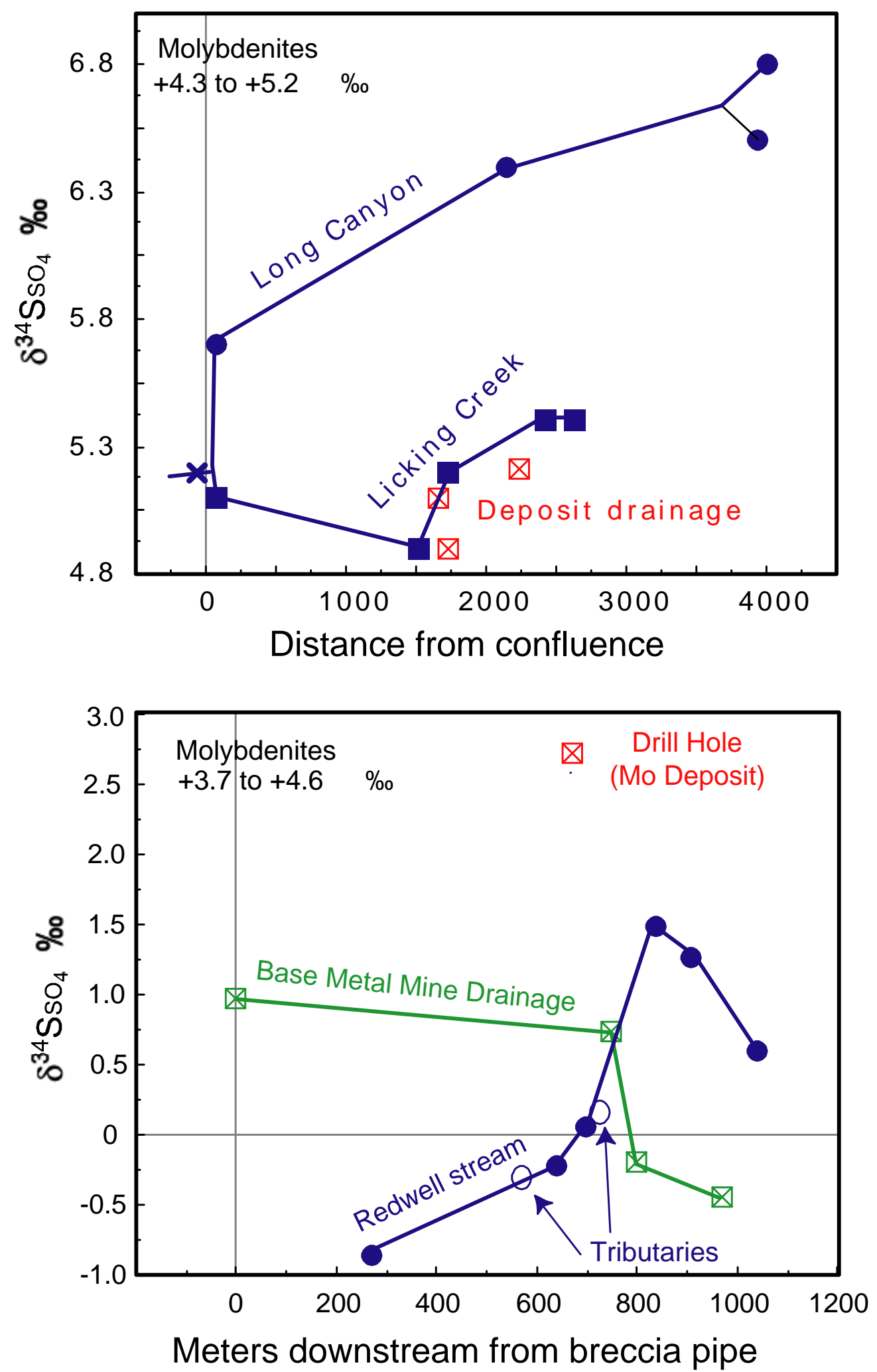

Figure 14. Distribution of ${ }^{34}$ S values in sulfate for Licking Creek and Long Canyon (upper graph) Redwell basin (lower graph). 


\section{REFERENCES CITED}

Cox, D.P., and Singer, D.A., 1986, Mineral deposit models: U.S. Geological Survey Bulletin 1693,379 p. Gaskill, D.L., Godwin, L.H., and Mutschler, F.E., 1967, Geologic map of the OH-BE-JOYFUL quadrangle, Gunnison County, Colorado: U.S. Geological Survey Geologic Quadrangle Map GQ-578, $1: 24,000$-scale.

Ludington, S., and Ellis, C.E., 1983, Mineral resource potential of the OH-BE-JOYFUL Wilderness Study Area, Gunnison County, Colorado: U.S. Geological Survey Miscellaneous Field Studies Map MF1582-A, 1:24,000-scale.

Roberts, R.J., 1964, Stratigraphy and structure of the Antler Peak quadrangle, Humboldt and Lander counties, Nevada: U.S. Geological Survey Professional Paper 459-A, 93 p.

Roberts, R.J., and Arnold, D.C., 1965, Ore deposits of the Antler Peak quadrangle, Humboldt and Lander counties, Nevada: U.S. Geological Survey Professional Paper 459-B, 94 p.

Sharp, J.E., 1978, A molybdenum mineralized breccia pipe complex, Redwell Basin, Colorado: Economic Geology, v. 73, p. 369-382.

Shevenell, L., 1996, Statewide potential evapotranspiration maps for Nevada: Nevada Bureau of Mines and Geology Report Number 48, 32 pp.

Soregaroli, A.E., and Sutherland Brown, A., 1976, Characteristics of Canadian Cordilleran molybdenum deposits, in Sutherland Brown, A., ed., Porphyry deposits of the Canadian Cordillera, Ney Volume, p. 432-443.

Stein, H.J., and Hannah, J.L., 1985, Movement and origin of ore fluids in Climax-type systems: Geology, v. 13 , p. $469-474$.

Theodore, T.G., Blake, D.W., Loucks, T.A., and Johnson, C.A., 1992, Geology of the Buckingham stockwork molybdenum deposit and surrounding area, Lander County, Nevada: U.S. Geological Survey Professional Paper 798-D, 307 p.

Thomas, J.A., and Galey, J.T., Jr., 1982, Exploration and geology of the Mt. Emmons molybdenite deposits, Gunnison County, Colorado: Economic Geology, v. 77, p. 1085-1104.

Winter, T., Harvey, J.W., Franke, O.L., Alley, W.M., 1998, Ground water and surface water: A single resource: U.S. Geological Survey circular 1139,79 p. 


\title{
Chapter E
}

\section{ENVIRONMENTAL GEOCHEMISTRY OF PLATFORM CARBONATE- HOSTED SULFIDE DEPOSITS}

\author{
Nora K. Foley \\ With Contributions from, Dave Leach, John Viets, \\ Geoffrey Plumlee, and Kathleen Smith
}

\section{INTRODUCTION}

Current efforts to develop geoenvironmental models for specific mineral deposit types are based on a foundation comprising geology, mineralogy, and environmental characteristics. This chapter will provide an overview of critical environmental issues that are common to many carbonate-hosted deposit types and distinguish aspects of geology, mineralogy, and geochemistry that lead to unique environmental concerns. More than any other factor, the geologic classification of ore deposits has provided the framework on which observations regarding environmental behavior have been based (e.g., Rytuba, 2002, Tuttle and others, 2002). The relatively recent developments of comprehensive models of environmental behavior of carbonate-hosted mineral deposits employ this geologic framework to evaluate the relative contribution of external conditions such as topography, rainfall, and temperature.

Geoenvironmental models are compilations of geologic, geochemical, and hydrologic information that describe pre- and post-mining environmental signatures of mineral deposits. The environmental behavior of carbonate-hosted deposits varies according to deposit type and this study considered two major groupings of carbonate-hosted deposits: (1) metallic ores deposited by the reaction of low temperature, basinal brines with platform carbonate host rocks and (2) metallic ores deposited by the reaction of higher temperature fluids with carbonate host rocks. The general category of carbonate-hosted deposits can be divided into distinct types on the basis of variability of host-rock types, and metal associations - for the purposes of this paper we've limited the discussions to platform carbonate or Mississippi Valley type deposits. For the purposes of this short course, we examined a broad class of platform carbonate hosted deposits consisting of sulfide ore including $\mathrm{Pb}-\mathrm{Zn}$, $\mathrm{Zn}$-rich, $\mathrm{Pb}$-rich, $\mathrm{Pb}-\mathrm{Zn}-\mathrm{Cu}$ and $\mathrm{Cu}-\mathrm{Pb}-\mathrm{Zn}$. Under the category of polymetallic replacement and skarn deposits, Hammarstrom (this volume) includes manto or Leadville-type deposits and skarns of the $\mathrm{W}, \mathrm{Sn}, \mathrm{Au}, \mathrm{Pb}-\mathrm{Zn}$, and Fe variety. A number of deposit types that are hosted by carbonate-bearing rocks including carbonatite, asbestos, Carlin-type Au, solution-collapse breccia pipe U, and some sedimentary Fe and Mn deposits, are outside the scope of this study. Silicacarbonate Hg deposits are covered by Rytuba (2002) in another chapter in this volume.

\section{Environmental Considerations}

All of the deposits considered in this review are hosted by rock packages that contain considerable amounts of carbonate minerals both in the rock itself and in veins and massive sulfide bodies that formed by mineralizing processes. In addition to $\mathrm{Fe}$ and $\mathrm{Al}$, metals and metalloids most commonly associated with these deposits are $\mathrm{Cu}, \mathrm{Mn}, \mathrm{Zn}, \mathrm{Cd}, \mathrm{Ge}, \mathrm{Co}, \mathrm{Ni}, \mathrm{Pb}, \mathrm{As}$, and $\mathrm{Tl}$. This geochemical suite reflects the primary character of the ores (e.g., Cox and Singer, 1986). In general, the potential for deleterious effects can be related to genetic classification in terms of acid-generating potential, associated heavy metal suites, acidbuffering capacity of host rocks, weathering products, and natural, pre-mining background characteristics of associated waters and rocks, among other characteristics (du Bray, 1995, and references therein). Carbonate-hosted deposits as a group have some of the lowest probabilities for adverse environmental impacts because their potential for generating acid and heavy metal contents due to their sulfide content, is balanced by the high acid-neutralizing potential of the carbonate host rocks.

The purpose of this course is to present a brief overview of the genetic classification of carbonatehosted deposits, and to identify specific geologic, mineralogical and chemical characteristics of the group that relate to the potential environmental behavior of these types of mineral deposits when disturbed by mining. The obvious links between genetic classification and environmental behavior have been established through the compilation of data from site-specific studies throughout North America (Leach and others, 1995; Hammarstrom and others, 1995a, b, c; Plumlee and others, 1999). On-going studies by the USGS are generating data to refine these links and make them more site-specific (D. Leach and J. 
Viets, personel communications, 2000). This paper presents a summary of past developments in this area of research and some refinements of previous geoenvironmental models created for these carbonate-hosted deposits (du Bray, 1995, and references therein).

\section{Geological Characteristics}

Carbonate-hosted deposits can be expected to share many common aspects of environmental behavior due to their general geological and mineralogical similarities. However, significant differences can also be expected due to specific geochemical characteristics of the rock and mineral hosts that relate to their genetic classification. In 1985, Cox and Singer published a valuable compilation of the general descriptive characteristics of a wide variety of carbonate-hosted deposits models (e.g., specific references). Deposits of this type are classified by host rock, ore type, and thermal, chemical, and physical environment of ore deposition.

For the deposit models considered in this course, the thermal and chemical environment of ore deposition is probably the most distinguishing genetic criteria. Carbonate-hosted deposits can be subdivided into two groupings based on the temperature and chemistry of the mineralizing fluid. Polymetallic and skarn deposits form by reaction of hydrothermal fluids $\left(>>250^{\circ} \mathrm{C}\right)$ generated in high temperature igneous (e.g., porphyry) environments with carbonate-bearing sequences. These fluids can be of low to high salinity and may contain $\mathrm{CO}_{2}$ and other gaseous components. In contrast, platform carbonate deposits form by the interaction of low to moderate temperature (generally $<200^{\circ} \mathrm{C}$ ), high salinity (10-30 equivalent weight percent $\mathrm{NaCl}$ ) basinal brines with carbonate-bearing sequences. The resulting ore and gangue mineralogies in each grouping of deposits reflect (1) the ability of the two distinct fluid types to leach metals from the original source rocks and transport them to the depositional sites and (2) the interaction of the fluids and host rocks at the site of deposition.

Genetic models that incorporate process-related information have been published for polymetallic replacement, carbonate-skarn and Mississippi Valley type deposits (e.g., Cox and Singer, 1986, and references therein). The following is a summary of specific geological and geochemical characteristics that comprise platform carbonate-type deposits.

\section{PLATFORM CARBONATE-HOSTED DEPOSITS}

In general, carbonate-hosted deposits are zinc-, lead, or copper-rich ores that are hosted predominantly by dolostones, with lesser amounts of limestone, sandstone and other siliciclastic units that formed within continental basins. Most of these deposits are found in rocks of Cambrian, Ordovician, Devonian, Carboniferous, and Triassic ages; Proterozoic examples also are found. MVT deposits occur throughout the world (Figure 1); the largest and most important economically are located in North America.

Predominantly lead-rich deposits include the Viburnum Trend and Old Lead Belt (within the Southeast Missouri lead district). Zinc-rich types include Tri-State (Missouri-Kansas-Oklahoma) district, AustinvilleIvanhoe (Virginia); Upper Mississippi Valley (Wisconsin), Central Tennessee, East Tennessee (Mascot Jefferson and Copper Ridge subdistricts) in the United States and Pine Point, Polaris, Daniel's Harbor, Gays River, and Nanisivik in Canada. Table 1 lists general geologic characteristics of Mississippi Valley type deposits. Kipushi deposits generally are smaller although they also cluster in districts. The Apex mine, Utah, and Ruby Creek, Alaska, are North American examples.

\section{Related Deposit Types}

Deposits hosted by carbonate rocks are part of a broad spectrum of deposits hosted by sedimentary rocks (Cox and Singer, 1986; Sangster and Leach, 1995) that includes sedimentary exhalative lead-zincbarite deposits (Model 31a), carbonate-hosted flourite deposits (for example, Illinois- Kentucky fluorite deposits), MVT deposits (Model 32a), carbonate-platform deposits (for example, Mt. Isa and HYC, Australia; Balmat-Edwards, NY), Kipushi copper deposits (model 32c) and sandstone lead deposits (Model 30a) (for example Laisvall, Sweden and Largentiere, France). Another group of deposits to be included in this spectrum are siliciclastic-hosted deposits such as the Irish type $\mathrm{Zn}-\mathrm{Pb}-\mathrm{Cu}-\mathrm{Ag}$ (Lion Hill, $\mathrm{Vt}$; Silvermines, Navan, Ireland). 


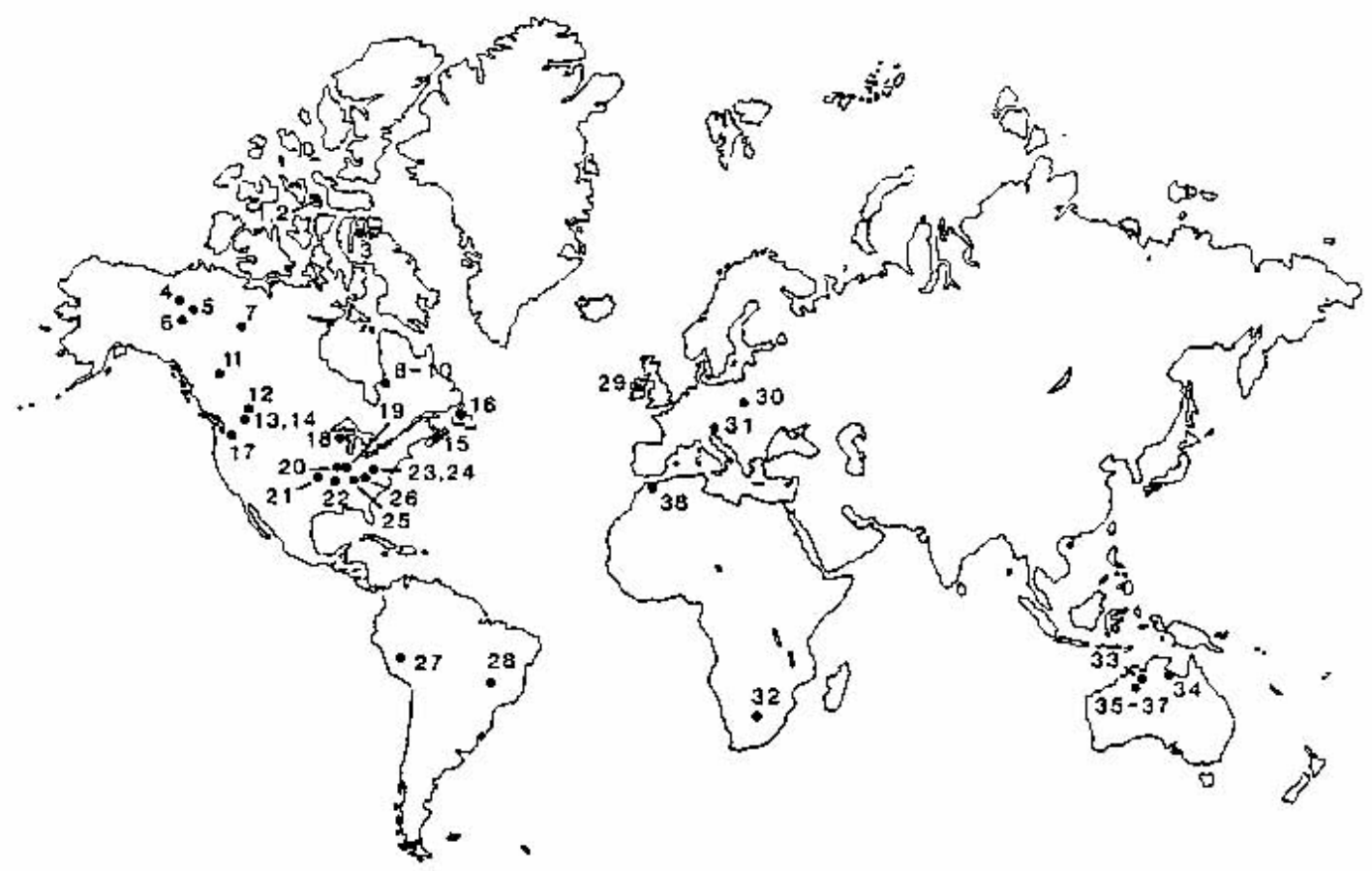

Figure 1. Distribution of carbonate-hosted $\mathrm{Zn}-\mathrm{Pb}$ deposits occurring throughout the world. Figure from Leach and others (1995). Locations shown: 1, Polaris; 2, Eclipse; 3, Nanisivik; 4, Gayna; 5, Bear-Twit; 6, Godlin; 7, Pine Point district; 8, Lake Monte; 9, Nancy Island; 10, Ruby Lake; 11, Robb Lake; 12, Monarch-Kicking Horse; 13, Giant; 14, Silver Basin; 15, Gays River; 16, Daniels Harbour; 17, Metaline district; 18, Upper Mississippi Valley district; 19, southeast Missouri district)Old Lead Belt, Viburnum Trend, Indian Creek); 20, central Missouri district; 21, tri-State district; 22, northern Arkansas district; 23, Austinville-Ivanhoe district; 24, Friedensville; 25, central Tennessee district; 26, east Tennessee district; San Vicente; 28, Vazante; 29, Harberton Bridge; 30, Silesian district; 31, Alpine district; 32, Pering; 33, Sorby Hills; 34, Coxco; 35-37, Lennard Shelf district (Cadjebut, Blendvale, Twelve Minle Bore); 38, ElAbad-Mekta district. (Adapted from Sangster, 1990).

\section{Deposit Size}

Platform carbonate deposits typically occur in districts covering hundreds, or even thousands, of square kilometers. Although individual ore zones may be small, these zones tend to cluster into districts that constitute world-class sources of lead and zinc. Leach and others (1995) complied data for deposits versus districts. District totals for metals may represent several dozen individual deposits; for example, the Pine Point and Upper Mississippi Valley districts contain more than 80 and nearly 400 deposits, respectively. Individual deposits are generally small; most yield less than ten million tons of ore. An analysis of the Pine Point district, for example, showed that most deposits contained between 0.2 and 2 million tons of ore, and the largest had nearly 18 million tons (Sangster, 1990). For the Upper Mississippi Valley district, Heyl and others (1959) reported that the average deposit size was between 0.1 and 0.5 million tons, although a few contained as much as 3 million tons of ore.

Combined lead plus zinc grades in MVT deposits (districts) seldom exceed 10 percent. The Polaris deposit, in the Canadian Arctic Archipelago, is not only unusually large (22 million tonnes), but is anomalously high grade as well (18 percent lead plus zinc). A majority (about 85 percent) of deposits (districts) are zinc-rich relative to lead and have $\mathrm{Zn} /(\mathrm{Zn}+\mathrm{Pb})$ values between 0.5 and 1.0 , with a distinct mode at 0.8. A smaller group, consisting of the entire Southeast Missouri district plus a few other small deposits, has a modal value of about 0.05 and is distinctly anomalous in this regard. 
Table 1. Critical geological characteristics of MVT deposits (Leach and Sangster, 1993; Leach and others, 1995).

\begin{tabular}{|l|l|}
\hline 1. & Most deposits are hosted by dolostone; less commonly in limestone or sandstone \\
\hline 2. & Ores are epigenetic and stratabound \\
\hline 3. & Deposits are not associated with igneous activity \\
\hline 4. & Deposits are at shallow depths at the flanks of basins \\
\hline 5. & $\begin{array}{l}\text { Deposits are in platform carbonate sequences, either located in relatively undeformed rocks } \\
\text { bordering foreland deeps or in foreland thrust belts. }\end{array}$ \\
\hline 6. & $\begin{array}{l}\text { Many deposits are in districts that cover hundreds of square kilometers; some districts form } \\
\text { metallogenic provinces. }\end{array}$ \\
\hline 7. & $\begin{array}{l}\text { Deposits form districts that are localized by geologic features, including breccias, depositional } \\
\text { margins of shale units, facies tracts, faults, and basement highs that permit upward migration of } \\
\text { ore fluids. }\end{array}$ \\
\hline 8. & $\begin{array}{l}\left.\text { Ore-deposition temperatures are low (50 }{ }^{\circ} \mathrm{C}-200^{\circ} \mathrm{C}\right), \text { but typically higher than those attributable to } \\
\text { local basement-controlled thermal gradients; mineralization is in thermal equilibrium with respect } \\
\text { to common host rocks. }\end{array}$ \\
\hline 9. & $\begin{array}{l}\text { Deposits are mineralogically simple; dominant minerals are sphalerite, galena, pyrite, marcasite, } \\
\text { chalcopyrite, dolomite, calcite, and quartz. }\end{array}$ \\
\hline 10. & $\begin{array}{l}\text { Alteration associated with mineralization consists mainly of dolomitization, brecciation, host-rock } \\
\text { dissolution, and dissolution/recrystallization of feldspar and clay. }\end{array}$ \\
\hline 11. & $\begin{array}{l}\text { Evidence of carbonate rock dissolution is common and expressed as slumping, collapse, } \\
\text { brecciation, or some combination of these. }\end{array}$ \\
\hline 12. & Ore fluids were dense basinal brines, typically containing 10-30 weight percent salt. \\
\hline 13. & Isotopic data indicate crustal sources for both metal and reduced sulfur. \\
\hline 14. & $\begin{array}{l}\text { Sulfide mineral textures are varied, nature of the ore can range from coarsely crystalline to fine- } \\
\text { grained, and massive to disseminated. }\end{array}$ \\
\hline
\end{tabular}

Table 2. Classification of selected deposits hosted by siliciclastic and carbonate-bearing rock sequences

\begin{tabular}{|l|l|l|}
\hline Metal Suite & Clastic sedimentary $\geq$ Carbonate & Carbonate> Clastic sedimentary \\
\hline $\mathrm{Pb}-\mathrm{Zn}$-Cu-(Ag) & $\begin{array}{l}\text { Irish type } \\
\text { Silvermines, Ireland } \\
\text { Navan, Ireland } \\
\text { Lion Hill, Vt }\end{array}$ & $\begin{array}{l}\text { MVType } \\
\text { Southeast Missouri } \\
\text { Upper Mississippi Valley }\end{array}$ \\
\hline $\mathrm{Cu}-\mathrm{Pb}-\mathrm{Zn}$ & $\begin{array}{l}\text { Sediment-hosted Cu type } \\
\text { Kupferschiefer, Germany } \\
\text { White Pine, MI } \\
\text { Kamoto, Zaire }\end{array}$ & $\begin{array}{l}\text { Brushy mine, SE MO } \\
\text { Kipushi type } \\
\text { Ruby Creek, AK } \\
\text { Apex, UT } \\
\text { Kipushi, Zaire }\end{array}$ \\
& Balmat-Edwards, NY & $\begin{array}{l}\text { Appalachian type } \\
\text { Austinville, VA, } \\
\text { Copper Ridge, TN }\end{array}$ \\
\hline $\mathrm{Zn}$-rich & & $\begin{array}{l}\text { MVType } \\
\text { Viburnum Trend, SE MO } \\
\text { Old Lead Belt, SE MO }\end{array}$ \\
\hline $\mathrm{Pb}-$-rich & Laisvall type & \\
& Laisvall, Sweden \\
& Largentierre, France & \\
\hline
\end{tabular}

\section{Host Rocks}

Classic MVT deposits are hosted by dolostones and contain $\mathrm{Zn}$-rich and $\mathrm{Pb}-\mathrm{Zn}$ ores. Deposits hosted by rock sequences that predominantly consist of sandstone (e.g., the Pb-rich Laisvall district, Sweden) are lead-rich. Mixed carbonate-siliciclastic rocks contain deposits (e.g., the Lion Hill deposit, Vermont; Silvermines district, Ireland) comprised of the suite $\mathrm{Zn}-\mathrm{Pb}-\mathrm{Cu}-(\mathrm{Ag})$. Kipushi deposits formed in dolomite breccias with a shale component are characterized by $\mathrm{Cu}-\mathrm{Pb}-\mathrm{Zn}$ (Kipushi, Zaire). 
Surrounding Geologic Terrane

MVT deposits commonly are at shallow depths along basin flanks (Figure 2). They form in platform carbonate sequences, located either in relatively undeformed rocks bordering foredeeps or in foreland thrust belts. Some deposits are associated with salt diapirs (for example, Bou Grine in Tunisia). Most deposits are surrounded by carbonate rocks with high acid buffering capacity.
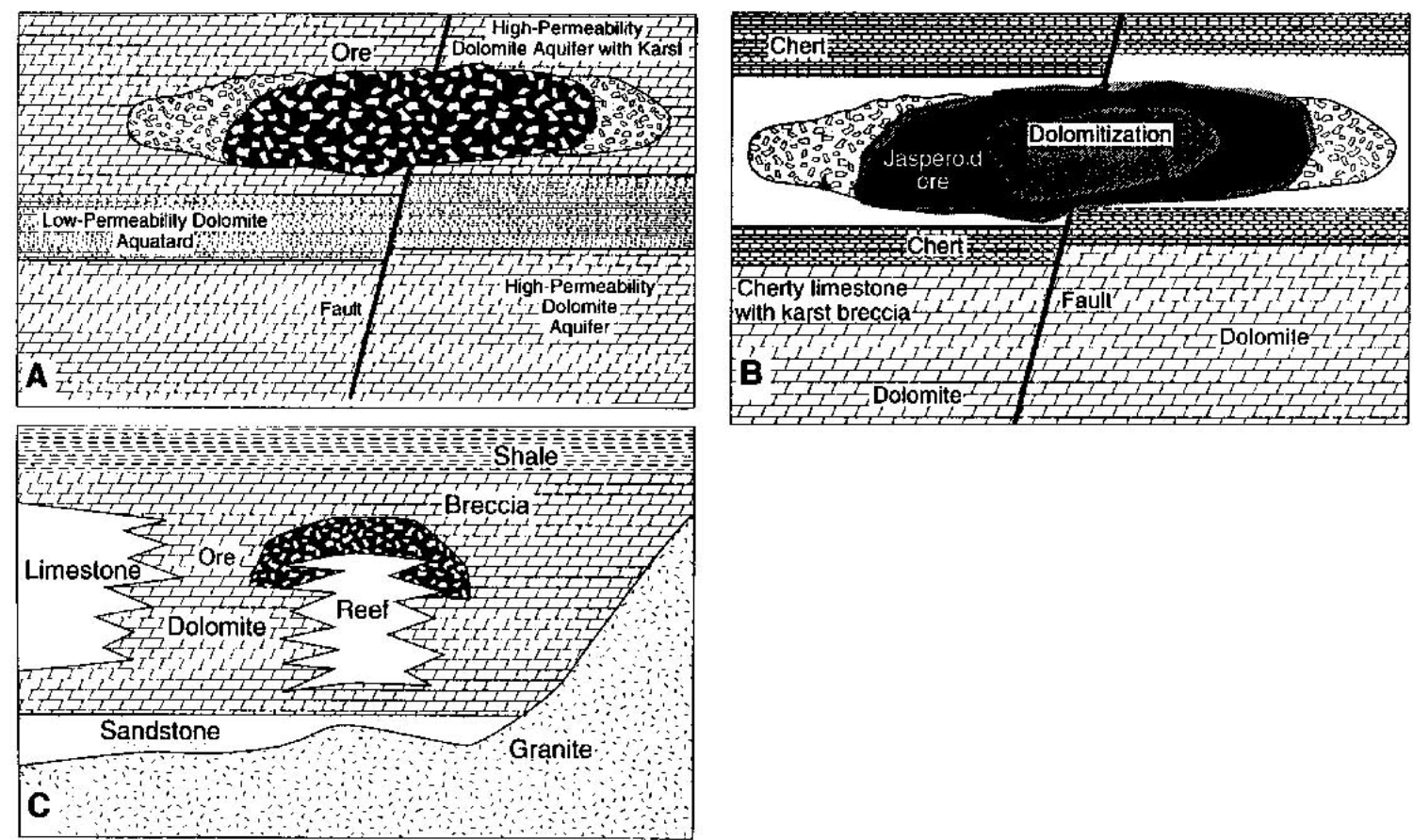

Figure 2. Schematic cross-sections showing geologic features of various platform carbonate deposits, from Plumlee and others (1999). The cross sections reflect concepts presented by Leach and Sangster (1983) and references therein: A. Central Missouri district, B. Tri-State district, and C. Viburnum Trend.

The deposits typically occur in undeformed, orogenic foreland carbonate platform environments. Some occur in carbonate sequences in foreland thrust belts bordering foredeeps and a few are associated with rift zones. Others, such as Kipishi-type deposits form in carbonaceous laminated stromatolitic dolomites where high fluid flow occurs along tabular or pipe-like fault or karst (?) breccia zones.

\section{Wall-Rock Alteration}

Dissolution, recrystallization, and hydrothermal brecciation of host carbonate rocks within and peripheral to mineralized rock is common to virtually all the deposits. These effects may develop in conjunction with silicification and dolomitization and constitute the major form of wall-rock alteration in most districts. Ore-related silicification of host rocks limits the buffering capacity of rocks near ore deposits and therefore influences the extent of metal-bearing water dispersion in some districts (for example, Tri-State). Hydrothermal dolomite may be pre-, syn-, or post-ore and has commonly replaced preore carbonate host rocks to form distinctive alteration halos around deposits (for example, the East Tennessee and Tri-State districts). Formation of authigenic clay and feldspar minerals and destruction of detrital potassium-silicate minerals are recognized in some districts.

\section{Nature of Ore}

Platform carbonate ore is extremely varied in both character and form. Orebodies range in nature from massive replacement zones to open space layered fillings of fractures and coatings on breccias to disseminated clusters of crystals that occupy intergranular pore space. Crystal size ranges from 
cryptocrystalline to museum quality specimens as much as a meter or more in length (e.g., "crystal caverns" in the Tri-State and Central Tennessee districts). In some districts, notably Pine Point, Silesia, Polaris, and Cadjebut, much of the ore occurs as extremely fine-grained, laminated aggregates of botryoidal (colloform) sphalerite which is commonly intergrown with dendritic or skeletal galena. Most platform carbonate deposits show clear evidence that open space deposition was accompanied by dissolution and replacement of host carbonate rocks. Carbonate host rock replacement can be nearly total (e.g., massive sulfide zones at Nanisivik and Polaris) or selective (zebra rock facies at Austinville, VA). Ore-hosting structures are most commonly zones of highly brecciated dolomite; in some instances (for example, Pine Point and Daniels Harbour) these zones are arranged in linear patterns suggesting a tectonic control, although faults of large displacement are never present. Faults that reflect reactivated basement structures are the most important ore control in some districts, notably Upper Silesia and Ireland. In other cases, more localized structures, such as breccia pipes in stromatolitic dolostone, focused mineralization.

\section{Mining and Ore Processing Methods}

Current mining methods use underground room-and pillar or longwall mining technologies. Ore is processed by pulverizing and flotation, and the concentrates are usually shipped to smelters.

\section{Deposit Trace Element Geochemistry}

Zinc, lead, and copper are the primary commodities produced in deposits of this kind, and constitute the dominant metal suite (Table 3). Variability in the dominant metallogeny of the districts has been suggested to result from controls imposed on bulk chemistry by the impact of large-scale fluid-flow regimes on regional lithotectonic setting (craton- $\mathrm{Pb}$, basinal- $\mathrm{Zn}-\mathrm{Pb}$, and platform- $\mathrm{Zn}$ ). Although the general deposit type can have a diverse metallogeny, typically individual districts have a more limited suite of associated metals (Table 3 ).

Carbonate-hosted deposits can contain a minor but complex suite of trace minerals and elements (Table 3). Other commodities reportedly produced at some deposits of this type include, silver, copper, cadmium, germanium, barite, fluorite, and nickel. Minor and trace minerals may include arsenate minerals, arsenopyrite, barite, bravoite, bornite, chalcopyrite, carrollite, celestite, chalcocite, covellite, digenite, djurleite, enargite, gallite, germanite, galena, greenockite, linnaeite, marcasite, millerite, molybdenite, pyrrhotite, renierite, siegenite, tennantite, and tungstenite and vaesite (co-sulfide). Some of these phases are present in trace amounts in many deposits, however only a few deposits (examples in Table 3 ) can be expected to contain the entire suite. Southeast Missouri deposits contain relatively abundant Ni and Co sulfides, whereas the Silesian deposits contain strong enrichments of arsenic and thallium in sphalerite and marcasite (Viets and others, 1996).

Primary Mineralogy and Zonation

The simple sulfide mineral assemblages of these deposits consist of galena, sphalerite, pyrite, marcasite, and chalcopyrite; trace amounts of other sulfide and sulfosalt minerals make up the balance. Within a given district, individual deposit mineralogy may be quite variable, although this is atypical for MVT deposits. The Viburnum Trend is one of the best studied, and most variable deposits in North America. For example, $\mathrm{Pb}-\mathrm{Zn}-\mathrm{Cu}$ deposits occurring within the Southeast Missouri district contain substantial pyrite, marcasite, and chalcopyrite although the amounts vary considerably from mine to mine. The mineralogical paragenesis of the Viburnum Trend subdistrict Number 28 mine is dominated by late marcasite and pyrite, whereas, the Brushy mine contains large amounts of chalcopyrite, lesser pyrite, and negligible marcasite (Horrall and others, 1983). In contrast, the deposits at East Tennessee almost uniformly consist of coarse yellow sphalerite and calcite. Chalcopyrite-rich types typically have a more diverse trace element geochemistry (e.g., Table 3).

Iron sulfide content is clearly the most important consideration for platform carbonate deposits (Leach and others, 1995). Most deposits of this type contain less than $5 \%$ iron sulfide by volume. For example, the Austinville-Ivanhoe district contains only trace to minor amounts of iron sulfide. A rare exception, the sulfide mineral assemblage at Nanisivil is dominated by pyrite. The most critical aspect of the iron sulfide mineralogy is that it generally occurs in fairly reactive forms. Anisotropic pyrite and marcasite are common. For example, the Silesian MVT district contains a late-stage of botryoidal marcasite that occurs in some deposits and is absent in others (Sutley and others, 1999). Sutley and others (1999) demonstrates that forms salts and release of trace metals. For example, Plumlee and others (1999) of iron sulfide 
Table 3. Mineralogical and metal associations of MVT and associated deposits types

\begin{tabular}{|c|c|c|c|c|c|c|c|c|}
\hline Deposit & $\begin{array}{l}\text { General } \\
\text { MVT }\end{array}$ & $\begin{array}{l}\text { Viburnum } \\
\text { Trend, SE } \\
\text { MO }\end{array}$ & $\begin{array}{l}\text { Ruby } \\
\text { Creek* } \\
\text { Apex* }\end{array}$ & $\begin{array}{l}\text { East } \\
\text { Tenn }\end{array}$ & Tri-state & $\begin{array}{l}\text { Austin } \\
\text {-ville }\end{array}$ & $\begin{array}{l}\text { Upper } \\
\text { Silesia, } \\
\text { Poland }\end{array}$ & $\begin{array}{l}\text { Nanisivik* } \\
\text { Pine Point* }\end{array}$ \\
\hline $\begin{array}{l}\text { Major } \\
\text { metals }\end{array}$ & $\begin{array}{l}\mathrm{Zn}, \mathrm{Pb}, \\
\mathrm{Fe}\end{array}$ & $\mathrm{Pb}, \mathrm{Zn}, \mathrm{Fe}$ & $\begin{array}{l}\mathrm{Cu}, \\
\mathrm{Zn}, \mathrm{Pb}, \\
\mathrm{As},\end{array}$ & $\mathrm{Zn}$ & $\mathrm{Zn}, \mathrm{Pb}$ & $\begin{array}{l}\mathrm{Zn}, \mathrm{Pb}, \\
\mathrm{Fe}\end{array}$ & $\begin{array}{l}\mathrm{Fe}, \mathrm{Zn}, \\
\mathrm{Pb}, \mathrm{S}\end{array}$ & $\mathrm{Zn}, \mathrm{Pb}, \mathrm{Fe}$ \\
\hline $\begin{array}{l}\text { Minor and } \\
\text { trace } \\
\text { metals }\end{array}$ & $\begin{array}{l}\mathrm{Cu}, \mathrm{Ba} \\
\mathrm{Cd}, \mathrm{Ag}, \\
\mathrm{Ge}, \mathrm{Ga} \text {, } \\
\mathrm{Co}, \mathrm{Ni}, \\
\mathrm{As}\end{array}$ & $\begin{array}{l}\mathrm{Cu}, \mathrm{Co}, \\
\mathrm{Ni} \\
\mathrm{Cd}, \mathrm{Ag}, \\
\mathrm{In}, \mathrm{Ge}, \\
\mathrm{Ga}, \mathrm{Sb}, \\
\mathrm{Bi}, \mathrm{As}, \\
\mathrm{Mo}, \mathrm{Sn}, \\
\mathrm{Au}\end{array}$ & $\begin{array}{l}\text { Co, } \\
\mathrm{Ag}, \\
\mathrm{Ge}, \\
\mathrm{Ga}, \\
\text { Mo, } \\
\mathrm{W}, \mathrm{Sn}, \\
\mathrm{Bi}, \mathrm{U}, \\
\mathrm{V}\end{array}$ & & $\begin{array}{l}\mathrm{Fe}, \mathrm{Cu} \\
\mathrm{Cd}, \mathrm{Ba} \text {, } \\
\mathrm{Ag}, \mathrm{Ge} \text {, } \\
\mathrm{Ga}, \mathrm{Co}, \\
\mathrm{Ni}, \mathrm{In}, \\
\mathrm{Sb}, \mathrm{Bi}\end{array}$ & $\begin{array}{l}\mathrm{Cu} \\
\mathrm{Cd}, \\
\mathrm{Ge}, \\
\mathrm{Ga}, \mathrm{F}, \\
\mathrm{Ba}, \mathrm{As}\end{array}$ & $\begin{array}{l}\mathrm{Zn}, \mathrm{Cd}, \\
\mathrm{Fe}, \mathrm{Pb}, \\
\mathrm{As}, \mathrm{Ag}, \\
\mathrm{Tl}, \mathrm{Cd}\end{array}$ & $\begin{array}{l}\mathrm{Ba}, \mathrm{Cd}, \mathrm{Ag}, \\
\mathrm{As}, \mathrm{Ni}, \mathrm{Ge}\end{array}$ \\
\hline $\begin{array}{l}\text { Dominant } \\
\text { Fe sulfide }\end{array}$ & Py & $\mathrm{Py}, \mathrm{mc}$ & Py & $\mathrm{Py}$ & Py & $\begin{array}{l}\begin{array}{l}\text { Py } \\
\text { (aniso) }\end{array} \\
\end{array}$ & $\mathrm{Mc}$ & Py \\
\hline $\begin{array}{l}\text { Major ore } \\
\text { sulfides }\end{array}$ & $\mathrm{Sp}$, gn & $\begin{array}{l}\text { Gn, sp, } \\
\mathrm{cp}, \mathrm{py}, \mathrm{mc}\end{array}$ & $\begin{array}{l}\text { Py, bo, } \\
\text { ch, gn, } \\
\text { cp, ca, } \\
\text { sp, tn, } \\
\text { mc, as }\end{array}$ & $\begin{array}{l}\text { Sp, } \\
\text { py }\end{array}$ & $\mathrm{Sp}$, gn & $\mathrm{Sp}, \mathrm{gn}$ & $\begin{array}{l}\text { Sp, gn, } \\
\mathrm{mc}\end{array}$ & Py, sp, gn \\
\hline $\begin{array}{l}\text { Minor } \\
\text { sulfides }\end{array}$ & $\begin{array}{l}\text { Py, mc, } \\
\text { cp, as, } \\
\text { br }\end{array}$ & $\begin{array}{l}\text { Si, bo, tn, } \\
\text { br, dg, cv, } \\
\text { ar, po, as, } \\
\text { ml, dj, ch, } \\
\text { en }\end{array}$ & $\begin{array}{l}\text { Co-py, } \\
\text { ln, ge, } \\
\text { re, ga, } \\
\text { tu, mo, } \\
\text { mc }\end{array}$ & $\begin{array}{l}\text { Gn, } \\
\text { cp }\end{array}$ & $\begin{array}{l}\text { Cp, mc, } \\
\text { br }\end{array}$ & $\begin{array}{l}\mathrm{Py}, \\
\mathrm{mc}, \mathrm{cp}, \\
\text { as }\end{array}$ & Gn & As, br \\
\hline $\begin{array}{l}\text { Primary } \\
\text { sulfate }\end{array}$ & $\mathrm{Ba}$ & $\mathrm{Ba}$ & & & $\mathrm{Ba}$ & $\mathrm{Ba}$, & & $\mathrm{Ba}$ \\
\hline $\begin{array}{l}\text { Major } \\
\text { carbonate }\end{array}$ & Do & Do & Do & Do & Do & Do & Ara & Do \\
\hline $\begin{array}{l}\text { Minor } \\
\text { carb }\end{array}$ & $\begin{array}{l}\text { Sm, cc, } \\
\text { cr, cs }\end{array}$ & $\mathrm{Cc}$ & $\mathrm{Cc}$ & $\mathrm{Cc}$ & $\mathrm{Cc}$ & $\begin{array}{l}\text { Cc, do, } \\
\text { sm }\end{array}$ & $\mathrm{Sm}$ & $\mathrm{Cc}$ \\
\hline $\begin{array}{l}\text { Secondary } \\
\text { oxides, } \\
\text { arsenates, } \\
\text { sulfates, } \\
\text { oxy- } \\
\text { hydroxide } \\
\text { etc. }\end{array}$ & $\begin{array}{l}\text { gr, an, } \\
\text { cl } \\
\text { go, ep, } \\
\text { gy, ma, } \\
\text { me, sz, } \\
\text { co, di, } \\
\text { Fe-ox, } \\
\text { hm }\end{array}$ & & $\begin{array}{l}\text { Co-ox, } \\
\text { Co-ar } \\
\text { ja, ma, } \\
\text { az, Fe- } \\
\text { ox }\end{array}$ & & & $\begin{array}{l}\text { an, cr, } \\
\text { gy, ag, } \\
\text { ce }\end{array}$ & $\begin{array}{l}\text { Fe-ox, } \\
\text { hm, an, } \\
\text { he, li, } \\
\text { pa, lo, } \\
\text { hyzn, } \\
\text { cr, gy, } \\
\text { ja }\end{array}$ & \\
\hline
\end{tabular}

Abreviations: an-anhydrite, ag-anglesite,ar-arsenate, ara-aragonite,as-arsenopyrite, ba-barite, az-azurite, brbravoite, py-pyrite, bo-bornite, cp-chalcopyrite, ca-carrollite, cc-calcite, ce -celestite, ch-chalcocite, clcalamine, co-copiatite, cr-cerrusite, cs-carphosiderite, cv-covellite, dg-digenite, di-diadochite, dj-djurleite, do-dolomite, en-enargite, ep-epsomite, ga-gallite, ge-germanite, gn-galena, go-goslarite, gr-greenockite, gy-gypsum, hyzn-hydrozincite, hm-hematite, he-hemimorphite, ja-jarosite, li-litharge, ln-linnaeite, lolollingite, ma-malachite, me-melanterite, mc-marcasite, ml-millerite, mo-molybdenite, ox-oxide, paparabutlerite, po-pyrrhotite, re-renierite, si-siegenite, sm-smithsonite, sp-sphalerite, sz-szomolnokite, tntennantite, tu-tungstenite, zn-carb. 
may contain the bulk of the trace metals, which are readily released as the iron sulfide weathers. Mixtures of reactive iron sulfide and other sulfide may accelerate the formation of secondary have noted that underground workings of the Viburnum trend that contain bornite intergrown with marcasite weather extensively to secondary copper sulfate salts whereas bornite alone is generally unreactive.

Recrystallized dolomite is the most common gangue mineral. Alteration haloes of dolomite surround many MVT and Kipushi deposits; they are particularly well-developed at East Tennessee and in the Tristate district. The primary form of carbonate intergrown with ore in these deposits is hydrothermal dolomite. Dolomite is less reactive than simple carbonates such as calcite. Smithsonite is also present in many of these deposits, and was the primary source of the zinc ore in some deposits during early mining years. Hydrothermal calcite occur in many deposits of this type, but is generally much less abundant than dolomite. Jasperoid and botryoidal forms of quartz also occur as gangue material.

Secondary Mineralogy

Secondary minerals consist of smithsonite, calamine, anglesite, cerussite, celestite, malachite, sulfur, goslarite, epsomite, gypsum, melanterite, szomolnokite, copiatite, carphosiderite, diadochite, hydrous iron oxide minerals, hematite, and greenockite. Malachite and azurite are reported in copper-rich deposits. Jarosite, has also been reported rarely. ADD $\underline{\text { Sutley }}$

\section{Soil and Sediment Signatures}

Many MVT deposits are thought to have essentially no geochemical signature outside of the zone of wall rock alteration because of limited primary dispersion of ore related elements into the surrounding carbonate rocks (Lavery and others, 1994), except along structures that acted as fluid conduits. However, in some districts where ore-bearing zones have been weathered, soil contains anomalous concentrations of lead and zinc. Soil geochemistry in the Irish district (Hitzman and others, 1992) and in the Newfoundland zinc district (Davenport and others, 1975) are effectively used in exploration.

Although MVT deposits are hosted by carbonate rocks, residual soil overlying some deposits can be acidic; it can have moderate to high permeability, medium to high erosion potential, and moderate to high water capacity. These factors can influence the mobility of metals into the environment. In the area of the Austinville-Ivanhoe, Va., district background carbonate rocks typically contain about $20 \mathrm{ppm}$ zinc and 9 ppm lead. However, extensive volumes of rock containing dolomite cement are widely peripheral to mineralized zones (for example, Wythe County, Va.; Barnaby, 1989); replacement dolomite and late calcite have considerably elevated abundances of some trace metals, including as much as 9,300 ppm iron, $200 \mathrm{ppm}$ strontium, 1,500 ppm lead, 1,000 ppm manganese, and 10,000 ppm zinc.

In the region of the East Tennessee district, readily detectable zinc, iron, and locally lead anomalies are found in residual soil and stream sediment. For example, NURE data for stream sediment indicate that over 100 samples from the Bluefield 1 x2 quadrangle (Va., W. Va., Tenn., and N.C.) have anomalous lead and zinc abundances ( $>20 \mathrm{ppm}$ zinc and $>10 \mathrm{ppm}$ lead) that may be attributable to lead and zinc deposits in the region. Proctor and others (1981) conducted a survey of the acid soluble lead content of 416 stream sediment samples collected from active streams throughout a 7,000 square mile area that includes much of the Southeast Missouri lead district. Samples from areas underlain by Paleozoic carbonate rock and considered to be largely non-mineralized have a mean lead content of $25 \mathrm{ppm}$, whereas samples from areas of active mining and milling contain an average of $393 \mathrm{ppm}$ lead. The specific residence of lead was not identified but Proctor and others (1981) considered metal from insoluble rock residues, primary dispersion halos, secondary dispersion of primary mineralization, and recent dispersion due to mining and milling and smelting activities as possible lead sources.

\section{Topography and Physiography}

Most platform-carbonate deposits are located in flat-lying carbonate sequences. However, some deposits are located in thrust and fold belts (for example, Monarch-Kicking Horse, British Columbia; Alpine district in Europe). The deposits typically occur in undeformed, orogenic foreland carbonate platform environments. Some occur in carbonate sequences in foreland thrust belts bordering foredeeps and a few are associated with rift zones. Others form in carbonaceous laminated stromatolitic dolomites along tabular or pipe-like fault or karst (?) breccia zones and in zones of higher permeability due to structural effects such as block faulting and caving due to carbonate dissolution. 
Hydrology

Platform-carbonate deposits originally form as a result of the interaction of large-scale fluid-flow regimes that leach extensive sedimentary rock sequences and deposit metals when the fluids reach carbonate rocks. The ores in MVT deposits form from heated basinal brines that migrate regionally away from mountain uplift and compressional collision zones on basin edges. The brines deposit small amounts of sulfide minerals (iron sulfides, sphalerite, galena) regionally in the sedimentary aquifers through which they flow. Ore-grade mineral deposits form where fluids from different aquifers intersect zones of higher permeability due to structural effects such as block faulting and caving due to carbonate dissolution. Precipitation of minerals may occur by mixing of brines from different aquifers or by a change in the chemistry of the fluid that might result from flow of a brine from one aquifer to another. An example of this might be flow of fluid from a dolostone aquifer to a chemically more reactive limestone aquifer. Kipishi deposit form in dolomites where high fluid flow occurs along tabular or pipe-like breccia zones. Thus, high fluid transmissivity is a dominant characteristic of all platform-carbonate deposits and most districts have some spatial connection to major aquifers, karsts, breccia pipes, or faults occurring within the geologic record. Post-mineralization events such as tectonism, uplift, weathering, and metamorphism have altered the present-day hydrological setting.

\section{Drainage Signatures}

Metal mobility away from platform-carbonate deposits is limited by the abundance of carbonate rock associated with these deposits; carbonate rock consumes acid mine drainage and inhibits aqueous metal mobility (Figure 3). Heavy metals abundances were determined at four seepage sites related to mine wastes in the Old Lead Belt (Smith and Schumacher, 1991). Maximum concentrations measured were: $850 \mathrm{mg} / \mathrm{l}$ $\mathrm{SO}$, less than $10 \mathrm{~g} / \mathrm{l}$ copper, $80 \mathrm{~g} / \mathrm{l}$ lead, $18,000 \mathrm{~g} / \mathrm{l}$ zinc, and $28 \mathrm{~g} / \mathrm{l}$ cadmium. During two years of monitoring at the four sites, $\mathrm{pH}$ of the seeps ranged from 6.23 to 8.61. A lead-zinc ratio of 5 for Old Lead Belt ore (Snyder and Gerdmann, 1968) indicates that zinc is clearly more mobile than lead or cadmium in water leaching waste materials; these relative mobilities also appear to apply to Big River water. The presence of $\mathrm{Pb}$-sulfate in some of the districts (e.g., Austinville, VA) indicates that $\mathrm{Pb}$ can be sequestered in an insoluble sulfate form. Near-neutral waters having elevated concentrations of dissolved $\mathrm{Zn}$ (as high as $100 \mathrm{mg} / \mathrm{l}$ ) and $\mathrm{Pb}$ and $\mathrm{Cd}$ have been reported in mine workings with high iron sulfide contents (Plumlee and others, 1999). Near-neutral zinc-bearing river waters are also reported for low iron sulfide districts (Austinville, VA). In this case, others factors besides iron sulfide content are working to increase the zinc contents of mine drainage waters, these include reactivity of the iron sulfide form and zinc mineralogy (Foley, 2001).

Ground water. Water from a depleted part of one mine in the Viburnum Trend is used as the municipal water supply for Viburnum, Mo. This water meets all U.S. Environmental Protection Agency water quality standards with the exception of that for sulfate (Missouri Department of Natural Resources, 1991).

Reported sulfate content is $436 \mathrm{mg} / \mathrm{l}$, whereas the accepted water quality standard is $250 \mathrm{mg} / \mathrm{l}$. Other parameters are $\mathrm{pH}=7$; alkalinity $=260 ; 0.18 \mathrm{mg} / 1$ iron; $5.7 \mathrm{mg} / \mathrm{l}$ sodium; $72 \mathrm{mg} / \mathrm{l}$ magnesium; $0.24 \mathrm{mg} / \mathrm{l}$ fluorine; $856 \mathrm{mg} / \mathrm{l}$ total dissolved solids; and lead, zinc, and cadmium abundances are in the $\mathrm{g} / \mathrm{l}$ range. In addition, several communities in Upper Silesia, Poland, use water from underground lead-zinc mines as their only domestic water supply. The sulfate content of this water is variable but is commonly in the 400 to $800 \mathrm{mg} / \mathrm{l}$ range and lead is present in the $\mathrm{g} / \mathrm{l}$ range.

Surface water. The Big River flows through the Old Lead Belt and near many waste piles. Water quality data (Smith and Schumacher, 1991) for a site about $15 \mathrm{~km}$ above mining and smelting activity reflect background water parameters: $\mathrm{SO}<24 \mathrm{mg} / \mathrm{l}$, lead $<10 \mathrm{~g} / \mathrm{l}$, cadmium $<2 \mathrm{~g} / \mathrm{l}$, and zinc $<27 \mathrm{~g} / \mathrm{l}$. During its flow through the district, carbonate buffering causes water $\mathrm{pH}(6.6-8.5)$ to be virtually unchanged. However, SO, lead, and zinc abundances increase due to inputs primarily from surface mine wastes. At a site $5 \mathrm{~km}$ below the district, the water contains $40-140 \mathrm{mg} / \mathrm{l} \mathrm{SO}, 10 \mathrm{~g} / \mathrm{l} \mathrm{lead,}<1 \mathrm{~g} / \mathrm{l} \mathrm{cadmium}$, and 110-160 $\mathrm{g} / \mathrm{l}$ zinc. 


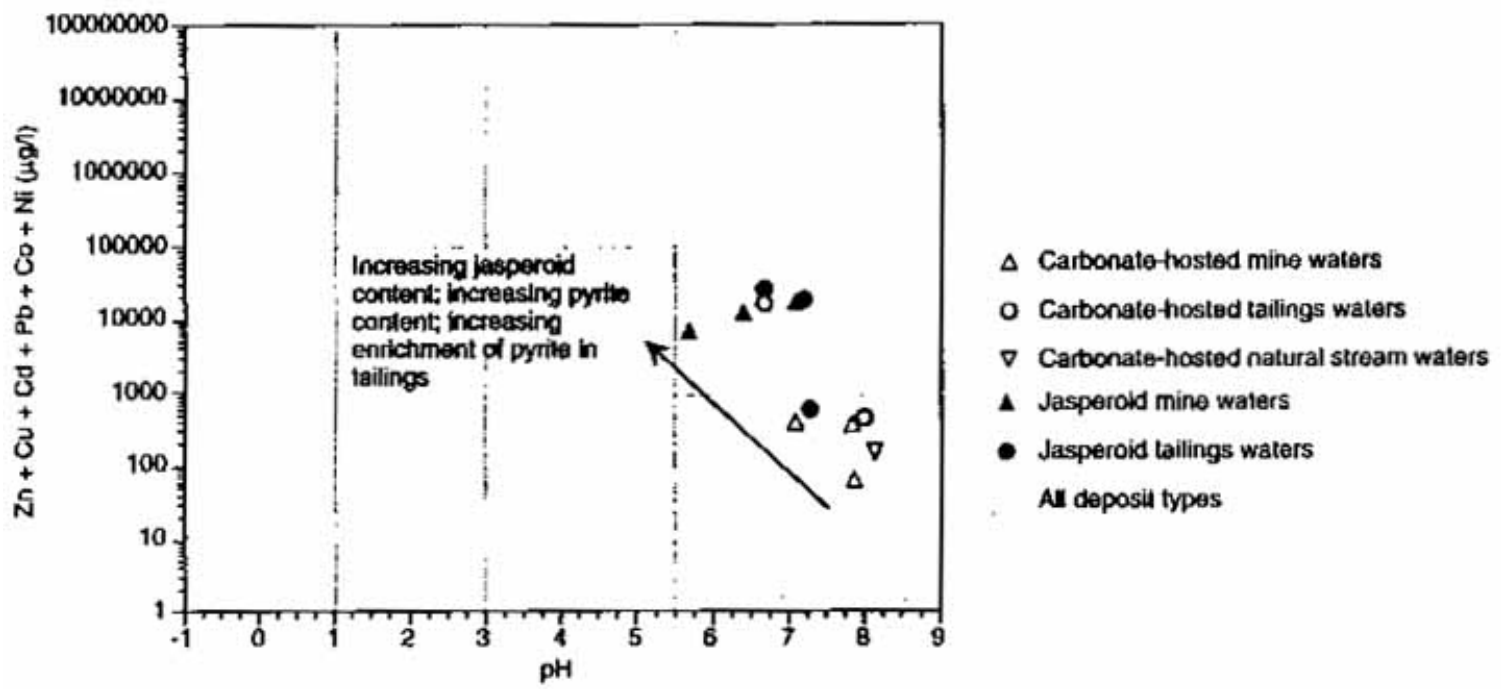

Figure 3. Ficklin plot showing some compositions of mine waters, tailing waters, and a natural water draining carbonate-hosted and jasperoid-rich MVT deposits. The plot is used to compare the sum of dissolved base metals $(\mathrm{Zn}, \mathrm{Cu}, \mathrm{Cd}, \mathrm{Pb}, \mathrm{Co}$, and $\mathrm{Ni}$ ) to $\mathrm{pH}$ and illustrate how mine drainage chemistry can vary as a function of the mineral deposit type. Figure is from Plumlee and others (1999).

\section{Climatic Effects}

Climate is extremely critical in assessing the environmental concerns associated with this deposit type. Current climatic setting can be as varied as Sahara conditions in North African deposits to permafrost conditions at the Polaris mine (Leach and others, 1995). Many North American deposits occur in humid temperate, and dry temperate regimes (e.g., Bailey, 1996). Potential acid-mine drainage problems related to MVT deposits in relatively dry climate settings are much less than those of deposits in warm, wet climates. Acid-rain aggravates potential environmental problems in the mid-Atlantic and northeastern United States, especially the Appalachians. Small MVT deposits are present throughout the Appalachians in Cambrian to Mississippian carbonate rock sequences (for example, Shady Dolomite and Knox Dolomite). The Austinville-Ivanhoe, Va., deposit is a prime example of how climatic conditions and soil properties interact to increase potential environmental problems. For example, in Wythe County, Va., soil is moderately to very strongly acidic ( $\mathrm{pH} 5.6$ to $<4.5$ ) although as much as 30 percent of the surface may consist of dolomitic limestone outcrops; the soil has moderate permeability, medium to high erosion potential, and moderate water capacity. Much of the soil is deemed suitable for cultivated crops (legumes), hay, or pasture and much is prime farmland (corn, vegetables, small grain, and strawberries) (U.S. Department of Agriculture, 1992). Most of the area is in the drainage basin of the New River, which has water quality problems including excessive concentrations of trace metals such as zinc, copper, lead, iron, and locally acidification caused by mining activities (Virginia Water Control Board, 1990a,b). Prime farmlands of the valley and ridges within and adjacent to the Appalachian Mountains (near historic lead and zinc mines) may be affected by metal contamination attributable to past releases of lead and zinc into soil and ground water as a result of environmental conditions specific to the region.

In contrast to the Appalachian deposits, the Polaris deposit is in a region of permafrost with little opportunity for dispersion into the environment from surface or ground water. Likewise, deposits in arid regions such as Bou Grine in Tunisia, have little opportunity for metal mobility in water.

\section{Potential Environmental Concerns}

Mine sites. Most modern underground carbonate hosted zinc-lead mining operations return a significant amount of mine waste and mill tailings to underground workings as fill. In the case of the Polaris mine in the Canadian Arctic, waste slurries are used to fill mining voids in their modified room and long pillar galleries. Once frozen, waste supports the roof and long pillars are mined so that essentially the entire deposit is mined. In Upper Silesia, Poland, surface disposal of iron sulfide-mineral-rich-tailings presents a potentially serious environmental problem in the district. Surface mill tailings pose the major 
potential environmental concern associated with MVT deposits. Although modern processing facilities carefully monitor water draining from processing sites, some water, with elevated concentrations of lead, zinc, cadmium, arsenic, thallium, and a variety of trace elements characteristic of the ore deposit, may escape. Airborne dust from tailing ponds can potentially contribute ore particulates.

Smelter signatures. Studies of the effects of airborne smelter effluent in the Viburnum Trend of southeast Missouri by Bornstein and Bolter (1991) indicate that soil pH at distances of as much as $6.4 \mathrm{~km}$ from the smelter source and as deep as $15 \mathrm{~cm}$ are significantly reduced, ranging from 4.4 at $15 \mathrm{~cm}$ to 5.1 at $5 \mathrm{~cm}$ depths. At $9.6 \mathrm{~km}, \mathrm{pH}$ ranged from 6.8 to 7.0 . The sulfur content of the soil correlates with the pattern of $\mathrm{pH}$ depletion. Lead, zinc, copper, cadmium, cobalt and nickel contents of leaf litter and underlying soil decrease with distance from the point source and depth below surface. The extent of heavy metal enrichment was about half that of the area affected by sulfur enrichment suggesting that $\mathrm{SO}$ is the principal sulfur species. 2 Palmer and Kucera (1980) conducted a similar study for lead, by sampling both sycamore leaves and twigs and soil, around four smelter sites in southeast Missouri. Their results were very similar to those of Bornstein and Bolter (1991) and indicate that dominant wind directions and degree of lead enrichment are correlated.

\section{ACKNOWLEDGMENTS}

Special appreciation is extended to Don F. Sangster of the Geological Survey of Canada for many years of cooperation with authors of the original geoenvironmental studies concerning MVT deposits. Many data compilations on MVT deposits from Don were used in preparing the original geoenvironmental model and contribute to these short course notes. Contributions from New Jersey Zinc, Company to the study of the Austinville $\mathrm{Pb}$ district are also gratefully acknowledged.

\section{REFERENCES CITED}

Allingham, J.W., 1966, Aeromagnetic anomalies in the Bonne Terre area of the southeast Missouri Mining District:Mining Geophysics, v. 1, Society Exploration Geophysics, p. 36-53.

Anderson, G.M. and Macqueen, R.W., 1982, Ore deposit models-6. Mississippi Valley-type lead-zinc deposits: Geoscience Canada, v. 9, p. 107-117.

Ayuso, R.A., Foley, N.K., and Brown, C.E., 1987, Source of lead and mineralizing brines for Rossie-type $\mathrm{Pb}-\mathrm{Zn}$ veins in the Frontenac axis area, New York: Economic Geology, v. 82, p. 489-496.

Balogh, A.G., 1991, Lead-zinc sulfides in the Dunham Dolomite, northwestern Vermont: Burlington, Vermont, Implications for models of Mississippi Valley-type deposits: unpub. M.Sc. thesis, The University of Vermont, $101 \mathrm{p}$.

Boast, A.M., Coleman, M. L., and Halls, C., 1981, Textural and stable isotopic evidence for the genesis of the Tynagh base metal deposit, Ireland: Economic Geology, v. 76, p. 27-55.

Bailey, R.G., 1996, Ecosystem Geography: Springer, New York, 241 p.

Blacksburg, Virginia Polytechnic Institute and State University, Ph.D. dissertation, 204 p.

Berger, B.R., 2000, Classification of mineral deposits, in Seal, R.R., II, and Foley, N.K., eds., Geoenvironmental Models of Mineral Deposits: U.S Geological Survey Open-File Report 02-195, p.

Briskey, J.A., 1986a, Descriptive model of southeast Missouri Pb-Zn, in Cox, D.P., and Singer, D.A., eds., Mineral deposit models: U.S. Geological Survey Bulletin 1693, p. 220-221.

1986b, Descriptive model of Appalachian Zn, in Cox, D.P., and Singer, D.A., eds., Mineral deposit models: U.S. Geological Survey Bulletin 1693, p. 222-223.

Bornstein, R.E. and Bolter, E., 1991, Long-term effects of lead smelting in soils, in Beck, B.D., ed., Trace substances in environmental health XXV, Gradient Corporation, Cambridge, Mass., United-States: Trace Substances in Environmental Health, v. 25, p. 71-83.

Brown, J.S., 1967, Genesis of stratiform lead-zinc-barite-fluorite deposits: Monograph 3, Economic Geology Publishing Company, Lancaster, Pennsylvania, 443 p.

Cordell, L., 1979, Gravity and aeromagnetic anomalies over basement structure in the Rolla quadrangle and the southeast Missouri lead district: Economic Geology, v. 74, p. 1383-1394.

Cordell, Lindrith, and Knepper, D.H., 1987, Aeromagnetic images: fresh insight to the buried basement, Rolla quadrangle, southeast Missouri: Geophysics, v. 52, no. 2, p. 218-213.

Cox, D.P., and Singer, D.A., 1986, Mineral deposit models: U.S. Geological Survey Bulletin 1693, 379 p. 
Davenport, P.H., Hornbrook, E.H.W., and Butler, A.J., 1975, Regional lake sediment geochemical survey for zinc mineralization in western Newfoundland: Developments in Economic Geology, no. 1 (Geochemical exploration 1974), p. 555-578.

du Bray, E.A., ed., 1995, Preliminary compilation of descriptive geoenvironmental mineral deposit models: U.S. Geological Survey Open-File Report 95-831, 272 p.

Dudka, S., Piotrowska, A, and Witek, T., 1995, Trace metal contamination of soils and crop plants by the mining and smelters in Upper Silesia, Southern Poland: Journal of Exploration Geochemistry, v. 52, p. 237-250.

Foley, N. K., 1990, The Lion Hill Zn-Pb-Cu deposit, Brandon, Vermont: Source of lead and fluid systematics, in Slack, J.F., ed., Summary results of the Glens Falls CUSMAP project, New York, Vermont, and New Hampshire: U.S. Geological Survey Bulletin 1887-L, 9 p.

Foley, N.K., and Craig, J.R., 1989, Mineralogy and geochemistry of the lead-zinc ores of the AustinvilleIvanhoe district, Wythe County, Virginia, in Evans, N.H., ed., Contributions to Virginia Geology - VI: Virginia Division of Mineral Resources, Publication 88, p. 23-40.

Foley, N.K., Sinha, A.K., and Craig, J.R., 1981, Isotopic composition of lead in the Austinville-Ivanhoe $\mathrm{Pb}-\mathrm{Zn}$ district, Virginia: Economic Geology, v. 76, p. 2012-2017.

Grundmann, Jr., W.H., 1977, Geology of the Viburnum No. 27 Mine, Viburnum Trend, Southeast Missouri: Economic Geology, v. 72, p. 349-364.

Guinness, E.A., Arvidson, R.E., Leff, C.E., Edwards, M.H., Bindschadler, D.L., 1983, Digital image processing applied to analysis of geophysical and geochemical data for southern Missouri: Economic Geology, v. 78, p. 654-663

Hagni, R.D., 1983, Minor elements in Mississippi Valley-type ore deposits, in Shanks, W.C., ed., Cameron Volume on Unconventional Mineral Deposits, Society of Economic Geology and Society of Mining Engineers, AIME, New York, p. 44-88.

Hammarstrom, J.M., Kotlyar, B.B., Theodore, T.G., Elliott, J.E., John, D.A., Doebrich, J.L., Nash, J.T., Carlson, R.R., Lee, G.K.., Livo, K.E., and Klein, D.P., 1995a, Cu, Au, and Zn-Pb skarn deposits, in du Bray, E.A., ed., 1995, Preliminary compilation of descriptive geoenvironmental mineral deposit models: U.S. Geological Survey Open-File Report 95-831, p. 90-111.

Hammarstrom, J.M., Elliott, J.E , Kotlyar, B.B., Theodore, T.G., Nash, J.T., John, D.A., Hoover, D.B., and Knepper, D.H., Jr., 1995b, Sn and (or) W skarn and replacement deposits, in du Bray, E.A., ed., 1995, Preliminary compilation of descriptive geoenvironmental mineral deposit models: $\underline{\text { U.S. Geological }}$ Survey Open-File Report 95-831, p. 54-61.

Hammarstrom, J.M., Theodore, T.G., Kotlyar, B.B., Doebrich, J.L., Elliott, J.E., Nash, J.T., John, D.A., and Livo, K.E., 1995c, Fe skarn deposits, in du Bray, E.A., ed., 1995, Preliminary compilation of descriptive geoenvironmental mineral deposit models: U.S. Geological Survey Open-File Report 95$\underline{831}$, p. $112-120$.

Hallof, P.G., 1966, The use of resistivity results to outline sedimentary rock types in Ireland: Mining Geophysics, v. 2, Society of Exploration Geophysics, p. 18-27.

Heyl, A.V., Agnew, A.F., Lyons, E.J. and Behre, C.H., 1959, The geology of the Upper Mississippi Valley zinc-lead district: U.S. Geological Survey Professional Paper 309, 310 p.

Heyl, A.V., Delevaux, M.H., Zartman, R.E., and Brock, M.R., 1966, Isotopic study of galenas from the Upper Mississippi Valley, the Illinois-Kentucky, and some Appalachian Valley mineral districts: Economic Geology, v. 61, p. 933-961.

Hitzman, M.W., O'Connor, P.O., Shearley, E., Schaffalitzky, C., Beaty, D.W., Allan, J.R., and Thompson, T., 1992, Discovery and geology of the Lisheen $\mathrm{Zn}-\mathrm{Pb}-\mathrm{Ag}$ prospect, Rathdowney Trend, Ireland, in Bowden, A., Earls, G., O'Connor, P.G., and Pyne, J.F., The Irish Minerals Industry 1980-1990: Irish Association of Economic Geology, Dublin, Ireland, p. 227-246.

Hitzman, M.W., and Large, D., 1986, A review and classification of the Irish carbonate-hosted base metal deposits, in Andrew, C.J., Crowe, R.W.A., Finlay, S., Pennell, W.M., and Pyne, J.F., eds., Geology and genesis of mineral deposits in Ireland: Dublin, Irish Association for Economic Geology, p. 217238.

Kesler, S.E., and van der Pluijm, B.A., 1990, Timing of Mississippi Valley-type mineralization: Relation to Appalachian orogenic events: Geology, v. 18, p. 1115-1118.

Kisvarsanyi, G., Grant, S.K., Pratt, W.P. and Koenig, J.W., eds., 1983, Proceedings of International Conference on Mississippi Valley Type Lead-Zinc Deposits: Rolla, University of Missouri, 603 p. 
Kyle, J.R., 1981, Geology of the Pine Point lead-zinc district, in Wolf, K.H., ed., Handbook of stratabound and stratiform ore deposits: Elsevier Publishing Company, New York, v. 9, p. 643-741.

Lavery, N.G., Leach, D.L., and Saunders, J.A., 1994, Lithogeochemical investigations applied to exploration for sediment-hosted $\mathrm{Zn}-\mathrm{Pb}$ ore deposits, in Fontebote, L. and Boni, M., eds., Sediment Hosted Zn-Pb Ores, Springer-Verlag, p. 393-428. 243

Leach, D.L., 1994, Genesis of the Ozark Mississippi Valley-type metallogenic province, in Fontebote, L. and Boni, M., eds., Sediment Hosted Zn-Pb Ores, Springer-Verlag, p.104-138.

Leach, D.L. and Sangster, D.F., 1993, Mississippi Valley-type lead-zinc deposits, in Kirkham, R.V., Sinclair, W.D., Thorp, R.I., and Duke, J.M., eds., Mineral Deposit Modeling, Geological Association of Canada Special Paper 40, p. 289-314.

Leach, D.L., J.B., Viets, N.K. Foley, and D.P. Klein, 1995, Misisisippi Valley-type Pb-Zn deposits, in du Bray, E.A., ed., Preliminary compilation of descriptive geoenvironmental mineral deposit models: $\underline{\text { U.S. }}$. Geological Survey Open-File Report 95-831, $272 \mathrm{p}$.

Mavrogenes, J.A., Hagni, R.D. and Dingess, P.R., 1992, Mineralogy, paragenesis, and mineral zoning of the West Fork mine, Viburnum Trend, Southeast Missouri: Economic Geology, v. 87, p. 113-124.

Missouri Department of Natural Resources, 1991, Census of Missouri Public Water Systems, Missouri Department of Natural Resources, Division of Environmental Quality, $460 \mathrm{p}$.

Mosier, E.L., and Motooka, J.M., 1983, Induction coupled plasma--atomic emission spectrometry: Analysis of subsurface Cambrian carbonate rocks for major, minor, and trace elements, in Kisvarsanyi, G., Grant, S.K., Pratt, W.P., and Koenig, J.W., eds., International Conference on Mississippi Valley Type Lead-Zinc Deposits: Rolla, Missouri, University of Missouri-Rolla, p. 155-165.

Palmer, K.T. and Kucera, C.L., 1980, Lead contamination of sycamore and soil from lead mining and smelting operations in eastern Missouri: Journal of Environmental Quality, v. 9, p. 106-110.

Plumlee, G.S., 1999, The environmental geology of mineral deposits, in Plumlee, G.S., and Logsdon, M.J., eds., The Environmental Geochemistry of Mineral Deposits, Part A: Processes, Techniques, and Health Issues: Reviews in Economic Geology, v. 6A, p. 71-116.

Plumlee, G.S., Smith, K.S., Montour, M.R., Ficklin, W.H., and Mosier, E.L., 1999, Geologic controls on the composition of natural waters and mine waters draining diverse mineral-deposit types, in Filipek, L.H., and Plumlee, G.S., eds., The Environmental Geochemistry of Mineral Deposits, Part B: Case Studies and Research Topics: Reviews in Economic Geology, v. 6B, p. 373-432.

Plumlee, G.S., and Nash, J.T., 1995, Geoenvironmental models of mineral deposits - fundamentals and applications: U.S. Geological Survey Open-File Report 95-831, p. 1-9.

Proctor, P.D., Afzali, B., Collins, S., Panhorst, T., and Sinha, B., 1981, Lead additions to stream sediments, Southeast Missouri: [abst] Abstracts with Programs, Geological Society of America, v. 13, No. 5, p. 261.

Rogers, R.K. and Davis, J.H., 1977, Geology of the Buick Mine, Viburnum Trend, Southeast Missouri: Economic Geology, v. 72, p. 372-380.

Rytuba, J.J., 2002, Mercury geoenvironmental models, in Seal, R.R., II, and Foley, N.K., eds., Geoenvironmental Models of Mineral Deposits: U.S Geological Survey Open-File Report 02-195, p. 161-175.

Sangster, D.F., 1968, Some chemical features of lead-zinc deposits in carbonate rocks: Canada Geological Survey Paper 68-39, $17 \mathrm{p}$.

1990, Mississippi Valley-type and sedex deposits: a comparative examination: Transactions of the Institution of Mining and Metallurgy, Section B, v. 99, p. B21-B42.

Sangster, D.and Leach, D.L., 1995, Evidence for a genetic link between SEDEX and MVT deposits, in Leach, D.L. and Goldhaber, M.B., eds., Extended Abstracts, International Field Conference on Carbonate-hosted Lead-Zinc deposits, St. Louis Missouri, June 1-4, p. 260-263.

Smith, B.J. and Schumacher, J.G., 1991, Hydrochemical and sediment data for the Old Lead Belt, southeastern Missouri, 1988-89: U.S. Geological Survey Open File Report 91-0211, 98 p. Schrijver, K., Marcoux, E., Beadoin, G., and Calvez, J.Y., 1988, Pb-Zn occurrences and their Pb-isotopic signatures bearing on metallogeny and mineral exploration--Paleozoic sedimentary rocks, northern Appalachians, Quebec: Canadian Journal of Earth Sciences, v. 25, p. 1777- 1790.

Snyder, F.G., and Gerdemann, P.E., 1968, Geology of the southeast Missouri lead district, in Ridge, J.D., ed., Ore deposits of the United States, 1933-1967 (Graton-Sales vol.): New York, American Institute of Mining, Metallurgy, and Petroleum Engineers, Inc., p. 326-358. 
Sumner, J.S., 1976, Principles of induced polarization for geophysical exploration: Developments in Economic Geology 5, New York, Elsevier Scientific Publishing Co., 165 p.

Sutley, S., Gustkiewicz, M., Mayer, W., and Leach, D., 1999, Mineralogy and chemistry of oxidized ores from the Upper Silesia Mississippi Valley-type zinc-lead deposits, Poland: U.S. Geological Survey Open-file report 99-394, $36 \mathrm{p}$.

Sverjensky, D.A., 1986, Genesis of Mississippi Valley-type lead-zinc deposits: Annual Review of Earth and Planetary Sciences, v. 14, p. 177-199.

Sweeney, P.H., Harrison, E.D. and Bradley, M., 1977, Geology of the Magmont Mine, Viburnum Trend, Southeast Missouri: Economic Geology, v. 72, p. 365-371.

Tuttle, M., Wanty, R.B., and Berger, B.R., 2002, Environmental behavior of two molybdenum porphyry systems, in Seal, R.R., II, and Foley, N.K., eds., Geoenvironmental Models of Mineral Deposits: U.S Geological Survey Open-File Report 02-195, p. 65-86.

United States Department of Agriculture, 1992, Soil Survey of Wythe County, Virginia: Soil Conservation Service in cooperation with Virginia Polytechnic Institute and State University, $201 \mathrm{p}$.

Viets, J.G., Leach, D.L., Lichte, F.E., Hopkins, R.T., Gent, C.A., and Powell, J.W., 1996, Paragenetic and minor and trace-element studies of Mississippi Valley-type ore deposits of the Cracow-Silesia district, southern Poland: Prace Geologiczne (Polish Geological Institute Quarterly).

Virginia Water Control Board, 1990a, Virginia water quality assessment, 1990: Richmond, Virginia Water Control Board Information Bulletin 579, v. 1, variously paginated. 1990b, Virginia water quality assessment, 1990: Richmond, Virginia Water Control Board Information Bulletin 579, v. 2, variously paginated.

Whelan, J.F., Rye, R.O., Delorraine, W.F., and Ohmoto, H., 1990, Isotopic geochemistry of the midProterozoic evaporite basin, Balmat, New York: American Journal of Science, v. 270, p. 396-424. 


\title{
Chapter F
}

\section{A GEOENVIRONMENTAL LIFECYLE MODEL: THE AUSTINVILLE PLATFORM CARBONATE DEPOSIT, VIRGINIA}

\section{INTRODUCTION}

\author{
Nora Foley
}

Ore bodies of the Austinville platform carbonate deposit make up one of the few major base-metal sulfide districts situated in Cambrian age rocks in the eastern United States, and constitute the most recently active base-metal mine in the Appalachians between Tennessee and Pennsylvania. The Austinville-Ivanhoe district is located two kilometers north of the Wythe-Carroll county line in southwestern Virginia and extends northeastward for over 11 kilometers roughly paralleling the New River (Fig. 1). The highly mineralized sphalerite, galena, and pyrite-bearing bodies are crudely pencil-shaped with lenticular cross-sections and range from tens to hundreds of meters in length.

By the time the mine closed in the early 1980's, the deposit was the most continuously mined basemetal deposit in North America. Mining operations began in 1756 with the application of surface and shallow underground techniques. Over 21,000 tons of lead ore were extracted during a period of mining that lasted until the 1860's. Much of this lead was used for ammunition for soldiers in the U.S. Civil war. Iron was mined near Austinville from surficial goethite and limonite during the years ranging from 1800 to the early 1900's and this was used in $19^{\text {th }}$ century pig iron production. Mining of zinc from oxidized ores (mainly hemimorphite) was initiated during the post-Civil War years and lasted until 1902 when the New Jersey Zinc Company purchased the mine for its zinc oxide potential. During the next quarter century, the company developed reserves of sulfide ore and after the perfection of the flotation process in the 1920's, a separation plant was built and put into production. During 230 years, over 1,000,000 tons of zinc metal, and 200,000 tons of lead metal were extracted from more than 30,000,000 tons of ore mined at Austinville. In more recent years, 500,000 tons of ore averaging 3 percent zinc and 0.4 percent lead mined each year using modified open stope methods (Weinberg, 1980). The residual dolomite gangue was crushed and sold as agricultural dolomitic limestone. The lead and zinc mine ceased operation in December 1981 and was allowed to flood. In the early 1990's, a limestone quarrying operation purchased the property and produces and markets crushed limestone for the agricultural market.

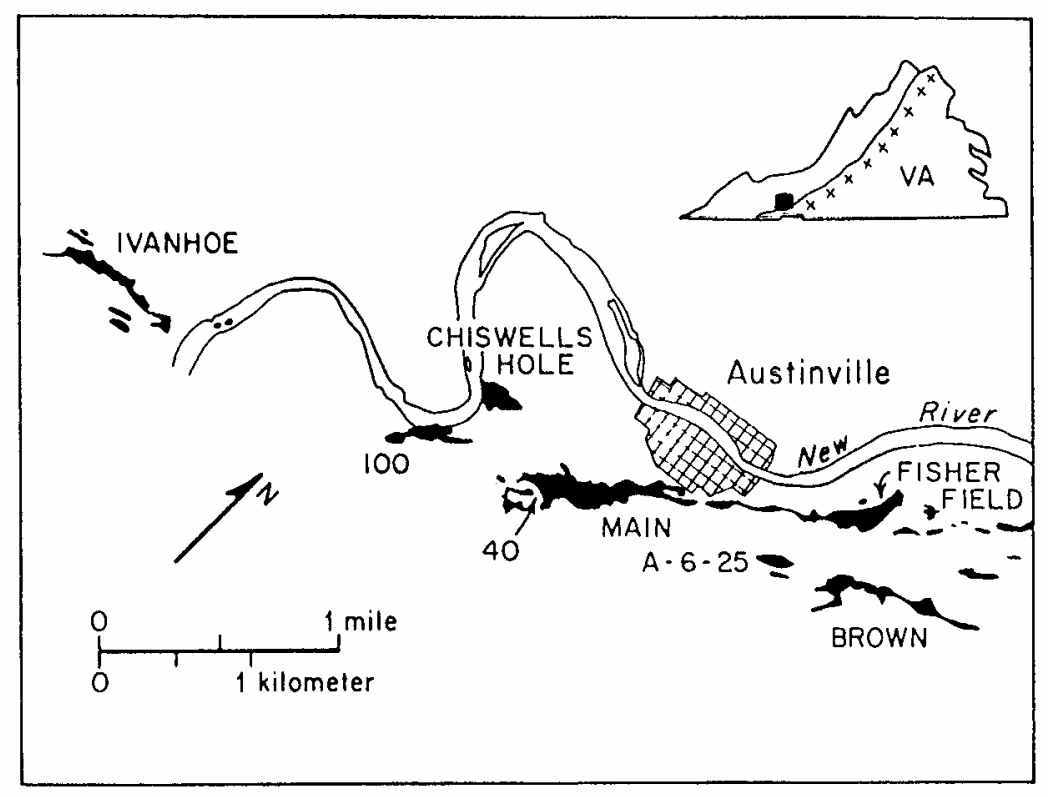

Figure 1. Locations of ore bodies that comprise the Austinville-Ivanhoe district, VA. 


\section{GEOLOGY OF THE DEPOSIT}

The Austinville-Ivanhoe is deposit situated near the southeast margin of the folded and faulted Valley and Ridge province (Fig. 2). The basal stratigraphic sequence consists of Precambrian basement rocks nonconformably overlain by the Chilhowie Group of Early Cambrian age. The uppermost formation in the Chilhowie Group, the Erwin Formation, is graditionally overlain by the Early to Middle Cambrian Shade Dolomite. The Early to Middle Cambrian Rome Formation overlies the Shady and is overlain by the Early to Middle Cambrian Elbrook Formation.

The Shady Formation, the ore host, is approximately 640 meters thick in the Austinville area, where is has three conformable members (Fig. 2). The Patterson member is a 300-meter thick sequence of ribbonlaminated limestones and dolomites. The Austinville member consists of a 300-meter thick sequence of stromatolitic and massive dolomite that has minor quartzose grainstones and black shaly carbonate tongues. The Ivanhoe member consists of a thick-bedded stromatolitic limestone with minor dolomite and shale and is up to 43 meter in thickness (Pfiel and Read, 1980). The mineralized zones lie within a 400-meter stratigraphic interval that straddles the contact between the Patterson and Austinville members of the Shady Formation. Pfiel and Read (1980) have suggested that the Austinville region represents a Cambrian platform to platform margin, foreslope, and slope facies transition.

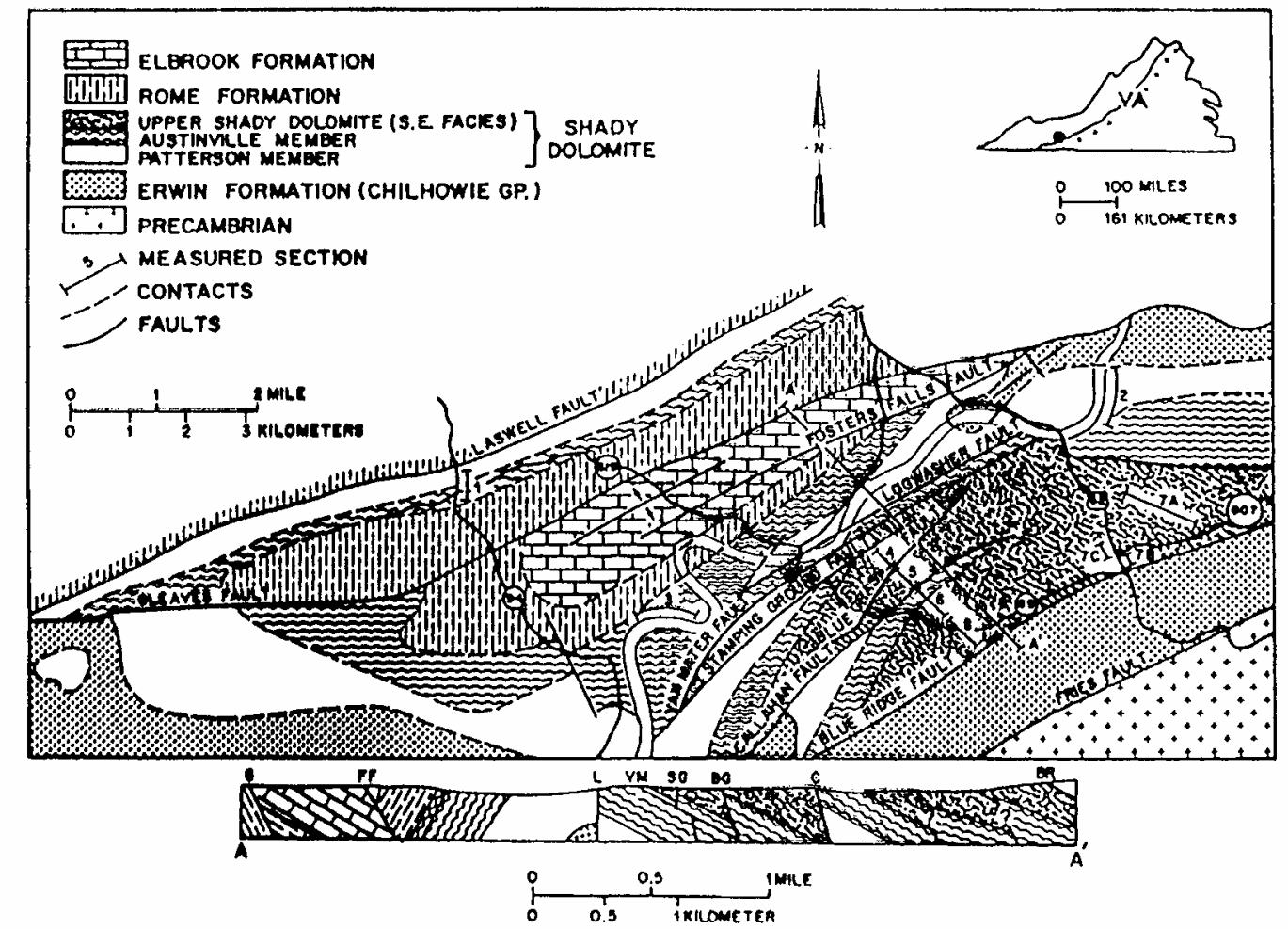

Figure 2. Geology of the Austinville-Ivanhoe region showing distribution of the Shady Dolomite, which contains the zinc and lead ore bodies

\section{ORE TEXTURES, MINERALOGY, AND PARAGENESIS}

The ore minerals occur within a 400-meter stratigraphic interval defined by marker beds in the Austinville and Patterson members of the Shady Formation. Ore bodies are separated from each other by faults and areas of sub-economic mineralization. The ore occurs as ribbon and disseminated replacements and as open-space fillings. Ribbon and disseminated replacements of dolomite by sphalerite, galena, and pyrite are usually accompanied by total recrystallization of the surrounding dolomite. The mineralized zones at Austinville contain sphalerite, galena, pyrite, and traces of marcasite, chalcopyrite, and arsenopyrite intergrown with at least three generations of dolomite gangue; minor amounts of quartz, fluorite, barite, gypsum, anhydrite, and calcite are also present. Alteration minerals occur in near-surface parts of the ore lenses and, locally, at depth near faults; these include smithsonite, cerussite, anglesite, ironoxides, hydrozincite, plumbo-aragonite, and hemimorphite. 
The open-space filling ore consists of symmetrically and asymmetrically banded coatings and rosettes on brecciated dolomite fragments (Fig.3). Polycrystalline aggregates of pyrite, admixed with minor marcasite and galena, encrust the dolomite fragments. Three generations of crustiform pyrite, sphalerite, and galena exist in the open-space filling ore. Earlier galena and sphalerite is partially replaced by dolomite. Low grade metamorphism and deformation resulted in minor recrystallization and microfaulting of all generations of ore minerals.
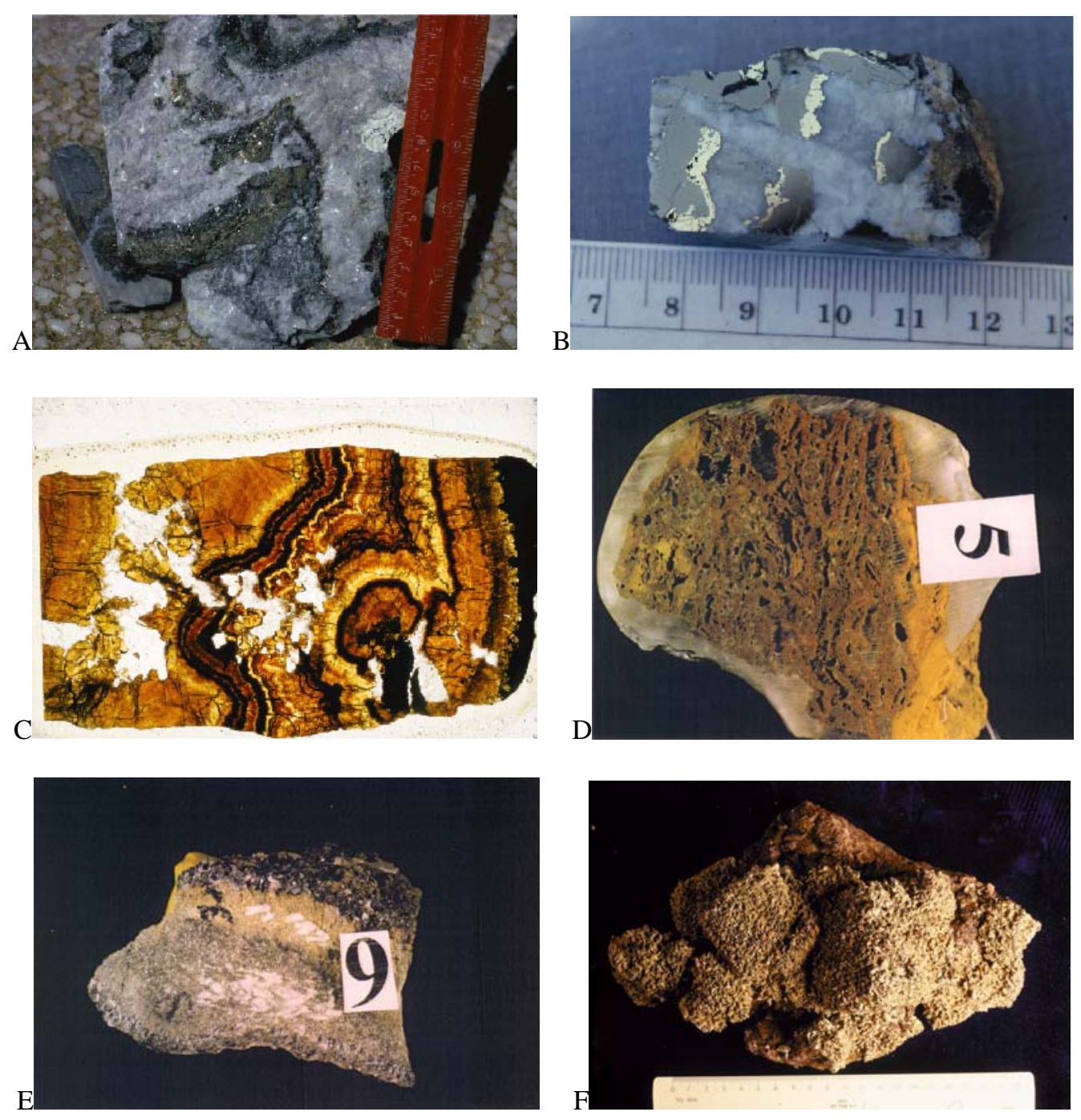

Figure 3. Primary and secondary ore textures typical of platform carbonate deposits: A. Carbonate breccia with ribbon ore fragments; B. Polished samples showing ribbon texture of dolomitic carbonate and sphalerite coated by pyrite, cut by later recrystallized dolomitic gangue; C. Polished thin section showing delicate growth banding in sphalerite (pale yellow to red-brown); D. Iron oxide minerals (primarily goethite) forming box-work patterns on quartzite waste rock; E. Layered altered iron-oxide, zinc and lead-bearing carbonate crusts; F. Massive iron oxide gossan that occurs as filling vugs within some ore bodies. 
Sphalerite is the most abundant of the primary ore minerals, followed by pyrite, galena, marcasite, and chalcopyrite. Pyrite and marcasite comprise about $5 \%$ of the total sulfide content, although they are very abundant locally, as in the Pyrite ore body. Pyrite was the first mineral to form and it is ubiquitous. It occurs as polycrystalline crustiform overgrowths 100 micrometers to 3 millimeters in thickness on dolomite fragments, as layers in banded sphalerite, and as cubes scattered in sphalerite, dolomite, and most of the late stage minerals. The pyrite overgrowths contain thin layers of dolomite and sphalerite, interstitial galena and, rarely laths of marcasite and arsenopyrite. Galena was the last sulfide mineral to form in major proportions. Galena crystals include fragments of pyrite, sphalerite, and dolomite. Silver contents of up to 0.7 ounces per ton of ore are reported (Foley and Craig, 1989) although the average is slightly less than 0.5 ounces of silver per ton of lead ore ( $\sim 17 \mathrm{ppm})$. During the later stages of mineralization, fluorite, quartz, barite, gypsum, and anhydrite were deposited locally in vugs and veins. Gypsum and anhydrite usually contain scattered cubes of pyrite and feather-like aggregates of marcasite. Barite contains pyrite cubes aligned along growth zones. Secondary carbonate minerals, smithsonite (Zn), hydrozincite (Zn carbonate hydroxide), cerussite $(\mathrm{Pb})$, and plumbo-aragonite, formed within the zone of oxidation of the sulfide ore under conditions of high carbonate activity. Metals contained in these mineral phases are available for release to the ground water during breakdown of the carbonate minerals. Where minerals oxidized to form metal-sulfate and metal-oxide minerals such as anglesite, which occurs within and rimming galena and hemimorphite (Zn silicate hydroxide) and goethite, which form coatings on fragments of zinc and ironbearing ore.

\section{SOIL AND SEDIMENT SIGNATURES}

Many MVT deposits are thought to have essentially no geochemical signature outside of the zone of wall rock alteration because of limited primary dispersion of ore related elements into the surrounding carbonate rocks (Lavery and others, 1994), except along structures that acted as fluid conduits. In the Austinville-Ivanhoe district background carbonate rocks typically contain about 20-ppm zinc and 9-ppm lead. However, extensive volumes of rock containing dolomite cement are widely peripheral to mineralized zones (for example throughout most of Wythe County, Virginia). Replacement dolomite and late calcite in these rocks have considerably elevated abundances of trace metals associated with of deposits, including as much as 9,300 ppm iron, $200 \mathrm{ppm}$ strontium, 1,500 ppm lead, 1,000 ppm manganese, and 10,000 ppm zinc (Barnaby, 1989).

Although MVT deposits are hosted by carbonate rocks, residual soil overlying some deposits can be acidic. The soils can have moderate to high permeability, medium to high erosion potential, and moderate to high water capacity. These factors can influence the mobility of metals into the environment. Soils in the immediate vicinity of the zinc mines and smelter (now a state park) at Austinville had elevated $\mathrm{Pb}$ and zinc contents which related directly to the mining and smelter processes which required removal and regrading of the site. In Wythe County, Va., soil is moderately to very strongly acidic ( $\mathrm{pH} 5.6$ to $<4.5$ ) although as much as 30 percent of the surface may consist of dolomitic limestone outcrops; the soil has moderate permeability, medium to high erosion potential, and moderate water capacity. Much of the soil is deemed suitable for cultivated crops (legumes), hay, or pasture and much is prime farmland (corn, vegetables, small grain, and strawberries) (U.S. Department of Agriculture, 1992). No soils containing elevated lead or zinc were found in farm fields during preliminary regional sampling. In contrast, bed sediments of the New River (Fig. 1) do contain elevated Zn and Cd.

\section{DRAINAGE SIGNATURES}

Metal mobility away from platform-carbonate deposits typically is limited by the abundance of carbonate rock associated with these deposits; carbonate rock consumes acid mine drainage and inhibits aqueous metal mobility. In southwestern Virginia, acidic rain from the Northeast affect surface conditions in the region. The presence of $\mathrm{Pb}$-sulfate in some of the ore at Austinville, indicates that some $\mathrm{Pb}$ is sequestered in an insoluble sulfate form, however, $\mathrm{Pb}$ contained within cerussite and other carbonate minerals is available to groundwater and soils. Near-neutral waters having elevated concentrations of dissolved $\mathrm{Zn}$ (as high as $100 \mathrm{mg} / \mathrm{l}$ ) and $\mathrm{Pb}$ and $\mathrm{Cd}$ have been reported in mine workings with high iron sulfide contents (Plumlee and others, 1995). Near-neutral zinc-bearing river waters also occur near Austinville. In this case, others factors besides iron sulfide contents may control zinc contents of mine drainage waters because the deposits are low in pyrite and marcasite. 


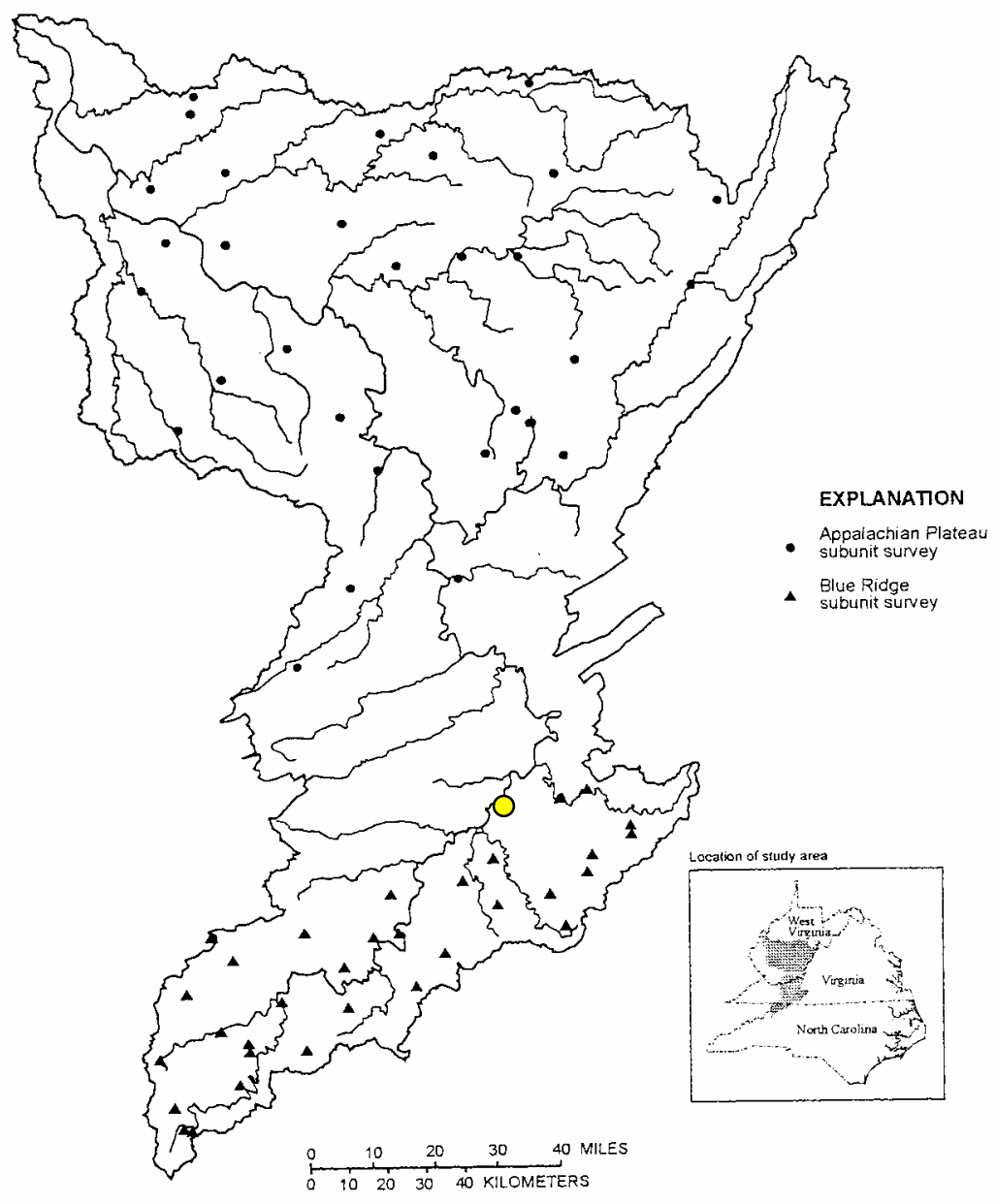

Figure 4. The outline of the Kanawha-New River Basin showing the location of Austinville mines.

The Austinville mine is contained within the Kanawha-New River basin (Fig. 4). The rivers of the catchment drain across three physiographic provinces: the Blue Ridge, Valley and Ridge and, finally, the Appalachian plateaus. The New River begins in North Carolina at the confluence of the North and South Forks and flows generally north for 250 miles to Gauley Bridge, West Virginia where it joins with the Gauley River to form the Kanawha River. Upriver from the Austinville mine site, the New River traverses crystalline rocks of the Blue Ridge Province and carbonate rocks of the Valley and Ridge Province. Groundwater occurs primarily in fractures in the sedimentary and crystalline rocks of the basin and in the pore spaces of unconsolidated sediments and regolith. Elevated concentrations of cadmiun, zinc, nickel, mercury and selenium were found in bed sediments and fish tissues at some sites downriver from the mines, however, coal mining activities in the Appalachian plateau may contribute considerable metals to the groundwater and bed sediments (Paybins and others, 2000). Near Austinville, zinc, copper, lead, iron occurs at only slightly elevated levels in the near-neutral river waters (Fig. 5). 


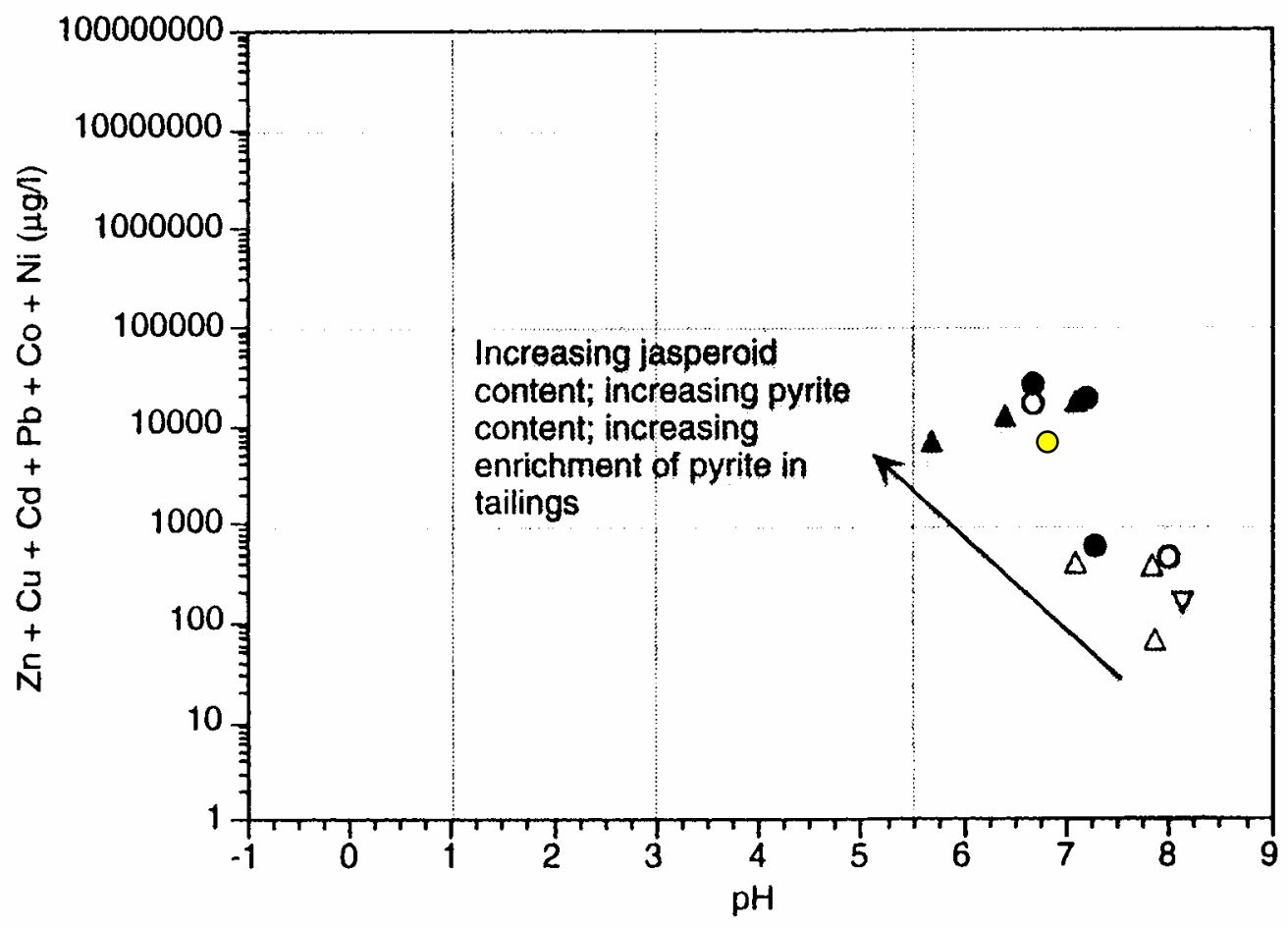

Figure 5. Ficklin plot for platform carbonate deposits showing data for Austinville, compared to data for other platform carbonate deposits.

\section{CLIMATIC EFFECTS}

Climate is extremely critical in assessing the environmental concerns associated with the platform carbonate deposit type. Current climatic setting can be as varied as Sahara conditions in North African deposits to permafrost conditions at the Polaris mine (Leach and others, 1995). Many North American deposits occur in humid temperate, and dry temperate regimes (e.g., Bailey, 1983). Potential acid-mine drainage problems related to MVT deposits in relatively dry climate settings are much less than those of deposits in warm, wet climates. Acid-rain aggravates potential environmental problems in the mid-Atlantic and northeastern United States, especially the Appalachian region.

\section{POTENTIAL ENVIRONMENTAL CONCERNS}

Small MVT deposits are present throughout the Appalachians in Cambrian to Mississippian carbonate rock sequences (for example, Shady Dolomite and Knox Dolomite). The Austinville-Ivanhoe, Va., deposit is a prime example of how climatic conditions and soil properties may interact to increase the potential for local environmental problems. Most of the area is in the drainage basin of the New River, which has water quality problems including excessive concentrations of trace metals such as zinc, copper, lead, iron, and locally acidification caused by mining activities (Virginia Water Control Board, 1990a,b). Prime farmlands of the valley and ridges within and adjacent to the historic lead and zinc mines may have be locally affected by metal contamination attributable to past releases of lead and zinc into soil and ground water as a result of environmental conditions specific to the region. Currently, the closure of the mines and cleanup of area adjacent to the mines, smelter, and the development of workings related to limestone quarrying has mitigated any long-term consequences of the lead and zinc mining operations. The development of the limestone quarrying operation, which produces crushed limestone for the agricultural market, demonstrates an important facet of platform carbonate deposit models. Geoenvironmental models of this deposit type (any many others) should be expanded to consider the effects of mining industrial minerals in this geologic setting. 


\section{REFERENCES CITED}

Barnaby, R.J., 1989, Sedimentology and diagenesis of Lower to Middle Cambrian carbonate platform: Blacksburg, Virginia Polytechnic Institute and State University, Ph.D. dissertation, 204 p.

Brown, J.S., 1967, Genesis of stratiform lead-zinc-barite-fluorite deposits: Monograph 3, Economic Geology Publishing Company, Lancaster, Pennsylvania, 443 p.

Foley, N.K., and Craig, J.R., 1989, Mineralogy and geochemistry of the lead-zinc ores of the AustinvilleIvanhoe district, Wythe County, Virginia, in Evans, N.H., ed., Contributions to Virginia Geology - VI: Virginia Division of Mineral Resources, Publication 88, p. 23-40.

Foley, N.K., Sinha, A.K., and Craig, J.R., 1981, Isotopic composition of lead in the Austinville-Ivanhoe Pb-Zn district, Virginia: Economic Geology, v. 76, p. 2012-2017.

Lavery, N.G., Leach, D.L., and Saunders, J.A., 1994, Lithogeochemical investigations applied to exploration for sediment-hosted Zn-Pb ore deposits, in Fontebote, L. and Boni, M., eds., Sediment Hosted Zn-Pb Ores, Springer-Verlag, p. 393-428. 243

Leach, D.L., J.B., Viets, N.K. Foley, and D.P. Klein, 1995, Misisisippi Valley-type Pb-Zn deposits, in du Bray, E.A., ed., Preliminary compilation of descriptive geoenvironmental mineral deposit models: $\underline{\text { U.S. }}$ Geological Survey Open-File Report 95-831, 272 p.

Paybins, K.S., Messinger, T., Eychaner, J.H., Chambers, D.B., Kozar, M.D., 2000, Water Quality in the Kanawha-New River Basin, West Virginia, Virginia, North Carolina, 1996-98: U.S. Geological Survey Circular 1204, 32p.

Pheil, R.W., and Read, J.F., 1980, Cambrian carbonate platform margin facies, Shady Dolomite, southwestern Virginia, U.S.A., Journal Sed. Pet., v. 50, no.1, p.91-116.

Plumlee, G.S., Smith, K.S., Montour, M.R., Ficklin, W.H., and Mosier, E.L., 1999, Geologic controls on the composition of natural waters and mine waters draining diverse mineral-deposit types, in Filipek, L.H., and Plumlee, G.S., eds., The Environmental Geochemistry of Mineral Deposits, Part B: Case Studies and Research Topics: Reviews in Economic Geology, v. 6B, p. 373-432.

Plumlee, G.S., and Nash, J.T., 1995, Geoenvironmental models of mineral deposits - fundamentals and applications: U.S. Geological Survey Open-File Report 95-831, p. 1-9.

United States Department of Agriculture, 1992, Soil Survey of Wythe County, Virginia: Soil Conservation Service in cooperation with Virginia Polytechnic Institute and State University, 201 p.

Virginia Water Control Board, 1990a, Virginia water quality assessment, 1990: Richmond, Virginia Water Control Board Information Bulletin 579, v. 1, variously paginated. 1990b, Virginia water quality assessment, 1990: Richmond, Virginia Water Control Board Information Bulletin 579, v. 2, variously paginated.

Weinburg, E.L., 1971, Sulfide mineralization in southwestern Virginia, Austinville0-Ivanhoe mine, in Guidebook to Appalachian Tectonics and Sulfide Mineralization: Geological Society of America, p.723. 


\title{
Chapter G
}

\section{A GEOENVIRONMENTAL MINERAL DEPOSIT MODEL FOR THE NEW WORLD POLYMETALLIC REPLACEMENT/SKARN DEPOSIT}

\author{
Lisa Bithell Kirk and Allan R. Kirk
}

\begin{abstract}
INTRODUCTION
The historic New World mining district lies about 2.5 miles north of the town of Cooke City, Montana (about 3 miles east of the northeast corner of Yellowstone National Park). Minable reserves of $\mathrm{Au}-\mathrm{Cu}-\mathrm{Ag}$ mineralization in the New World district are contained in three, carbonate hosted (Cambrian Meagher Limestone), massive sulfideiron oxide replacement deposits (Como, McLaren, and Miller Creek deposits) adjacent to high-angle contacts with hydrothermally altered porphyritic stocks. Mineralization also occurs in a geologically complex deposit zone within and adjacent to a phreatic explosion-collapse breccia pipe (Homestake deposit). Deep exploration drilling also led to the discovery of a "porphyry-type" copper-gold mineralized shell in a hydrothermal intrusion breccia within the porphyry stock, at depth, lying adjacent to the breccia pipe. Mining of the Miller Creek and Homestake deposits (7.9 MM tons averaging 0.261 opt gold, $0.74 \%$ copper, and 1.05 opt silver, totalling 2 million ounces of gold) was proposed by Crown Butte Mines between 1989 and 1996, until the proposal was withdrawn after a federal buyout. The entire New World District was subsequently withdrawn from future mineral entry. As part of its agreement with Crown Butte Mines, the United States government paid \$22.5 million for closure of historic mining properties in the district. Efforts to control historic mining impacts through management of ARD in historic surface and underground mine facilities are ongoing, led by the USDA Forest Service Region 1 in consultation with a variety of other state and federal agencies and environmental interest groups.

The environmental hydrogeochemistry of the New World project was closely scrutinized during the mine permitting and NEPA review process and a significant body of hydrogeochemical data is available characterizing the mineralized portions of the deposits prior to mining operations. Historical mining operations also produced mixed lithologic wastes from different deposit types that have varied ARD and metal release potential.

Hydrogeochemical data characterizing these mined wastes and related existing water quality impacts are also available. The New World ore deposits therefore provide an excellent opportunity to apply a geoenvironmental mineral deposit model to a polymetallic replacement/skarn deposit.
\end{abstract}

\section{HYDROGEOCHEMICAL OVERVIEW OF THE NEW WORLD DEPOSIT GEOLOGY}

The New World mining district is located in the south-central part of the Beartooth uplift, a fault bounded block of Precambrian crystalline rocks. Paleozoic sandstone, siltstone, shale, limestone, and dolomite, with associated Tertiary intrusive and volcanic rocks, overlie the Precambrian basement at New World (Lovering, 1929; Elliott, 1979; Elliott, Kirk, and Johnson, 1992; Johnson and Meinert, 1994). Intermediate to felsic calc-calkaline rocks, including diorite, andesite, trachyandesite, dacite, quartz latite, and rhyolite, occur as shallow stocks, laccoliths, and numerous sills and dikes. The intrusions are spatially related to alteration, mineralization, and location of breccia pipes in the district. The plutons, shown from north to south in Figure 1, are the Scotch Bonnet Diorite Stock, the Fisher Mountain dacite porphyry intrusive complex, the Homestake dacite porphyry stock, and the Lulu Pass dacite porphyry laccolith. Breccia pipes include the Homestake breccia, the Henderson Mountain Stock, and the Alice E. Breccia.

The New World Au-Cu-Ag deposit is actually comprised of 5 separate deposits, including the Como, Fisher Mountain, McLaren, Miller Creek and Homestake deposits. The ore deposits are developed in skarns and replacement zones at sedimentary-rock contacts with four intrusive complexes and in breccia complexes where entrained blocks of limestone have been selectively mineralized. The principal ore mineral is native gold, which occurs as inclusions within pyrite and chalcopyrite and as particles along fractures and grain boundaries, with associated magnetite and specularite mineralization.

Skarn-replacement deposits are located adjacent to steep contacts of the Fisher Mountain and Homestake intrusive contacts, along sill and dike margins; at upper and lower contacts of the Cambrian Meagher Limestone; 
and along faults where these features served as conduits for mineralizing fluids. The skarn-replacement deposits wrap around the west margins of the intrusives, as shown in Figure 1, and include the McLaren, Como, and Fisher Mountain deposits. Another stratiform skarn and replacement deposit is located to the east of Miller Creek, in the

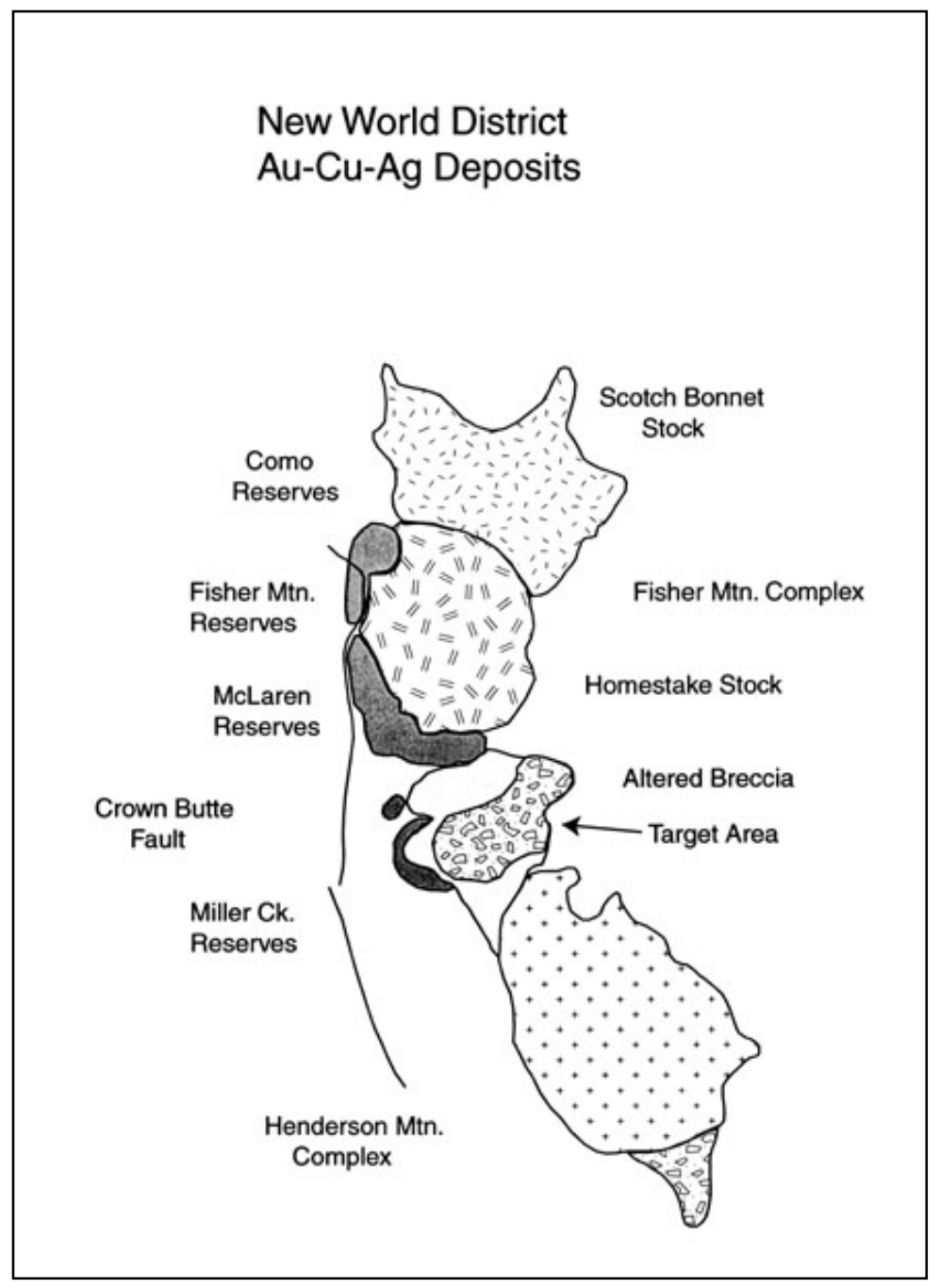

Figure 1. Geologic map of New World Ore deposits, showing intrusives and contact/replacement zones of mineralization (after Elliott et al, 1992)

Meagher formation to the west of Henderson Mountain as shown in Figure 1. Replacement mineralization also occurs in zone enriched in blocks of Paleozoic limestone entrained in the Homestake breccia.

\section{HYDROLOGY}

The New World district is located at an elevation that ranges from 7,380 feet to over 10,400 feet, sits at the headwaters of three watersheds; Daisy Creek, Fisher Creek, and Miller Creek. (Figure 2). Average annual precipitation exceeds 60 inches, and the site is snow covered much of the year. Groundwater recharge occurs primarily during seasonal snowmelt, when surface runoff peaks in all three drainages. Groundwater in the vicinity of Como basin is controlled by near vertical fractures, joints, and faults, with limited to moderate interconnectedness. 
Water flows into the abandoned Glengarry adit, where oxygen interacts with sulfide rich mineralization to produce ARD that is discharged into the headwaters of Fisher Creek.

Groundwater is also impacted by recharge through the mine wastes and mineralized rock at the historic McLaren pit, with subsequent discharge to Daisy Creek. The cold climate and strongly variable surface water flows exert important controls on surface and groundwater impacts at New World. The conceptual hydrogeochemical model for the New World Closure is summarized in Figure 3.

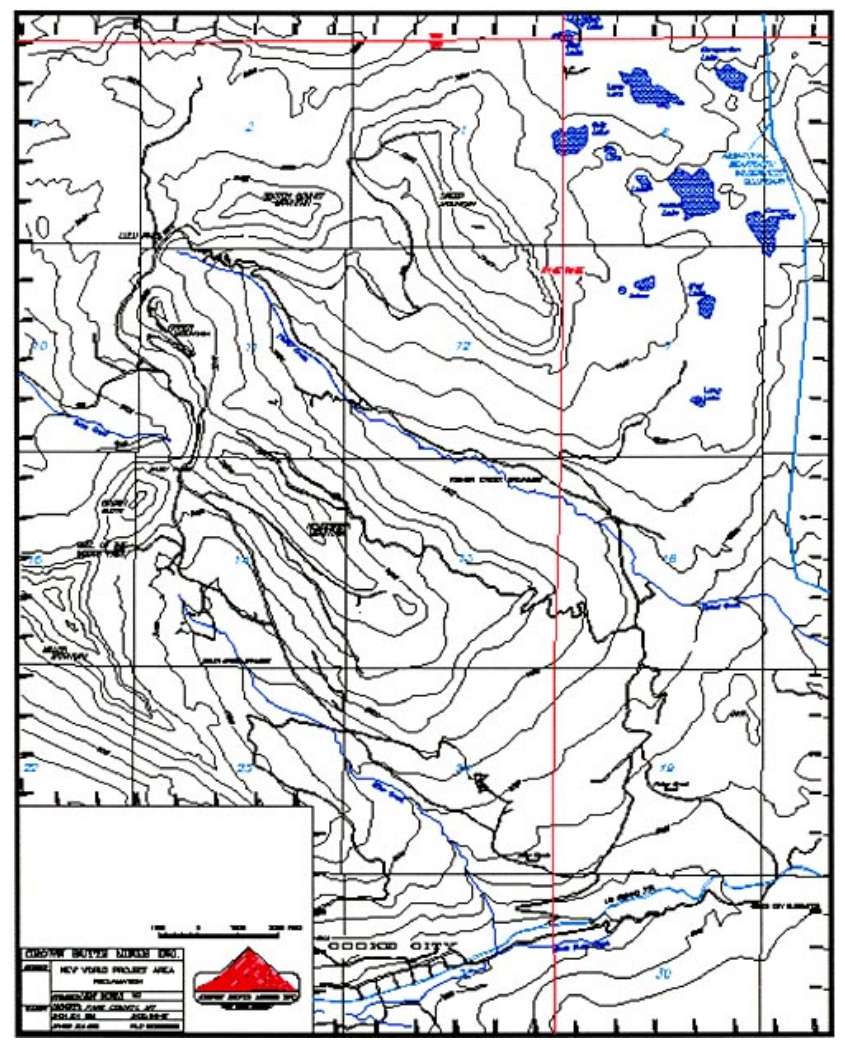

Figure 2. Map showing district location and surface water resources (Maxim, 1999).

\section{GEOCHEMISTRY}

Despite the fact that carbonate-hosted deposits as a group have some of the lowest probability for adverse environmental impact, the majority of rocks at New World are acid generating. The widespread and locally massive sulfide mineralization that is prevalent at New World produces acid generation potential throughout the district. Neutralization potential varies, however, with the result that some materials are more strongly acid generating than others. Sulfide mineralization in intrusive porphyry rocks and massive sulfide replacement deposits in limestones are strongly acid generating, but local portions of the limestone hosted replacement/skarn deposits are net neutralizing. Generally, the McLaren/Como/Fisher Mountain deposits are strongly acid generating, and historic ARD impacts are evident in both Daisy and Fisher Creeks. Water quality in the New World district is summarized using the USGS geoenvironmental models approach in Figure 4; virtually all analyses fall into the Cu-skarn category. The water quality measured in the Gold Dust adit, which is developed in Precambrian granodiorite and metasediments, and ends in the Homestake Breccia, is much different and falls into the pyrite-poor, carbonate hosted category. This portion of the ore deposit, although it does locally host some strong sulfide mineralization, also has significant acid neutralization potential. The metals that are associated with the New World deposit include Al, Fe, 
$\mathrm{Cu}, \mathrm{Pb}, \mathrm{Cd}$, and $\mathrm{Zn}$. The relative concentrations of each metal in receiving water vary between deposits in the district, as a function of flow and sediment load as well as the primary character of the ore in each deposit.

Natural deposits of ferricretes formed 8,800 years before present (Furniss and Hinman, 1998) occur at New World, indicating that acid rock drainage has occurred naturally in the district for thousands of years. Two springs at New World located upgradient of historic mine workings that are typical of background geoenvironmental conditions at New World were described by Runnells et al, 1992. The chemistry of these springs is shown in Figure $\underline{4}$ for comparison.

As is typical of carbonate hosted deposits, the metal ratios and $\mathrm{pH}$ of mine drainage attenuate fairly rapidly down gradient at New World. Dilution and mixing along gradient with bicarbonate rich, low-metal groundwater dramatically improves water quality in both Fisher Creek and Daisy Creek within a mile of the ARD impacts. From this standpoint, the carbonate-hosted character of the deposit serves to limit the geographic impact of ARD generated in the more heavily mineralized deposits.

\section{STYLES OF MINERALIZATION IN THE NEW WORLD DEPOSIT}

Three principal types of mineralization are recognized by Elliott et al, 1992. Each of these deposit types has a unique suite of mineralogic, alteration, and oxidation characteristics which must be incorporated into a meaningful environmental geochemistry analysis. Key factors include the distribution of pyrite and chalcopyrite, calcite, and calc-silicate mineralization. The three styles of mineralization are:

1) Stratiform retrograde skarn and replacement deposits hosted mostly by the Meagher formation (Como/Glengarry, McLaren, and Miller Creek deposits).

2) Replacement and vein deposits along high-angle faults (Fisher Mountain deposit).

3) Sulfide-and iron-oxide rich replacement of limestone blocks in diatreme and intrusion breccias of the Homestake breccia complex (Gold Dust adit/Homestake deposit).

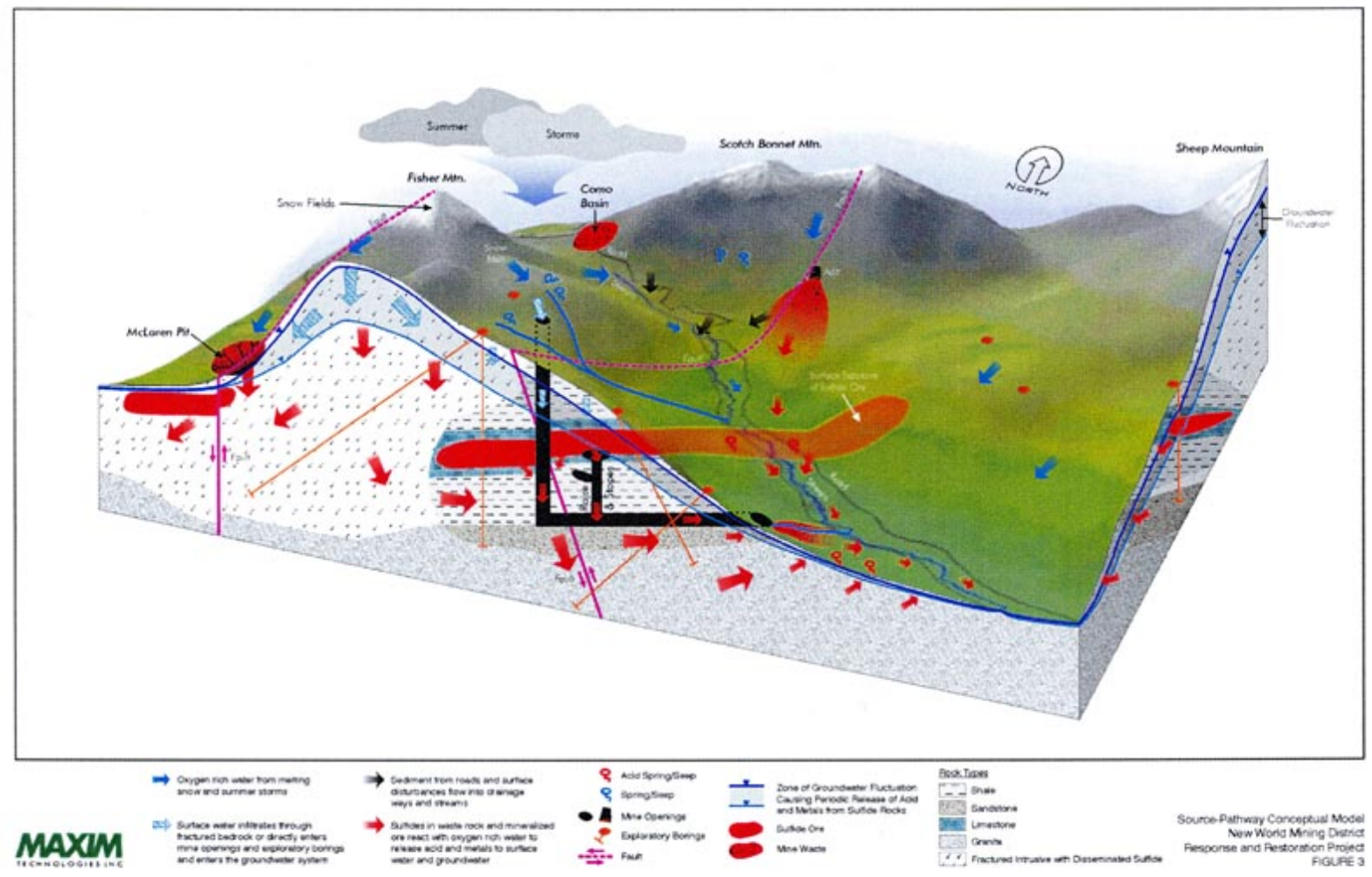

Figure 3. Source pathway conceptual model of New World district closure hydrogeochemistry 


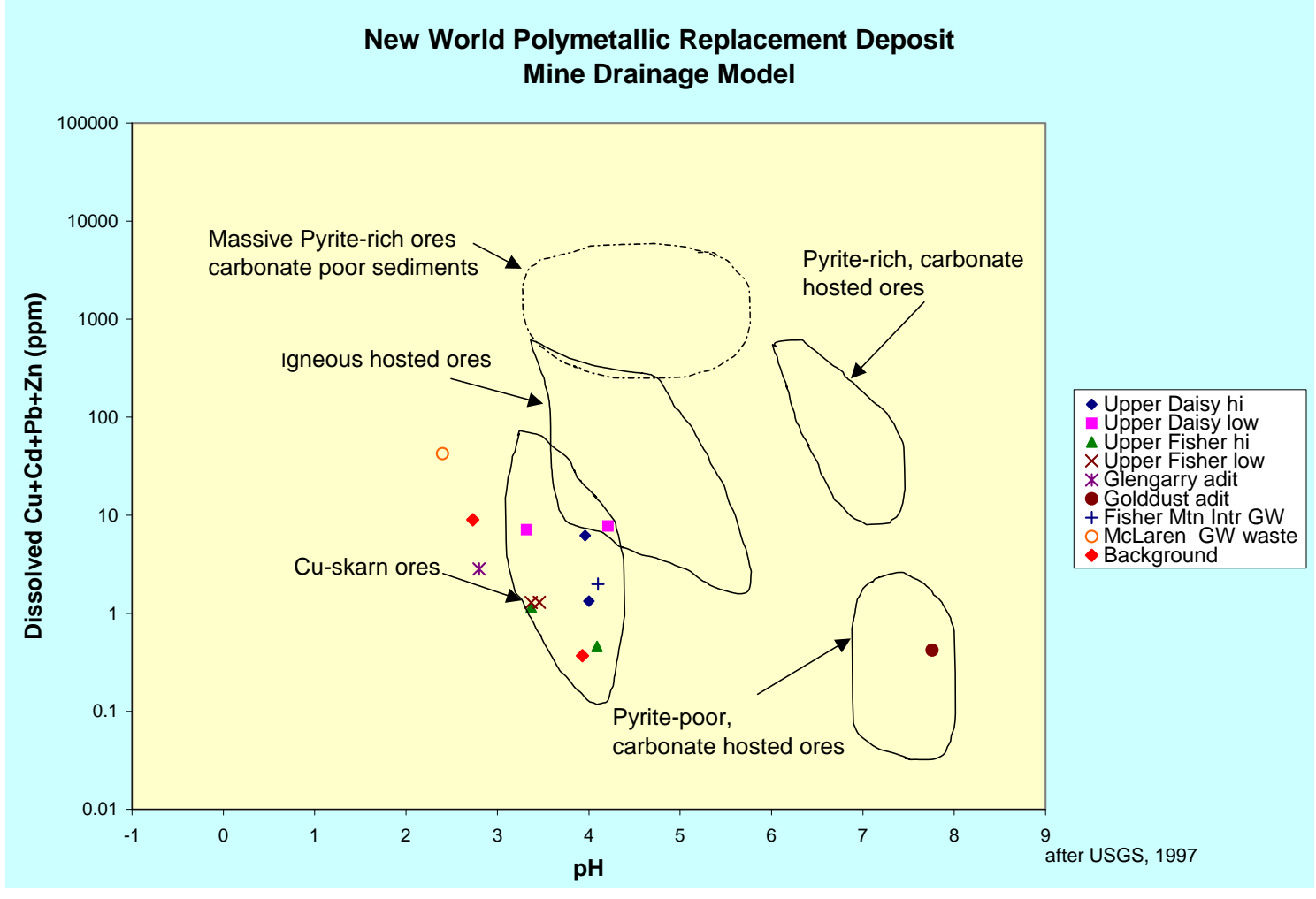

Figure 4. New World Polymetallic Replacement/Skarn deposit mine drainage model, based on USGS geoenvironmental model approach.

This case study focuses on the polymetallic replacement/skarn styles of mineralization, in the historically mined Como/Glengarry, Fisher Mountain, and McLaren ore deposits. Similar mineralization occurs in the Miller Creek Deposit, which was does not outcrop and was not mined historically at New World, and is therefore not considered further here. Sulfide-rich retrograde skarn and replacement deposits are hosted dominantly by the Cambrian Meagher limestone. Calc-silicate minerals that occur with both sulfide and iron oxide minerals indicate acidic and oxidizing hydrothermal fluids that were neutralized by reaction with the limestone host, thus forming the $\mathrm{Au}-\mathrm{Cu}-\mathrm{Ag}$ deposits. Minerals commonly occurring in these deposits include pyrite, magnetite, quartz, sericite, epidote, chlorite, biotite, muscovite, chalcopyrite, amphibole, clays, garnet and pyroxene.

In the Como/Glengarry Deposit, mineralization occurs where epidote-rich retrograde skarn and limestone replacement with massive pyrite and chalcopyrite were developed at the Meagher limestone- Fisher Mountain Intrusive contact . The geology of the Como Basin is dominated by the Fisher Mountain Intrusive Complex. Cambrian Park Shale, Meagher Limestone, and Wolsey Shale Formations are mineralized in the deposit.

Neutralization potential in rocks mined from this portion of the district is provided by calcite and calc-silicate mineralization in the Meagher limestone, and by feldspars and biotite in the Fisher Mountain Intrusive. Wastes produced from the Como portion of the ore deposit include Cambrian Meagher and Park shale lithologies, as well as Fisher Mountain Intrusive, which contain variable degrees of sulfide mineralization and show a large range in ARD potential, from -480 to 11 tons $\mathrm{CaCO}_{3} / \mathrm{ktons}$ rock.

The Glengarry adit, located at the headwaters of Fisher Creek, was driven 1,500 feet northwest under Como Basin. The adit intercepted tertiary intrusive rocks along the Glengarry fault, as well as blocks of mineralized Meagher limestone in contact with the Fisher Mountain Intrusive complex. The adit is connected to the surface near the center of the main Como ore body, so that the adit receives continual recharge. The geochemistry of 
groundwater in the Fisher Mountain Intrusive Complex and of water flowing from the Glengarry adit are shown with surface water data for Fisher Creek (under low and high flow conditions) in Figure 4. Waters are acidic, but show relatively low concentrations of metal relative to igneous and massive sulfide polymetallic ore deposits.

Both source and migration control options are being evaluated for management of the Glengarry adit drainage. In 2000, an underground de-watering and mapping program will be undertaken to evaluate options for reducing flow of water into the adit and for reducing the solute load contributed by sulfide oxidation reactions.

In the McLaren deposit, stratiform replacement mineralization in the Meagher formation was mined in an historic open-pit operation. McLaren mineralization consists chiefly of epidote-rich retrograde skarn, quartz-pyrite replacement bodies, and magnetite-rich replacement bodies. (Johnson and Meinert, 1994). Mine wastes that exist in the historic McLaren pit include Cambrian Wolsey Shale, Meagher Limestone, and Park Shale as well as Fisher Mountain intrusive and zones of replaced Cambrian Pilgrim limestone. These varied lithologies exhibit variable sulfide and metal content, with trimodal distribution of acid generation risk based on static test ABA data that range from +779 to -160 tons $\mathrm{CaCO}_{3} / \mathrm{kton}$. Wastes from this portion of the district are likely to range in acid generation potential, from slightly to strongly acid generating. The occurrence of strongly net neutralizing material is rare in this portion of the district.

Water quality data from groundwater monitored in McLaren pit mine wastes, as well as surface water data from upper Daisy Creek (immediately downgradient of the pit) under low and high flow conditions, are also presented in Figure 4. The Cu-skarn geoenvironmental signature dominates in these waters as well. The floor of the McLaren pit is rich in sulfide mineralization, so that acid generating waste removal may (paradoxically) expose bedrock with very high sulfide contents that is capable of further acid generation. Capping, waste removal, backfilling, and water management options are being considered for closure of the McLaren deposit. The smaller Fisher Mountain deposit, located between the Como and McLaren deposits, consists of quartz-pyrite replacement ore in the Pilgrim Limestone and sulfide-rich fracture fillings along the Crown Butte fault. Limited sampling data indicate that the waste from this deposit is acid generating.

\section{GEOENVIRONMENTAL MODELS IN MINE CLOSURE}

The New World deposit presents several challenges in mine closure, due to the sub-alpine setting; the geochemical variability of the mineralization and high ARD potential of mine wastes; the natural occurrence of near surface sulfide mineralization in the McLaren and Como pits; and the hydrologic complexity of groundwater recharge in the vicinity of the Glengarry adit. In any mine closure, a "big picture" understanding of closure goals, options, and limitations is needed to optimize environmental protection within economic constraints. Application of the geoenvironmental model at New World correctly identifies the Cu-skarn mineralized portions of the mining district as the primary goals for ARD management. Control of the McLaren pit and Glengarry adit point sources of ARD at New World will accomplish a significant portion of the possible improvement in water quality. Further, reference to the background water quality data plotted in Figure 4 indicates that the success of closure actions will be limited by the geoenvironmental nature of the unmined, naturally occurring mineralization throughout the New World district. Fortunately, the natural remediation offered by the carbonate-hosted deposit will serve to minimize any remaining ARD impacts in Fisher and Daisy Creeks.

\section{REFERENCESCITED}

Elliott, J.E., 1979, Geologic map of the southwest part of the Cooke City quadrangle, Montana and Wyoming: U.S. Geological Survey Miscellaneous Investigations Series Map I-1084, scale 1:24,000.

Elliot, J.E, Kirk, A.R. and Johnson, T.W., 1992, Field Guide Gold-Copper-Silver Deposits of the New World District, in Elliot, J.E. (ed), Guidebook for the Red Lodge-Beartooth Mountains-Stillwater area, Seventeenth annual field conference, Tobacco Root Geological Society, p. 1-19.

Furniss, G. and N.W. Hinman, 1998. Ferricrete provides record of natural acid drainage, New World District, Montana. Water Rock Interaction, Arehart and Hulston (eds). Rotterdam: Balkema, 1998, p. 973-976.

Johnson, T.W. and L.D. Meinert, 1994. Au-Cu-Ag Skarn and Replacement Mineralization in the McLaren Deposit, New World District, Park Country, Montana. Econ. Geology, Vol. 89, No. 5, August 1994, p. 969-993.

Lovering, T.S., 1929, The New World or Cooke City mining district, Park County, Montana: U.S. Geological Survey Bulletin 811, p. 1-87. 
Maxim Technologies, Inc., 1999. Final Overall Project Work Plan: New World Mining District Response and Restoration Project. A report prepared for USDA Forest Service, Region 1, November 1999.

Maxim Technologies, Inc., 2000. Technical Memorandum: Data Summary McLaren Pit, Como Basin, and Glengarry and Goldust Adit Areas, New World Mining District. A report prepared for USDA Forest Service Region 1, February 2000.

Runnells, D.D, T. A. Shepherd, and E.E. Angino, 1992. Metals In Water: Determining Natural Background Concentrations in Mineralized Areas. Environ. Sci. Technol., Vol. 26, No. 12, p. 2316-2323. 


\title{
Chapter H
}

\section{ENVIRONMENTAL GEOCHEMISTRY OF SKARN AND POLYMETALLIC CARBONATE-REPLACEMENT DEPOSIT MODELS}

\author{
Jane M. Hammarstrom \\ With contributions from Brad Van Gosen and Bob Eppinger
}

\section{INTRODUCTION}

Geoenvironmental models are compilations of geologic, geochemical, and hydrologic information that describe pre- and post-mining environmental signatures of mineral deposits. The environmental behavior of carbonate-hosted deposits varies according to deposit type. This discussion of the environmental geochemistry of carbonate-hosted sulfide deposits considers two major groups of deposits: (1) metallic ores deposited by lowtemperature, basinal brines in platform carbonate host rocks, and (2) metallic ores deposited by the reaction of higher temperature fluids with carbonate host rocks. In part I, Foley and others address low-temperature platformcarbonate deposits of the Mississippi Valley type. In part II, we discuss high-temperature skarn and polymetallic carbonate-replacement deposits. General environmental considerations and characteristics of the deposits are discussed in part I.

Skarn and polymetallic carbonate-replacement deposits form by reaction of hydrothermal fluids $\left(>>250{ }^{\circ} \mathrm{C}\right)$ generated in high-temperature igneous (e.g., porphyry) environments with carbonate-bearing country rocks. These fluids can be of low to high salinity and may contain $\mathrm{CO}_{2}$ and other gaseous components. In contrast, the platform-carbonate deposits described in part I form by the interaction of low to moderate temperature (generally $<200{ }^{\circ} \mathrm{C}$ ), high salinity (10-30 equivalent weight percent $\mathrm{NaCl}$ ) basinal brines or meteoric waters with carbonatebearing sequences. The resulting ore and gangue mineralogies of these two deposit types reflect the ability of the two distinct fluid types to leach metals from the original source rocks and transport them to the depositional sites.

This paper presents a summary and some refinements of previous geoenvironmental models for hightemperature, carbonate-hosted deposits (du Bray, 1995, and references therein).

\section{SKARN AND POLYMETALLIC CARBONATE-REPLACEMENT DEPOSITS}

Skarn and polymetallic carbonate-replacement deposits are related genetically to magmas that intrude into sedimentary rocks (fig. 1). The deposits form when magmatic-hydrothermal fluids expelled from cooling magmas react chemically with carbonate-rich sedimentary rocks. Skarn and polymetallic carbonate-replacement deposits are associated with many other types of magmatic-hydrothermal deposits in mineral districts. In fact, distinction between skarn and other deposit types is not always easy. In many districts, skarns form an intermediate "zone" of deposits between porphyry deposits in the center of mining districts and outer zones of polymetallic vein and replacement, and distal-disseminated, deposits.

Carbonate-hosted mineral deposits generally are less likely than other deposit types to generate acid mine drainage because of the availability of acid- neutralizing minerals, such as carbonates and reactive silicates, the coarse mineral grain size, and the high metal to sulfur ratios of many sulfide minerals in skarns (Kwong, 1993).

However, these deposits locally can include massive concentrations of sulfide minerals as well as potentially toxic elements that remain in solution at high $\mathrm{pH}$ (e.g., $\mathrm{Zn}, \mathrm{Mn}$ ) and therefore are difficult to remove in order to meet water-quality standards. We know of three cases where significant environmental problems associated with processed waste from carbonate-hosted mineral deposits led to U.S. Environmental Protection Agency (EPA) National Priority listing for site clean-up under the Superfund program. The Cleveland mill in Grant County, southwestern New Mexico (U.S. EPA, 2000a; Boulet and Larocque, 1997) processed ores from copper and zinc skarns. Mill tailings washed into a creek resulting in locally acidic surface waters ( $\mathrm{pH}$ as low as 2.2) and elevated dissolved-metal concentrations ( $\mathrm{As}, \mathrm{Pb}, \mathrm{Cd}, \mathrm{Zn}, \mathrm{Be}$ ). In western Colorado, a century of mining of polymetallic carbonate-replacement deposits in the Leadville and Gilman mining districts generated large volumes of mining wastes that impacted area soils and rivers. In the 1980s, ecological impacts and human health threats associated with mine waste led to Superfund site designations at California Gulch in the Leadville mining district, Colorado and at the Eagle mine in the historic Gilman mining district near Vail, Colorado (U.S. EPA 2000b, 2000c; Engineering Science, Inc., 1985). 


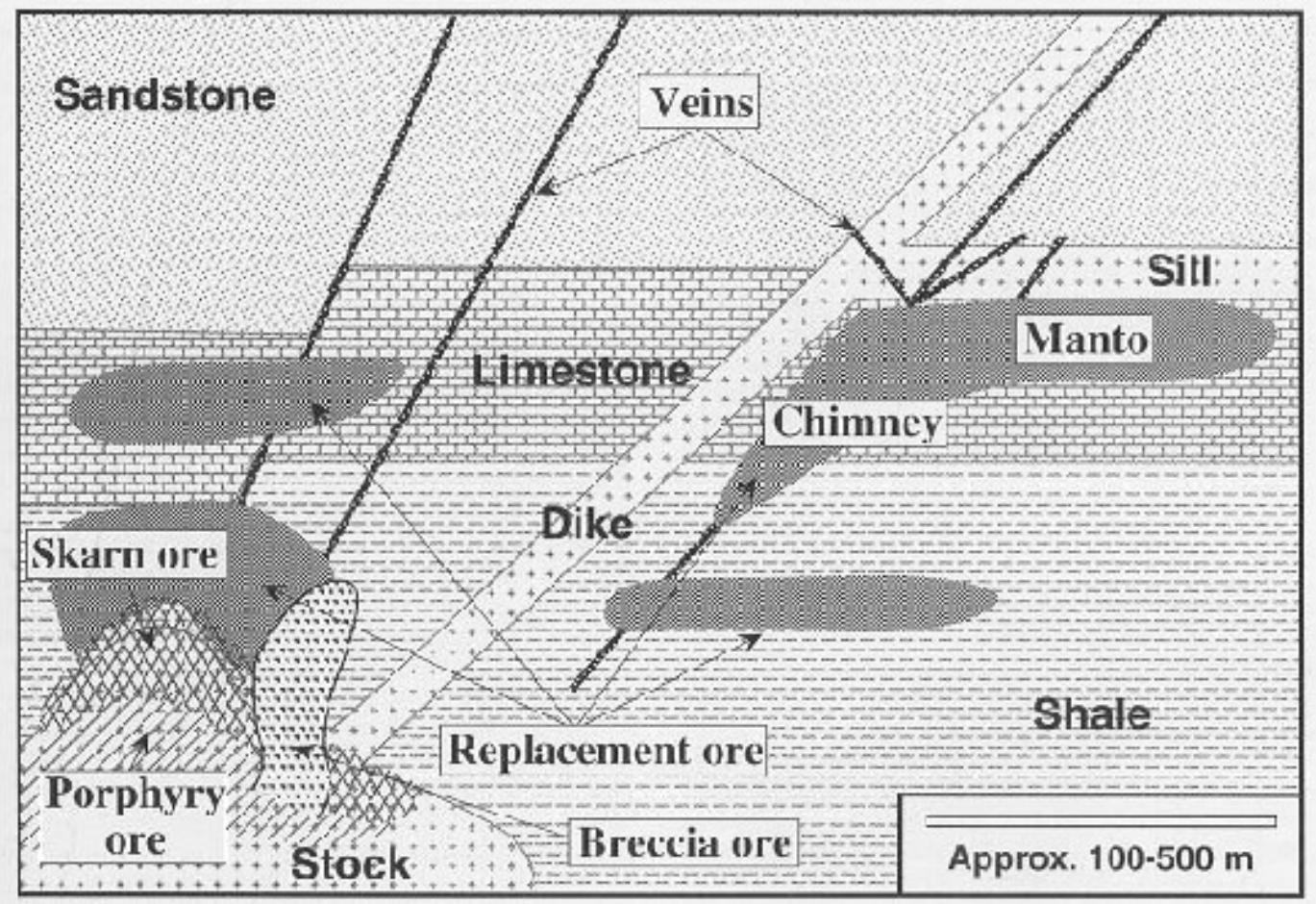

Figure 1. Generalized conceptual model for the geologic setting of high-temperature, carbonate-hosted and related deposits associated with igneous intrusions. (From Plumlee and others, 1999, figure 19.18)

Preliminary geoenvironmental models (duBray, 1995) were developed for skarns and polymetallic replacement deposits (Plumlee and others, 1995; Hammarstrom and others, 1995a, b, c). The most important geological characteristics shared by these types of deposits are listed in table 1. In the following discussion, we synthesize data included in the preliminary models, incorporate new data, and focus on salient differences between skarns and polymetallic carbonate-replacement deposits and differences among skarn types, with particular emphasis on differences that bear on their environmental signatures (table 1).

Table 1. Most important geological characteristics of skarn and polymetallic carbonate- replacement deposits (based largely on Meinert, 1998, 1992).

\begin{tabular}{|c|c|}
\hline 1. & Deposits are hosted by carbonate rocks (limestones, dololstones, calcareous clastic sediments). \\
\hline 2. & $\begin{array}{l}\text { Deposits are epigenetic, formed at high temperature }\left(>250^{\circ} \mathrm{C}\right) \text {, cut across host rocks, and have sharply } \\
\text { discordant contacts with host rocks. }\end{array}$ \\
\hline 3. & Deposits are associated with igneous activity, typically with plutons or batholiths. \\
\hline 4. & $\begin{array}{l}\text { Depth of formation varies from near-surface to about 10-12 km; depth of formation controls size, } \\
\text { geometry, and type of alteration. }\end{array}$ \\
\hline 5. & $\begin{array}{l}\text { Deposits cluster around igneous intrusions in mineralized districts that typically include other intrusion- } \\
\text { related deposit types (e.g., porphyry deposits, polymetallic veins). }\end{array}$ \\
\hline 6. & $\begin{array}{l}\text { Deposit types and metals are zoned spatially with respect to intrusions such that copper and gold are } \\
\text { found proximal to intrusions; zinc and lead are distal to intrusions. }\end{array}$ \\
\hline 7. & $\begin{array}{l}\text { Ore-mineral assemblages typically include pyrite or pyrrhotite, and other sulfide minerals, and } \\
\text { calcsilicate and carbonate gangue minerals. }\end{array}$ \\
\hline 8. & Local concentrations of ore can consist of massive concentrations (>50\%) of sulfide minerals. \\
\hline 9. & $\begin{array}{l}\text { Deposits form in stages, which may overprint one another in time and space. Early hornfels } \\
\text { metamorphism can reduce permeability but fracturing associated with igneous emplacement, and late- } \\
\text { stage hydrofracturing increase permeability and provide pathways for fluid flow. }\end{array}$ \\
\hline 10. & Ore minerals typically are coarsely crystalline. \\
\hline 11. & Late-stage pyrite and other alteration minerals can be disseminated over a wide area. \\
\hline
\end{tabular}


Deposit geology

Skarns

Skarns (tactites) are coarsely-crystalline metamorphic rocks composed of calcium-iron-magnesiummanganese-aluminum silicate minerals (commonly referred to as "calcsilicate" minerals) that form by replacement mainly of carbonate-bearing rocks during contact or regional metamorphism and metasomatism. The majority of the world's major skarn deposits are thought to be related to hydrothermal systems (Einaudi and others, 1981). Skarns can be barren or may contain metals or other minerals with economic value. Skarn deposits are important sources of base and precious metals as well as tin, tungsten, and iron. Skarns are relatively high-temperature mineral deposits resulting from magmatic-hydrothermal activity associated with granitoid plutons in orogenic tectonic settings. Skarns generally form where a granitoid pluton has intruded sedimentary strata that include limestone or other carbonate-rich rocks. The processes that lead to formation of all types of skarn deposits include the following stages: (1) isochemical contact metamorphism during pluton emplacement, (2) prograde metasomatic skarn formation as the pluton cools and an ore fluid develops, and (3) retrograde alteration of earlierformed mineral assemblages. Deposition of ore minerals accompanies stages 2 and 3. Skarn deposit mineralogy is spatially zoned with respect to pluton contacts, host rock lithology, and (or) fluid pathways. Later petrogenetic processes may partly or completely obliterate earlier stages of skarn development. Skarns are classified as calcic if the protolith was limestone, and as magnesian if the protolith was dolostone. Skarns also are classified by the most economically important metal present, including copper, iron, zinc-lead, gold, tin, tungsten, and molybdenum (table 2). In some cases, subdivisions also are made on the basis of oxidation state (oxidized versus reduced) as reflected by mineralogy. A variety of different skarn types can occur in a relatively small geographic area. In the Winnemucca area of north-central Nevada, for example, all skarn types except tin skarns are observed (fig. 2). In this part of Nevada, iron, tungsten, and base-metal skarns are associated with Jurassic and Cretaceous intrusions whereas gold skarns are associated with Tertiary intrusions.

Each class of skarn deposit has a characteristic, though not necessarily unique, size, grade, tectonic setting, granitoid association, and mineralogy (Einaudi and Burt, 1982; Einaudi and others, 1981; Meinert, 1983; Ray and Webster, 1990). Not surprisingly, therefore, the various classes of skarn deposits have different geochemical signatures and oxidation-sulfidation states. Some skarn deposits are best described as polymetallic and are difficult to classify by existing schemes. The Nabesna Fe-Au skarn in Alaska, for example, has been classified as an iron skarn with by-product gold and as a gold-rich copper skarn by different workers (Eppinger and others, 2000, 1999, 1997). In addition, some skarns contain unusual concentrations of rare-earth minerals and uranium or platinum group elements (Meinert, 1998). Many skarns mined in the past for iron, copper, or tungsten have been reexamined and developed for gold in the past 30 years. The Bonfim W-Au deposit in northeastern Brazil , for example, has proven total reserves of 70 tons of scheelite, but discovery of gold in abandoned dumps in the 1990s led to further development and production of 100 kilos of gold (Souza Neto and others, 1998).

Most economic skarn ore is present as exoskarn, which forms in carbonate host rocks proximal to an intrusion. The parts of the intrusion that are altered and can host ore are referred to as endoskarn. Endoskarn is variably developed on the intrusion side of intrusion-wallrock contacts. Endoskarn may include high-grade ore zones or may be part of the waste rock. For a recent review of skarn classification, geology, mineralogy, genesis, exploration strategies, and case examples, see Meinert (1992).

\section{Polymetallic carbonate-replacement deposits}

Polymetallic carbonate- replacement deposits are massive lenses, pods, and (or) pipes (mantos or chimneys) of sulfide minerals that comprise $\mathrm{Pb}-\mathrm{Zn}-\mathrm{Ag}-\mathrm{Cu}-\mathrm{Au}$ ores hosted by, and replacing, limestone, dolostone, and other sedimentary rocks. Most massive replacement ores contain more than 50 percent sulfide minerals (Plumlee and others, 1995; Megaw, 1998). Some polymetallic carbonate-replacement deposits occur with, or grade into, skarn deposits at the contact between sediments and intrusion. In both polymetallic carbonate-replacement deposits and base-metal-rich skarn deposits, ore metals typically are zoned. Copper and gold are enriched proximal to the intrusion and lead-zinc-silver ores occur in distal parts of the mineralized system.

Examples of skarns and polymetallic carbonate-replacement deposits are listed in table 2, along with comments about associated igneous rocks and with references. Some types of igneous rocks potentially provide long-term acid-neutralizing capacity because mafic silicate minerals such as biotite, chlorite, pyroxene, and calcic plagioclase consume acid upon weathering. Many of these same minerals also are present in retrograde skarn mineral assemblages. Calcite (or dolomite) is ubiquitous in skarn and replacement deposits. Calcite in ores, along with carbonate host rocks, typically provides enough neutralization capacity to mitigate any acid generated by weathering of iron sulfide minerals. Endoskarn minerals or altered igneous rocks may neutralize acid, albeit at a much slower rate than the highly reactive carbonate minerals. 
Table 2. Classification of skarn and polymetallic carbonate-replacement deposits. [Mt, million tonnes. Examples include individual deposits well as mining districts; for U.S. deposits, state abbreviations are listed]

\begin{tabular}{|c|c|c|c|c|c|}
\hline Metal Suite & Deposit type & $\begin{array}{l}\text { Subtype and } \\
\text { Size }\end{array}$ & Examples & Comments & References \\
\hline \multirow[t]{3}{*}{$\begin{array}{l}\mathrm{Fe}(\mathrm{Cu}, \mathrm{Co}, \mathrm{Ni}, \\
\mathrm{Au})\end{array}$} & \multirow[t]{3}{*}{ Fe skarn } & $\begin{array}{l}\text { Calcic } \\
\text { Size: } 5 \text { to } 200 \\
\text { Mt } \\
\text { Grade: } 50 \% \\
\text { Fe }\end{array}$ & $\begin{array}{l}\text { Hancock, NV } \\
\text { Jumbo, MT } \\
\text { Shinyama, } \\
\text { Japan } \\
\text { Daquiri, } \\
\text { Cuba } \\
\text { Empire, } \\
\text { Canada }\end{array}$ & $\begin{array}{l}\text { Form large skarn } \\
\text { deposits. } \\
\text { Mined primarily for iron. } \\
\text { Intrude limestones and } \\
\text { volcanics. } \\
\text { Igneous rocks are Fe-rich } \\
\text { and altered (feldspars, } \\
\text { scapolite). }\end{array}$ & $\begin{array}{l}\text { Meinert, 1998a } \\
\text { Einaudi and } \\
\text { others, 1981 } \\
\text { Sangster, 1969 } \\
\text { Cox, 1986 } \\
\text { Mosier and } \\
\text { Menzie, } 1986 \\
\end{array}$ \\
\hline & & $\begin{array}{l}\text { Magnesian } \\
\text { Size: } 5 \text { to100 } \\
\text { Mt } \\
\text { Grade: } 50 \% \\
\text { Fe }\end{array}$ & $\begin{array}{l}\text { Fierro- } \\
\text { Hanover, NM } \\
\text { Cornwall, PA } \\
\text { Eagle } \\
\text { Mountain, } \\
\text { CA } \\
\text { Janggun, } \\
\text { Korea }\end{array}$ & $\begin{array}{l}\text { Dolomitic wallrocks. } \\
\text { Skarn minerals are Mg- } \\
\text { rich silicates (Fe forms } \\
\text { magnetite). }\end{array}$ & $\begin{array}{l}\text { Meinert, 1998a } \\
\text { Hall and others, } \\
\underline{1988} \\
\underline{\text { Lapham, } 1968}\end{array}$ \\
\hline & & $\begin{array}{l}\text { Scapolite- } \\
\text { albite } \\
\text { Size: } 5 \text { to100 } \\
\text { Mt } \\
\text { Grade: } 40 \% \\
\text { Fe }\end{array}$ & $\begin{array}{l}\text { West } \\
\text { Humboldt, } \\
\text { NV } \\
\text { Kachar, } \\
\text { Sarbay, } \\
\text { USSR }\end{array}$ & $\begin{array}{l}\text { Very large tonnage } \\
\text { deposits. } \\
\text { Albite and scapolite in } \\
\text { addition to garnet and } \\
\text { pyroxene. } \\
\text { Form in volcanic- } \\
\text { sedimentary basins so } \\
\text { host rocks include } \\
\text { volcanics as well as } \\
\text { carbonates. } \\
\text { Some deposits are } \\
\text { enriched in cadmium. }\end{array}$ & $\begin{array}{l}\text { Zitzmann, } 1977 \\
\text { Einaudi and } \\
\text { others, } 1981 \\
\text { Sokolov and } \\
\text { Grigorev, } 1977 \\
\end{array}$ \\
\hline$\overline{\mathrm{Au}}$ & Au skarn & $\begin{array}{l}\text { Calcic } \\
\text { Reduced } \\
\text { Size: } 0.2 \mathrm{Mt} \\
\text { Grade: } 9 \mathrm{~g} / \mathrm{t} \\
\mathrm{Au}, 5 \mathrm{~g} / \mathrm{t} \mathrm{g}\end{array}$ & $\begin{array}{l}\text { Fortitude, NV } \\
\text { Crown Jewel, } \\
\text { WA } \\
\text { Elkhorn, Beal } \\
\text { MT } \\
\text { Junction Reefs, } \\
\text { Australia } \\
\text { Itajubatiba, } \\
\text { Brazil } \\
\text { Nickel Plate, } \\
\text { British } \\
\text { Columbia, } \\
\text { Canada }\end{array}$ & $\begin{array}{l}\text { Mined for gold. } \\
\text { Associated with reduced, } \\
\text { ilmenite-bearing diorite- } \\
\text { granodiorite plutons. } \\
\text { Form in clastic-rich } \\
\text { protoliths rather than pure } \\
\text { limestones. } \\
\text { Wide (100's of meters) } \\
\text { hornfels halos. } \\
\text { Distinctive Au-Bi-Te-As } \\
\text { geochemical signature. } \\
\text { Low garnet:pyroxene ratios. } \\
\text { Abundant sulfides } \\
\text { (pyrrhotite, arsenopyrite). } \\
\text { Pyrrhotite>pyrite. }\end{array}$ & $\begin{array}{l}\text { Meinert, } \\
\text { 1998a,b } \\
\text { Meinert, 1989 } \\
\text { Theodore and } \\
\text { others, 1991 } \\
\text { Souza Neto and } \\
\text { others, 1998 } \\
\underline{\text { Souza Neto, }} \\
\underline{1999} \\
\text { Ettlinger and } \\
\underline{\text { Ray, 1989 }}\end{array}$ \\
\hline
\end{tabular}




\begin{tabular}{|c|c|c|c|c|c|}
\hline Metal Suite & Deposit type & $\begin{array}{l}\text { Subtype and } \\
\text { Size }\end{array}$ & Examples & Comments & References \\
\hline & & $\begin{array}{l}\text { Calcic } \\
\text { Oxidized } \\
\text { Size: } 0.4 \mathrm{Mt} \\
\text { Grade: } 4 \mathrm{~g} / \mathrm{t} \\
\mathrm{Au}\end{array}$ & $\begin{array}{l}\text { McCoy, NV } \\
\text { Nambija, } \\
\text { Ecuador }\end{array}$ & $\begin{array}{l}\text { Low total sulfides (minor } \\
\text { but ubiquitous } \\
\text { chalcopyrite, sphalerite, } \\
\text { galena). } \\
\text { Pyrite>pyrrhotite. } \\
\text { High garnet:pyroxene } \\
\text { ratios. } \\
\text { Gold associated with K- } \\
\text { feldspar and quartz as } \\
\text { part of late retrograde } \\
\text { alteration. }\end{array}$ & $\begin{array}{l}\text { Meinert, } \\
\text { 1998a,b } \\
\text { Brooks and } \\
\text { others, 1991 } \\
\text { Theodore and } \\
\text { others, 1991 }\end{array}$ \\
\hline & & Magnesian & $\begin{array}{l}\text { Butte } \\
\text { Highlands, } \\
\text { MT } \\
\text { Cable, MT }\end{array}$ & $\begin{array}{l}\text { Dolomitic protolith. } \\
\text { Magnetite rich (strong } \\
\text { magnetic signature). } \\
\text { Mg-rich silicate minerals. }\end{array}$ & $\begin{array}{l}\text { Meinert, } \\
\text { 1998a,b } \\
\text { Ettlinger and } \\
\text { others, } 1996 \\
\end{array}$ \\
\hline \multirow[t]{2}{*}{$\mathrm{Cu}(\mathrm{Au})$} & Cu skarn & $\begin{array}{l}\text { None } \\
\text { Size: } 0.6 \mathrm{Mt} \\
\text { Grade: } 2 \% \\
\mathrm{Cu},<1 \mathrm{~g} / \mathrm{t} \\
\mathrm{Au}, 10 \mathrm{~g} / \mathrm{t} \mathrm{gg}\end{array}$ & $\begin{array}{l}\text { Carr Fork, } \\
\text { UT } \\
\text { Cyprus-Pinos } \\
\text { Altos, NM } \\
\text { Cananea, } \\
\text { Mexico } \\
\text { Meme, Haiti }\end{array}$ & $\begin{array}{l}\text { Most abundant skarn type } \\
\text { Associated with I-type, } \\
\text { calcalkaline magnetite- } \\
\text { series porphyritic } \\
\text { plutons. } \\
\text { Largest are associated } \\
\text { with porphyry copper } \\
\text { deposits. } \\
\text { Garnet>pyroxene. } \\
\text { Zoned: pyrite and } \\
\text { chalcopyrite proximal to } \\
\text { pluton, bornite in distal } \\
\text { zones. } \\
\text { Intense retrograde } \\
\text { alteration (sericite, K- } \\
\text { feldspar). }\end{array}$ & 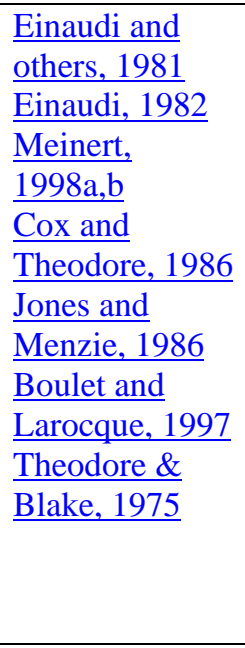 \\
\hline & Cu-Au skarn & $\begin{array}{l}\text { None } \\
\text { Size: } 37.4 \mathrm{Mt} \\
\text { Grade: } 2.7 \% \\
\mathrm{Cu}, 1 \mathrm{~g} / \mathrm{Au} \text {, } \\
16 \mathrm{~g} / \mathrm{t} \mathrm{gg}\end{array}$ & $\begin{array}{l}\text { Big Gossan, } \\
\text { Ertsberg, } \\
\text { Indonesia }\end{array}$ & $\begin{array}{l}\text { Gold is a by-product of } \\
\text { copper mining. } \\
\text { Sulfide-rich } \\
\text { (chalcopyrite, pyrite } \\
\text { dominant). } \\
\text { Locally, massive } \\
\text { orebodies of sulfides . }\end{array}$ & $\begin{array}{l}\text { Meinert, 1998a } \\
\text { Meinert and } \\
\text { others, 1997 }\end{array}$ \\
\hline \multirow[t]{2}{*}{$\mathrm{W}(\mathrm{Cu})(\mathrm{Mo})$} & \multirow[t]{2}{*}{ W skarn } & $\begin{array}{l}\text { Reduced } \\
\text { Size: } 0.1 \text { to } 5 \\
\text { Mt } \\
\text { Grade: } 0.8 \% \\
W_{3}\end{array}$ & $\begin{array}{l}\text { Fairbanks, } \\
\text { AK } \\
\text { MacTung, } \\
\text { Canada } \\
\text { Salau, France } \\
\text { Sandong, } \\
\text { Korea } \\
\end{array}$ & $\begin{array}{l}\text { Associated with granites. } \\
\text { Pyroxene>garnet. } \\
\text { Scheelite is main ore } \\
\text { mineral, with pyrrhotite, } \\
\text { chalcopyrite, sphalerite. }\end{array}$ & $\begin{array}{l}\text { Newberry, } 1998 \\
\text { Menzie and } \\
\text { others, } 1992\end{array}$ \\
\hline & & $\begin{array}{l}\text { Oxidized } \\
\text { Size: } 0.1 \text { to } 5 \\
\text { Mt } \\
\text { Grade: } 0.7 \% \\
\mathrm{WO}_{3}\end{array}$ & $\begin{array}{l}\text { Pine Creek, } \\
\text { CA } \\
\text { Mill City, NV } \\
\text { Brown's } \\
\text { Lake, MT } \\
\text { King Island, } \\
\text { Australia }\end{array}$ & $\begin{array}{l}\text { Associated with granites } \\
\text { and granodiorites. } \\
\text { Garnet>pyroxene. } \\
\text { Scheelite is main ore } \\
\text { mineral, with pyrite, } \\
\text { chalcopyrite, magnetite. }\end{array}$ & Newberry, 1998 \\
\hline
\end{tabular}




\begin{tabular}{|c|c|c|c|c|c|}
\hline Metal Suite & Deposit type & $\begin{array}{l}\text { Subtype and } \\
\text { Size }\end{array}$ & Examples & Comments & References \\
\hline \multirow[t]{2}{*}{$\begin{array}{l}\text { W-F (Be) (Bi) } \\
\text { (Mo) }\end{array}$} & W-F skarn & $\begin{array}{l}\text { Mo-poor } \\
\text { Size: } 0.1 \text { to } 1 \\
\text { Mt } \\
\text { Grade: } 0.2 \% \\
W_{3}\end{array}$ & $\begin{array}{l}\text { McCullogh } \\
\text { Butte, NV } \\
\text { Upper } \\
\text { Salcha, AK }\end{array}$ & $\begin{array}{l}\text { Associated with S-type } \\
\text { peraluminous granites. } \\
\text { Garnet, pyroxene, } \\
\text { scapolite. } \\
\text { Ore includes fluorite and } \\
\text { scheelite, Be minerals, } \\
\text { sphalerite, and pyrite. }\end{array}$ & Newberry, 1998 \\
\hline & W-F skarn & $\begin{array}{l}\text { Mo-rich } \\
\text { Size: }>9 \mathrm{Mt} \\
\text { Grade: } 0.2 \% \\
\mathrm{WO}_{3}, 0.05 \% \\
\mathrm{MoS}_{2}\end{array}$ & $\begin{array}{l}\text { Blue Ribbon, } \\
\text { NV } \\
\text { Shizhuyuan, } \\
\text { China } \\
\text { Mt. Reed, } \\
\text { Canada } \\
\text { Logtung, } \\
\text { Canada }\end{array}$ & $\begin{array}{l}\text { Associated with granite } \\
\text { Alteration includes } \\
\text { greisen, quartz- } \\
\text { molybdenite-wolframite } \\
\text { stockworks. } \\
\text { Garnet>pyroxene, } \\
\text { vesuvianite. } \\
\text { Ore includes Mo-rich } \\
\text { scheelite, fluorite, pyrite, } \\
\text { molybdenite, cassiterite, } \\
\text { and wolframite. }\end{array}$ & $\begin{array}{l}\text { Newberry, } 1998 \\
\text { Kwak, 1987 } \\
\text { Einaudi and } \\
\text { others, } 1981 \\
\text { Zhao, 1989 } \\
\text { Meinert, } \\
\text { 1995a,b } \\
\text { Elliott, 1988 }\end{array}$ \\
\hline \multirow[t]{2}{*}{ Sn } & \multirow[t]{2}{*}{ Sn skarn } & $\begin{array}{l}\text { Skarn sensu } \\
\text { stricto } \\
\text { Size: } 0.1 \text { to } 5 \\
\text { Mt } \\
\text { Grade: } \\
0.25 \% \text { Sn }\end{array}$ & $\begin{array}{l}\text { Lost River, } \\
\text { AK } \\
\text { Moina, } \\
\text { Australia }\end{array}$ & $\begin{array}{l}\text { Associated with S-type, } \\
\text { ilmenite series granite. } \\
\text { Ore includes cassiterite, } \\
\text { stannite, arsenopyrite, } \\
\text { pyrrhotite, and } \\
\text { wolframite. } \\
\text { Greisen can be minor to } \\
\text { extensive. } \\
\text { Garnet, pyroxene, } \\
\text { vesuvianite. }\end{array}$ & $\begin{array}{l}\text { Newberry, } 1998 \\
\text { Ray and } \\
\text { Webster, } 1997 \\
\frac{\text { Kwak, } 1987}{\text { Meinert, }} \\
\frac{1995 \mathrm{a}, \mathrm{b}}{\text { Zhao, 1989 }} \\
\frac{\text { Reed and Cox, }}{1986} \\
\underline{\text { Menzie \& Reed, }} \\
\text { 1986a }\end{array}$ \\
\hline & & $\begin{array}{l}\text { Sn } \\
\text { replacement } \\
\text { Size: } 1 \text { to } 5 \\
\text { Mt } \\
\text { Grade: } 0.7 \% \\
\text { Sn }\end{array}$ & $\begin{array}{l}\text { Geiju district, } \\
\text { China } \\
\text { Renison Bell, } \\
\text { Mt. Bishoff, } \\
\text { and } \\
\text { Cleveland, } \\
\text { Australia }\end{array}$ & $\begin{array}{l}\text { Associated with A-, S- } \\
\text { type, ilmenite-series } \\
\text { granite. } \\
\text { Ore includes pyrrhotite, } \\
\text { arsenopyrite, cassiterite, } \\
\text { sphalerite, and galena. } \\
\text { Extensive greisen } \\
\text { development. } \\
\text { Prograde calcsilicate } \\
\text { minerals absent. }\end{array}$ & $\begin{array}{l}\text { Newberry, } 1998 \\
\text { Kwak, } 1987 \\
\text { Einaudi and } \\
\text { others, } 1981 \\
\text { Zhao, 1989 } \\
\text { Menzie \& Reed, } \\
\text { 1986b } \\
\text { Reed, } 1986\end{array}$ \\
\hline
\end{tabular}




\begin{tabular}{|c|c|c|c|c|c|}
\hline Metal Suite & Deposit type & $\begin{array}{l}\text { Subtype and } \\
\text { Size }\end{array}$ & Examples & Comments & References \\
\hline Zn-Pb-Ag & Zn-Pb skarn & $\begin{array}{l}\text { None } \\
\text { Size: } 1.4 \mathrm{Mt} \\
\text { Grade: } 5.9 \% \\
\mathrm{Zn}, 2.8 \% \mathrm{~Pb}, \\
0.5 \% \mathrm{Cu}, 0.5 \\
\mathrm{~g} / \mathrm{t} \mathrm{Au}, 100 \\
\mathrm{~g} / \mathrm{t} \mathrm{Ag}\end{array}$ & $\begin{array}{l}\text { Groundhog, } \\
\text { NM } \\
\text { Cleveland, } \\
\text { NM } \\
\text { Kelly, NM } \\
\text { Bismark, } \\
\text { Mexico }\end{array}$ & $\begin{array}{l}\text { Most are distal to, or not } \\
\text { obviously associated } \\
\text { with, intrusive rocks. } \\
\text { Distinctive manganese- } \\
\text { rich skarn mineralogy. } \\
\text { Pyroxene, garnet, } \\
\text { pyroxenoid. } \\
\text { Zoned from proximal } \\
\text { silicates to distal sulfide } \\
\text { replacement bodies } \\
\text { (mantos, chimneys). } \\
\text { Ore includes sphalerite, } \\
\text { galena, pyrrhotite, pyrite, } \\
\text { magnetite, chalcopyrite, } \\
\text { arsenopyrite. }\end{array}$ & $\begin{array}{l}\text { Einaudi and } \\
\text { Burt, 1982 } \\
\text { Mosier, 1986 } \\
\text { Cox, 1986c } \\
\text { Boulet and } \\
\text { Larocque, 1998 } \\
\text { Larocque and } \\
\text { others, 1995 }\end{array}$ \\
\hline Pb-Zn-Ag & $\begin{array}{l}\text { Polymetallic } \\
\text { carbonate } \\
\text { replacement }\end{array}$ & $\begin{array}{l}\text { None } \\
\text { Size: } 1.8 \mathrm{Mt} \\
\text { Grade: } 5.2 \% \\
\mathrm{~Pb}, 3.9 \% \mathrm{Zn} \text {, } \\
0.3 \% \mathrm{Cu}, 2 \\
\mathrm{~g} / \mathrm{t} \mathrm{Au}, 150 \\
\mathrm{~g} / \mathrm{t} \mathrm{g}\end{array}$ & $\begin{array}{l}\text { Leadville, } \\
\text { Gilman, } \\
\text { Breckenridge, } \\
\text { CO } \\
\text { Eureka, NV } \\
\text { Magdalena, } \\
\text { NM } \\
\text { Tintic, Park } \\
\text { City,UT } \\
\text { Nakatatsu, } \\
\text { Japan } \\
\text { Naica, } \\
\text { Mexico } \\
\text { Drina, } \\
\text { Yugoslovia }\end{array}$ & $\begin{array}{l}\text { Wide spectrum of } \\
\text { deposits that grade from } \\
\text { skarn to massive sulfide } \\
\text { chimneys and mantos. } \\
\text { Generally in thick } \\
\text { carbonate sequences; host } \\
\text { rock can include } \\
\text { limestone, dolostone, and } \\
\text { other calcareous } \\
\text { sedimentary rocks. } \\
\text { Calcsilicate (skarn) } \\
\text { minerals may or may not } \\
\text { be present. } \\
\text { Simple ore assemblages } \\
\text { of galena, sphalerite, } \\
\text { chalcopyrite, } \\
\text { arsenopyrite, pyrite, and } \\
\text { pyrrhotite. } \\
\text { Carbonate, sulfate, and } \\
\text { quartz gangue minerals. }\end{array}$ & $\begin{array}{l}\text { Megaw, } 1998 \\
\text { Vikre, } 1998 \\
\text { Plumlee and } \\
\text { others, } 1995 \\
\text { Mosier and } \\
\text { others, } 1986 \\
\text { Morris, 1986 } \\
\text { Wallace, 1993 } \\
\text { Titley, 1993 } \\
\end{array}$ \\
\hline
\end{tabular}

\section{Related Deposit Types}

A variety of other types of mineral deposits associated with igneous rocks can be spatially or genetically related to skarns and polymetallic carbonate-replacement deposits (fig. 1). Related deposit types vary as a function of igneous rock composition. Deposit types (models of Cox and Singer, 1986) related to tin and tungsten skarns include other deposit types related to relatively evolved (silica-rich) granites; examples are tin greisens (Model 15c) and tin or tungsten veins and stockworks (Model 15b). On a regional or district scale, copper, gold, iron and zinc-lead skarns and polymetallic carbonate-hosted replacement deposits are associated with porphyry copper (Model 17), polymetallic vein (Model 22c) and replacement (Model 19a), placer gold (Model 39a), and distal disseminated silver-gold (Model 19c; Cox, 1992) deposits, and with each other. Some deposits contain local concentrations of a metal that is atypical of the principal commodities for the deposit type. Therefore, many skarn and replacement deposits are classified as different deposit types by different investigators. For example, magnetite-rich ore is mined as a by-product at some of the tin skarns in Malayasia, and at many copper skarns. Recently, gold skarns have been recognized as a discrete type of skarn deposit (Meinert, 1989). Before the 1970s, most gold from skarns was mined as a by-product of mining for copper, iron, or zinc and lead (Meinert, 1998b). 


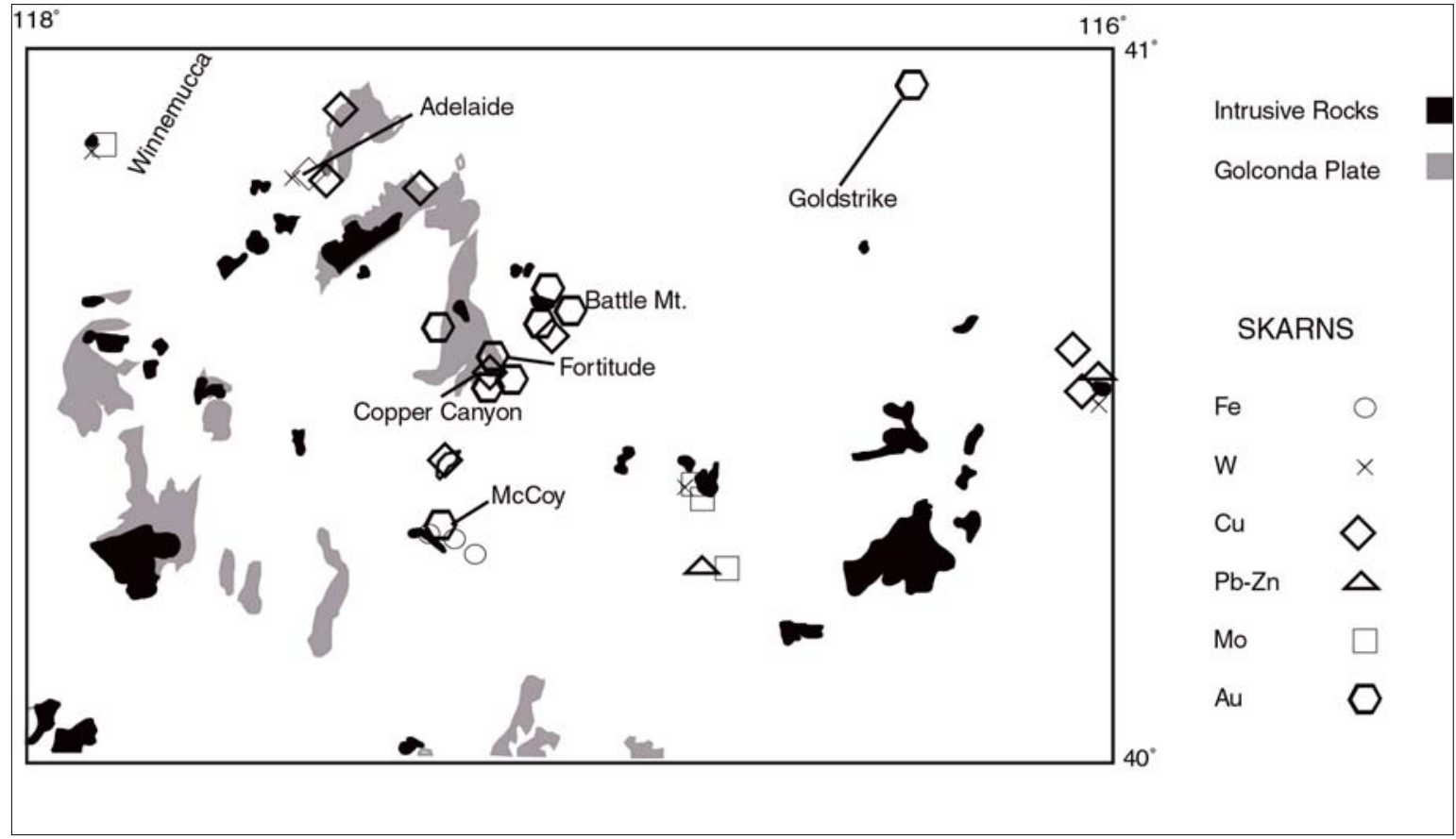

Figure 2. Distribution of skarn types in the Winnemucca $1^{\circ} \times 2^{\circ}$ quadrangle, north-central Nevada. The Fortitude deposit is an example of a calcic, reduced gold skarn; McCoy is a calcic, oxidized gold skarn (table 2). At McCoy, calcic Fe skarn formed at the contact between Jurassic diorite and dolostone whereas the $\mathrm{Au}$ skarn formed along the contact of a Tertiary granodiorite stock. Intrusive rocks are shown in black; thick sequences of predominantly carbonate-rich Paleozoic sedimentary rocks crop out in the Golconda thrust plate (gray) in the western half of the quadrangle.

\section{Deposit Size}

The largest deposits are the iron skarns, which can approach 200 million tonnes or ore (table 2). Median or typical tonnages and grades for different deposit types and subtypes are listed in table 2. Tin and tungsten skarns tend to be larger than base metal-skarns. Polymetallic carbonate-replacment deposits range from quite small (10,000 tonnes) to as much as 30 to 40 million tones, but average about 1.8 million tonnes. Relative to porphyry deposits and Carlin-type gold deposits, for example, skarns and polymetallic carbonate-replacement deposits are small and high-grade. The environmental implication of deposit size relates to the amount of land disturbed by the mining, the mining methods used to extract ores, and the amount of iron sulfide minerals available to generate acid waters.

\section{Host rocks}

Host rocks include limestone, dolostone, marble, and other calcareous sedimentary rocks such as pelite, argillite, shale, greywacke, and other clastic rocks. Host rocks are highly calcareous sedimentary or metamorphosed calcareous sedimentary rocks (type IV of Glass and others, 1982) that have extensive acidneutralizing capacity. Reduced gold skarns tend to occur in rocks with a significant clastic component, rather than

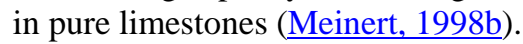

\section{Geologic Setting}

Skarns and polymetallic carbonate-replacement deposits are associated with batholiths and their sedimentary wallrocks. Associated volcanic rocks may or may not be present. Skarn can form in roof pendants within batholiths as well as along contacts. Skarn can underlie intrusive rocks, such as along the basal margins of laccoliths. Most base-metal skarns are associated with magmatic arcs related to subduction zones and form in tectonic settings that also host porphyry copper deposits. Tin and some tungsten deposits are more typical of anorogenic or continental settings. 
Wall-Rock Alteration

Wall-rock alteration styles vary with deposit type. Extensive development of greisen and sericitic and silicic alteration are hallmarks of Sn-W deposits. Copper and some gold skarns associated with plutons that host porphyry deposits develop alteration zones that correlate with hydrothermal events in the pluton (Einaudi, 1982). Wall-rock can be altered to hornfels over areas as large as 15 to $20 \mathrm{~km}^{2}$. Marbles, bleached zones, and skarn mineral assemblages can form in wall rocks. Potassic, sericitic, argillic, and propylitic alteration assemblages are variably developed and endoskarn may form within plutons. Silica and marble "fronts" may be present. In polymetallic carbonate-replacement deposits, calcsilicate minerals may or may not form. Host rocks typically are recrystallized, dolomitized, bleached, and (or) sanded (carbonate cement removed). Alteration of host rocks to jasperoid occurs in some deposits.

\section{Nature of Ore}

In gold and base-metal skarns, ore minerals may be present in massive, stratiform, vein, and (or) disseminated forms; crystal size is highly variable and ranges from fine to very coarse. Ore may be present in sulfide mineral zones, oxide zones, and in supergene, clay-rich oxidized zones. Sulfide minerals and gold generally are deposited during late, retrograde alteration within zones of hydrous calcsilicate minerals. Retrograde alteration may be best developed along faults cutting paragenetically earlier assemblages. Gold commonly is associated with a late pyrite + quartz assemblage. Total sulfide mineral content at the McCoy, Nevada calcic oxidized gold skarn (table 2) is low ( $<2$ volume percent) and many sulfide minerals are oxidized. In contrast, at the Fortitude, Nevada calcic reduced gold skarn (table 5 , fig. 2b) about $30 \mathrm{~km}$ to the north, high- grade ore is pyrrhotite-rich, with smaller amounts of chalcopyrite, pyrite, arsenopyrite, and native bismuth.

Iron skarn ore consists of massive magnetite layers or lenses. Orebodies are associated spatially with garnet zones or form in limestone outward beyond calc-silicate skarn zones. Calcic magnetite skarns and scapolite(albite) iron skarns may be present within mafic stocks as replacements of gabbro and diorite, or of limestone xenoliths (Einaudi and others, 1981). Stockwork veins may be present in mafic volcanic rocks overlying altered gabbro. Orebodies may be lenticular, lensoid, tabular, contact-controlled deposits extending hundreds of meters to $4 \mathrm{~km}$ or more along strike and having thicknesses of tens to hundreds of meters. The deposits also occur as irregular and pipelike replacements of mafic intrusions and as stockworks. Ore may be present in nearly monomineralic veins, pods, layers, or lenses of magnetite, or may consist of magnetite-rich lamina or layers alternating with, or intergrown with, gangue minerals. Ore mineral associations in the Cornwall, Pennsylvania iron skarn include magnetite-chalcopyrite-pyrite, magnetite-pyrite-actinolite, magnetite-chlorite, magnetitehematite-calcite, and magnetite alone. Magnetite varies from anhedral and granular to euhedral, and forms platy pseudomorphs after hematite (Lapham, 1968).

Tungsten skarn orebodies are stratiform deposits that can extend for hundreds of meters along lithologic contacts. Stockwork and local crosscutting veins are common. The crystal size and molybdenum content of scheelite in tungsten skarns varies. Paragenetically early, anhydrous skarn generally contains finely-crystalline, high-molybdenum scheelite, whereas retrograde skarn contains medium to coarsely crystalline, low-molybdenum scheelite. Coarsely crystalline, vuggy skarn with uneven ore grades forms from impure marble. More finely crystalline, compact skarns with evenly distributed ore grades tend to form from pure marbles (Einaudi and others, 1981).

Tin skarn orebodies may develop at intrusive contacts with carbonate rocks, or along intrusion-related fractures and veins at distances up to $300 \mathrm{~m}$ from the intrusion (Reed and Cox, 1986). Tin occurs in very finely crystalline cassiterite, and in some deposits, in silicate minerals, including garnet and hornblende (Eadington, 1983). Tin in silicate minerals poses metallurgical problems. Therefore, most of the deposits that have been economic to mine are those that contain cassiterite as the primary tin ore mineral (Newberry, 1998). Other tin skarn ore minerals include stannite, arsenopyrite, pyrrhotite, and wolframite. Magnetite and fluorite are common tin skarns minerals and may form alternating light and dark lamellae.

In polymetallic carbonate-replacement deposits, ore is present in massive lenses (mantos), pipes (chimneys), and veins of iron, lead, zinc, and copper sulfide minerals. Massive ore contains $>50$ percent sulfide minerals. A specific district or mine may contain a single massive orebody or a series of orebodies aligned along structural features. Ore controls include fractures, joints, fold limbs, karst openings, or lithologic discontinuities that control fluid movement (fig. 2). Manto and chimney ore is compact and can be relatively impermeable. Some ore replaces carbonate clasts in karst breccias and may fill interstices between clasts.

Mining and Ore-Processing Methods 
Base-metal skarns and polymetallic carbonate-replacement deposits have been developed as underground mines and as open pit mines. At many small historic mines, ores were sorted by hand and transported to smelters; metal- and sulfide-rich ore piles remain at many abandoned mine sites. By about 1900, the development of efficient flotation processes allowed on-site milling to produce zinc-, lead-, and (or) copper-rich concentrates that were subsequently smelted. Modern processing typically involves milling followed by concentrate smelting. Mine stopes are backfilled with coarse tailings. Fine-grained tailings are stored in surface impoundments. Coppergold ore is milled primarily by gravity and flotation methods. Copper is usually recovered by flotation. Gold is recovered by cyanide leaching of crushed ore or by a modern pyrite flotation process that substitutes for cyanide processing of pyrite-rich gold ore. Some copper-mining operations use sulfuric acid heap leach, followed by solvent extraction-electrowinnowing, to extract copper. The primary drawback of the acid-leach method for copper recovery is generation of potentially large volumes of acidic, iron- and aluminum-rich wastewater that must be treated. Differential flotation and separation processes are used to produce metals concentrates from complex polymetallic ores such as the ores at the Minera Bismark lead-zinc skarn in Mexico (Mining Magazine, 1994). Gravity separation was used on high-grade zinc ores at the Hanover, New Mexico, lead-zinc skarn (Walder and Chavez, 1995) when mining began. Subsequently, a froth flotation process was used. The additional crushing necessitated by the flotation process resulted in finer-grained tailings, which potentially are more reactive due to increased surface area and are more susceptible to wind erosion.

The mining method used for tungsten skarns generally depends on the grade and shape of the deposit; high average ore grades ( 0.7 weight percent $\mathrm{WO}_{3}$ or more) generally are required to support the high costs of underground mining. Underground methods include room-and-pillar (Cantung, British Columbia; King Island, Australia), cut-and-fill, stoping (Pine Creek, California) or combinations of these methods (Anstett and others, 1985). Gravity, flotation, and chemical methods are used to produce natural and artificial scheelite, and ammonium paratungstate (APT) (Smith, 1994). Scheelite concentrate was produced in Nevada in the past using gravity, flotation, and magnetic separation techniques (Stager and Tingley, 1988). After crushing and grinding, sulfide minerals and scheelite were separated by flotation, and the sulfide slimes were removed to tailings piles. Molybdenum was removed via a precipitation process and an organic solvent extraction technique is used to produce crystalline APT.

Modern mining of the large tin replacement deposit at Renison Bell, Tasmania, is accomplished by cut-andfill stoping methods. Sulfide-mineral-rich and sulfide-mineral-poor ore are stockpiled selectively on the surface. Blended ore is fed into a three-stage open crushing circuit that reduces ore from $750 \mathrm{~mm}$ to $15 \mathrm{~mm}$. The ore is processed by flotation to remove sulfide minerals prior to gravity concentration of cassiterite (Morland, 1986). Staged grinding is used to liberate fine-grained cassiterite. Residual sulfide minerals in the gravity concentrate are removed by flotation. Cassiterite concentrates are leached with sulfuric acid to remove siderite. Magnetic material is removed using magnetic separators. The refined concentrates are shipped to smelters. Tailings are combined with lime to adjust $\mathrm{pH}$ to 8.5 before being pumped to impoundments.

Ores may need to be very finely ground for efficient flotation, depending on the ore textures. Grinding increases mineral surface area. Grinding also liberates fast-weathering ore minerals from enclosing silicate minerals that may protect against oxidative weathering. Pressures and stresses of milling increase the rate and susceptibility of pyrrhotite and magnetite to oxidative weathering (Pratt and others, 1996). Iron sulfide minerals are abundant in all of the mineral deposit types considered here (table 2) and end up in sulfide-rich mill tailings, where they are susceptible to oxidation that can produce acid-mine drainage. Because of the water requirements of milling, most mills are located along or near creeks. Early miners discharged mill tailings directly into creeks, or dammed tailings in holding ponds near creeks. Modern mining operations discharge mill tailings to lined surface tailings ponds, or dispose of tailings by backfilling and cementing mined stopes. Pyrite-rich tailings produced as a milling by-product have high potential for generation of highly acidic, metal-bearing water, especially if the water is evaporatively concentrated. Spring snowmelt or storm flushing of soluble secondary salts from mill tailings surfaces can degrade downstream surface water quality.

\section{Deposit Trace Element Geochemistry}

Minor- and trace- element geochemical signatures typical of each deposit type are listed in table 3a. Trace element signatures can be diagnostic of some deposit types. Calcic reduced gold skarns, for example, typically contain arsenic, bismuth, or tellurium. Zinc-lead skarns contain distinctive manganese minerals and manganeseenriched garnet and pyroxene. Trace amounts of cadmium, lead, arsenic are characteristic of the scapolite-albite iron skarn subtype, but not of other iron skarns. Copper skarns are enriched in copper, gold, and silver in proximal zones; in lead, zinc, and silver in distal zones (Cox and Theodore, 1986). Cobalt, arsenic, antimony, bismuth and molybdenum are enriched in some copper skarns. The geochemical signature of zinc-lead skarns includes a wide 
variety of metals (table 3a). Meinert and others (1997) documented vertical zonation of metals at the Big Gossan Cu-Au skarn, Irian Jaya . Analysis of assay data showed that copper, gold, silver, lead, and zinc increased upwards in the system and molybdenum increased with depth. Kotlyar and others $(\underline{1998})$ used drill-hole sample geochemistry to document 3-dimensional district- and deposit-scale metal zonation at the Fortitude gold skarn at Copper Canyon in north central Nevada. In the highly mineralized porphyry and skarn system at Copper Canyon, gold and copper are concentrated in proximal parts of the porphyry system. An unexpected result of the study was the identification of a mercury anomaly on the fringes of some gold and copper skarn orebodies; highest mercury concentrations coincided with polymetallic veins peripheral to the skarns. Thus, the trace element signature and zoning patterns around the skarns are affected by other mineral deposit types in the mining district.

Polymetallic carbonate-replacement deposits are characterized by elevated abundances of gold, molybdenum, arsenic, bismuth, and (or) antimony. In some districts, ore proximal to igneous intrusions is copper- and goldrich, and grades laterally and sometimes vertically into lead-zinc-silver-rich ore. A distal, manganese-enriched zone is present in some districts.

\section{Primary Mineralogy and Zonation}

Primary ore and gangue minerals are tabulated by deposit type and by mineral groups (table 3) to facilitate comparisons of expected environmental signatures. Weathering of iron sulfide minerals is the leading cause of acid mine drainage. Although pyrrhotite oxidizes more rapidly than pyrite, it produces less acid, or, in some cases, consumes acid depending on reaction pathways. For skarn deposit types that can be subdivided into oxidized and reduced variants, the oxidized type contains pyrite in excess of pyrrhotite and greater variety in base-metal sulfide minerals (table 3a). Pyrrhotite typically alters to marcasite, and subsequently can generate significant amounts of acid in reactions with oxygen and water. Many of the other sulfide minerals in skarn ores have metal/sulfur ratios $<1$, such as sphalerite, galena, and chalcopyrite. These minerals are strongly oxidized by aqueous ferric iron, but typically do not produce acid when oxygen is the oxidant (Plumlee, 1998). Some deposit types rich in zinc and manganese may not contribute much acid to ground and surface waters, yet may contribute metals that are transported readily as dissolved species at near-neutral $\mathrm{pH}$ and are difficult to remove. High dissolved zinc concentrations in surface waters may be less of a problem in carbonate-hosted deposits than in other types of zinc deposits because zinc tends to be redeposited as the secondary carbonate mineral smithsonite (Walder and Chavez, 1995).

In skarn deposits, early, prograde zones are characterized by high temperature, anhydrous minerals, especially garnet and pyroxene. Subsequent lower-temperature retrograde skarn zones are marked by hydrous minerals that can overprint, crosscut, or completely replace prograde assemblages. Retrograde minerals include amphibole, chlorite, epidote as well as variety of other minerals that comprise gangue (table 3b). The relative reactivity of skarn calc-silicate minerals in acid solutions is not well understood. Kwong (1993) and Sverdup (1990) ranked garnet, pyroxene, and wollastonite as fast-weathering minerals that could contribute to acid neutralization. Based on the observation that low $\mathrm{pH}$ waters drain some skarn deposits (Plumlee and others, 1999) that contain these minerals in abundance, Plumlee (1999) concluded that they do not readily react with acid waters. He included garnet, pyroxene, and wollastonite as an intermediate-weathering mineral group, along with retrograde minerals.

Ores typically are associated with later stages of skarn evolution. Mineral assemblages and mineral compositions vary among skarns of different types and subtypes (table 3). For detailed information on skarn zone mineralogy and mineral chemistry for the various skarn subtypes, see Hammarstrom and others (1995a, b, and c) and the references in table 2. Examples of some of the distinguishing mineralogical characteristics of various deposit types are discussed below.

The primary ore minerals vary among the different skarn deposit types. The type of primary ore mineral (e.g., oxide, sulfide, or tungstate) and the abundance of iron sulfide minerals in ore mineral assemblages will affect the weathering behavior and acid generation potential of mine waste and mill tailings. Magnetite is the principal ore mineral in all iron skarn subtypes (table 3). However, the mineralogy of the prograde, retrograde, and ore zones of iron skarn subtypes are distinct (table 4). Sulfide mineral contents in iron skarns generally are low, but can be quite variable. Reported magnetite:pyrite ratios range from 100:1 to 3: 1 for the Larap calcic iron skarn in the Phillipines (Einaudi and others, 1981). In addition to magnetite, the magnesian iron skarn at Cornwall, Pennsylvania, produced copper, gold, and silver from chalcopyrite and cobalt from pyrite. In gold skarns, gold may be present in sulfide-mineral-rich, massive lenses or pods, or it may be disseminated. At the Nickel Plate calcic reduced gold skarn deposit in Canada, $<25$-micron-diameter grains of native gold associated with hedleyite are adjacent to arsenopyrite and gersdorffite. In other parts of the same deposit, electrum is concentrated in microfractures in and around chalcopyrite, pyrrhotite, sphalerite, and bismuth (Ettlinger and Ray, 1989). In contrast, gold at the McCoy, Nevada calcic oxidized gold skarn deposit (Brooks and others, 1991) is spatially and 
paragenetically associated with late-stage pyrite. Gold grains bordering pyrite cubes are 20- to 100-microns in diameter. Mineral characteristics in skarns are likely to vary considerably within a single deposit because of the zoned nature of skarns and the replacement of early-formed minerals by later mineral assemblages. Manganeserich silicate and carbonate minerals are a distinctive characteristic of prograde and retrograde mineral zones in zinc-lead skarn deposits. In zinc-lead skarns, ore commonly forms massive pods of pyrrhotite, sphalerite, galena, and chalcopyrite in pyroxene zones. The oxidation state of tungsten skarns is reflected in the mineralogy. In reduced tungsten skarns, pyroxene is more abundant than garnet in prograde mineral assemblages. Pyroxene is iron-rich hedenbergite and garnet is iron-poor (Newberry, 1998). Retrograde zones contain iron-rich amphibole and chlorite, and ores include molybdenum-poor scheelite, gold, pyrrhotite, chalcopyrite, sphalerite. In oxidized tungsten skarns, garnet is more abundant than pyroxene. Garnet is iron-rich andradite and pyroxene is intermediate in composition. Epidote is present in retrograde zones, and ores contain molybdenum-rich scheelite, pyrite, chalcopyrite, and magnetite. In tungsten skarns, scheelite is deposited near the marble front during early prograde metasomatism but generally is remobilized and redeposited in coarse-grained, high-grade masses with sulfide minerals in zones of hydrous alteration. In all of the W-F and Sn skarns deposit subtypes, garnet is more abundant than pyroxene in prograde zones and white mica and fluorite are present as retrograde minerals. In tinbearing Mo-rich W-F skarns (table 2), tungsten is concentrated proximal to intrusive rock whereas tin is concentrated in more distal parts of skarns (for example, Shizhuyuan, China). Tin replacement deposits (table 2) are grouped with tin skarns sensu stricto because they appear to form a continuum with classic skarn deposits. Although they lack prograde calcsilicate mineral assemblages, the tin carbonate replacement deposits are spatially associated with plutons and exhibit mineral and metal zoning (Newberry, 1998). Extensive greisen alteration is present, and ore minerals include cassiterite, pyrrhotite, arsenopyrite, sphalerite, and galena.

Most polymetallic carbonate-replacement deposits are pyrite-rich; however, a few (rare?) deposits are pyritepoor and are dominated by sphalerite and galena. The following list of minerals in polymetallic carbonatereplacement ores is based on Plumlee and others (1995). Minerals are listed in approximate decreasing order of abundance. Potentially acid-generating minerals are underlined and minerals that are acid-generating when oxidized by aqueous ferric iron are denoted by *: Pyrite, sphalerite*, galena*, siderite, quartz, marcasite, rhodochrosite, dolomite, chalcopyrite, pyrrhotite, tetrahedrite, digenite ${ }^{*}$, argentite, electrum, \pm enargite, $\pm \underline{\text { bornite, }}$ \pm arsenopyrite, $\pm \mathrm{Bi}$-Te-Hg-Au-Ag minerals (hessite, petzite, pyrargyrite, etc.), \pm barite, \pm fluorite. In many deposits, ore grades from copper-mineral-rich (chalcopyrite, enargite, bornite) within and near igneous intrusions, to sphalerite- and galena-rich away from intrusions, to sphalerite- and manganese carbonate-bearing distal ore.

\section{Secondary Mineralogy}

Secondary minerals form by weathering in the oxidized parts of mineral deposits. Secondary minerals can form in-situ on exposed ore bodies, or on mine waste dumps and tailings. In-situ weathering promotes gossan development over sulfide-mineral- rich parts of skarn deposits; supergene alteration enhances ore metal grades in parts of some skarn deposits. Secondary minerals reported in skarns and polymetallic carbonate-replacement deposits are listed by mineral group in table 5 . Notably absent from the list are the halotrichite-pickeringite group minerals common in massive sulfide deposits. These minerals may be under reported in skarns, or may not form because of the low availabilty of dissolved aluminum. Reports of aluminum oxyhydroxides or hydroxysulfate minerals also are notably absent. Examples of secondary mineral assemblages for different deposit types are described in the following discussion.

Supergene alteration leads to formation of clays, hematite and goethite (after pyrite and other sulfide minerals), and secondary copper minerals (after chalcopyrite). The calcic oxidized gold skarn deposit at McCoy, Nevada, is highly oxidized and argillized to as much as $245 \mathrm{~m}$ below the present surface (Brooks and others, 1991). Minerals in these argillized zones include a variety of clays (montmorillonite, nontronite, and illite), manganese oxide minerals, supergene copper oxide minerals, claudetite $\left(\mathrm{As}_{2} \mathrm{O}_{3}\right)$, willemite $\left(\mathrm{Zn}_{2} \mathrm{SiO}_{4}\right)$, marcasite, and hydrated iron oxide minerals. At the Red Dome Au skarn deposit in North Queensland, Australia, high-grade gold ore is concentrated in highly oxidized karst-collapse breccia that formed during post-mineralization uplift and erosion; oxidation of primary tellurium-rich hypogene sulfide ore enhanced karst formation and concentration of free gold (Torrey and others, 1986). Minerals and mineral zoning that develops during supergene alteration of zinc-lead-silver sulfide ore in carbonate rocks depends on local Eh and $\mathrm{pH}$ conditions, permeability, and the relative activities of carbonate species and sulfate ions in leaching ground water (Sangameshwar and Barnes, 1983). For example, cerussite is the first lead mineral to precipitate where dissolved carbonate is more abundant than sulfate, but anglesite precipitates if the situation is reversed. Supergene minerals associated with base- and precious metal skarns include azurite, malachite, smithsonite, and cerargyrite, as well as cerussite, anglesite, manganese minerals (pyrolusite, groutite), and goethite. Manganese-rich gossans are associated with zinc-lead 
Table 3. Mineralogical and metal associations of skarn and polymetallic carbonate-replacement deposits.

A. Primary ore minerals. [XX, most common iron sulfide mineral. See references in table 2 for data sources]

\begin{tabular}{|c|c|c|c|c|c|c|c|c|}
\hline Deposit Type & \multicolumn{3}{|c|}{ Fe skarn } & \multicolumn{3}{|c|}{ Au skarn } & \multicolumn{2}{|c|}{ Cu skarn } \\
\hline Subtype & Calcic & Magnesian & $\begin{array}{l}\text { Scapolite- } \\
\text { albite }\end{array}$ & Calcic reduced & Calcic & Magnesian & Copper & $\begin{array}{l}\text { Copper- } \\
\text { gold }\end{array}$ \\
\hline Major metals & $\mathrm{Fe}$ & $\mathrm{Fe}$ & $\mathrm{Fe}$ & $\mathrm{Au}$ & $\mathrm{Au}$ & $\mathrm{Au}$ & $\mathrm{Cu}$ & $\mathrm{Cu} \mathrm{Au}$ \\
\hline $\begin{array}{l}\text { Minor and trace } \\
\text { metals }\end{array}$ & $\begin{array}{l}\mathrm{Cu} \mathrm{Co} \mathrm{Au} \\
\mathrm{Ni}\end{array}$ & $\mathrm{Cu} \mathrm{Zn}$ As & $\begin{array}{l}\mathrm{Cu} \mathrm{Zn} \mathrm{Pb} \mathrm{As} \\
\mathrm{Cd}\end{array}$ & $\begin{array}{l}\text { Ag Cu As Pb Zn } \\
\text { Bi Co Sb Te Se } \\
\text { Cd }\end{array}$ & $\mathrm{Ag} \mathrm{Cu} \mathrm{Pb} \mathrm{Zn} \mathrm{As}$ & $\begin{array}{l}\mathrm{Ag} \mathrm{Cu} \mathrm{Pb} \\
\mathrm{Zn}\end{array}$ & $\begin{array}{l}\mathrm{Au} \mathrm{Ag} \mathrm{Pb} \mathrm{Zn} \\
\text { Fe As Mo Co } \\
\text { Sb Bi }\end{array}$ & $\begin{array}{l}\text { Ag Pb Zn } \\
\text { As Mo Co }\end{array}$ \\
\hline \multicolumn{9}{|c|}{ Ore minerals } \\
\hline \multicolumn{9}{|c|}{ Iron sulfide minerals } \\
\hline Marcasite & & & $\mathrm{X}$ & $\mathrm{X}$ & & & & \\
\hline Pyrite & & $\mathrm{X}$ & $\mathrm{X}$ & $\mathrm{X}$ & $\mathrm{XX}$ & & $\mathrm{XX}$ & $\mathrm{XX}$ \\
\hline Pyrrhotite & $\mathrm{X}$ & $\mathrm{X}$ & $\mathrm{X}$ & $\mathrm{XX}$ & $\mathrm{X}$ & $\mathrm{XX}$ & $\mathrm{X}$ & $\mathrm{X}$ \\
\hline \multicolumn{9}{|c|}{ Other sulfide minerals } \\
\hline Arsenopyrite & & $\mathrm{X}$ & $\mathrm{X}$ & $\mathrm{X}$ & $\mathrm{X}$ & & & \\
\hline Bismuthinite & & & & $\mathrm{X}$ & & & $\mathrm{X}$ & \\
\hline Bornite & & & & & $\mathrm{X}$ & & $\mathrm{X}$ & $\mathrm{X}$ \\
\hline Cobaltite & $\mathrm{X}$ & & & & & & $\mathrm{X}$ & \\
\hline Chalcopyrite & $\mathrm{X}$ & $\mathrm{X}$ & $\mathrm{X}$ & $\mathrm{X}$ & $\mathrm{X}$ & & $\mathrm{X}$ & $\mathrm{X}$ \\
\hline Galena & & & & $\mathrm{X}$ & $\mathrm{X}$ & & $\mathrm{X}$ & $\mathrm{X}$ \\
\hline Molybdenite & & & & & $\mathrm{X}$ & & $\mathrm{X}$ & \\
\hline Sphalerite & & $\mathrm{X}$ & $\mathrm{X}$ & $\mathrm{X}$ & $\mathrm{X}$ & & $\mathrm{X}$ & $\mathrm{X}$ \\
\hline \multicolumn{9}{|c|}{ Non-sulfide ore minerals } \\
\hline Cassiterite & X(rare) & & & & & & & \\
\hline Gold/electrum & & & & $\mathrm{X}$ & $\mathrm{X}$ & $\mathrm{X}$ & $\mathrm{X}$ & $\mathrm{X}$ \\
\hline Hematite & & & $\mathrm{X}$ & & $\mathrm{X}$ & & $\mathrm{X}$ & \\
\hline Magnetite & $\mathrm{X}$ & $\mathrm{X}$ & $\mathrm{X}$ & & $\mathrm{X}$ & $\mathrm{X}$ & $\mathrm{X}$ & \\
\hline \multicolumn{9}{|l|}{ Scheelite } \\
\hline $\begin{array}{l}\text { Other ore } \\
\text { minerals (minor } \\
\text { or less common) }\end{array}$ & & & & $\begin{array}{l}\mathrm{Bi}^{0} \text {, maldonite, } \\
\text { loellingite, } \\
\text { hedleyite,pearcite, } \\
\text { stannite,hessite, } \\
\text { and gersdorffite }\end{array}$ & $\begin{array}{l}\mathrm{Bi}^{\circ} \text {, hedleyite, } \\
\text { and hessite }\end{array}$ & & $\begin{array}{l}\text { Cosalite, } \\
\text { enargite, } \\
\text { tennantite, } \\
\text { tetrahedrite, and } \\
\text { loellingite }\end{array}$ & \\
\hline
\end{tabular}


Table 3a. Continued.

\begin{tabular}{|c|c|c|c|c|c|c|c|c|}
\hline \multirow{2}{*}{$\begin{array}{l}\text { Deposit Type } \\
\text { Subtype } \\
\end{array}$} & \multicolumn{2}{|c|}{ W skarn } & \multicolumn{2}{|c|}{ W-F skarn } & \multicolumn{2}{|c|}{ Sn skarn } & \multirow[t]{2}{*}{ Zn-Pb skarn } & \multirow{2}{*}{$\begin{array}{l}\text { Polymetallic } \\
\text { carbonate- } \\
\text { replacement }\end{array}$} \\
\hline & Reduced & Oxidized & Mo-poor & Mo-rich & Skarn & Sn replacement & & \\
\hline Major metals & $\mathrm{W} \mathrm{Cu}$ & W Mo & W F Be & W Mo Bi F & Sn W F As & Sn F As Bi & $\mathrm{Zn} \mathrm{Pb} \mathrm{Ag}$ & $\mathrm{Pb} \mathrm{Zn} \mathrm{Ag} \mathrm{Cu}$ \\
\hline Minor and trace metals & $\mathrm{Bi} \mathrm{Au}$ & $\begin{array}{l}\mathrm{Cu} \mathrm{Zn} \mathrm{Ag} \\
\mathrm{Bi}\end{array}$ & Zn Sn & Be Sn Ag Zn & $\mathrm{Be} \mathrm{Bi}$ & $\mathrm{Zn} \mathrm{Ag} \mathrm{Pb}$ & $\begin{array}{l}\text { Mn Cu Cu Au As } \\
\text { W F Sn W Be }\end{array}$ & $\begin{array}{l}\text { Au Mo As Bi Sb } \\
\text { Mn }\end{array}$ \\
\hline \multicolumn{9}{|c|}{ Ore minerals } \\
\hline \multicolumn{9}{|l|}{ Iron sulfide minerals } \\
\hline Marcasite & & & & & & & & $\mathrm{X}$ \\
\hline Pyrite & & $\mathrm{X}$ & $\mathrm{X}$ & $\mathrm{X}$ & $\mathrm{X}$ & $\mathrm{X}$ & $\mathrm{X}$ & $\mathrm{XX}$ \\
\hline Pyrrhotite & $\mathrm{X}$ & & & & $\mathrm{XX}$ & $\mathrm{XX}$ & $\mathrm{X}$ & $\mathrm{X}$ \\
\hline \multicolumn{9}{|l|}{ Other sulfide minerals } \\
\hline Arsenopyrite & & & & & $\mathrm{X}$ & $\mathrm{X}$ & $\mathrm{X}$ & $\mathrm{X}$ \\
\hline Bismuthinite & & & & & & & & $\mathrm{X}$ \\
\hline Bornite & & & & & & & & $\mathrm{X}$ \\
\hline \multicolumn{9}{|l|}{ Cobaltite } \\
\hline Chalcopyrite & $\mathrm{X}$ & $\mathrm{X}$ & & & $\mathrm{X}$ & $\mathrm{X}$ & $\mathrm{X}$ & $\mathrm{X}$ \\
\hline Galena & & & & & & $\mathrm{X}$ & $\mathrm{X}$ & $\mathrm{X}$ \\
\hline Molybdenite & & & & $\mathrm{X}$ & & & & \\
\hline Sphalerite & $\mathrm{X}$ & & $\mathrm{X}$ & & $\mathrm{X}$ & $\mathrm{X}$ & $\mathrm{X}$ & $\mathrm{X}$ \\
\hline \multicolumn{9}{|l|}{ Non-sulfide ore minerals } \\
\hline Cassiterite & & & & $\mathrm{X}$ & $\mathrm{X}$ & $\mathrm{X}$ & & \\
\hline Gold/electrum & $\mathrm{X}$ & & & & & & & $\mathrm{X}$ \\
\hline \multicolumn{9}{|l|}{ Hematite } \\
\hline Magnetite & & $\mathrm{X}$ & & & & & $\mathrm{X}$ & $\mathrm{X}$ \\
\hline Scheelite & $\mathrm{X}$ & $\mathrm{X}$ & $\mathrm{X}$ & $\mathrm{X}$ & $\mathrm{X}$ & & & \\
\hline $\begin{array}{l}\text { Other ore minerals } \\
\text { (minor or less } \\
\text { common) }\end{array}$ & & & $\begin{array}{l}\text { Fluorite, } \\
\text { Be } \\
\text { silicates }\end{array}$ & $\begin{array}{l}\text { Fluorite, } \\
\text { wolframite }\end{array}$ & $\begin{array}{l}\text { Stannite, } \\
\text { wolframite }\end{array}$ & Ilmenite & & $\begin{array}{l}\text { Digenite, enargite, } \\
\text { argenite, } \\
\text { tetrahedrite, Bi- } \\
\text { Te-Hg minerals } \\
\text { such as hessite, } \\
\text { petzite, and } \\
\text { pyrargyrite }\end{array}$ \\
\hline
\end{tabular}


Table 3. Mineralogical and metal associations of skarn and polymetallic carbonate-replacement deposits.

B. Gangue minerals. [In addition to the minerals listed, quartz is ubiquitous. See references in table 2 for data sources]

\begin{tabular}{|c|c|c|c|c|c|c|c|c|}
\hline Deposit Type & \multicolumn{3}{|c|}{ Fe skarn } & \multicolumn{3}{|c|}{ Au skarn } & \multicolumn{2}{|l|}{ Cu skarn } \\
\hline Subtype & Calcic & Magnesian & $\begin{array}{l}\text { Scapolite- } \\
\text { albite }\end{array}$ & Calcic reduced & Calcic & Magnesian & Copper & $\begin{array}{l}\text { Copper- } \\
\text { gold }\end{array}$ \\
\hline \multicolumn{9}{|c|}{ Gangue minerals (Carbonates in bold) } \\
\hline Albite & & & $\mathrm{X}$ & & & & & \\
\hline Amphibole & $\mathrm{X}$ & $\mathrm{X}$ & $\mathrm{X}$ & $\mathrm{X}$ & & $\mathrm{X}$ & $\mathrm{X}$ & \\
\hline Anhydrite & & & & & & & & $\mathrm{X}$ \\
\hline \multicolumn{9}{|l|}{ Barite } \\
\hline Biotite & & $\mathrm{X}$ & & & $\mathrm{X}$ & $\mathrm{X}$ & $\mathrm{X}$ & \\
\hline Calcite & $\mathrm{X}$ & $\mathrm{X}$ & $\mathrm{X}$ & $\mathrm{X}$ & $\mathrm{X}$ & $\mathrm{X}$ & $\mathrm{X}$ & $\mathrm{X}$ \\
\hline Chlorite & $\mathrm{X}$ & $\mathrm{X}$ & $\mathrm{X}$ & $\mathrm{X}$ & $\mathrm{X}$ & $\mathrm{X}$ & $\mathrm{X}$ & \\
\hline Epidote & $\mathrm{X}$ & & $\mathrm{X}$ & $\mathrm{X}$ & $\mathrm{X}$ & & $\mathrm{X}$ & \\
\hline \multicolumn{9}{|l|}{ Fluorite } \\
\hline Forsterite & & $\mathrm{X}$ & & & & $\mathrm{X}$ & & \\
\hline Garnet & $\mathrm{X}$ & & $\mathrm{X}$ & $\mathrm{X}$ & $\mathrm{X}$ & & $\mathrm{X}$ & $\mathrm{X}$ \\
\hline K-feldspar & & & & $\mathrm{X}$ & $\mathrm{X}$ & $\mathrm{X}$ & $\mathrm{X}$ & \\
\hline \multicolumn{9}{|c|}{ Muscovite/sericite } \\
\hline Pyroxene & $\mathrm{X}$ & $\mathrm{X}$ & $\mathrm{X}$ & $\mathrm{X}$ & $\mathrm{X}$ & $\mathrm{X}$ & $\mathrm{X}$ & $\mathrm{X}$ \\
\hline Scapolite & & & $\mathrm{X}$ & $\mathrm{X}$ & & & & \\
\hline Serpentine & & $\mathrm{X}$ & & & & $\mathrm{X}$ & & \\
\hline Siderite & & & & $\mathrm{X}$ & & & & \\
\hline Talc & & $\mathrm{X}$ & & & & & & \\
\hline Vesuvianite & & & & $\mathrm{X}$ & & $\mathrm{X}$ & $\mathrm{X}$ & \\
\hline Wollastonite & & & & $\mathrm{X}$ & & & $\mathrm{X}$ & \\
\hline \multicolumn{9}{|l|}{ Zeolites } \\
\hline $\begin{array}{l}\text { Other gangue } \\
\text { minerals }\end{array}$ & Ilvaite & $\begin{array}{l}\text { Spinel,apatite, } \\
\text { ludwigite, humite, } \\
\text { clinohumite, } \\
\text { chondrodite, } \\
\text { magnesite, and } \\
\text { periclase }\end{array}$ & $\begin{array}{l}\text { Zeolites, } \\
\text { apatite, } \\
\text { prehnite, and } \\
\text { titanite }\end{array}$ & $\begin{array}{l}\text { Clays, boron } \\
\text { minerals, and } \\
\text { prehnite }\end{array}$ & Clay & $\begin{array}{l}\text { Zoisite, } \\
\text { prehnite, } \\
\text { and spinel }\end{array}$ & & \\
\hline
\end{tabular}


Table 3b. Continued.

\begin{tabular}{|c|c|c|c|c|c|c|c|c|}
\hline \multirow{2}{*}{$\begin{array}{l}\text { Deposit type } \\
\text { Subtype }\end{array}$} & \multicolumn{2}{|c|}{ W skarn } & \multicolumn{2}{|r|}{ W-F skarn } & \multicolumn{2}{|c|}{ Sn skarn and replacement } & \multirow[t]{2}{*}{ Zn-Pb skarn } & \multirow{2}{*}{$\begin{array}{l}\text { Polymetallic } \\
\text { carbonate- } \\
\text { replacement }\end{array}$} \\
\hline & Reduced & Oxidized & Mo-poor & Mo-rich & Skarn & Sn replacement & & \\
\hline \multicolumn{9}{|c|}{ Gangue minerals (Carbonates in bold) } \\
\hline Albite & & & & & & & & \\
\hline Amphibole & $\mathrm{X}$ & $\mathrm{X}$ & $\mathrm{X}$ & $\mathrm{X}$ & $\mathrm{X}$ & & $\mathrm{X}$ & \\
\hline \multicolumn{9}{|l|}{ Anhydrite } \\
\hline Barite & & & & & & & & $\mathrm{X}$ \\
\hline Biotite & $\mathrm{X}$ & $\mathrm{X}$ & & $\mathrm{X}$ & & & & \\
\hline Calcite & $\mathrm{X}$ & $\mathrm{X}$ & $\mathrm{X}$ & $\mathrm{X}$ & $\mathrm{X}$ & $\mathrm{X}$ & $\mathrm{X}$ & $\mathrm{X}$ \\
\hline Chlorite & $\mathrm{X}$ & $\mathrm{X}$ & $\mathrm{X}$ & & $\mathrm{X}$ & $\mathrm{X}$ & $\mathrm{X}$ & \\
\hline Epidote & & $\mathrm{X}$ & $\mathrm{X}$ & & $\mathrm{X}$ & & $\mathrm{X}$ & \\
\hline Fluorite & & & $\mathrm{X}$ & $\mathrm{X}$ & $\mathrm{X}$ & $\mathrm{X}$ & & $\mathrm{X}$ \\
\hline \multicolumn{9}{|l|}{ Forsterite } \\
\hline Garnet & $\mathrm{X}$ & $\mathrm{X}$ & $\mathrm{X}$ & $\mathrm{X}$ & $\mathrm{X}$ & & $\mathrm{X}$ & \\
\hline \multicolumn{9}{|l|}{ K-feldspar } \\
\hline Muscovite/sericite & $\mathrm{X}$ & & $\mathrm{X}$ & $\mathrm{X}$ & $\mathrm{X}$ & $\mathrm{X}$ & & \\
\hline Pyroxene & $\mathrm{X}$ & $\mathrm{X}$ & $\mathrm{X}$ & $\mathrm{X}$ & $\mathrm{X}$ & & $\mathrm{X}$ & \\
\hline Scapolite & & & $\mathrm{X}$ & & & & & \\
\hline Serpentine & & & & & & $\mathrm{X}$ & & \\
\hline Siderite & & & & & & & & $\mathrm{X}$ \\
\hline \multicolumn{9}{|l|}{ Talc } \\
\hline Vesuvianite & & & & $\mathrm{X}$ & & & & \\
\hline Wollastonite & & $\mathrm{X}$ & & & $\mathrm{X}$ & & & \\
\hline \multicolumn{9}{|l|}{ Zeolites } \\
\hline Other gangue minerals & & & & & $\begin{array}{l}\text { Malayite, } \\
\text { danburite, } \\
\text { datolite, Be } \\
\text { silicates, and } \\
\text { tourmaline }\end{array}$ & & $\begin{array}{l}\text { Bustamite, } \\
\text { rhodonite, ilvaite, } \\
\text { dannemorite, and } \\
\text { rhodochrosite } \\
\text { Skarn silicates are } \\
\text { distinctly Mn-rich. }\end{array}$ & $\begin{array}{l}\text { Dolomite, } \\
\text { rhodochrosite }\end{array}$ \\
\hline
\end{tabular}


Table 4. Mineralogy of skarn stages for iron skarn subtypes.

\begin{tabular}{|l|l|l|l|}
\hline Iron skarn subtype & Calcic & Magnesian & Scapolite- albite \\
\hline Prograde minerals & $\begin{array}{l}\text { Garnet (grossular- } \\
\text { andradite), pyroxene } \\
\text { (ferrosalite). }\end{array}$ & $\begin{array}{l}\text { Forsterite, calcite, spinel, } \\
\text { diopside, magnetite, } \\
\text { apatite, and ludwigite- } \\
\text { group minerals. }\end{array}$ & Garnet, pyroxene. \\
\hline Retrograde minerals & $\begin{array}{l}\text { Amphibole, chlorite, and } \\
\text { epidote. }\end{array}$ & $\begin{array}{l}\text { Amphibole, humite, } \\
\text { serpentine, phlogopite, } \\
\text { talc, chlorite, chondrodite, } \\
\text { magnesite, and } \\
\text { clinohumite. }\end{array}$ & $\begin{array}{l}\text { Scapolite, albite, chlorite, } \\
\text { calcite, zeolites, actinolite, } \\
\text { epidote, apatite, quartz, } \\
\text { prehnite, and sphene. }\end{array}$ \\
\hline Ore minerals & $\begin{array}{l}\text { Magnetite, chalcopyrite, } \\
\text { cobaltite, and pyrrhotite. }\end{array}$ & $\begin{array}{l}\text { Magnetite, pyrite, } \\
\text { chalcopyrite, sphalerite, } \\
\text { pyrrhotite, and } \\
\text { arsenopyrite. }\end{array}$ & $\begin{array}{l}\text { Magnetite, hematite, } \\
\text { pyrite, marcasite, } \\
\text { chalcopyrite, sphalerite, } \\
\text { pyrrhotite, and } \\
\text { arsenopyrite. }\end{array}$ \\
\hline
\end{tabular}

skarn deposits; iron-rich gossans develop over copper skarns. In iron skarns, magnetite may alter to hematite, maghemite, goethite, limonite, or lepidocrocite during oxidation and weathering.

Secondary minerals formed by weathering prior to mining in polymetallic carbonate-replacement deposits (Plumlee and others, 1995) include relatively insoluble minerals indicative of deposition from relatively high-pH water: anglesite, cerussite, smithsonite, hemimorphite, hydrozincite, manganese oxide minerals (psilomelane, pyrolusite, and braunite), iron oxide minerals (limonite), cerargyrite, and jarosite. In contrast, secondary minerals formed by recent weathering after the onset of mining are primarily soluble sulfate minerals indicative of deposition from locally acidic water. Examples are zinc sulfate minerals, including goslarite, which grades to magnesium-rich epsomite and iron sulfate minerals such as copiapite, coquimbite, melanterite, szomolnokite, fibroferrite, and roemerite. Chalcanthite is the dominant copper sulfate mineral although others also may be present.

\section{Soil, Sediment, and Tailings Signatures}

Geochemical data for soils and sediments acquired during mineral exploration can be used to establish premining baseline conditions. Knowledge of the pre-mining soil and sediment signatures for specific deposit types in specific climates can help land managers set realistic post-mining remediation goals. These data also provide analogues for areas where historic mining has obliterated pre-existing baseline conditions (du Bray, 1995). In disturbed areas, stream sediment sampling upstream and downstream from mine sites provides a measure of the changes due to mining. Geochemical and mineralogical data for tailings, especially when paired with leaching studies, indicate the potential for metal mobility and acid generation. Examples of data for pre-mining soils and post-mining tailings for a number of deposit types are discussed in the following section.

\section{Pre-mining}

Soil sampling has been a useful exploration tool for finding gold skarns. Hastings and Harrold (1988, fig. 7) showed that ranges for selected trace elements in rocks and soil at the Beal calcic reduced gold-skarn deposit generally overlap. Arithmetic means for most trace element concentrations in soils over this deposit are similar to concentrations in rock samples, with the exception of gold ( $0.05 \mathrm{ppm}$ in soil, $1 \mathrm{ppm}$ in rock). Mean values for arsenic, copper, and zinc for both soil and rock at the Beal deposit are between 10 and 100 ppm, and soil appears to be slightly enriched in arsenic and zinc relative to rocks.

Soils associated with similar deposits in similar climates can have distinctly different soil geochemical signatures. A number of gold skarns and gold-bearing copper skarns are associated with 39 Ma granitoid intrusions in north-central Nevada (fig. 2). This region has an arid climate (Bailey and others, 1994); precipitation averages 100 to $300 \mathrm{~mm}$ and elevations range from 1,200 to 3,000 m. In the general area of the McCoy, Nevada, calcic oxidized gold skarn deposit (fig. 2), soil contains as much as 15 to $20 \mathrm{ppm}$ arsenic and as much as 200 to $300 \mathrm{ppm}$ copper. Prior to large-scale mining at McCoy, an area as much as $750 \mathrm{~m}$ wide contained soil with more than $5 \mathrm{ppm}$ arsenic. In contrast, soils associated with gold-rich copper skarn at the West orebody, a few miles north of McCoy at Copper Canyon, Nevada (fig. 2) are much more arsenic-rich. Analyses of the minus-80-mesh fraction of 140 soil samples in the general area of the West orebody, indicated alkaline soils ( $\mathrm{pH}$ typically 9.0 to 9.6). Calcite was 
present in about one-third of the samples (Theodore and Blake, 1978). Contents of silver, arsenic, gold, copper, lead, and mercury in soil above the West orebody skarn are generally anomalous. Arsenic is $>160 \mathrm{ppm}$ in some soil samples. Median values are: 3 ppm silver, 0.15 ppm gold, 150 ppm copper, 50 ppm lead, and 0.7 ppm mercury. Mercury contents in the soil appear to be higher along some traverses just outside or beyond the surface projection of underlying ore. These are natural concentrations, uncontaminated by mining activities.

The buried, carbonate-hosted Rubiales zinc-lead skarn deposit in the Lugo province, northwestern Spain, was discovered by a soil survey that detected soil metal anomalies generated by weathering of sphalerite, galena, and chalcopyrite in the silicified alteration halo around the deposit (Arias, 1996). The deposit was not detected by a stream sediment survey. The zinc soil anomaly was more extensive than the lead or copper anomalies, reflecting the greater mobility of zinc in the surface environment. The copper anomaly was highest over feeder zones where highest grade ores subsequently were discovered.

\section{Post-mining}

The mineralogy and geochemistry of mine waste and tailings, and the waters in contact with them, vary widely among skarn types and subtypes, and in response to climatic variables. For example, calcic iron skarn ore at Cornwall, Pennsylvania, has a grade of 40-42 percent iron. Mining of this ore produces typical final tailings containing 7.7 weight percent iron, 0.61 weight percent sulfur, and 0.04 weight percent copper (Lapham, 1968). These tailings are similar to typical iron ore tailings, which contain 7 to 9 weight percent iron as reported by Andrews (1975). Weathering of these tailings yields insoluble iron hydroxides.

Boulet and Larocque (1998) conducted a comparative mineralogical and geochemical study of sulfide-rich mine tailings at two sites in New Mexico. The copper skarn at the Cyprus-Pinos Altos mine, New Mexico, which closed in 1995, and the Cleveland zinc-lead skarn deposit, which closed in 1950, are similar in mineralogy, geochemistry, geology and climactic setting. The impounded copper skarn tailings from Pinos Altos mostly are water-saturated with no secondary phases developed and no evidence of dissolution of primary minerals. Tailings pond pH's are 7 to 8.3. In contrast, the older zinc skarn tailings at the Cleveland deposit, which are in a valley at the headwaters of an ephemeral stream, are oxidized, cemented, and dominated by the secondary minerals jarosite, goethite, hematite, and Fe-oxyhydroxides. A cemented hardpan layer at $46 \mathrm{~cm}$ depth in the Cleveland tailings sequesters a number of potentially toxic metals within the tailings pile. This study also demonstrated that although lead in the tailings was present at much greater concentrations than cadmium, the reverse is observed in the stream where mobile zinc and cadmium are enriched relative to lead. The result of this paired study of the solids and waters showed that zinc and cadmium mobility from tailings is of greater concern than lead mobility.

The Hillsboro mining district of New Mexico includes two types of polymetallic carbonate-replacement deposits: lead-zinc deposits and silver-manganese deposits. Munroe and others (1999) characterized waste rock piles at abandoned mines in the Hillsboro district. The study showed that: (1) a homogeneous composite of 15 to 30 samples was sufficient to adequately characterize the waste rock piles, which is similar to the USGS method developed by Smith and others (2000), (2) chemical analysis of six different size fractions showed that the less-than0.25 -mm-grain-size fraction contained the highest metal concentrations, (3) metal concentrations in the carbonatehosted lead-zinc waste rock pile, though somewhat variable by grain size, are $\mathrm{Zn} \geq \mathrm{Pb}(1,000$ to $10,000 \mathrm{ppm})>\mathrm{Cu}$ $(100 \mathrm{ppm})>$ As (20 to $100 \mathrm{ppm})$, and (4) metal concentrations in the carbonate-hosted Ag-Mn waste rock pile are $\mathrm{Zn} \geq \mathrm{Pb}(1,500$ to $2,000 \mathrm{ppm})>\mathrm{Cu}(100 \mathrm{ppm})>\mathrm{As}(<10 \mathrm{ppm})$.

In the semi-arid climate of the San Luis Potosi area of Mexico, mine waste from 200 years of mining and processing active $\mathrm{Cu}-\mathrm{Au}$ skarn (Cobriza and Dolores mines) and inactive Ag-Pb-Zn (Santa Maria de La Paz) vein deposits is dispersed from uncovered dumps by strong winds and washed out during seasonally heavy rains. This dispersal affects an area of $100 \mathrm{~km}^{2}$ (Castro-Larragoita and others, 1997). Most of this environmental effect is attributed to the oxidized La Paz tailings, which are composed of calcite, quartz, pyrite, arsenopyrite, sphalerite, galena, chalcopyrite, and bornite. Arsenic is released as dissolved arsenate from the base of the dumps where secondary iron sulfate salts contain up to $10 \%$ arsenic. Windblown tailings contaminate soils over distances of more than 5 kilometers. Contamination by waterborn material from tailings extends up to 10 kilometers from the site. Mine waters are near-neutral and some are used for irrigation. However, plants irrigated with this water and used for animal fodder contain elevated concentrations of lead and cadmium. The Cobriza skarn tailings consist of quartz, pyroxene, wollastonite, calcite, and relatively unoxidized sulfide minerals. 
Table 5. Secondary minerals associated with skarn and polymetallic carbonate-replacement deposits. [Secondary minerals formed by weathering prior to mining or by weathering after the onset of mining (includes outcrops, mine waste, and tailings). Secondary minerals are not widely reported for these deposit types, so this list should be considered preliminary. No data are available to distinguish secondary mineral assemblages among the deposit subtypes described in tables $\underline{2}$ and $\underline{3}$. Clays are ubiquitous as gangue minerals associated with retrograde alteration and as secondary minerals formed by weathering.]

\begin{tabular}{|c|c|c|c|c|c|c|c|}
\hline Deposit type & Fe skarn & Au skarn & Cu skarn & W skarn & Sn skarn & Zn-Pb skarn & $\begin{array}{l}\text { Polymetallic } \\
\text { carbonate- } \\
\text { replacement }\end{array}$ \\
\hline \multicolumn{8}{|c|}{ Fe and Mn oxide, oxyhydroxide, and hydroxysulfate minerals } \\
\hline Goethite & $\mathrm{X}$ & $\mathrm{X}$ & $\mathrm{X}$ & $\mathrm{X}$ & & $\mathrm{X}$ & $\mathrm{X}$ \\
\hline Hematite & $\mathrm{X}$ & $\mathrm{X}$ & $\mathrm{X}$ & & & & $\mathrm{X}$ \\
\hline $\begin{array}{l}\text { Jarosite (K, Na, } \\
\left.\mathrm{H}_{3} \mathrm{O}^{+}\right)\end{array}$ & & $\mathrm{X}$ & & & & $\mathrm{X}$ & $\mathrm{X}$ \\
\hline Lepidocrocite & & & & & & $\mathrm{X}$ & \\
\hline Schwertmannite & & & & & & $\mathrm{X}$ & \\
\hline $\begin{array}{l}\text { Mn -oxide } \\
\text { minerals } \\
\text { (pyrolusite, etc.) }\end{array}$ & & $\mathrm{X}$ & $\mathrm{X}$ & $\mathrm{X}$ & & $\mathrm{X}$ & $\mathrm{X}$ \\
\hline \multicolumn{8}{|c|}{ Secondary carbonate minerals } \\
\hline Azurite & & $\mathrm{X}$ & $\mathrm{X}$ & & & & \\
\hline Malachite & & $\mathrm{X}$ & $\mathrm{X}$ & & & & \\
\hline Cerussite & & & & & & $\mathrm{X}$ & $\mathrm{X}$ \\
\hline Smithsonite & & & & & & $\mathrm{X}$ & $\mathrm{X}$ \\
\hline \multicolumn{8}{|c|}{ Secondary sulfate minerals (*, highly soluble) } \\
\hline Anglesite & & & & & & $\mathrm{X}$ & $\mathrm{X}$ \\
\hline \multicolumn{8}{|l|}{ Butlerite* } \\
\hline Chalcanthite* & & & & & & & $\mathrm{X}$ \\
\hline Copiapite* & & & & & & & $\mathrm{X}$ \\
\hline Coqiumbite* & & & & & & & $\mathrm{X}$ \\
\hline Epsomite* & & & & & & & $\mathrm{X}$ \\
\hline Fibroferrite & & $\mathrm{X}$ & & & & & $\mathrm{X}$ \\
\hline Goslarite* & & & & & & & $\mathrm{X}$ \\
\hline Gypsum & & & & & & $\mathrm{X}$ & \\
\hline Hexahydrite* & & & & & & $\mathrm{X}$ & $\mathrm{X}$ \\
\hline Melanterite* & & & & & & $\mathrm{X}$ & $\mathrm{X}$ \\
\hline Penetahydrite* & & & & & & $\mathrm{X}$ & \\
\hline Rozenite* & & & & & & $\mathrm{X}$ & \\
\hline Starkeyite* & & $\mathrm{X}$ & & & & $\mathrm{X}$ & \\
\hline
\end{tabular}




\begin{tabular}{|c|c|c|c|c|c|c|c|}
\hline Deposit type & Fe skarn & Au skarn & Cu skarn & W skarn & Sn skarn & Zn-Pb skarn & $\begin{array}{l}\text { Polymetallic } \\
\text { carbonate- } \\
\text { replacement }\end{array}$ \\
\hline Other minerals & & $\begin{array}{l}\text { Chrysocolla } \\
\text { Nabesna Fe-Au skarn, } \\
\text { AK: cacoxenite, kalinite, } \\
\text { rostite, carbonate } \\
\text { hydroxylapatite, } \\
\text { aplowite, and ferrian } \\
\text { sepiolite } \\
\text { McCoy calcic, oxidized } \\
\text { Au skarn: claudetite, and } \\
\text { willemite }\end{array}$ & Chrysocolla & & varlamoffite & $\begin{array}{l}\text { Hemimorphite, } \\
\text { halite, } \mathrm{S}^{\mathrm{o}}\end{array}$ & $\begin{array}{l}\text { Chrysocolla, } \\
\text { hydrozincite, } \\
\text { cerargyrite, } \\
\text { szomolnokite, and } \\
\text { roemerite }\end{array}$ \\
\hline References & $\begin{array}{l}\text { Hammarstrom } \\
\text { and others, } \\
\underline{1995 \mathrm{a}}\end{array}$ & $\begin{array}{l}\text { Eppinger and others, } \\
\underline{1997} \\
\underline{\text { Brooks and others, } 1991}\end{array}$ & $\begin{array}{l}\frac{\text { Hammarstrom }}{\text { and others, }} \\
\underline{1995 \mathrm{c}}\end{array}$ & $\begin{array}{l}\frac{\text { Hammarstrom }}{\text { and others, }} \\
\underline{1995 \mathrm{~b}}\end{array}$ & $\begin{array}{l}\frac{\text { Hammarstrom }}{\text { and others, }} \\
\underline{1995 \mathrm{~b}}\end{array}$ & $\begin{array}{l}\text { Walder and } \\
\text { Chavez, 1995; } \\
\text { Boulet and } \\
\text { Larocque, } 1997\end{array}$ & $\begin{array}{l}\frac{\text { Plumlee and }}{\text { others, } 1995} \\
\text { Desborough and } \\
\text { others, } 1999 \\
\text { Wallace, } 1993\end{array}$ \\
\hline
\end{tabular}


Topography and Physiography

Skarn deposits in the western conterminous United States typically are present in mountain ranges, but also are known in a variety of other settings. Some skarn deposits are buried in fault blocks under Tertiary or Quaternary basin fill.

\section{Hydrology}

In some deposits, shear zones and faults are important structural controls for channeling hydrothermal and mineralizing fluids. In other deposits, lithologic contacts serve as fluid conduits. Post-mineralization faults also may channel subsequent fluids. At Minera Bismark, a zinc-lead skarn deposit in northern Mexico, water flows continuously along a major post-mineralization fault, as well as along other faults and fractures in the granitic rocks. A pumping system is required to dewater the orebody during mining (Mining Magazine, 1994). Surface ferricrete deposits represent iron remobilized from weathered sulfide minerals by surface and subsurface water and indicate locations of former springs or drainage seepages (Plumlee, 1998). Mapping of ferricrete deposits may provide clues to pre-mining discharge points that could be reactivated if the groundwater flow is perturbed by adit plugging, for example. Manganese or iron bog deposits provide similar clues to paleohydrology. Faults at Copper Canyon, Nevada, are known to have channeled ground water for several kilometers during periods of high ground-water availability. Natural ground water flow in the vicinity of polymetallic carbonate-replacement deposits dominantly is along fractures and faults or through karst systems in carbonate rocks. Mine workings also substantially enhance ground-water permeability. Karst, where present, can impose significant control on the local hydrologic regime because of its ability to channel ground water for long distances from mine sites. Some flow also may occur in sedimentary rock aquifers, including sandstone and fractured carbonate rocks.

\section{Drainage Signatures}

Relatively few data are available for skarn and polymetallic carbonate-replacement drainage signatures relative to the data available for other deposit types. In general, acid mine drainage is not a significant problem in most carbonate-hosted deposits. Plumlee and others (1999) and Ficklin and others (1992) showed that drainage water compositions from skarn and polymetallic carbonate-replacement deposits are variable. Water draining carbonatepoor copper skarn ores at New World, Montana, present an unusual case because the waters are relatively acidic and copper rich (see case study by Kirk and Kirk, this volume). Mine-drainage associated with most polymetallic carbonate-replacement deposits is near-neutral because of the acid-neutralizing capacity of the carbonate host rocks. However, waters draining pyrite-rich deposits may contain elevated concentrations of dissolved zinc (up to tens of $\mathrm{mg} / \mathrm{L} \mathrm{Zn}$ ) and copper (up to several $\mathrm{mg} / \mathrm{L} \mathrm{Cu}$ ), especially where low dissolved oxygen concentration inhibits ochre precipitation and therefore limits metal removal by sorption (Plumlee and others, 1999).

Oxidation of galena produced cerussite at the polymetallic carbonate-replacement deposit at Leadville, Colorado. Cerussite is very insoluble under oxidizing conditions and effectively immobilizes lead (Wallace, 1993). Although the ores at Leadville replaced part or all of some carbonate units including the Leadville dolomite, adjacent igneous rocks essentially were unaltered. Surface and groundwater contamination from mining at Leadville and Gilman, Colorado, along with heavy metal concentration in soils and mine tailings, resulted in both of these areas being remediated under Superfund, including the California Gulch and Eagle mine sites. Jerz (1998) conducted leach studies on fluvial tailings in the Arkansas River south of Leadville and showed that the soluble efflorescent sulfate minerals, especially copiapite that forms during wetting-drying cycles, affect the leaching behavior of the tailings and account for the very low $\mathrm{pH}(<2.0)$ and high metals in leachates.

Case studies illustrate the range of drainage signatures associated with some skarn and polymetallic carbonatereplacement deposits. Some case studies that describe drainage geochemistry include reports on (1) the Thompson Creek tungsten skarn in central Idaho (Van Gosen and others, 2000), (2) the Nabesna, Alaska, gold-bearing iron skarn (Eppinger and others, 1999; Eppinger and others, 2000), and (3) the Clayton silver mine, a polymetallic carbonate-replacement deposit in central Idaho (Hammarstrom and others, 2001).

The Thompson Creek tungsten skarn (Van Gosen and others, 2000) is an abandoned mine that was worked briefly in the 1950s. The mine produced 493 tons of ore containing an average grade of $0.77 \% \mathrm{WO}_{3}(\underline{\mathrm{Cook}, 1956)})$ The ore is composed of scheelite, powellite, pyrite, and pyrrhotite in a gangue of garnet, quartz, and calcite. The deposit formed in argillaceous limestone adjacent to granite. Waste piles from the underground and open-pit mining line the floodplain of a creek that drains into the Salmon River. A small pool 30 meters below the collapsed mine adit appears to be adit drainage. This mine effluent and creek waters have pH 5.5 to 5.8. Geochemical analysis of mine waste shows that $\mathrm{Cu}>\mathrm{Zn}>\mathrm{Pb}$. Mine waste leachate (Hageman and Briggs, 2000) had a pH of 3.1; in leachates, $\mathrm{Zn}>\mathrm{Cu}>\mathrm{Pb}$. Dissolved tungsten concentrations were less than $0.5 \mathrm{ppb}$ in all water samples. 
The environmental geochemistry of the Nabesna iron skarn and other mineral deposits in Wrangell-St. Elias National Park, Alaska, was studied by Eppinger and others (2000). Nabesna ore is composed of pyrite, pyrrhotite, magnetite, and chalcopyrite with minor amounts of galena, sphalerite, arsenopyrite, and stibnite. Gold ore mainly occurs in pyrite-quartz veins that crosscut limestone and silica-sulfide-rich skarn; some gold was produced from massive pyrrhotite and magnetite orebodies. Gangue minerals include garnet, wollastonite, vesuvianite, epidote, amphibole, chlorite, scapolite, serpentine, and quartz. Mill tailings form a thin cover ( $<1 \mathrm{~m}$ thick) over an area of several thousand square meters. A variety of soluble secondary sulfate salts were observed on tailings, mine waste, and outcrops (see table 4). Eppinger and others (2000) sampled surface waters over three field seasons that included dry summer periods, intermittent and extended rain events, and spring melt. Total dissolved solids and alkalinities varied over more than two orders of magnitude and $\mathrm{pH}$ ranged from 2.2 to 8.6. Maximum permissible contaminant levels were exceeded for a number of elements during spring melt and summer rain events. Although carbonate host rocks maintain near-neutral surface waters in the mine area and reduce downstream effects of seasonal discharges of acidic waters from fine-grained mill tailings, the study demonstrated that season and surface flow conditions are important controls on the major- and trace-element compositions of surface waters. We know of no other water data for iron skarn deposits. However, chemical analyses of water from iron-ore mines and milling operations in Canada (Ripley and others, 1995) probably are reasonable indicators of mine water discharge characteristics of iron skarns. Like the iron skarn deposits, Canadian iron ore has a low sulfide-mineral content and is dominated by magnetite, hematite, and siderite. Mine water and direct-discharge tailings effluent from these Canadian deposits have $\mathrm{pH}$ of 6.4 to 9 and relatively low dissolved metal contents, including: 0.01 to $0.4 \mathrm{mg} / \mathrm{L}$ copper, 0.05 to $1.3 \mathrm{mg} / \mathrm{L}$ iron, $<1$ $\mathrm{mg} / \mathrm{L}$ lead, and 0.01 to $0.15 \mathrm{mg} / \mathrm{L}$ zinc. Much higher dissolved-metal concentrations, including $>40 \mathrm{mg} / \mathrm{L}$ copper and $>6,000 \mathrm{mg} / \mathrm{L}$ iron, were reported for marine-discharge tailings effluent from these deposits. Although iron is an essential nutrient for plants and animals, extreme iron concentrations downstream from historic, large-scale iron-ore operations can harm salmon and benthic organisms. However, residual materials from iron ore mining generally are considered to have only minor toxicity.

Stream $\mathrm{pH}$ associated with Cyprus-Pinos Altos copper skarn tailings is as low as 2.2, and maximum dissolvedmetal concentrations are: 5,305 ppm Zn, 454 ppm Cu, 1.16 ppm Pb, 17.5 ppm Cd. 1.2 ppm As, and 0.01 ppm Hg (Boulet and Larocque, 1998). Low dissolved-lead concentrations are attributed to precipitation of plumbojarosite. Metal concentrations decrease downstream from the tailings because of dilution by a neutral seep and coprecipitation and sorption of metals by secondary ochre minerals in the streambed (Boulet and Larocque, 1998).

Drainage waters from polymetallic carbonate-replacement deposits typically are near-neutral and low in total dissolved-metal concentrations. However, pyrite-rich deposits, such as those at Leadville, Colorado, can be nearneutral yet carry elevated or extreme (>100,000 ppb) dissolved base-metal concentrations (Plumlee and others, 1999). The Clayton lead-zinc-silver deposit in Idaho is hosted by dolostone (Hammarstrom and others, 2001). Ore is composed of galena, sphalerite, tetrahedrite, and chalcopyrite. Gangue minerals included dolomite, quartz, barite, calcite, fluorite, pyrite, chlorite, siderite, goethite, and garnet. Mining ceased in 1986. An on-site flotation mill produced a lead concentrate. Mill tailings were placed as terraces along steep slopes along a narrow stream valley. Wind and water erosion of a 15-acre pile of fine-grained flotation mill tailings threaten aquatic life in the stream. The U.S. Environmental Protection Agency (2000) stabilized mill tailings and is working with other agencies to develop a long-term site remediation plan. Hammarstrom and others (2001) sampled adit drainage, a stream draining mine tailings, and mine waste for leaching in 1999, prior to tailings stabilization. Results show that all waters associated with the site plot in the near-neutral, low-metal field on a Ficklin diagram (fig. 3).

\section{Climatic Effects}

Acidity and total-metal concentrations in mine drainage in arid environments are several orders of magnitude greater than in more temperate climates because of the concentrating effects of mine effluent evaporation and the resulting "storage" of metals and acidity in highly soluble metal-sulfate minerals. In a 1995 report, the Nevada Bureau of Mines and Geology estimated that fewer than 100 of an estimated 200,000 or more inactive and abandoned mines in the state pose acid-mine drainage concerns. The low number of sites likely to produce acid drainage reflects the extremely arid climate of most of Nevada, where only $10 \%$ of about 15,000 mile of rivers and streams flow year round. The Nevada report included an examination of 72 mines in the state, which were classified by deposit types and included a number of skarn deposits and polymetallic carbonate-replacement deposits. Most of the carbonate-hosted deposits were dry when visited in August of 1995; shaft and adit waters at abandoned mines at two base-metal replacement deposits were near-neutral. Minimal surface water flow in arid areas inhibits generation of significant volumes of highly acidic, metal-enriched drainage. However, concentrated release of these stored contaminants into local watersheds may be initiated by precipitation from brief thunderstorms following a dry spell, or by spring runoff of snow melt. In areas where precipitation exceeds evaporation, metals and acidity can be 
recycled through secondary minerals on a regular basis and soluble secondary minerals can form locally in sheltered areas. Climate influences the extent of pre-mining oxidation and leaching of the upper parts of orebodies to form gossans.

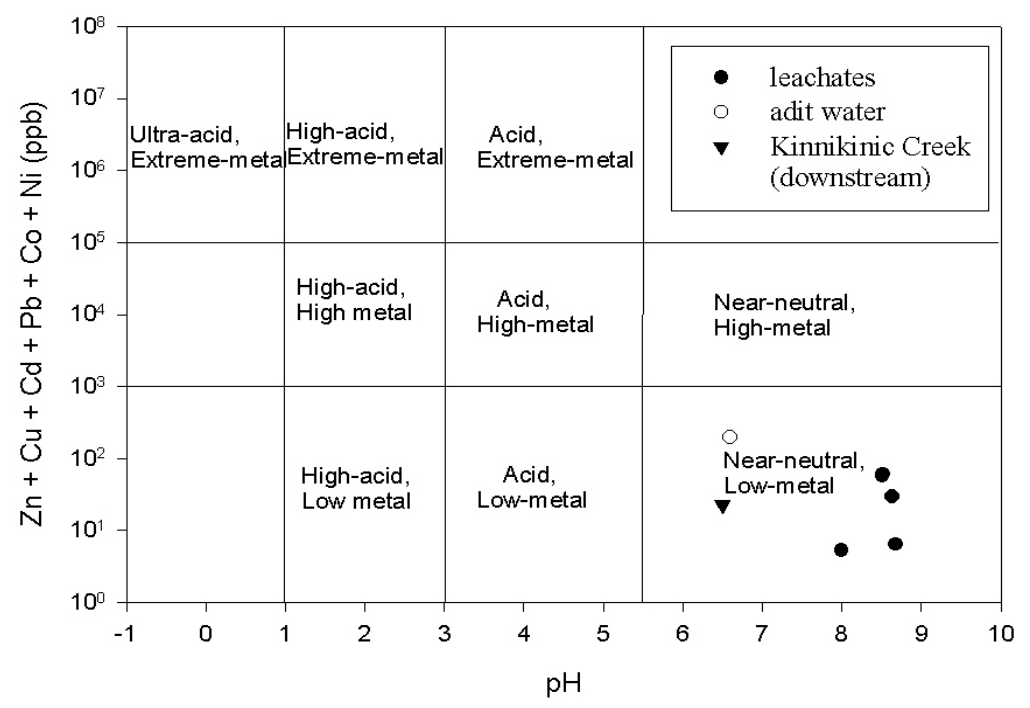

Figure 3. Ficklin diagram showing the sum of selected dissolved metal concentrations in waters associated with the Clayton mine, a polymetallic carbonate-replacement deposit in Custer County, Idaho (Hammarstrom and others, 2001). Water draining from the main adit, water in the creek that drains the mine workings, and leachates from mill tailings and mine waste plot in the near-neutral, low-metal field. Dissolved metal concentrations were below detection limits in creek waters upstream of the mine site.

\section{Potential Environmental Concerns}

(1) Differences in ore mineralogy among subtypes of skarns and polymetallic carbonate-replacement deposits indicate different potentials for acid mine drainage and differences in geoavailability of potentially toxic substances. For example, the principal ore minerals in base- and precious-metal skarns and polymetallic carbonate-replacement deposits are sulfide minerals. The principal ore minerals in tin and iron skarns are the oxide minerals cassiterite and magnetite, respectively. Pyrite is ubiquitous in copper, gold, and zinc-lead skarns and in polymetallic carbonatereplacement deposits and pyrite is reported from all other skarn types. Thus, the potential is present for acid-mine drainage to develop at least locally depending on the distribution of pyrite in mine waste and tailings, the exposure of pyritic waste to oxidative weathering, and the availability of acid-neutralizing minerals.

(2) Carbonate-rich host rocks consume acid, generally inhibit transport of most metals, and produce high alkalinity in surface waters that flow over and through them. Effluent waters from underground mines, and surface runoff from sulfide-rich tailings, can be acidic on a year-round or seasonal basis depending on climate. Maximum permissible contaminant levels in these effluents may be exceeded for dissolved concentrations of Fe, $\mathrm{Al}, \mathrm{Mn}, \mathrm{As}$, $\mathrm{Pb}, \mathrm{Zn}, \mathrm{Cd}, \mathrm{F}$, and sulfate. Some of these potentially toxic metals may be sequestered effectively in hardpan layers in tailings, or in iron ochre precipitating in streams.

(3) Mine waste and mill tailings typically are situated in stream floodplains. During natural floods and(or) impoundment failures, influxes of fine-grained sediments can rapidly degrade downstream aquatic ecosystems, especially fish habitat, both physically and, in some cases, chemically.

(4) Smelter slag may contain elevated $\mathrm{Cu}, \mathrm{Pb}, \mathrm{Zn}$, and other metals. Metal mobility from slag depends on the processing method: metals in slag cooled by air frothing tend to be more easily mobilized than metals in slag cooled by pouring the molten slag on the ground (Plumlee and others, 1995). Soils downwind from smelters can contain elevated concentrations of $\mathrm{Pb}, \mathrm{Zn}, \mathrm{Cu}, \mathrm{As}$, $\mathrm{Sb}, \mathrm{Mo}, \mathrm{Hg}$, and $\mathrm{Au}$.

(5) Mercury typically is not associated with any of the skarn deposit types or with polymetallic carbonate- 
replacement deposits. However, mercury may be present at inactive or abandoned mines that exploited these deposits types, especially where historic placer mining occurred or where gold was produced as a by-product.

\section{ACKNOWLEDGMENTS}

J.A. Souza-Neto kindly provided unpublished data on gold skarn deposits in northeastern Brazil. Joe Briskey provided a substantive and insightful review of the manuscript.

\section{REFERENCES CITED}

Andrews, R.D., 1975, Tailings-Environmental consequences and a review of control strategies, in International conference on heavy metals in the environment, Symposium proceedings, v. 2, Toronto, 1975, p. 645-675.

Anstett, T.F., Bleiwas, D.I., and Hurdelbrink, R.J., 1985, Tungsten availability-Market economy countries: U.S. Bureau of Mines Information Circular 9025.

Arias, D., 1996, A case of successful soil geochemistry - the Rubiales Zn-Pb orebody (NW Spain): Journal of Geochemical Exploration v. 56, p. 229-235.

Bailey, R.G., Avers, P.E., King, Thomas, and McNab, W.H., eds., 1994, Ecoregions and subregions of the United States: U.S. Department of Agriculture Forest Service, 2 sheets, Scale 1:7,500,000.

Boulet, M.P., and Larocque. A.C.L., 1998, A comparative mineralogical and geochemical study of sulphide minetailings at two sites in New Mexico, USA: Environmental Geology v. 33, no. 2/3, p. 130-142.

Boulet, M.P., and Larocque. A.C.L., 1997, Geochemistry of tailings, pore waters, and acidic drainage at the Cleveland Mine Superfund Site in New Mexico, USA: Geological Society of America Abstracts with Programs v. 29, no. 7, p. A174.

Brooks, J.W., Meinert, L.D., Kuyper, B.A., and Lane, M.L., 1991, Petrology and geochemistry of the McCoy gold skarn, Lander County, Nevada, in Raines, G.L. and others, eds., Geology and ore deposits of the Great Basin, Symposium Proceedings, Geological Society of Nevada, Reno, p. 419-442.

Castro-Larrogoitia, J., Kramar, U., and Puchelt, H., 1997, 200 years of mining activities at La Paz/San Luis Potosi/Mexico - Consequences for environment and geochemical exploration: Journal of Geochemical Exploration v. 58, p. 81-91.

Cook, E.F., 1956, Tungsten deposits of south-central Idaho: Idaho Bureau of Mines and Geology Pamphlet No. 108, $40 \mathrm{p}$.

Cox, D.P., 1986a, Descriptive model of W skarn deposits, in Cox, D.P. and Singer, D.A., eds., Mineral deposit models: U.S. Geological Survey Bulletin 1693, p. 55.

1986b, Descriptive model of Fe skarn deposits, in Cox, D.P. and Singer, D.A., eds., Mineral deposit models: U.S. Geological Survey Bulletin 1693, p. 94.

1986c, Descriptive model of Zn-Pb skarn deposits, in Cox, D.P. and Singer, D.A., eds., Mineral deposit models: U.S. Geological Survey Bulletin 1693, p. 90.

Cox, D.P., and Singer, D.A., 1986, Mineral deposit models: U.S. Geological Survey Bulletin 1693, 379 p.

Cox, D.P., and Theodore, T.G., 1986, Descriptive model of Cu skarn deposits, in D.P. and Singer, D.A., eds., Mineral deposit models: U.S. Geological Survey Bulletin 1693, p. 86.

Desborough, G., Leinz, R., Smith, K., Hageman, P. Fey, D., and Nash, T., 1999, Acid generation and metal mobility of some metal-mining related wastes in Colorado: U.S. Geological Survey Open-File Report 99-0332, 18 p.

du Bray, E.A., ed., 1995, Preliminary compilation of descriptive geoenvironmental mineral deposit models: U.S. Geological Survey Open-File Report 95-831, 272 p. (http://greenwood.cr.usgs.gov/pub/open-file-reports/ofr95-0831/)

Eadington, P.J., 1983, Geochemical exploration for tin-recent research results in Smith, R.E., ed., Geochemical exploration in deeply weathered terrain, CSIRO.

Einaudi, M.T., 1982, Description of skarns associated with porphyry copper plutons, in Titley, S.R., ed. Advances in geology of the porphyry copper deposits: The University of Arizona Press, Tucson, AZ, p. 139-183.

Einaudi, M.T., Meinert, L.D., and Newberry, R.J., 1981, Skarn deposits: Economic Geology $75^{\text {th }}$ Anniversary Volume, p. 317-391.

Einaudi, M.T., and Burt, D.M., 1982, Introduction: terminology, classification, and composition of skarn deposits: Economic Geology v. 77, p. 745-754.

Einaudi, M.T., Meinert, L.D., and Newberry, R.J., 1981, Skarn deposits: Economic Geology $75^{\text {th }}$ Anniversary Volume, p. 317-391.

Engineering Science, Inc., 1985, Eagle mine remedial investigation, Appendix A: prepared for Colorado Department of Law, p. A11-A21.

Eppinger, R.G., Briggs, P.H., Rosenkrans, Danny, and Ballestrazze, Vanessa, 2000, Environmental geochemical 
studies of selected mineral deposits in Wrangell-St. Elias National Park and Preserve, Alaska: U.S. Geological Survey Professional Paper 1619, 47 p. ( http://greenwood.cr.usgs.gov/pub/ppapers/p1619/)

Eppinger, R.G., Briggs, P.H., Rosenkrans, Danny, Ballestrazze, Vanessa, Aldir, José, Brown, Z.A., Crock, J.G., d’Angelo, W.M., Doughten, M.W., Fey, D.L., Hageman, P.L., Hopkins, R.T., Knight, R.J., Malcolm, M.J., McHugh, J.B., Meier, A.L., Motooka, J.M., O’Leary, R.M., Roushey, B.H., Sutley, S.J., Theodorakos, P.M., and Wilson, S.A.,1999, Geochemical data for environmental studies of mineral deposits at Nabesna, Kennecott, Orange Hill, Bond Creek, Bremner, and Gold Hill, Wrangell-St. Elias National Park and Preserve, Alaska: U.S. Geological Survey Open-File Report 99-342. Available on CD-ROM and accessed Oct 2, 1999 at URL $<$ http://greenwood.cr.usgs.gov/pub/open-file-reports/ofr-99-342>.

Eppinger, R.G., Sutley, S.J., and McHugh, J.B., 1997, Environmental geochemical study of the Nabesna gold skarn and Kennecott stratabound copper deposits, Alaska, in Dumoulin, J.A., and Gray, J.E., eds., Geologic studies in Alaska by the U.S. Geological Survey, 1995: U.S. Geological Survey Professional Paper 1574, p. 19-39.

Ettlinger, A.D., and Ray, G.E., 1989, Precious metal enriched skarns in British Columbia: An overview and geological study: British Columbia Ministry of Energy, Mines, and Petroleum Resources, Mineral Resources Division, Paper 1989-3, 128 p.

Ettlinger, A.D., Albers, D., Fredericks, R., and Urbsinov, S., 1996, The Butte Highlands project, Silver Bow County, Montana: an olivine-rich magnesian gold skarn, in Coyner, A.R., and Fahey, eds., Geology and Ore Deposits of the American Cordillera: Geological Society of Nevada, Reno/Sparks, v. 2, p. 1019-1033.

Ficklin, W.H., Plumlee, G.S., Smith, K.S., and McHugh, J.B., 1992, Geochemical classification of mine drainages and natural drainages in mineralized areas, in Kharaka, Y.K., and Maest, A.S., eds., Water-rock interaction: Seventh International Symposium on Water-Rock Interaction, Park City, Utah, July 13-18, 1992, Proceedings, v. 1, Rotterdam, A.A. Balkema, p. 381-384.

Glass, N.R., Arnold, D.E., Galloway, J.N., Henry, G.R., Lee, J.J., McFee, N.W., Norton, S.A., Powers, C.F., Rambo, D.L., and Schofield, C.L., 1982, Effects of acid precipitation: Environmental Science and Technology, v. 15, p. 162A-169A.

Hammarstrom, J.M., Eppinger, R.G., Van Gosen, B.S., Briggs, P.H., and Meier, A.L., 2001, Case study of the environmental signature of a recently abandoned, carbonate-hosted replacement deposits: The Clayton mine, Idaho: U.S. Geological Survey Open-File Report, 32 p. (in prep.)

Hammarstrom, J.M., Theodore, T.G., Kotlyar, B.B., Doebrich, J.L., Elliott, J.E., Nash, J.T., John, D.A., and Livo, K.E., 1995a, Fe skarn deposits, in du Bray, E.A., ed., 1995, Preliminary compilation of descriptive geoenvironmental mineral deposit models: U.S. Geological Survey Open-File Report 95-831, p. 112-120. (http://greenwood.cr.usgs.gov/pub/open-file-reports/ofr-95-0831/)

Hammarstrom, J.M., Elliott, J.E , Kotlyar, B.B., Theodore, T.G., Nash, J.T., John, D.A., Hoover, D.B., and Knepper, D.H., Jr., 1995b, Sn and (or) W skarn and replacement deposits, in du Bray, E.A., ed., 1995, Preliminary compilation of descriptive geoenvironmental mineral deposit models: U.S. Geological Survey Open-File Report 95-831, p. 54-61. (http://greenwood.cr.usgs.gov/pub/open-file-reports/ofr-95-0831/)

Hammarstrom, J.M., Kotlyar, B.B., Theodore, T.G., Elliott, J.E., John, D.A., Doebrich, J.L., Nash, J.T., Carlson, R.R., Lee, G.K.., Livo, K.E., and Klein, D.P., 1995c, Cu, Au, and Zn-Pb skarn deposits, in du Bray, E.A., ed., 1995c, Preliminary compilation of descriptive geoenvironmental mineral deposit models: U.S. Geological Survey Open-File Report 95-831, p. 90-111. (http://greenwood.cr.usgs.gov/pub/open-file-reports/ofr-95-0831/)

Hastings, J.S., and Harrold, J.L., 1988, Geology of the Beal gold deposits, German Gulch, Montana, in Schafer, R.W. and others, eds., Bulk minable precious metal deposits of the western United States: Geological Society of Nevada, Symposium Proceedings, April 6-8, 1987, Reno, NV, p. 207-220.

Jerz, J.K., 1998, Mechanism of acid and metal release from a fluvial tailings deposit: M.S. Thesis, Colorado School of Mines, $140 \mathrm{p}$.

Jones, G.M., and Menzie, W.D., 1986, Grade and tonnage model of Cu skarn deposits, in Cox, D.P. and Singer, D.A., eds., Mineral deposit models: U.S. Geological Survey Bulletin 1693, p. 86-89.

Kirk, L.B., and Kirk, A.R., 2001, Case study: A geoenvironemntal model for the New World polymetallic replacement/skarn deposit (this volume).

Kotlyar, B.B., Theodore, T.G., Singer, D.A., Moss, K., Campo, A.M., Johnson, S.D., 1998, Geochemistry of the Auskarn environment at Copper Canyon, Battle Mountain mining district, Nevada, in Lentz, D.R., Mineralized intrusion-related systems: Mineralogical Association of Canada Short Course Series, Short Course Volume 26, p. 415-443.

Kwak, T. A.P., 1983, The geology and geochemistry of the zoned, Sn-W-F-Be skarns at Mt. Lindsay, Tasmania, Australia: Economic Geology, v. 78, p. 1440-1465.

1987, W-Sn skarn deposits: Elsevier, New York, 451 p. 
Kwong, Y.T.J., 1993, Prediction and prevention of acid rock drainage from a geological and mineralogical perspective: Canadian National Hydrology Research Centre Contribution CS-92054, 47 p.

Lapham, D.M., 1968, Triassic magnetite and diabase at Cornwall, Pennsylvania, in Ore deposits of the United States 1937-1967: The Graton-Sales volume, York, Pennsylvania, The Maple Press Co., v. I, p. 73-94.

Larocque, A.C.L., Laughlin, A.W., Hickmont, D., and Chapin, C.E., 1995, Metal-residence sites in weathered sulfide-rich tailings and sediments, Kelley mining camp, Magdalena District, New Mexico: Geological Society of America Abstracts with Programs, v. 20, no. 6, p. A-192.

Loeppert, R.H., 1988, Chemistry of iron in calcareous systems, in Stuckli, J.W., Goodman, B.A., and Schwertmann, U., eds., Iron in soils and clay minerals: Boston, D. Reidel Publishing Company, Chapter 19, p. 689-713.

Megaw, P.K.M., 1998, Carbonate-hosted Pb-Zn-Ag-Cu-Ag replacement deposits: an exploration perspective, in Lentz, D.R., Mineralized intrusion-related systems: Mineralogical Association of Canada Short Course Series, Short Course Volume 26, p. 337-357.

Meinert, L.D., 1983, Variability of skarn deposits-guides to exploration, in Boardman, S.J., ed., Revolution in the earth sciences: Dubuque, Iowa, Kendall-Hunt Publishing Co, p. 301-316. 1989, Gold skarn deposits-geology and exploration criteria, in Groves, D., Keays, R., and Ramsay, R., eds., Proceedings of Gold '88: Economic Geology Monograph No. 6, p. 537-552. 1992, Skarns and skarn deposits: Geoscience Canada, v. 19, p. 145-162. 1995a, Igneous petrogenesis and skarn deposits: Geological Association of Canada Special paper 40, p. 569-583.

1995b, Compositional variation of igneous rocks associated with skarn deposits - chemical evidence for a genetic connection between paragenesis and mineralization, in Thompson, J.F.H., ed., Magmas, fluids, and ore deposits: Geological Society of Canada Short Course v. 23, p. 401-418. 1998a, Skarns and skarn deposits: http://www.wsu.edu:8080/ meinert/aboutskarn.html 1998b, A review of skarns that contain gold, in Lentz, D.R., Mineralized intrusion-related systems: Mineralogical Association of Canada Short Course Series, Short Course Volume 26, p. 359-414.

Meinert, L.D., Hefton, K.K., Mayes, D., and Tasiran, I., 1997, Geology, zonation, and fluid evolution of the Big Gossan Cu-Au skarn deposit, Ertsberg District: Economic Geology, v. 92, p. 509-534.

Menzie, W.D., and Reed, B.L., 1986a, Grade and tonnage model of Sn skarn deposits, in Cox, D.P. and Singer, D.A., eds., Mineral deposit models: U.S. Geological Survey Bulletin 1693, p. 58-60.

1986b, Grade and tonnage model of replacement Sn, in Cox, D.P. and Singer, D.A., eds., Mineral deposit models: U.S. Geological Survey Bulletin 1693, p. 62-63.

Menzie, W.D., Jones, G.M., and Elliott, J.E., 1992, Tungsten-Grades and tonnages of some deposits, in DeYoung, J.H.,Jr., and Hammarstrom, J.M., eds., Contributions to commodity geology research: U.S. Geological Survey Bulletin 1877, p. J1-J7.

Meyer, G.A., 1995, Tailings impoundment failure and floodplain sediment contamination along Soda Butte Creek, Yellowstone National Park, MT-WY: Geological Society of America Abstracts with Programs, v. 27, no. 4, p. 47.

Mining Magazine, 1994, Minera Bismark, p. 195-201.

Morland, R., compiler, 1986, Renison Bell tin mine-technical review: Unpublished report from Renison Limited, 32 p.

Morris, H.T., 1986, Descriptive model of polymetallic replacement deposits, in Cox, D.P., and Singer, D.A., eds., Mineral deposit models: U.S. Geological Survey Bulletin 1693, p. 99-100.

Mosier, D.L., 1986, Grade and tonnage model of Zn-Pb skarn deposits, in Cox, D.P. and Singer, D.A., eds., Mineral deposit models: U.S. Geological Survey Bulletin 1693, p. 90-93.

Mosier, D.L. and Menzie, W.D., 1986, Grade and tonnage model of Fe skarn deposits, in Cox, D.P. and Singer, D.A., eds., Mineral deposit models: U.S. Geological Survey Bulletin 1693, p. 94 -97.

Mosier, D.L., Morris, H.T., and Singer, D.A., 1986, Grade and tonnage model of polymetallic replacement deposits, in Cox, D.P. and Singer, D.A., eds., Mineral deposit models: U.S. Geological Survey Bulletin 1693, p. 101104.

Munroe, E.A., McLemore, V.T., and Kyle, Philip, 1999, Waste rock pile characterization, heterogeneity, and geochemical anomalies in the Hillsboro mining district, Sierra County, New Mexico: Journal of Geochemical Exploration v. 67, p. 391-405.

Newberry, R.J., 1998, W- and Sn-skarn deposits: A 1998 status report, in Lentz, D.R., Mineralized intrusion-related systems: Mineralogical Association of Canada Short Course Series, Short Course Volume 26, p. 289-335.

Nevada Bureau of Mines and Geology, 1995, Water quality and inactive and abandoned mines in Nevada: Nevada Bureau of Mines and Geology Open-File Report 95-4, 72 p. 
Plumlee, G.S., 1999, The environmental geology of mineral deposits, in Plumlee, G.A., and Logsdon, M.J., eds., Reviews in Economic Geologic vol. 6A, p. 71-116.

Plumlee, G.S., Smith, K.S., Montour, M.R., Ficklin, W.H., and Mosier, E.L., 1999, Geologic controls on the composition of natural waters and mine waters draining diverse mineral-deposit types, in Filipek, L.H., and Plumlee, G.S., eds., Reviews in Economic Geologic vol. 6B, p. 373-432.

Plumlee, G.S., Smith, K.S., Ficklin, W.H., Briggs, P.H., and McHugh, J.B., 1993, Empirical studies of diverse mine drainages in Colorado-implications for the prediction of mine-drainage chemistry: Proceedings, 1993 Mined Land Reclamation Symposium, Billings, Montana, v. 1, p. 176-186.

Plumlee, G.S., Montour, Maria, Taylor, C.D., Wallace, A.R., and Klein, D.P., 1995, Polymetallic vein and replacement deposits, in du Bray, E.A., ed., 1995, Preliminary compilation of descriptive geoenvironmental mineral deposit models: U.S. Geological Survey Open-File Report 95-831, p. 121-129. (http://greenwood.cr.usgs.gov/pub/open-file-reports/ofr-95-0831/)

Pratt, A.R., Nesbitt, H.W., and Mycroft, J.R., 1996, The increased reactivity of pyrrhotite and magnetite phases in sulphide mine tailings: Journal of Geochemical Exploration, v.56, p. 1-11.

Ray, G.E., and Webster, I.C.L., 1990, An overview of skarn deposits: Ore deposits, tectonics, and metallogeny in the Canadian Cordillera, Geological Society of Canada short course notes, p. 7-1-7-55.

Reed, B.L., 1986, Descriptive model of replacement Sn, in Cox, D.P. and Singer, D.A., eds., Mineral deposit models: U.S. Geological Survey Bulletin 1693, p. 61.

Reed, B.L., and Cox, D.P., 1986, Descriptive model of Sn skarn deposits, in Cox, D.P. and Singer, D.A., eds., Mineral deposit models: U.S. Geological Survey Bulletin 1693, p. 58.

Ripley, E.A., Redman, R.E., and Crauder, A.A., 1995, Environmental effects of mining: Delray Beach, Florida, St.Lucie Press, 356 p.

Sangmeshwar, S.R., and Barnes, H.L., 1983, Supergene processes in zinc-lead-silver sulfide ores in carbonates: Economic Geology, v. 78, p. 1379-1397.

Sangster, D.F., 1969, The contact metasomatic magnetite deposits of southwestern British Columbia: Canadian Geological Survey Bulletin 175, 85 p.

Schwertmann, U., 1988, Occurrence and formation of iron oxides in various pedoenvironments, in Stuckli, J.W., Goodman, B.A., and Schwertmann, U., eds., Iron in soils and clay minerals: Boston, D. Reidel Publishing Company, Chapter 11, p. 267-308.

Smith, G.R., 1994, Materials flow of tungsten in the United States: U.S. Bureau of Mines Information Circular 9388.

Smith, K.S., Ramsey, C.A., and Hageman, P.L., 2000, Sampling strategy for the rapid screening of mine-waste dumps on abandoned mine lands: ICARD 2000, Proceedings from the Fifth International Conference on Acid Rock Drainage, Society for Mining, Metallurgy, and Exploration Inc., v. II, p. 1453-1461.

Sokolov, G.A., and Grigor'ev, V.M., 1977, Deposits of iron, in Smirnov, V.I., ed., Ore deposits of the U.S.S.R.:London, Pittman, v. 1, p. 7-113.

Souza Neto, J.A., 1999, Genesis of the Bonfim and Itajubatiba gold skarn deposits, northeastern Brazil: a study based on isotopes, trace elements and fluid inclusions: Dr. Sc. Thesis, Universite Catholique de Louvain, Belgium, $240 \mathrm{p}$.

Souza Neto, J.A., Sonnet, Ph., Legrand, J.M., Volfinger, M., and Pascal, M.-L., 1998, Geochemistry of the ore fluids in the Bonfim and Itajubatiba gold skarn deposits, northeastern Brazil: A PIXE method study: Mineralogical Magazine, v. 62A, part 3, p. 1432-1433. (http://www.geocities.com/CapeCanaveral.Hangar/9008/gold.html)

Stager, H.K., and Tingley, J., 1988, Tungsten deposits in Nevada: Nevada Bureau of Mines and Geology Bulletin 105, $256 \mathrm{p}$.

Theodore, T.G., 1969, Surface distribution of selected elements around the Copper Canyon copper-gold-silver openpit mine, Lander County, Nevada: U.S. Geological Survey Open-File Report, 21 sheets.

Theodore, T.G., and Blake, D.W., 1975, Geology and geochemistry of the Copper Canyon porphyry copper deposit and surrounding area, Lander County, Nevada: U.S. Geological Survey Professional Paper 798-B, 86 p.

1978, Geology and geochemistry of the West ore body and associated skarns, Copper Canyon porphyry copper deposits, Lander County, Nevada: U.S. Geological Survey Professional Paper 798-C, p. C1-C85.

Theodore, T.G., Orris, G.J., Hammarstrom, J.M., and Bliss, J.D., 1991, Gold-bearing skarns: U.S. Geological Survey Bulletin 1930, $61 \mathrm{p}$.

Titley, S.R., 1993, Characteristics of high-temperature, carbonate-hosted massive sulfide ores in the United States, Mexico, and Peru in Kirkham, R.V., Sinclair, W.D., Thorpe, R.I., and Duke, J.M., eds., Mineral Deposit Modeling: Geological Association of Canada Special Paper 40, p. 585-614.

Torrey, C.E., Karjalainen, H., Joyce, P.J., Erceg, M., and Stevens, M., 1986, Geology and mineralization of the Red 
Dome (Mungana) gold skarn deposit, North Queensland, Australia, in Macdonald, A.J., ed., Proceedings of Gold '86, International Symposium on the Geology of Gold: Toronto, Geological Association of Canada, 1986, p. 3-22.

U.S. Environmental Protection Agency, 2000a, Cleveland Mill, New Mexico: EPA ID\#NMD981155930. EPA Region 6 website (Superfund sites).

U.S. Environmental Protection Agency, 2000b, California Gulch, Colorado: EPA ID\#COD980717938. EPA Region 8 website (Superfund sites).

U.S. Environmental Protection Agency, 2000c, Eagle mine, Colorado: EPA ID\#COD081961518 EPA Region 8 website (Superfund sites).

U.S. Environmental Protection Agency, 2000d, EPA and BLM move ahead with Clayton mine tailings cleanup: EPA Region 10 website at URL: http://yosemite.epa.gov/R10/HOMEPAGE.NSF/webpage/

Van Gosen, B.S., Eppinger, R.G., Hammarsrom, J.M., Briggs, P.H., Crock, J.G., Gent, C., Meier, A.L., Sutley, S.J, and Theodorakos, P.M., 2000, Analytical data for reconnaissance geochemical samples from mine dumps, stream sediments, and waters at the Thompson Creek tungsten mine, Custer County, Idaho: U.S. Geological Survey Open-File Report OF-00-239, 28 p.

Vikre, P.G., 1998, Intrusion-related polymetallic carbonate replacement deposits in the Eureka district, Eureka County, Nevada: Nevada Bureau of Mines and Geology Bulletin 110, 52 p.

Walder, I.F. and Chavez, Jr., 1995, Mineralogical and geochemical behavior of mill tailing material produced from lead-zinc skarn mineralization, Hanover Grant County, New Mexico, USA: Environmental Geology, v. 26, p. 1-18.

Wallace, A.R., 1993, Geologic setting of the Leadville mining district, Lake County, Colorado: U.S. Geological Survey Open-File Report 93-343, 19 p.

Zhao, B., 1989, Main skarns and skarn deposits in China. Geological Publishing House, Beijing, 342 p.

Zitzmann, Arnold, 1977, The iron ore deposits of the western U.S.S.R., in Zitzmann, A., ed., The iron ore deposits of Europe and adjacent areas: Hannover, Bundesanstalt fhr Geowissenschaften und Rohstoffe, v. 1, p. 325-391. 


\title{
Chapter I
}

\section{A GEOENVIRONMENTAL MODEL FOR POLYMETALLIC VEIN DEPOSITS: A CASE STUDY IN THE COEUR D'ALENE MINING DISTRICT AND COMPARISONS WITH DRAINAGE FROM MINERALIZED DEPOSITS IN THE COLORADO MINERAL BELT AND HUMBOLDT BASIN, NEVADA}

\author{
Laurie S. Balistrieri, Stephen E. Box, and Arthur A. Bookstrom
}

\begin{abstract}
A case study on drainage from polymetallic vein deposits in the world-class Coeur d'Alene mining district in northern Idaho is presented. The initial discussion focuses on our conceptual geoenvironmental model for these deposits, and then proceeds to examine the composition of waters, particularly those draining from adits and tailings piles within the district. The relative importance of the amount of reacting pyrite and carbonate minerals on drainage composition is discussed from a theoretical viewpoint and then compared with observed compositions from the district. Comparisons of drainage composition and reacting pyrite to carbonate ratios are made with diverse types of ore deposits, including polymetallic vein deposits, in Colorado and with polymetallic vein deposits in Nevada.

The results indicate that drainage from polymetallic vein deposits has highly variable $\mathrm{pH}$ (i.e., acidic to basic) and concentrations of sulfate, metals, and arsenic. These observations are largely due to variable amounts and types of sulfide minerals and predicted ratios of reacting pyrite to carbonate minerals that range from near zero to just under 20/1. The dominant dissolved base metal in these waters is zinc (Zn).

\section{INTRODUCTION}

Initial mineral deposit models classified ore deposits based on their geological, geophysical, geochemical, and genetic characteristics (Cox and Singer, 1986; Bliss, 1992). The next generation of models, defined as geoenvironmental models and discussed in du Bray (1995), built upon and expanded the definition of mineral deposit models to include their environmental signature or environmental behavior. Plumlee and Nash (1995) define this signature to be "the suites, concentrations, residences, and availabilities of chemical elements in soil, sediment, airborne particulates, and water at a site that result from the natural weathering of mineral deposits and from mining, mineral processing, and smelting”.

Our development of a geoenvironmental model for polymetallic vein deposits in the Coeur d'Alene (CdA) mining district has been strongly influenced by the impact of these deposits on the overall health of the ecosystem. Examples include high concentrations of lead $(\mathrm{Pb})$ and zinc $(\mathrm{Zn})$ in sediments not only in the mining district, but also 150+ miles downstream of the district, higher than recommended levels of $\mathrm{Pb}$ in the blood of children living outside of the Superfund site, poisoning of migrating, endangered water fowl in the lower valley by ingestion of $\mathrm{Pb}$ enriched sediment during feeding, and the absence of a viable fisheries in the upper CdA River and its tributaries due to high dissolved Zn concentrations. Therefore, our conceptual geoenvironmental model has components similar to mineral deposit and geoenvironmental models, but expands the definition to include impacts on bioreceptors.

Our geoenvironmental model has three basic components: 1) sources of elements (primarily metals and metalloids) from mineralized deposits and associated mine wastes, 2) zones of reaction and transport including identification of the reservoirs or residences of metals and the pathways or processes that transfer elements between reservoirs, and 3) impacts on the health of humans and other biota. The source component of our geoenvironmental model entails characterization of minerals deposits and mine wastes to define such things as the geologic structure of the deposits, mineralogy of the deposits and host phases, and solid phase speciation of toxic elements. The second component includes identifying and describing all of the physical, chemical, and biological processes that act to transform or re-distribute elements between dissolved and particulate phases or between locations within the system and the parameters that force those transformations (e.g., hydrologic transport, $\mathrm{pH}$, redox state, or microbial activity). This component also includes determining the concentration and locations of elements in different parts of the eco-system. For example, defining whether $\mathrm{Zn}$ and $\mathrm{Pb}$ reside primarily in sediment or in water or identifying how much $\mathrm{Pb}$ exists in riverbed sediments, in over bank deposits, or in marshes within the floodplain. The third
\end{abstract}


model component entails targeting the critical physical and biogeochemical pathways or processes that influence the bioavailability and bioaccumulation of toxic elements.

This paper discusses a very small portion of our geoenvironmental model for the polymetallic vein deposits in the CdA mining district. We examine the geochemical characteristics of waters, primarily drainage from adits and tailings piles, and key parameters and processes that influence their composition. Specifically, we address the effect of reacting pyrite and carbonate minerals on drainage composition. Comparisons are made with drainage from diverse types of ore deposits, including other polymetallic vein deposits, in the Colorado Mineral Belt and with polymetallic vein deposits in the Humboldt Basin in northern Nevada.

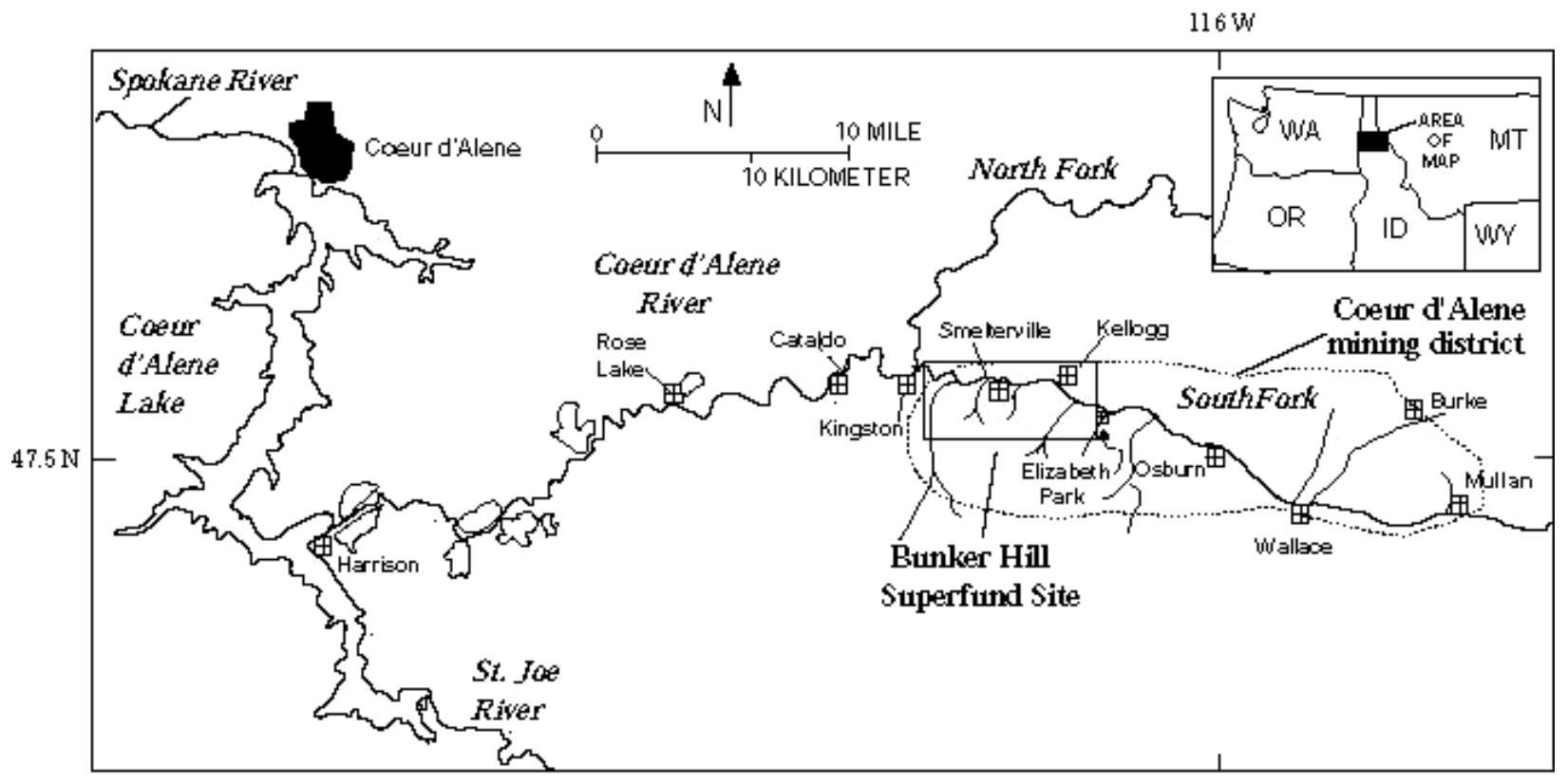

Figure 1. Location of the Coeur d'Alene mining district within the Coeur d'Alene River basin.

\section{STUDY AREA}

The CdA mining district is located in northern Idaho and western Montana in the northwestern United States (Fig. 1). Total production records indicate that deposits in this district rank as super giants (top 1\% of world producers) for $\mathrm{Ag}$ (34,300 metric tons) and $\mathrm{Pb}$ (7,288,300 metric tons) and as giants (top 10\% of world producers) for Zn (2,870,000 metric tons) (Singer, 1995; Long, 1998a). Ore deposits are steeply dipping, stratigraphically controlled Pb-Zn-Ag veins occurring in Precambrian rocks of the Belt Supergroup (Fryklund, 1964; Hobbs et al., 1965; Zartman and Stacey, 1971; Bennett and Venkatakrishnan, 1982; Reid, 1984; Leach et al., 1988; Criss and Fleck, 1990). The two major types of veins are galena (PbS)-sphalerite (ZnS) and argentiferous tetrahedrite $\left(\left[(\mathrm{Cu}, \mathrm{Fe})_{12} \mathrm{Sb}_{4} \mathrm{~S}_{13}\right]\right)$. They are spatially separated, most likely of differing ages, and are a distinct type unique to the district (Leach et al., 1998; Long, 1998b). Most veins contain small amounts of chalcopyrite $\left(\mathrm{CuFeS}_{2}\right)$. Pyrite $\left(\mathrm{FeS}_{2}\right)$ is ubiquitous, but variable in abundance, in the veins. Minor minerals include arsenopyrite (FeAsS) and pyrrhotite $\left(\mathrm{Fe}_{1-\mathrm{x}} \mathrm{S}\right)$. Host rocks are primarily quartzite and argillite with lesser amounts of interbedded carbonate and carbonate bearing rocks. The galena-sphalerite veins with the highest grade of $\mathrm{Zn}$ are located in the argillaceous middle Prichard formation, while galena-sphalerite veins with moderate amounts of $\mathrm{Pb}-\mathrm{Zn}$ - $\mathrm{Ag}$ are in the PrichardBurke formations. The stratigraphically higher Revett-St. Regis formations host the largest tonnage and highest Ag grade of the galena-sphalerite deposits. Tetrahedrite veins contain the highest $\mathrm{Ag}$ and $\mathrm{Cu}$ grades in the district and are only found in the Revett-St. Regis formations (Long, 1998b). The predominant gangue minerals are siderite $\left(\mathrm{FeCO}_{3}\right)$ and quartz $\left(\mathrm{SiO}_{2}\right)$. The absolute and relative abundance of sulfide and gangue minerals varies significantly between different vein systems.

Mineralogical work done at several mines in the district indicate that wall rocks around veins are concentrically zoned with respect to three carbonate minerals - siderite $\left(\mathrm{FeCO}_{3}\right)$, ankerite $\left[\mathrm{CaFe}\left(\mathrm{CO}_{3}\right)_{2}\right]$, and calcite $\left(\mathrm{CaCO}_{3}\right)$ (Gitlin, 1986). The carbonate mineral closest to the veins is siderite. The outer edge of the siderite zone grades to a 
much wider zone of ankerite either in assemblages of ankerite and siderite or ankerite and calcite. Wall rocks typically contain 10 to $15 \%$, but can have as much as $62 \%$, carbonate minerals.

Historical milling and tailings disposal practices have had a significant effect on the environmental impacts of mining in the CdA basin. Initial ore separation methods were not very efficient. Jig tailings produced before 1915 were highly enriched in metals, especially Zn. Development of more efficient flotation methods between 1915 and 1925 resulted in tailings with lower metal concentrations. Most tailings were deposited directly into the CdA River and its tributaries before environmental regulations required the installation of tailings ponds in 1968. Physical transport, including major flood events, subsequently re-distributed metal enriched tailings 150+ miles downstream throughout the channel of the South Fork and main stem of the CdA River and its floodplain, into Lake Coeur d'Alene, and into the Spokane River.

\section{DATA SOURCES}

The compositions of several types of waters are discussed in this paper. Drainage data from adits and tailing seeps in the CdA mining district were obtained from Balistrieri et al. (1998) and Box et al., (unpublished data). Information on the composition of waters from wells located within the CdA mining district either in floodplain soils covered by jig tailings (i.e., Woodland Park and Smelterville Flats) or in tailings piles at mill sites (i.e., Interstate-Callahan and Success) is from McCulley, Frick, and Gilman, Inc. (1994, 2000), Golder Associates, Inc. (1998), and Terragraphics Environmental Engineering, Inc. (1998). Historical data from the South Fork and main stem of the CdA River are from Mink et al. (1971) and U. S. Geological Survey (1973). Porewater data that were collected from the upper $30 \mathrm{~cm}$ of metal-enriched sediment near the river and in marshes in the lower CdA River valley (i.e., between Cataldo and Harrison; Fig. 1) are from Balistrieri et al. (2000). The composition of adit and tailings seep water draining diverse deposit types in the Colorado Mineral Belt (qCMB) and other polymetallic vein deposits in Colorado and Nevada was obtained from Plumlee et al. $(\underline{1993,1999})$ and Nash $(\underline{2000})$.

\section{DISCUSSION}

Concentrations of dissolved $\mathrm{Zn}$ in waters within the Coeur d'Alene River basin

Water quality within the Coeur d'Alene River basin is largely governed by dissolved Zn concentrations. The chronic aquatic life criteria for dissolved $\mathrm{Zn}$ for the State of Idaho are a function of the hardness of the water and range from $32.2 \mu \mathrm{g} / \mathrm{L}$ at a hardness of $25 \mathrm{mg} / \mathrm{L}$ to $188.3 \mu \mathrm{g} / \mathrm{L}$ at a hardness of $200 \mathrm{mg} / \mathrm{L}$ (Code of Federal Regulations, 1999). Water quality criteria for $\mathrm{pH}$ as set by EPA (1986) for freshwater range from 6.5 to 9 (chronic). As a benchmark, hardness in the CdA River varies from 15 to $65 \mathrm{mg} / \mathrm{L}$ depending on the season and $\mathrm{pH}$ is near neutral.

Dissolved Zn concentrations as a function of $\mathrm{pH}$ for a variety of waters impacted by ore deposits or mining wastes within the CdA River basin are plotted in Fig. 2. Both $\mathrm{pH}$ and dissolved concentrations of Zn show large variations, and many, particularly groundwaters, fall outside of the aquatic life criteria. Values of $\mathrm{pH}$ range from a low of 2.72 at the Kellogg Tunnel (adit) to a high of 9.1 in the CdA River. Dissolved Zn concentrations vary from $1.2 \mathrm{ppb}$ to $759 \mathrm{ppm}$. Table 1 summarizes the range and median values for $\mathrm{pH}$ and dissolved $\mathrm{Zn}$ concentrations in the various waters. Except for waters from the Kellogg Tunnel, groundwaters and tailing seeps have the lowest $\mathrm{pH}$ values and highest dissolved Zn concentrations. Porewaters in metal contaminated sediment tend to be acidic and can have moderately high dissolved Zn concentrations. Most adits, except the Kellogg Tunnel, have pH values near neutral with moderately high dissolved Zn concentrations. Most river waters are near neutral and tend to have the lowest dissolved $\mathrm{Zn}$ concentrations, although the median value is still above the aquatic life criteria. The acidic and Zn-enriched groundwaters and tailings seeps likely occur because acid-generating (e.g., pyrite) and Zn sulfide minerals (and their subsequent oxidation) are separated from buffering carbonate minerals during mining, processing, and disposal. 


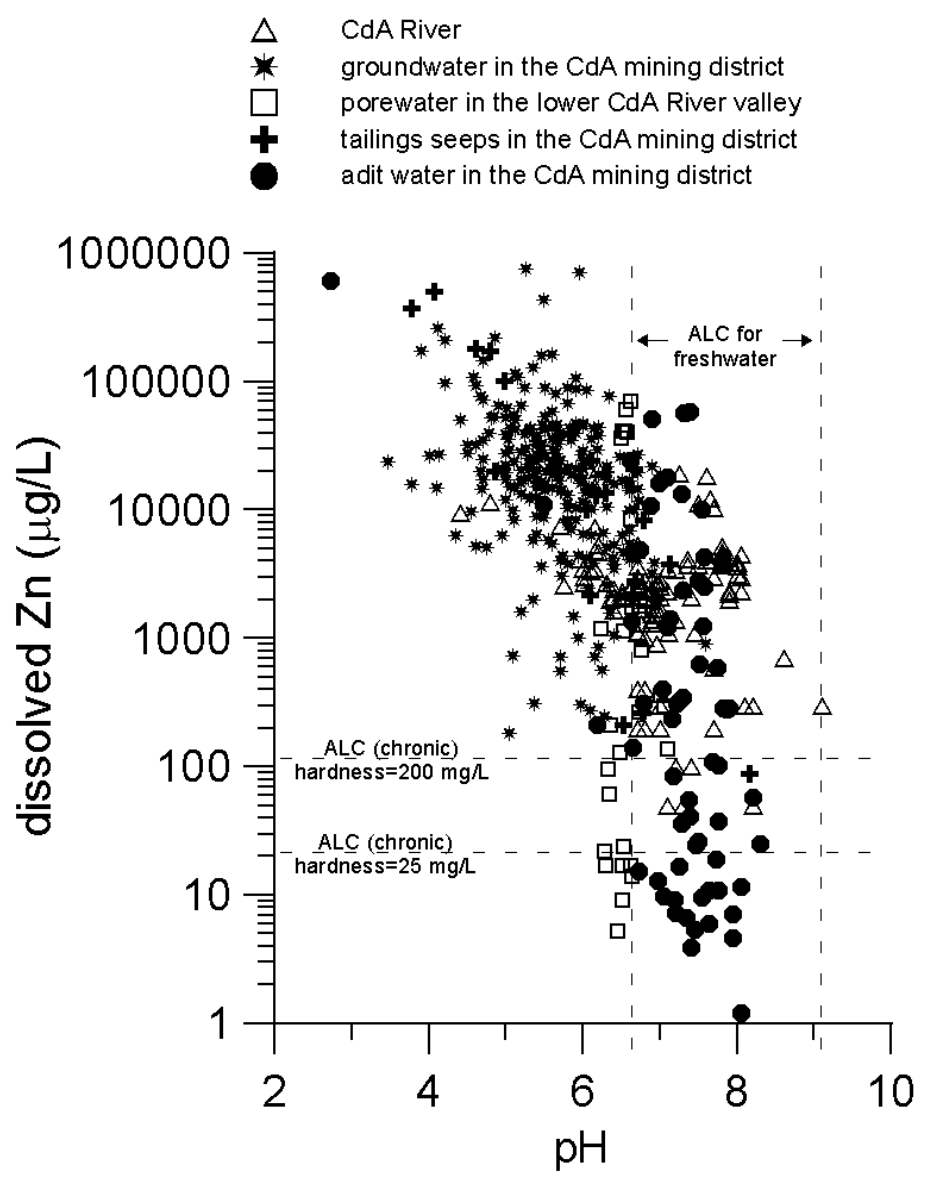

Figure 2. Values of $\mathrm{pH}$ and dissolved zine $(\mathrm{Zn})$ concentrations in waters from the Coeur d'Alene River Basin. ALC = aquatic life criteria.

Table 1. Range and median values of $\mathrm{pH}$ and dissolved $\mathrm{Zn}$ concentrations in waters in the Coeur d'Alene (CdA) River Basin.

\begin{tabular}{|c|c|c|c|c|c|}
\hline Water type & $\begin{array}{c}\text { No. } \\
\text { of samples }\end{array}$ & $\begin{array}{c}\text { Range } \\
\mathrm{pH}\end{array}$ & $\begin{array}{c}\text { Median } \\
\text { pH }\end{array}$ & $\begin{array}{c}\text { Range } \\
\text { dissolved Zn } \\
\text { mg/L }\end{array}$ & $\begin{array}{c}\text { Median } \\
\text { dissolved Zn } \\
\text { mg/L }\end{array}$ \\
\hline groundwaters & 246 & $3.5-7.6$ & 5.61 & $0.18-759$ & 38 \\
\hline tailings seeps & 26 & 3.8-8.2 & 5.93 & 0.09-498 & 66 \\
\hline porewaters & 30 & $6.2-7.1$ & 6.57 & $0.005-70$ & 10 \\
\hline adits: & & & & & \\
\hline Kellogg Tunnel & 1 & 2.7 & & 615 & \\
\hline all other adits & 61 & $5.5-8.3$ & 7.34 & $0.001-58$ & 5.8 \\
\hline CdA River & 117 & 4.4-9.1 & 7.05 & $0.05-21$ & 3.4 \\
\hline
\end{tabular}


Values of $\mathrm{pH}$ and concentrations of metals, metalloids, and other species in adits and tailings seeps in polymetallic vein districts

Drainage from adits and tailings piles in polymetallic vein deposits in the CdA mining district, in the Colorado Mineral Belt, and in the Humboldt Basin in northern NV are illustrated on a plot developed by Ficklin et al. (1992) (Fig. 3). This plot shows the sum of dissolved base metal (Cd, $\mathrm{Co}, \mathrm{Cu}, \mathrm{Ni}, \mathrm{Pb}$, and $\mathrm{Zn}$ ) concentrations as a function of $\mathrm{pH}$. The sum of dissolved base metal concentrations is dominated by $\mathrm{Zn}$ concentrations in nearly all drainage. Drainage data from polymetallic deposits in northern NV have the greatest range in $\mathrm{pH}$ and dissolved base metal concentrations. Although drainage from Au-quartz-pyrite and carbonate-rich polymetallic deposits in Colorado has a similar range in dissolved base metal concentrations as observed in drainage from the CdA mining district, values of $\mathrm{pH}$ tend to be higher in drainage from $\mathrm{CdA}$ versus $\mathrm{CO}$. As expected, drainage from pyrite-rich polymetallic vein deposits in $\mathrm{CO}$ that are poor in base metals $(\mathrm{Zn}, \mathrm{Pb}$, and $\mathrm{Cu})$ has lower dissolved base metal concentrations and lower $\mathrm{pH}$ values relative to drainage from other polymetallic deposits in CdA. The comparison of drainage from $\mathrm{CO}$ and NV suggests that certain polymetallic deposits in NV are also rich in pyrite but poor in base metals.

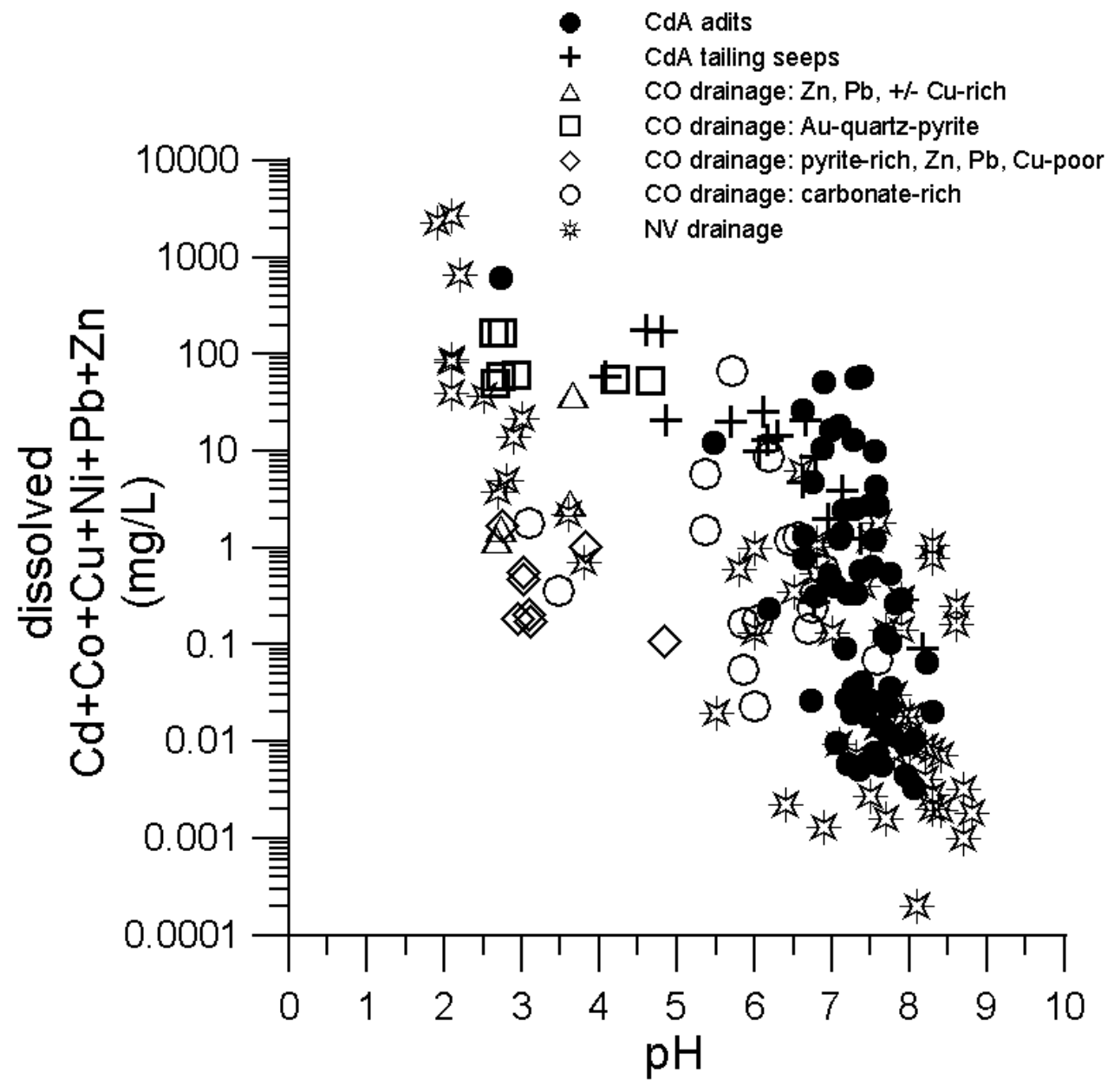

Figure 3. A Ficklin plot (i.e., sum of dissolved base metal concentrations versus $\mathrm{pH}$ ) for drainage from polymetallic vein deposits in the Coeur d'Alene mining district, in the Colorado Mineral Belt, and in the Humboldt Basin in northern Nevada.

Comparisons between dissolved concentrations of sulfate, As, Mn, and Fe and values of $\mathrm{pH}$ in mine drainage from polymetallic deposits CdA, CO, and NV are shown in Fig. 4. Only those concentrations of As, $\mathrm{Mn}$, and Fe greater than the detection limits of the analyses are plotted. Drainage from most of the polymetallic deposits in CO and many of the same type of deposits in NV has higher concentrations of sulfate than almost 
all of the adit drainage in CdA (Fig. 4A). This observation suggests that greater amounts of metal sulfides are being oxidized in the $\mathrm{CO}$ mining districts and in some $\mathrm{NV}$ districts relative to the CdA district. Concentrations of As in drainage from polymetallic deposits in CdA, CO, and NV range from $0.05 \mu \mathrm{g} / \mathrm{L}$ to 3,800 mg/L (Fig. 4B). The highest concentrations of As are observed in drainage from some sites in
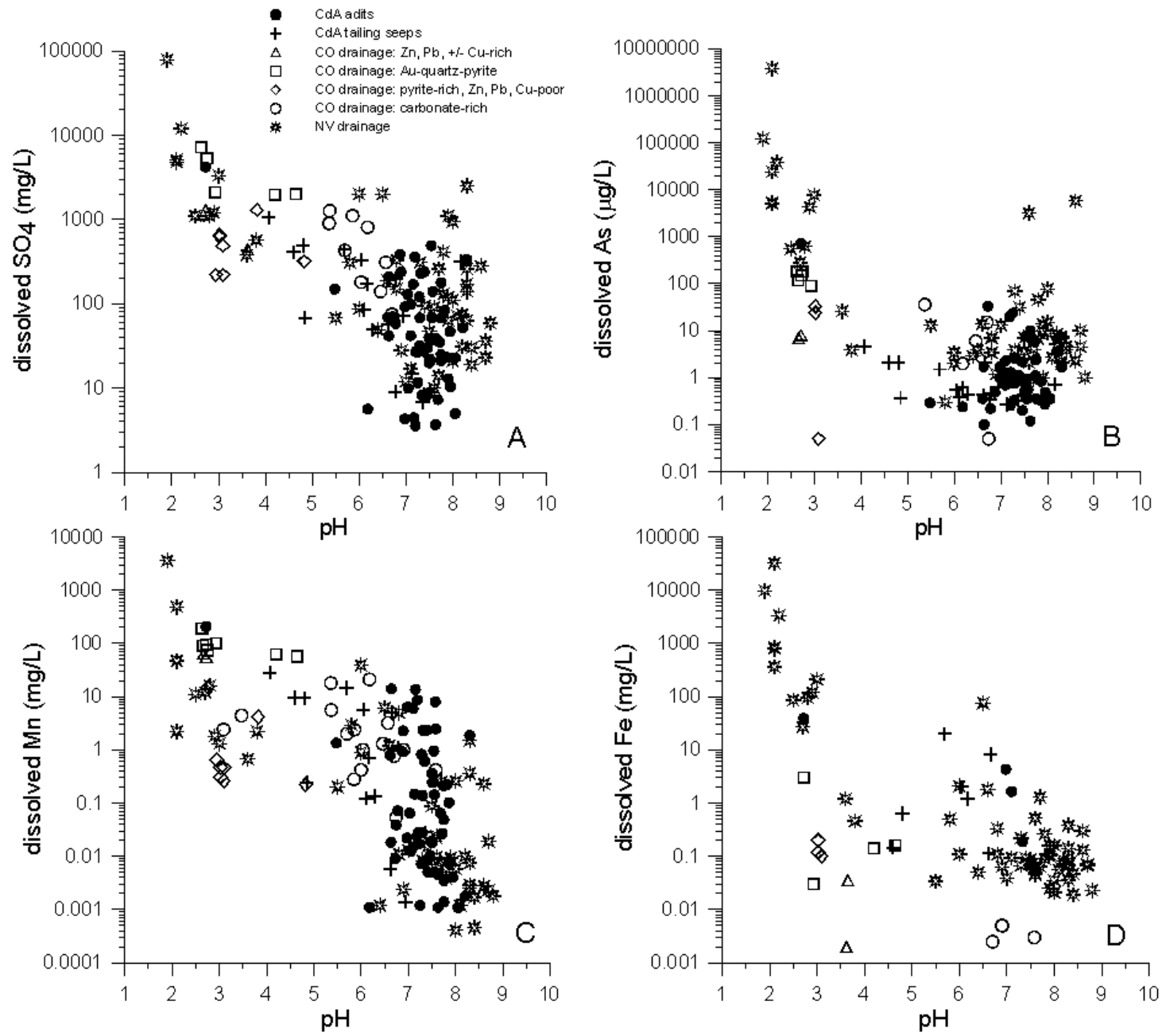

Figure 4. Dissolved concentrations of A) sulfate ( $\left.\mathrm{SO}_{4}\right), \mathrm{B}$ ) arsenic (As), C) manganese (Mn), and D) iron $(\mathrm{Fe})$ versus $\mathrm{pH}$ in drainage from polymetallic vein deposits in the Coeur d'Alene mining district, in the Colorado Mineral Belt, and in the Humboldt Basin in northern Nevada.

NV, from the Kellogg Tunnel in CdA, and from Au-quartz-pyrite polymetallic deposits in CO. Concentrations of $\mathrm{Mn}$ in drainage as a function of $\mathrm{pH}$ show some similarities to plots for total dissolved base metal concentrations as a function of $\mathrm{pH}$ (Fig. 4C). Dissolved Mn concentrations in drainage from NV vary by 7 orders of magnitude, while concentrations in CdA drainage vary by 5 orders of magnitude. The highest concentrations of Mn occur in drainage from certain sites in NV, from the Kellogg Tunnel ( $\mathrm{pH}$ 2.7) in CdA, and in drainage from Au-quartz-pyrite and Zn, $\mathrm{Pb},+/$ - Cu-enriched polymetallic deposits in $\mathrm{CO}$. Drainage from pyrite-rich and $\mathrm{Zn}, \mathrm{Pb}$, and $\mathrm{Cu}$-poor polymetallic deposits in $\mathrm{CO}$ tends to have lower concentrations of $\mathrm{Mn}$ compared to drainage of the same $\mathrm{pH}$ from other polymetallic deposits. Drainage from adits and tailings with the highest $\mathrm{pH}$ values tends to have the lowest dissolved Fe concentrations (Fig. 4D), while the drainage with the lowest $\mathrm{pH}$ (i.e., sites in NV, Kellogg Tunnel in CdA, Au-quartz-pyrite and pyrite-rich, base metal-poor polymetallic deposits in CO) has the highest Fe concentrations. These trends are consistent with the solubility of Fe minerals (Bigham et al., 1996; Langmuir, 1997). The data in Figs. 3 and $\underline{4}$ indicate that mine drainage is not necessarily acidic and that near neutral mine drainage can have high concentrations of metals and other species (Plumlee et al., 1993). 
Studies in the Colorado Mineral Belt (CMB) examined the relationship between mine drainage composition and mineralogy of diverse ore deposit types (including, but not limited to, polymetallic deposits) and host rocks (Plumlee et al., 1993). One of the key parameters that influenced drainage composition was the relative abundance of sulfide minerals, especially pyrite, and carbonate minerals. Their adit data and classification of deposits with respect to their relative abundance of pyrite and carbonate minerals in deposits and host rocks are compared with drainage data from polymetallic deposits in mining districts in CdA, ID and the Humboldt Basin in NV in Fig. 5.

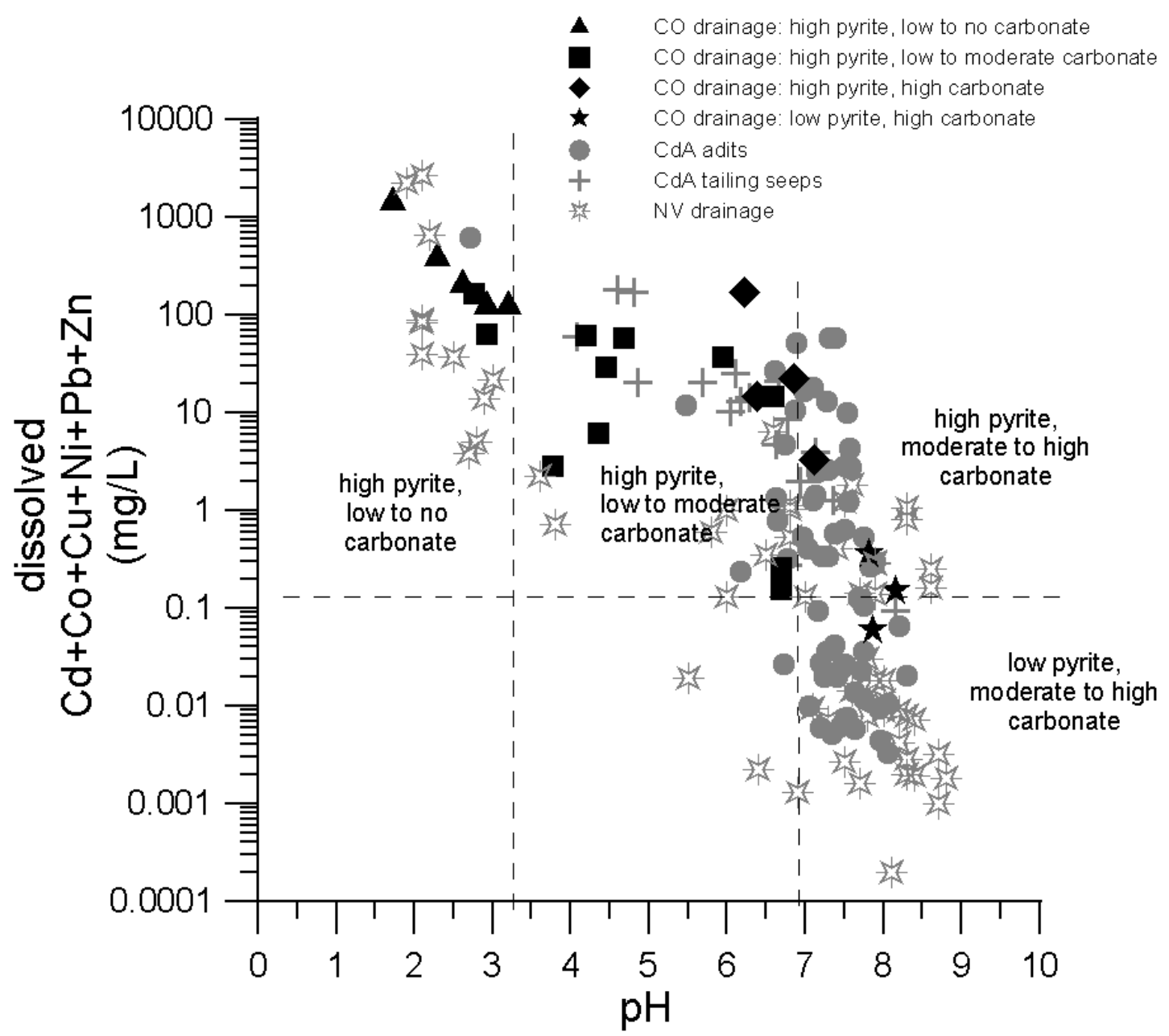

Figure 5. Relationship between the sum of dissolved base metals ( $\mathrm{Cd}, \mathrm{Co}, \mathrm{Cu}, \mathrm{Ni}, \mathrm{Pb}$, and $\mathrm{Zn}$ ) and $\mathrm{pH}$ in mine drainage from diverse deposit types in the Colorado Mineral Belt and from polymetallic vein deposits in the Coeur d'Alene mining district and in the Humboldt Basin in northern Nevada.

This comparison indicates that the wide ranging $\mathrm{pH}$ and metal concentrations found in drainage from polymetallic deposits in CdA and NV likely are due to variable amounts of sulfide and carbonate minerals in the individual deposits and host rocks. The dominance of acid generating minerals (e.g., pyrite) results in acid $\mathrm{pH}$ values and the mobilization of metals into solution, whereas significant amounts of acid neutralizing minerals (e.g., calcite) increase the $\mathrm{pH}$ and possibly result in the precipitation of oxides and hydroxysulfates that scavenge metals from solution. Thus, low $\mathrm{pH}$ values and high dissolved metal concentrations are found in drainage from deposits 
with high pyrite to carbonate ratios. Deposits that are enriched in both pyrite and carbonate minerals produce drainage that has high dissolved metal concentrations and near neutral $\mathrm{pH}$ values. The lowest dissolved metal concentrations are found in near neutral drainage from deposits that contain low pyrite to carbonate ratios.

\section{Reacting pyrite to carbonate ratios}

Why is there such a range in $\mathrm{pH}$ and metal concentrations in drainage from these mineralized terranes?

Comparisons in Fig. 5 are based on empirical observations of drainage composition and mineralogy of the deposits and host rocks. In reality, the composition of drainage is a function of the amount of reacting sulfide and carbonate minerals, not the absolute abundance of the minerals in the deposits and host rocks. A more quantitative approach can be used to assess the relative abundance of reacting pyrite and carbonate minerals on drainage composition (Balistrieri et al., 1999). This approach compares relationships between selected dissolved ion concentrations and alkalinity (or acidity) in drainage with stoichiometric relationships between these variables predicted from chemical reactions. The predictions are derived from reactions describing the oxidation of pyrite, precipitation of hydrous Fe oxide or Fe hydroxysulfate minerals, and dissolution of carbonate minerals, and from the definitions of alkalinity and acidity. As only a few samples from the CO and NV datasets have measured alkalinity, most of the following discussion will focus on drainage from CdA.

It is well known that a major source of acid to waters in mineralized areas is the oxidation of pyrite. Although the overall oxidant that drives pyrite oxidation is $\mathrm{O}_{2}$ from the atmosphere, dissolved $\mathrm{Fe}(\mathrm{III})$ appears to be the primary oxidant that attacks the pyrite surface to form $\mathrm{Fe}(\mathrm{II}), \mathrm{SO}_{4}$, and protons (Taylor et al., 1984; Reedy et al., 1991):

$$
\mathrm{FeS}_{2}+14 \mathrm{Fe}^{3+}+8 \mathrm{H}_{2} \mathrm{O} \rightarrow 15 \mathrm{Fe}^{2+}+2 \mathrm{SO}_{4}{ }^{2-}+16 \mathrm{H}^{+}
$$

The $\mathrm{Fe}(\mathrm{II})$ that is produced in reaction 1 can oxidize in the presence of $\mathrm{O}_{2}$ to $\mathrm{Fe}(\mathrm{III})$ :

$$
\mathrm{Fe}^{2+}+0.25 \mathrm{O}_{2}+\mathrm{H}^{+} \rightarrow \mathrm{Fe}^{3+}+0.5 \mathrm{H}_{2} \mathrm{O}
$$

This reaction is the rate-determining step and is usually catalyzed by autotrophic bacteria (Singer and Stumm, 1970).

The $\mathrm{Fe}(\mathrm{III})$ produced in reaction 2 can either further oxidize pyrite (reaction 1) or hydrolyze and then precipitate as hydrous Fe oxide (goethite $[\alpha \mathrm{FeOOH}]$ or ferrihydrite $\left[\sim \mathrm{Fe}_{5} \mathrm{OH}_{8} .4 \mathrm{H}_{2} \mathrm{O}\right]$ ) or as Fe hydroxysulfate minerals (jarosite $\left[\mathrm{KFe}_{3}\left(\mathrm{SO}_{4}\right)_{2}(\mathrm{OH})_{6}\right]$ or schwertmannite $\left[\mathrm{Fe}_{8} \mathrm{O}_{8}(\mathrm{OH})_{6} \mathrm{SO}_{4}\right]$ ) depending on kinetic factors, $\mathrm{pH}$, and concentrations of $\mathrm{Fe}(\mathrm{III}), \mathrm{SO}_{4}$, and bicarbonate (Nordstrom et al., 1979; Bigham et al., 1996). Bigham et al. (1996) indicates that although goethite and jarosite ultimately control the concentration of $\mathrm{Fe}(\mathrm{III})$ in mine drainage, the metastable phases of ferrihydrite or schwertmannite are frequently found in such systems. Both mineralogical and thermodynamic data suggest that jarosite controls the activity of dissolved $\mathrm{Fe}(\mathrm{III})$ in drainage with $\mathrm{pH}$ values less than about 2.7, schwertmannite for $\mathrm{pH}$ values from about 2.8 to 4.5, mixtures of schwertmannite and ferrihydrite for $\mathrm{pH}$ values between 4.5 and 6.5, and ferrihydrite for higher $\mathrm{pH}$ values. Given the $\mathrm{pH}$ range of drainage in CdA, schwertmannite, mixtures of schwertmannite and ferrihydrite, or predominantly ferrihydrite likely control dissolved Fe(III) concentrations.

The precipitation of $\mathrm{Fe}(\mathrm{III})$ as schwertmannite consumes $\mathrm{SO}_{4}$ and produces protons:

$$
8 \mathrm{Fe}^{3+}+\mathrm{SO}_{4}{ }^{2-}+14 \mathrm{H}_{2} \mathrm{O} \leftrightarrow \mathrm{Fe}_{8} \mathrm{O}_{8}(\mathrm{OH})_{6} \mathrm{SO}_{4}+22 \mathrm{H}^{+}
$$

whereas the precipitation of ferrihydrite [hereafter denoted by the formula $\mathrm{Fe}(\mathrm{OH})_{3}$ ] only produces protons:

$$
\mathrm{Fe}^{3+}+3 \mathrm{H}_{2} \mathrm{O} \leftrightarrow \mathrm{Fe}(\mathrm{OH})_{3}+3 \mathrm{H}^{+}
$$

The principal reactions that generate base, in sequential order based on reactivity, are the dissolution of carbonate minerals (calcite $\left[\mathrm{CaCO}_{3}\right]$, dolomite $\left[\mathrm{CaMg}\left(\mathrm{CO}_{3}\right)_{2}\right]$, or ankerite $\left[\mathrm{CaFe}\left(\mathrm{CO}_{3}\right)_{2}\right]$ ), oxides and hydroxides of $\mathrm{Al}$ and Fe, and aluminosilicates (feldspars, chlorite, and muscovite) (Blowes and Ptacek, 1994; Sherlock et al., 1995). The most important acid neutralizing reactions are the dissolution of carbonate minerals. The carbonate minerals of importance in the CdA mining district are calcite, ankerite, and siderite. Several analyses of the composition of these minerals for the district have been done and are summarized in Table 2. 
Table 2. Composition of carbonate minerals in the Coeur d'Alene mining district.

\begin{tabular}{|c|c|c|c|c|c|c|c|}
\hline Mineral & Mine & $\begin{array}{c}\mathrm{Ca} \\
\text { moles }\end{array}$ & $\begin{array}{c}\text { Fe } \\
\text { moles }\end{array}$ & $\begin{array}{c}\mathrm{Mg} \\
\text { moles }\end{array}$ & $\begin{array}{c}\mathrm{Mn} \\
\text { moles }\end{array}$ & $\begin{array}{c}\mathrm{CO}_{3} \\
\text { moles }\end{array}$ & Reference \\
\hline calcite & $\begin{array}{r}\text { Lucky Friday }(\mathrm{n}=8) \\
\text { average } \\
\text { standard deviation }\end{array}$ & $\begin{array}{l}0.94 \\
0.01\end{array}$ & $\begin{array}{l}0.041 \\
0.008\end{array}$ & $\begin{array}{l}0.003 \\
0.002\end{array}$ & $\begin{array}{l}0.018 \\
0.002\end{array}$ & 1 & Gitlin, 1986 \\
\hline ankerite & 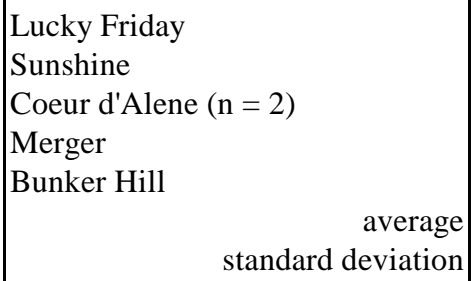 & $\begin{array}{l}1.07 \\
1.04 \\
1.07 \\
1.05 \\
1.02 \\
1.05 \\
0.02\end{array}$ & $\begin{array}{l}0.7 \\
0.68 \\
0.49 \\
0.63 \\
0.56 \\
0.61 \\
0.08\end{array}$ & $\begin{array}{l}0.13 \\
0.17 \\
0.38 \\
0.22 \\
0.32 \\
0.24 \\
0.09\end{array}$ & $\begin{array}{c}0.097 \\
0.1 \\
0.068 \\
0.098 \\
0.098 \\
0.093 \\
0.013\end{array}$ & $\begin{array}{l}2 \\
2 \\
2 \\
2 \\
2 \\
2\end{array}$ & $\begin{array}{l}\text { Gitlin, } 1986 \\
\text { Fryklund, } 1964 \\
\text { Fryklund, } 1964 \\
\text { Fryklund, } 1964 \\
\text { Fryklund, } 1964\end{array}$ \\
\hline siderite & \begin{tabular}{|} 
Lucky Friday $(\mathrm{n}=8)$ \\
Sunshine $(\mathrm{n}=7)$ \\
Bunker Hill (only ranges given) \\
average \\
standard deviation
\end{tabular} & $\begin{array}{c}0.024 \\
0.006 \\
0.02-0.06 \\
0.023 \\
0.014 \\
\end{array}$ & $\begin{array}{c}0.83 \\
0.87 \\
0.75-0.85 \\
0.84 \\
0.03 \\
\end{array}$ & $\begin{array}{c}0.07 \\
0.04 \\
0.06-0.10 \\
0.06 \\
0.02 \\
\end{array}$ & $\begin{array}{c}0.077 \\
0.078 \\
0.08-0.10 \\
0.082 \\
0.006 \\
\end{array}$ & $\begin{array}{l}1 \\
1 \\
1 \\
1\end{array}$ & $\begin{array}{l}\text { Gitlin, } 1986 \\
\text { Fryklund, } 1964 \\
\text { Fryklund, } 1964\end{array}$ \\
\hline
\end{tabular}

The carbonate phases are not pure and analyses are limited to only a few locations in the district. The calculations that follow assume that the average compositions of carbonate minerals at these locations are representative of the entire district. The dissolution of these minerals results in the release of divalent metal $\left(\mathrm{Ca}^{2+}, \mathrm{Fe}^{2+}, \mathrm{Mg}^{2+}\right.$, and $\left.\mathrm{Mn}^{2+}\right)$ and bicarbonate $\left(\mathrm{HCO}_{3}{ }^{-}\right)$ions to solution. The dissolution reactions for the $\mathrm{CdA}$ carbonates are written as follows:

for calcite:

$$
\begin{array}{r}
\left(\mathrm{Ca}_{0.94} \mathrm{Fe}_{0.041} \mathrm{Mg}_{0.003} \mathrm{Mn}_{0.018}\right) \mathrm{CO}_{3}+\mathrm{H}^{+} \\
0.94 \mathrm{Ca}^{2+}+0.041 \mathrm{Fe}^{2+}+0.003 \mathrm{Mg}^{2+}+0.018 \mathrm{Mn}^{2+}+\mathrm{HCO}_{3}^{-}
\end{array}
$$

for ankerite:

$$
\begin{array}{r}
\mathrm{Ca}_{1.05}\left(\mathrm{Fe}_{0.61} \mathrm{Mg}_{0.24} \mathrm{Mn}_{0.093}\right)\left(\mathrm{CO}_{3}\right)_{2}+2 \mathrm{H}^{+} \\
1.05 \mathrm{Ca}^{2+}+0.61 \mathrm{Fe}^{2+}+0.24 \mathrm{Mg}^{2+}+0.093 \mathrm{Mn}^{2+}+2 \mathrm{HCO}_{3}^{-}
\end{array}
$$

for siderite:

$$
\begin{array}{r}
\left(\mathrm{Ca}_{0.023} \mathrm{Fe}_{0.84} \mathrm{Mg}_{0.06} \mathrm{Mn}_{0.082}\right) \mathrm{CO}_{3}+\mathrm{H}^{+} \\
0.023 \mathrm{Ca}^{2+}+0.84 \mathrm{Fe}^{2+}+0.06 \mathrm{Mg}^{2+}+0.082 \mathrm{Mn}^{2+}+\mathrm{HCO}_{3}^{-}
\end{array}
$$

The Fe(II) that is released during dissolution of the carbonate minerals can oxidize and precipitate either as Fe oxide or Fe hydroxysulfate minerals.

Alkalinity [Alk] is the acid neutralizing capacity of water (Stumm and Morgan, 1996). For most waters alkalinity can be defined in terms of the carbonate ions $\left(\mathrm{HCO}_{3}{ }^{-}\right.$and $\left.\mathrm{CO}_{3}{ }^{2-}\right)$ as the concentrations of other proton acceptors (e.g., $\mathrm{NH}_{3}, \mathrm{HS}^{-}$, or $\mathrm{B}(\mathrm{OH})_{4}^{-}$) are negligible:

$$
[\mathrm{Alk}]=\left[\mathrm{HCO}_{3}^{-}\right]+2\left[\mathrm{CO}_{3}^{2-}\right]+\left[\mathrm{OH}^{-}\right]-\left[\mathrm{H}^{+}\right]
$$

Acidity [Acy] is the base neutralizing capacity of water (Stumm and Morgan, 1996). Acidity is measured by titrating water with a strong base to a designated pH, typically pH 8.2 or 8.3 (US EPA, 1974; APHA, 1976). For mine drainage waters, reactions that contribute to acidity during a base titration to $\mathrm{pH} 8.3$ include the neutralization of strong and weak acids $\left(\mathrm{H}^{+}, \mathrm{HSO}_{4}{ }^{-}, \mathrm{H}_{2} \mathrm{CO}_{3}{ }^{0}\right)$, the hydrolysis of metal ions $\left(\mathrm{Fe}^{3+}, \mathrm{Al}^{3+}\right)$, and the oxidation and hydrolysis of redox sensitive metals $\left(\mathrm{Fe}^{2+}, \mathrm{Mn}^{2+}\right)$ (Langmuir, 1997). Thus, acidity is defined as: 


$$
[\text { Acy }]=\left[\mathrm{H}^{+}\right]+\left[\mathrm{HSO}_{4}^{-}\right]+\left[\mathrm{H}_{2} \mathrm{CO}_{3}{ }^{0}\right]+3\left[\mathrm{Al}^{3+}\right]+3\left[\mathrm{Fe}^{3+}\right]+2\left[\mathrm{Fe}^{2+}\right]+2\left[\mathrm{Mn}^{2+}\right]
$$

It should be noted that acidity, as defined above, is not strictly the negative of alkalinity as other species besides carbonate species are included in the acidity definition.

The above reactions and definitions for alkalinity and acidity can be used to predict the relative amounts of pyrite and carbonate minerals that react to form drainage. Concentrations of dissolved $\mathrm{SO}_{4}$ are the net result of oxidation of all sulfide minerals and the precipitation of secondary sulfate minerals such as Fe hydroxysulfates. Dissolved Ca and Mg concentrations represent the net concentration of Ca and Mg produced during the dissolution of carbonate minerals and $\mathrm{Ca}$ and $\mathrm{Mg}$ consumed during the precipitation of secondary minerals. Alkalinity is the net result of protons consumed and bicarbonate produced during the dissolution of carbonate minerals and protons generated during pyrite oxidation and precipitation of Fe oxide or Fe hydroxysulfate minerals. Acidity accounts for the strong acids and metals generated during pyrite oxidation, for the consumption of protons and production of metals during carbonate mineral dissolution, and for protons generated during the precipitation of Fe oxides or Fe hydroxysulfate minerals.

The stoichiometric relationships between the sum of dissolved $\mathrm{Ca}$ and $\mathrm{Mg}$, dissolved $\mathrm{SO}_{4}$, and alkalinity or acidity are derived from the reactions and definitions given above. We consider the oxidation of pyrite, dissolution of average CdA calcite, ankerite, or siderite, and either no oxidation of Fe(II) produced from the previous reactions or oxidation of $\mathrm{Fe}(\mathrm{II})$ with subsequent precipitation of schwertmannite and ferrihydrite. The stoichiometry for the various cases is determined by combining the appropriate reactions given above. For example, the reaction describing the oxidation of pyrite and precipitation of ferrihydrite is determined by combining reaction 1 plus 15 times reaction 2 plus reaction 4 :

$$
\mathrm{FeS}_{2}+3.75 \mathrm{O}_{2}+3.5 \mathrm{H}_{2} \mathrm{O} \rightarrow \mathrm{Fe}(\mathrm{OH})_{3}+2 \mathrm{SO}_{4}{ }^{2-}+4 \mathrm{H}^{+}
$$

The dissolution of average $\mathrm{CdA}$ calcite and oxidation and precipitation of released $\mathrm{Fe}(\mathrm{II})$ as ferrihydrite is determined by combining reaction 5 plus 0.041 times reaction 2 plus 0.041 times reaction 4 :

$$
\begin{gathered}
\left(\mathrm{Ca}_{0.94} \mathrm{Fe}_{0.041} \mathrm{Mg}_{0.003} \mathrm{Mn}_{0.018}\right) \mathrm{CO}_{3}+0.918 \mathrm{H}^{+}+0.1 \mathrm{H}_{2} \mathrm{O}+0.01 \mathrm{O}_{2} \\
0.041 \mathrm{Fe}(\mathrm{OH})_{3}+0.94 \mathrm{Ca}^{2+}+0.003 \mathrm{Mg}^{2+}+0.018 \mathrm{Mn}^{2+}+\mathrm{HCO}_{3}^{-}
\end{gathered}
$$

These reactions are used to predict relationships between dissolved $\mathrm{Ca}$ and $\mathrm{Mg}$, dissolved $\mathrm{SO}_{4}$, and alkalinity for variable ratios of reacting pyrite to carbonate minerals for the case where Fe(II) oxidizes and precipitates as ferrihydrite. Assuming comparable oxidation and dissolution rates, a reacting pyrite to calcite mineral ratio of 1 to 4, considering precipitation of ferrihydrite, would yield 2 moles of dissolved $\mathrm{SO}_{4}$ and 4 moles of protons for every mole of oxidized pyrite (equation 10), while 4 moles of average CdA calcite would consume 3.672 moles of protons and produce 3.76 moles of dissolved Ca, 0.012 moles of dissolved Mg ions, 0.072 moles of dissolved Mn ions, and 4 moles of dissolved bicarbonate ions (equation 11; coefficients multiplied by 4). Thus, 3.672 moles of alkalinity (i.e., 4 moles of bicarbonate -0.328 moles of protons; equation 8 ) and 0.472 moles of acidity (i.e., 0.328 moles of protons +0.144 moles of $\mathrm{Mn}$; equation 9 ) are generated for this system. The stoichiometries for other cases are summarized in Table 3. 
Table 3. Stoichiometric coefficients for reactions describing pyrite oxidation and dissolution of average Coeur d'Alene (CdA) carbonate minerals considering no precipitation (ppt) of Fe, precipitation of ferrihydrite (ppt F), or precipitation of schwertmannite (ppt S).*

\begin{tabular}{|c|c|c|c|c|c|c|c|}
\hline \multicolumn{4}{|c|}{ oxidation of 1 mole of pyrite } & \multicolumn{4}{|c|}{ dissolution of 1 mole of average CdA calcite } \\
\hline \multirow{8}{*}{\begin{tabular}{|l} 
\\
$\mathrm{SO}_{4}$ \\
$\mathrm{Fe}(\mathrm{II})$ \\
$\mathrm{Fe}(\mathrm{III})$ \\
$\mathrm{H}^{+}$
\end{tabular}} & no ppt & \multirow{2}{*}{$\frac{\mathrm{ppt} F}{2}$} & ppt S & \multicolumn{2}{|c|}{ no ppt } & \multirow{2}{*}{$\frac{\mathrm{ppt} \mathrm{F}}{0.94}$} & \multirow{2}{*}{$\frac{\text { ppt S }}{0.94}$} \\
\hline & 2 & & 1.875 & Сa & 0.94 & & \\
\hline & 15 & 0 & 0 & $\mathrm{Mg}$ & 0.003 & 0.003 & 0.003 \\
\hline & 14 & 0 & 0 & $\mathrm{SO}_{4}$ & 0 & 0 & -0.005 \\
\hline & 16 & 4 & 3.75 & $\mathrm{Fe}(\mathrm{II})$ & 0.041 & 0 & 0 \\
\hline & & & & Mn & 0.018 & 0.018 & 0.018 \\
\hline & & & & $\mathrm{H}^{+}$ & -1 & -0.918 & -0.928 \\
\hline & & & & $\mathrm{HCO}_{3}^{-}$ & 1 & 1 & 1 \\
\hline & & & & dissolut & $\begin{array}{l}\text { of } 1 \mathrm{mc} \\
\text { no ppt }\end{array}$ & $\begin{array}{l}\text { of aver } \\
\text { ppt F }\end{array}$ & $\begin{array}{l}\text { e CdA ankerite } \\
\text { ppt S }\end{array}$ \\
\hline & & & & $\mathrm{Ca}$ & 1.05 & 1.05 & 1.05 \\
\hline & & & & Mg & 0.24 & 0.24 & 0.24 \\
\hline & & & & $\mathrm{SO}_{4}$ & 0 & 0 & -0.077 \\
\hline & & & & $\mathrm{Fe}(\mathrm{II})$ & 0.61 & 0 & 0 \\
\hline & & & & Mn & 0.093 & 0.093 & 0.093 \\
\hline & & & & $\mathrm{H}^{+}$ & -2 & -0.77 & -0.93 \\
\hline & & & & $\mathrm{HCO}_{3}^{-}$ & 2 & 2 & 2 \\
\hline & & & & dissolut & $\begin{array}{l}\text { of } 1 \mathrm{~m} \\
\text { no ppt }\end{array}$ & $\begin{array}{c}\text { of aver } \\
\text { ppt F }\end{array}$ & $\begin{array}{l}\text { e CdA siderite } \\
\text { ppt S }\end{array}$ \\
\hline & & & & $\mathrm{Ca}$ & 0.023 & 0.023 & 0.023 \\
\hline & & & & Mg & 0.06 & 0.06 & 0.06 \\
\hline & & & & $\mathrm{SO}_{4}$ & 0 & 0 & -0.104 \\
\hline & & & & $\mathrm{Fe}(\mathrm{II})$ & 0.84 & 0 & 0 \\
\hline & & & & $\mathrm{Mn}$ & 0.082 & 0.082 & 0.082 \\
\hline & & & & $\mathrm{H}^{+}$ & -1 & 0.67 & 0.46 \\
\hline & & & & $\mathrm{HCO}_{3}^{-}$ & 1 & 1 & 1 \\
\hline
\end{tabular}

The moles of dissolved $\mathrm{Ca}$ and $\mathrm{Mg}$, dissolved $\mathrm{SO}_{4}$, and alkalinity or acidity resulting from the calculations for variable ratios of reacting pyrite to average $\mathrm{CdA}$ carbonate minerals are normalized to $100 \%$. Normalization involves calculating the proportion of one of the components relative to the sum of all components [e.g., $\% \mathrm{SO}_{4}=$ moles of $\mathrm{SO}_{4} /$ (moles of $\mathrm{SO}_{4}+$ moles of $(\mathrm{Ca}+\mathrm{Mg})+$ moles of alkalinity) times 100] and reflects the relationships between components. The example above (i.e., a reacting pyrite to calcite ratio of 1 to 4 with precipitation of ferrihydrite) yields 2 moles of dissolved $\mathrm{SO}_{4}, 3.77$ moles of $\mathrm{Ca}+\mathrm{Mg}$, and 3.672 moles of alkalinity. The normalization results in $21 \% \mathrm{SO}_{4}, 40 \%(\mathrm{Ca}+\mathrm{Mg})$, and $39 \%$ alkalinity. The ratio of the normalized values for $\mathrm{SO}_{4}$ and $(\mathrm{Ca}+\mathrm{Mg})$ are plotted versus the normalized values for alkalinity or acidity for different reacting pyrite to carbonate ratios in Figs. 6 and $\underline{7}$. These diagrams indicate how variations in the reacting solid phase ratios and either no precipitation or precipitation of various Fe minerals influence solution compositions. Drainage that leaches rocks with relatively very low reacting pyrite to carbonate (i.e., calcite, ankerite, or siderite) ratios is predicted to have lower ratios of dissolved $\mathrm{SO}_{4}$ to $(\mathrm{Ca}+\mathrm{Mg})$ concentrations, higher proportions of alkalinity, and lower proportions of acidity. This type of drainage plots near the bottom of the diagrams. Waters draining ore deposits with higher reacting pyrite to carbonate ratios are predicted to have higher ratios of $\mathrm{SO}_{4}$ to $(\mathrm{Ca}+\mathrm{Mg})$ concentrations, lower proportions of alkalinity, and higher proportions of acidity. These waters plot near the top of the diagrams. The locations of the specific carbonate minerals are uniquely defined in the diagrams by the relative amounts of $\mathrm{Ca}$ and $\mathrm{Mg}$ that are released during their dissolution. Predictions with siderite as the buffering carbonate are clearly separated from calcite and ankerite, except for the acidity diagram with no precipitation of Fe minerals. Although predictions for calcite and ankerite are close to each other in the alkalinity diagrams (Fig. 6), there is better separation between these carbonates in the acidity diagrams with precipitation of Fe minerals (Fig. 7). In addition, there are clear differences in the relationships if Fe(II) does not oxidize and precipitate or if it oxidizes and precipitates as Fe hydroxysulfate or Fe oxide minerals. 

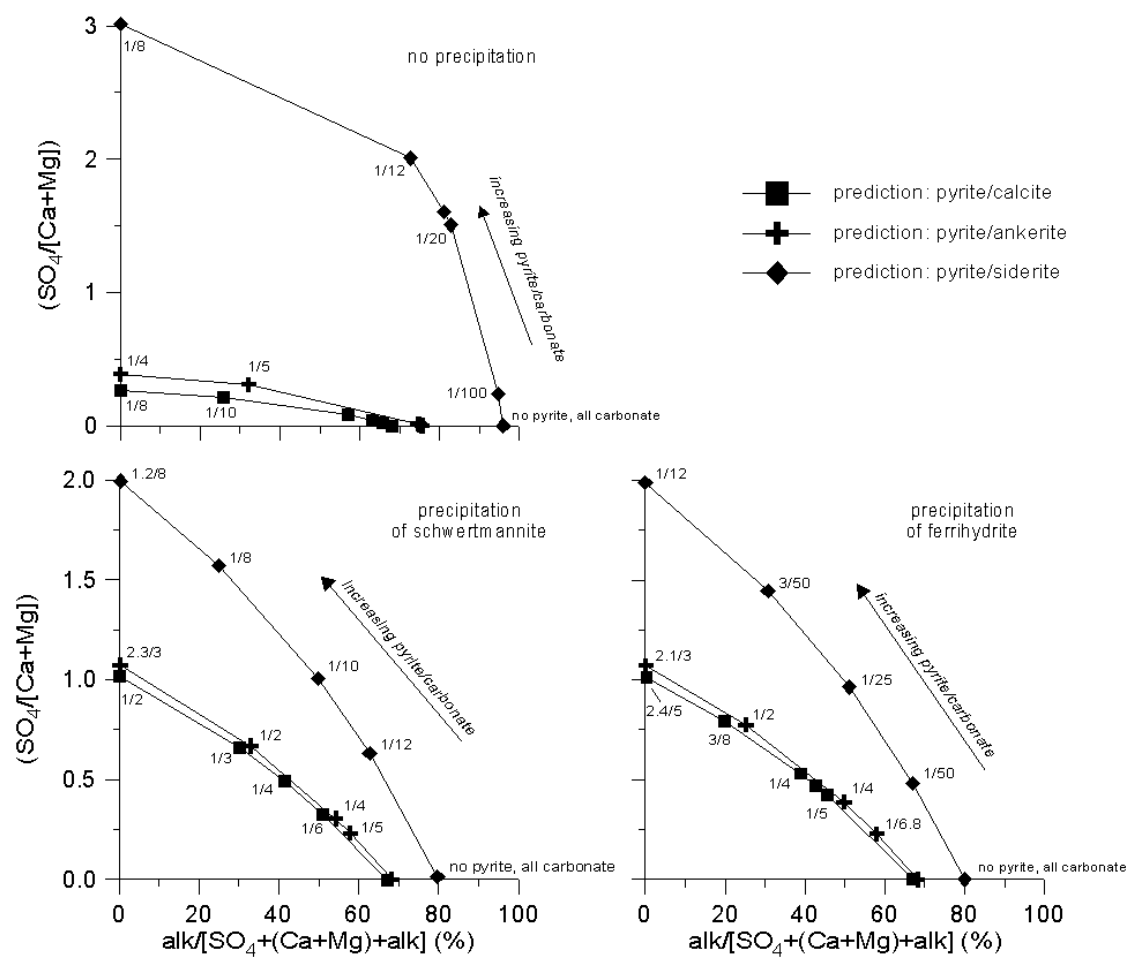

Figure 6. Predicted relationships between the ratio of sulfate $\left(\mathrm{SO}_{4}\right)$ to the sum of dissolved calcium (Ca) and magnesium (Mg) and normalized alkalinity (alk) for various ratios of reacting pyrite to carbonate (i.e., calcite, ankerite, or siderite) considering no precipitation of $\mathrm{Fe}$ or precipitation of schwertmannite or ferrihydrite.
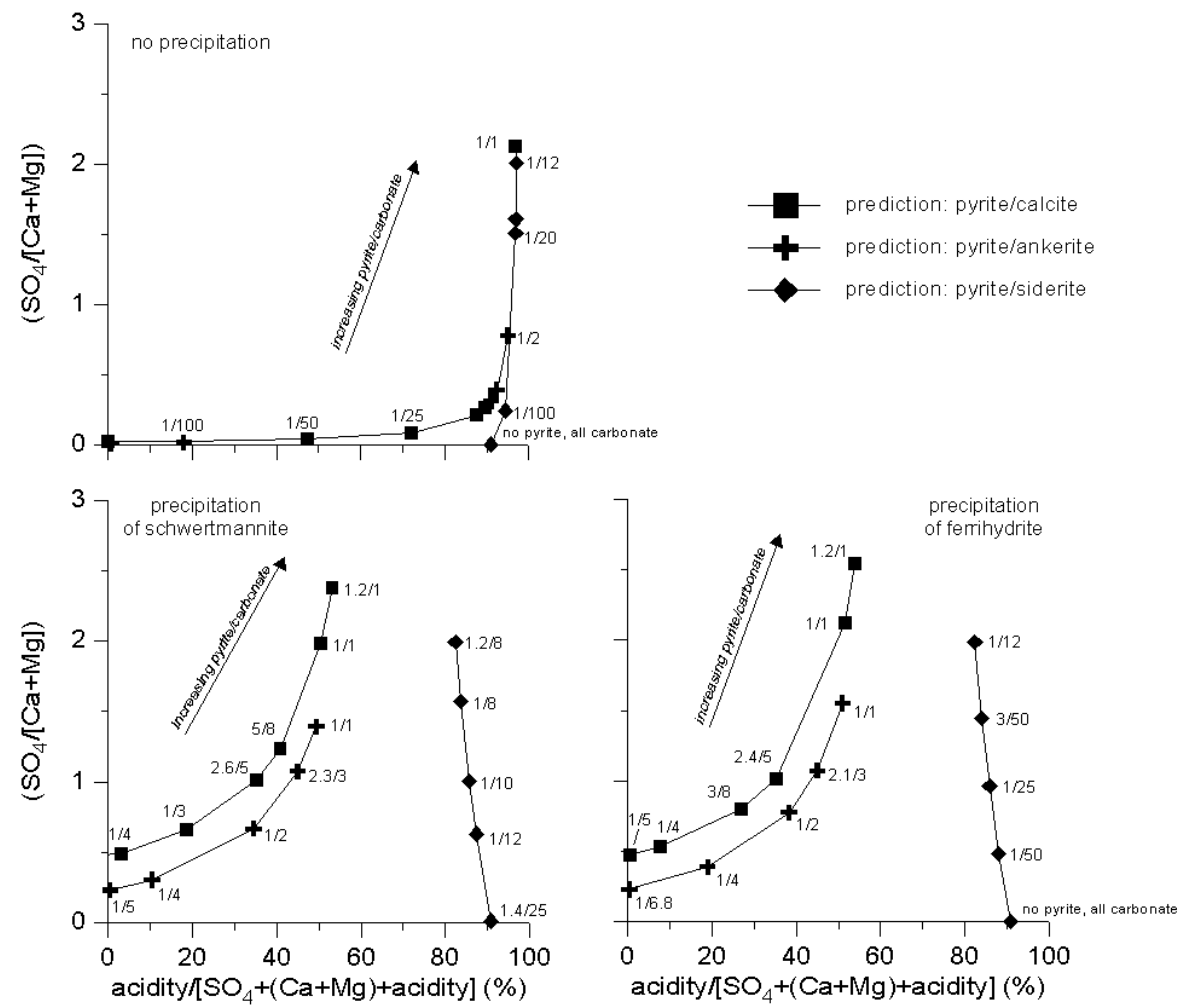

Figure 7. Predicted relationships between the ratio of sulfate $\left(\mathrm{SO}_{4}\right)$ to the sum of dissolved calcium (Ca) and magnesium $(\mathrm{Mg})$ and normalized acidity for various ratios of reacting pyrite to carbonate (i.e., calcite, ankerite, or siderite) considering no precipitation of $\mathrm{Fe}$ or precipitation of schwertmannite or ferrihydrite. 
These diagrams do not clearly distinguish between schwertmannite and ferrihydrite because differences in the moles of protons and $\mathrm{SO}_{4}$ produced per mole of pyrite oxidized or consumed per mole of carbonate mineral dissolved are too small during precipitation of the two Fe phases (Table 3). Successful predictions of the exact ratios of reacting pyrite to carbonate minerals from drainage data require an understanding of the particular Fe phase that is precipitating. This point is demonstrated by the different locations of the same pyrite/carbonate ratios for the precipitation of schwertmannite and ferrihydrite phases. However, an estimate of the ratios can be made because the locations for the reacting mineral ratios are nearly the same for the precipitation of these Fe minerals.

The next step is to use the predictions of the relationships between $\mathrm{SO}_{4}, \mathrm{Ca}$ and $\mathrm{Mg}$, and alkalinity or acidity to interpret drainage data from the $\mathrm{CdA}$ mining district. Dissolved $\mathrm{SO}_{4}$ concentrations in drainage from the district represent the oxidation of various sulfide minerals. However, only a portion of these minerals (i.e., pyrite) produces acidity during oxidation. In order to predict how the relative ratios of acid generating and acid consuming minerals vary throughout the district, we correct dissolved $\mathrm{SO}_{4}$ concentrations in drainage from the district for contributions from the major sulfide minerals that do not produce acidity during oxidation (i.e., sphalerite and galena) by assuming that all dissolved $\mathrm{Zn}$ and $\mathrm{Pb}$ concentrations are derived from the oxidation of these minerals. The dissolved concentrations of $\mathrm{SO}_{4}, \mathrm{Zn}$, and $\mathrm{Pb}$ are converted to a molar basis. Then dissolved $\mathrm{SO}_{4}$ derived from pyrite (i.e., pyritic $\mathrm{SO}_{4}$ ) is calculated as the difference between dissolved $\mathrm{SO}_{4}$ and the sum of dissolved $\mathrm{Zn}$ and $\mathrm{Pb}$ concentrations.

Thermodynamic speciation calculations using MINTEQA2 (Allison et al., 1991) indicate that drainage in the CdA mining district is undersaturated with respect to secondary Ca and Mg minerals. Thus, it is assumed that Ca and $\mathrm{Mg}$ concentrations are not affected by the precipitation of secondary minerals.

All adit waters, except the Kellogg Tunnel, and almost all tailings seeps collected in the CdA mining district contain alkalinity with values ranging from 0.1 to $7.2 \mathrm{mM}$. Because acidity was not measured by titration for the drainage waters from the CdA mining district, we calculated [Acy] for a subset of the data using equation 9 . We used measured dissolved concentrations of $\mathrm{Al}, \mathrm{Fe}(\mathrm{III}), \mathrm{Fe}(\mathrm{II})$, and $\mathrm{Mn}(\mathrm{II})$ to include the free metal ion as well as its solution complexes. Concentrations of $\mathrm{H}^{+}$, HSO4-, and $\mathrm{H} 2 \mathrm{CO} 30$ were determined from solution speciation calculations done for the drainage waters using MINTEQA2. The calculated [Acy] range from 0.02 to $41 \mathrm{mM}$. These calculations assume that titrations of drainage samples would result in complete oxidation and precipitation of $\mathrm{Fe}(\mathrm{II})$ and $\mathrm{Mn}(\mathrm{II})$. Furthermore, the calculations assume that filtration results in the accurate partitioning of Fe(III) between dissolved and particulate or colloidal forms. If particulate or colloidal Fe(III) passes through the filter and is considered to be dissolved, then the calculated acidity would be too high. These assumptions are only critical for drainage from the Kellogg Tunnel where $64 \%$ of the calculated acidity is due to Fe species. Because of their higher $\mathrm{pH}$ values, carbonic acid generally is the primary contributor to the calculated acidities of the remaining drainage samples. In addition, because reactions that contribute $\mathrm{Al}$ to acidity (e.g., buffering by $\mathrm{Al}$ oxides and aluminosilicate minerals) are not considered in our theoretical approach, we correct the calculated acidity values for the $\mathrm{Al}$ contribution. This correction is less than $5 \%$. Finally, the corrected or pyritic dissolved $\mathrm{SO}_{4}$, the sum of dissolved Ca and Mg, and alkalinity (or corrected acidity) data are converted to a molar basis, normalized to $100 \%$, and plotted on the same diagram as the predictions (Figs. 8 and $\underline{9}$ ).

Comparisons between the predictions and drainage from CdA indicate that these waters drain mineralized areas with reacting pyrite to carbonate ratios ranging from near zero (i.e., very, very little pyrite to carbonate) to about $1 / 2$ to $2 / 3$ for most of the drainage in the district to about equal portions of reacting pyrite and carbonate (i.e., 1/1) for the very acidic drainage from the Kellogg Tunnel. The relative concentrations of dissolved Ca and $\mathrm{Mg}$ in these waters suggest that, depending on location within the district, either calcite or ankerite appear to buffer the waters. The acidity diagram shows a clearer distinction between drainage that is buffered by calcite or ankerite. The location of CdA drainage within the diagrams indicates that Fe(II) oxidizes and precipitates. Drainage data are consistent with the precipitation of schwertmannite or ferrihydrite. 

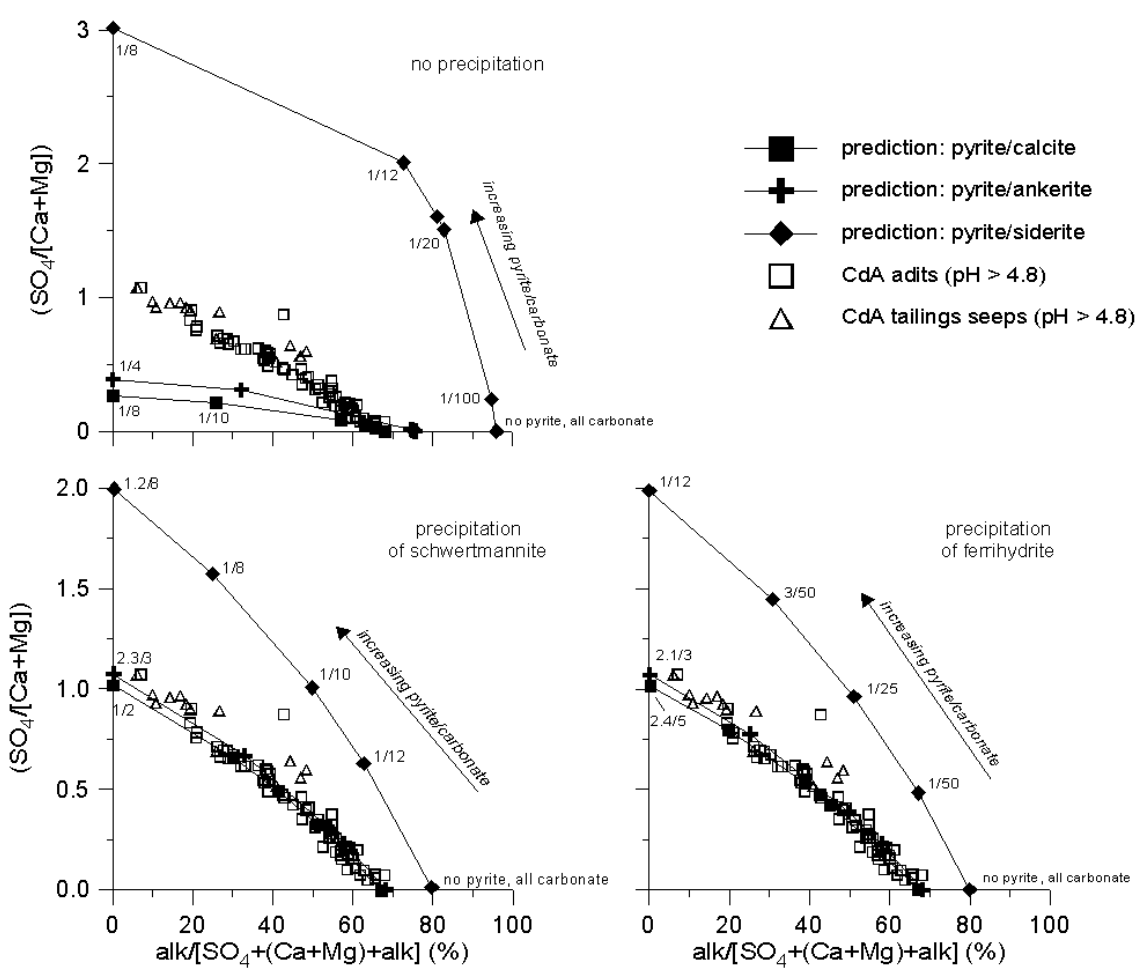

Figure 8. Comparisons between the predictions presented in Figure 6 and the composition of drainage from adits and tailings piles in the Coeur d'Alene (CdA) mining district.
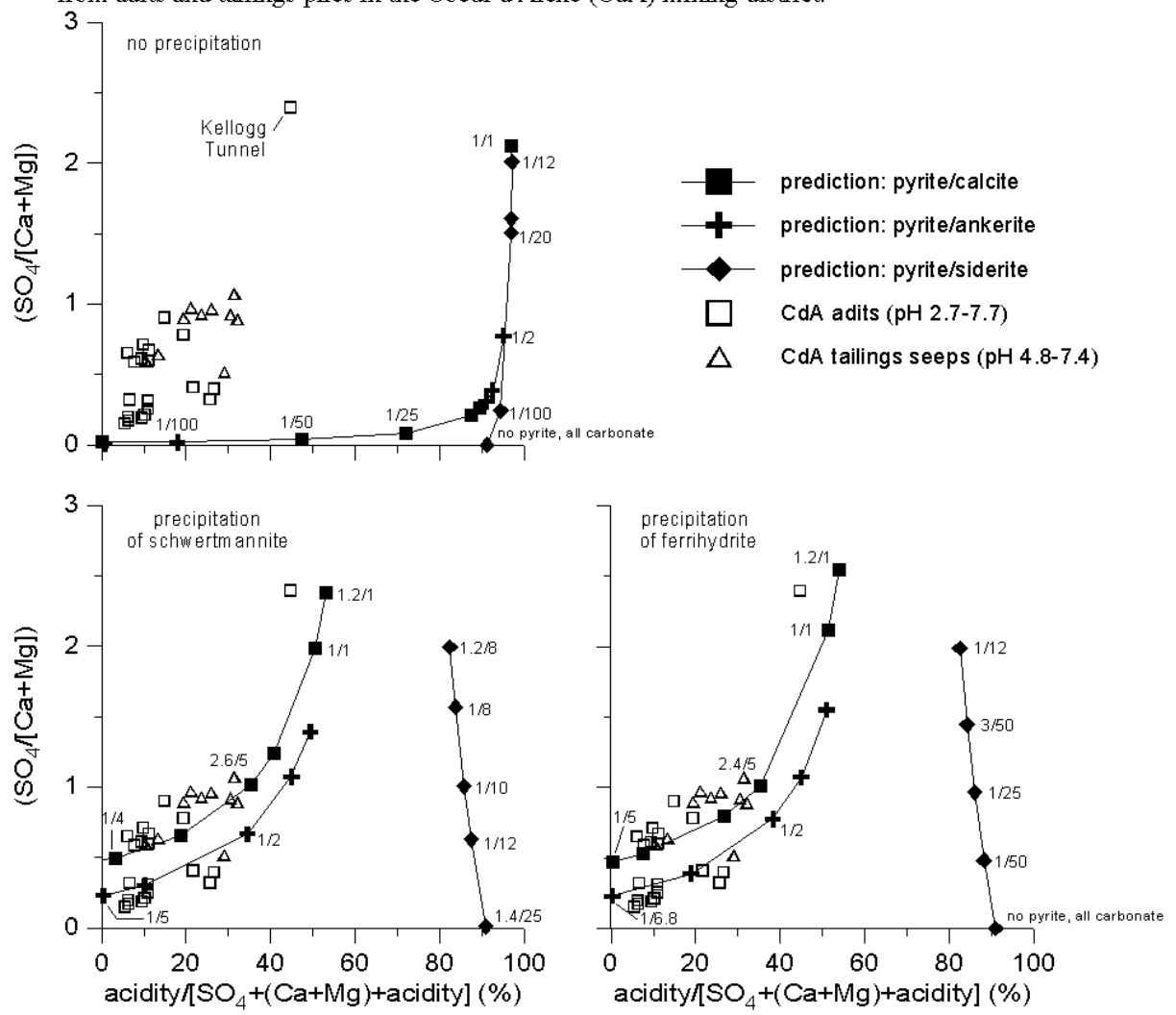

Figure 9. Comparisons between the predictions in Figure 7 and the composition of drainage from adits and tailings piles in the Coeur d'Alene (CdA) mining district. 
Reacting pyrite to carbonate ratios and $\mathrm{pH}$

What is the relationship between the $\mathrm{pH}$ of drainage and the relative amounts of pyrite and carbonate minerals that have reacted in a mineralized deposit? Using the theoretical approach presented above, we can estimate the reacting pyrite to calcite or reacting pyrite to ankerite ratios of the deposits from the measured pyritic $\mathrm{SO}_{4}$ to $(\mathrm{Ca}+$ $\mathrm{Mg}$ ) ratios in the drainage. If we consider precipitation of ferrihydrite, the reacting pyrite to calcite ratio is equal to [pyritic $\left.\mathrm{SO}_{4} /(\mathrm{Ca}+\mathrm{Mg})\right] / 2.12$, while the reacting pyrite to ankerite ratio is equal to [pyritic $\left.\mathrm{SO}_{4} /(\mathrm{Ca}+\mathrm{Mg})\right] / 1.55$. The predicted reacting pyrite/calcite ratios, considering ferrihydrite precipitation, for the polymetallic vein deposits in $\mathrm{CdA}, \mathrm{CO}$, and $\mathrm{NV}$ are plotted versus the $\mathrm{pH}$ of the drainage in Fig. 10. Note that the results would be very similar if the reacting pyrite to ankerite relationship is used. As expected, drainage from deposits and host rocks with the highest reacting pyrite to calcite ratios, as determined by pyritic $\mathrm{SO}_{4}$ to $(\mathrm{Ca}+\mathrm{Mg})$ ratios in drainage, have the lowest $\mathrm{pH}$ values. The results indicate that the $\mathrm{pH}$ of drainage is near neutral or slightly basic when the polymetallic deposits and their host rocks have reacting pyrite to calcite ratios less than $3 / 10$. The $\mathrm{pH}$ of drainage is very acidic $(\mathrm{pH} \leq 3)$ when the reacting pyrite to calcite ratios of the deposits and host rocks are near or greater than about 6/10. The transition between neutral and acidic $\mathrm{pH}$ values occurs in drainage when the reacting pyrite to calcite ratios of the deposits and host rocks are between $3 / 10$ and 6/10.

What values of drainage $\mathrm{pH}$ should be expected based on the stoichiometry of the pyrite oxidation and calcite dissolution reactions? Acid-Base Accounting (ABA) measurements, which determine the relative acid generating and acid neutralizing potentials of rocks, are based on the following reaction (Cravotta et al., 1990; Perry, 1998):

$$
\mathrm{FeS}_{2}+2 \mathrm{CaCO}_{3}+3.75 \mathrm{O}_{2}+1.5 \mathrm{H}_{2} \mathrm{O} \rightarrow 2 \mathrm{SO}_{4}{ }^{2-}+\mathrm{Fe}(\mathrm{OH})_{3}+2 \mathrm{Ca}^{2+}+2 \mathrm{CO}_{2}
$$

That is, for each mole of pyrite that is oxidized, two moles of calcite are required for acid neutralization, assuming loss of $\mathrm{CO}_{2}$ to the atmosphere. If $\mathrm{CO}_{2}$ is not lost, but is retained within the system resulting in additional acid generating capacity, then up to 4 moles of calcite are needed for neutralization of one mole of pyrite (Cravotta et al., 1990):

$$
\mathrm{FeS}_{2}+4 \mathrm{CaCO}_{3}+3.75 \mathrm{O}_{2}+3.5 \mathrm{H}_{2} \mathrm{O} \rightarrow 2 \mathrm{SO}_{4}{ }^{2-}+\mathrm{Fe}(\mathrm{OH})_{3}+4 \mathrm{Ca}^{2+}+4 \mathrm{HCO}_{3}{ }^{-}
$$

Hence, neutralization of acid generated during oxidation of one mole of pyrite theoretically requires between 2 and 4 moles of calcite (i.e., reacting pyrite to calcite ratios ranging between 2.5/10 and 5/10). Thus, drainage data from polymetallic deposits in $\mathrm{CdA}, \mathrm{CO}$, and $\mathrm{NV}$ are consisted with the theoretical predictions as predicted reacting pyrite to calcite ratios $<3 / 10$ for the deposits and host rocks result in near neutral to basic drainage.

\section{ACKNOWLEDGMENTS}

The manuscript is largely based on the publication by Balistrieri et al. (1999). The authors wish to acknowledge Mohammed Ikramuddin from Eastern Washington University who did the analyses on the drainage from the adits and tailings piles in the CdA mining district and Vic Mossotti who helped in developing the initial conceptual geoenvironmental model for CdA deposits. The term "transport and reaction zones" for the second component of the geoenvironmental model for CdA deposits was coined during a meeting of the environmental geochemists in the Western Region of the USGS-Minerals Program in March 2000. Michelle Tuttle (USGS) did a helpful review of an earlier draft of the manuscript. 


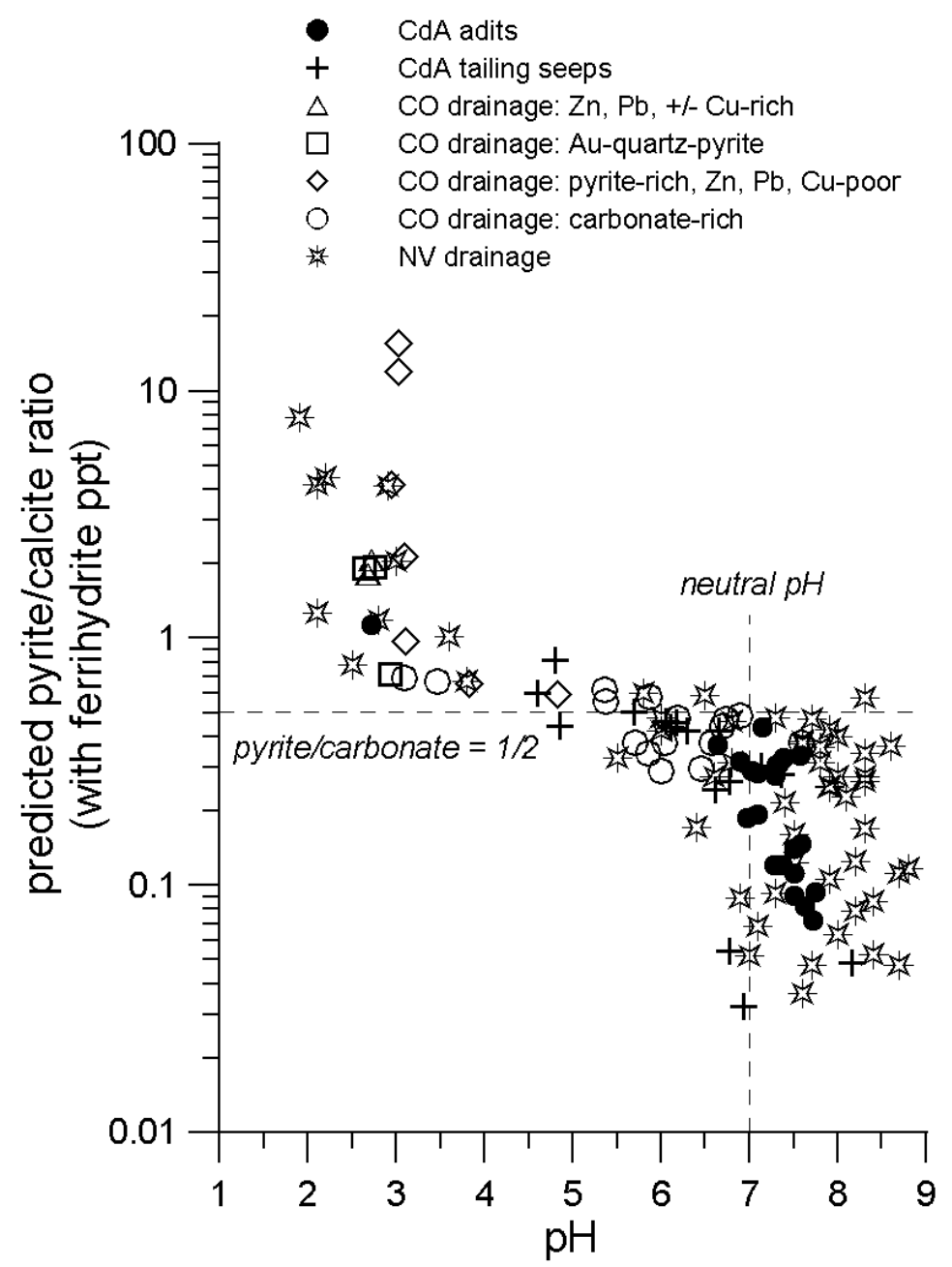

Figure 10. Comparisons between the predicted ratios of reacting pyrite to calcite, considering precipitation of ferrihydrite and calculated as pyritic $\mathrm{SO}_{4} /(\mathrm{Ca}+\mathrm{Mg})$ in drainage, versus the $\mathrm{pH}$ of drainage from polymetallic vein deposits in the Coeur d'Alene mining district, in the Colorado Mineral Belt, and in the Humboldt Basin in northern Nevada.

\section{REFERENCES CITED}

Allison, J.D., Brown, D.S., and Novo-Gradac, K. J., 1991, MINTEQA2/PRODEFA2, A geochemical assessment model for environmental systems, Version 3.0 User's manual: U.S. EPA, Athens, Georgia.

APHA, 1976, Standard Methods for the Examination of Water and Wastewater: American Public Health Association, Washington, D.C.

Balistrieri, L.S., Bookstrom, A.A., Box, S.E., and Ikramuddin, M., 1998, Drainage from adits and tailings piles in the Coeur d'Alene mining district, Idaho: Sampling, analytical methods, and results: U.S. Geological Survey Open-File Report 98-127, 19 p.

Balistrieri, L.S., Box, S.E., Bookstrom, A.A., and Ikramuddin, M., 1999, Assessing the influence of reacting pyrite and carbonate minerals on the geochemistry of drainage in the Coeur d'Alene mining district: Environmental Science \& Technology, v. 33, p. 3347-3353.

Balistrieri, L.S., Box, S.E., Ikramuddin, M., Horowitz, A.J., and Elrick, K.A., 2000, A study of porewater in water saturated sediments of levee banks and marshes in the lower Coeur d'Alene River valley, Idaho: Sampling, analytical methods, and results: U.S. Geological Survey Open-File Report 00-126, 59 p.

Bennett, E. H., and Venkatakrishnan, R., 1982, A palinspastic reconstruction of the Coeur d'Alene mining district based on ore deposits and structural data: Economic Geology, v. 77, p. 1851-1866. 
Bigham, J.M., Schwertmann, U., Traina, S.J., Winland, R.L., and Wolf, M., 1996, Schwertmannite and the chemical modeling of iron in acid sulfate waters: Geochimica et Cosmochimica Acta, v. 60, p. 2111-2121.

Bliss, J.D., 1992, Developments in mineral deposit modeling: U.S. Geological Survey Bulletin 2004, 168 p.

Blowes, D.W., and Ptacek, C.J., 1994, Acid-neutralization mechanisms in inactive mine tailings, in Jambor, J.L., and Blowes, D.W., eds., Short Course Handbook on Environmental Geochemistry of Sulfide Mine-Wastes: Mineralogical Association of Canada, p. 271-292.

du Bray, E.A. (ed.), 1995, Preliminary compilation of descriptive geoenvironmental mineral deposit models: U.S. Geological Survey Open-File Report 95-831, 272 pp. (available online at http://minerals.cr.usgs.gov).

Code of Federal Regulations, 1999, Title 40, Part 131.36 (available online at http://www.access.gpo.gov/nara/cfr).

Cox, D.P., and Singer, D.A., 1986, Mineral deposit models: U.S. Geological Survey Bulletin 1693, 379 p.

Cravotta, C.A., III, Brady, K.B.C., Smith, M.W., and Beam, R.L., 1990, Effectiveness of alkaline addition at surface mines in preventing or abating acid mine drainage: Part 1. Geochemical Considerations, in Proceedings of the 1990 Mining and Reclamation Conference and Exhibition Volume, pp. 221-226.

Criss, R.E., and Fleck, R.J., 1990, Oxygen isotope map of the giant metamorphic-hydrothermal system around the northern part of the Idaho batholith, U.S.A.: Applied Geochemistry, v. 5, p. 1-15.

Ficklin, W.H., Plumlee, G.S., Smith, K.S., and McHugh, J.B., 1992, Geochemical classification of mine drainages and natural drainages in mineralized areas: in Kharaka, Y.K., and Maest, A.S., eds., Proceedings, $7^{\text {th }}$ International Water-Rock Interaction Conference, Park City, Utah, p. 381-384.

Fryklund, V. C., Jr., 1964, Ore deposits of the Coeur d'Alene district, Shoshone County, Idaho: U.S. Geological Survey Professional Paper 445, 139 p.

Gitlin, E.C., 1986, Wall rock geochemistry of the Lucky Friday Mine, Shoshone County, Idaho: Thesis (Ph.D.), University of Washington.

Golder Associates, Inc., 1998, Hydrological investigation, Interstate mill, Wallace, Idaho: Report to Silver Valley Natural Resource Trustees (February 18, 1998); Golder Associates, Inc., $4104148^{\text {th }}$ Ave NE, Redmond, WA 98052, $10 \mathrm{p}$.

Hobbs, S. W., Griggs, A. B., Wallace, R. E., and Campbell, A.B., 1965, Geology of the Coeur d'Alene district, Shoshone County, Idaho: U.S. Geological Survey Professional Paper 478, 139 p.

Langmuir, D., 1997, Aqueous Environmental Geochemistry: Prentice Hall, 600 p.

Leach, D.L., Hofstra, A.H., Church, S., Snee, L.E., Vaughn, B., and Zartman, R., 1998, Evidence for Proterozoic and Late Cretaceous-Early Tertiary ore formation in the Coeur d'Alene district, Idaho and Montana: Economic Geology, v. 93, p. 1106-1109.

Leach, D.L., Landis, G.P., and Hofstra, A.H., 1988, Metamorphic origin of the Coeur d'Alene base- and preciousmetal veins in the Belt Basin, Idaho and Montana: Geology, v. 16, p. 122-125.

Long, K.R., 1998a, Production and disposal of mill tailings in the Coeur d'Alene mining region, Shoshone County, Idaho; Preliminary estimates: U.S. Geological Survey Open-File Report 98-595, 14 p.

Long, K.R., 1998b, Grade and tonnage models for Coeur d'Alene-type polymetallic veins: U.S. Geological Survey Open-File Report 98-583, 28 p.

McCulley, Frick, and Gilman, Inc., 1994, Bunker Hill Superfund Site, 1993 annual groundwater monitoring report: Basic data report; prepared for 10 mining companies, Boulder, Colorado, April 29, 1994, 41 p.

McCulley, Frick, and Gilman, Inc., 2000, 1999 Annual water-quality data report, Woodland Park, Idaho: Consultant report prepared for Hecla Mining Co. and Silver Valley Resource Trustees, 809 East Mullan Ave., Osburn, Idaho 83849, $24 \mathrm{p}$.

Mink, L.L., Williams, R.E., and Wallace, A.T., 1971, Effect of Industrial and Domestic effluents on the water quality of the Coeur d'Alene river basin: Idaho Bureau of Mines and Geology, Pamphlet 149, $30 \mathrm{p}$.

Nash, J.T., 2000, Hydrogeochemical data for historic mining areas, Humboldt watershed and adjacent areas, northern Nevada: U.G. Geological Survey Open-File Report 00-459, 13 p and associated spreadsheets (http://greenwood.cr.usgs.gov/pub/open-file-reports/ofr-00-0459/).

Nordstrom, D.K.; Jenne, E.A., and Ball, J.W., 1979, Redox equilibria of iron in acid mine waters, in Jenne, E.A., ed., Chemical Modeling in Aqueous Systems: American Chemical Society Symposium Series 93, p. 51-79.

Perry, E.F., 1998, Interpretation of acid-base accounting, in Brady, K.B.C., Smith, M.W., and Schueck, J., eds., Coal Mine Drainage Prediction and Prevention in Pennsylvania: Pennsylvania Department of Environmental Protection.

Plumlee, G.S., and Nash, J.T., 1995, Geoenvironmental models of mineral deposits—Fundamentals and applications, in du Bray, E.A., ed., Preliminary compilation of descriptive geoenvironmental mineral deposit 
models: U.S. Geological Survey Open-File Report 95-831, p. 1-9. (available online at http://minerals.cr.usgs.gov).

Plumlee, G.S., Smith, K.S., Ficklin, W.H., Briggs, P.H., and McHugh, J. B., 1993, Empirical studies of diverse mine drainages in Colorado: Implications for the prediction of mine-drainage chemistry, in Proceedings: Planning, Rehabilitation, and Treatment of Disturbed Lands; Montana State University Reclamation Research Unit: Billings, Publication 9301, v. 1, p. 176-186.

Plumlee, G.S., Smith, K.S., Montour, M.R., Ficklin, W.H., and Mosier, E.L., 1999, Geologic controls on the composition of natural waters and mine waters draining diverse mineral-deposit types, in Filipek, L.H., and Plumlee, G.S., eds., The environmental geochemistry of mineral deposits Part B: Case studies and research topics: Reviews in Economic Geology, v. 6B, 373-432.

Reedy, B.J., Beattie, J.K., and Lowson, R.T., 1991, A vibrational spectroscopic ${ }^{18} \mathrm{O}$ study of pyrite oxidation: Geochimica et Cosmochimica Acta, v. 55, p. 1609-1614.

Reid, R.R., 1984, Structural controls of the Coeur d'Alene ore deposits, in Hobbs, S.W., ed., The Belt: Montana Bureau of Mines and Geology Special Publication 90, p. 49-51.

Sherlock, E.J., Lawrence, R.W., and Poulin, R., 1995, On the neutralization of acid rock drainage by carbonate and silicate minerals: Environmental Geology, v. 25, p. 43-54.

Singer, D.A., 1995, World class base and precious metal deposits - a quantitative analysis: Economic Geology, v. 90, no. 1, p. 88-104

Singer, P.C., and Stumm, W., 1970, Acidic mine drainage: The rate-determining step: Science, v. 167, p. 11211123.

Stumm, W., and Morgan J.J., 1996, Aquatic Chemistry: Wiley, New York, 1022 p.

Taylor, B.E., Wheeler, M.C., and Nordstrom, D.K., 1984, Stable isotope geochemistry of acid mine drainage: Experimental oxidation of pyrite: Geochimica et Cosmochimica Acta, v. 48, p. 2669-2678.

Terragraphics Environmental Engineering, Inc., 1998, Preliminary engineering design report, Success mine site passive treatment project: Prepared for Idaho Dept. of Health and Welfare, Division of Environmental Quality, Coeur d'Alene, Idaho, October, 1998, 25 p.

USEPA, 1974, Methods for Chemical Analysis of Water and Wastes (EPA-625-/6-74-003): U.S. Environmental Protection Agency, Washington, D.C.

U.S. Geological Survey, 1973, Water Resources data for Idaho in 1972, Part 2, water quality records: U.S. Geological Survey Water-data Report ID-72-2, 239 p.

Zartman, R.E., and Stacey, J.S., 1971, Lead-isotopes and mineralization ages in Belt Supergroup rocks, northwestern Montana and northern Idaho: Economic Geology, v. 66, p. 849-860. 


\title{
Chapter J
}

\section{MERCURY GEOENVIRONMENTAL MODELS}

\author{
James J. Rytuba
}

\section{INTRODUCTION}

Mercury mines and mines that produce byproduct mercury can impact the environment through the release of mercury-enriched sediment, mercury-rich mine drainage, and mercury vapor released to the atmosphere. Most mercury mines contain mercury contaminated mine wastes and soils that are a source for both soluble and particulate mercury species. Environmental concerns related to mining and processing of mercury-bearing ores consist of contamination of soils, sediments, and waters by mine wastes; mercury vapor released during ore processing and from mine tailings; and mercury mine drainage and toxic metal release into watersheds. Significant environmental impacts on watersheds also are associated with the release and transport of elemental mercury from past and present gold placer operations, and from tailings generated during the processing of precious metal ores where the amalgamation process was used. Although geoenvironmental models of mercury deposits can be used to establish the environmental effects caused by these deposits, the models must be used in the context of global cycling of mercury.

\section{GLOBAL MERCURY CYCLE AND ENVIRONMENTAL}

The global atmospheric pool of mercury contributes mercury to watersheds and lakes through both wet and dry depositional processes that are mediated by leaf uptake of mercury by plants (Mason and others, 1994). Because of this atmospheric contribution of mercury, the magnitude of the flux of mercury to the environment from mineralized areas and mine sites reflects both local and global contributions of mercury, although the local source typically predominates in mineralized areas. The primary natural sources of mercury to the atmosphere include, in decreasing importance, the oceans, soil degassing, volcanoes, and geothermal systems (Varekamp and Buseck, 1986, Mason and others, 1994). Anthropogenic sources of mercury to the atmosphere are primarily from coal combustion, waste incineration, and smelters (Nriagu and Pacyna, 1988). Since the beginning of industrial period in the middle 1800s, the global atmospheric mercury deposition increased until about 1970 and then decreased slightly in the past three decades (Fitzgerald and others, 1997). This increase in atmospheric mercury deposition is reflected in the sedimentary record of lakes, estuaries, and bogs. Cores of recently deposited sediments from all these environments record an increase in mercury concentration of about 2 to 5 times over background mercury concentrations established prior to the industrial period (Fitzgerald and others, 1997, Hurley and others, 1994; Verta and others, $\underline{1990)}$. For this reason mercury background levels in various media such as soils generally cannot be established and only baseline concentrations can be determined now.

Unlike most metals, plants uptake mercury primarily through leaves rather than through the root system. Under high ambient air mercury concentration, plants uptake and concentrate mercury in their leaves, and conversely, under low ambient air concentrations of mercury, plants give off mercury through their leaves (Lindberg and others, 1992). In mine areas where ambient air concentrations of mercury are high either due to roasting of mercury ores or from emission of mercury vapor from contaminated or naturally anomalous soils, plant communities down wind from these sites concentrate both mercury and methylmercury in their leaves. For example, at mercury contaminated mine sites in southwest Alaska, plant leaves contain elevated mercury and methylmercury concentration, up to 970 ppb and $37 \mathrm{ppb}$ respectively, as compared to baseline values of $190 \mathrm{ppb}$, and $1.5 \mathrm{ppb}$, respectively, in unmineralized areas (Bailey and Gray, 1997, Bailey et al., 1999). Wash off and litter fall are the primary routes for introduction of mercury into creeks and lakes from these plant communities. This process will augment any direct contamination of watersheds and lakes by mercury contaminated mine wastes and waters.

The mercury species of greatest environmental concern is methylmercury, because it may become highly concentrated through bioaccumulation in fish and other fish consuming biota. Methylmercury is a neurotoxin and its pathway into humans is primarily through consumption of methylmercury-contaminated fish. A secondary pathway into humans is the direct ingestion of mercury contaminated mine wastes by children displaying pica activity (soil ingestion). Mercury released from point sources and deposited from the atmosphere into streams, wetlands, and lakes may become methylated and incorporated into the food web. Methylation of mercury and its uptake by biota is a complex process and dependent on several variables. As a result, although fisheries downstream from mercury mine sites are generally contaminated, the levels of methylmercury do not always exceed the federal action level of $1.0 \mathrm{ppm}$ (for example see Gray et al., 1996, for fisheries below mercury mines in Alaska). Formation of 
methylmercury $\left(\mathrm{CH}_{3} \mathrm{Hg}^{+}\right)$is favored by the presence of ionic mercury and high concentrations of dissolved organic carbon and sulfate. Mercury methylation is a co-metabolic reaction and sulfate-reducing bacteria are the primary mediators in the biotic methylation process (Campeau and Bartha, 1985, Summers, 1986). Acid mine drainage from mercury deposits commonly has both high sulfate and mercury concentration and introduction of these waters into streams, wetlands, and lakes increases the methylation process (Rytuba and Enderlin, 1999). Although methylmercury can be formed at mine sites in mercury-contaminated soils and mine waters, most mercury methylation occurs downstream from the mine site in wetlands and larger aquatic bodies. Detrital particles, such as clays, organic phases, and iron oxyhydroxide, adsorb $\mathrm{Hg}^{2+}$ from the water column in streams and lakes, and sedimentation of these particles reduces the methylation process. Sequestration of mercury in sediment is the primary mode of removing mercury from the environment.

\section{MERCURY PRODUCTION}

Mercury has been mined in North America since the early 1800's with over 6 million flasks (a flask equals 76 pounds of mercury) of mercury being produced from ten major mercury mineral belts (fig. 1). The mercury mineral belts consist of mercury deposits with significant production (greater than 1000 flasks of mercury), small mercury occurrences having small or no production, and areas of country rock containing elevated concentrations of mercury. In North America, the California Coast Range mercury mineral belt has been the largest producer of mercury and contains fifty-one mines that have produced over 1000 flasks of mercury. The New Almaden mine in central California is the largest mercury mine in North America having produced about four million flasks. Mercury also has been produced as a byproduct from zinc-rich volcanogenic massive sulfide deposits and from hot-spring-type

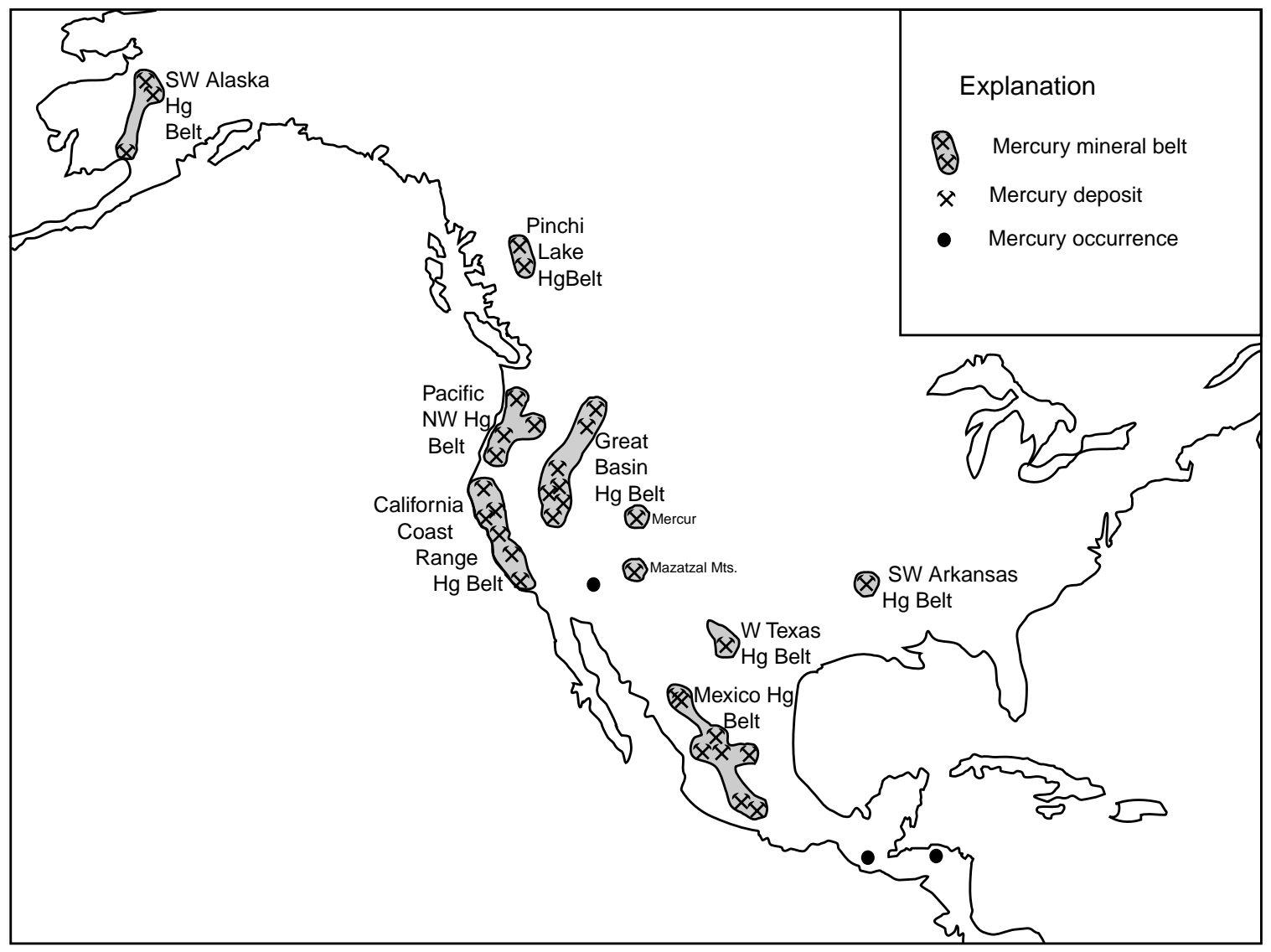

Figure 1. Mercury mineral belts in North America consist of mercury deposits with significant production and mercury occurrences with little or no production. Shaded areas in mineral belts indicate areas that include altered areas with elevated mercury concentration.

gold-silver deposits. Much of the mercury produced has been used in the recovery of gold from placer deposits and in the processing of precious metal ores that utilized the mercury amalgamation process. Because of environmental concerns and the consequent low price of mercury, large scale mercury mining ceased by 1980 in North America 
except for some small scale mercury mining in Mexico. Primary mercury production continues in the Almaden mercury district in Spain, which contains the largest and richest mercury ore bodies in the world, as well as from mercury deposits (listed in decreasing amount of production) in Kyrgystan, China, Algeria, Russia, Slovakia, Tajikistan, Ukraine, Mexico, and Slovenia. Mercury also continues to be produced in Finland as a byproduct from massive sulfide deposits. Similar deposits in the Urals, (former Soviet Union) and India also produce mercury, but it is released to the atmosphere rather than recovered during the smelting process. In the United States, gold mines are the only producers of byproduct mercury, because the mercury content of gold and silver ores from hot-spring-type, and Carlin-type gold deposits can be as high as several hundred $\mu \mathrm{g} / \mathrm{g}$ (ppm). However, some of these mines still release significant mercury to the atmosphere. In Mexico, significant byproduct mercury production continues to come from the reprocessing of silver and gold mine tailings, such as in the Zacatecas precious metal district.

\section{MERCURY DEPOSIT TYPES}

Most mercury deposits that occur in the large mercury mineral belts in North America can be classified as either silica-carbonate-type or hot-spring-type mercury deposits (Rytuba, 1996). However, the largest mercury deposits in the world are the Almaden-type deposits, but this deposit type is primarily restricted to the Almaden district in Spain. Silica-carbonate-type and hot-spring-type mercury deposits are usually spatially separate but in the California mercury mineral belt, hot-spring type mercury mineralization can overprint earlier formed silicacarbonate type mercury deposits, such as in the Knoxville district (Rytuba, 1996).

Silica-carbonate-type mercury deposits are associated spatially with serpentinite that has been altered to a mineral assemblage of silica and carbonate minerals. These deposits are generally small to moderate in size, and contain from 0.1 to 10 million metric tons of ore containing from 0.2 to 0.8 weight percent mercury. The deposits consist of vein and replacement ore bodies developed within and adjacent to silica-carbonate altered serpentinite. Silica-carbonate alteration is localized along regional faults that separate serpentinite from adjacent country rock and the alteration commonly extends up to several kilometers beyond the margins of the ore bodies. The alteration assemblage is zoned from a central core of quartz-chalcedony-magnesite-pyrite-marcasite to a peripheral zone of magnesite-calcite-dolomite-magnetite. The initial alteration process consists of the addition of carbonate to the serpentinite followed by introduction of silica into the central core (Sherlock, et al., 1993). The peripheral zone of calcite-dolomite veining may extend for several kilometers outward from the mercury deposit. In addition to mercury, these deposits commonly have elevated concentrations of antimony $(0.1-1,000 \mathrm{ppm})$, arsenic (2-200 $\mathrm{ppm})$, nickel (10-3,000 ppm), cobalt (5 - $100 \mathrm{ppm})$, thallium (1-12 ppm), and zinc (2 -50 ppm). Copper is generally low, less than $50 \mathrm{ppm}$, and lead is essentially absent in these deposits. Pyrite and marcasite comprise from 2 to 10 volume percent in the ores except in deposits that formed adjacent to mafic volcanic vents where iron sulfide can comprise up to 50 volume percent. The grain size of both iron sulfides ranges from 0.5 to $5 \mathrm{~mm}$. Cinnabar is generally fine grained, about $0.2 \mathrm{~mm}$, but can be have a larger grain size, up to $5 \mathrm{~mm}$, in veins and vugs. This deposit type formed from low-temperature, less than $120^{\circ} \mathrm{C}, \mathrm{CO}_{2}-\mathrm{CH}_{4}-\mathrm{H}_{2} \mathrm{~S}$-rich fluids that commonly contained petroleum compounds (Peabody, 1992; Sherlock et al., 1993). The impermeable serpentinite bodies are important in the localization of silica-carbonate-type mercury deposits because their fault-bounded margins impede and channel the flow of mercury-bearing hydrothermal fluids (Rytuba, 1996). Elevated levels of mercury and small mercury occurrences are present in the silica-carbonate-alteration zones. The large productive mercury deposits formed in structural traps, such as antiformal structures, where fluids were localized below impermeable strata. In the large deposits, the ore bodies are hosted both in silica-carbonate altered serpentinite and in adjacent clastic sedimentary rocks.

Hot-spring-type mercury deposits are associated closely with volcanic centers and form in the near surface environment. The volcanic host rocks and associated clastic sedimentary rocks are altered to an assemblage of adularia, quartz, and sericite at depth, and in the near surface, to an advanced argillic alteration assemblage of kaolinite, alunite, and cristobalite that commonly contains elemental sulfur. Some of these deposits are hosted in hot-spring sinter that was deposited at the surface and that consists of banded silica phases and beds of hydrothermal eruption breccia. These deposits have a trace element association of lithium, boron, arsenic, antimony, gold, silver, thallium, and tungsten. Hot-spring-type mercury deposits are often the near-surface expression of hot-spring type gold deposits that occur at deeper levels below mercury-enriched sinter, such as at the McLaughlin gold deposit (Lehrman, 1986). The hydrothermal fluid source for the hot-spring-type mercury and associated gold deposits ranges in composition from dominantly meteoric to mixed meteoric-magmatic and the fluids are typically lowsalinity, moderate-temperature (about $200^{\circ} \mathrm{C}$ ) (Rytuba 1993).

Almaden-type mercury deposits are the largest and highest-grade mercury deposits. These deposits commonly contain from 10 to 100 million metric tons of ore that ranges from 2.0 to 20 weight percent Hg. The Almaden deposit in central Spain is the single largest mercury deposit in the world. These deposits are associated spatially 
with mafic submarine vent complexes that consist of mafic dikes and sills, and oval craters typically with dimensions of $300 \mathrm{~m}$ by $150 \mathrm{~m}$ (Hernandez, 1985), and submarine calderas, such as at the Las Cuevas deposit (Rytuba et al., 1988). Juvenile magma clasts within the craters are typically alkali basalts. The deposits consist of massive cinnabar and elemental mercury replacement bodies hosted in quartzite, tuff breccias, submarine mafic to intermediate composition pyroclastic flows, mafic dikes, and organic-rich black shales. Primary veins in these deposits are uncommon and cinnabar veins that are present consist of gash fractures developed during later regional metamorphism of these deposits (Rytuba et al., 1988). The replacement deposits hosted in quartzite consist of stratiform zones of cross cutting ore consisting of cinnabar, native mercury, pyrite, calcite, and quartz. The grade and thickness of ore bodies is highest near the margin of the volcanic craters and decreases systematically away from the craters. Mercury is the only ore metal in these deposits and the only other trace metal present is zinc. No other mineral deposit type is associated with these mercury deposits.

\section{MINERALOGIC CHARACTERISTICS}

The primary ore mineral in all mercury deposit types is cinnabar, (HgS). Elemental mercury is also common in all deposit types but generally in small amounts. Only in one deposit of the Almaden type, Las Cuevas, Spain, is elemental mercury the primary ore mineral. The high temperature polymorph of mercury sulfide, metacinnabar, commonly is present in silica-carbonate-type mercury deposits and in a few of these deposits, it is the primary ore mineral. More rarely, under extreme oxidizing and low $\mathrm{pH}$ conditions, mercury sulfates and chlorides may form as coatings on surface exposures. These yellow and green minerals are photosensitive and typically turn black on exposure to the sun and can be easily confused with manganese oxides. Mercury silicates and chromates also are present in silica-carbonate-type deposits. All of these minerals can be present in very small amounts except in a few silica-carbonate-type deposits where they comprise the main ore minerals. In hot-spring type mercury deposits, mercury sulfate, chloride, and oxide minerals are present in the upper parts of the ore bodies and these phases may form during supergene alteration of the ore body. Because these phases are very soluble, they commonly are preserved in sealed vugs and fracture coatings within the upper parts of ore bodies. The mineral corderoite, a mercury chloro-sulfide, is the dominant ore mineral at only one hot-spring type mercury deposit, the McDermitt deposit, Nevada.

Other sulfide minerals present in silica-carbonate type deposits include pyrite, and marcasite and in hot-springtype deposits, pyrite and native sulfur are present. In silica-carbonate deposits iron sulfides comprise from 5-10 percent by volume of the ores and altered country rock except where these deposits are localized adjacent to mafic volcanic centers and sulfidation of the country rock results in up to 50 percent iron sulfides being present in the ores. Pyrite and marcasite are the primary acid-generating sulfides in silica-carbonate type deposits. In hot-spring-type and Almaden-type deposits, pyrite is the primary acid generating sulfide. Cinnabar is the most insoluble of the metal sulfides under ambient oxidizing conditions, and as a result, its acid-generating capacity is very limited. Other sulfide minerals present in silica-carbonate and hot-spring-type deposits are stibnite, realgar, and orpiment, but the small amount of these phases contributes minimally to acid generation.

\section{MINING AND PROCESSING METHODS}

Mercury mining operations typically are small and their surface impact covers an area of a square kilometer or less. In the larger mercury districts, deposits commonly are localized along the same regional fault zone and mines may extend for several kilometers along the mineralized structure. Most mines were underground operations with open stope mining of high-grade ore shoots. Waste rock often was used to backfill underground workings resulting in only a small fraction of waste rock being brought to the surface. The high-grade ore zones usually have sharp contacts with low-grade ore or unmineralized country rock. Because low-grade ore is only rarely mined, stopes tend to follow the outline of high-grade ore bodies and are irregular in shape. Ore bodies that were present in the near surface were mined by open pit methods but only a few mines have been exclusively open pit operations.

The primary processing method for mercury ores utilizes the comparatively simple and inexpensive process of heating ores above the upper stability temperature of cinnabar to volatilize mercury and sulfur followed by a condensing process to recover elemental mercury. This procedure permitted the recovery of elemental mercury at most mine sites without the need to ship ores to a central processing facility. At some of the mines, a beneficiation process was used to minimize the amount ore being processed. Beneficiation processes included screening, jigging, tabling, or flotation, the latter process especially being used at the more recently developed mines. In the mid1960 's, flotation plants located at Gabbs and Mina, Nevada, processed ores from several deposits within the Great Basin mercury belt. The largest of the flotation plants was established in 1975 at the McDermitt mine, Nevada, where ores from the unusual ore body consisting of both cinnabar and corderoite, $\mathrm{Hg}_{3} \mathrm{~S}_{2} \mathrm{Cl}_{2}$, were concentrated prior to roasting in a Herreshoff furnace. 
Mercury ores have been heated in a variety of retorts and several types of furnaces. Furnaces differ from retorts in that furnaces internally heat the ores, mix fuel and mercury vapor, and process a continuous feed of ore. Retorts consist of one or more pipes that contain a single charge of ore. In retorts, the ore is externally heated and vapors from the fuel do not mix with the volatilized mercury. Retorts generally have a small capacity, about 500 pounds of ore per pipe. Because of their low cost, retorts have been utilized at small mines having small but high-grade ore bodies. Two basic types of retorts have been utilized. The Rossi type consists of several iron tubes that serve both as ore roasting and condensing systems. The D type retorts, are "D" shaped in cross section and are either used for roasting ore and condensing, and in the Pan type retorts, the roasting is done in a separate chamber. In some of the larger mines with ore processing furnaces, retorts were utilized to purify sooty mercury recovered from the furnace condensing system. Furnaces that have been utilized include the Scott, Herreshoff, and several types of rotary furnaces. The capacity of furnaces ranged from less than 10 tons to 350 tons per day. The rotary furnace was the most commonly utilized. It consists of a rotating, inclined iron cylinder into which ore is continuously fed and from which the roasted ore, calcine, is removed. Mercury vapors and other gases are drawn from the upper end of the cylinder into a dust collector (cyclone) and then processed in a condenser before being released through a stack. The Herreshoff furnace was used at larger mines and consists of a series of circular hearths into which ore is continuously fed and mechanically advanced to successive hearths of higher temperature. In the Herreshoff furnace, calcine is removed from the base and gases are fed through a dust collector and then a condensing system. The Scott furnace generally was built from brick and consisted of a series of baffles upon which the ore migrated downward as it was heated. The calcines were drawn from the base. The Scott furnaces initially were inefficient until considerable ore had been processed through them and the bricks had become saturated with elemental mercury. At the end of mining, the bricks from the furnace were processed in a retort to recover the mercury.

Condensing systems, which cool the vapor from the furnaces in order to separate the liquid mercury from other stack gases, range from simple single pipe to complex multiple pipe condensers. The condensing system usually consists of a pipe 8-15 inches in diameter and several hundred feet in length that is folded into inverted U shapes. The bases of the condensing system pipes are immersed in water tank and equipped with a drain hole at the base so that condensed elemental mercury can be collected in the tank. Both air- and water-cooled condensing systems have been utilized. In the more simple retorts, the condensing system consists of an iron pipe 2-4 inches in diameter and 5-10 feet long sloping downward from the top of the retort to a collection tank. About two thirds of the product recovered from the condensers consists of elemental mercury and the remainder consists of fine soot composed of rock dust, mercury sulfides and sulfates, fuel soot, water, and finely dispersed elemental mercury. In the older mines this material was dried on steam tables. However, this process released mercury to the atmosphere and often was a serious source of mercury poisoning. Calcium carbonate was used to aid in the mechanical coagulation of finely condensed particles of mercury from soot and collected from the table through a small pipe leading to a collecting tank. In the larger and more modern mines, mechanical mixers or a centrifuge was employed to remove mercury from the soot.

Mercury has been bottled at the processing site in iron flasks that contain 76 pounds of elemental mercury. More recently the metric ton flask has been used. Inefficiencies and spillage during the bottling process has caused mercury contamination of mill sites and calcines. For a more complete discussion of the processing techniques, the reader is referred to Von Bernewitz (1937) and Schuette (1931, 1938).

\section{ENVIRONMENTAL CONCERNS ASSOCIATED WITH MINERAL PROCESSING}

Because of the inefficiencies in the roasting process, mercury vapor and mercury- enriched particles were released to the atmosphere and deposited down wind from furnace and retort sites causing local enrichment of mercury in soils. Mercury content is highest in organic rich, surface soils, ranging from 5 to $25 \mu \mathrm{g} / \mathrm{g}$ (ppm), and decreases to background levels at a maximum depth of 0.5 meters. A typical vertical profile of soils impacted by long term furnace release is shown in figure 2 from the New Idria district, the second largest producer of mercury in North America. The background concentration of mercury, $100 \mathrm{ng} / \mathrm{g}$ (ppb), is reached at a depth of $33 \mathrm{~cm}$. The leaching and transport of mercury into the soil column indicates that the mercury phases deposited from furnace release are soluble and include elemental mercury and other chloride and sulfates of mercury (see discussion below on speciation). In the larger mercury districts where processing occurred over a long period, the loading of mercury to soils adjacent to the mine site constitutes a potential source of mercury- enriched sediment. Soils naturally accumulate mercury deposited from the global atmospheric pool of mercury, and as result, even soils present outside of mineralized areas have mercury concentrations that reflect increased mercury deposition since the inception of the industrial period. Although soils from mercury mine areas have significantly elevated levels of total mercury, the ratio of methylmercury to total mercury is lower in mine areas than in the baseline sites in unmineralized areas (Bailey and others, 1999). This is because an enzyme-catalyzed (organomercurial lyase) microbial demethylation 


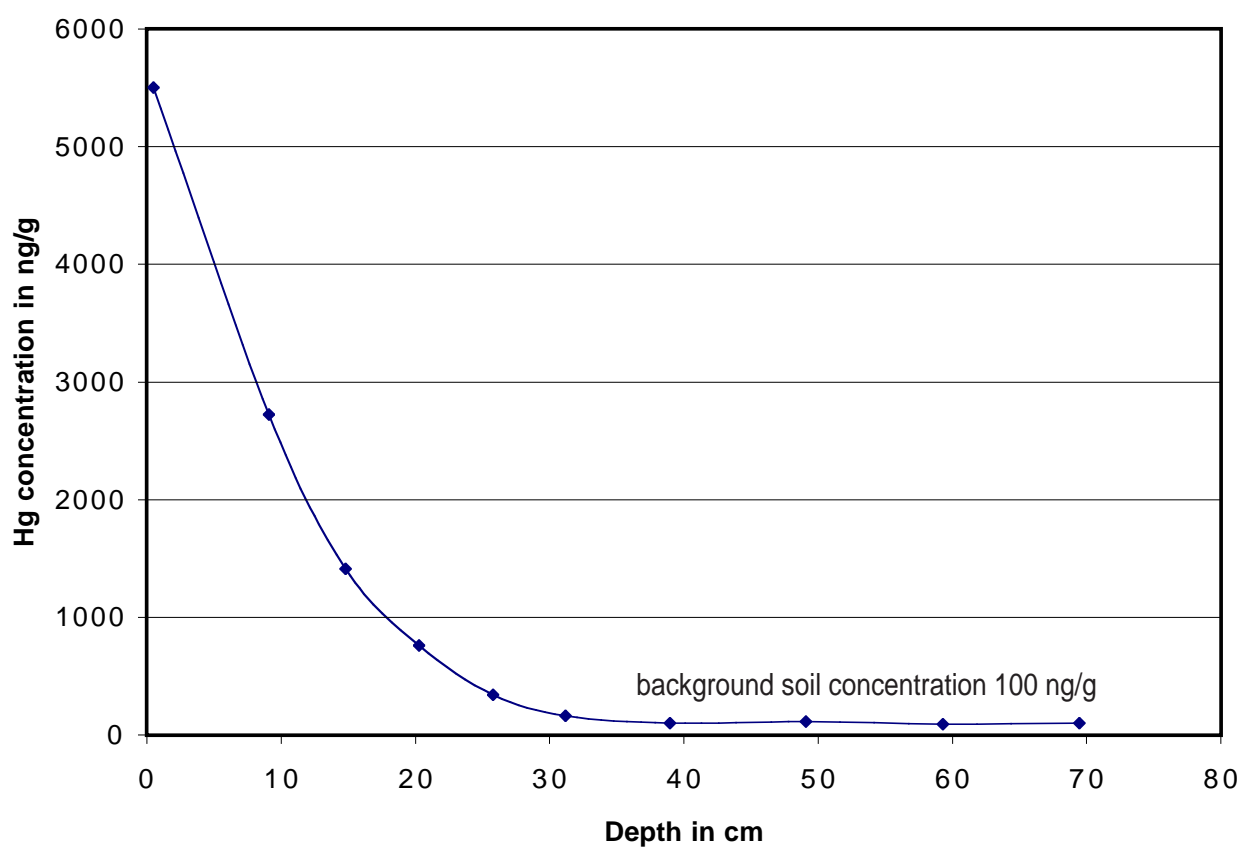

Figure 2. Profile of mercury concentration in soil impacted by release of particulate mercury and vapor from mercury mines in the New Idria mercury district, California.

reaction breaks the Hg-C bond to produce Hg (II) and CH4 (Summers, 1986), thus preventing high concentrations of methylmercury from accumulating in these soils (Hines and others, 1999).

The potential environmental impact of mercury-mine wastes varies considerably depending on the total mercury concentration and speciation of phases present in the mine waste. Mercury mine wastes, listed in increasing content of mercury, include waste rock, low grade ore, mine tailings, condenser soot, and cyclone dust. Dust generated during roasting of the ores was collected in a cyclone prior to the mercury-rich vapor entering the condensing system at the larger mines that employed rotary furnaces. Cyclone dust has a distinctive maroon color and can contain up to several weight percent mercury. Soot that accumulates in the condensing columns represents the fine material that escaped the cyclone collectors or that was directly released from the furnace to the condenser at mines that did not have collectors. This fine-grained, well-sorted material can contain up to several tenths of a percent of mercury that is present as elemental mercury and as mercury sulfate and chloride phases. Condenser soot was generally collected and reprocessed in a retort. A major environmental concern is posed by soot that was not reprocessed and was discarded on waste dumps, because of its high concentration of soluble mercury phases. Condenser soot has the consistency of fine silt and can be readily transported by the wind throughout mine site. The mercury vapor flux from condenser soot to the atmosphere also can be very high especially under hot and sunny weather conditions where it can pose a risk to humans through the inhalation pathway.

Mercury mine ore tailings, termed calcines, have a characteristic red color that results from the oxidation of iron sulfides during the roasting of the sulfide ores. The term calcine comes from the common historic practice of adding lime $(\mathrm{CaO})$ to the mercury ore as a desulfurizer. Calcines were typically deposited adjacent to the furnace site or discarded into nearby stream channels. Flood events periodically removed the tailings from the stream channel thus providing space for continuous tailings disposal during the life of the mine. As a result, mercury mine tailings commonly occur within stream channels and in overbank deposits for several to tens of kilometers downstream from mine sites. Transport of mercury from mercury mine sites where the source of mass loading is from mine tailings occurs primarily in the particulate phase and most of the mercury flux occurs during peak flow events (Whyte and Kirchner, 1999; Whyte, 1998). Mine tailings can impact waters at great distances the mine area. For example, downstream from the Idrija mine in Slovenia, the second largest mercury district in the world, sediments in the River Soca and in the seawater of the Gulf of Trieste are contaminated with inorganic mercury more than $50 \mathrm{~km}$ 
from the mine area (Horvat et al. 1999). Sediments contaminated with tailings are a concern because they are a source of elemental mercury and ionic mercury that can become methylated in downstream aquatic environments. For example, inorganic mercury phases in mine tailings from the Idrija mine introduced into Gulf of Trieste contribute to methylation of mercury in bottom seawater sediments (Horvat et al. 1999). Stream sediments that drain mercury mineralized areas contain from 2 to $200 \mathrm{ppm}$ mercury, and heavy mineral concentrates contain metal concentrations, in ppm, as high as the following: $\mathrm{Hg}, 4,400$; $\mathrm{Ba}, 10,000 ; \mathrm{Cr}, 7,000 ; \mathrm{Cu}, 150$; $\mathrm{Ni}, 500$; Pb, 200; $\mathrm{Sn}$, 300; and $\mathrm{Zn}, 500$. The fine-grained nature of the calcine also contributes to water turbidity. Calcines also were commonly used for road material and most dirt roads adjacent to mines were covered with calcines. Recovery of mercury during retorting of ores ranges from 90 to 95percentresulting in calcine that may contain from 5 to 10percentof the original mercury in the ore. The amount of mercury removed during the roasting process in small mines is extremely variable so that calcine in these operations may contain significant mercury concentrations. Mercury content in calcine ranges from 10 to $1500 \mu \mathrm{g} / \mathrm{g}$ (ppm) depending on the efficiency of the retort or furnace used. Other trace metals originally present in elevated concentration in silica-carbonate mercury ores, such as nickel and chrome, also are present in high concentrations, 100 to 5,000 ppm. Calcines adjacent to condensing systems where mercury was recovered and bottled into flasks may have very high mercury content, up to several $1000 \mathrm{ppm}$, because the mercury commonly was spilled in this area and was adsorbed by the iron oxide phases in the calcine fragments.

In addition to the concentration of mercury present in mine tailings, the speciation of mercury phases in mine wastes is important in determining the amount of mercury that is bioavailable when the exposure pathway is through direct ingestion of mine tailings. The speciation of mercury phases also determines the amount of mercury that is released from tailings and that becomes available for methylation and subsequent incorporation into biota as methylmercury. A variety of techniques have been used to determine mercury speciation. The mineralogy of mercury phases in mine tailings has been examined using indirect methods such as sequential extraction (Revis et al., 1989; Sakamoto et al., 1992) and thermal desorption (Azzaria and Aftabi, 1991; Biester and Nehrke, 1997). More recently x-ray absorption spectroscopy has been used to directly identify mercury phases (Kim and others, 1998). Extended x-ray adsorption fine structure spectroscopy (EXAFS) indicates that several mercury phases are formed during roasting of mercury ores: metacinnabar (high temperature polymorph of $\mathrm{HgS}$ ), corderoite $\left(\mathrm{HgS}_{2} \mathrm{Cl}_{2}\right)$, schuetteite $\left(\mathrm{HgSO}_{4} \cdot \mathrm{H}_{2} \mathrm{O}\right)$ and mercury chlorides (Kim and others, 2000). All of these minerals are more soluble than cinnabar, and thus mine tailings can be a significant source of soluble mercury. Metacinnabar commonly is the dominant mercury phase in calcines derived from silica-carbonate-type mercury deposits, because during the roasting process cinnabar is converted to metacinnabar and impurities introduced into the metacinnabar structure impedes its reversion back to cinnabar upon cooling to ambient conditions (Kim and others, 1998).

Table 1. Geologic and geochemical factors that control mine drainage composition

\begin{tabular}{|c|c|c|}
\hline & $\begin{array}{l}\text { Silica-carbonate } \\
\text { type mercury deposits }\end{array}$ & $\begin{array}{l}\text { Hot-spring } \\
\text { type mercury deposits }\end{array}$ \\
\hline Trace Metals & Ni-Co-Cr-Sb-Zn-Cu & Au-As-Sb-Li-Tl-W \\
\hline$\overline{\text { Alteration }}$ & Carbonates-quartz & Adularia-quartz-clays \\
\hline$\overline{\underline{\text { Sulfides }}}$ & $\begin{array}{l}\text { Pyrite-marcasite } 5-50 \% \\
+/ \text { - millerite(NiS) }\end{array}$ & $\begin{array}{l}\text { Pyrite } 2-5 \% \\
+/- \text { native sulfur }\end{array}$ \\
\hline Host Rocks & Serpentinite-(shale) & Clastic and volcanic rocks \\
\hline $\begin{array}{l}\text { Structural } \\
\text { Control }\end{array}$ & $\begin{array}{l}\text { Serpentinite contacts- } \\
\text { faults }\end{array}$ & Faults-volcanic vents \\
\hline$\underline{\text { Ore Minerals }}$ & $\begin{array}{l}\text { Cinnabar-metacinnabar (HgS)- } \\
\text { elemental Hg }\end{array}$ & $\begin{array}{l}\text { Cinnabar }(\mathrm{HgS})- \\
\text { corderoite }\left(\mathrm{Hg}_{3} \mathrm{~S}_{2} \mathrm{Cl}_{2}\right)\end{array}$ \\
\hline$\frac{\text { Secondary }}{\text { Minerals }}$ & $\begin{array}{l}\text { Mercury sulfates- } \\
\text { chlorides-chromates }\end{array}$ & $\begin{array}{l}\text { Mercury sulfates- } \\
\text { chloride-oxides }\end{array}$ \\
\hline
\end{tabular}

\section{MERCURY MINE DRAINAGE COMPOSITION}

The geology of the mercury deposit type provides an important control on the composition of mercury mine drainage. Geologic factors (table 1) such as ore mineralogy, host- rock composition, and type and amount of iron sulfides present are important in determining the $\mathrm{pH}$, and metal and anion concentrations in mine drainage. Acidity of mine drainage from silica-carbonate-type deposits is mitigated by the carbonate alteration mineral assemblage 
and serpentinite host rocks of this deposit type (fig. 3). However, in silica-carbonate-type deposits that are localized adjacent to mafic vent complexes where large amounts of pyrite have been introduced into the country rock, mine drainage can have extreme acidity, as low as $\mathrm{pH}$ 2.4. The content of iron sulfides (pyrite and marcasite) in these mercury ores can be as high as 50 volume percent and the acid-generating capacity of these sulfides exceeds the neutralizing capacity of the serpentinite and carbonate minerals in the alteration assemblage. Mine drainage from hot-spring-type mercury deposit are only moderately acidic, because the pyrite content is typically low, 2-5\%, and the host rock buffering capacity is sufficient to partially mitigate the acidity. The sum of the base metal concentrations (nickel, cobalt, chrome, antimony, zinc, and copper) in mine drainage from silica-carbonate-type mercury deposits is moderate to high, from 100 to $100,000 \mu \mathrm{g} / \mathrm{L}$ (ppb) (fig. 3). In contrast, hot-spring type mercury deposits have an epithermal geochemical suite of elements associated with them: gold, silver, antimony, arsenic, lithium, and tungsten (table 1). The sum of the base-metal concentrations is typically low because this suite of trace metals characterizes the base metal composition of mine drainage from this type of mercury deposit (Rytuba, 1997).

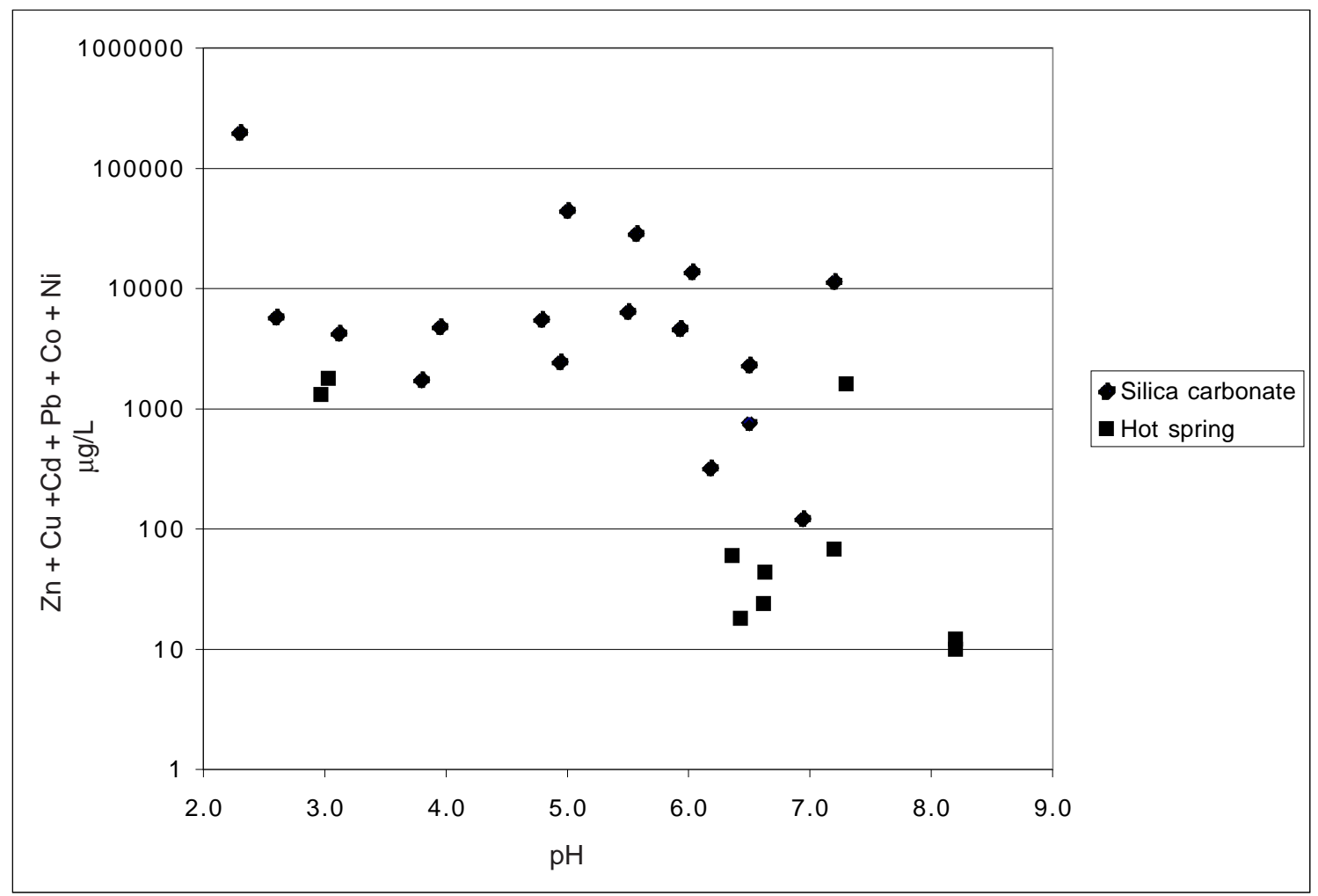

Figure 3. The sum of the base metals $\mathrm{Zn}, \mathrm{Cu}, \mathrm{Cd}, \mathrm{Pb}, \mathrm{Co}$, and $\mathrm{Ni}$ versus $\mathrm{pH}$ (Ficklin plot) for mercury mine drainage from silica-carbonate and hot-spring type mercury deposits. 


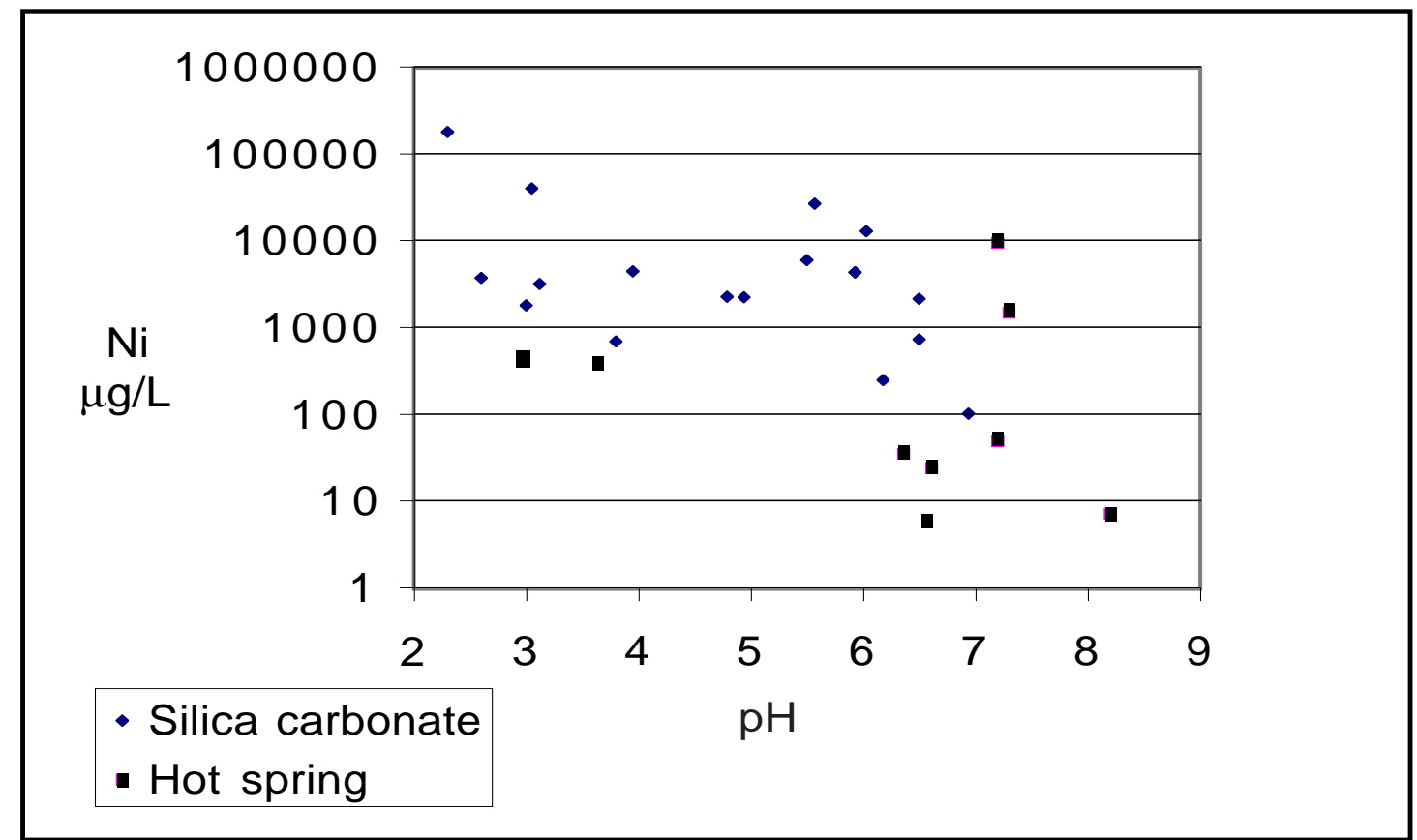

Figure 4. Nickel concentration versus $\mathrm{pH}$ in mercury mine drainage from silica-carbonate type and hot-spring type mercury deposits.

Nickel concentration in mine drainage waters associated with silica-carbonate-type mercury deposits are very high (fig. 4), often exceeding 10,000 $\mu \mathrm{g} / \mathrm{L}$ (ppb), and commonly accounts for most of the total base metal loading in these waters (fig. 3). The unusually high nickel content of these waters reflects the high nickel content of serpentinite host rocks that are associated with this deposit type (Rytuba and Kleinkopf, 1995). The protolith for the serpentinite is seafloor basalt and associated mafic cumulates. During hydrothermal alteration of serpentinite to the silica-carbonate alteration assemblage, the nickel sulfide, millerite, was deposited in vugs and fractures within alteration zones and mercury ore bodies (Bailey and Everhart, 1964). Although not abundant, millerite is widespread throughout silica-carbonate alteration zones and is readily oxidized in mine workings and mine wastes exposed to oxygenated surface waters. Nickel sulfates formed from oxidation of millerite are readily soluble as $\mathrm{Ni}\left(\mathrm{H}_{2} \mathrm{O}\right)_{6}$ complex at a pH less than 8 and remain in solution unless adsorbed onto iron hydroxides. Above $\mathrm{pH}$ of 8 , nickel is precipitated as the $\mathrm{NiOH}$. Because silica-carbonate alteration zones extend along major fault zones beyond mercury districts for several kilometers, springs and seeps developed along these fault zones can be expected also to have high nickel concentrations. Toxicity of nickel to fish occurs at concentrations above $50 \mu \mathrm{g} / \mathrm{L}(\mathrm{ppb})$ and the drinking water standard of $200 \mu \mathrm{g} / \mathrm{L}(\mathrm{ppb}$ ) is often exceeded in streams impacted by this deposit type.

Total mercury concentration (dissolved and adsorbed onto particulate phases) in mine drainage shows extreme variability even within deposit type, ranging from less than $1 \mu \mathrm{g} / \mathrm{L}$ to over $200 \mu \mathrm{g} / \mathrm{L}$ (ppb) (fig. 5). The mercury concentration often exceeds the drinking water standard, $2 \mu \mathrm{g} / \mathrm{L}(\mathrm{ppb})$, and the aquatic criteria for continuous concentration, $0.012 \mu \mathrm{g} / \mathrm{L}$ (ppb). 


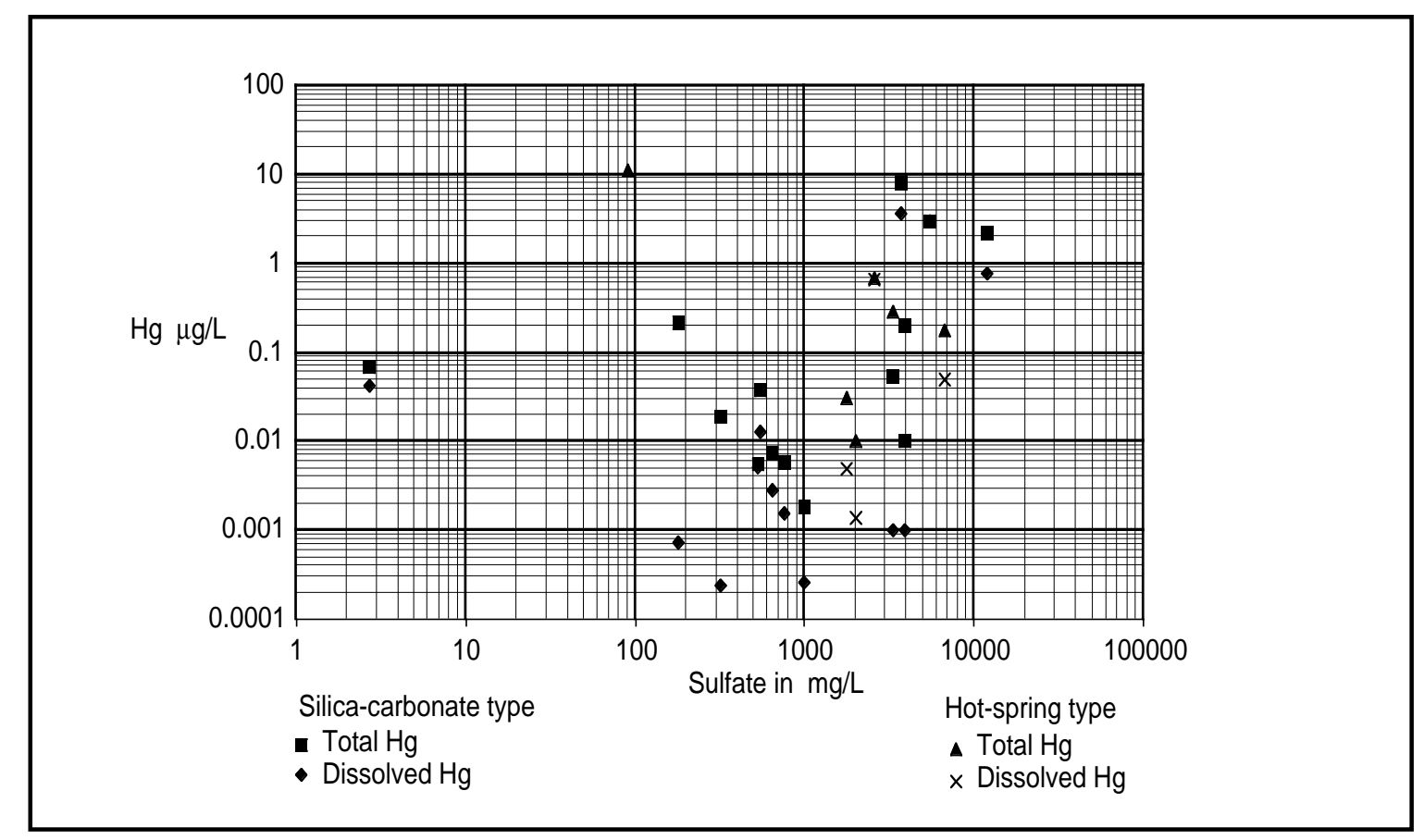

Figure 5. Mercury concentration in mercury mine drainage from silica-carbonate type and hot-spring type mercury deposits.

The large range in mercury concentration is caused by several factors. The most import factors are the solubility of the mercury phases with which the mine drainage interacts and the amount and adsorption capacity of the particulate phases present. Mercury speciation, as well as the concentration of mercury in mine drainage, is also an important variable in assessing the potential environmental impact that mine drainage may have on water quality and biota. Elevated levels of mercury, as well as high sulfate concentration in mine drainage, enhance methylation of mercury by sulfate-reducing bacteria in environments impacted by mine drainage. The mercury species present in mine drainage are strongly affected by chemical processes that occur when mine drainage reacts with mine wastes and surface waters. For this reason the composition of mine drainage is discussed for three different mine environments: (1) at the point of discharge from underground mine workings; (2) mine drainage that has reacted with mine wastes; and (3) mine drainage that has mixed with stream water.

Mine Drainage from Underground Mine Workings

At the point of discharge from underground mine workings, the $\mathrm{pH}$ of mine drainage from silica-carbonate type mercury deposits is moderately to weakly acidic ranging from 3.1 to 6.9. The $\mathrm{pH}$ of hot-spring type mercury deposits is variable, because these deposits are hosted in a variety of rock types that have varying degrees of neutralizing capacity. Low $\mathrm{pH}$ is associated with deposits hosted in clastic sedimentary rocks, or volcanic rocks that have been intensely altered to an advanced argillic assemblage of quartz-kaolinite-cristobalite-alunite. Neutral to alkaline $\mathrm{pH}$ is associated with deposits hosted in mafic volcanic rocks and in recently formed deposits that contain thermal waters having a high alkalinity (Donnelly-Nolan and others, 1993: Janik and others, 1994). Some mine drainage is composed dominantly of thermal water, such as at the Elgin mine, California, where the $\mathrm{pH}$ is alkaline, 8.15. The iron concentration in mine drainage ranges from 0.1 to $7600 \mathrm{mg} / \mathrm{L}$, and is present dominantly in the reduced form, Fe (II). The highest iron concentrations are associated with silica-carbonate type deposits that are localized in and adjacent to mafic intrusions where large amounts of pyrite and marcasite, up to 50percentby volume, were introduced into the country rock. Mine drainage waters from hot-spring type deposits have lower concentrations of iron because the deposits have lower iron sulfide content. The range in total (unfiltered) mercury concentration is comparable for both deposit types ranging from .005 to $8.0 \mu \mathrm{g} / \mathrm{L}$ for silica-carbonate type deposits and from .01 to $10.0 \mu \mathrm{g} / \mathrm{L}$ for hot-spring type deposits (fig. 5). For both deposit types, filtered samples (0.45 $\mu \mathrm{m})$ of mine drainage always have lower concentrations of mercury indicating that a significant portion of the mercury present is adsorbed onto particulate phases and colloids (fig. 5). Oxidation and weathering of iron sulfides exposed in underground mine workings and in back fill waste rock contributes to the high sulfate concentration in both 
deposit types. Sulfate concentration exceeds several thousand $\mathrm{mg} / \mathrm{L}$ and is highest in silica-carbonate type mercury deposits that have a high iron sulfide content. Total methylmercury concentration of mine drainage ranges from $<.003$ to $1.26 \mathrm{ng} / \mathrm{L}$ with highest concentrations associated with silica- carbonate type deposits (fig. 6). Filtered samples of mine drainage typically contain lower concentration of methylmercury indicating that methylmercury is also adsorbed onto particulate phases and colloids (see discussion below). Highest methylmercury concentrations occur in waters with high sulfate concentration indicating that underground mines provide an environment for sulfate-reducing bacteria to methylate mercury but methylation is limited by the availability of dissolved organic carbon in this environment.

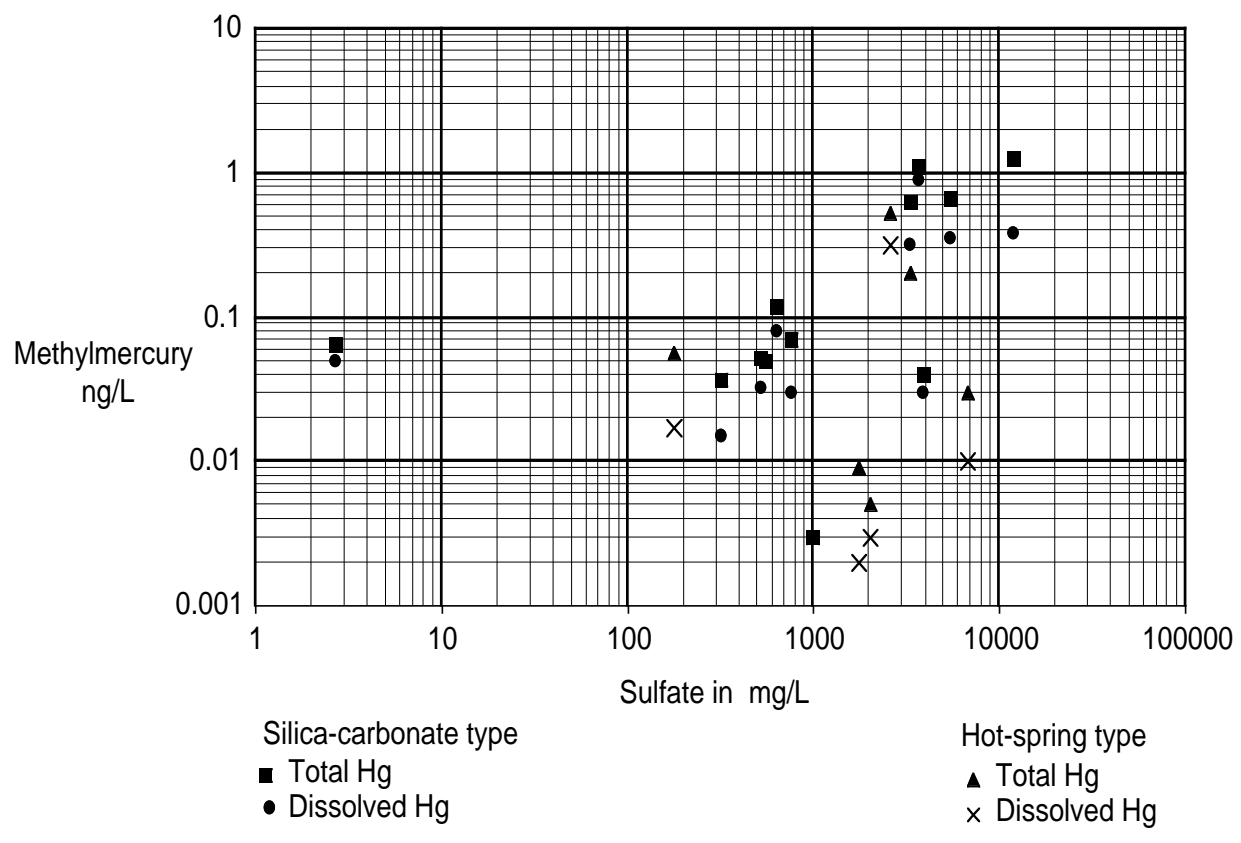

Figure 6. Methylmercury concentration in mercury mine drainage from silica-carbonate type and hotspring type mercury deposits.

Mine Drainage Composition after Reaction with Atmospheric Oxygen and Mine Wastes

After mine drainage exits the underground mine workings, reaction with atmospheric oxygen results in the oxidation of the dissolved iron (II) to iron (III) and precipitation of iron oxyhydroxide. Mine drainage from silicacarbonate type deposits that have high iron concentration can develop extreme acidity (pH as low as 2.6) (fig. 3 ) after reaction with atmospheric oxygen causes precipitation of iron oxyhydroxide. Mine drainage often flows over and through mercury-enriched waste rock and mine tailings, because this material typically was disposed in and adjacent to a stream channel that was closest to the mine workings. In mine tailings, mercury commonly is present in soluble phases such as mercury sulfates and oxy-chlorides that were formed during the ore-roasting process (Kim and others, 1998, 2000). As mine drainage reacts with calcines, mercury and methylmercury concentrations in the water increase dramatically, up to two orders of magnitude, because soluble mercury phases are dissolved and the addition of sulfate to the calcines allows sulfate-reducing bacteria to methylate the dissolved mercury (fig. 5) (Rytuba, 2000). Mercury-contaminated soils, especially those that are saturated with water, have been shown to provide a favorable environment for methylation of mercury (Hines and others, 1999). The saturation of mercurycontaminated soils and various types of mine wastes by mine drainage having a high sulfate concentration enhance methylation of mercury in these mine environments. 


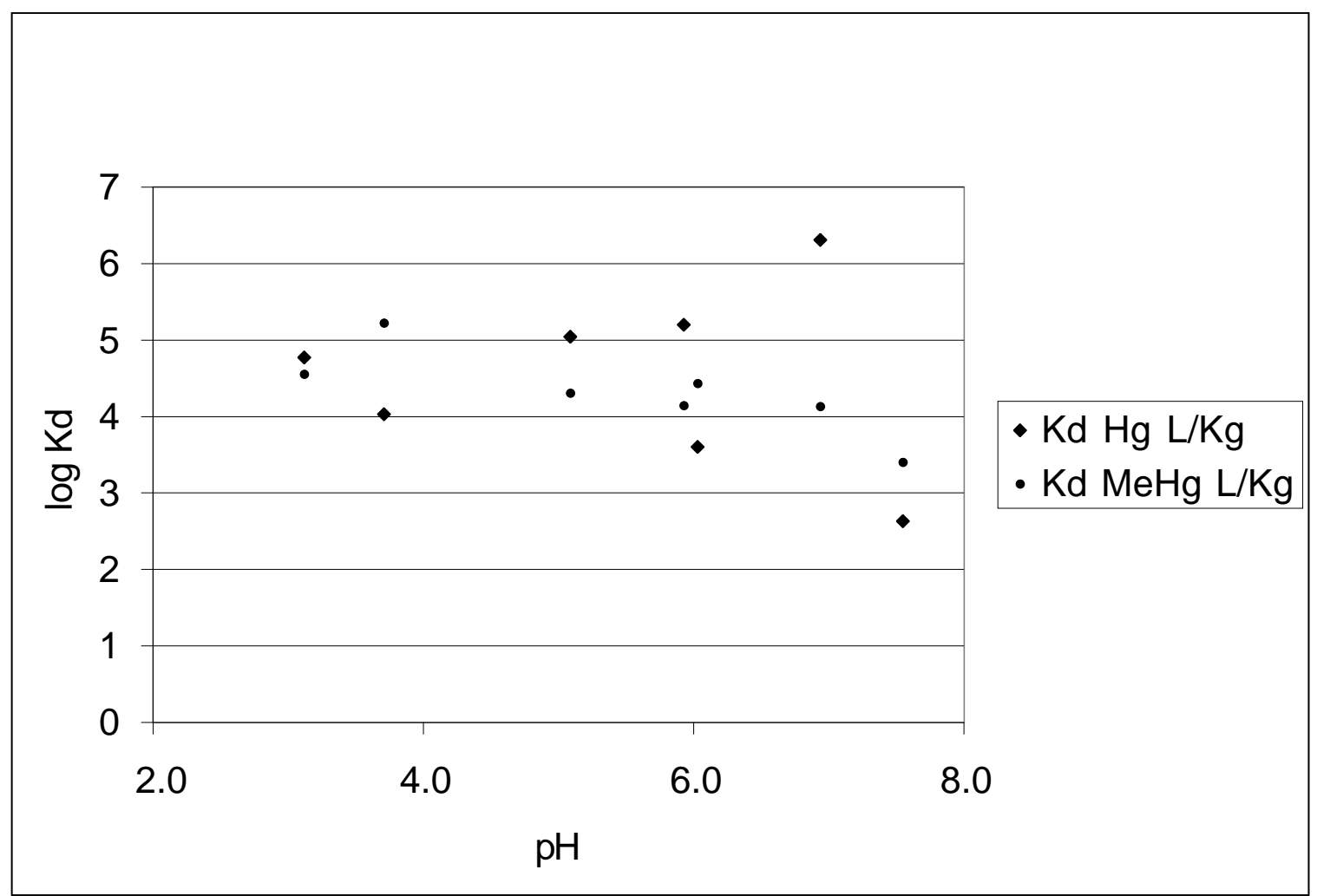

Figure 7. Distribution coefficient, log $\mathrm{Kd}$ in L/kg, for mercury and methylmercury with respect to iron oxyhydroxide versus pH (Rytuba, 2000).

Methylmercury Formation and Adsorption in Streams Impacted by Mine Drainage

Streams impacted by mercury mine drainage have elevated levels of mercury, methylmercury, and anions such as sulfate, low pH, and streambeds that are coated by iron oxyhydroxides. Both sulfate- and iron-reducing bacteria (Marvin-DiPasquale and others, 2000) are important methylators of mercury in this high iron and sulfate environment, and stream waters may contain up to several ng/L methylmercury (Rytuba, 1997). As mercury mine drainage mixes with oxygenated stream waters, dissolved iron (II) is oxidized to iron (III) and precipitated as iron oxyhydroxide. High concentration of dissolved iron (up to $8800 \mathrm{ppm}$ ) results in iron oxyhydroxide being the most abundant particulate phase present in streams impacted by mine drainage. Aluminum hydroxide and other aluminum silicate phases are also important adsorption substrates. Adsorption of mercury and methylmercury onto iron oxyhydroxide and other aluminum phases is an important process that controls the concentration of mercury species in streams impacted by mercury mine drainage. As a result, most of the mercury species present in streams impacted by mine drainage are present in the particulate phases and the concentration of dissolved mercury species concentrations is very low (Rytuba, 2000). Over the $\mathrm{pH}$ range of 3.2 to 7.1, the concentration of mercury in iron oxyhydroxide may be as much as three orders of magnitude greater than that in the coexisting stream water and be as high $220 \mu \mathrm{g} / \mathrm{g}$. Above $\mathrm{pH}$ 7.1, mercury adsorption is less effective and macroscopic experiments have demonstrated that the sorptive behavior of mercury (II) onto goethite exhibits a gradual decrease with increasing $\mathrm{pH}$ after reaching a maximum adsorption at neutral $\mathrm{pH}$ (Barrow and Cox, 1992). Over the pH range 3.2 to 7.1, methylmercury is also strongly adsorbed. Methylmercury concentration is as much as two orders of magnitude greater than that in the coexisting water, up to $105 \mathrm{ng} / \mathrm{g}$. In waters with high sulfate concentration, the negatively charged sulfate complex, $\mathrm{CH}_{3} \mathrm{HgSO}_{4}^{-}$predominates at low $\mathrm{pH}$ (Sanz and others, 1999). It is more effectively adsorbed by iron oxyhydroxide in low $\mathrm{pH}$ stream waters than is the neutral methylmercury hydroxide species that is the predominant species in alkaline waters. The distribution coefficient, Kd in L/kg (fig. 7), for both mercury and methylmercury with respect to iron oxyhydroxide significantly decreases at $\mathrm{pH}$ above 7.1. Thus, the total amount of mercury and methylmercury present in mine drainage impacted streams primarily reflects the amount of mercuryand methylmercury-enriched iron and aluminum phases present as particles in the water column. The concentration of dissolved mercury species is very low as a consequence of effective adsorption. 
Environmental Impact of Mercury Mine Drainage

Mine drainage provides a favorable environment for methylation of mercury because the high concentration of sulfate typically present in these low $\mathrm{pH}$ waters is microbially reduced and ionic mercury $\left(\mathrm{Hg}^{2+}\right)$ is methylated as part of a cometabolic process carried out by sulfate- reducing bacteria. In watersheds impacted by mercury mine wastes and drainage, mercury and methylmercury adsorbed onto iron precipitates, clays, and organic particles accumulate in the streambed during the dry season when water flow is low. A relatively small amount of mercury and methylmercury is transported downstream into larger aquatic systems during this period. During the wet season when stream flows are high, mercury- and methylmercury-enriched sediment is removed from the bed load of the stream and distributed downstream into wetlands, lakes, and reservoirs. The process of sediment redistribution from watersheds impacted by mercury mine drainage and mercury-enriched mine tailings provides a seasonal supply of mercury into aquatic systems where microbial methylation causes methylmercury to enter the trophic levels of the aquatic food web. Methylmercury is biomagnified as it passes upward through the food web to higher organisms, such as fish. Because historic mercury mine sites and active hot springs (or combinations of the two) typically generate the highest concentrations of iron-rich mercury-bearing precipitates, these sites tend to be a primary sources for new mercury entering the cycle.

\section{CLIMATE}

In wet climates oxidation and dissolution of pyrite and marcasite increase the possibility of acid- mine drainage and enhance the release of mercury from mine wastes. Wet climates have a higher biologic productivity and as a result dissolved organic carbon concentrations are higher, thus increasing the potential for methylation of mercury by sulfate-reducing bacteria. In dry, high temperature climates, soil-gas emission of elemental mercury is important, and this process may increase the area affected by elevated mercury if adjacent plant communities are present to uptake mercury in their leaves.

\section{REFERENCES CITED}

Azzaria L.M., Aftabi A., 1991, Stepwise thermal-analysis technique for estimating mercury phases in soils and sediments: Water Air and Soil Pollution, v. 56, p. 203-217.

Bailey, E.A., and Gray, J.E., 1997, Mercury in the terrestrial environment, Kuskokwim mountains region southwestern Alaska, in Dumoulin, J.A., and Gray, J.E., eds., Geologic studies in Alaska by the U. S. Geological Survey, 1995: U. S. Geological Survey Professional Paper 1574, p.41-56.

Bailey, E.A., Hines, M.E., and Gray, J.E., 1999 Mercury methylation and demethylation in soils near abandoned mercury mines in southwest Alaska. In: 5th International Conference on Mercury as a Global Pollutant, Rio de Janeiro, Brazil, p. 471.

Bailey, E. H., and Everhart, D. L., 1964, Geology and quicksilver deposits of the New Almaden District Santa Clara County, California: U. S. Geol. Survey Professional Paper 360, 206 p.

Barrow, N.J., and Cox, V.C., 1992, The effects of pH and chloride concentration on mercury sorption; I, by goethite: Journal of Soil Science, v. 43, no. 2, p. 295-304.

Biester H., Nehrke G., 1997, Quantification of mercury in soils and sediments - acid digestion versus pyrolysis: Fresenius Journal of Analytical Chemistry: v. 358, no.3, p.446-452.

Compeau, G. C., and Bartha, R., 1985, Sulfate reducing bacteria: principal methylators of mercury in anoxic estuarine sediment: Applied Environmental Microbiology, v. 50, p. 498-502.

Donnelly-Nolan, J. M., Burns, M. G., Goff, F. E., Peters, E. K., and Thompson, J. M., 1993, The Geysers-Clear Lake area, California: thermal waters, mineralization, volcanism, and geothermal potential: Economic Geology, v. 88, p. 301-316.

Fitzgerald, W.F, Engstrom, D.R., Mason, R. P. and Nater, E.A., 1997, The case for atmospheric mercury contamination in remote areas: Environmental Science and Technology, v. 32, no. 1, p.1 -7.

Gray, J.E., Meier, A.L., O'Leary, R.M., Outwater, C., and Theodorakos, P.M., 1996a, Environmental geochemistry of mercury deposits in southwestern Alaska mercury contents in fish, stream-sediment, and stream-water samples in Moore, T.E., and Dumoulin, J.A., eds., Geologic studies in Alaska by the U. S. Geological Survey, 1994: U. S. Geological Survey Bulletin 2152, p.17-29.

Hernandez, A., 1985, Estructura y genesis de los yacimientos de mercurio de la zona de Almaden: Unpublished resumen de tesis doctoral, University Salamanca, $64 \mathrm{p}$.

Hines, M.E., Bailey, E.A., Gray, J.E. and Rytuba, J.J., 1999, Transformations of mercury in soils near mercury contaminated sites in the USA. In: 5th International Conference on Mercury as a Global Pollutant, Rio de Janeiro, Brazil, p. 471. 
Horvat, M., Covelli, S., Faganeli, J., Logar, M., Mandic,V., Rajar, R, and Sirca, A., and Zagar, D., 1999, Mercury in contaminated coastal environments; a case study : the Gulf of Trieste: Science of the Total Environment, v. 237/238, p.43-56.

Hurley, J. P., Krabbenhoft, D. P., Babiarz, C. L., and Andren, A. W., 1994, Cycling of mercury across the sedimentwater interface in seepage lakes, in Baker, A., ed., Environmental chemistry of lakes and reservoirs: American Chemical Society Series No. 237, p. 425-449.

Janik, C. J., Goff, F., and Rytuba, J. J., 1994, Mercury in waters and sediments of the Wilbur Hot Springs area, Sulphur Creek Mining District, California: EOS Transactions American Geophysical Union, v. 75, no. 44, p. 243.

Kim, C.S., Brown, G.E. Jr., and Rytuba, J.J., 2000, Characterization and speciation of mercury-bearing mine wastes using X-ray absorption spectroscopy (XAS): Science of the Total Environment, v. 261, p.157-168.

Kim, C.S., Rytuba, J.J., and Brown, G.E. Jr., 1998, Utility of EXAFS in speciation and characterization of mercurybearing mine wastes: Journal of Synchrotron Radiation, v. 6, p. 648-650.

Lehrman, N. J., 1986, The McLaughlin mine, Napa and Yolo counties, California: Nevada Bureau of Mines and Geology, Report 41, p. 85-89.

Lindberg, S. E., Meyers, T. P., Taylor, G. E., Turner, R. R., and Schroeder, W. H., 1992, Atmosphere-surface exchange of mercury in a forest: results of modeling and gradient approaches: Journal of Geophysical Research, v. 97, no. D2, p. 2519-2528.

Lindberg, S. E., Kim, K., Meyers, T. P., and Owens, J. G., 1995, Micrometeorological gradient approach for quantifying air/surface exchange of mercury vapor: tests over contaminated soils: Environmental Science and Technology, v. 29, no. 1, p. 126-135.

Marvin-DiPasquale, M., and Oremland, R. S., 2000, Methylmercury degradation pathways: a comparison among three mercury impacted ecosystems: Environmental Science and Technology, (in press)

Mason, R.P., Fitzgerald, W.F., and Morel, F.M., 1994, The biogeochemical cycling of elemental mercury: Anthropogenic influences: Geochimica et Cosmochimica Acta, v. 58, no. 15, p. 3191-3198.

Nriagu, J. O., and Pacyna, J. M., 1988, Quantitative assessment of worldwide contamination of air, water and soils by trace metals: Nature, v. 333, p. 134-139.

Peabody, C.E., and Einaudi, M.T., 1992, Origin of petroleum and mercury in the Culver-Bear Cinnabar deposit, Mayacamas district, California: Economic Geology, v. 87, p. 1078-1102.

Revis N.W., Osborne T.R., Holdsworth G., Hadden C., 1989, Distribution of mercury species in soil from a mercury-contaminated site: Water, Air, and Soil Pollution, v. 45, p. 105-113.

Rytuba, J. J., 1993, Epithermal precious-metal and mercury deposits in the Sonoma and Clear Lake volcanic fields, California, in Rytuba, J. J., ed., Active geothermal systems and gold-mercury deposits in the Sonoma-Clear Lake volcanic fields: Soc. Econ. Geol. Guidebook Series, v. 16, p. 38-51.

Rytuba, J.J., 1996, Cenozoic metallogeny of California, in Coyner, A.R., and Fahey, P.L., eds., Geology and Ore Deposits of the American Cordillera: Geological Society of Nevada Symposium Proceedings, Reno/Sparks, NV, April 1995, p. 803-822

Rytuba, J.J., 1997, Environmental geochemistry of mercury deposits in the Coast Range mercury belt, California, in Wanty, R., Marsh, S., and Gough, L., eds., Fourth International Symposium on Environmental Geochemistry program with abstracts: USGS Open-File Report 97-496, p. 56.

Rytuba, J.J., 2000, Mercury mine drainage and processes that control its environmental impact: Science of the Total Environment, v. 260, p. 57-71.

Rytuba, J. J., and Enderlin, D. A., 1999, Geology and environmental geochemistry of mercury and gold deposits in the northern part of the California Coast Range mercury mineral belt: California Division of Mines and Geology Special Publication 119, p. 214-234.

Rytuba, J.J. and Kleinkopf, M.D., 1995, Silica-carbonate mercury deposits in du Bray E.A. ed., Preliminary compilation of descriptive geoenvironmental mineral deposit models: U.S. Geological Survey Open-File Report 95-831, p. 199-203.

Rytuba, J.J., and Kim, C.S., 1999, Geochemical controls on the release and transport of mercury from mercury ores and mine wastes, Coast Range California[abs.]: Geological Society of America Cordilleran Section, Abstracts with programs, p. A90.

Rytuba, J.J., Rye, R.O., Hernandez, A.M., Deen, J.A., and Arribas, A., Sr., 1988, Genesis of Almadén-type mercury deposits: Almaden, Spain, 28th International Geologic Congress Abstracts with Program, p. 2-741. 
Sakamoto H.T., Tomiyasu T., Yonehara N., 1992, Differential determination of organic mercury, mercury(II) oxide and mercury(II) sulfide in sediments by cold vapor atomic adsorption spectrometry: Analytical Science, v. 8, p. 35-39.

Sanz, J., Diego, A., and Madariaga, J.M., 1999, Studies on the hydrolysis of methylmercury: definition of a thermodynamic mode, in 5th International Conference on Mercury as a Global Pollutant, Rio de Janeiro, Brazil, p. 182.

Schuette, C. N., 1931, Quicksilver, U. S. Bureau of Mines Bulletin, 335, 168 p.

Schuette, C. N., 1938, Quicksilver in Oregon, Oregon Department of Geology and Mineralogy Bulletin, 4, 168 p.

Sherlock, R.L., Logan, M.A.V., and Jowett, E.C., 1993, Silica carbonate alteration of serpentinite, implications for the association of precious metal and mercury mineralization in the Coast Ranges, in Rytuba, J. J., ed., Active geothermal systems and gold-mercury deposits in the Sonoma-Clear Lake volcanic fields: Society of Economic Geology Guidebook v. 16, p. 90-116.

Summers, A. O., 1986, Organization, expression, and evolution of genes for mercury resistance: Annual Reviews Microbiology, v. 40, p. 607-634.

Varekamp, J. C., and Buseck, P. R., 1986, Global mercury flux from volcanic and geothermal sources: Applied Geochemistry, v. 1, p. 65-73.

Verta, M., Mannio, J., Iivonen, P., Hirvi, J. P., Jarvinen, O., and Piepponen, S., 1990, Trace metals in Finnish headwater lakes-effects of acidification and airborne load, in Kauppi and others, eds., Acidification of Finland, p. 883-908

Von Bernewitz, M. W., 1937, Occurrence and treatment of mercury ore at small mines: U. S. Bureau of Mines Information Circular 6966, 40p.

Whyte, D.C., 1998, Reclamation Plan for Gambonini Mercury Mine: Conceptual Design Document prepared by the California Department of Conservation Abandoned Mine Lands Unit, and the San Francisco Bay Regional Water Quality Control Board. P.1-20.

Whyte, D. C., and Kirchner, J.W., 1999, Assessing water quality impacts and cleanup effectiveness in streams dominated by episodic mercury discharges. In: 5th International Conference on Mercury as a Global Pollutant, Rio de Janeiro, Brazil, p. 471. 


\title{
Chapter K
}

\section{GEOENVIROMENTAL MODEL FOR LOW-SULFIDE GOLD-QUARTZ VEIN DEPOSITS}

\author{
Roger P. Ashley
}

\section{Deposit geology}

These deposits include quartz and quartz-carbonate veins mined primarily for gold. They are found in accreted terranes dominated by greenstone and slate sequences that have been metamorphosed to greenschist, or less commonly to amphibolite or granulite facies (Berger, 1986a; Goldfarb and others, 1995). These veins generally contain no more than a few percent sulfide minerals. Wall rocks, which in some deposits include disseminated ore bodies, contain abundant carbonate minerals, quartz, sericite, and sulfides. Mineralization is commonly associated with regional shear zones, which may include melange zones with varied lithologies and tectonically-emplaced ultramafic rocks and serpentinite. Deposits spatially associated with plutonic rocks tend to have more varied suites of metals, and are more likely to contain more silver and to yield copper, lead, and zinc as byproducts. Arsenic is the minor element most commonly enriched in alteration haloes. These deposits are also known as mesothermal, Mother Lodetype, orogenic, metamorphic rock-hosted, shear zone-hosted, greenstone-hosted or greenstone gold, turbidite-hosted, and slate-belt gold (Groves and others, 1998).

Low-sulfide gold-quartz veins are found in deformed metamorphic rocks of all ages, world-wide; they are the most widespread type of gold-bearing mineral deposit. Since the late 1970's, accreted terranes of all ages in the United States have been explored for these deposits, resulting in production from the southern Appalachians, the Lake Superior region, the Sierra Nevada region of California, and southeastern and central Alaska. Individual deposits have yielded from a few tonnes to more than 100 tonnes of gold.

\section{Examples}

Yilgarn Block, Western Australia; Abitibi Belt, Superior Province, Canada; Yellowknife, Northwest Territory, Canada; Bendigo/Ballarat, Victoria, Australia; Murantau, Uzbekistan; Otago Schist Belt, South Island, New Zealand; Sierra Nevada (including Mother Lode), California; Juneau Gold Belt, Alaska; Tintina Gold Belt, Alaska; Slate Belt, North and South Carolina; Dahlonega Belt, Georgia; Virginia GoldPyrite Belt, Virginia.

\section{$\underline{\text { Related deposit types }}$}

The deposit type most closely related genetically to low-sulfide gold-quartz veins is Homestake gold (Berger, 1986b; Klein and Day, 1994), which is produced by similar hydrothermal systems superimposed on Precambrian iron formation host rocks. Related deposits found at shallower depths in accreted terranes include gold-antimony deposits (Berger, 1993), and silica-carbonate mercury deposits (Rytuba, 1986). Either of these deposit types could conceivably represent the near-surface expression of the hydrothermal systems that produce low-sulfide gold-quartz lodes at depth (fig. 1). All these deposits form from carbonic fluids derived from metamorphic dewatering reactions.

Volcanogenic massive sulfide deposits of all types (Cyprus, Kuroko, and Besshi; see Singer, 1986a,

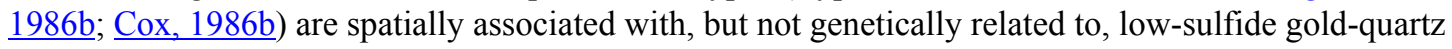
veins, because both are found in greenstone or greenstone-slate terranes. Podiform chromite deposits (Albers, 1986) may be spatially associated in regional shear zones that host ultramafic rocks as well as lowsulfide gold-quartz veins. Polymetallic vein deposits (Cox, 1986a) may also be spatially associated, especially where plutons intrude accreted terranes. Indeed there may be a continuum between low-sulfide gold-quartz veins produced by fluids that show no clear evidence of magmatic fluid contributions, and precious-metal bearing polymetallic veins produced by alkali chloride-rich magmatic-dominated fluids. For example, deposits of the Tintina Gold Belt, Alaska and Yukon, although spatially and temporally associated with the mid-Cretaceous Tombstone and Tungsten plutonic suites, have many characteristics in common with low-sulfide gold quartz veins (Lang and others, 2000; Goldfarb and others, 1997a), and are included in this geoenvironmental model. 


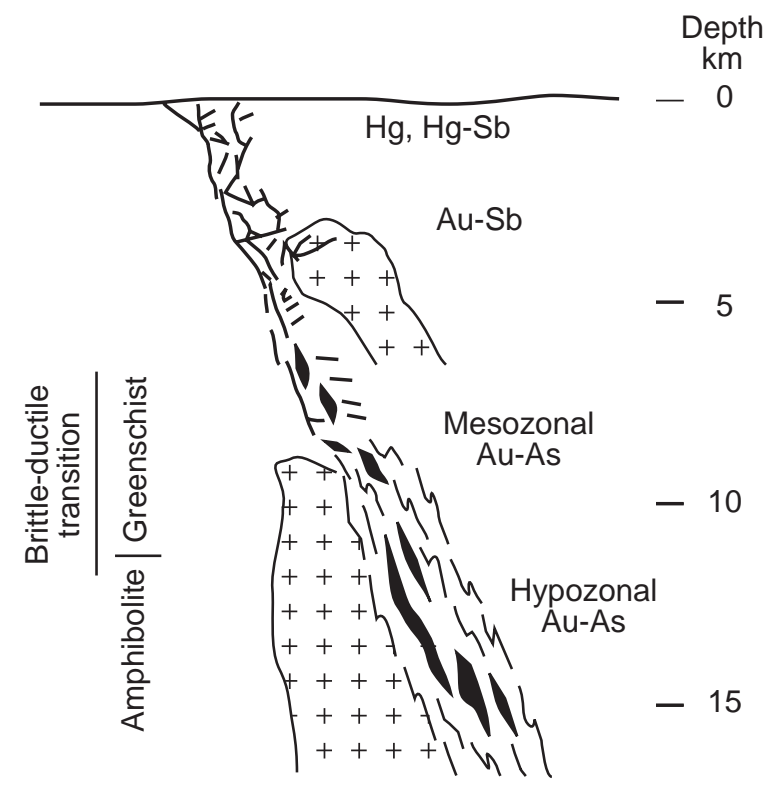

Figure 1. Schematic representation of shear-zone setting of low-sulfide gold-quartz veins and related deposits. Mod-ified from Groves and others (1998), and McCuiag and Kerrich (1998).

In almost all areas where low-sulfide gold quartz veins are exposed, gold released by erosion is concentrated in placers (Yeend, 1986). In regions where erosion is deep and geomorphic history is favorable, as in the Sierra Nevada and Klamath Mountains, California, and Seward Peninsula, Alaska, the bulk of the gold endowment may be found in the placer deposits. Low-sulfide gold-quartz vein deposits subjected to deep tropical or temperate-humid weathering can produce lateritic or saprolitic (eluvial placer) deposits (McKelvey, 1992).

\section{Deposit size}

The size of low-sulfide gold-quartz deposits varies considerably from region to region. Archean deposits are the largest, but their greater median size may be the result of particularly favorable regional tectonic and structural features rather than any factors directly related to age. Table 1 shows summary statistics for four tonnage models available for various groups of low-sulfide gold-quartz veins. It is important to note that some historic deposits include mineralized wall rock (called "gray ore" in the Sierra Nevada), which usually results in higher tonnages and lower grades, and many recently mined deposits have exploited bulk-minable mineralized wall rock or densely-veined stockworks. The historic disseminated deposits are included in the present models, whereas many recently-mined deposits are not included.

Table 1

\begin{tabular}{|l|l|l|l|l|}
\hline Deposit group & $\begin{array}{l}\text { Median size, } \\
\text { million mt }\end{array}$ & $\begin{array}{l}\text { 90th \%tile size, } \\
\text { million mt }\end{array}$ & $\begin{array}{l}\text { 10th \%tile size, } \\
\text { million mt }\end{array}$ & Reference \\
\hline Archean & 1.1 & 0.089 & 13 & $\underline{\text { Klein \& Day, 1994 }}$ \\
\hline Phanerozoic & 0.03 & 0.001 & 0.91 & Bliss, 1986 \\
\hline $\begin{array}{l}\text { California } \\
\text { (Mesozoic) }\end{array}$ & 0.025 & 0.0008 & 0.78 & $\begin{array}{l}\text { Ashley, unpub } \\
\text { (derived from } \\
\text { Bliss, 1986) }\end{array}$ \\
\hline $\begin{array}{l}\text { Chugach, AK } \\
\text { (Cenozoic) }\end{array}$ & 0.0032 & 0.0004 & 0.026 & $\underline{\text { Bliss, 1992 }}$ \\
\hline
\end{tabular}




\section{Host rocks}

Mafic to intermediate metavolcanic rocks (greenstones) are the most important host rocks for lowsulfide gold-quartz veins, especially in the case of the Archean deposits. Slate and graywacke are also important hosts, especially in Phanerozoic rocks. Ultramafic rocks and serpentinite occur in some mineralized shear zones. Pre-ore plutons may also host deposits. Carbonate and other types of sedimentary rocks are not usually associated with low-sulfide gold-quartz deposits, but may occur locally in melange belts associated with mineralized regional shear zones. Some ore minerals and alteration minerals are restricted to certain host rock types, whereas others are always present regardless of rock type, and still others vary from deposit to deposit but are not associated with any particular rock type.

\section{Surrounding geologic terrane}

Most low-sulfide gold-quartz deposits occur in highly-deformed metamorphosed accreted volcanicsedimentary terranes of greenschist facies, but ranging from sub-greenschist to granulite facies. Many deposits, especially the larger ones, are associated with major regional shear zones. High-angle faults that either splay from, or are cut by, these major shear zones are commonly sites of mineralization. Synkinematic and late-kinematic intermediate to felsic plutons are common in accreted terranes, and usually pre-date gold mineralization. Serpentinized ultramafic rocks and dikes of all compositions may be associated with the shear zones.

Unaltered greenschist-facies metavolcanic and metasedimentary rocks usually have moderate buffering capacity because mineral assemblages include albite, mica, chlorite, epidote, and carbonate, and may include relict pyroxenes and amphiboles. Slates, on the other hand, may contain disseminated sedimentary pyrite or pyrite porphyroblasts. Rocks in the contact aureoles of plutons, which usually reach amphibolite grade, tend to have lower buffering capacity.

\section{Wall-rock alteration}

Alteration zones are always present, and are generally better developed in metavolcanic rocks than in slates. Widths of alteration zones vary with lithology, size of the vein system, and abundance of minor faults. Alteration can extend away from deposits for many kilometers along shear zones and fault zones. Carbonic hydrothermal fluids replace calcium, magnesium, and iron silicates of the wall rocks with carbonate minerals, and add potassium mica, quartz, and sulfides. Components most notably added are $\mathrm{CO}_{2}, \mathrm{H}_{2} \mathrm{O}$, potassium, and sulfur. Silica may be added, or redistributed from wall rocks into veins. Hydrothermal carbonate minerals include dolomite, ankerite, magnesite, siderite, and calcite. Although the dominant carbonate mineral is frequently described as ankerite, it is usually ferroan dolomite.

Assemblages vary with host rock lithology (Böhlke, 1989). Typical assemblages include ferroan dolomite, albite, quartz, potassium-mica, chlorite, pyrite, and arsenopyrite. Albite is particularly abundant in altered granitic rocks. Assemblages in altered serpentinite also include talc, magnesite, and fuchsite/mariposite, and lack albite.

\section{Nature of ore}

Individual veins are generally 1 to 10 meters wide and less than a few hundred meters long, but orebearing zones are typically larger, and include multiple veins. Veins and ore zones are equally persistent laterally and vertically, and most deposits show no notable vertical or along-strike zoning of vein minerals, ore minerals, or alteration minerals. Among deposits that show such zoning, patterns vary from deposit to deposit.

Veins commonly show ribbon texture or contain wall-rock fragments. In typical ore, both gold and sulfide grains occur scattered through the quartz, but gold tends to be concentrated at the margins of the ribbons and wall-rock fragments, whereas sulfides tend to be concentrated within the ribbons and fragments. Some gold is associated with sulfides, located on grain boundaries or on microfractures within grains, or forming inclusions. Proportions of gold associated with sulfides vary; e.g., in Sierra Nevada deposits, typically about two-thirds of the gold occurs as isolated, free-milling grains, and the rest is intimately associated with sulfides. The most common minor sulfide minerals are galena, sphalerite, and chalcopyrite. Carbonate in the veins tends to occur in discrete growth bands, commonly near or at the vein 
walls. High-grade ore consists of coarse crystalline or leaf gold intergrown with quartz, commonly with no associated sulfide minerals (e.g., Nelson and Leicht, 1994).

Parts of the alteration zones may contain enough gold to be ore-grade. Sulfides, especially pyrite and arsenopyrite, tend to be more abundant in such disseminated ore, as much as about 10 percent, and gold grades are generally lower than in veins (e.g., data for deposits of the Yilgarn Block, Western Australia, in Ridley and others, 1996). Sulfides also tend to be more abundant in altered rocks that host stockworks. In many districts ore bodies are restricted to veins. In some districts both ore-bearing veins and disseminated ore occur, and in a few districts the veins are low-grade or even barren, and the ore bodies are restricted to altered wall rocks.

Mining and ore processing methods

Because low-sulfide gold-quartz veins are relatively small and high-grade (e.g., the tonnage-weighted average gold grade for historic mines in California is about $14 \mathrm{~g} /$ tonne), underground methods were used in most historic mines, and are still used in the majority of active mines worldwide. Because these deposits are equally likely to extend to depth or laterally (see above), they were not effectively exploited until the 1870 's, when several technological developments (steel cable, improved explosives and power drills) permitted efficient development and ore removal. It has long been common practice to use waste rock from underground development drifts to backfill stopes, especially where the ground is unstable or timber is expensive. Developments in milling technology also had an impact on mining methods, as efficient classifiers developed in the late 1800's allowed coarser tailings (sands) to be separated and used underground as backfill. Thus at some mines a significant proportion of the waste rock and ore processed (but not more than 50 percent) was disposed of underground rather than on the surface.

From the early 19th century to World War II the most common device used world-wide for fine ore crushing and pulverizing was the stamp mill (Richards, 1918). It consisted of cylindrical mortars raised by rotating cams and allowed to drop on dies set in an enclosure called a battery box, into which coarsely crushed ore, water, and mercury were fed. The recommended amount of mercury in early practice was 2 to 3 avoirdupois ounces (57 to 85 grams) per troy ounce gold to be saved (Churchill, 1999a), and 1 to 2 avoirdupois ounces (28 to 57 grams) in later practice (Dufourcq, 1918). Thus the maximum possible loss of mercury into tailings for ore with an anticipated grade of 0.5 troy ounce free-milling gold per avoirdupois ton would be about 43 grams per ton ( $47 \mathrm{~g} /$ tonne). In practice, of course, the mercury that formed amalgam was recovered and recycled. The pulp produced in the battery box was discharged through a screen onto secondary plates coated with mercury, to catch any gold that escaped amalgamation in the battery box. Most mercury loss occurred in the battery box, owing to "flouring" caused by the battering action of the stamps. Flouring refers to breakup of mercury into very fine particles, which will not amalgamate or reunite. Around 1890 in California, mercury losses into mill tailings averaged 14 grams per avoidupois ton (Churchill, 1999a). At mines where amalgamation was employed, the amalgam was usually retorted on site to produce sponge gold and recover mercury for reuse. Areas around retort sites are likely to have mercury contamination.

As cyanidation was introduced beginning in the early 1890 's, milling practices changed. For efficient cyanidation, finer pulverizing was needed than could be achieved economically with stamp mills, but most mines chose to keep their stamp mills rather than invest in completely new equipment, adding grinders of various types to achieve the necessary fine grinding. The stamps were used for coarser crushing, greatly reducing the time that pulp remained in the battery box, and many mills abandoned battery box amalgamation entirely. By about 1910, typical mercury losses had been reduced to 2-3 grams per avoirdupois ton (Finlay, 1918).

If mercury is present in pulp subjected to cyanide leaching, some will dissolve, although not enough to consume significant cyanide (Dufourcq, 1918). At the Kennedy and Argonaut mines, Amador County, California, some tailings that were subjected to amalgamation were reprocessed using cyanidation.

Mercury concentrations in the reprocessed tailings are not significantly lower than those in the original tailings (Dames \& Moore, 1995; R. Ashley and D. Ziarkowski, unpub. data), indicating that except perhaps in unusually $\mathrm{Hg}$-rich samples, cyanidation does not result in significant removal of mercury from tailings. However, mercury taken into cyanide solution will precipitate with gold when zinc is added, with the result that mercury contamination could be found around sites of refining furnaces, where precipitates were 
smelted to produce bullion. Cyanide itself is generally not a problem because it degrades rapidly under oxidizing conditions (U.S. Bureau of Mines, 1994).

The flotation process, installed at some gold mines beginning in the 1930's to remove and concentrate sulfides (which were often shipped to regional smelters), resulted in another class of processing chemicals being introduced to mill sites and tailings. Most compounds used for flotation, however, are organic compounds that are not highly toxic or persistent, and before World War II only a few reagents were used

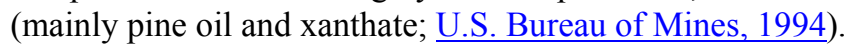

Modern milling practice involves grinding of ore in various types of rotary mills, usually ball mills, separation of free gold by gravity concentration, and cyanidation with adsorption of the gold on activated carbon; mercury is no longer used. Mercury is still used, however, in small operations in less developed countries.

To predict composition of mill tailings and their environmental impacts, it is essential to know whether and how sulfide minerals were treated in the milling process. At one extreme, they may have been ignored, and therefore not removed but reduced to small, highly reactive particles that were passed to the tailings. On the other extreme, they may have been separated, concentrated, and shipped to an off-site smelter, so that only a small fraction of the sulfide was passed to tailings. Such residual sulfide, however, tends to be dominated by the extremely fine particles that could not be captured, which will decompose very rapidly and release metals when exposed to oxidizing conditions. Where it is not economic to remove and concentrate sulfides, or operators do not have the necessary know-how to do so, the ore may be roasted. Uncontrolled roasting of sulfides results in dispersal of airborne sulfur gases and toxic metals, including arsenic and lead.

\section{Trace element geochemistry}

In addition to gold and silver, minor elements most strongly enriched in low-sulfide gold-quartz deposits include arsenic, antimony, tellurium, selenium, tungsten, molybdenum, bismuth, and boron (Berger, 1986a; McCuaig and Kerrich, 1998). The degree of enrichment of these elements varies greatly among regions, and within regions and districts, but usually not much within deposits. The gold-silver ratio averages 5:1 (McCuaig and Kerrich, 1998). The element most consistently enriched along with the precious metals is arsenic; arsenopyrite and arsenian pyrite are frequently reported (Bliss and Jones, 1988; Klein and Day, 1994; Clark, 1970; Savage and others, 2000). Enrichment factors for gold range from about 1,000 to 10,000 for most deposits, and factors for arsenic range from about 100 to 10,000 (McCuaig and Kerrich, 1998; Ashley and Ziarkowski, 1998; Savage and others, 2000).

Figure 2 shows arsenic concentrations in ore-grade rocks from several districts in the Sierra Nevada, California. The lower cut-off of $1 \mathrm{~g} /$ tonne gold is arbitrary; material of this grade is processed in modern open-pit mining operations, but minimum grades of ores processed at historic mines were probably higher. Because arsenic was not recovered from the ores, the plot provides an indication of maximum amounts of arsenic to be expected in mining wastes. It shows that amounts of arsenic in ore-grade materials vary greatly, from less than $10 \mathrm{~g}$ /tonne to more than 1 percent, and ores from individual mining districts show distinctive ranges of arsenic values. With the possible exception of the Alleghany district, however, arsenic concentrations do not increase notably with increasing gold grade.

In the Jamestown and Hodson districts, California, where the ores have relatively little arsenic, altered wall rocks ( $<1 \mathrm{mg} / \mathrm{kg}$ gold) have about the same amounts of arsenic as ores, whereas in the districts where arsenic is more abundant in the ores, altered wall rocks have less arsenic than ores.

Relatively few high-quality analyses are available for mercury in low-sulfide gold-quartz deposits. Data compiled for the same Sierra Nevada districts as above show no enrichment in ores in some districts and maximum enrichment factors generally less than 20 in others, and no enrichment in altered wall rocks with low gold grades in any district (Ashley, 1999b, 2000; figure 3).

The base metals lead, copper, zinc, and cadmium are commonly present in accessory sulfides (galena, chalcopyrite and sphalerite), but enrichment factors are generally less than 10, and in some deposits one or more of these elements may be depleted relative to average crustal abundance (McCuaig and Kerrich, $\underline{1998)}$.

Other elements that may show enrichment in low-sulfide gold-quartz deposits include chromium, nickel, cobalt, vanadium, platinum-group elements (PGE), and scandium. Modest enrichment of these elements in deposits hosted by greenstone or slate may be attributed to hydrothermal scavenging from 
metavolcanic rocks in the host terrane (Gao and Kwak, 1997). Chromium, nickel, and cobalt may be substantially enriched in deposits in which host rocks include altered ultramafics and serpentinite. The chromium is retained in fuchsite/mariposite, and nickel and cobalt form accessory sulfides, arsenides, and sulfarsenides, including millerite, niccolite, gersdorffite, loellingite, and cobaltite (Savage and others, 2000a).

Wall-rock alteration in rocks of the greenschist facies involves addition of large-ion lithophile elements (LILE; McCuaig and Kerrich, 1998; Groves and others, 1998). This group of elements includes potassium, rubidium, barium, lithium, cesium, and thallium. The only element of possible environmental concern here is thallium. Analytical data for thallium are scarce, but absolute values appear to be generally low (a few ppm; R. Ashley, unpub. data). Alteration produces little change in rare-earth elements (REE) or in the minor high field-strength elements (HFSE), including titanium, zirconium, niobium, tantalum, yttrium, gallium, thorium, and uranium (McCuaig and Kerrich, 1998, Gao and Kwak, 1997; Bierlein and others, 1999).

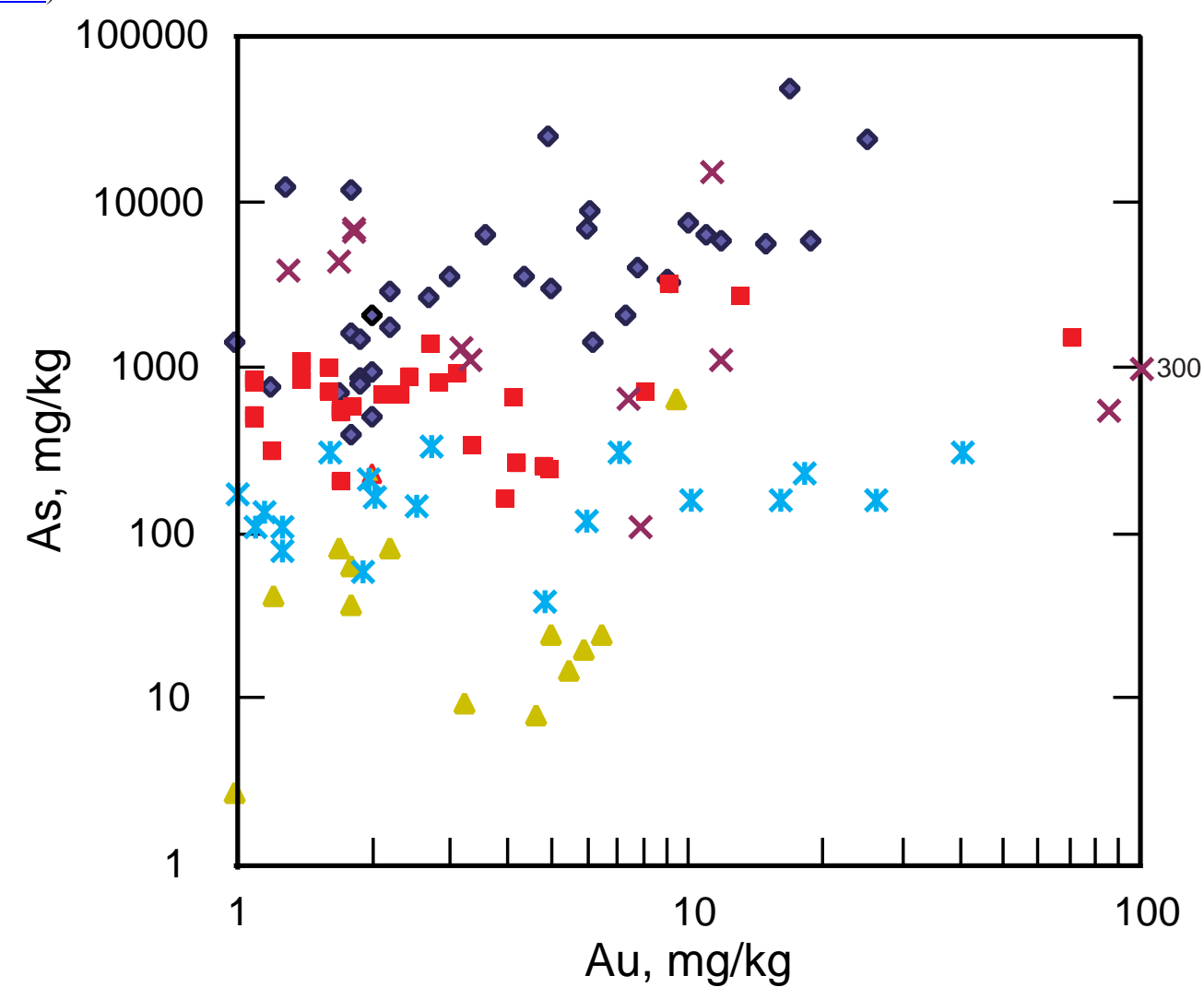

- Alleghany district (Böhlke, 1986)

- Shingle Springs district (Nash, 1988)

* Hodson district (Chaffee and Sutley, 1994)

- Harvard mine, Jamestown district (Ashley, unpub. data)

X N. Mother Lode districts (Sutter Cr., Nashville, Kelsey, Spanish Flat; Ashley, unpub. data)

Figure 2. Arsenic concentrations in ores from selected gold districts, Sierra Nevada region, California. 


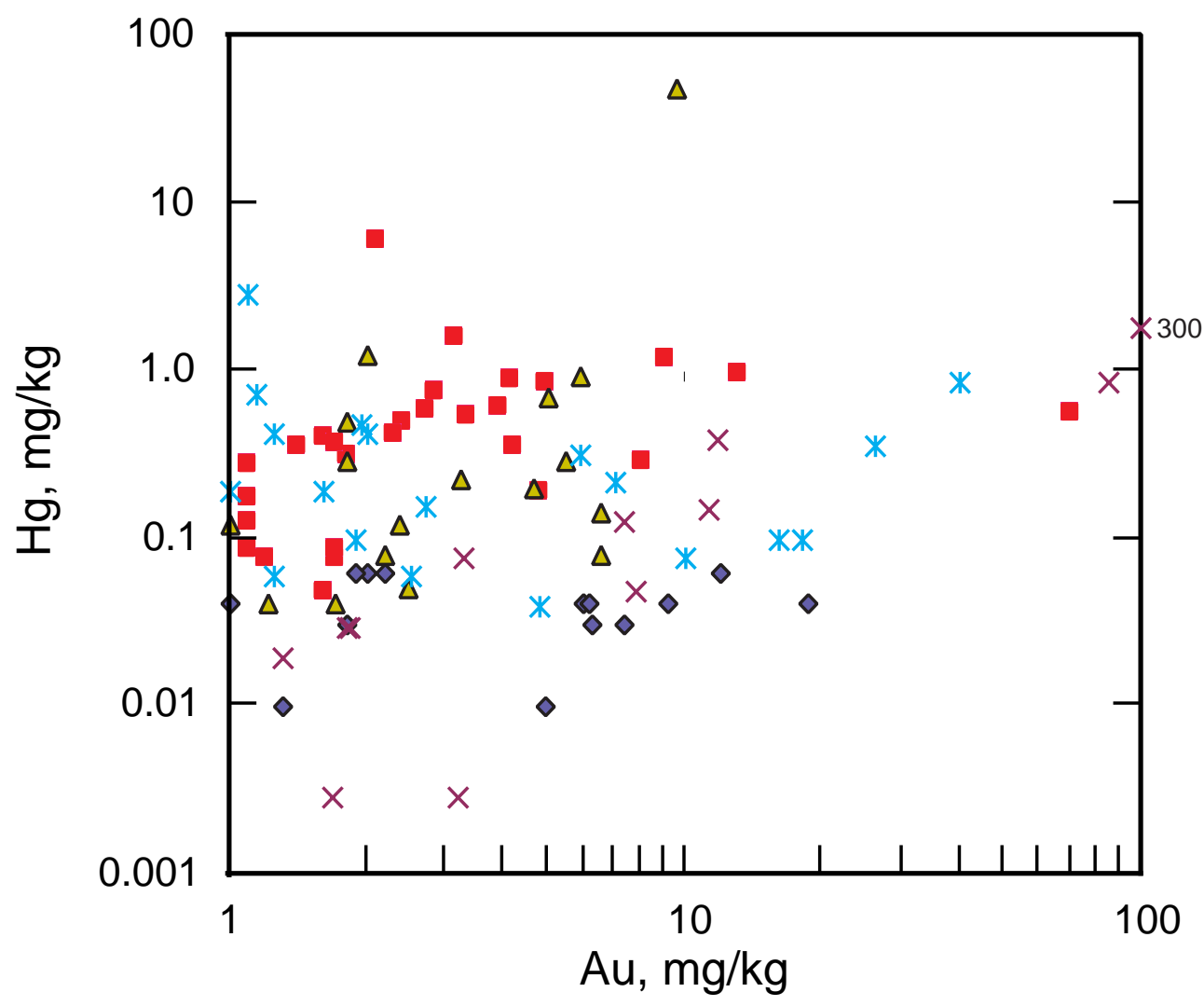

- Alleghany district (Böhlke, 1986)

X Northern Mother Lode districts (Sutter Creek, Jackson, Nashville, Kelsey, Spanish Flat, Nevada City; Ashley, unpub. data)

- Shingle Springs district (Nash, 1988)

* Hodson district (Chaffee and Sutley, 1994)

$\Delta$ Harvard mine, Jamestown district (Ashley, unpub. data)

Figure 3. Mercury concentrations in ores from selected gold districts, Sierra Nevada region, California.

Primary mineralogy and zonation

In most low-sulfide gold-quartz deposits native gold containing 15 to 20 weight percent silver is the ore mineral, and neither gold nor silver occur in any other minerals. In most deposits tellurides are scarce or absent, but in a few deposits they account for much of the gold and silver (Clark, 1970). In some relatively base-metal rich and high-silver deposits, silver may occur in sulfosalts (ruby silvers) and tetrahedrite (freibergite) (Ashley and Ziarkowski, 1999).

The important ore-related minerals, listed in decreasing order of frequency reported, are pyrite, galena, arsenopyrite, chalcopyrite, sphalerite, pyrrhotite, stibnite, tetrahedrite, and scheelite (Bliss and Jones, 1988). All of these minerals except scheelite can potentially generate acid and release metals. Among them, pyrite is commonly the most abundant. Galena, arsenopyrite, and pyrrhotite are commonly second in abundance (pyrrhotite tends to be relatively abundant if it is present at all). Chalcopyrite, sphalerite, and tetrahedrite are subsidiary in abundance. Stibnite and scheelite vary greatly from deposit to deposit, (Bliss 
and Jones, 1988). Bismuth and boron, which occur in bismuthinite and tourmaline respectively, each tend to be characteristic of certain gold regions or mineral belts.

Because total sulfide contents are generally less than 5 percent in veins and 10 percent in disseminated ores, and carbonate minerals are abundant (variable in veins, but 5 to 15 percent or more in altered wall rocks), the bulk mineralized rock is generally well buffered. As stated above, consistent zoning patterns are not observed, although unusual concentrations of certain minerals, particularly scheelite, molybdenite, or tellurides, are reported from certain veins or stopes within individual mines.

Arsenian pyrite may be fairly common in low-sulfide gold-quartz deposits, especially where arsenopyrite is scarce or absent, although it may not always be recognized and reported. The arsenic content of such pyrite is generally less than 2 weight percent, but individual grains may contain as much as 4 weight percent (Savage and others, 2000a; 2000b).

\section{$\underline{\text { Secondary mineralogy }}$}

Much work has been done on weathered residual soils over low-sulfide gold-quartz veins and their alteration haloes, for geochemical exploration. The focus of these studies has been on bulk mineralogy and behavior of minor elements with respect to various leaches. Less attention has given to identifying specific binding sites and binding mechanisms for minor and trace metals and metalloids.

Where iron is abundant and sulfate scarce, scorodite forms. Locally pyrite oxidation may produce conditions sufficiently acidic to form jarosite, especially in pyritic slates with relatively low carbonate contents, and significant amounts of arsenic can substitute in such jarosite (Savage and others, 1999; Savage and others, 2000a). Typically, however, weathering involves formation of iron oxyhydroxide minerals, especially goethite, which adsorb arsenic (Smith and others, 1994; Foster and others, 1998) and significant proportions of available transition metals and other metalloids (Plumlee and others, 1999). Details of the mechanism of pyrite oxidation in carbonate-buffered solutions have been extensively investigated (e.g., Evangelou and others, 1998). Arsenian pyrite oxidizes more rapidly than arsenic-free pyrite (Plumlee and others, 1999).

Oxidation of low-grade ore and sulfide-bearing altered rock exposed in mine workings, walls of open pits, and waste rock piles should ultimately result in mineral assemblages similar to those in natural outcrops. Until oxidation is complete, however, soluble efflorescent salts form during dry periods. Because acid generated by decomposing sulfides reacts promptly with carbonates, releasing calcium and magnesium, efflorescent salts are dominated by epsomite, hexahydrite, and gypsum (R. Ashley and K. Savage, unpub. data). Locally, however, hydrated ferric sulfates that store metals, especially copiapite and jarosite, may also form (Savage and others, 2000). It appears that significant amounts of arsenic may be associated with the iron-free salts, possibly owing to formation of hydrated calcium arsenate minerals (K. Savage, unpub. data). Calcite/aragonite dripstone forms on some pit walls and underground workings. The same efflorescent minerals form on tailings. Where sulfides have been removed during milling, ferric sulfates do not form, but usually enough sulfate remains to form hydrated calcium and magnesium sulfates. Where sulfide concentrates have been stockpiled, efflorescent salts form similar to those that form on other metal sulfide-rich ores (R. Ashley, unpub. data).

Pre-mining soil and sediment signatures

Arsenic concentrations in soils overlying unmined deposits reach about 1,000 ppm, and concentrations in soils over surrounding alteration zones range from tens to several hundreds of ppm (Savage and others, 2000a, 2000b; Sutter Gold Mining Company, unpub. data; Bowell and others, 1994). Although gold itself is the primary target element in geochemical soil-sampling exploration programs, arsenic has been used as a pathfinder element. Antimony may also show anomalies.

Deep and intense weathering of deposits removes most geochemical signatures except for gold itself. Low-sulfide gold-quartz veins are likely the ultimate source of gold in most economic laterite-saprolite gold deposits. Residual enrichment of arsenic, lead, tin, and scandium has been noted along with iron, aluminum and gallium in ferruginous zones that form near the surface in laterite-saprolite gold deposits (McKelvey, 1992).

Anomalous concentrations of REE and HFSE have been observed in soils overlying deposits, even though these elements are not enriched in ores or altered rocks. The anomalies have been attributed to 
release of these elements from dissolution of accessory minerals, particularly apatite, resulting from the breakdown of sulfides during oxidation (Bierlein and others, 1999).

\section{Topography and physiography}

Many deposits are located in belts within Precambrian cratons and are poorly exposed, showing no topographic expression. In continental margin tectonic settings (e.g. California, southeast Alaska), resistant low-grade or barren quartz veins ("bull veins"), which may be found in the same fault zones as productive veins, are likely to be prominently exposed. Ore-bearing veins are rarely well exposed, owing to presence of ribbon structure, wall-rock fragments, carbonate-rich bands, and vugs. Vuggy textures are enhanced by weathering of sulfides. Alteration zones, because they are heterogeneous and carbonate- and sulfidebearing, also tend to be poorly exposed, especially where associated with shear zones or melange.

\section{Hydrology}

Fault zones that localize low-sulfide gold-quartz veins vary greatly in permeability and hydraulic conductivity. In the Sierra Nevada foothills of California, where a large rural population depends upon domestic water wells, some areas with poor water quality (owing to high levels of sulfate and hardness) correlate with gold mineralization and associated altered rocks (California State Water Resources Board, unpub. data; Sonora Mining Corporation, unpub. compilation of water well data from County of Tuolumne, California). High levels of arsenic could be present in domestic wells in these areas, but to date no specific cases clearly related to gold mineralization have been documented or publicized.

Three pit lakes at two recently mined deposits in the Sierra Nevada foothills (Skyrocket and North pits at the Royal-Mountain King mine, and Harvard pit at the Jamestown mine) have $\mathrm{pH}$ values between 7.0 and 8.1, arsenic concentrations between $100 \mu \mathrm{g} / \mathrm{L}$ and about $1 \mathrm{mg} / \mathrm{L}$, sulfate concentrations between about 500 and $1200 \mathrm{mg} / \mathrm{L}$, and very low iron concentrations (Meridian Gold Company, 1997; Ashley and Savage, 2001, figures 4 and $\underline{5}$ ). Although there are complicating factors including evapo-concentration and contributions from rain-water runoff and process waters, the pit lakes provide an indication of what might be expected in ground waters affected by mineralized rocks undergoing oxidation.

The Harvard pit, which exploited ore bodies on the Melones Fault Zone in the southern Mother Lode belt, Tuolumne County, California, demonstrates possible complexities of hydrologic regimes around lowsulfide gold deposits. Since the pit was abandoned in 1994 at a depth of about $160 \mathrm{~m}$, the pit has been filling rapidly, mainly from sulfate-rich but arsenic-poor water entering along open low-dipping fractures in the slate of the hanging-wall. Elevated arsenic levels (about $1 \mathrm{mg} / \mathrm{L}$ ) in the lake, however, indicate that there are significant contributions from oxidizing sulfides, and suggest that water also enters the pit after traversing hydrothermally altered rocks in the Melones Fault Zone.

The best example of elevated arsenic in ground water that may be related to gold mineralization is the Fairbanks area, Alaska, where many inhabitants rely on ground water from private domestic wells. Natural background concentrations as high as $10 \mathrm{mg} / \mathrm{L}$ have been measured (Wilson, 1975; Hawkins and others, 1982). The source for the arsenic remains unclear, although it is generally assumed to reflect dissolution of widespread arsenopyrite and its oxidation product, scorodite. The area is mainly underlain by schist of Late Proterozoic to early Paleozoic age which was intruded by felsic to intermediate plutons at about 90 Ma. Widespread hydrothermal fluid flow associated with this thermal event was responsible for abundant gold vein formation (McCoy and others, 1997). The areas of highest arsenic in ground waters are not spatially associated with known gold occurrences, but abundant sulfide minerals disseminated in the schist indicate that the 90 Ma hydrothermal event was likely responsible for very widespread sulfidation of some strata. Disseminated arsenopyrite and pyrite are the most likely sources for the ppm-level arsenic concentrations in water. Background levels of dissolved arsenic in stream and spring waters from most areas underlain by the schist are $<5 \mu \mathrm{g} / \mathrm{L}$ (Goldfarb et al., 1999), but these levels increase by 2 to 3 orders of magnitude locally. Dissolved antimony $(\leq 50 \mu \mathrm{g} / \mathrm{L})$, manganese $(\leq 5.6 \mathrm{mg} / \mathrm{L})$ and/or iron $(\leq 2 \mathrm{mg} / \mathrm{L})$ are also elevated in some but not all of the arsenic-rich $(0.5$ to $10 \mathrm{mg} / \mathrm{L}$ ) waters (Farmer and others, 2000). Values for $\mathrm{pH}$, however, are near neutral (6.3 to 7.5; Mueller and others, 2000). Drainage signatures

Owing to low sulfide content of ores and buffering capacity of carbonates associated with mineralization, significant acid drainage is generally not associated with this deposit type, and base-metal loadings are consistently low. Near-neutral sulfate-bicarbonate waters that result from contact with these 
ores and altered rocks, however, are effective for mobilizing metalloids and metals that form oxyanions, including arsenic, selenium, antimony, and molybdenum. The following discussion will rely mostly on examples from deposits in Alaska and the Sierra Nevada, where U.S.G.S. chemical data are available. Drainage waters from both mine workings and mill tailings in the Sierra Nevada tend to contain similar molar amounts of $\mathrm{Ca}+\mathrm{Mg}$ and $\mathrm{SO}_{4}$, as is expected if acid formed from oxidizing pyrite is neutralized by carbonate minerals (R. Ashley, unpub. data).

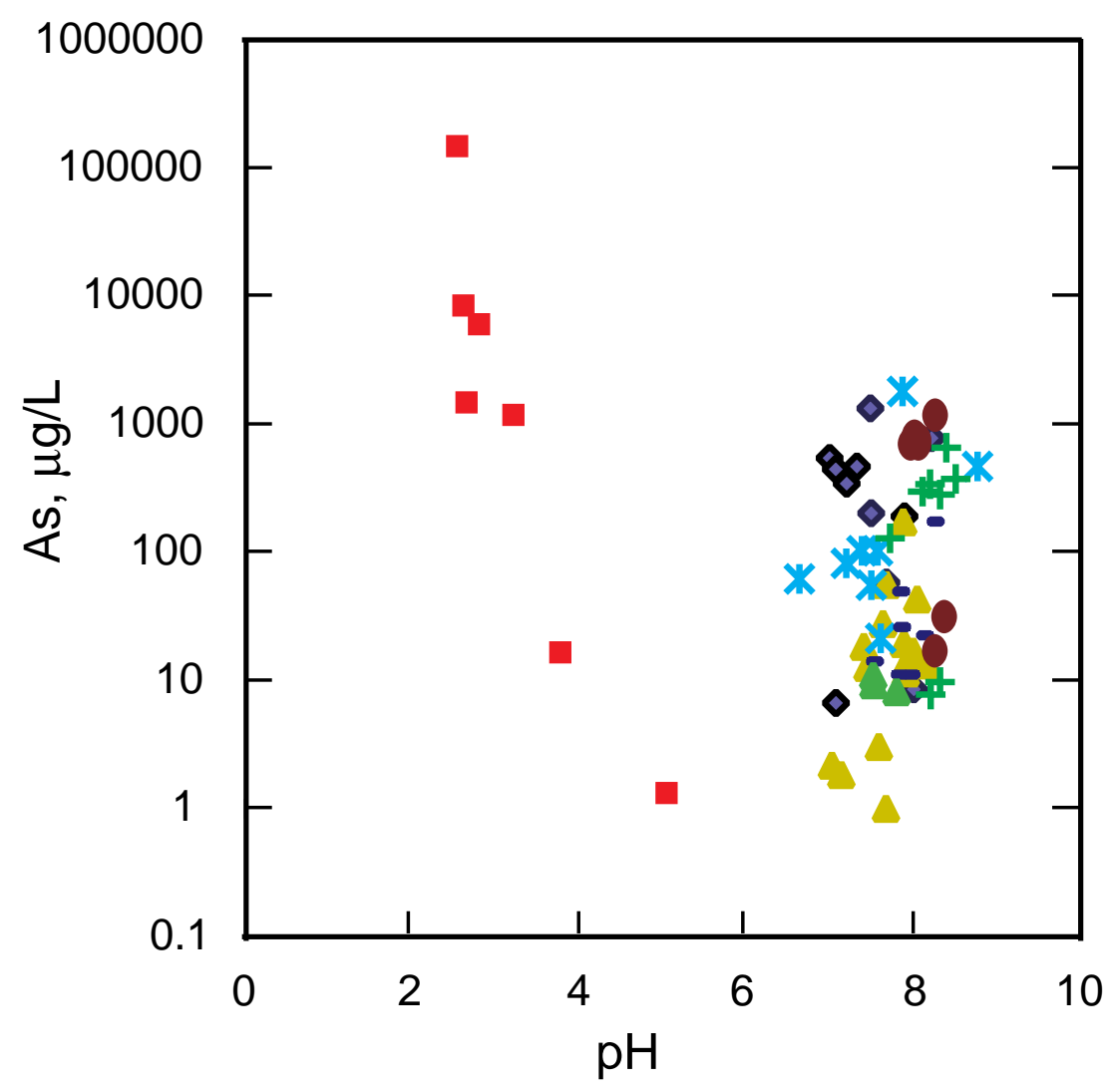

- Mine drainage, several N. Mother Lode mines (Ashley, unpub. data)

Argonaut mine, Jackson district, concentrates (Ashley, unpub. data)

Argonaut mine, Jackson district, tailings (Ashley, unpub. data)

Kennedy mine, Jackson district, tailings (Dames \& Moore, 1995)

* Lava Cap mine, Nevada City district, tailings (Ashley, unpub. data)

- Harvard mine pit lake, Jamestown district (County of Tuolumne, 1998)

+ Skyrocket pit lake, Hodson district (Meridian Gold Company, 1997)

- North pit lake, Hodson district (Meridian Gold Company, 1997)

Figure 4. $\mathrm{pH}$ and arsenic concentrations of mine drainage, drainage from mill tailings and concentrates, and pit lake waters from low-sulfide gold-quartz deposits, Sierra Nevada region, California. 


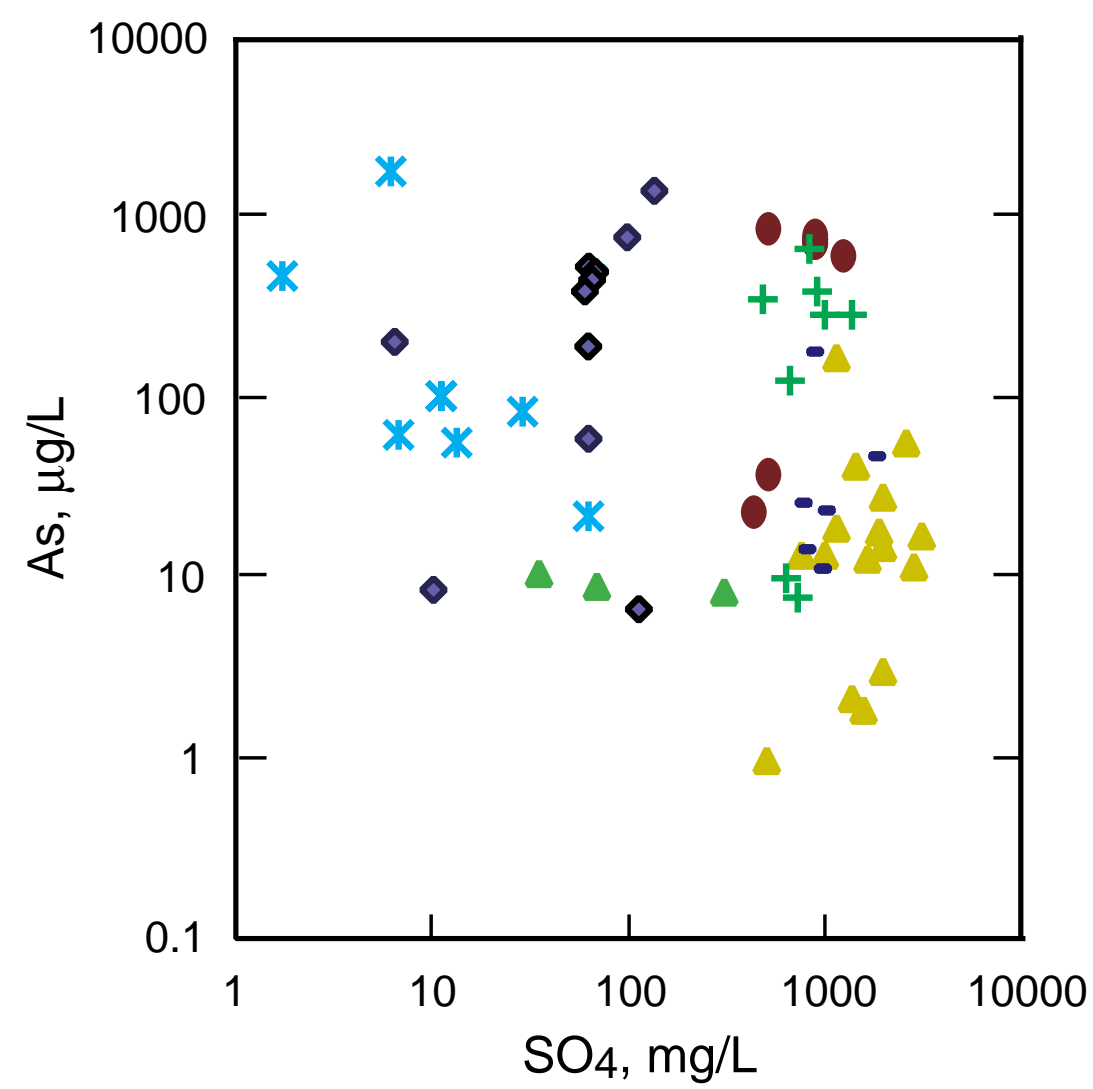

- Mine drainage, several N. Mother Lode mines (Ashley, unpub. data)

Argonaut mine, Jackson district, tailings (Ashley, unpub. data)

Kennedy mine, Jackson district, tailings (Dames \& Moore, 1995)

Lava Cap mine, Nevada City district, tailings (Ashley, unpub. data)

Harvard mine pit lake, Jamestown district (County of Tuolumne, 1998)

+ Skyrocket pit lake, Hodson district (Meridian Gold Company, 1997)

- North pit lake, Hodson district (Meridian Gold Company, 1997)

Figure 5. Sulfate and arsenic concentrations of mine drainage, drainage from mill tailings, and pit lake waters from low-sulfide gold-quartz deposits, Sierra Nevada region, California.

Natural drainage: Rivers that drain the gold-mining region of the northern Sierra Nevada and their major tributaries generally show low arsenic concentrations ( 1 to $3 \mu \mathrm{g} / \mathrm{L}$ ), and very low concentrations of other metals where they are not impacted by drainage from VMS deposits (Montoya and Pan, 1992). An exception is Kanaka Creek, a tributary of the North Fork Yuba River that is impacted by numerous gold mines of the Alleghany district, which shows arsenic concentrations of 15 to $25 \mu \mathrm{g} / \mathrm{L}$. Because the terranes that host low-sulfide gold-quartz deposits in California have been intensively explored beginning 150 years ago, no significant unmined near-surface deposits are known, and consequently there are no data on natural drainage from in-place ore bodies. In Alaska, background concentrations of arsenic in waters are generally 
less than $5 \mu \mathrm{g} / \mathrm{L}$, and waters in contact with undeveloped gold occurrences of this type increase by no more than a few $\mu \mathrm{g} / \mathrm{L}$ (Goldfarb and others, 1995).

Mine drainage: Data for mine drainage waters from a dozen sites scattered through the Sierra Nevada region show $\mathrm{pH}$ values mostly between 6.0 and 8.0, and arsenic concentrations ranging from $2 \mu \mathrm{g} / \mathrm{L}$ to about $1 \mathrm{mg} / \mathrm{L}$ (Montoya and Pan, 1992; Ashley, 1998, 1999; figures 4 and 5). Although there are few data available on arsenic loadings in drainage waters, arsenic values above $100 \mu \mathrm{g} / \mathrm{L}$ are restricted to lowvolume discharges (less than 5 to $6 \mathrm{~L} / \mathrm{sec}$ ). Total mercury concentrations range from about 1 to $100 \mathrm{ng} / \mathrm{L}$, and in many cases a relatively large proportion of the mercury is dissolved; methylation rates are mostly in the usual range of 5 percent or less (Ashley, 1999; figs. 6, 7, and $\underline{8}$ ).

In southeastern Alaska, drainage waters from adits and tailings piles at small- (less than 2 tonnes gold) to medium-sized ( 2 to 25 tonnes gold) deposits are generally not greatly enriched in dissolved arsenic. Arsenic concentrations locally may reach 100 to $150 \mu \mathrm{g} / \mathrm{L}$ in small discharge volumes from a few mine workings, but these values are rapidly diluted to background levels once they enter larger streams within a few tens of meters of the mine workings (Cieutat and others, 1994; Trainor and others, 1996). Granitoidhosted veins in the Fairbanks district (Fort Knox deposit) are extremely low in sulfide content, and waters in contact with the ores do not contain more than about $2 \mu \mathrm{g} / \mathrm{L}$ arsenic (R. Goldfarb, unpub. data from Fairbanks Gold Mining Company, Inc.). Drainage from the Independence mine, the largest mine in the Willow Creek district, contains $37 \mu \mathrm{g} / \mathrm{L}$ arsenic, which is attenuated to about one-third that level within 1.5 $\mathrm{km}$ downstream (Goldfarb and others, 1997). Discharge from the Alaska-Juneau mine, the largest historic gold mine in Alaska, does not exceed $7 \mu \mathrm{g} / \mathrm{L}$ arsenic and has an average $\mathrm{pH}$ of about 8.0 (Goldfarb and others, 1997).

At a small deposit in Virginia, waters in shafts and surface water down-gradient from the shafts all have no more than $1 \mu \mathrm{g} / \mathrm{L}$ arsenic, and $\mathrm{pH}$ values range from 5.9 to 6.7 (Seal and others, 1998a, 1998b). These waters, however, show total mercury values at the high end of the range given above, and in the shafts an unusually large proportion of this mercury (as much as about one-third to one-half) is dissolved methylmercury (Seal and others, 1998b). The source of mercury in the waters is suspected to be mercury used for amalgamation at the site.

Tailings drainage: Data for three Sierra Nevada sites (Argonaut, Kennedy, and Lava Cap mines) show that waters which have percolated through mill tailings have $\mathrm{pH}$ values between 6.0 and 8.1 (generally above 7.0), arsenic concentrations generally less than $100 \mu \mathrm{g} / \mathrm{L}$, sulfate concentrations ranging from 3 to 3,000 $\mathrm{mg} / \mathrm{L}$, and alkalinity values ranging from 20 to $500 \mathrm{mg} / \mathrm{L}$ (Dames \& Moore, 1995; Ashley, 1997, 1998, figures 4 and 5 ). Mercury and methylmercury values are generally the same as for mine drainage, except that water containing suspended tailings particles may have high total mercury levels (as much as $60 \mu \mathrm{g} / \mathrm{L}$ observed; figures 6, 7, and $\underline{8}$ ). Lost Lake, the remaining impoundment for the Lava Cap mine, Nevada County, California, has $\mathrm{pH}$ values of 6.2 to 6.7 , arsenic concentrations consistently in the range 90 to 100 $\mu \mathrm{g} / \mathrm{L}$, sulfate concentrations less than $10 \mu \mathrm{g} / \mathrm{L}$, and iron concentrations around $5 \mathrm{mg} / \mathrm{L}$. Arsenic concentrations in pore waters immediately below the tailings-water interface of Lost Lake range from 1 $\mathrm{mg} / \mathrm{L}$ to $30 \mathrm{mg} / \mathrm{L}$ (Ashley and Ziarkowski, 1999). Arsenic concentrations in the lake cycle seasonally from wintertime lows less than $10 \mu \mathrm{g} / \mathrm{L}$ to summertime highs just over $100 \mu \mathrm{g} / \mathrm{L}$.

Arsenic concentrations in waters draining gold mine tailings piles in southeastern Alaska and in the Fairbanks district are similar to the concentrations in mine drainage waters described above. In the Fairbanks district, dissolved arsenic levels at the Scrafford mine increased from $5 \mu \mathrm{g} / \mathrm{L}$ to $92 \mu \mathrm{g} / \mathrm{L}$, and at the $\mathrm{Hi}-\mathrm{Yu}$ mine from $24 \mu \mathrm{g} / \mathrm{L}$ to $80 \mu \mathrm{g} / \mathrm{L}$, at sampled sites above and below the associated tailings piles (Goldfarb, 1997).

Sulfide concentrates stockpiled at the Argonaut mine mill tailings site, Amador County, California, produce an acid drainage plume in the wet season. At the head of the plume, $\mathrm{pH}$ is 2.5 and metal values are very high, with extreme concentrations of arsenic (more than $100 \mathrm{mg} / \mathrm{L}$; figure 4). Arsenic levels, however, are drastically reduced with increasing $\mathrm{pH}$ and continuous iron oxyhydroxide precipitation downstream from the stockpile area. Within $500 \mathrm{~m}$ downstream, $\mathrm{pH}$ increases to about 5.0 and arsenic is reduced to $<2 \mu \mathrm{g} / \mathrm{L}$ owing to adsorption on the iron oxyhydroxides (Ashley and Ziarkowski, 1998; figure 4). Obviously sulfides from these deposits, if concentrated and removed from buffering carbonates, can 
have the same impacts as sulfides from any other type of deposit; fortunately abandoned sulfide concentrate stockpiles are rare at historic gold mine sites.

\section{Climatic effects}

Because low-sulfide gold-quartz veins are the most common and widespread type of gold deposit world wide, it is no surprise that they occur in almost all climates and ecosystems, from subarctic to humid tropical. In wet climates with abundant water available, impacts on water quality are minimal. In climates with pronounced seasonal wet and dry cycles, such as California, efflorescent salts accumulate in the dry season, store metals in the summer months, and release them at the beginning of the rainy season. Even the relatively benign hydrated magnesium and calcium sulfates associated with these deposits may store some metals (K. Savage, personal communication, 2000). In arid, semi-arid, and seasonally-dry areas these deposits may have significant negative impacts on ground water quality, mainly by increasing sulfate and oxyanion contents, and hardness.

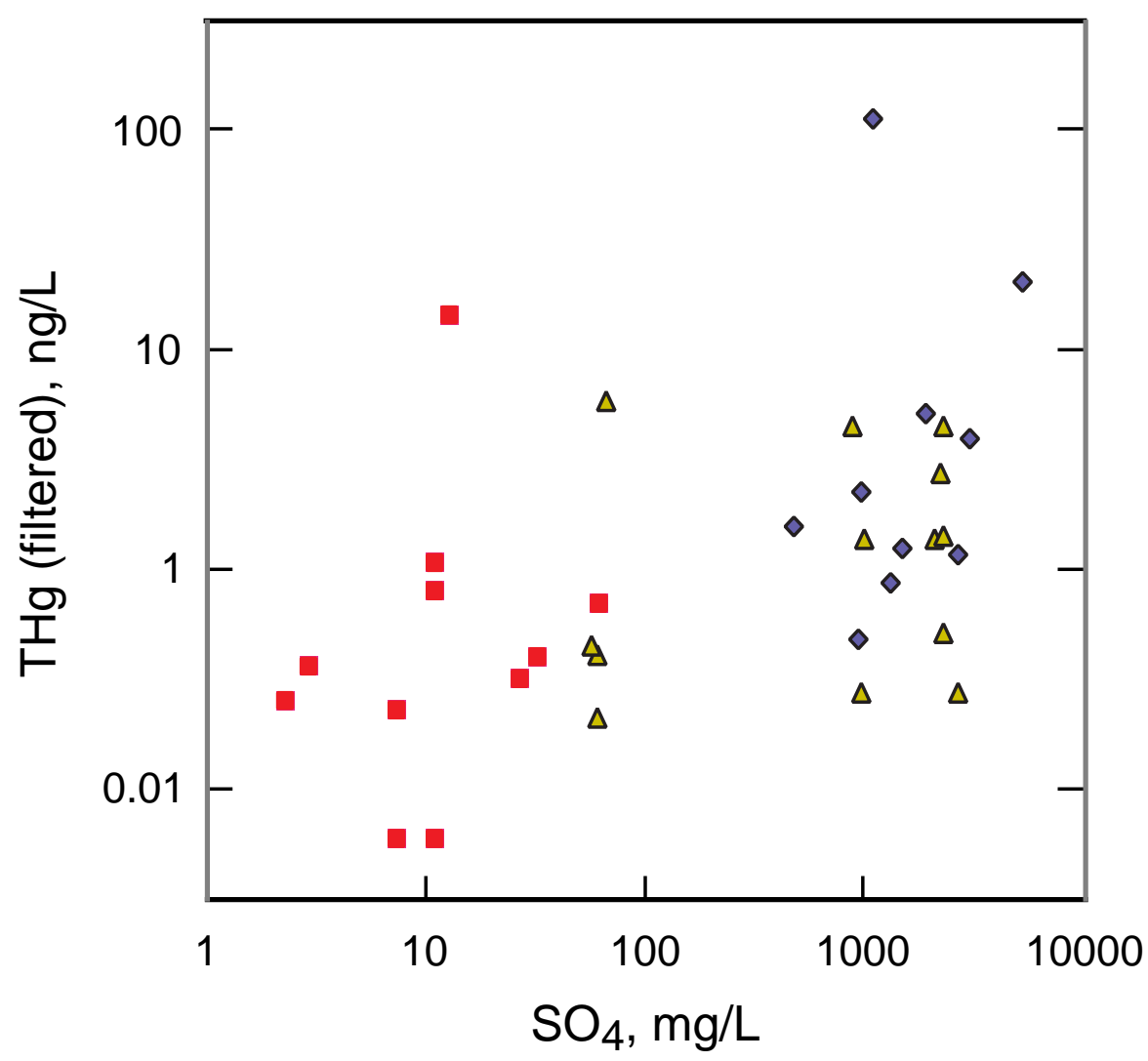

• Drainage, Argonaut mine mill tailings (Ashley, unpub. data)

- Mill tailings impoundment and drainage, Lava Cap mine (Ashley \& Ziarkowski, 1999; Ashley, unpub. data)

$\Delta$ Mine drainage, 6 sites in 5 Sierra Nevada districts (Ashley, unpub. data)

Figure 6. Sulfate and mercury concentrations of mine drainage and drainage from mill tailings, low-sulfide gold-quartz deposits, Sierra Nevada region, California. 


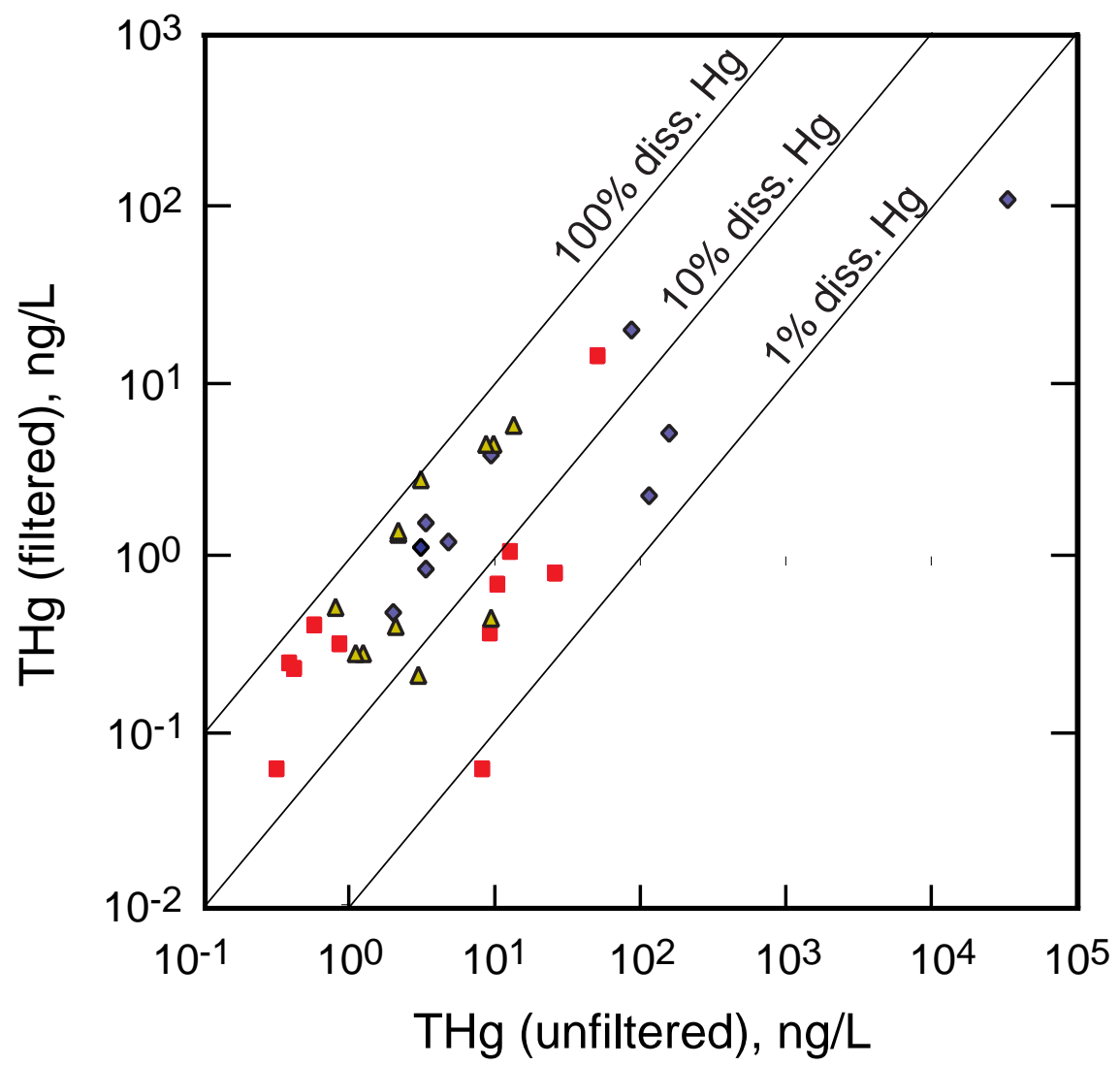

- Drainage, Argonaut mine mill tailings (Ashley, unpub. data)

- Mill tailings impoundment and drainage, Lava Cap mine (Ashley \& Ziarkowski, 1999; Ashley, unpub. data)

$\Delta$ Mine drainage, 6 sites in 5 Sierra Nevada districts (Ashley, unpub. data)

Figure 7. Total dissolved mercury (filtered) vs. total mercury (unfiltered) for mine drainage and drainage from mill tailings, lowsulfide gold-quartz deposits, Sierra Nevada region, California.

Perhaps one of the more important implications of climate relates to stability of stored mill tailings. In wet or even cyclically wet climates, tailings impoundments may remain saturated and largely under reducing conditions. If such impoundments are breached, especially during major storm events, tailings can suddenly be exposed to oxidizing conditions. Under such circumstances at the Lava Cap mine, arsenic and base metals in 60-year-old tailings proved to be easily leached and highly mobile when released and exposed to oxidation in the winter of 1996-1997 (Ashley and Ziarkowski, 1999).

Potential environmental concerns

Human health risks: Surface water contamination associated with low-sulfide gold-quartz deposits does not appear to be a significant problem, as described above, because mine drainage and tailings drainage discharges generally involve relatively small metal loadings. Also arsenic, iron, and other metals are attenuated, and sulfate is usually quickly diluted, within a short distance downstream. Ground water contamination is a potential problem, as demonstrated by the recently-formed pit lakes at two California 
gold mines, which have arsenic concentrations in the range of 100-1,000 $\mu \mathrm{g} / \mathrm{L}$ (see Hydrology section). Wells in hydrothermally altered rocks, where high arsenic concentrations are most likely, are also likely to have relatively high iron and sulfate, which tends to discourage completion and use of wells in potentially arsenic-bearing rocks.

Recent studies have demonstrated that elevated levels of mercury, in dissolved and suspended fractions as well as bedload sediments, exist in the rivers draining the gold-mining region of the Sierra Nevada (Domagalski, 1998), and that mercury becomes available to the aquatic food chain through methylation (Slotton and others, 1997). Analysis of mercury production and use in California, however, indicates that 90 percent or more of the mercury lost to the environment was used in placer operations (mainly hydraulic mines) rather than the lode mines (Churchill, 1999a, 1999b; Hunerlach and others, 1999). Both lode gold mines and placer mines are commonly sources of substantial mercury contamination of soil and water in less-developed parts of the world, owing to inefficient use of mercury in milling (e.g. for barrel amalgamation of coarsely-crushed material) and burning of mercury in open pans for recovery of gold from amalgam (Filho and Maddock, 1997).

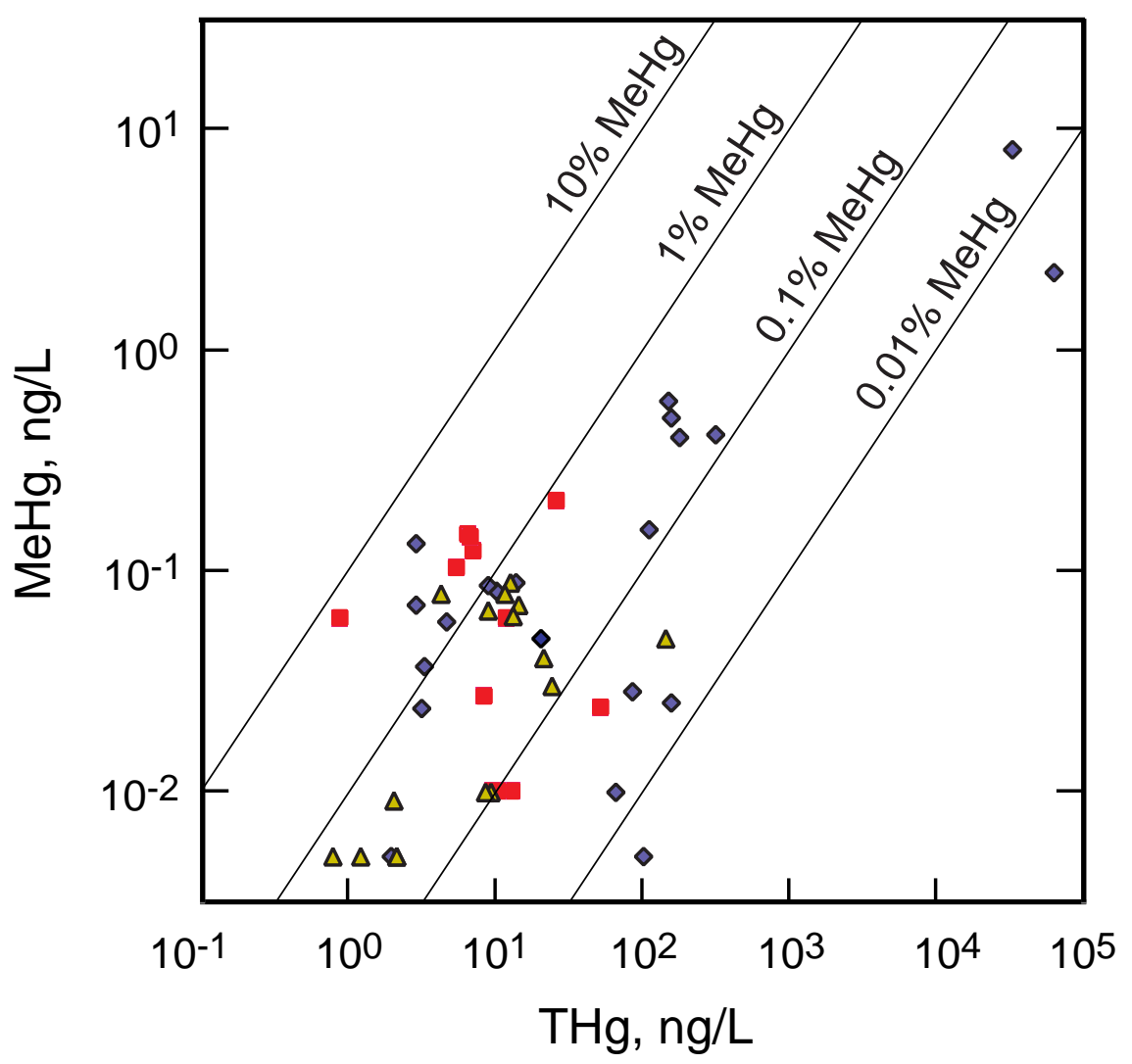

• Drainage, Argonaut mine mill tailings (Ashley, unpub. data)

- Mill tailings impoundment and drainage, Lava Cap mine (Ashley \& Ziarkowski, 1999, Ashley, unpub. data)

$\Delta$ Mine drainage, 6 sites in 5 Sierra Nevada districts (Ashley, unpub. data)

Figure 8. Methylmercury vs. total mercury in mine drainage and drainage from mill tailings, low-sulfide gold-quartz deposits, Sierra Nevada region, California. 
In recent years, concern has risen over exposure to mill tailings in the Sierra Nevada foothills, where housing developments are encroaching on historic mining areas, the main pathways being inhalation of dust and dermal exposure. In the early 1990's concerns over arsenic concentrations at Mesa de Oro, a subdivision built directly on tailings of the Central Eureka mine in Amador County, California, were well publicized (Time Magazine, September 25, 1995), and resulted in a substantial remediation program. Sequential leaching studies and a later in vivo study demonstrated that significant amounts of arsenic in the Mesa de Oro tailings are bioavailable (Walker and others, 1994; Golub and others, 1999). In recent years, the California Environmental Protection Agency has required formal Preliminary Endangerment Assessments of four gold mine tailings sites in the Sierra Nevada, and arsenic has proved to be the only component that consistently exceeds California and USEPA screening levels. Mercury, lead, and cadmium exceed screening levels in some cases, especially the levels for children (California Department of Toxic Substances Control, Site Mitigation Unit, unpub. file reports, 1994-1997).

Ecosystem risks: Aquatic organisms are more sensitive to base metals (copper and zinc) in water than arsenic, so impacts are generally minor because acid drainage and associated high base-metal concentrations rarely occur. Mercury concentrations in water are likely low enough that they are not a problem for organisms at lower trophic levels, but through biomagnification they may be a problem for organisms at higher trophic levels, culminating in the human health concern discussed above.

Based on a biological assessment done shortly after tailings were released at the Lava Cap mine, reduced populations of fish and various insects were reported in the reparian habitat area of the receiving creek, where tailings blanketed the stream terraces. Physical and chemical effects, however, were not separated in this reconnaissance study (State of California Environmental Protection Agency, Department of Toxic Substances Control, 1997).

Physical hazards: As described above, most historic mining of these deposits was done by underground methods. Owing to the tabular geometry of the veins and ore bodies and the tendency of ore shoots to pitch at high angles, vertical workings (shafts and winzes) are almost always present, and unstable glory holes are sometimes present at the surface. Thus, even small gold mines with little or no recorded production may be relatively hazardous.

Further details on physical hazards are available in handbooks by U.S. Bureau of Mines (1994) and State of California Environmental Protection Agency, Department of Toxic Substances Control (1998).

\section{REFERENCES CITED}

Albers, J.P., 1986, Descriptive model of podiform chromite, in Cox, D.P., and Singer, D.A., eds., Mineral deposit models: U.S. Geological Survey Bulletin 1693, p. 34.

Ashley, R. P., 1997, Environmental geochemistry of gold deposits in the Mother Lode Belt, California, in Wanty, R.B., Marsh, S.P., and Gough, L.P., eds., $4^{\text {th }}$ International Symposium on Environmental Geochemistry, Program with Abstracts: U.S. Geological Survey Open File Report 97-496, p. 7.

Ashley, R. P., 1999a, Historical gold mining in California and its environmental consequences: AAAS Annual Meeting and Science Innovation Exposition, Challenges for a New Century, 21-26 January, Anaheim, California, p. A54.

Ashley, R. P., 1999b, Mercury associated with lode gold mining in the Sierra Nevada region, California: $5^{\text {th }}$ International Conference Mercury as a Global Pollutant, Rio de Janeiro, May 23-28, Book of Abstracts, p. 483.

Ashley, R. P., 1999c, Environmental impacts of lode gold mining in the Sierra Nevada, California: Geological Society of America Abstracts with Programs, v. 31, no. 6, p. A-35.

Ashley, R.P., 2000, Mercury associated with lode gold mining in the Sierra Nevada region, California, in Assessing and Managing Mercury from Historic and Current Mining Activities, Nov. 28-30, 2000, Cathedral Hill Hotel, San Francisco, Calif., Final Agenda, List of Speakers, Extended Abstracts, Slide Presentations: U.S. Environmental Protection Agency Office of Research and Development, sponsor, p. 42-45, S59-S70.

Ashley, R.P., and Savage, K.S., 2001, Analytical data for waters of the Harvard open pit, Jamestown mine, Tuolumne County, California, March 1998-September 1999: U.S. Geological Survey Open-File Report 01-074, 13 p. plus 3 tables, available at http://geopubs.wr.usgs.gov/open-file/of01-074/. 
Ashley, R.P., and Ziarkowski, D.V., 1998, Lode gold deposits of the Sierra Nevada region, California, as sources of environmental arsenic: Third International Conference on Arsenic Exposure and Health Effects, San Diego, CA, July 12-15, Book of Abstracts, p. 96.

Ashley, R.P., and Ziarkowski, D.V. 1999, Arsenic in waters affected by mill tailings at the Lava Cap mine, Nevada County, California: Geological Society of America Abstracts with Programs, v. 31, no. 6, p. A-35.

Berger, B.R., 1986a, Descriptive model of low-sulfide Au-quartz veins, in Cox, D.P., and Singer, D.A., eds., Mineral deposit models: U.S. Geological Survey Bulletin 1693, p. 239.

Berger, B.R., 1986b, Descriptive model of Homestake Au, in Cox, D.P., and Singer, D.A., eds., Mineral deposit models: U.S. Geological Survey Bulletin 1693, p. 244.

Berger, V.I., 1993, Descriptive and grade and tonnage model for gold-antimony deposits: U.S. Geological Survey Open-file Report 93-194, 24 p.

Bliss, J.D., 1986, Grade and tonnage model of low-sulfide Au-quartz veins, in Cox, D.P., and Singer, D.A., eds., Mineral deposit models: U.S. Geological Survey Bulletin 1693, p. 239-243.

Bliss, J.D., 1992, Grade and tonnage model of Chugach-type low-sulfide Au-quartz veins, in Bliss, J.D., ed., Developments in mineral deposit modelling: U.S. Geological Survey Bulletin 2004, p. 44-46.

Bliss, J.D., and Jones, G.M.,1988, Mineralogic and grade-tonnage information on low-sulfide Au-quartz veins: U.S. Geological Survey Open-file Report 88-229, 99 p.

Böhlke, J.K.F.P., 1986, Local wall rock control of alteration and mineralization reactions along discordant gold quartz veins, Alleghany, California: $\mathrm{PhD}$ dissertation, University of California, Berkeley, $308 \mathrm{p}$.

Böhlke, J.K., 1989, Comparison of metasomatic reactions between a common $\mathrm{CO}_{2}$-rich vein fluid and diverse wall rocks: intensive variables, mass transfers and Au mineralization at Alleghany, California: Economic Geology, v.84, p. 291-327.

Bowell, R.J., Morley, N.H., and Din, V.K., 1994, Arsenic speciation in soil porewaters from the Ashanti mine, Ghana: Applied Geochemistry, v. 9, p. 15-22.

Chaffee, M.A., and Sutley, S.J., 1994, Analytical results, mineralogical data, and distributions of anomalies for elements and minerals in three Mother Lode-type gold deposits, Hodson mining district, Calaveras County, California: U.S. Geological Survey Open-file Report 94-640, 216 p.

Churchill, R.K., 1999a, Mercury losses from milling lode gold ores in California: Geological Society of America Abstracts with Programs, v. 31, no. 6, p. A-45.

Churchill, R.K., 1999b, Insights into California mercury production and mercury availability for the gold mining industry from the historical record: Geological Society of America Abstracts with Programs, v. 31 , no. 6, p. A-45.

Cieutat, B.A., Goldfarb, R.J., Borden, J.C., McHugh, J., and Taylor, C.D., 1994, Environmental geochemistry of mesothermal gold deposits, Kenai Fjords National Park, south-central Alaska, in Till, A.B., and Moore, T., eds., Geological Studies in Alaska by the U.S. Geological Survey, 1993: U.S. Geological Survey Bulletin 2107, p. 21-25.

Clark, W.B., 1970, Gold districts of California: California Division of Mines and Geology Bulletin 193, $186 \mathrm{p}$.

County of Tuolumne, 1998, Jamestown mine, annual and fourth quarter 1997 report to California Regional Water Quality Control Board, Central Valley Region: Water Quality Compliance Monitoring Report.

Cox, D.P., 1986a, Descriptive model of polymetallic veins, in Cox, D.P., and Singer, D.A., eds., Mineral deposit models: U.S. Geological Survey Bulletin 1693, p. 125.

Cox, D.P., 1986b, Descriptive model of Besshi massive sulfide, in Cox, D.P., and Singer, D.A., eds., Mineral deposit models: U.S. Geological Survey Bulletin 1693, p. 136.

Dames \& Moore, 1995, Final environmental assessment, Kennedy mine tailings site, Jackson, CA, v. 1: unpub. report for Oro de Amador, Inc., 61 p.

Domagalski, J., 1998, Occurrence and transport of total mercury and methyl mercury in the Sacramento River Basin, California: Journal of Geochemical Exploration, v. 64, p. 277-291.

Dufourcq, E.L., 1918, Gold amalgamation and cyanidation, Section 33 in Peele, Robert, ed., Mining Engineers Handbook, 1st Ed.: John Wiley \& Sons, New York, p. 1809-1841.

Evangelou, V.P., Seta, A.K., and Holt, A., 1998, Potential role of bicarbonate during pyrite oxidation: Environmental Science and Technology, v. 32, p. 2084-2091. 
Farmer, G.L., Goldfarb, R.J., Lilly, M.R., Bolton, B., Meier, A.L., and Sanzolone, R., 2000, The chemical characteristics of groundwater near Fairbanks, Alaska, in Kelley, K.D., and Gough, L.P., eds., Geological Studies in Alaska by the U.S. Geological Survey 1998: U.S. Geological Survey Professional Paper 1615, p. 167-178.

Filho, S.R., and Maddock, J.E.L., 1997, Mercury pollution in two gold mining areas of the Brazilian Amazon: Journal of Geochemical Exploration, v. 58, p. 231-240.

Finlay, J.R., 1918, Cost of mining, Section 21 in Peele, Robert, ed., Mining Engineers Handbook, 1st Ed.: John Wiley \& Sons, New York, p. 1282-1355.

Foster, A.L., Brown, G.E., Jr., Tingle, T.N., and Parks, G.A., 1998, Quantitative arsenic speciation in mine tailings using x-ray absorption spectroscopy: American Mineralogist, v. 83, p. 553-568.

Gao, Z.L., and Kwak, T.A.P., 1997, The geochemistry of wall rock alteration in turbidite-hosted gold vein deposits, central Victoria, Australia: Journal of Geochemical Exploration, v. 59, p. 259-274.

Goldfarb, R.J., Berger, B.R., Klein, T.L., Pickthorn, W.J., and Klein, D.P.,1995, Low sulfide Au quartz veins, in duBray, E.A., ed., Preliminary compilation of descriptive geoenvironmental mineral deposit models: U.S. Geological Survey Open-file Report 95-831, p. 261-267.

Goldfarb, R.J., Farmer, G.L., Cieutat, B.A., and Meier, A.L., 1999, Major element, trace element, and strontium isotope systematics of natural waters in the Fairbanks mining district--Constraints from local geology, in Kelley, K.D., ed., Geological Studies in Alaska by the U.S. Geological Survey 1997: U.S. Geological Survey Professional Paper 1614, p. 139-150.

Goldfarb, R.J., Miller, L.D., Leach, D.L. and Snee, L.W., 1997a, Gold deposits in metamorphic rocks in Alaska, in Goldfarb, R.J., and Miller, L.D., Mineral Deposits of Alaska: Economic Geology Monograph v. 9, p. 151-190.

Goldfarb, R.J., Taylor, C.D., Meier, A.L., d'Angelo, W.M., and O'Leary, R.M., 1997b, Hydrogeochemistry of mine drainage waters associated with low sulfide gold quartz veins in Alaska in Dumoulin, J.A., and Gray, J.E., eds., Geological Studies in Alaska by the U.S. Geological Survey 1995: U.S. Geological Survey Professional Paper 1574, p. 3-17.

Golub, M.S., Keen, C.L., Commisso, J.F., Salocks, C.B., and Hathaway, T.R., 1999, Arsenic tissue concentration of immature mice one hour after oral exposure to gold mine tailings: Environmental Geochemistry and Health, v. 21, p. 199-209.

Groves, D.I., Goldfarb, R.J., Gebre-Mariam, M., Hagemann, S.G., and Robert, F., 1998, Orogenic gold deposits--A proposed classification in the context of their crustal distribution and relationship to other gold deposit types, Ore Geology Reviews, v. 13, p. 7-27.

Hawkins, D.B., Forbes, R.B., Hok, C.I., and Dinkel, D., 1982, Arsenic in water, soil, bedrock, and plants of the Ester dome area of Alaska: Institute of Water Resources, University of Alaska, Fairbanks, Report IWR-103, $82 \mathrm{p}$.

Hunerlach, M.P., Rytuba, J.J., and Alpers, C.N., 1999, Mercury contamination from hydraulic placer-gold mining in the Dutch Flat mining district, California: U.S. Geological Survey Water-Resources Investigations Report 99-4018B, p. 179-189.

Klein, T.L., and Day, W.C., 1994, Descriptive and grade-tonnage models of Archean low-sulfide Au-quartz veins and a revised grade-tonnage model of Homestake Au: U.S. Geological Survey Open-file Report 94-250, $29 \mathrm{p}$.

Lang, J.R., Baker, Tim, Hart, C.J.R., and Mortensen, J.K., 2000, An exploration moldel for intrusionrelated gold systems: SEG Newsletter, Number 40, p. 1, 6-15.

McCoy, D., Newberry, R.J., Layer, P., DiMarchi, J.J., Bakke, A., Masterman, J.S., and Minehane, D.L., 1997, Plutonic-related gold deposits of interior Alaska, in Goldfarb, R.J., and Miller, L.D., eds., Mineral Deposits of Alaska: Economic Geology Monograph 9, p. 191-241.

McCuaig, T.C., and Kerrich, Robert, 1998, P-T-t-deformation-fluid characteristics of lode gold deposits: evidence from alteration systematics: Ore Geology Reviews, v. 12, p. 381-453.

McKelvey, G.E., 1992, Descriptive model of laterite-saprolite gold, in Bliss, J.D., ed., Developments in mineral deposit modelling: U.S. Geological Survey Bulletin 2004, p. 47-49.

Meridian Gold Company, 1997, Royal Mountain King mine, annual report to California Regional Water Quality Control Board, Central Valley Region, 1996: Water Quality Compliance Monitoring Report (Volumes I and II). 
Montoya, B.L., and Pan, Xiaomang, 1992, Inactive mine drainage in the Sacramento Valley, California: Staff Report, California Regional Water Quality Control Board, Central Valley Region, 76 p.

Mueller, S.H., Goldfarb, R.J., Farmer, G.L., Sanzalone, R., Richmond, S.A., and Adams, M., 2000, Controls on the Concentration and Mobility of Arsenic in Groundwaters, Fairbanks, Alaska: Geological Society of America Abstracts with Programs, v. 32, no. 6, p. A-57.

Nash, J.T., 1988, Geology and geochemistry of gold deposits of the Big Canyon area, El Dorado County, California: U.S. Geological Survey Bulletin 1854, 40 p.

Nelson, G.M., and Leicht, W., 1994, Native gold from the Jamestown mine, Tuolumne County, California: Mineralogical Record, v. 25, p. 7-14.

Plumlee, G.S., 1999, The environmental geology of mineral deposits: in Plumlee, G.S., and Logsdon, M.J., eds., The Environmental Geochemistry of Mineral Deposits, Part A: Processes, Techniques, and Health Issues: Reviews in Economic Geology, v. 6A, p. 71-116.

Richards, R.H., 1918, Ore dressing, Section 28 in Peele, Robert, ed., Mining Engineers Handbook, 1st Ed.: John Wiley \& Sons, New York, p. 1620-1729.

Ridley, J., Mikucki, E.J., and Groves, D.I., 1996, Archean lode-gold deposits: fluid flow and chemical evolution in vertically extensive hydrothermal systems: Ore Geology Reviews, v. 10, p. 279-293.

Rytuba, J.J., 1986, Descriptive model of silica-carbonate Hg, in Cox, D.P., and Singer, D.A., eds., Mineral deposit models: U.S. Geological Survey Bulletin 1693, p. 181.

Savage, K.S., Bird, D.K., O’Day, P.A., and Mehta, Apurva, 1999, Characterization of synthetic and natural arsenian jarosite using synchrotron-based techniques [abstract]: EOS, Transactions, American Geophysical Union, 1999 Fall Meeting, v. 80, p. F377.

Savage, K.S., Bird, D.K., and Ashley, R.P., 2000a, Legacy of the California gold rush: environmental geochemistry of arsenic in the southern Mother Lode gold district: International Geology Review, in press.

Savage, K.S., Tingle, T.N., O’Day, P.A., Waychunas, G.A., and Bird, D.K., 2000b, Arsenic speciation in pyrite and secondary weathering phases, Mother Lode gold district, Tuolumne County, California: Applied Geochemistry, in press.

Seal, R.R., II, Haffner, D.P., and Meier, A.L., 1998a, Environmental characteristics of the abandoned Greenwood mine area, Prince William Forest Park, Virginia: implications for mercury geochemistry: U.S. Geological Survey Open-file Report 98-326, 19 p.

Seal, R.R., II, Haffner, D.P., and Meier, A.L., 1998b, Geochemical data including mercury speciation for surface waters at the abandoned Greenwood mine area, Prince William Forest Park, Virginia: U.S. Geological Survey Open-file Report 98-756, 14 p.

Singer, D.A., 1986a, Descriptive model of Cyprus massive sulfide, in Cox, D.P., and Singer, D.A., eds., Mineral deposit models: U.S. Geological Survey Bulletin 1693, p. 131.

Singer, D.A., 1986b, Descriptive model of Kuroko massive sulfide, in Cox, D.P., and Singer, D.A., eds., Mineral deposit models: U.S. Geological Survey Bulletin 1693, p. 189-190.

Smith, K.S., Plumlee, G.S., and Ficklin, W.H., 1994, Predicting water contamination from metal mines and mining wastes: U.S. Geological Survey Open-file Report 94-264, 112 p.

Slotton, D.G., Ayers, S. M., Reuter, J.E., and Goldman, C.R., 1997, Gold mining impacts on food chain mercury in northwestern Sierra Nevada steams (1997 revision), Appendix B in Larry Walker Associates, 1997, Sacrameto River watershed mercury control planning project—report for the Sacramento Regional County Sanitation District, 74 p.

State of California Environmental Protection Agency, Department of Toxic Substances Control, 1997, Update: Lava Cap mine, Little Clipper Creek, Lost Lake: Fact Sheet, 4 p.

State of California Environmental Protection Agency, Department of Toxic Substances Control, 1998, Abandoned mine lands preliminary assessment handbook: $75 \mathrm{p}$. plus 12 appendices.

Trainor, T.P., Fleisher, S., Wildeman, T.R., Goldfarb, R.J., and Huber, C., 1996, Environmental geochemistry of the McKinley Lake gold district, Chugach National Forest, Alaska, in Moore, T.E., and Dumoulin, J.A., eds., Geological Studies in Alaska by the U.S. Geological Survey, 1994: U.S. Geological Survey Bulletin 2152, p. 3-15.

U.S. Bureau of Mines, 1994, Abandoned mine land inventory and hazard evaluation handbook (draft): U.S. Department of the Interior, Bureau of Mines, $162 \mathrm{p}$. 
Walker W. J., Galleni A. M., and Dragoo J. P., 1994, Arsenic speciation and solubility in mine tailings from Mesa de Oro, California: Science and Engineering Analysis Corporation (SEACOR) Report N2901, submitted to Dept. of Toxic Substances Control Site Mitigation Unit, August 31, 1994.

Wilson, F.H., 1975, Arsenic and water, Pedro Dome-Cleary Summit area, Alaska: M.S. thesis, University of Alaska-Fairbanks, $80 \mathrm{p}$.

Yeend, W.E., 1986, Descriptive model of placer Au-PGE, in Cox, D.P., and Singer, D.A., eds., Mineral deposit models: U.S. Geological Survey Bulletin 1693, p. 261. 


\title{
Chapter L
}

\section{GEOENVIRONMENTAL MODELS FOR SEAFLOOR MASSIVE SULFIDE DEPOSITS}

\author{
Robert R. Seal II, Jane M. Hammarstrom, and Nora K. Foley
}

\begin{abstract}
INTRODUCTION
Massive sulfide deposits have some of the greatest potential for adverse environmental impacts. If improperly exploited, these deposits have high acid-generating potential due to high sulfide content, high heavy metal contents, and low acid-neutralizing potential due to their silicate host rocks, all of which can contribute to deleterious effects on aquatic ecosystems and human health. Massive sulfide deposits are typified by ores that comprise greater than 50 percent sulfide minerals, such as pyrite, pyrrhotite, chalcopyrite, sphalerite, and galena, among others. They can be classified into at least six distinct deposit types on the basis of host rocks, and metal associations. Their potential for deleterious effects is related to their genetic classification in terms of acid-generating potential, associated heavy metal suites, acidneutralizing capacity of host rocks, weathering products, and natural, pre-mining background characteristics of associated waters and rocks.

The purpose of this paper is to describe the potential behavior of seafloor massive sulfide deposits in relation to their geochemical attributes and in the context of their genetic classification. The link between genetic classification and environmental behavior is established through the compilation of data from sitespecific studies. By definition, massive sulfide deposits can be expected to share many common aspects of their environmental behavior. However, significant differences can also be caused by their differences in geochemical characteristics that distinguish the various massive sulfide deposit types. This paper represents an extension and refinement of previous geoenvironmental models for massive sulfide deposits (Taylor and others 1995; Kelley and others 1995; Alpers and Zierenberg 1998).
\end{abstract}

\section{CLASSIFICATION OF MASSIVE SULFIDE DEPOSITS}

Most massive sulfide deposits form in submarine geothermal systems on or near the ocean floor. These seafloor deposits are dominated by massive accumulations of pyrite and (or) pyrrhotite, with lesser amounts of base-metal sulfide minerals, such as chalcopyrite, sphalerite, and galena. The host rocks for these deposits are typically felsic or mafic volcanic rocks, or siliciclastic sedimentary rocks. Carbonate minerals are typically absent or are a minor component of the host rocks and associated alteration assemblage. Locally, Besshi-type deposits may have carbonate units in the stratigraphic package on a regional scale. Thus, these deposits and surrounding rocks have a high acid-generating capacity and a low acidneutralizing capacity. Economic geologists have chosen to classify massive sulfide deposits by a variety of schemes that emphasize metal associations, tectonic setting, or host-rock composition, among other characteristics. This paper uses a classification of seafloor massive sulfide deposits based dominantly on host-rock composition, which is a modification and expansion of the classification presented by Franklin and others (1998). This classification emphasizes geochemical controls on metal associations and bulk characteristics of host rocks such as acid-generating and -neutralizing potentials. This paper does not include discussion of types of massive sulfide deposits commonly known as magmatic Ni-sulfide, skarn, and manto deposits, which do not form on the seafloor and are genetically distinct.

Seafloor massive sulfide deposits are divided into six categories based on associated volcanic rocks (or lack thereof) and the relative proportions of volcanic and sedimentary host rocks (Table 1). These six categories, organized from volcanic- to sediment-rich, are (1) Kuroko-type, (2) Noranda-type, (3) Cyprustype, (4) Bathurst-type, (5) Besshi-type, and (6) Sedimentary-exhalative-type deposits (Franklin and others 1998; Franklin 1993; Goodfellow and others 1993; Slack 1993). Kuroko- (felsic >mafic), Noranda(mafic $>$ felsic), and Cyprus-type (mafic-only) deposits are dominated by volcanic host rocks. Bathurst(felsic $>$ mafic) and Besshi- (mafic $>$ felsic) type deposits are characterized by subequal proportions of sedimentary and volcanic rocks, with the dominance of felsic and mafic rocks distinguishing the two types. Sedimentary-exhalative deposits are hosted by dominantly siliciclastic sedimentary rocks with subordinate to no associated volcanic/intrusive rocks. Examples of these deposits are listed in Table 1. Locations of selected deposits in the United States and Canada are shown in Figure 1. 
Table 1. Classification of seafloor massive sulfide deposits with examples

\begin{tabular}{|c|c|c|c|}
\hline Volcanic Assemblage & Sediments $>$ Volcanics & Volcanics $\approx$ Sediments & Volcanics $>$ Sediments \\
\hline $\begin{array}{l}\text { Bimodal } \\
\text { Felsic }>\text { Mafic }\end{array}$ & & $\begin{array}{l}\text { Bathurst (Type 5*) } \\
\text { Halfmile Lake \& } \\
\text { Restigouche, NB }\end{array}$ & $\begin{array}{l}\text { Kuroko (Type } 2^{*} \text { ) } \\
\text { Holden, WA; Penn, CA; } \\
\text { Mineral District, VA; } \\
\text { Kidd Creek, Ontario; } \\
\text { Hokuroko district, Japan }\end{array}$ \\
\hline $\begin{array}{l}\text { Bimodal } \\
\text { Mafic }>\text { Felsic }\end{array}$ & $\begin{array}{l}\text { Sedimentary-exhalative } \\
\text { Red Dog, Lik, \& } \\
\text { Drenchwater, AK; } \\
\text { Sullivan \& Cirque, BC; } \\
\text { Balmat, NY; Meggan \& } \\
\text { Rammelsberg, Germany; } \\
\text { Faro, Tom, Jason, \& } \\
\text { Howards Pass, Yukon } \\
\text { Terrotory; MacArthur } \\
\text { River, Mount Isa, Broken } \\
\text { Hill, Australia }\end{array}$ & $\begin{array}{l}\text { Besshi (Type } 4^{*} \text { ) } \\
\text { Fontana \& Hazel Creek, } \\
\text { NC; Ducktown, TN; } \\
\text { Elizabeth \& Ely, VT; } \\
\text { Prince William Sound, } \\
\text { AK; Windy Craggy, BC; } \\
\text { Besshi, Japan }\end{array}$ & $\begin{array}{l}\text { Noranda (Type } 1 * \text { ) } \\
\text { Iron Mountain, CA; Bald } \\
\text { Mountain, ME }\end{array}$ \\
\hline Mafic and Ultramafic & & & $\begin{array}{l}\text { Cyprus (Type } 3^{*} \text { ) } \\
\text { Prince William Sound, } \\
\text { AK; Skouriotissa, } \\
\text { Cyprus; Big Mike, NV; } \\
\text { Turner-Albright;;OR }\end{array}$ \\
\hline
\end{tabular}

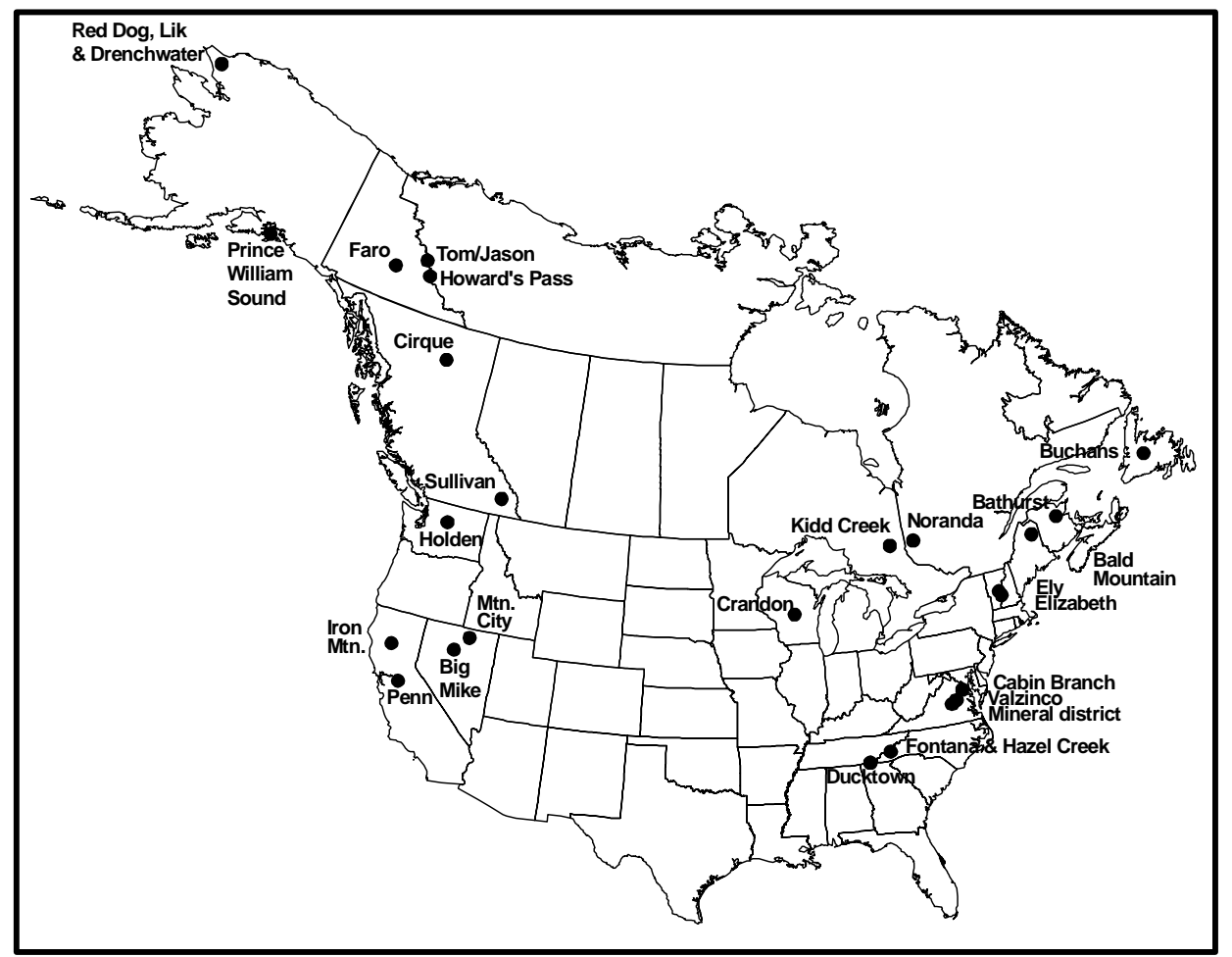

Figure 1. Location of selected seafloor massive sulfide deposits in the United States and Canada. 


\section{GEOLOGIC CHARACTERISTICS}

\section{General Characteristics}

Seafloor massive sulfide deposits are collectively defined by the fact that they formed syngenetically on or near the ancient seafloor as lens-like or tabular bodies of stratiform sulfide minerals. Their formation resulted from seafloor hot-spring activity. Differences in geologic and tectonic setting among the various types of seafloor massive sulfide deposits cause distinct differences in host-rock compositions, chemistry of the ores, and morphological features of the deposits, all of which affect the environmental behavior of these deposits. Kuroko-, Noranda-, Bathurst-, and Besshi-type deposits form in island-arc settings. Cyprus-type deposits form in mid-ocean-ridge settings. Sedimentary-exhalative deposits form along rifted continental margins.

Kuroko-type deposits are hosted by volcanic rocks that range from basalt to rhyolite in composition. Shales, mudstones, and volcanoclastic sedimentary rocks also are common. Noranda-type deposits are dominated by basaltic host rocks with lesser amounts of felsic volcanic host rocks and subordinate shales. Cyprus-type deposits are dominated by basaltic host rocks with minimal siliciclastic sedimentary rocks. Besshi-type deposits are hosted by turbiditic shales, graywackes, and sandstones, with lesser amounts of basaltic sills and locally minor amounts of dolomitic shales. Bathurst-type deposits are dominantly hosted by rhyolitic volcanic rocks, and siliciclastic sedimentary rocks. Sedimentary-exhalative deposits are hosted by shales, siltstones, and sandstones. Locally, carbonate rocks are important, with igneous rocks, typically basaltic, being absent or comprising up to half of the host-rock package.

\section{Related Deposit Types}

For sedimentary-exhalative massive deposits, deposit types that can be associated on a local to regional scale include bedded barite, Mississippi Valley type lead-zinc, sedimentary manganese, sedimentary phosphate, Besshi massive sulfide, Chinese-type black shale deposits from the models presented by Cox and Singer (1986). The other classes of seafloor massive sulfide deposits are associated with a number of other mineral deposit types. Seafloor massive sulfide deposits are commonly associated with regionally developed iron- and (or) manganese-rich metalliferous sediment and chert developed at the same timestratigraphic horizon as the massive sulfide deposits. Some Archean deposits may be transitional to volcanic-associated iron formation. All of these related deposit types have strong genetic links to the geochemical environment in which massive sulfide deposits form. There is a common association of seafloor base- and precious-metal massive sulfide deposits with younger low-sulfide quartz-gold vein (mesothermal or "Mother Lode") deposits. The close associations of low-sulfide quartz gold vein deposits with volcanic-associated massive sulfide deposits may reflect the results of the metamorphism of preexisting metal-rich lithotectonic units.

\section{Deposit Size}

For all classes of massive sulfide deposits, mined deposits are historically in the 1 to 5 million tonnes range, but individual deposits can approach 500 million tonnes (Singer, 1986c, d; Singer and Mosier, 1986). Development of new deposits from all classes in frontier areas likely requires at least 10 million tonnes of reasonably high grade ore. Most Cyprus-type deposits contain less than 15 million tonnes of ore. Most Besshi-type deposits are also fairly small; notable exceptions include the $>300$ million tonne Windy Craggy, British Columbia, deposit. Kuroko-type deposits, especially those of Precambrian age, can be very large, such as the world class Kidd Creek, Ontario, deposit. Most economic sedimentary-exhalative deposits are between 1.5 and 130 million tons; the median deposit size is 15 million tons (Menzie and Mosier, 1986). The Howards Pass deposit, Yukon Territory, contains 550 million tonnes of ore (Goodfellow and others, 1993).

\section{Host Rocks}

The mineralogy and geochemistry of the host rocks are especially important because of the acidgenerating or acid-neutralizing potential of mineable lithologic units. Mafic (basaltic) host rocks typically have sufficient acid-neutralizing capacity, whereas felsic (rhyolitic) host rocks do not. The host rocks of a mineral deposit can also serve to naturally elevate background acidity and aqueous contributions of metals as comnpared to adjacent rock types. Cyprus-type deposits are hosted by submarine mafic-volcanic rocks, typically in brecciated rocks commonly associated with pillow lavas. Host-rocks for Kuroko-type deposits range from basalt to rhyolite. Host rocks are commonly brecciated and are moderately to highly altered. Some deposits are hosted by associated volcaniclastic or hemipelagic sedimentary rocks that overly 
submarine volcanic sequences. Host rocks for Noranda-type deposits are dominated by basaltic rocks, but are otherwise geologically similar to those for Kuroko-type deposits. Besshi-type deposits are typically hosted by turbiditic to hemipelagic graywacke interbedded with or intruded by basalt. Host rocks for sedimentary-exhalative deposits consist of a variety of marine sedimentary rocks such carbonaceous shale and chert, dolomitic shale or siltstone, and micritic limestone. Turbidites and slump breccias are present locally; minor volcanic rocks, usually mafic, may be temporally, but not necessarily spatially, associated. Sangster (1990) indicates that tuff units are present within ore-hosting sequences at a number of these deposits.

\section{Surrounding Geologic Terrane}

Mineral deposits form in specific geologic settings, which have certain predictable geochemical attributes. Thus, even though the immediate host rocks of a deposit are devoid of carbonate rocks, such as those associated with Besshi-type massive sulfide deposits, the larger scale lithotectonic terrane can contain significant amounts of limestone and (or) dolomite, which can serve to increase the alkalinity and hardness of watersheds receiving acid drainage from these types of deposits. Also, the structural setting of the deposit can greatly influence the distribution of fractures and associated permeability.

Submarine volcanic activity is a defining characteristic of the environment of formation of volcanicassociated massive sulfide deposits. Most of these deposits, including many ophiolite-hosted deposits of the Cyprus-type, are associated with arc-related volcanism. Local extensional tectonic environments are particularly conducive to deposition of massive sulfide deposits. The geologic terrane surrounding sedimentary-exhalative deposits primarily consists of thick sequences of deep-water marine sedimentary rocks that include fine-grained clastic and carbonate rocks. The formation of these deposits along active plate margins can lead to the juxtaposition of unrelated rock types in compressional regimes.

\section{Wall-Rock Alteration}

Wall-rock alteration changes the chemistry of the host rock for a significant distance away from the ore zones. Alteration can increase the acid-neutralizing capacity of a rock by introducing carbonate minerals, or it can decreasing the acid-neutralizing capacity of a rock by transforming feldspars into clay minerals. In fault zones, footwall alteration associated with volcanic-associated massive sulfide deposits is moderate to locally intense around most deposits. Hanging-wall alteration is typically absent, but may be weakly developed in some deposits. Many deposits that have not been tectonically disrupted are underlain by a stringer-zone of mineralized and altered rock. Stringer-zones are characterized by anastomosing quartzsulfide veins. Zones of silicification are present near and within mineralized zones. The most common alteration is chloritization, which is less well developed with increasing depth and distance from hydrothermal vent zones. Deposits hosted by felsic rocks typically have extensively developed quartzsericite alteration. Most altered rocks associated with massive sulfide deposits have low to very low acid buffering capacity. Some massive sulfide deposits are associated with pervasive carbonate alteration in the footwall. These carbonate alteration zones typically have low to moderate abundances of calcitic to ankeritic carbonate minerals (Taylor and others, 1995).

Alteration assemblages associated with sedimentary-exhalative deposits consists of stockwork and disseminated minerals locally present beneath or adjacent to stratiform deposits. These commonly consist of silicified or iron-carbonate altered rocks that locally contain tourmaline, albite, and chlorite, and represent the feeder zones of these deposits. In some deposits, silicification is the dominant or only alteration (Meggen, Germany and Red Dog, Alaska). In others, alteration is less extensive and (or) carbonate-rich (Large, 1981). Large (1983) describes more subtle types of alteration near some deposits, including increased dolomite-calcite ratios (McArthur River, Australia; deposits in Ireland) and increased potassium feldspar-albite ratios in tuffs (McArthur River).

\section{Nature of Ore}

Volcanic-associated massive sulfide deposits range from lens shaped to sheet-like bodies of sulfidemineral-rich rock spatially associated with volcanic rocks ranging in composition from basalt to rhyolite. By definition, they contain zones of massive sulfide minerals, many with sulfide mineral contents exceeding 90 volume percent. Most deposits also contain extensive zones of semi-massive sulfide rock ( 25 to 50 volume percent) that contain economically exploitable ore. Stringer ore zones in the footwall of the massive sulfides typically contain 5 to 20 volume percent sulfide minerals. These are hosted in quartz veins and disseminated in chloritic wall rocks. Disseminated sulfide rock is extensively developed in 
footwall alteration zones; sulfide mineral abundances decrease with depth below the massive sulfide zone horizon. Lateral development of disseminated pyrite can be continuous for large distances at and immediately below the stratigraphic horizon of the massive sulfide lens. In contrast to other volcanichosted deposits, many Besshi-type deposits form thin, laterally extensive sheets of pyrrhotite- and (or) pyrite-rich massive sulfide rock.

Sedimentary-exhalative deposits form as lens-like bodies of stratiform sulfide minerals (lead, zinc, and iron) as much as a few tens of meters in thickness and are interbedded with fine-grained dark clastic and chemical sedimentary rocks. These deposits may have large lateral extent (hundreds of meters to kilometers). Mineralized rock varies from a single layer to numerous bodies that may be vertically stacked or be lateral equivalents (Kelley and others, 1995). Within stratiform mineralized rocks of sedimentaryexhalative deposits, sulfide minerals are generally fine-grained, and commonly form nearly monomineralic laminae several $\mathrm{mm}$ to $\mathrm{cm}$ thick that have continuity over large parts of the deposits. Some deposits are not laminated (Meggen, Germany and Red Dog, Alaska). Sphalerite, galena, and iron-sulfide minerals (pyrite, marcasite, and pyrrhotite) are the most common sulfide minerals, but chalcopyrite and sulfosalt minerals may also be present in minor amounts (Large, 1981; 1983; Lydon, 1983). The most common associated sulfate mineral is barite. It may be peripheral to or stratigraphically above the deposit, or it may form crudely segregated mixtures with sulfide minerals, but many deposits have no associated barite.

\section{Primary Mineralogy and Zonation}

The primary ore mineralogy defines the suite of heavy metals that may cause potential environmental problems. In addition to pyrite and pyrrhotite, the ore minerals chalcopyrite $\left(\mathrm{CuFeS}_{2}\right)$, sphalerite $(\mathrm{ZnS})$, and galena $(\mathrm{PbS})$ are commonly major constituents in these deposits, and are the principal sources of elevated concentrations of $\mathrm{Cu}, \mathrm{Zn}$, and $\mathrm{Pb}$ in mine drainage. Trace element concentrations in mine drainage are also related to the composition and abundance of trace elements in ore minerals and accessory minerals. For example, elevated dissolved concentrations of $\mathrm{Cd}$ are correlated with its substitution into sphalerite. Cadmium rarely forms a discrete mineral in these types of deposits. Arsenic commonly substitutes into pyrite, up to several weight percent, and arsenopyrite (FeAsS) is also a common accessory in some deposit types. Both phases constitute a significant source of As in some deposits. The primary mineralogical characteristics of massive sulfide deposits and associated heavy elements are summarized in Table 2.

The primary and secondary mineralogy of the ores, their solid mine wastes, and associated rock types can affect the acid-base accounting (ABA) calculations. Acid-base accounting is based on the stoichiometric reaction:

$$
\mathrm{FeS}_{2}+2 \mathrm{CaCO}_{3}+3.75 \mathrm{O}_{2}+1.5 \mathrm{H}_{2} \mathrm{O} \rightarrow \mathrm{Fe}(\mathrm{OH})_{3}+2 \mathrm{SO}_{4}{ }^{2-}+2 \mathrm{Ca}^{2+}+2 \mathrm{CO}_{2}(\mathrm{~g})
$$

which describes acid generation through the oxidation of pyrite and subsequent neutralization by calcite (Sobek and others 1978). Cravotta and others (1990) considered a variation on this reaction where $\mathrm{CO}_{2}$ was not exsolved, but contributed carbonic acid. In the case of Besshi-type and some sedimentaryexhalative massive sulfide deposits, pyrrhotite $\left(\mathrm{Fe}_{1-\mathrm{x}} \mathrm{S}\right.$; where $\mathrm{x}$ ranges from 0.000 to 0.106 ) is the dominant sulfide mineral. For pyrrhotite, acid-base accounting can be approximated by the simplified stoichiometric reaction:

$$
\mathrm{FeS}+\mathrm{CaCO}_{3}+2.25 \mathrm{O}_{2}+1.5 \mathrm{H}_{2} \mathrm{O} \rightarrow \mathrm{Fe}(\mathrm{OH})_{3}+\mathrm{SO}_{4}{ }^{2-}+\mathrm{Ca}^{2+}+\mathrm{CO}_{2}(\mathrm{~g})
$$

The net result of the proportion of $\mathrm{CaCO}_{3}$ per unit of total $\mathrm{S}$ is the same as in reaction 1, but the total $\mathrm{S}$ per unit of solid will be lower because pyrrhotite has approximately half of the $\mathrm{S}$ of pyrite.

The dominant sulfide mineral in most volcanic-associated massive sulfide deposits is pyrite, but pyrrhotite is dominant in Besshi-type and sedimentary-exhalative. Marcasite, which is present either intergrown with fine grained pyrite or as a replacement product of pyrrhotite, is generally a minor constituent, but locally can constitute a potential source of acidic drainage because of its higher reactivity relative to pyrite. The other dominant phases include sphalerite and chalcopyrite, accompanied by galena in deposits associated with felsic rock. Other ore minerals are present in much lower abundances, but constitute important potential heavy metal sources. The most common accessory sulfide and sulfosalt minerals are those of the tennantite-tetrahedrite series, arsenopyrite, and various lead-antimony-bismuth sulfosalt minerals, particularly in deposits associated with felsic rock. Deposits associated with mafic rock may contain cobalt sulfide or thiospinel. Magnetite is present in some deposits and barite can be very 
abundant in Kuroko-type deposits, in which it commonly forms an important ore facies. Gypsum and anhydrite are also abundant in some Kuroko deposits. The most common silicate gangue minerals are quartz and chlorite, which are accompanied by sericite in deposits associated with felsic rocks. Other gangue phases are much less abundant, except in massive sulfide deposits that have been metamorphosed to greenschist or higher metamorphic grades. In these metamorphosed deposits, phases such as anthophyllite and cordierite form from chloritic protoliths (Taylor and others, 1995). In sedimentaryexhalative deposits, the dominant sulfide ore minerals are sphalerite and galena, although minor chalcopyrite, arsenopyrite, and tetrahedrite are present in some deposits (Large, 1983; Kelley and others, 1995). The most common gangue minerals are iron sulfide (pyrite, marcasite, or pyrrhotite) and quartz.

Barite may be present. Numerous other sulfide and sulfosalt minerals have been reported in some deposits (Cox and Curtis, 1977; Large, 1983; Taylor and others, 1994).

Table 2. Mineralogical and metal associations of massive sulfide deposits

\begin{tabular}{|c|c|c|c|c|c|c|}
\hline & Noranda & Kuroko & Cyprus & Besshi & Bathurst & Sed-Ex \\
\hline $\begin{array}{l}\text { Major } \\
\text { metals }\end{array}$ & $\begin{array}{l}\mathrm{Fe}, \mathrm{Cu}, \mathrm{Zn}, \\
\text { (Al) }\end{array}$ & $\begin{array}{l}\mathrm{Fe}, \mathrm{Zn}, \mathrm{Pb}, \\
\mathrm{Cu},(\mathrm{Al})\end{array}$ & $\mathrm{Fe}, \mathrm{Cu}$ & $\begin{array}{l}\mathrm{Fe}, \mathrm{Cu}, \mathrm{Zn}, \\
\text { (Al) }\end{array}$ & $\begin{array}{l}\mathrm{Fe}, \mathrm{Zn}, \mathrm{Pb}, \\
\text { (Al) }\end{array}$ & $\begin{array}{l}\mathrm{Fe}, \mathrm{Zn}, \mathrm{Pb}, \\
\text { (Al) }\end{array}$ \\
\hline $\begin{array}{l}\text { Minor } \\
\text { metals }\end{array}$ & $\begin{array}{l}\mathrm{Pb}, \mathrm{Cd}, \mathrm{As}, \\
\mathrm{Ag}, \mathrm{Au}\end{array}$ & $\begin{array}{l}\mathrm{Cd}, \mathrm{As}, \mathrm{Ag}, \\
\mathrm{Au}\end{array}$ & $\begin{array}{l}\mathrm{Zn}, \mathrm{Cd}, \mathrm{Pb}, \\
\mathrm{Ag}, \mathrm{Au}\end{array}$ & $\begin{array}{l}\mathrm{Pb}, \mathrm{Cd}, \mathrm{Ag}, \\
\mathrm{Ag}\end{array}$ & $\mathrm{Cu}, \mathrm{Cd}, \mathrm{As}$ & $\mathrm{Cu}, \mathrm{Cd}, \mathrm{Ag}$ \\
\hline $\begin{array}{l}\text { Dominant Fe } \\
\text { sulfide }\end{array}$ & $\mathrm{py} \geq \mathrm{po}$ & py & py & po $\geq$ py & py & $\mathrm{py} \geq \mathrm{po}$ \\
\hline $\begin{array}{l}\text { Major ore } \\
\text { Sulfides }\end{array}$ & cpy, sph & sph, gn, cpy & cpy & cpy, sph & sph, gn & sph, gn \\
\hline $\begin{array}{l}\text { Minor } \\
\text { sulfide }\end{array}$ & apy, td & $\begin{array}{l}\text { apy, cs, cb, } \\
\text { po, td }\end{array}$ & po, sph & $\begin{array}{l}\text { apy, cb, gn, } \\
\text { td }\end{array}$ & cpy, po, apy & $\begin{array}{l}\text { apy, cpy, st, } \\
\text { td }\end{array}$ \\
\hline $\begin{array}{l}\text { Primary } \\
\text { sulfates }\end{array}$ & ba & ba, anh & & & ba & $\mathrm{ba}$ \\
\hline $\begin{array}{l}\text { Minor } \\
\text { carbonates }\end{array}$ & sd, cal & cal, dol, sd & cal & ank, cal & cal & cal, dol \\
\hline $\begin{array}{l}\text { Secondary } \\
\text { sulfides }\end{array}$ & $\begin{array}{l}\text { en, cv, cc- } \\
\text { dg, mc }\end{array}$ & $\mathrm{ac}, \mathrm{cv}$, en & bn & $\begin{array}{l}\mathrm{mc}, \mathrm{cv}, \mathrm{cc}- \\
\mathrm{dg}\end{array}$ & & $\mathrm{mc}$ \\
\hline $\begin{array}{l}\text { Secondary } \\
\text { alkaline } \\
\text { earth } \\
\text { sulfates }\end{array}$ & ba, anh & ba, anh & & ba, anh & & ba, anh \\
\hline $\begin{array}{l}\text { Secondary } \\
\text { metal } \\
\text { sulfates }\end{array}$ & $\begin{array}{l}\text { ang, gos, } \\
\text { hal-pk, mel, } \\
\text { roz, cop }\end{array}$ & $\begin{array}{l}\text { ang, gos, } \\
\text { aln, chc, eps, } \\
\text { hal-pk, mel, } \\
\text { roz, cop }\end{array}$ & $\begin{array}{l}\text { chc, eps, } \mathrm{Cu}- \\
\mathrm{Mg} \text { mel, gos }\end{array}$ & $\begin{array}{l}\text { ang, aln, } \\
\text { gos, hal-pk, } \\
\text { mel, roz, cop }\end{array}$ & & $\begin{array}{l}\text { ang, gos, } \\
\text { hal-pk, mel, } \\
\text { roz }\end{array}$ \\
\hline $\begin{array}{l}\text { Secondary } \\
\text { ferric } \\
\text { hydroxide- } \\
\text { hydrates }\end{array}$ & $\begin{array}{l}\text { fer, goe, hm, } \\
\text { sch, jar }\end{array}$ & $\begin{array}{l}\text { fer, goe, sch, } \\
\text { sc }\end{array}$ & fer, goe, sch & $\begin{array}{l}\text { fer, goe, jar, } \\
\text { sch }\end{array}$ & & fer, goe \\
\hline
\end{tabular}

Abbreviations: py: pyrite; po: pyrrhotite; cpy: chalcopyrite; sph: sphalerite; gn: galena; apy: arsenopyrite; td: tetrahedrite-tennantite; cs: cassiterite; cb: cubanite; st: stannite; en: enargite; cv: covellite; cc-dg: chalcocite-digenite; mc: marcasite; bn: bornite; cal: calcite; dol: dolomite; ank: ankerite; sd: siderite; ba: barite; anh: anhydrite; ang: anglesite; gos: goslarite; hal-pk: halotrichite-pickeringite; mel: melanterite; roz: rozenite; cop; copiapite; aln: alunogen; chc: chalcanthite; eps: epsomite; fer: ferrihydrite; goe; goethite; hm: hematite; sch: schwertmannite; sc: scorodite; jar: jarosite.

For all deposit types, grain size is highly variable and is generally controlled by primary sulfide mineralogy and the extent of metamorphic recrystallization. Primary sulfide minerals of most zinc-leadcopper deposits are fine grained and intergrown, whereas those of most copper-zinc deposits are coarser grained (Franklin, 1993). The extent of grain size changes depends upon pressure and temperature conditions attained during metamorphism, and on the ductility of sulfide minerals. For example, cataclastic deformation significantly reduces grain-size and therefore reactivity of brittle sulfide minerals such as chalcopyrite and pyrite, but plastically deforms ductile sulfide minerals such as galena. Thermal metamorphism commonly causes sulfide ore to become much coarser grained and develop mosaic or 
porphyroblastic sulfide textures (Stanton, 1972). Metamorphism partially or completely replaces primary textures and causes grain size increases. Recrystallization causes porphyroblastic textures in pyrite and sphalerite, barite is recrystallized to an elongate habit, and galena may be remobilized to fill fractures (McClay, 1983).

Metal zoning is well developed in volcanic-associated massive sulfide deposits. Copper abundances are elevated in footwall and stringer ore zones, and zinc content increases upward and outward from the core of hydrothermal upwelling zones. In felsic-associated deposits, lead, arsenic, and antimony abundances are enriched upward and outward from the zinc-rich zones. Barite and silica are also enriched toward the stratigraphic tops and distal edges of most Kuroko-type deposits. In sedimentary-exhalative deposits, relative abundances of major base-metal sulfide minerals vary among deposits and within deposits as a result of zonation. Large (1983) reports that lead-zinc ratios of ore range from approximately 1:1 (Mount Isa, Australia; Sullivan, British Columbia; and Tynagh, Ireland) to 1:8 (Meggen, Germany). The sequence of zonation is generally lead-zinc-(barium-copper) extending outward in laterally zoned deposits and zinc-lead-(barium) extending upward in vertically zoned deposits (Large, 1983; Lydon, 1983). Iron is sometimes enriched at the center of zonation assemblages (Large, 1983), or an iron-manganese halo may encircle the base-metal sulfide minerals (Tynagh, Ireland) (Maynard, 1983).

\section{Deposit Trace Element Geochemistry}

Massive sulfide deposits of all types are typically dominated by iron, derived from pyrite, pyrrhotite, or marcasite. Kuroko-, Bathurst-, and Noranda-type deposits, relative to Cyprus- and Besshi-type deposits, generally have much higher contents of zinc, lead, silver, and antimony, which reflect the composition of their felsic volcanic host rocks. Kuroko-, Bathurst-, and Noranda-type deposits also tend to be underlain by copper-rich stringer zones and commonly have well developed geochemical zonation with progressive zinc, lead, and silver enrichment both vertically and laterally away from vent centers. Besshi-type deposits are typically copper-rich and contain small abundances of lead and other lithophile elements. Sedimentary exhalative deposits are characterized by iron, zinc, and lead, with generally insignificant copper. Thus, in terms of $\mathrm{Cu} / \mathrm{Zn}$ ratio, these deposits generally decrease in the order Cyprus $>$ Besshi $>$ Noranda $>$ Kuroko $>$ Bathurst $>$ Sedimentary-exhalative.

Deposits associated with mafic rocks, such as Cyprus-, Besshi-, and Noranda-type deposits, can contain anomalous concentrations of gold, silver, and cobalt. In addition to lead, deposits associated with felsic volcanic and sedimentary rocks contain minor to significant concentrations of silver, arsenic, antimony, cadmium, and locally bismuth, tin, and selenium. Cadmium is ubiquitous in all classes of massive sulfides, where it occurs as a solid solution in sphalerite. Concentrations of mercury are high in some deposits, where it is primarily in pyrite, sphalerite, or sulfosalt minerals (Ryall, 1981).

\section{MINING AND ORE PROCESSING METHODS}

Mining methods have a large influence on the potential environmental impacts of massive sulfide deposits. Both open-pit and underground methods have been used to mine massive sulfide deposits in historic and modern operations. Local climatic and hydrologic conditions influence the acid generating capacity of deposits. Most massive sulfide deposits contain a large excess of iron-sulfide minerals relative to valuable base-metal sulfide minerals. The nature of ore processing and the method of deposition of the sulfide-mineral-rich tailings and waste rocks are critical parameters that influence the scope of environmental impacts associated with mining massive sulfide deposits. Fine-grained and intergrown sulfide minerals may require very fine grinding during the beneficiation process, which can result in highly reactive tailings. Many modern mines discharge fine-grained sulfide-mineral-rich tailings into surface tailings ponds underlain by a number of impermeable linings. Previous mining operations often discharged tailings in a manner that resulted in significant contamination of surface and shallow ground water. In addition, early flotation operations did not separate a zinc concentrate. Thus, older tailings piles are high in zinc. Some active underground mines are able to dispose of essentially all tailings by backfilling and cementing mined stopes; consequently, surface contamination is virtually eliminated. Base-metal sulfide minerals are typically separated by flotation. Some surfactants used in the process are toxic, but most of these surfactants are recycled and only a relatively minor amount is discharged to tailings ponds. Base metal sulfide minerals separated by flotation are usually shipped to smelters as ore concentrates. However, historic flotation circuits and cyanide leach operations add exotic chemicals to mine wastes.

The hydrologic differences between underground and open pit mines are significant, especially at abandoned mines. Evaporative concentration is prominent in open pit settings, particularly in semi-arid to 
arid settings. At historic abandoned mines, such as the Elizabeth mine in Vermont, the evolution of ore beneficiation techniques can cause different "vintages" of mine wastes to be variably endowed in metals.

\section{ENVIRONMENTAL GEOCHEMISTRY}

\section{Secondary Mineralogy}

The secondary mineralogy associated with the weathering of a deposit or its mine wastes tends to sequester metals and (or) acidity on either a long-term or short-term basis. Hydrated ferric oxides can sorb metals on a somewhat refractory substrate, whereas efflorescent metal sulfate salts, such as melanterite, serve as a means of stored metals and acidity during dry periods. These salts readily dissolved during rain storm or spring melt of snow and deliver their metals and acidity to the surrounding watershed. For many deposit types, pre-mining oxidation of primary ores was a major contributing factor in enriching some deposits to economic grades. Secondary minerals also have important implications for acid-base accounting. General secondary mineralogical features of massive sulfide deposits are summarized in Table 2.

Oxidation of massive sulfide minerals results in the formation of iron-rich gossan zones, both initially on the seafloor and later, in subaerial surface environments. Sedimentary-exhalative deposits typically form in anoxic seafloor environments (Goodfellow and others, 1993); therefore, sulfide oxidation is restricted to the more recent history of these deposits. Intermediate stages of oxidation also can result in the formation of a wide range of iron- and base-metal sulfate and sulfate-hydrate minerals. Secondary minerals formed in temperate climates include goethite, crystalline and amorphous silica, jarosite, a variety of metal-bearing hydroxy-sulfate minerals (beudantite, plumbojarosite, argentojarosite, woodhouseite, beaverite, meta-aluminite, hinsdalite, and brochantite), scorodite, native gold, native silver, native bismuth, barite, anglesite, litharge, covellite, chalcocite, digenite, enargite, luzonite, and acanthite (Taylor and others, 1995). Anglesite and cerussite are the most abundant secondary lead minerals but coronadite, mimetite, nadorite, pyromorphite, and lanarkite have also been reported (Kelley and others, 1995). Secondary zinc minerals are rare, with the exception of goslarite. Rock may be oxidized to $100 \mathrm{~m}$ below the surface, and may extend to $300 \mathrm{~m}$ adjacent to major faults and shear zones. Oxidation depth is controlled partly by fracture density near orebodies and presence of pyrrhotite, which is highly reactive with oxygenated ground water (Taylor and others, 1984).

Soluble sulfate salt minerals derived from weathering and oxidation of sulfide minerals in mine dumps and tailings piles represent a potential source of metal contamination and acid generation. As surface and ground water evaporates during dry periods or winter freeze, efflorescent metal-sulfate salt minerals form on and below the surface of waste piles, which effectively stores acidity and metals from mine drainage. Subsequent rainfall or snowmelt is likely to release a highly concentrated pulse of acid mine water. Secondary minerals associated with waste piles include a variety of less soluble iron oxyhydroxides (goethite, lepidocrocite, akaganeite, maghemite, and ferrihydrite), and sulfates (jarosite, hydronium jarosite, anglesite). More soluble secondary minerals include gypsum, bassanite, melanterite, goslarite, ferrohexahydrite, epsomite, hexahydrite, siderotil, rozenite, alunogen, and copiapite. Secondary sulfide minerals that can form include marcasite, covellite, and native sulfur (Jambor, 1994).

From an acid-base accounting perspective, significant differences are found among the various deposit types with regard to the speciation of sulfur in primary ores, host rocks and mine wastes. Sulfide minerals such as pyrite, pyrrhotite, chalcopyrite, and sphalerite dominate the primary mineralogy of these deposits (Table 2) and contribute to the maximum potential acidity. Secondary metal-sulfate salts that commonly accumulate as intermediate products of sulfide oxidation also will contribute acidity (Alpers and others 1994a; Cravotta 1994). For example, melanterite, rozenite, copiapite, and halotrichite, among others, are quite common and highly soluble; less soluble sulfate minerals such as jarosite and schwertmannite also are common in mining environments (Table 2). In contrast, alkaline earth-sulfate minerals such as barite and anhydrite also are common as both primary and secondary minerals (Table 2), but do not contribute acidity even though their $\mathrm{S}$ content will be reported in total $\mathrm{S}$ determinations. The most prominent differences in secondary sulfur mineral speciation among mine wastes from the different deposit types are found in their metal-sulfate salts, particularly in the presence or absence of chalcanthite $\left(\mathrm{CuSO}_{4} \cdot 5 \mathrm{H}_{2} \mathrm{O}\right)$, goslarite $\left(\mathrm{ZnSO}_{4} \cdot 7 \mathrm{H}_{2} \mathrm{O}\right), \mathrm{Cu}-\mathrm{Mg}$ melanterite $(\mathrm{Cu}, \mathrm{Mg}) \mathrm{SO}_{4} \cdot 7 \mathrm{H}_{2} \mathrm{O}$, and alunogen $\left(\mathrm{Al}_{2}\left(\mathrm{SO}_{4}\right)_{3} \bullet 17 \mathrm{H}_{2} \mathrm{O}\right)$, among others.

Various carbonate minerals, most of which contribute neutralizing potential, are associated locally with primary alteration assemblages of some of these deposit types. Calcite and ankerite $\left(\mathrm{Ca}(\mathrm{Fe}, \mathrm{Mg}) \mathrm{CO}_{3}\right)$ dominate the carbonate mineralogy (Table 2). Sedimentary-exhalative deposits may have dolomitic shales in their host rocks, and siderite, which has no net neutralizing potential (Alpers and Zierenberg 1998), in 
their alteration assemblages. Post-mineralization tectonism can introduce late calcite veinlets into the rock units surrounding these deposits, such as at the Big Mike Cyprus-type deposit in Nevada, where pit waters have neutral $\mathrm{pH}$.

\section{$\underline{\text { Soil and Sediment Signatures }}$}

Pre-mining soil and stream sediment signatures may be useful for establishing pre-mining backgrounds. Also, soils around abandoned mine sites represent a significant sink for metals. The elemental suite and magnitude of geochemical anomalies in soil and sediment collected from undisturbed massive sulfide deposits depend upon a number of factors, including deposit type, extent of ore outcrop or overburden, climate, and topography, among others. Stream sediment samples collected downstream Kuroko-type deposits in temperate rain forest on Admiralty Island, Alaska, contain 5 to 10 weight percent iron, as much as 10,000 ppm barium, hundreds to several thousand ppm zinc, hundreds of ppm lead, tens to hundreds of ppm arsenic, copper, and nickel, as well as 0 to $20 \mathrm{ppm}$ silver, bismuth, cadmium, mercury, molybdenum, and antimony (Kelley, 1990; Rowan and others, 1990; Taylor and others, 1992; C.D. Taylor, unpub. data, 1995). Stream sediment geochemical signatures associated with undisturbed to variably disturbed Cyprus- and Besshi-type deposits in the Prince William Sound, Alaska, are similar to those just described. They contain 10 to 40 weight percent iron, several hundred ppm barium, hundreds of ppm arsenic and zinc, tens to hundreds of ppm lead, hundreds to thousands of ppm copper, and 0 to $20 \mathrm{ppm}$ silver, bismuth, mercury, molybdenum, and antimony (R.J. Goldfarb, unpub. data, 1995).

Stream sediment samples $(<0.2 \mathrm{~mm}$ and $<0.5 \mathrm{~mm}$ fractions $)$ associated with sedimentary-exhalative depoists in cold semi-arid settings in Alaska contain anomalous concentrations of many metals, including as much as $10 \mathrm{ppm}$ silver; $10 \mathrm{~s}$ of ppm arsenic, cadmium, and antimony; 100s of ppm copper and nickel; $1000 \mathrm{~s}$ of ppm manganese, lead, and zinc; and hundreds of thousands of ppm barium (Theobald and others, 1978; Kelley and others, 1992). Soil that overlies mineralized rock contains hundreds to tens of thousands of ppm lead, hundreds to thousands of ppm barium and zinc, tens of ppm silver; and tens to hundreds of ppm copper, but concentrations of other metals, including $<2$ ppm cadmium, hundreds of ppm manganese, and tens of ppm nickel are low relative to stream sediment abundances (Briggs and others, 1992; Meyer and Kurtak, 1992). Soil overlying sedimentary-exhalative deposits in warm semi-arid settings in Australia contains hundreds to thousands of ppm copper, lead, and zinc, and tens of ppm silver (Cox and Curtis, 1977).

\section{Hydrology}

The hydrologic setting, especially relative to the water table, is a key variable in determining the magnitude of mine drainage problems. The extent of mineralized outcrop and (or) mine-related excavations exposed to the atmosphere or oxidized groundwater, and their position relative to the water table, are hydrologic factors that can significantly influence the intensity and scale of environmental problems related to massive sulfide deposits. Availability of oxidizing water is a controlling factor for acid generating potential and dissolved metal carrying capacity of water interacting with massive sulfide deposits or their mine-related products. Similarly, the geologic setting of a deposit can influence the distribution of fracture-controlled permeability.

A comparison of mine drainage from pyritic ores at Iron Mountain (Noranda-type) and the Penn mine (Kuroko-type), California emphasizes the importance of the location of the deposit relative to the water table. Both deposits are situated in similar climatic settings. At Iron Mountain, the deposit is mostly located above the water table, whereas at the Penn mine, the deposit is mostly below the water table, but has waste piles above the water table that contribute to water-quality degradation (Alpers and others 1994b; 1999). At Iron Mountain, $\mathrm{pH}$ values range as low as -3.4 and total dissolved solids concentrations exceed 100,000 $\mathrm{mg} / \mathrm{L}$ (Alpers and others 1994b; Nordstrom and Alpers 1999). In contrast, $\mathrm{pH}$ values of mine waters from the Penn mine range as low as 3.1 and total dissolved solids concentrations reach a maximum of approximately 5,500 mg/L (Alpers and others 1999).

Mine drainage from the pyrrhotitic Elizabeth mine (Besshi-type), Vermont also emphasizes the importance of hydrologic setting. Two dominant hydrologic settings are present at Elizabeth: one dominated by surface flow over mine wastes, and one dominated by ground water flow through tailings piles. In these two environments, the relationship of dissolved $\mathrm{Fe}$ to $\mathrm{pH}$ varies significantly. Surface waters show a general negative correlation between dissolved $\mathrm{Fe}$ and $\mathrm{pH}$; in contrast, waters flowing through the tailings piles are near-neutral to slightly acidic, but carry amounts of dissolved Fe that are comparable to those in the surface waters (Fig. 2; Seal and others 1999). The geochemical differences between these two 
environments can be related to the presence of pyrrhotite as the dominant Fe-sulfide mineral. The oxidation of pyrrhotite by dissolved oxygen can be described by the reaction:

$$
\mathrm{Fe}_{1-\mathrm{x}} \mathrm{S}+(2-\mathrm{x} / 2) \mathrm{O}_{2}+\mathrm{x} \mathrm{H}_{2} \mathrm{O} \rightarrow(1-\mathrm{x}) \mathrm{Fe}^{2+}+\mathrm{SO}_{4}{ }^{2-}+2 \mathrm{x} \mathrm{H}^{+}
$$

where one mole of pyrrhotite generates from 0 to less than 0.25 moles of acid depending on the composition of the pyrrhotite. In contrast, the similar oxidation reaction for pyrite yields 2 moles of acid for each mole of pyrite. Under acidic conditions, $\mathrm{Fe}^{3+}$ can be an important oxidizer of pyrite and generates 16 moles of acid for each mole of pyrite. Likewise, at low $\mathrm{pH}$ values capable of carrying significant amounts of $\mathrm{Fe}^{3+}$, the acid-generating potential of pyrrhotite is enhanced. However, at Elizabeth, precipitation and regional ground waters that infiltrate the tailings pile are slightly acidic to near-neutral. The addition of lime in mineral processing circuits prior to disposal may also contribute to the present-day near neutral $\mathrm{pH}$ of ground waters emerging from the tailings pile. Therefore, pyrrhotite oxidation is dominated by dissolved oxygen, which has limited acid-generating capacity. Because of the near-neutral $\mathrm{pH}$, the ground waters flowing through the tailings do not have elevated concentrations of heavy metals such as $\mathrm{Cu}, \mathrm{Zn}$, and $\mathrm{Cd}$. Upon emerging from the base of the tailings pile, $\mathrm{Fe}$ in the ground waters undergoes rapid oxidation from $\mathrm{Fe}^{2+}$ to $\mathrm{Fe}^{3+}$, followed by hydrolysis and a concomitant drop in $\mathrm{pH}$. Despite the decreased $\mathrm{pH}$, the $\mathrm{Cu}, \mathrm{Zn}$, and $\mathrm{Cd}$ concentrations are low because of the prior history of these waters.

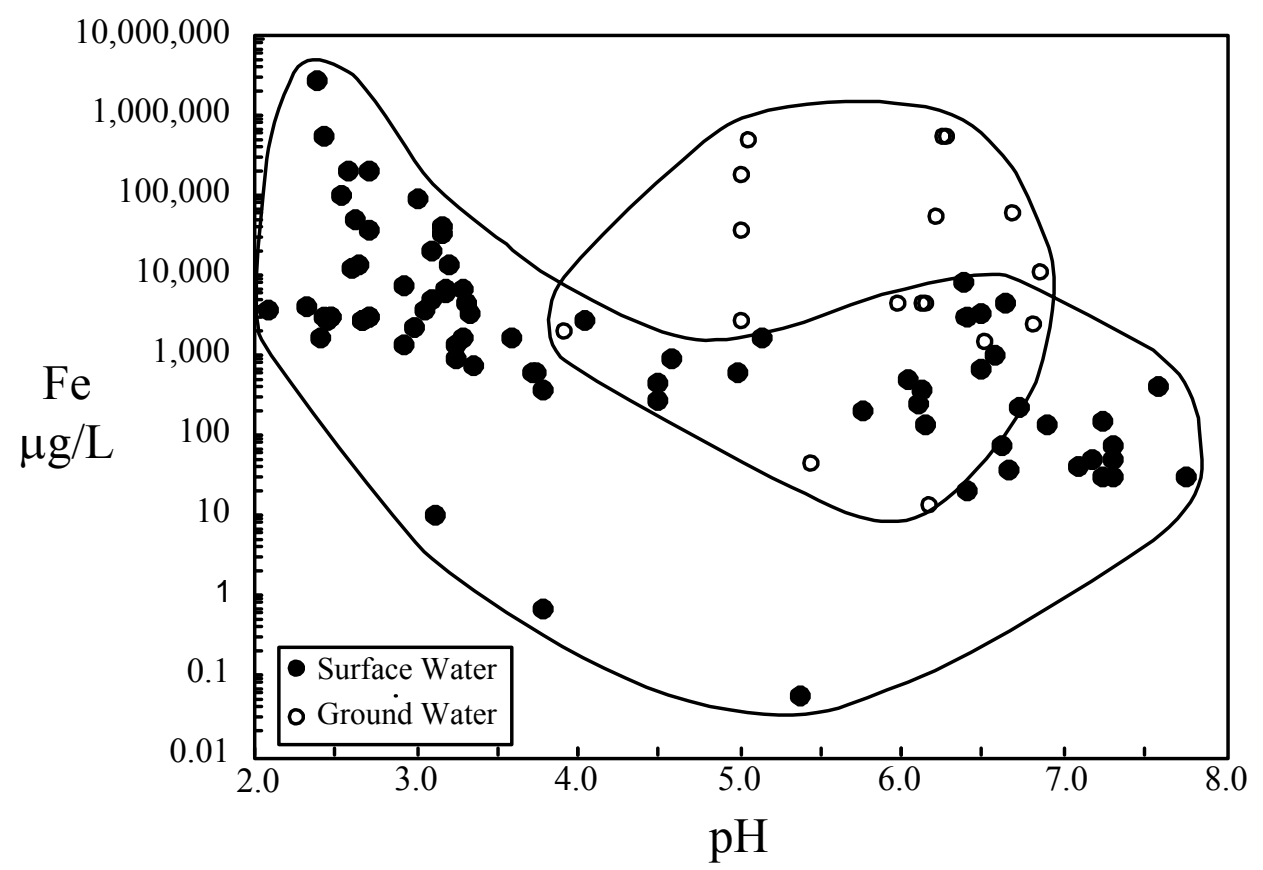

Figure 2. Fe versus $\mathrm{pH}$ for filtered mine drainage samples from Besshi-type deposits. Note that ground waters (seeps) from this deposit type have elevated $\mathrm{Fe}$ concentrations at comparable $\mathrm{pH}$ values relative to surface waters because of the higher solubility of ferrous iron found in ground waters.

\section{Drainage Signatures}

The geology of a deposit exerts a major influence on both pre-mining background water compositions and on mine drainage. In general, increases in total dissolved base metals generally correlate with increases associated pyrite content, decreases in acid-neutralizing capacity, and increases in base metal content of deposits (Plumlee, 1999).

Natural backgrounds: Mine permitting and remediation require an estimate of pre-mining natural background to serve as a goal for post-mining reclamation. A variety of methods have been used to estimate pre-mining backgrounds for abandoned mines (Runnells and others 1992; 1998; Alpers and others 1999; Alpers and Nordstrom 2000). Baseline data from undisturbed mineral deposits are useful for comparing and contrasting geochemical signatures among different types of massive sulfide deposits. 
These comparisons illustrate the importance of using a geochemically based classification of massive sulfide deposits in selecting an appropriate baseline. Besshi-type deposits are typically hosted by sulfiderich black shales that are enriched in sub-economic concentrations of heavy metals and which formed through many of the same geochemical processes responsible for massive sulfide mineralization. Thus, drainage from watersheds underlain by these black shale units provides useful background data for Besshitype deposits (Seal and others 1998a). In this paper, we compile data from in and around undisturbed Noranda-type (Seal and others, 1998b), Bathurst-type (Leybourne and others 1998), and sedimentaryexhalative deposits (Kelley and Taylor 1997). Comparison of these data with data from black shale terranes that host Besshi-type deposits (Seal and others 1998a) illustrates several important points about natural backgrounds.

The availability of atmospheric oxygen and the position of the ground-water table are key related factors in determining the natural weathering behavior of massive sulfide deposits. The Alaskan sedimentary-exhalative deposits and the black shales that host the Fontana and Hazel Creek Besshi-type deposits in North Carolina are exposed at the surface of the Earth, whereas the Bald Mountain (Norandatype) deposit and the Restigouche and Halfmile Lake (Bathurst-type) deposits are buried beneath glacial overburden and unmineralized rock. Surface waters around exposed deposits generally are more acidic and carry more dissolved iron than those draining buried deposits (Fig. 3a).

Significant differences can be found in the metal ratios of natural ground and surface waters around undisturbed deposits that can be related to the primary character of the deposits. The $\mathrm{Zn}: \mathrm{Cu}$ ratio of waters around sedimentary-exhalative and Bathurst-type deposits is generally greater than 1:1 and can exceed 1,000:1, consistent with the $\mathrm{Zn}$-rich/Cu-poor character of these deposits; in contrast, the $\mathrm{Zn}: \mathrm{Cu}$ ratio of waters associated with $\mathrm{Cu}$-rich Besshi- and Noranda-type deposits is generally between 1:10 and 10:1, but can reach 100:1 (Fig. 3b). An important implication of this observation is that natural background data from a sedimentary-exhalative deposit such as Red Dog (Alaska) may not represent an appropriate proxy for natural backgrounds that might be expected around a Noranda-type deposit such as Iron Mountain (California).

Mine drainage: Mine-drainage data compiled in this study include studies at the Elizabeth and Ely mines (Besshi-type), Vermont (Seal and others 1999), the Fontana and Hazel Creek mines (Besshi-type), North Carolina (Seal and others 1998a), the Prince William Sound district (Cyprus- and Besshi-type), Alaska (Goldfarb and others 1995), the Holden mine (Kuroko-type), Washington (Kilburn and others 1999), the Mineral district (Kuroko-type), Virginia (R.R. Seal, II, unpub. data, 1999), the Penn mine (Kuroko-type), California (Alpers and others 1999), and Iron Mountain (Noranda-type), California (Alpers and others 1994b). Mine drainage associated with massive sulfide deposits tend to show a general, negative correlation between dissolved metals and $\mathrm{pH}$ for most divalent metals such as $\mathrm{Cu}$ (Fig. 4a) $, \mathrm{Zn}, \mathrm{Ni}, \mathrm{Co}, \mathrm{Cd}$, and $\mathrm{Pb}$, and sulfate. Likewise, $\mathrm{Fe}$ and $\mathrm{Al}$ also exhibit increased solubility with decreased $\mathrm{pH}$. The correlations between $\mathrm{pH}$, metals and sulfate reflect acid generation dominantly through the aqueous, oxidative weathering of pyrite and (or) pyrrhotite and associated ore sulfides. For the divalent metals, Fe, and Al, mine-drainage compositions overlap significantly with natural background compositions, but range to higher heavy metal concentrations and lower $\mathrm{pH}$ values (Fig. 4b). Relative to the divalent metals, limited data on As presents an intriguing contrast. With the exception of the low-pH, high-As waters from Iron Mountain, California (Noranda-type), the natural background waters tend to have higher As concentrations than mine drainage (Fig. 4b). Data for the Bald Mountain deposit (Noranda-type) have established that the development of an ancient goethite gossan was an important controlling factor on As distribution in the deposit, which presumably was reflected in ancient ground-water compositions (Foley and Flohr 1998). The most likely explanation for higher concentrations of As in natural background waters compared to mine drainage is that the near-neutral, low-Fe background waters tend to remain undersaturated with respect to hydrous ferric oxide, which can sorb significant amounts of As (Smith and others, 1998). Thus, any proposed remediation plan should carefully consider As behavior and mobility relative to $\mathrm{Fe}$ geochemistry.

The dissolved chemistry of mine drainage from massive sulfide deposits shows clear evidence of both primary controls based on deposit type and mineralogical controls for individual metals. In terms of dissolved $\mathrm{Cu}$ and $\mathrm{Zn}$, the data are correlated positively with individual deposit types falling at distinct ranges of $\mathrm{Zn}: \mathrm{Cu}$ ratios, which are directly related to the primary character of the ores (Fig. 5a). $\mathrm{Zn}: \mathrm{Cu}$ ratios (mass basis) associated with the $\mathrm{Cu}$-rich Cyprus-type deposits range from 1:100 to 10:1, whereas those 
associated with $\mathrm{Cu}>\mathrm{Zn}$ Besshi-type deposits range from 1:10 to more than 10:1, those associated with $\mathrm{Zn}>\mathrm{Cu}$ Kuroko-type deposits are the highest, ranging from 1:1 to 10,000:1. Correlations between $\mathrm{Cu}$ and
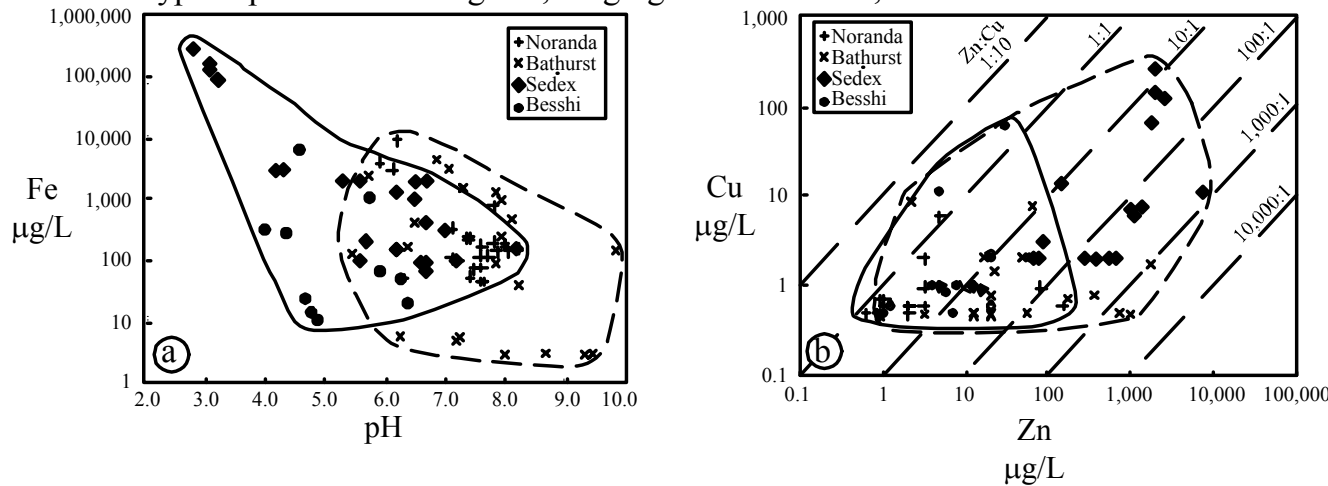

Figure 3. Natural background geochemical data for filtered ground and surface waters around massive sulfide deposits. a. Fe vs. pH. Data outlined by solid line are from deposits exposed at the surface; data outlined by dashed line are from buried deposits. b. $\mathrm{Cu}$ vs. $\mathrm{Zn}$. Dashed lines represent $\mathrm{Zn}: \mathrm{Cu}$ ratios (mass basis). Note that waters from Zn-rich deposits (Sedimentary-exhalative and Bathurst) range to higher $\mathrm{Zn}: \mathrm{Cu}$ ratios than $\mathrm{Cu}$-rich deposits (Noranda and Besshi).
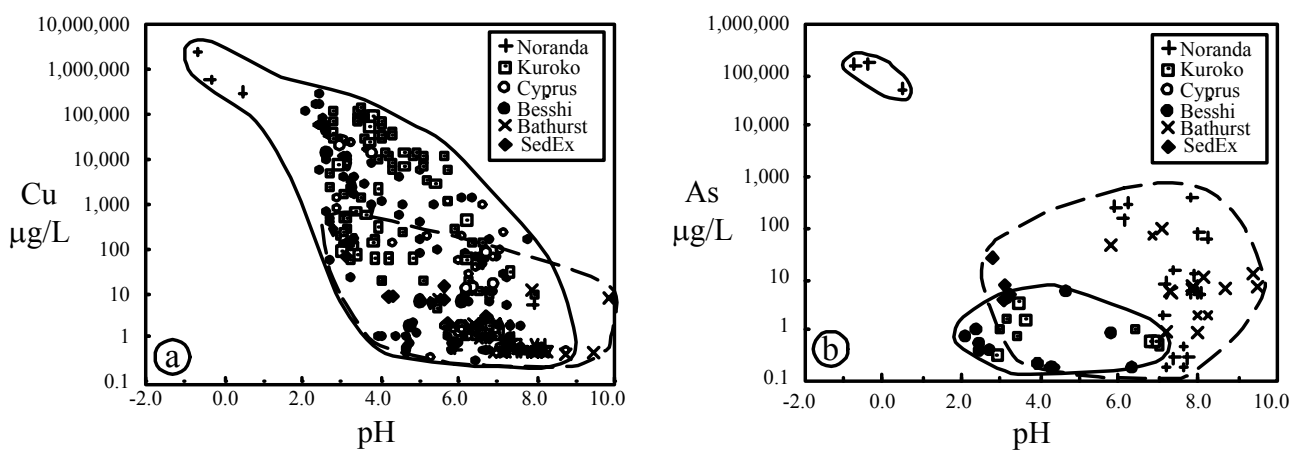

Figure 4. Comparison of filtered mine drainage waters with natural background waters. Data outlined by solid lines are mine drainage; data outlined by dashed lines are natural backgrounds. a $\mathrm{Cu}$ vs. $\mathrm{pH}$. The general negative slope of the data is typical of most divalent metals. b. As vs. pH. Note that many of the natural background samples have higher As concentrations than the mine drainage samples.
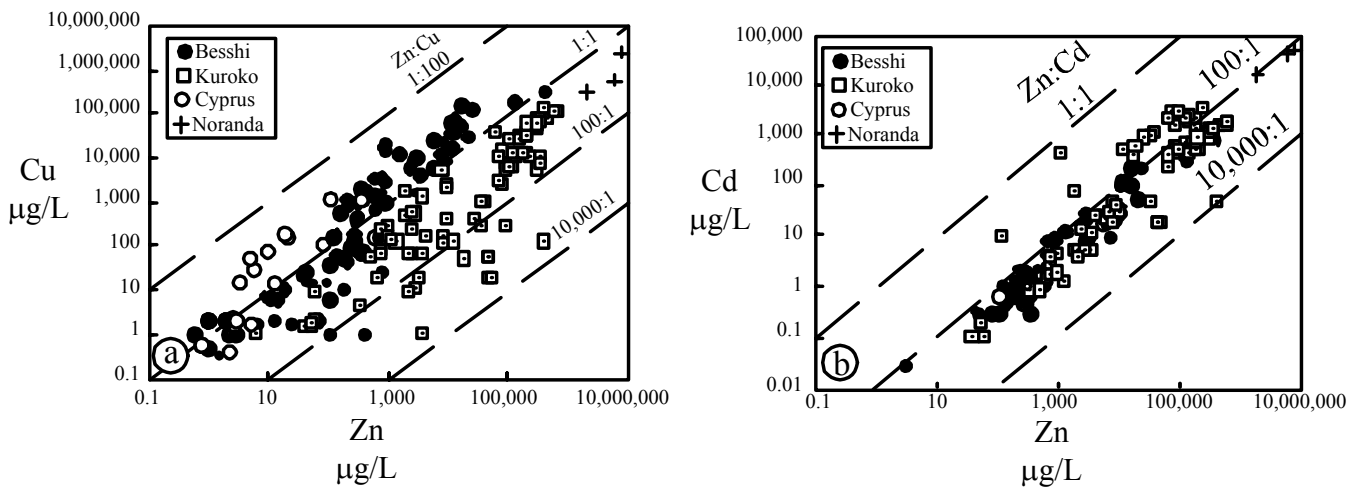

Figure 5. Filtered mine drainage geochemical data. a. $\mathrm{Cu}$ vs. $\mathrm{Zn}$. Note the separation of deposit types by $\mathrm{Zn}: \mathrm{Cu}$ ratio (mass basis), which reflects primary differences in deposit types. b. Cd vs. Zn. Note the overlap among deposit types in terms of $\mathrm{Zn}: \mathrm{Cd}$ ratios (mass basis), which reflects the common source control of $\mathrm{Cd}$ as a trace element in sphalerite.

$\mathrm{Pb}$ are less distinct, presumably due to the saturation of $\mathrm{Pb}$ with respect to anglesite $\left(\mathrm{PbSO}_{4}\right)$. Unlike $\mathrm{Cu}$ and $\mathrm{Zn}$, the systematics of dissolved $\mathrm{Cd}$ and $\mathrm{Zn}$ are different; the fields for all massive sulfide types overlap 
in a range of $\mathrm{Zn}: \mathrm{Cd}$ ratios (mass basis) that scatter about 100:1 (Fig. 5b). The overlap reflects the fact that $\mathrm{Cd}$ occurs primarily in all massive sulfide deposits as a minor element in sphalerite as a solid solution.

Pore water from tailings impoundments associated with the Heath Steele, New Brunswick, deposit is acidic (pH 1.8 to 5.2), have Eh of 280 to $580 \mathrm{mV}$, and contain significant dissolved metal abundances, including 0.3 to $600 \mathrm{mg} / \mathrm{L}$ copper, 0.8 to $11 \mathrm{mg} / \mathrm{L}$ lead, 23 to $4,880 \mathrm{mg} / \mathrm{L}$ zinc, 1,200 to $36,000 \mathrm{mg} / \mathrm{L}$ iron, and 600 to $67,600 \mathrm{mg} / \mathrm{L}$ sulfate (Boorman and Watson, 1976). Similarly, pore water from tailings impoundments associated with the Waite Amulet, Quebec, deposit are acidic (pH 2.5 to 6.0), have Eh of 200 to $700 \mathrm{mV}$, and contain significant dissolved metal abundances, including as much as $65 \mathrm{mg} / \mathrm{L}$ copper, as much as $5 \mathrm{mg} / \mathrm{L}$ lead, as much as $250 \mathrm{mg} / \mathrm{L}$ zinc, as much as $8,000 \mathrm{mg} / \mathrm{L}$ iron, and as much as 20,000 $\mathrm{mg} / \mathrm{L}$ sulfate (Blowes and Jambor, 1990). Finally, pore water from tailings impoundments associated with the Kidd Creek, Ontario, deposit are acidic (pH 3.5 to 7.5), have Eh of 50-500 mV, and contain significant dissolved metal abundances, including 0 to $38 \mathrm{mg} / \mathrm{L}$ copper, 0 to $2 \mathrm{mg} / \mathrm{L}$ lead, 0 to $6,200 \mathrm{mg} / \mathrm{L}$ zinc, 0 to $350 \mu \mathrm{g} / \mathrm{L}$ arsenic, 1 to $990 \mathrm{mg} / \mathrm{L}$ iron, and 1,860 to $27,000 \mathrm{mg} / \mathrm{L}$ sulfate (Al and others, 1994).

\section{Climatic Effects}

Climate plays an important role in the environmental behavior of mineral deposits. Differences in temperature, amount of precipitation, and humidity are probably the most important climatic variables (Plumlee, 1999). From the perspective of massive sulfide deposits, this factor is probably the least well understood because of the limited data for specific deposits types that span different climatic settings.

Temperature and humidity are the prime variables that control evaporation. Evaporation limits the amount of water in semi-arid to arid climates. Evaporation can concentrate solutes in all climates. Acidity and total metal concentrations in mine drainage in arid environments are several orders of magnitude greater than in more temperate climates because of the concentrating effects of mine effluent evaporation and the resulting "storage" of metals and acidity in highly soluble metal-sulfate-salt minerals. However, minimal surface water flow in these areas inhibits generation of significant volumes of highly acidic, metalenriched drainage. Concentrated release of these stored contaminants to local watersheds may be initiated by precipitation following a dry spell. In wet climates, high water tables may reduce exposure of abandoned orebodies to oxidation and continually flush existing tailings and mine dumps. Although metalladen acid mine water does form, it is may be diluted to benign metal abundances within several hundred meters of mixing with a higher order stream. Winter freezing conditions can lead to seasonally episodic fluctuations in drainage chemistry.

\section{POTENTIAL ENVIRONMENTAL CONCERNS}

Potential environmental concerns associated with mineral deposits can generally be divided into three broad categories: (1) human health risks; (2) ecosystem risks; and (3) physical hazards. All of these concerns are ultimately established in the geologic framework of the mineral deposit. Human-health risks (exclusive of physical hazards) generally focus on metals, such as lead, arsenic, selenium, and mercury, associated with various mineral deposit types, and elements and compounds used in ore processing, such as mercury or cyanide. Ecosystem risks are associated with acidity and several metals, such as $\mathrm{Al}, \mathrm{Cu}, \mathrm{Zn}$, $\mathrm{Cd}, \mathrm{Se}, \mathrm{Hg}$, and others. Physical hazards such as open shafts and open pits are related to the mining required to exploit specific mineral deposit types.

Human health risks: Human health risks associated with massive sulfide deposits are most prominent in terms of their contained lead and arsenic, and cyanide used in some recovery circuits. In addition, smelting may produce $\mathrm{SO}_{2}$-rich and metal-rich emissions, which may increase acidity and foster accumulation of heavy metals in downwind areas. Lead risks are generally related to ingestion of lead-rich mine waste through incidental contact. Extreme fine grinding required for beneficiation of enhances airborne transport of lead- -bearing dust. This phenomenon is most probable in semi-arid to arid regions in which strong winds prevail. Data compiled by Gulson and others (1994) around the Broken Hill sedimentary-exhalative deposit documented the relationship between lead in soil near smelters and blood lead in children. Arsenic risks are generally related to contamination of ground waters. Seal and others (1998) documented ground water As concentrations up to $430 \mu \mathrm{g} / \mathrm{L}$ around the undisturbed Bald mountain deposit, Maine. Tailings ponds below mills can contain significant cyanide and other reactants used in flotation and recovery circuits (Taylor and others, 1995).

Ecosystems risks: The most significant ecosystem impacts related to massive sulfide deposits are through acid mine drainage. Mine drainage can reach extreme acidity and high heavy metal-rich compositions due 
to the abundance of metallic sulfide minerals in mine wastes and the lack of carbonate minerals in the mineralized rocks. Ecosystem impacts can result from low $\mathrm{pH}$, and dissolved $\mathrm{Fe}, \mathrm{Al}, \mathrm{Cu}, \mathrm{Zn}, \mathrm{Pb}, \mathrm{Cd}$, and As. The alkalinity and hardness of waters receiving mine drainage can be highly variable. Thus, natural mitigation and attenuation processes can be highly variable. Downstream effects can be very localized or can extent at least $100 \mathrm{~km}$ downstream from mine sites. Heavy metal contamination can also be dispersed downstream by the erosion and transport of tailings.

Atmospheric contamination can also occur because highly pyritic-pyrrhotitic orebodies that are exposed to oxidation by air circulating through open adits, manways, and exploration drill holes may evolve $\mathrm{SO}_{2}$ gas; in some cases, spontaneous combustion can cause sulfide ore to burn. "Hot muck", the spontaneous combustion high sulfide ore in mine workings, is an environmental concern associated with processing ore from deposits with high pyrrhotite orebodies. The primary environmental concern is evolved sulfur dioxide. Fires are ignited by the build-up of heat, caused by ore oxidation, in stock piles, or may be triggered by blasting in areas of previously broken ore. Periodically, air emission can exceed 9.5 ppm SO 2 (Brown and Miller, 1977; Good, 1977); $\mathrm{SO}_{2}$ release can acidify water in areas downwind from release site. Because hot muck is easily avoided by proper blasting techniques, it does not pose significant risks in modern mining operations.

\section{CONCLUSIONS}

Seafloor massive sulfide deposits show significant variations in their environmental behavior based on differences in deposit types within this class of mineral deposit. As a class, these deposits have high acidgenerating potential, and low acid-buffering capacity due to the sulfide-rich and carbonate-poor nature of the ores and host rocks. Some metal ratios of mine drainage and natural background waters reflect the primary character of the ores, whereas others reflect the mineralogical host of heavy metals in the deposits. Secondary processes, such as precipitation of secondary minerals and sorption obscure the primary geochemical controls in mine drainage for some elements like $\mathrm{Pb}$ and As. The magnitude of the potential environmental impact is strongly dependent upon the hydrologic setting of each individual deposit and its solid wastes. Climate, as it relates to variables such as temperature, amount of precipitation, and seasonality of precipitation, among others, is undoubtedly an important variable but difficult to assess because of the limited amount of data available for individual deposit types from various climatic settings.

\section{REFERENCES CITED}

Al, T.A., Blowes, D.W., and Jambor, J.L., 1994, A geochemical study of the tailings impoundment at the Falconbridge Limited, Kidd Creek division metallurgical site, Timmons, Ontario, in Jambor, J.L, and Blowes, D.W. eds., Short Course Handbook on Environmental Geochemistry of Sulfide Mine-wastes, Mineralogical Association of Canada, v. 22, p. 333-364.

Alpers, C.N., and Nordstrom, D.K., 2000, Estimation of pre-mining conditions for trace metal conditions for trace metal mobility in mineralized areas: an overview. In: International Conference on Acid Rock Drainage 2000 Proceedings, May 21-24, 2000, Denver, CO, this volume.

Alpers, C.N., and Zierenberg, R.A., 1998, Geoenvironmental characteristics of volcanogenic massive sulfide deposits, in Metallogeny of Volcanogenic Arcs: British Columbia Geological Survey Open File 1998-8.

Alpers, C.N., Blowes, D.W., Nordstrom, D.K., and Jambor, J.L., 1994a. Secondary minerals and acid minewater chemistry. Mineralogical Association of Canada Short Course Handbook on Environmental Geochemistry of Sulfide Mine-wastes, v. 22, p. 247-270.

Alpers, C.N., Nordstrom, D.K., and Thompson, J.M., 1994b, Seasonal variations of $\mathrm{Zn} / \mathrm{Cu}$ ratios in acid mine water from Iron Mountain, California, in Alpers, C.N., and Blowes, D.W., eds., Environmental Geochemistry of Sulfide Oxidation: Amer. Chem. Soc. Symposium Series 550, p. 324-344.

Alpers, C.N., Nordstrom, D.K., Verosub, K.L., and Helm, C.M., 1999a, Paleomagnetic reversal in Iron Mountain gossan provides limits on long-term premining metal flux rates: Geol. Soc. Amer., Abstracts with Programs, v. 31(6), p. 33.

Alpers, C.N., Hamlin, S.N. and Hunerlach, M.P., 1999b, Hydrogeology and geochemistry of acid mine drainage in ground water in the vicinity of Penn Mine and Comanche Reservoir, Calaveras County, California: Summary Report, 1993-95: U.S. Geol. Survey Water-Resources Investigations Report 96$4287,59 \mathrm{p}$.

Blowes, D.W., and Jambor, J.L., 1990, The pore-water geochemistry and the mineralogy of the vadose zone of sulfide tailings, Waite Amulet, Quebec, Canada: Applied Geochemistry, v. 5, p. 327-346. 
Boorman, R.S., and Watson, D.M., 1976, Chemical processes in abandoned sulphide tailings dumps and environmental implication for northeastern New Brunswick, Canadian Institute of Mining and Metallurgy Bulletin, v. 69, no. 772, p. 86-96.

Briggs, P.H., Motooka, J.M., Bailey, E.A., Cieutat, B.A., Burner, S.A., Kelley, K.D., and Ficklin, W.H., 1992, Analytical results of soil, stream sediment, panned concentrate, and water samples from the Lik deposit, northwestern Brooks Range, Alaska: U.S. Geological Survey Open-File Report 92-15A (paper version) and 92-15B (diskette version).

Brown, R.L., and Miller, F.J.L., 1977, Pollution problems associated with Sullivan mine hot muck: Canadian Institute Mining and Metallurgy Bulletin, v. 70, n. 782, p. 89-92.

Cox, D.P., 1986, Descriptive model of Besshi massive sulfide, in Cox, D.P., and Singer, D.A., eds., Mineral deposit models: U.S. Geological Survey Bulletin 1693, p. 136.

Cox, D.P., and Singer, D.A., 1986, Mineral deposit models: U.S. Geological Survey Bulletin 1693, 379 p.

Cox, R., and Curtis, R., 1977, The discovery of the Lady Loretta zinc-lead-silver deposit, northwest Queensland, Australia--A geochemical exploration case history: Journal of Geochemical Exploration, v. 8 , p. $189-202$.

Cravotta, C.A., III, Brady, K.B.C., Smith, M.W., and Beam, R.L., 1990, Effectiveness of the addition of alkaline materials at surface coal mines in preventing or abating acid mine drainage: Part 1. geochemical considerations, in Proceedings of the 1990 Mining and Reclamation Conference, Charleston, WV, v. 1, p. 221-225.

Cravotta, C.A., III, 1994, Secondary iron-sulfate minerals as sources of sulfate and acidity: geochemical evolution of acidic ground water at a reclaimed surface coal mine in Pennsylvania, in Alpers, C.N., and Blowes, D.W., eds., Environmental Geochemistry of Sulfide Oxidation: Amer. Chem. Soc. Symposium Series 550, p. 345-364.

Dames \& Moore, 1983, Environmental baseline studies, Red Dog project: Water Quality Report, Chapter 3, by L.A. Peterson and Associates, Inc., for the Red Dog Mine project, Cominco, Alaska, Inc., Anchorage, Alaska.

Foley, N.K., and Flohr, M.J.K., 1998, Ancient gossan formation at the Bald Mountain volcanogenic massive sulfide deposit, northern Maine: Geol. Soc. Amer., Abstracts with Programs, v. 29, p. A166.

Franklin, J.M., 1993, Volcanic-associated massive sulphide deposits, in Kirkham, R.V., Sinclair, W.D., Thorpe, R.I., and Duke, J.M., eds., Mineral deposit modeling, Geological Association of Canada Special Paper 40, p. 315-34.

Franklin, J.M., M.D. Hannington, I.R. Jonasson, and C.T. Barrie. 1998. Arc-related volcanogenic massive sulfide deposits. In: Metallogeny of Volcanogenic Arcs, British Columbia Geol. Survey, Open-File 1998-8.

Goldfarb, R.J., Nelson, S.W., Taylor, C.D., d'Angelo, W.M., and Meier, A.L., 1995, Acid mine drainage associated with volcanogenic massive sulfide deposits, Prince William Sound, Alaska: U.S. Geological Survey Bulletin 2152, p. 3-16.

Good, B.H., 1977, The oxidation of sulphide minerals in the Sullivan mine: Canadian Institute of Mining and Metallurgy Bulletin, v. 70, no. 782, p. 83-88.

Goodfellow, W.D., Lydon, J.W., and Turner, R.J.W., 1993, Geology and genesis of stratiform sedimenthosted (SEDEX) zinc-lead-silver sulphide deposits, in Mineral Deposit Modeling: Geol. Assoc. of Canada Special Paper 40, p. 201-251.

Gulson, B.L., Mizon, K.J., Law, A.J., Korsch, M.J., Davis, J.J., and Howarth, D., 1994, Source and pathways of lead in humans from the Broken Hill mining community--An alternative use of exploration methods: Economic Geology, v. 89, p. 889-908.

Jambor, J.L., 1994, Mineralogy of sulfide-rich tailings and their oxidation products, in Jambor, J.L, and Blowes, D.W., eds., Short Course Handbook on Environmental Geochemistry of Sulfide Mine-wastes: Mineralogical Association of Canada, v. 22, p. 59-102.

Kelley, K.D., 1990, Interpretation of geochemical data from Admiralty Island, Alaska--Evidence for volcanogenic massive sulfide mineralization, in Goldfarb, R.J., Nash, J.T., and Stoeser, J.W., eds., Geochemical studies in Alaska by the U.S. Geological Survey, 1989, U.S. Geological Survey Bulletin 1950, p. A1-A9.

Kelley, K.D., and Taylor, C.D., 1997, Environmental geochemistry of shale-hosted Ag-Pb-Zn massive sulfide deposits in northwest Alaska: natural background concentrations of metals in water from mineralized areas. Applied Geochem. 12: 397-409. 
Kelley, K.D., Borden, J.C., Bailey, E.A., Fey, D.L., Motooka, J.M., and Roushey, B., 1992, Geochemically anomalous areas in the west-central part of the Howard Pass Quadrangle, National Petroleum Reserve, Brooks Range, Alaska--Evidence for sediment-hosted Zn-Pb-Ag-Ba mineralization, in Evans, D.C. and Dusel-Bacon, Cynthia, eds., Geologic studies in Alaska by the U.S. Geological Survey during 1991: U.S. Geological Survey Bulletin 2041, p. 60-69.

Kelley, K.D., Seal, R.R., II, Schmidt, J.M., Hoover, D.B., and Klein, D.P., 1995, Sedimentary exhalative Zn-Pb-Ag deposits. U.S. Geol. Survey Open-File Report 95-831, p. 225-233.

Kilburn, J.E., Sutley, S.J., and Whitney, G.C., 1995, Geochemistry and mineralogy of acid mine drainage at the Holden mine, Chelan County, Washington:Explore, Association of Exploration Geochemists newsletter, no. 87, p. 9-14.

Kilburn, J.E., Smith, D.B., and Sutley, S.J., 1999, Analytical results and conceptual model of mine drainage at the Holden Mine, Chelan County, Washington. U.S. Geol. Survey Open-File Report 99-348, 36 p.

Large, D.E., 1981, Sediment-hosted submarine exhalative lead-zinc deposits--A review of their geological characteristics and genesis, in Wolf, K.H., ed., Handbook of stratabound and stratiform ore deposits: Amsterdam, Elsevier, v. 9, p. 469-508.

Large, D.E., 1983, Sediment-hosted massive sulfide lead-zinc deposits: an empirical model, in Sangster, D.F., ed., Sediment-hosted stratiform lead-zinc deposits: Mineralogical Association of Canada Short Course Handbook, v. 8, p. 1-30.

Leybourne, M.I., W.D. Goodfellow, and D.R. Boyle. 1998. Hydrogeochemical, isotopic, and rare earth element evidence for contrasting water-rock interactions at two undisturbed $\mathrm{Zn}-\mathrm{Pb}$ massive sulfide deposits, Bathurst Mining Camp, N.B., Canada. Jour. Explor. Geochem. 64: 237-261.

Lopaschuk, R.S., 1979, Drainage control and mine dewatering at Faro open pit mine, in Argall, G.O., Jr., and Brawner, C.O., eds., Mine Drainage: Proceedings of the first international mine drainage symposium, Miller Freeman Publications, p. 233-257.

Lydon, J.W., 1983, Chemical parameters controlling the origin and deposition of sediment-hosted stratiform lead-zinc deposits, in Sangster, D.F., ed., Sediment-hosted stratiform lead-zinc deposits: Mineralogical Association of Canada Short Course Handbook, v. 8, p. 175-250.

Maynard, J.B., 1983, Geochemistry of sedimentary ore deposits: Springer-Verlag, New York, New York, $305 \mathrm{p}$.

McClay , K.R., 1983, Deformation of stratiform lead-zinc deposits, in Sangster, D.F., ed., Sediment-hosted stratiform lead-zinc deposits: Mineralogical Association of Canada Short Course Handbook, v. 8, p. 283-309.

Menzie, W.D., and Mosier, D.L., 1986, Grade and tonnage model of sedimentary exhalative $\mathrm{Zn}-\mathrm{Pb}$, in Cox, D.P., and Singer, D.A., eds., Mineral deposit models: U.S. Geological Survey Bulletin 1693, p. 212215.

Meyer, M.P., and Kurtak, J.M., 1992, Results of the 1991 U.S. Bureau of Mines Colville Mining District study: U.S. Bureau of Mines Open-File Report 75-92, 101 p.

Nordstrom, D.K., and Alpers, C.N., 1999, Negative pH, efflorescent mineralogy, and consequences for environmental restoration at the Iron Mountain Superfund site, California. In: ed. Smith, J.V., Geology, Mineralogy, and Human Welfare, Proceedings of the National Academy of Science, USA, v. 96, p. 3455-3462.

Nordstrom, D.K., Alpers, C.N., Ptacek, C.J., and Blowes, D.W., 2000, Negative pH and extremely acidic mine waters from Iron Mountain, California: Environmental Science and Technology, v. 34, p. 254258.

Plumlee, G.S., 1999, The environmental geology of mineral deposits, in Plumlee, G.S., and Logsdon, M.J., eds., The Environmental Geochemistry of Mineral Deposits, Part A: Processes, Techniques, and Health Issues: Reviews in Economic Geology, v. 6A, p. 71-116.

Plumlee, G.S., and Nash, J.T., 1995, Geoenvironmental models of mineral deposits--fundamentals and applications. U.S. Geol. Survey Open-File Report 95-831, p. 1-18.

Rowan, E.L., Bailey, E.A., and Goldfarb, R.J., 1990, Geochemical orientation study for identification of metallic mineral resources in the Sitka quadrangle, southeastern Alaska, in Goldfarb, R.J., Nash, J.T., and Stoeser, J.W., eds., Geochemical studies in Alaska by the U.S. Geological Survey, 1989, U.S. Geological Survey Bulletin 1950, p. B1-B12.

Runnells, D.D., Shepherd, T.A., and Angino, E.E., 1992, Metals in water--determining natural background concentrations in mineralized areas: Environmental Science Technology, v. 26, p. 2316-2323. 
Runnells, D.D., Dupon, D.P., Jones, R.L., and Cline, D.J., 1998, Determination of natural background concentrations of dissolved components in water at mining, milling, and smelting sites: Mining Eng., v. 50(2), p. 65-71.

Ryall, W.R., 1981, The forms of mercury in some Australian stratiform Pb-Zn-Ag deposits of different regional metamorphic grades: Mineral Deposita, v. 16, p. 425-435.

Sangster, D.F., 1990, Mississippi Valley-type and sedex lead-zinc deposits--a comparative examination: Transactions of the Institution of Mining and Metallurgy, section B, v. 99, p. B21-B42.

Seal, R.R. II, J.M. Hammarstrom, C.S. Southworth, A.L. Meier, D.P. Haffner, A.P. Schultz, G.S. Plumlee, M.J.K. Flohr, J.C. Jackson, S.M. Smith, and P.L. Hageman. 1998a. Preliminary report on water quality associated with the abandoned Fontana and Hazel Creek mines, Great Smoky Mountains National Park, North Carolina and Tennessee: U.S. Geol. Survey Open-File Report 98-476, 50 p.

Seal, R.R. II, N.K. Foley, D.P. Haffner, and A.L. Meier. 1998b, Environmental geochemistry of surface and ground waters around the Bald Mountain massive sulfide deposit, northern Maine: natural backgrounds from a mineralized, but unmined area: Geol. Soc. Amer. Abstracts with Programs 30: A128.

Seal, R.R., II, D.P. Haffner, A.L. Meier, R. Krishnaswamy, R., and J.M. Hammarstrom. 1999. Geochemistry of acid mine drainage from the abandoned Elizabeth copper mine, South Strafford, Vermont: Geol. Soc. Amer. Abstracts with Programs (NE) 31: A-66.

Seal, R.R., II, Hammarstrom, J.M., Foley, N.K., and Alpers, C.N., 2000a, Geoenvironmental models for seafloor base- and precious-metal massive sulfide deposits, $5^{\text {th }}$ International Conference on Acid Rock Drainage 2000 Proceedings Volume, p. 151-160.

Singer, D.A, 1986a, Descriptive model of Cyprus massive sulfide, in Cox, D.P., and Singer, D.A., eds., Mineral deposit models: U.S. Geological Survey Bulletin 1693, p. 131.

Singer, D.A, 1986b, Descriptive model of Kuroko massive sulfide, in Cox, D.P., and Singer, D.A., eds., Mineral deposit models: U.S. Geological Survey Bulletin 1693, p. 189-190.

Singer, D.A, 1986c, Grade and tonnage model of Cyprus massive sulfide, in Cox, D.P., and Singer, D.A., eds., Mineral deposit models: U.S. Geological Survey Bulletin 1693, p. 131-135.

Singer, D.A, 1986d, Grade and tonnage model of Besshi massive sulfide, in Cox, D.P., and Singer, D.A., eds., Mineral deposit models: U.S. Geological Survey Bulletin 1693, p. 136-138.

Singer, D.A., and Mosier, D.L., 1986, Grade and tonnage model of Kuroko massive sulfide, in Cox, D.P., and

Singer, D.A., eds., Mineral deposit models: U.S. Geological Survey Bulletin 1693, p. 190-197.

Slack, J.F., 1993, Descriptive and grade-tonnage models for Besshi-type massive sulfide deposits, in Kirkham, R.V., Sinclair, W.D., Thorpe, R.I., and Duke, J.M., eds., Mineral deposit modeling, Geological Association of Canada Special Paper 40, p. 343-372.

Smith, K.S., Ranville, J.F., Plumlee, G.S., and Macalady, D.L., 1998, Predictive double-layer modeling of metal sorption in mine-drainage systems, in Jenne, E.A., ed., Adsorption of Metals by Geomedia: Academic Press, p. 521-547.

Sobek, A.A., Schuller, W.A., Freeman, J.R., and Smith, R.M., 1978, Field and laboratory methods applicable to overburdens and minesoils. U.S. Environmental Protection Agency Protection Technology EPA-600/2-78-054, Cincinnati, Ohio, 203 p.

Stanton, R.L., 1972, Ore Petrology, McGraw-Hill, New York, 713 p.

Taylor, C.D., Cieutat, B.A., and Miller, L.D., 1992, A followup geochemical survey of base metal anomalies in the Ward Creek/Windfall Harbor and Gambier Bay areas, Admiralty Island S.E. Alaska, in Bradley, D., and Dusel-Bacon, C., eds., 1991 Geologic Studies in Alaska: U.S. Geological Survey Bulletin 2041, p. 70-85.

Taylor, C.D., Zierenberg, R.A., Goldfarb, R.J., Kilburn, J.E., Seal, R.R., II, and Kleinkopf, M.D., 1995, Volcanic-associated massive sulfide deposits. U.S. Geol. Survey Open-File Report 95-831, p. 137-144.

Taylor, G.F., Wilmshurst, J.R., Togashi, Y., and Andrew, A.S., 1984, Geochemical and mineralogical halos about the Elura $\mathrm{Zn}-\mathrm{Pb}-\mathrm{Ag}$ orebody, western New South Wales: Journal of Geochemical Exploration, v. 22, p. 265-290.

Theobald, P.K., Barton, H.N., Billings, T.M., Frisken, J.G., Turner, R.L., and VanTrump, G., Jr., 1978, Geochemical distribution of elements in stream sediment and heavy-mineral concentrate samples in the southern half of the National Petroleum Reserve, Alaska: U.S. Geological Survey Open-File Report 78-517, scale 1:500,000. 


\title{
Appendix 1
}

\section{DEFINITIONS AND REFERENCES FOR AQUEOUS GEOCHEMISTRY}

\author{
Laurie Balistrieri
}

Acid: a substance containing hydrogen that gives free hydrogen ions $\left(\mathrm{H}^{+}\right)$when dissolved in water; e.g., hydrochloric acid $(\mathrm{HCl})$, nitric acid $\left(\mathrm{HNO}_{3}\right)$. Strong acids release a greater proportion of their protons than weak acids.

Acidity: the base neutralizing capacity of an aqueous system or the capacity to donate protons. Usually determined by titration with a standardized base to a reference $\mathrm{pH}$.

Alkalinity: the acid neutralizing capacity (ANC) of an aqueous system or the capacity to accept protons. Usually determined by titration with a standardized acid to a reference $\mathrm{pH}$.

Adsorption: the attachment of dissolved substances (e.g., ions) to solid surfaces.

Aqueous geochemistry: the study of chemical reactions occurring between water and rocks.

Base: a substance containing a hydroxyl group $(-\mathrm{OH})$ that yields hydroxyl ions $\left(\mathrm{OH}^{-}\right)$when dissolved in water; e.g., potassium hydroxide $(\mathrm{KOH})$, sodium hydroxide $(\mathrm{NaOH})$.

Compounds: substances that are composed of two or more elements in the same proportions, e.g., calcium carbonate $\left(\mathrm{CaCO}_{3}\right)$ or pyrite $\left(\mathrm{FeS}_{2}\right)$

Dissolution of minerals: the act or process of separating into component parts, e.g., dissolution of salt (sodium chloride; $\mathrm{NaCl}$ ) by water forming dissolved sodium ions $\left(\mathrm{Na}^{+}\right)$and chloride ions $\left(\mathrm{Cl}^{-}\right)$.

Elements: substances that are composed of atoms that exhibit unique and identical properties, e.g., Fe, Zn, or $\mathrm{Cu}$; see the attached periodic table of elements.

Equilibrium: time-invariant, most stable state of a system at a given temperature and pressure.

Hydrolysis: reactions leading to an excess of protons $\left(\mathrm{H}^{+}\right)$or hydroxyl ions $\left(\mathrm{OH}^{-}\right)$in solution; e.g., hydrolysis of ferric $\mathrm{Fe}\left(\mathrm{Fe}^{3+}\right)$ where $\mathrm{Fe}^{3+}+2 \mathrm{H}_{2} \mathrm{O} \leftrightarrow \mathrm{Fe}(\mathrm{OH})_{2}{ }^{+}+2 \mathrm{H}^{+}$.

Ion: an atom or group of atoms that carries a negative or positive charge as a result of having gained or lost one or more electron. Positive ions are called cations and negative ions are called anions.

Kinetics: rates of change in a physical or chemical system.

Neutralization: reactions between acid and bases that result in neither acidic nor basic conditions.

Oxidation half-reactions: reactions that involve the loss of electrons from an atom or atoms.

$\mathrm{pH}$ : the negative, base-10 logarithm of the hydrogen ion activity $\left[\mathrm{pH}=-\log \left(\mathrm{H}^{+}\right)\right]$; $\mathrm{pH}$ values of most natural waters lie between 4 and 9 (e.g., $\mathrm{pH}_{\text {seawater }}=8.1-8.3$ ). The lowest observed $\mathrm{pH}$ values, including negative values, are found in systems where pyrite is being oxidized.

Precipitation of minerals: reactions where dissolved ions combine to form insoluble solids.

Reduction half reactions: reactions that involve the gain of electrons by an atom or atoms.

Reduction-oxidation (redox) reactions: reactions that involve both oxidizing agents (a substance that accepts electrons) and reducing agents (a substance that donates electrons).

\section{REFERENCE BOOKS}

Brownlow, A.H., 1979, Geochemistry: Prentice-Hall, 498 p.

Drever, J.I., 1988, The Geochemistry of Natural Waters: Prentice Hall, 437 p.

Krauskopf, K.B., and Bird, D.K., 1995, Introduction to Geochemistry: McGraw-Hill, 647 p.

Langmuir, D., 1997, Aqueous Environmental Geochemistry: Prentice-Hall, 600 p.

Morel, F.M.M., and Herring, J.G., 1993, Principles and Applications of Aquatic Chemistry: WileyInterscience, $588 \mathrm{p}$.

Stumm, W., and Morgan, J.J., 1996, Aquatic Chemistry: Wiley-Interscience, 1022 p. 